\title{
A study of chemical interactions between the Marcellus shale and attapulgite and bentonite clays
}

\author{
Virginia Price Naryka \\ West Virginia University
}

Follow this and additional works at: https://researchrepository.wvu.edu/etd

\section{Recommended Citation}

Naryka, Virginia Price, "A study of chemical interactions between the Marcellus shale and attapulgite and bentonite clays" (2012). Graduate Theses, Dissertations, and Problem Reports. 432.

https://researchrepository.wvu.edu/etd/432

This Thesis is protected by copyright and/or related rights. It has been brought to you by the The Research Repository @ WVU with permission from the rights-holder(s). You are free to use this Thesis in any way that is permitted by the copyright and related rights legislation that applies to your use. For other uses you must obtain permission from the rights-holder(s) directly, unless additional rights are indicated by a Creative Commons license in the record and/ or on the work itself. This Thesis has been accepted for inclusion in WVU Graduate Theses, Dissertations, and Problem Reports collection by an authorized administrator of The Research Repository @ WVU. For more information, please contact researchrepository@mail.wvu.edu. 


\title{
A STUDY OF CHEMICAL INTERACTIONS BETWEEN THE MARCELLUS SHALE AND ATTAPULGITE AND BENTONITE CLAYS
}

\section{VIRGINIA PRICE NARYKA}

Thesis to the Benjamin M. Statler College of Engineering and Mineral Resources at West Virginia University

in partial fulfillment of the requirements for the degree of

\author{
MASTER OF SCIENCE \\ in \\ Petroleum and Natural Gas Engineering \\ H. Ilkin Bilgesu, PhD., Chair \\ Kashy Aminian PhD. \\ Sam Ameri, M.S. \\ Department of Petroleum and Natural Gas Engineering \\ Morgantown, West Virginia \\ 2012
}

Keywords: Marcellus Shale; Attapulgite Clay; Bentonite Clay; Chemical Interactions, Scanning Electron Microscope, X-Ray Microanalysis System

Copyright 2012 Virginia Price Naryka 


\section{Abstract \\ A Study of Chemical Interactions Between the Marcellus Shale and Attapulgite and Bentonite Clays}

\section{Virginia Price Naryka}

Chemical interactions occur between water based muds and shale formations. These shalefluid interactions are often associated with problems that arise when drilling. This paper presents results from a study investigating chemical interactions that occurred between the Marcellus shale and attapulgite and bentonite clays. The aim of this project was to determine if there were particular elemental changes that could be directly associated with either an attapulgite or bentonite clay. In this study, samples from two wells in West Virginia were analyzed. A Scanning Electron Microscope (SEM) was used to observe the surface of each sample, and an INCA X-Ray Microanalysis System (EDX) provided a quantitative chemical composition analysis of the samples as well. There is large mineralogical variability among the Marcellus shale thus leading to variation among the mineral composition of the studied samples. 


\section{Table of Contents}

List of Tables

. $\mathrm{xV}$

Acknowledgements...................................................................................Error! Bookmark not defined.

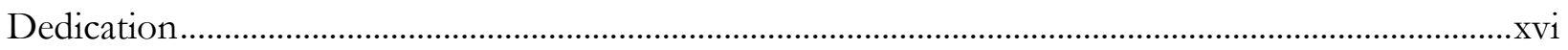

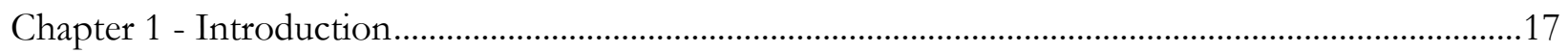

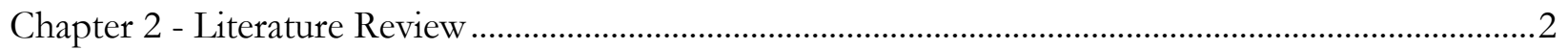

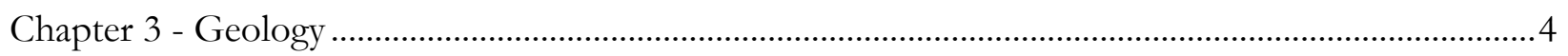

Monongalia County Well A Geology ………................................................................................

Wetzel County Well B Geology ………………….............................................................................

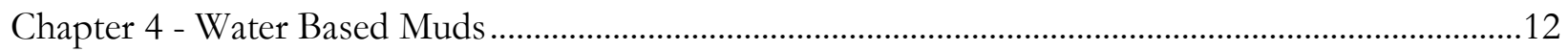

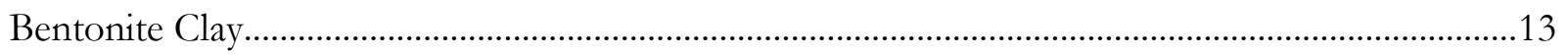

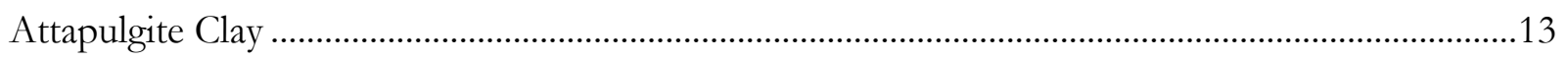

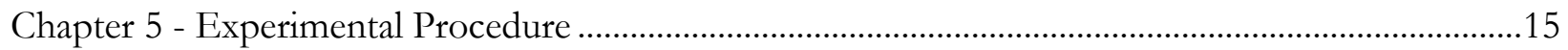

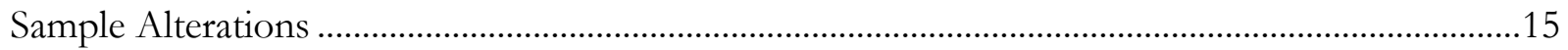

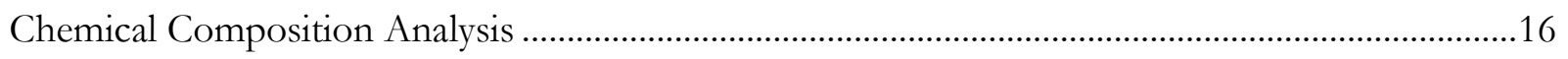

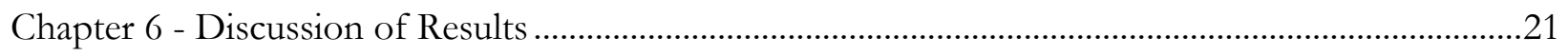

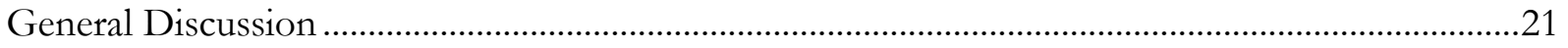

Monongalia County Well Sample Analysis By Alteration .......................................................................22

Monongalia County Well A No Alteration ........................................................................................22

Monongalia County Well A No Alteration SEM Photographs..................................................26

Monongalia County Well $\mathrm{A} \mathrm{H}_{2} \mathrm{O}$ Alteration.....................................................................................35

Monongalia County Well $\mathrm{A} \mathrm{H}_{2} \mathrm{O}$ Alteration SEM Photographs ................................................39

Monongalia County Well A Aquagel® Alteration .............................................................................4 48

Monongalia County Well A Aquagel ${ }^{\circledR}$ Alteration SEM Photographs.....................................52

Monongalia County Well A Quik-Gel ${ }^{\circledR}$ Alteration........................................................................61

Monongalia County Well A Quik-Gel ${ }^{\circledR}$ Alteration SEM Photographs ....................................65

Monongalia County Well A Zeogel ${ }^{\circledR}$ Alteration ............................................................................74

Monongalia County Well A Zeogel ${ }^{\circledR}$ Alteration SEM Photographs ........................................78

Wetzel County Well Sample Analysis By Alteration...........................................................................8

Wetzel County Well B No Alteration ...............................................................................................8 
Wetzel County Well B No Alteration SEM Photographs........................................................91

Wetzel County Well B H

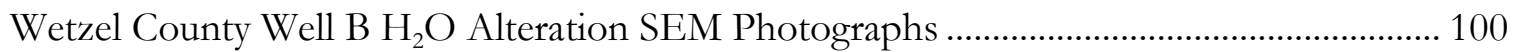

Wetzel County Well B Aquagel ${ }^{\circledR}$ Alteration .................................................................................. 105

Wetzel County Well B Aquagel ${ }^{\circledR}$ Alteration SEM Photographs.............................................. 109

Wetzel County Well B Quik-Gel ${ }^{\circledR}$ Alteration................................................................................ 114

Wetzel County Well B Quik-Gel® Alteration Photographs .................................................... 118

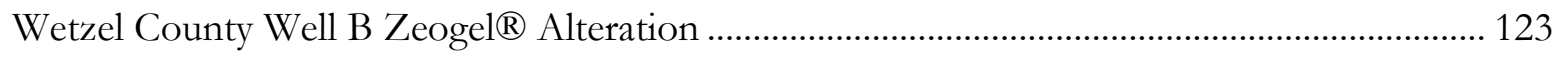

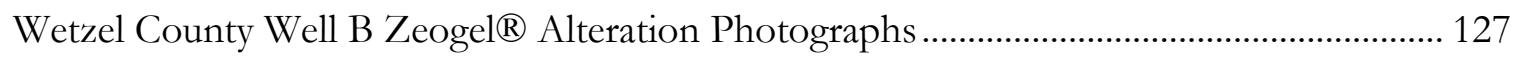

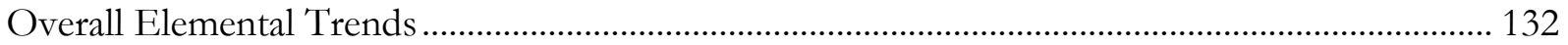

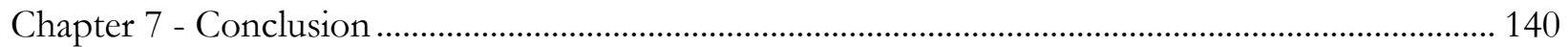

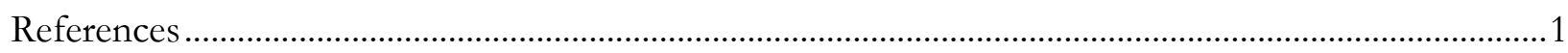

Appendix A - Comparison of Elemental Composition ………..................................................... A-1

Appendix B - Elemental Composition Per Individual Sample .............................................................. 


\section{List of Figures}

Figure 3.1 Marcellus shale is found throughout the Allegheny Plateau region of the northern

Appalachian Basin of North America (Swarthmore College, 2012) ..... 4

Figure 3.2 Stratigraphic nomenclature for the Middle Devonian System in the northern Appalachian

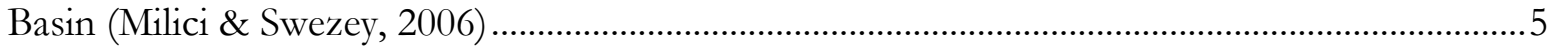

Figure 3.3 Subsurface isopach map of the Marcellus shale in West Virginia.........................................6

Figure 3.4 Location map of the two wells used for this study (Monongalia County Well A and the

Wetzel County Well B are indicated by red stars) …...................................................................... 7

Figure 3.5 Marcellus shale section of the geophysical log for Monongalia County Well A (Cliff

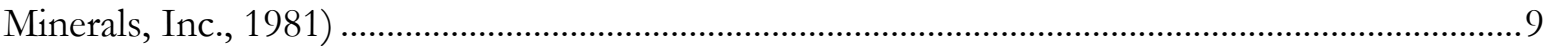

Figure 3.6 Marcellus shale section of the geophysical log for Wetzel County Well B (Cliff Minerals,

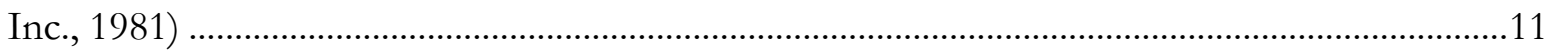

Figure 5.1 Marcellus shale samples prior to sputtering ....................................................................16

Figure 5.2 Marcellus shale samples after being sputtered with platinum ............................................17

Figure 5.3 WVU's Shared Research Facility's Sputtering Station ..........................................................17

Figure 5.4 WVU' Shared Research Facility's JEOL JSM 7600F Scanning Electron Microscope ......18

Figure 5.5 A closer view of the JEOL JSM 7600F Scanning Electron Microscope ............................18

Figure 5.6 Wetzel County Well Sample 1B (No Alteration) X-ray spectrum .........................................19

Figure 6.1 Weight percent of each element found in Monongalia County Well A control samples

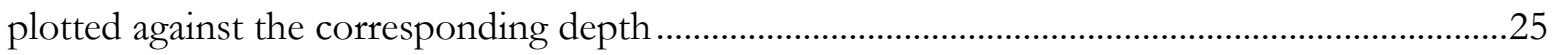

Figure 6.2 SEM image of the control specimen for the first depth interval of Well A at 800X.........26

Figure 6.3 SEM image of the control specimen for the first depth interval of Well A at 5000X......26

Figure 6.4 SEM image of the control specimen for the second depth interval of Well A at 800X ...27

Figure 6.5 SEM image of the control specimen for the second depth interval of Well A at 5000X.27

Figure 6.6 SEM image of the control specimen for the third depth interval of Well A at 800X .......28

Figure 6.7 SEM image of the control specimen for the third depth interval of Well A at 5000X.....28

Figure 6.8 SEM image of the control specimen for the fourth depth interval of Well A at 800X.....29

Figure 6.9 SEM image of the control specimen for the fourth depth interval of Well A at 5000X ..29

Figure 6.10 SEM image of the control specimen for the fifth depth interval of Well A at 800X......30

Figure 6.11 SEM image of the control specimen for the fifth depth interval of Well A at 5000X....30 
Figure 6.12 SEM image of the control specimen for the sixth depth interval of Well A at 800X .....31

Figure 6.13 SEM image of the control specimen for the sixth depth interval of Well A at 5000X...31

Figure 6.14 SEM image of the control specimen for the seventh depth interval of Well A at 800X 32

Figure 6.15 SEM image of the control specimen for the seventh depth interval of Well A at 5000X

Figure 6.16 SEM image of the control specimen for the eighth depth interval of Well A at 800X...33

Figure 6.17 SEM image of the control specimen for the eighth depth interval of Well A at 5000X.33

Figure 6.18 SEM image of the control specimen for the ninth depth interval of Well A at 800X ....34

Figure 6.19 SEM image of the control specimen for the ninth depth interval of Well A at 5000X..34

Figure 6.20 Weight percent of each element found in Monongalia County Well A water treatment sampled plotted against the corresponding depth

Figure 6.21 SEM image of the water treatment specimen for the first depth interval of Well A at $800 \mathrm{X}$

Figure 6.22 SEM image of the water treatment specimen for the first depth interval of Well A at $5000 \mathrm{X}$

Figure 6.23 SEM image of the water treatment specimen for the second depth interval of Well A at $800 \mathrm{X}$

Figure 6.24 SEM image of the water treatment specimen for the second depth interval of Well A at 5000X.

Figure 6.25 SEM image of the water treatment specimen for the third depth interval of Well A at 800X.

Figure 6.26 SEM image of the water treatment specimen for the third depth interval of Well A at 5000X.

Figure 6.27 SEM image of the water treatment specimen for the fourth depth interval of Well A at 800X.

Figure 6.28 SEM image of the water treatment specimen for the fouth depth interval of Well A at 5000X.

Figure 6.29 SEM image of the water treatment specimen for the fifth depth interval of Well A at 800X.

Figure 6.30 SEM image of the water treatment specimen for the fifth depth interval of Well A at $5000 \mathrm{X}$ 
Figure 6.31 SEM image of the water treatment specimen for the sixth depth interval of Well A at 800X.

Figure 6.32 SEM image of the water treatment specimen for the sixth depth interval of Well A at $5000 \mathrm{X}$

Figure 6.33 SEM image of the water treatment specimen for the seventh depth interval of Well A at 800X. .45

Figure 6.34 SEM image of the water treatment specimen for the seventh depth interval of Well A at 5000X..

Figure 6.35 SEM image of the water treatment specimen for the eighth depth interval of Well A at 800X. .46

Figure 6.36 SEM image of the water treatment specimen for the eighth depth interval of Well A at $5000 \mathrm{X}$.

Figure 6.37 SEM image of the water treatment specimen for the ninth depth interval of Well $\mathrm{A}$ at 800X.

Figure 6.38 SEM image of the water treatment specimen for the ninth depth interval of Well A at $5000 \mathrm{X}$

Figure 6.39 Weight percent of each element found in Monongalia County Well A Aquagel® treatment samples plotted against the corresponding depth

Figure 6.40 SEM image of the Aquagel® treatment sample for the first depth interval of Well A at $800 \mathrm{X}$

Figure 6.41 SEM image of the Aquagel ${ }^{\circledR}$ treatment sample for the first depth interval of Well A at $5000 \mathrm{X}$

Figure 6.42 SEM image of the Aquagel ${ }^{\circledR}$ treatment sample for the second depth interval of Well A at $800 \mathrm{X}$

Figure 6.43 SEM image of the Aquagel ${ }^{\circledR}$ treatment sample for the second depth interval of Well A at $5000 \mathrm{X}$

Figure 6.44 SEM image of the Aquagel ${ }^{\circledR}$ treatment sample for the third depth interval of Well A at $800 \mathrm{X}$

Figure 6.45 SEM image of the Aquagel ${ }^{\circledR}$ treatment sample for the third depth interval of Well A at $5000 \mathrm{X}$

Figure 6.46 SEM image of the Aquagel ${ }^{\circledR}$ treatment sample for the fourth depth interval of Well A at $800 \mathrm{X}$ 
Figure 6.47 SEM image of the Aquagel ${ }^{\circledR}$ treatment sample for the fourth depth interval of Well A at $5000 \mathrm{X}$

Figure 6.48 SEM image of the Aquagel ${ }^{\circledR}$ treatment sample for the fifth depth interval of Well A at $800 \mathrm{X}$

Figure 6.49 SEM image of the Aquagel ${ }^{\circledR}$ treatment sample for the fifth depth interval of Well A at $5000 \mathrm{X}$ .56

Figure 6.50 SEM image of the Aquagel ${ }^{\circledR}$ treatment sample for the sixth depth interval of Well $A$ at $800 \mathrm{X}$

Figure 6.51 SEM image of the Aquagel ${ }^{\circledR}$ treatment sample for the sixth depth interval of Well $A$ at $5000 \mathrm{X}$ .57

Figure 6.52 SEM image of the Aquagel ${ }^{\circledR}$ treatment sample for the seventh depth interval of Well A at $800 \mathrm{X}$. .58

Figure 6.53 SEM image of the Aquagel ${ }^{\circledR}$ treatment sample for the seventh depth interval of Well A at $5000 \mathrm{X}$ .58

Figure 6.54 SEM image of the Aquagel® treatment sample for the eighth depth interval of Well A at $800 \mathrm{X}$

Figure 6.55 SEM image of the Aquagel ${ }^{\circledR}$ treatment sample for the eighth depth interval of Well A at $5000 \mathrm{X}$

Figure 6.56 SEM image of the Aquagel ${ }^{\circledR}$ treatment sample for the ninth depth interval of Well A at $800 \mathrm{X}$

Figure 6.57 SEM image of the Aquagel ${ }^{\circledR}$ treatment sample for the ninth depth interval of Well A at $5000 \mathrm{X}$

Figure 6.58 Weight percent of each element found in Monongalia County Well A Quik-Gel® treatment samples plotted against the corresponding depth

Figure 6.59 SEM image of the Quik-Gel® treatment sample for the first depth interval of Well A at $800 \mathrm{X}$

Figure 6.60 SEM image of the Quik-Gel® treatment sample for the first depth interval of Well A at $5000 \mathrm{X}$

Figure 6.61 SEM image of the Quik-Gel® treatment sample for the second depth interval of Well A at $800 \mathrm{X}$ .66

Figure 6.62 SEM image of the Quik-Gel@ treatment sample for the second depth interval of Well $\mathrm{A}$ at $5000 \mathrm{X}$ 
Figure 6.63 SEM image of the Quik-Gel® treatment sample for the third depth interval of Well A at $800 \mathrm{X}$.

Figure 6.64 SEM image of the Quik-Gel® treatment sample for the third depth interval of Well A at $5000 \mathrm{X}$

Figure 6.65 SEM image of the Quik-Gel@ treatment sample for the fourth depth interval of Well A at $800 \mathrm{X}$.

Figure 6.66 SEM image of the Quik-Gel® treatment sample for the fourth depth interval of Well A at $5000 \mathrm{X}$

Figure 6.67 SEM image of the Quik-Gel® treatment sample for the fifth depth interval of Well A at 800X.

Figure 6.68 SEM image of the Quik-Gel® treatment sample for the fifth depth interval of Well A at 5000X

Figure 6.69 SEM image of the Quik-Gel® treatment sample for the sixth depth interval of Well A at $800 \mathrm{X}$

Figure 6.70 SEM image of the Quik-Gel® treatment sample for the sixth depth interval of Well A at $5000 \mathrm{X}$.

Figure 6.71 SEM image of the Quik-Gel® treatment sample for the seventh depth interval of Well A at $800 \mathrm{X}$ .71

Figure 6.72 SEM image of the Quik-Gel® treatment sample for the seventh depth interval of Well A at $5000 \mathrm{X}$

Figure 6.73 SEM image of the Quik-Gel® treatment sample for the eighth depth interval of Well A at $800 \mathrm{X}$ .72

Figure 6.74 SEM image of the Quik-Gel® treatment sample for the eighth depth interval of Well A at $5000 \mathrm{X}$.

Figure 6.75 SEM image of the Quik-Gel ${ }^{\circledR}$ treatment sample for the ninth depth interval of Well A at $800 \mathrm{X}$.

Figure 6.76 SEM image of the Quik-Gel ${ }^{\circledR}$ treatment sample for the ninth depth interval of Well A at $5000 \mathrm{X}$

Figure 6.77 Weight percent of each element found in Monongalia County Well A Zeogel® treatment samples plotted against the corresponding depth

Figure 6.78 SEM image of the Zeogel® treatment sample for the first depth interval of Well A at $800 \mathrm{X}$ 
Figure 6.79 SEM image of the Zeogel ${ }^{\circledR}$ treatment sample for the first depth interval of Well A at 5000X .78

Figure 6.80 SEM image of the Zeogel ${ }^{\circledR}$ treatment sample for the second depth interval of Well A at $800 \mathrm{X}$

Figure 6.81 SEM image of the Zeogel ${ }^{\circledR}$ treatment sample for the second depth interval of Well A at 5000X.

Figure 6.82 SEM image of the Zeogel ${ }^{\circledR}$ treatment sample for the third depth interval of Well A at 800X.

Figure 6.83 SEM image of the Zeogel ${ }^{\circledR}$ treatment sample for the third depth interval of Well A at 5000X .80

Figure 6.84 SEM image of the Zeogel ${ }^{\circledR}$ treatment sample for the fourth depth interval of Well A at 800X.

Figure 6.85 SEM image of the Zeogel ${ }^{\circledR}$ treatment sample for the fourth depth interval of Well A at 5000X .81

Figure 6.86 SEM image of the Zeogel® treatment sample for the fifth depth interval of Well A at $800 \mathrm{X}$

Figure 6.87 SEM image of the Zeogel ${ }^{\circledR}$ treatment sample for the fifth depth interval of Well A at $5000 \mathrm{X}$

Figure 6.88 SEM image of the Zeogel ${ }^{\circledR}$ treatment sample for the sixth depth interval of Well A at $800 \mathrm{X}$

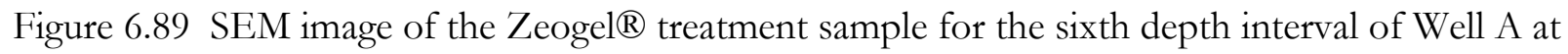
$5000 \mathrm{X}$

Figure 6.90 SEM image of the Zeogel@ treatment sample for the seventh depth interval of Well A at $800 \mathrm{X}$

Figure 6.91 SEM image of the Zeogel ${ }^{\circledR}$ treatment sample for the seventh depth interval of Well A at $5000 \mathrm{X}$

Figure 6.92 SEM image of the Zeogel® treatment sample for the eighth depth interval of Well A at $800 \mathrm{X}$

Figure 6.93 SEM image of the Zeogel ${ }^{\circledR}$ treatment sample for the eighth depth interval of Well A at 5000X.

Figure 6.94 SEM image of the Zeogel ${ }^{\circledR}$ treatment sample for the ninth depth interval of Well A at 800X. 
Figure 6.95 SEM image of the Zeogel ${ }^{\circledR}$ treatment sample for the ninth depth interval of Well A at $5000 \mathrm{X}$ .86

Figure 6.96 Weight percent of each element found in Wetzel County Well B control samples plotted against the corresponding depth .90

Figure 6.97 SEM image of the control specimen for the first depth interval of Well B at 800X.......91

Figure 6.98 SEM image of the control specimen for the first depth interval of Well B at 5000X.....91

Figure 6.99 SEM image of the control specimen for the second depth interval of Well B at 800X..92 Figure 6.100 SEM image of the control specimen for the second depth interval of Well B at 5000X

Figure 6.101 SEM image of the control specimen for the third depth interval of Well B at 800X...93 Figure 6.102 SEM image of the control specimen for the third depth interval of Well B at 5000X.93 Figure 6.103 SEM image of the control specimen for the fourth depth interval of Well B at 800X.94 Figure 6.104 SEM image of the control specimen for the fourth depth interval of Well B at 5000X

Figure 6.105 SEM image of the control specimen for the fifth depth interval of Well $\mathrm{B}$ at $800 \mathrm{X} \ldots . .95$ Figure 6.106 SEM image of the control specimen for the fifth depth interval of Well B at 5000X..95 Figure 6.107 Weight percent of each element found in Wetzel County Well B water treatment samples plotted against the corresponding depth.

Figure 6.108 SEM image of the water treatment specimen for the first depth interval of Well B at $800 \mathrm{X}$

Figure 6.109 SEM image of the water treatment specimen for the first depth interval of Well B at $5000 \mathrm{X}$ 100

Figure 6.110 SEM image of the water treatment specimen for the second depth interval of Well B at $800 \mathrm{X}$ 101

Figure 6.111 SEM image of the water treatment specimen for the second depth interval of Well B at $5000 \mathrm{X}$ 101

Figure 6.112 SEM image of the water treatment specimen for the third depth interval of Well B at $800 \mathrm{X}$

Figure 6.113 SEM image of the water treatment specimen for the third depth interval of Well B at $5000 \mathrm{X}$ 102

Figure 6.114 SEM image of the water treatment specimen for the fourth depth interval of Well B at $800 \mathrm{X}$ 
Figure 6.115 SEM image of the water treatment specimen for the fourth depth interval of Well B at 5000X.

Figure 6.116 SEM image of the water treatment specimen for the fifth depth interval of Well B at $800 \mathrm{X}$

Figure 6.117 SEM image of the water treatment specimen for the fifth depth interval of Well B at $5000 \mathrm{X}$ 104

Figure 6.118 Weight percent of each element found in Wetzel County Well B Aquagel® treatment samples plotted against the corresponding depth. 108

Figure 6.119 SEM image of the Aquagel ${ }^{\circledR}$ treatment sample for the first depth interval of Well B at 800X. 109

Figure 6.120 SEM image of the Aquagel ${ }^{\circledR}$ treatment sample for the first depth interval of Well B at 5000X

Figure 6.121 SEM image of the Aquagel ${ }^{\circledR}$ treatment sample for the second depth interval of Well B at $800 \mathrm{X}$ 110

Figure 6.122 SEM image of the Aquagel ${ }^{\circledR}$ treatment sample for the second depth interval of Well B at $5000 \mathrm{X}$ 110

Figure 6.123 SEM image of the Aquagel ${ }^{\circledR}$ treatment sample for the third depth interval of Well B at $800 \mathrm{X}$ 111

Figure 6.124 SEM image of the Aquagel ${ }^{\circledR}$ treatment sample for the third depth interval of Well B at $5000 \mathrm{X}$

Figure 6.125 SEM image of the Aquagel ${ }^{\circledR}$ treatment sample for the fourth depth interval of Well B at $800 \mathrm{X}$

Figure 6.126 SEM image of the Aquagel ${ }^{\circledR}$ treatment sample for the fourth depth interval of Well B at $5000 \mathrm{X}$

Figure 6.127 SEM image of the Aquagel ${ }^{\circledR}$ treatment sample for the fifth depth interval of Well B at $800 \mathrm{X}$

Figure 6.128 SEM image of the Aquagel ${ }^{\circledR}$ treatment sample for the fifth depth interval of Well B at $800 \mathrm{X}$

Figure 6.129 Weight percent of each element found in Wetzel County Well B Quik-Gel® treatment samples plotted against the corresponding depth. 117

Figure 6.130 SEM image of the Quik-Gel® treatment sample for the first depth interval of Well B at $800 \mathrm{X}$ 
Figure 6.131 SEM image of the Quik-Gel ${ }^{\circledR}$ treatment sample for the first depth interval of Well B at $5000 \mathrm{X}$ 118

Figure 6.132 SEM image of the Quik-Gel ${ }^{\circledR}$ treatment sample for the second depth interval of Well $B$ at $800 \mathrm{X}$

Figure 6.133 SEM image of the Quik-Gel ${ }^{\circledR}$ treatment sample for the second depth interval of Well $B$ at $5000 X$

Figure 6.134 SEM image of the Quik-Gel ${ }^{\circledR}$ treatment sample for the third depth interval of Well B at $800 \mathrm{X}$ 120

Figure 6.135 SEM image of the Quik-Gel ${ }^{\circledR}$ treatment sample for the third depth interval of Well B at $5000 \mathrm{X}$

Figure 6.136 SEM image of the Quik-Gel® treatment sample for the fourth depth interval of Well $\mathrm{B}$ at $800 \mathrm{X}$

Figure 6.137 SEM image of the Quik-Gel® treatment sample for the fourth depth interval of Well B at 5000X

Figure 6.138 SEM image of the Quik-Gel® treatment sample for the fifth depth interval of Well B at $800 \mathrm{X}$

Figure 6.139 SEM image of the Quik-Gel® treatment sample for the fifth depth interval of Well B at $5000 \mathrm{X}$

Figure 6.140 Weight percent of each element found in Wetzel County Well B Zeogel® treatment samples plotted against the corresponding depth.

Figure 6.141 SEM image of the Zeogel ${ }^{\circledR}$ treatment sample for the first depth interval of Well B at $800 \mathrm{X}$

Figure 6.142 SEM image of the Zeogel@ treatment sample for the first depth interval of Well B at $5000 \mathrm{X}$

Figure 6.143 SEM image of the Zeogel ${ }^{\circledR}$ treatment sample for the second depth interval of Well B at $800 \mathrm{X}$.

Figure 6.144 SEM image of the Zeogel ${ }^{\circledR}$ treatment sample for the second depth interval of Well B at $5000 \mathrm{X}$

Figure 6.145 SEM image of the Zeogel ${ }^{\circledR}$ treatment sample for the third depth interval of Well B at $800 \mathrm{X}$

Figure 6.146 SEM image of the Zeogel ${ }^{\circledR}$ treatment sample for the third depth interval of Well B at $5000 \mathrm{X}$ 
Figure 6.147 SEM image of the Zeogel ${ }^{\circledR}$ treatment sample for the fourth depth interval of Well B at $800 \mathrm{X}$ 130

Figure 6.148 SEM image of the Zeogel ${ }^{\circledR}$ treatment sample for the fourth depth interval of Well B at $5000 \mathrm{X}$.

Figure 6.149 SEM image of the Zeogel ${ }^{\circledR}$ treatment sample for the fifth depth interval of Well B at $800 \mathrm{X}$

Figure 6.150 SEM image of the Zeogel ${ }^{\circledR}$ treatment sample for the fifth depth interval of Well B at $5000 \mathrm{X}$

Figure 6.151 Comparison of the weight percent data for oxygen found in the control samples and the water treatment samples for Monongalia County Well A

Figure 6.152 Comparison of the weight percent data for iron found in the control samples and the Aquagel ${ }^{\circledR}$ treatment samples for Monongalia County Well A

Figure 6.153 Comparison of the weight percent data for carbon found in the control samples and the Zeogel ${ }^{\circledR}$ treatment samples for Monongalia County Well A. 134

Figure 6.154 Comparison of the weight percent data for oxygen found in the control samples and the Zeogel ${ }^{\circledR}$ treatment samples for Monongalia County Well A

Figure 6.155 Comparison of the weight percent data for aluminum found in the control samples and the water treatment samples for Wetzel County Well B

Figure 6.156 Comparison of the weight percent data for magnesium found in the control samples and the water treatment samples for Wetzel County Well B

Figure 6.157 Comparison of the weight percent data for oxygen found in the control samples and the Aquagel ${ }^{\circledR}$ treatment samples for Monongalia County Well B 136

Figure 6.158 Comparison of the weight percent data for potassium found in the control samples and the Quik-Gel® treatment samples for Monongalia County Well B....

Figure 6.159 Comparison of the weight percent data for magnesium found in the control samples and the Quik-Gel® treatment samples for Monongalia County Well B...

Figure 6.160 Comparison of the weight percent data for silicon found in the control samples and the Quik-Gel® treatment samples for Monongalia County Well B.

Figure 6.161 Comparison of the weight percent data for magnesium found in the control samples and the Zeogel ${ }^{\circledR}$ treatment samples for Monongalia County Well B.

Figure 6.162 Comparison of the weight percent data for silicon found in the control samples and the Zeogel ${ }^{\circledR}$ treatment samples for Monongalia County Well B ..... 


\section{List of Tables}

Table 3.1 The depth intervals and the corresponding designation for the Monongalia County Well

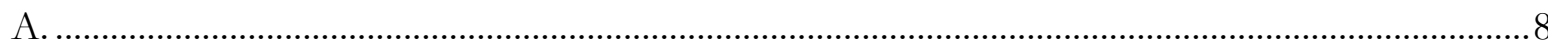

Table 3.2 The depth intervals and the corresponding designation for the Wetzel County Well B....10

Table 4.1 Comparison between bentonite and attapulgite clays (Sharma \& Sangeeta, 1994).............14

Table 5.1 Quantitative analysis of the Wetzel County Well Sample 1B (No Alteration) calculated

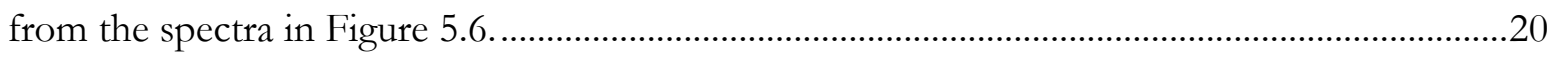

Table 6.1 Weight percent ranges for each element found in the Monongalia County Well A control

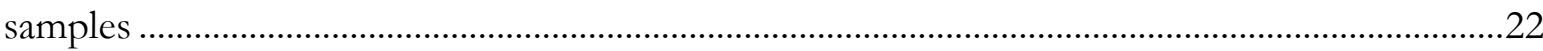

Table 6.2 Weight percent ranges for each element found in the Monongalia County Well A water

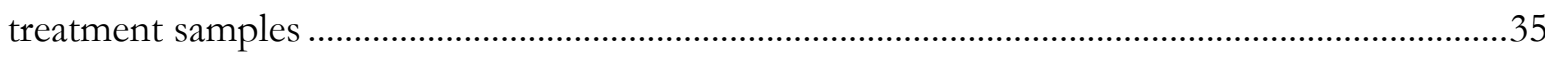

Table 6.3 Weight percent ranges for each element found in the Monongalia County Well A

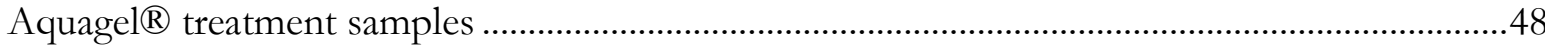

Table 6.4 Weight percent ranges for each element found in the Monongalia County Well A QuikGel® treatment samples

Table 6.5 Weight percent ranges for each element found in the Monongalia County Well A Zeogel® treatment samples .74

Table 6.6 Weight percent ranges for each element found in the Wetzel County Well B control samples

Table 6.7 Weight percent ranges for each element found in the Wetzel County Well B water

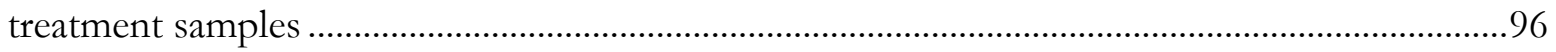

Table 6.8 Weight percent ranges for each element found in Wetzel County Well B Quik-Gel@ treatment samples

Table 6.9 Weight percent ranges for each element found in Wetzel County Well B Quik-Gel® treatment samples

Table 6.10 Weight percent ranges for each element found in Wetzel County Well B Zeogel® treatment samples 


\section{Dedication}

This thesis is dedicated to my parents, Joe and Price Naryka, for their continuous support, constant encouragement, and instilling the value of education. I also dedicate this work to my uncle, Bob Connor, for everything he has done for me during my graduate school career. Finally, I am thankful my grandparents, Dick and Virginia Connor, for leading me to the wonderful state of West Virginia. 


\section{Chapter 1 - Introduction}

The purpose of this project is to study the chemical interactions between the Marcellus shale and attapulgite and bentonite clays. Drilling fluid is used to aid in successfully drilling boreholes into the earth. Fluid is necessary in the wellbore as it provides hydrostatic pressure to control the well while drilling, suspend and remove the drilled material, cool and lubricate the drill bit and drilling assembly, transmit hydraulic energy to the tools and bit, and prevent formation damage.

Drilling fluids are made of a base fluid (water, diesel or oil, or a synthetic compound), weighting agents, viscosifers, and other additives for controlling the wellbore. Water based mud is the primary drilling fluid used for Marcellus shale. While these muds perform adequately, there are still problems associated with drilling fluids when water hydrates the shale. Hydration of the Marcellus shale can cause bit balling, formation caving, sloughing, and stuck pipe - all ultimately leading to lost revenue. Engineers have researched additional additives to reduce the amount of water entering the formation in hopes of minimizing some of these problems.

This project focuses on how the clays, which are predominantly used as viscosifers in the drilling fluid, chemically interact with the Marcellus shale. Simple water based muds were created using only water and bentonite and attapulgite clays in order to see how different elements interact within the samples. Including other additives to the clay suspension would inhibit determining how just these viscosifers are changing the composition of the shale.

Marcellus shale core samples for this project were generously donated from the West Virginia Geological and Economic Survey located in Morgantown, West Virginia. The samples were cored by the US Department of Energy in Wetzel County and Monongalia County, West Virginia. All testing for this project took place at the Benjamin M. Statler College of Engineering and Mineral Resources at West Virginia University. 


\section{Chapter 2 - Literature Review}

Many aspects and types of characterization have taken place on the unconventional reservoir referred to as the Marcellus shale. The geology and lithology have been extensively studied, and others have studied the mineral composition of the shale using various microscopic techniques. Because shale causes nearly $90 \%$ of wellbore stability problems, engineers continue to research all aspects of shale in order to develop new techniques to control the wellbore.

A study of additives for aquagel and bentonite based drilling fluids in relation to rheological properties and smectite inhibition has been completed on the Marcellus shale. Onuoha illustrated the properties associated with shale swelling and the dispersion of shale (Onuoha, 2011). Santarelli and Carminati have also investigated water and shale interactions. They found that many mineralogical transformations were occurring upon contact of shale and drilling fluids. These transformations were affecting the mechanical response of the rock. Their large amount of data contained too many contradictions in order to be used as a thorough basis for engineering (Santarelli \& Carminati, 1995).

Steiger and Leung, employees from Exxon Production Research Company, acquired quantitative shale strength data in order to determine the mechanical properties of shale. The goal of their experiments was to understand and define shale strength and behavior under typical downhole conditions. Their research concluded that low permeability shales follow the Terzaghi effectivestress principle, and the effective-stress/strain relationship can be assumed using direct pore pressure measurements (Steiger \& Leung, 1992).

Laboratory methods have been developed to assess shale reactivity with drilling fluid. Stephens, Gomez-Nava, and Churan described testing methods involving standard laboratory equipment. They also explained how the data acquired from the different methods could be used to asses the reactivity of the shale and design shale inhibitive drilling fluids. Others have also tried to characterize gas shales on the micro and nano scale. The Scanning Electron Microscope and the XRay Diffraction Microscope have been used to determine the mineral composition of the Marcellus Shale. These results have all been reported by mineral compounds, while this project looked at the individual elements that compose the Marcellus shale (Stephens, Gomez-Nave \& Churan, 2009). 
The geology of the Appalachian Basin has been researched extensively for various projects. In the late 1970s, the U.S. Department of Energy initiated the Eastern Gas Shales Project to evaluate the gas potential of the Devonian and Mississippian organic rich black shales within the Appalachian, Illinois, and Michigan basins. Cliff Minerals completed multiple detailed characterizations of Devonian Shale wells for this project. The information in the reports included stratigraphic and lithologic summaries, fracture analyses, and geophysical log interpretations. 


\section{Chapter 3 - Geology}

Marcellus shale is a black, organic rich shale that extends from the eastern Kentucky to New York. This shale underlies the majority of West Virginia and Pennsylvania, and it is present in a large part of Ohio. Small areas of the shale can also be found beneath the subsurface of Virginia and Maryland. Figure 3.1 shows the full extent of the Marcellus shale throughout the Allegheny Plateau region of the Appalachian Basin. Estimates of the amount of gas trapped within the pores of the Marcellus range from 50 to 500 trillion cubic feet (TCF). The United States currently uses nearly 21 TCF of gas annually. If a median value of 275 TCF is assumed for the estimated ultimate recovery, the Marcellus shale play could provide the United States with enough natural gas for over 13 years at the current rate of consumption.

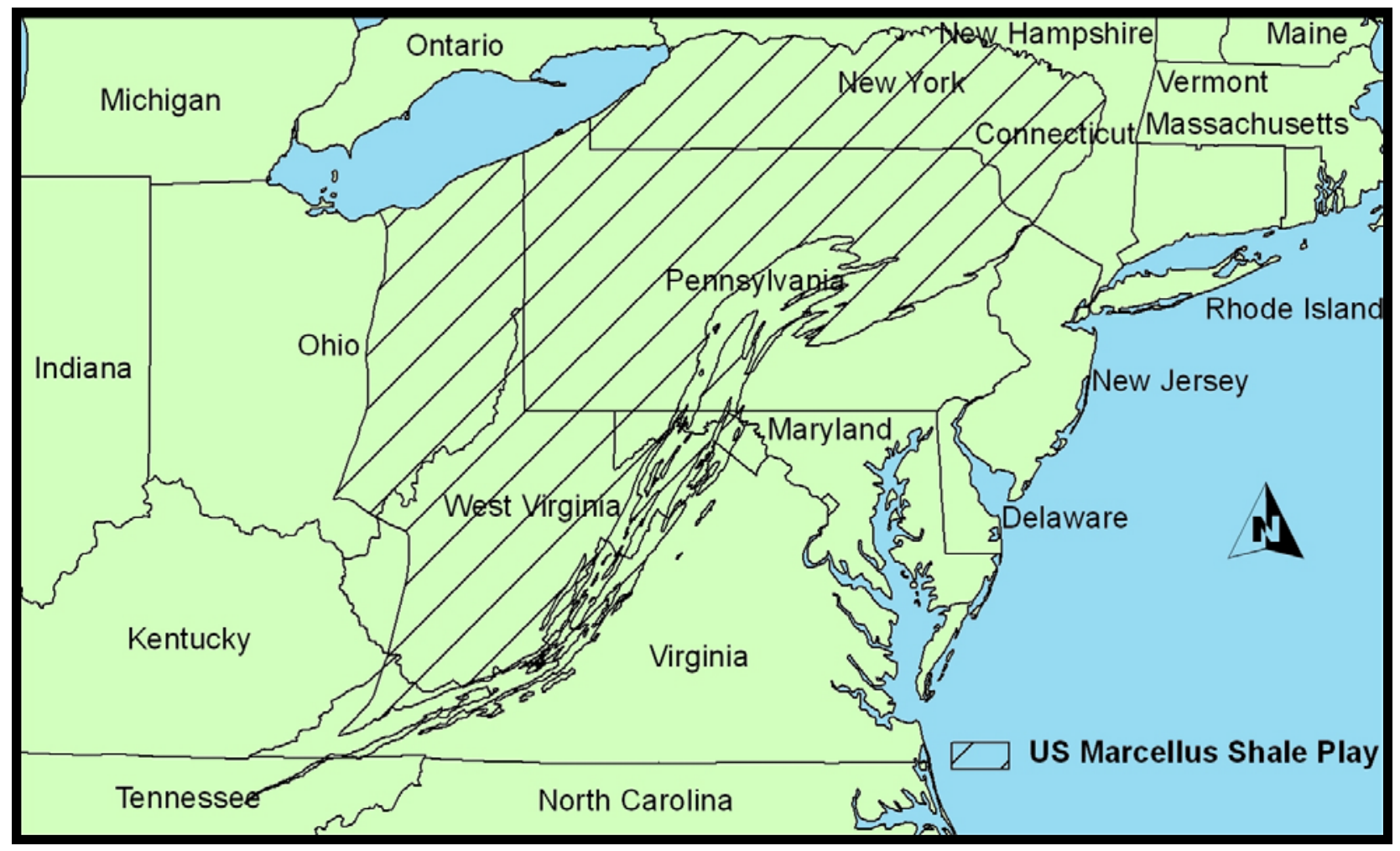

Figure 3.1 Marcellus shale is found throughout the Allegheny Plateau region of the northern Appalachian Basin of North America (Swarthmore College, 2012)

The depositional environment of the Marcellus shale is the direct cause of the formation's ability to produce natural gas. The Devonian aged shale formed in a marine environment nearly 400 million 
years ago. Organic-rich mud was deposited in an anoxic environment. Younger Devonian sediments eventually covered the mud, and after millions of years of heating and compaction, the black mud turned to shale. The stratigraphic nomenclature for the Middle Devonian System in the northern Appalachian Basin can be seen in Figure 3.2.

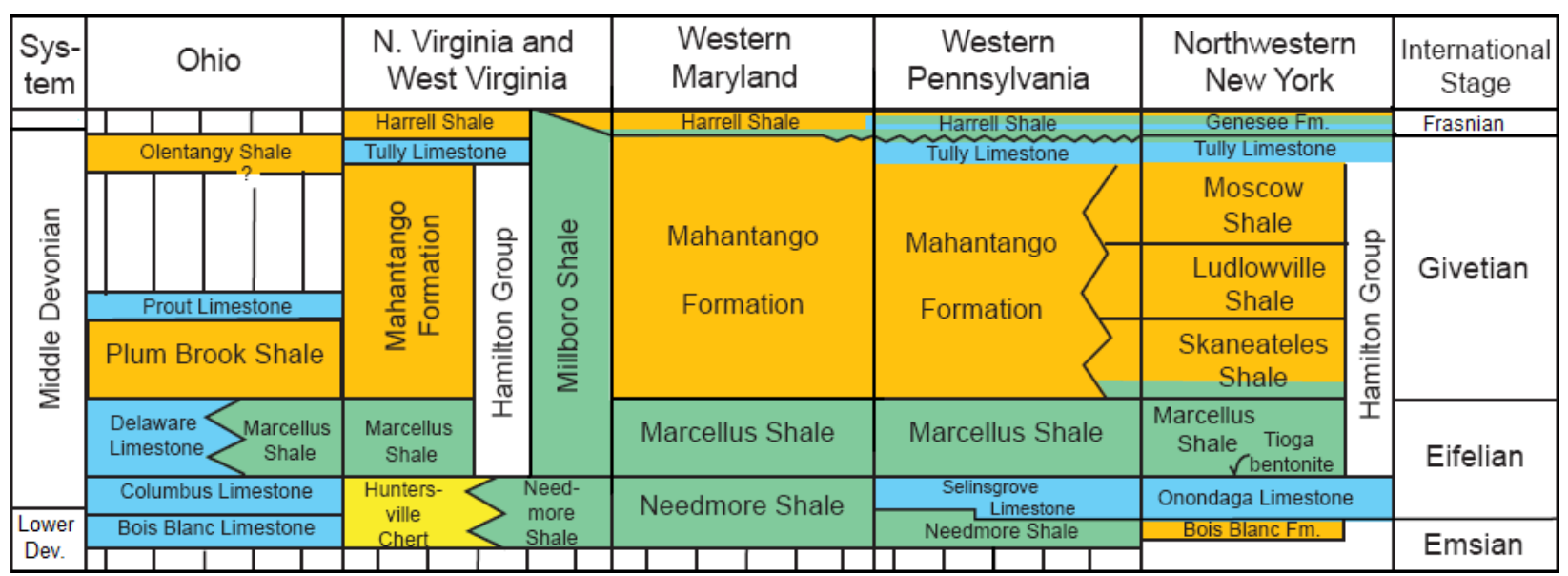

Figure 3.2 Stratigraphic nomenclature for the Middle Devonian System in the northern Appalachian Basin (Milici \& Swezey, 2006)

Marcellus shale varies in both depth and thickness throughout the Appalachian Basin. Outcrops of the shale are present in central Pennsylvania, yet along the Virginia border the shale can be as deep as 9000 feet. The average depth of the Marcellus shale is 5,300 feet in West Virginia, but core samples for this project came from West Virginia wells that exceeded this average depth by over 1000 feet. The Marcellus shale ranges in thickness from less than 10 feet to over 100 feet as seen in the subsurface isopach map below (Error! Reference source not found.). 


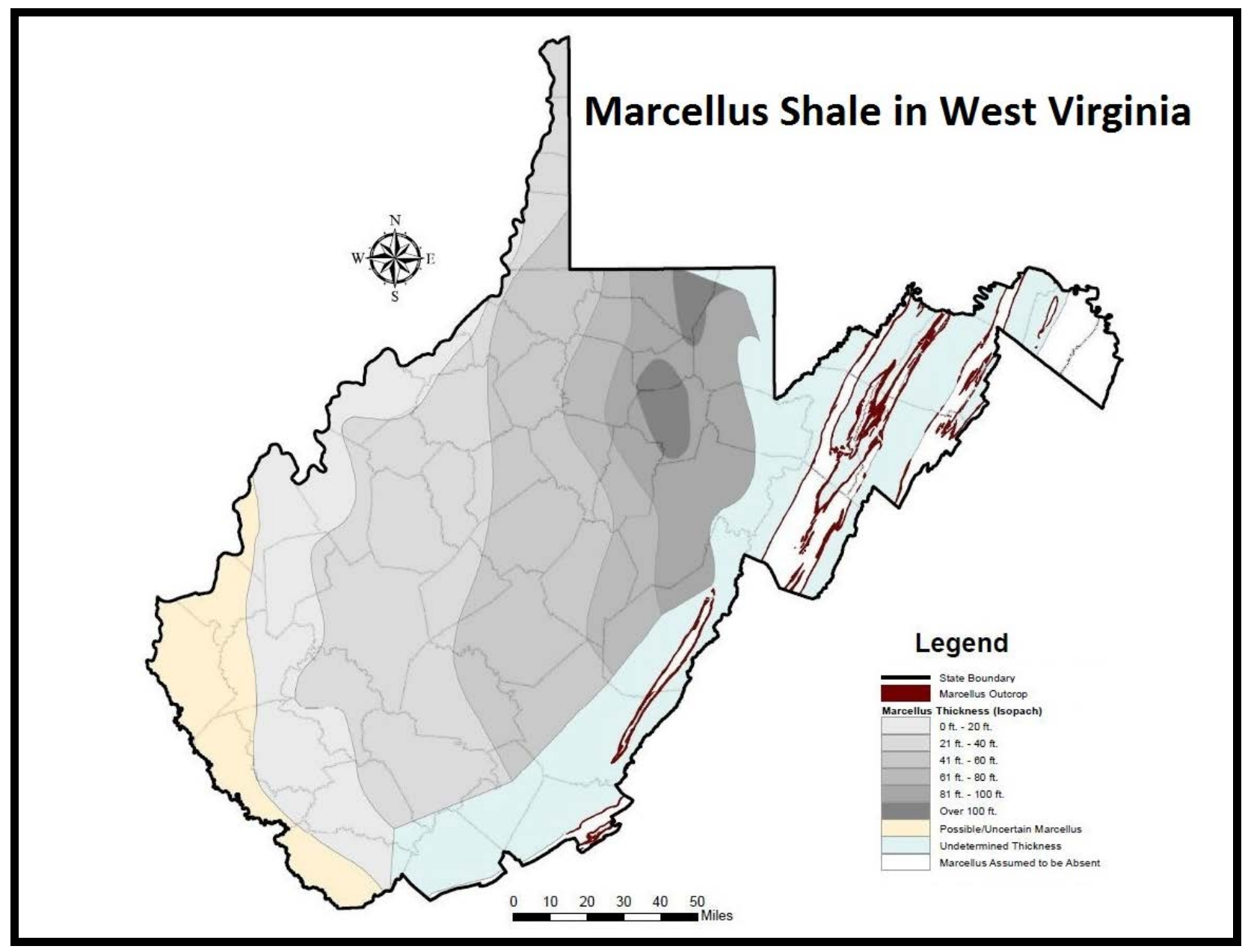

Figure 3.3 Subsurface isopach map of the Marcellus shale in West Virginia

The core samples provided by the West Virginia Geological and Economic Survey are from two wells in north central West Virginia as seen in Error! Reference source not found.. The samples are from a well in Monongalia County and a well in Wetzel County. Throughout the paper, the wells are referred to as Monongalia County Well A and Wetzel County Well B respectively. 


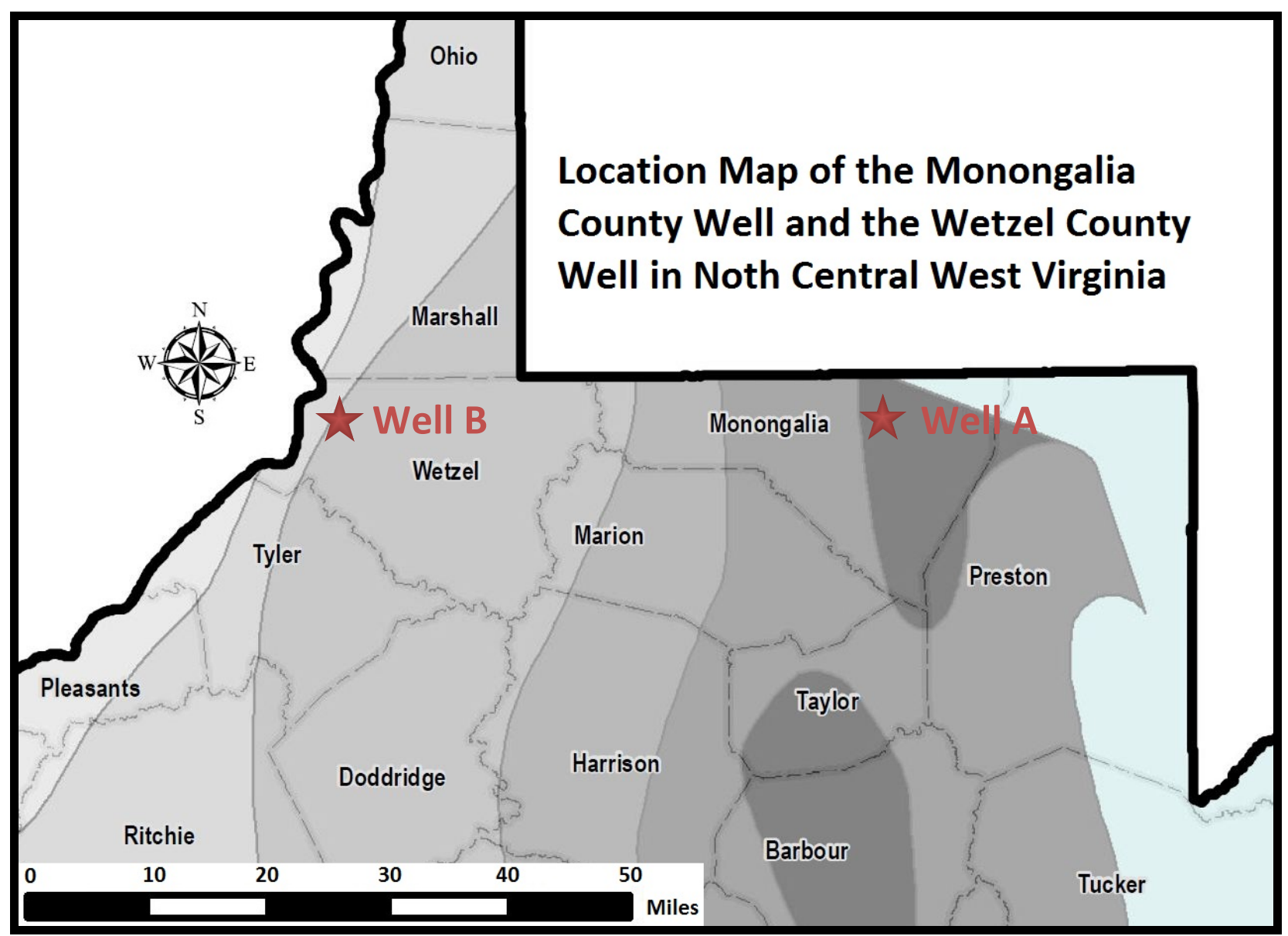

Figure 3.4 Location map of the two wells used for this study (Monongalia County Well A and the Wetzel County Well B are indicated by red stars)

Monongalia Well $A$ and Wetrel Well B were characterized by Cliff Minerals, Inc. for the Eastern Gas Shale Project. The data in the following two sections came from the Phase III reports for each well.

\section{Monongalia County Well A Geology}

The Marcellus Shale formation is 7,396 feet to 7,500 feet below the surface in Well A. The shale provided by the West Virginia Geological and Economic Survey included samples from 7,409 feet to 7,487 feet. The core samples provided were in nine individual containers divided into the intervals listed in Table 3.1. The shale samples were described as thinly laminated, shaly mudstone.

Calcareous zones were present in the lower half of the core, and they increased in thickness and frequency with depth. Articulate and inarticulate brachiopods existed between 7,400 feet and 7,425 feet and below 7,460 feet. An ostracod valve was discovered at 7,424 feet, a single fish scale at 7,445 feet, and cephalod casts from 7,424 feet to the end of the formations. The presence of marine 
fossils further confirmed the Marcellus shale's depositional environment. Calcareous concretions occured between 7,410 feet and 7,470 feet. Pyrite was located in the uppermost 20 feet and below 7,450 feet. The contact between the Marcellus shale and the underlying Onondaga limestone was easily identified on the geophysical log due to the decrease in gamma radiation as seen in Figure 3.5.

\begin{tabular}{l|l}
\hline \multicolumn{2}{c}{ Monongalia County Well } \\
\hline Depth Interval & Designation \\
\hline $7409-7412$ & $1 \mathrm{~A}$ \\
$7424-7427$ & $2 \mathrm{~A}$ \\
$7434-7442$ & $3 \mathrm{~A}$ \\
$7442-7445$ & $4 \mathrm{~A}$ \\
$7454-7457$ & $5 \mathrm{~A}$ \\
$7469-7472$ & $6 \mathrm{~A}$ \\
$7472-7475$ & $7 \mathrm{~A}$ \\
$7481-7484$ & $8 \mathrm{~A}$ \\
$7484-7487$ & $9 \mathrm{~A}$ \\
\hline
\end{tabular}

Table 3.1 Depth intervals and the corresponding designation for the Monongalia County Well A 


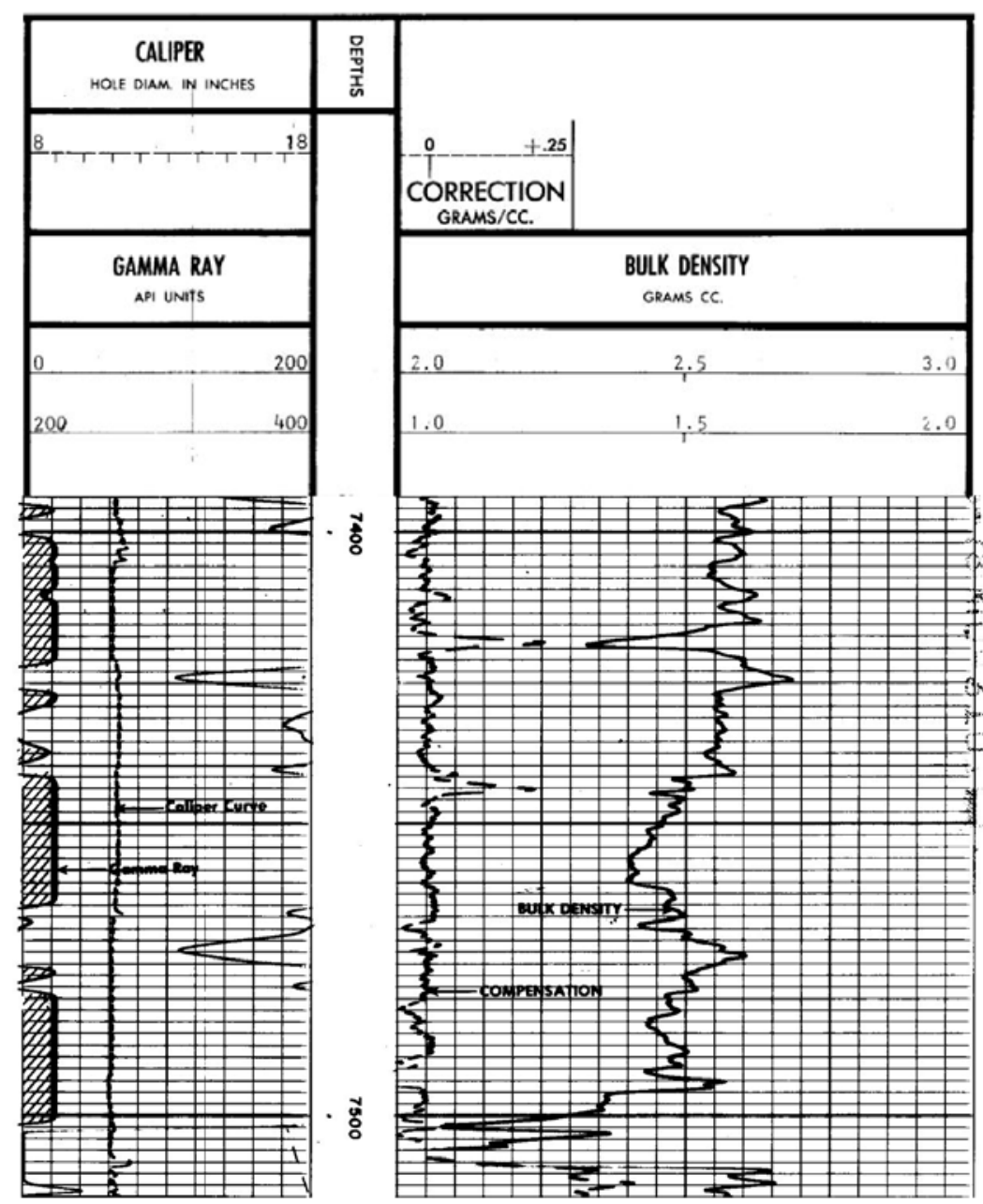

Figure 3.5 Marcellus shale section of the geophysical log for Monongalia County Well A (Cliff Minerals, Inc., 1981)

\section{Wetzel County Well B Geology}

Marcellus shale occured from 6,568 feet to 6,625 feet in the core retrieved from Well B. The core samples provided were in five individual containers divided into the intervals listed in Table 3.2. The samples provided from the West Virginia Geological and Economic Survey included 16 feet of the Mahantango shale according to Cliff Minerals, Inc. Phase III Report for this particular well. Mahantango shale overlaid the Marcellus shale, but the Marcellus shale was distinguishable by its increased disc fracture frequency, darker color, and lower carbonate content. It was difficult to observe the mentioned physical differences in the provided samples, therefore testing was performed on all samples in the event there was difficulty distinguishing the different formations once the core was extracted. 
Marcellus shale from Well B was a black shaly mudstone, containing several zones of silty mudstone and calcareous mudstone in the lower 20 feet of the formation. The shaly mudstone was extremely fissile and separated into small disc shapes resembling poker chips. Articulate and inarticulate brachiopods were noted throughout the core as well as pyrite nodules and grains. Similarly to Well A, the contact between the Marcellus shale and the underlying Onondaga limestone was identifiable on the geophysical log by the sudden decrease in gamma radiation and a corresponding increase in rock density as seen in Figure 3.6.

\begin{tabular}{l|l}
\hline \multicolumn{2}{c}{ Wetzel County Well } \\
\hline Depth Interval & Designation \\
\hline $6552-6556$ & $1 \mathrm{~B}$ \\
$6558-6561$ & $2 \mathrm{~B}$ \\
$6564-6567$ & $3 \mathrm{~B}$ \\
$6567-6570$ & $4 \mathrm{~B}$ \\
$6570-6573$ & $5 \mathrm{~B}$ \\
\hline
\end{tabular}

Table 3.2 Depth intervals and the corresponding designation for the Wetzel County Well B 


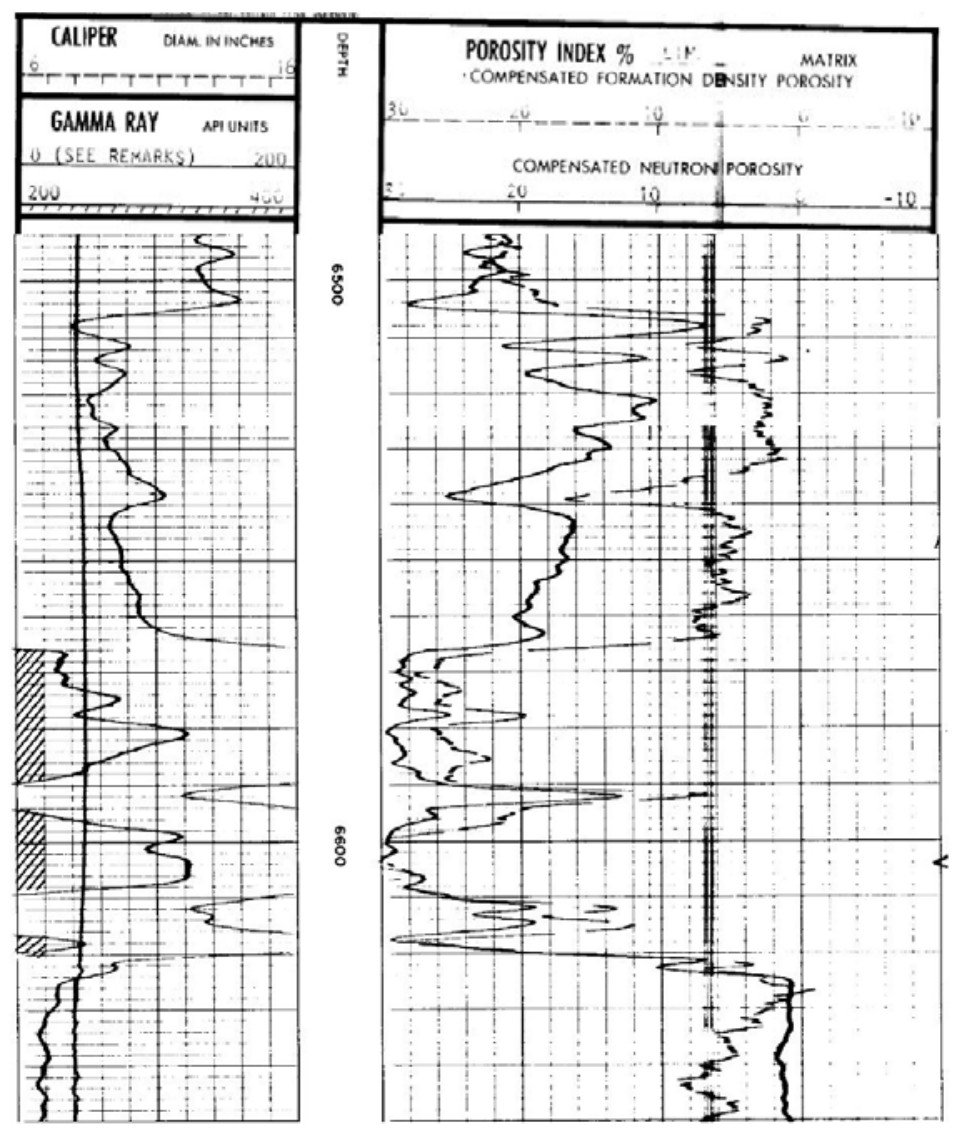

Figure 3.6 Marcellus shale section of the geophysical log for Wetzel County Well B (Cliff Minerals, Inc., 1981) 


\section{Chapter 4 - Water Based Muds}

The earliest water based mud (WBM) was simply composed of clay and a weighting agent (Neff, 2005). The performance of these early WBMs was not optimal under some down-hole conditions; therefore additional chemicals were added to the formula to improve the performance (Neff, 2005). For this experiment simple two ingredient WBMs were used. This project focuses on how different clays alter the chemical composition of the Marcellus shale, so adding additional chemicals would alter the desired results.

Typically the most abundant ingredients in WBMs are water, barite weighting material, salts, and bentonite clay or attapulgite clay. (Neff, 2005). While drilling is occurring the drilling mud is free flowing; however, once drilling has ceased, the fluid forms a gel-like substance. These clays are added to drilling mud to act as a viscosifier. They uphold the gel strength required to suspend the drill cuttings and bring them to the surface. Additionally, these additives in the drilling fluid help stabilize the borehole wall, lubricate and cool the drilling equipment, and enhance the rate of penetration. Components of WBMs are divided into 18 functional categories listed below (World Oil, 1999):

- Alkalinity, pH control additives

- Calcium reducers

- Defoamers

- Filtrate reducer

- Foaming agents

- Lubricants

- Shale control inhibitors

- Temperature stability agents

- Viscosifiers
- Bactericides

- Corrosion inhibitors

- Emulsifiers

- Flocculants

- Lost circulation materials

- Pipe-freeing agents

- Surface-active agents

- Thinners, dispersants

- Weighting materials

For this project two bentonite clays (Aquagel® and Quik-Gel®) and one attapulgite clay (Zeogel@) were mixed with water to create simple WBMs. Major differences between the bentonite and attapulgite clays can be see in Table 4.1. 


\section{Bentonite Clay}

Bentonite is a naturally occurring clay mineral primarily composed of montmorillonite. In addition to the montmorillionte, bentonite also typically contains a small portion of quartz, feldspar, volcanic ash, organic matter, gypsum, or pyrite (Clem \& Doehler, 1961). Bentonite it typically strip-mined, and it is currently mined throughout the world. The United States produces bentonite in Wyoming and South Dakota ("western” bentonites) from sodium bentonite deposits, and in Mississippi and Alabama ("southern" bentoites) from calcium bentonite deposits (Sorptive Minerals Institute, 2007). Both Baroid's Aquagel ${ }^{\circledR}$ and Quik-Gel ${ }^{\circledR}$ are premuium-grade Wyoming sodium bentonite. Sodium bentonite has a greater increase in volume in an aqueous suspension compared to calcium bentonite (Clem \& Doehler, 1961).

Bentonite is extremely well known in the drilling industry due to its swelling and adhesive properties. The unique structure of montmorilliontie allows the mineral to adsorb large amounts of water and other liquids whenever available. An aluminum octahedral sheet is layered between two silica tetrahedral sheets creating plate-like structures (Clem \& Doehler, 1961). Liquid hydrates onto the layers of the interaction site, and the mineral can swell up to 10 times its weight in liquid (Sorptive Minerals Institute, 2007).

\section{Attapulgite Clay}

Attapulgite is a clay mineral that is popular in the drilling industry due to its unique particle shape and size. The mineral is primarily produced in Georgia and Florida in the United States. Attapulgite is an attractive drilling fluid additive due to its ability to yield viscosity in the presence of containments such as salt and organics. Bentonite, on the other hand, requires chemical treatments in areas where salt, calcium sulfate, or magnesium sulfate are encountered (Haden Jr., 1961). Attapulgite is only slightly affected by electrolytes, therefore the mineral disperses well and displays excellent thickening, suspending, and gelling properties (Sorptive Minerals Institute, 2007).

The crystal structures of attapulgite resemble bunches of needles rather than the plate-like structure

of bentonite (Sharma \& Sangeeta, 1994). Long double chains of silica tetrahedral run parallel to the fiber axis, and these layers are connected by magnesium and aluminum in an octahedral formation (Haden Jr., 1961). The ribbon like layers are then connected at the corners to give attapulgite a three dimensional structure with voids that can be filled with liquids (Sharma \& Sangeeta, 1994). 
The table below lists compares the chemical and physical properties of bentonite and attpulgite clays.

\begin{tabular}{l|ll}
\hline Property & Bentonite & Attapulgus Clay \\
\hline Principal Mineral & Montmorillonite & Attapulgite \\
Crystal Structure & Three-layer Sheet & Chain \\
Particle Shape & Flake & Needle \\
Surface Area & Medium & High \\
Swell Potential & High & Low \\
Cation-exchange Potential & High & Low \\
Effects of Electrolytes & Flocculates & Slight \\
Sorptivity & Medium & High \\
\hline
\end{tabular}

Table 4.1 Comparison between bentonite and attapulgite clays (Sharma \& Sangeeta, 1994) 


\section{Chapter 5 - Experimental Procedure}

\section{Sample Alterations}

In order to determine the effect of drilling fluid clay additives on the mineral composition of two West Virginia Marcellus shale well samples, five different experiments were conducted on each of the wells. Each set of samples from the Monongalia County well included nine specimens, and each set of samples from the Wetzel County well included five specimens. Therefore a total of 14 specimens were used for each of the five tests. The first test simply involved taking the samples just as they were provided from the West Virginia Geological Survey and collecting the mineral composition data using a Scanning Electron Microscope (SEM). A small flake was taken from each specimen container at a different footage interval and prepared for analysis in the SEM. These two sets of samples are referred to as "No Alteration" throughout this paper, and they served as a control for the other four remaining experiments.

The later four tests involved actually altering the chemical composition of the Marcellus shale samples. The second set of samples underwent a water soaking treatment. The purpose of this test was to see how water chemically alters the specimens. All water based muds have a large volume of water, therefore if water is altering the shale specimens without the clay additives then it will also alter the samples when mixed with the clay to form a water based mud. Distilled water was used for this experiment in order to maintain the integrity of the results. Each of the 14 samples were underwent the soaking treatment for two hours, and then dried for at least 48 hours prior to prepping for the SEM.

The remaining three sets of specimens underwent a water based mud treatment. Three WBMs were created using Aquagel ${ }^{\circledR}$ Viscosifier, Quik-Gel ${ }^{\circledR}$ Viscosifier, and Zeogel ${ }^{\circledR}$ Viscosifier. The density of each WBM was measured to be $8.7 \mathrm{ppg}$. All the samples soaked overnight in order to allow ample time for the samples to soak in the fluid. The samples then dried for a minimum of 48 hours prior to preparation for observation in the SEM. 


\section{Chemical Composition Analysis}

An SEM was used to analyze the core samples from the two West Virginia Marcellus shale wells. The SEM microscope and the sputter station that wasused to prepare the samples for observation both belonged to West Virginia University's (WVU) Shared Research Facilities. The SEM allows users to observe individual sample structures at a nanometer scale resolution. Pictures were taken of each sample at different magnifications to show surface texture, presence of imbedded minerals, and thw size and shape of existing pores. An INCA X-Ray Microanalysis System (EDX) provided a quantitative chemical composition analysis.

Each sample was prepped following the same procedure. A dry flake of shale was mounted onto a strip of copper tape and placed on a piece of a silicon wafer. In order to be able to properly analyze the shale samples in the SEM, the flakes must be covered in a film of conductive metal. The conductive material allows a way for electrons to escape and reduce the amount of charging when placed directly under an electron beam. Figure 5.1 and Figure 5.2 show photographs of the Marcellus shale samples both before and after sputtering. The forceps in the figures are provided for scale. For this study both platinum and gold were used to provide the thin coat of metal depending on the availability of materials. The silicon wafers were attached with carbon tape to a steel sample holder and then sputtered using a CVC 610 Sputter Station. WVU's Sputter station can be seen in Figure 5.3.

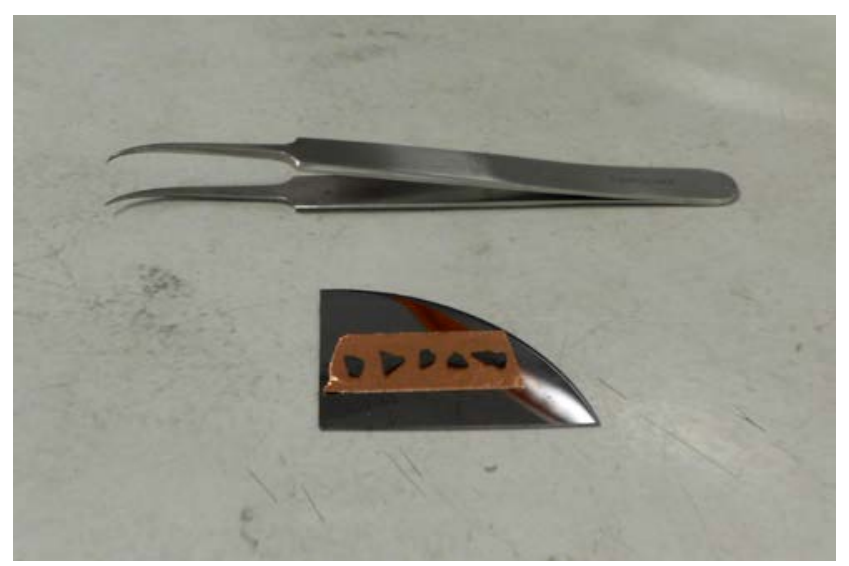

Figure 5.1 Marcellus shale samples prior to sputtering 


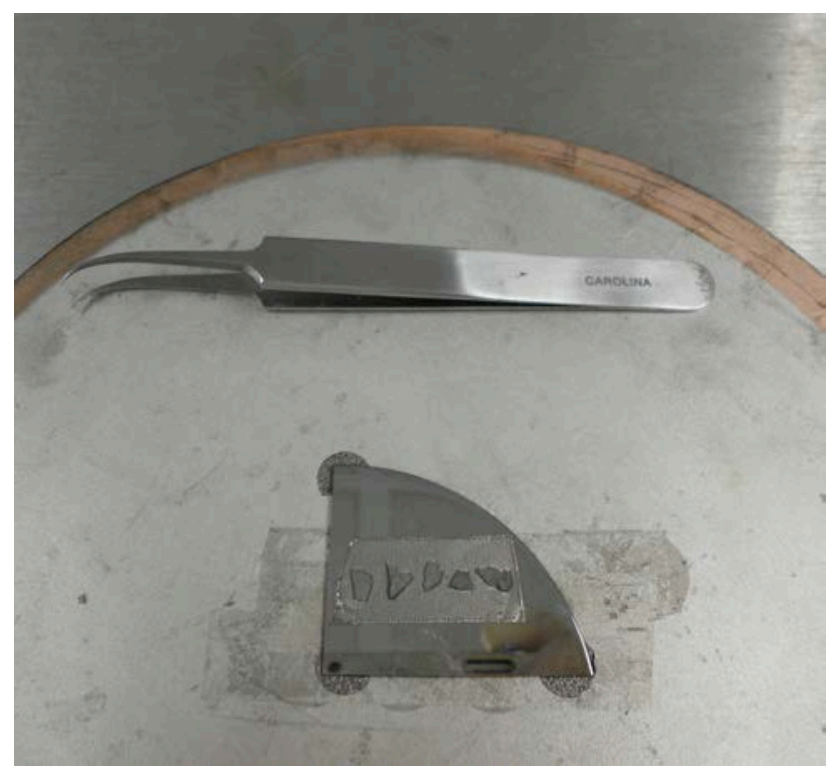

Figure 5.2 Marcellus shale samples after being sputtered with platinum

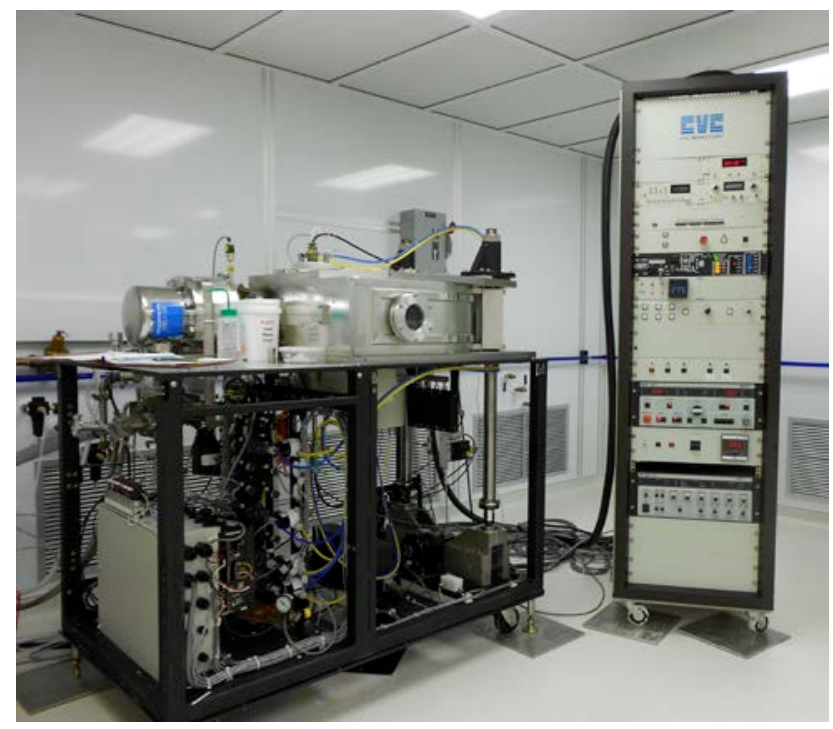

Figure 5.3 WVU's Shared Research Facility's Sputtering Station

Once the samples had been properly sputtered, they were then ready to be prepared for analysis in the SEM. The silicon wafer containing the sputtered samples was mounted onto a sample holder using carbon tape. The distance from the top of the specimen holder to the surface of the specimen must be recorded in order to determine a proper stage height for the selected working distance. For every set of samples studied the offset ranged from $2.8 \mathrm{~mm}$ to $3.0 \mathrm{~mm}$. A $20.0 \mathrm{kV}$ accelerating voltage was used for all the shale samples. A high accelerating voltage of the electron beam allows 
for greater resolution. Figure 5.4 and Figure 5.5 are photographs of the JEOL JSM 7600F Scanning Electron Microscope used during this study.

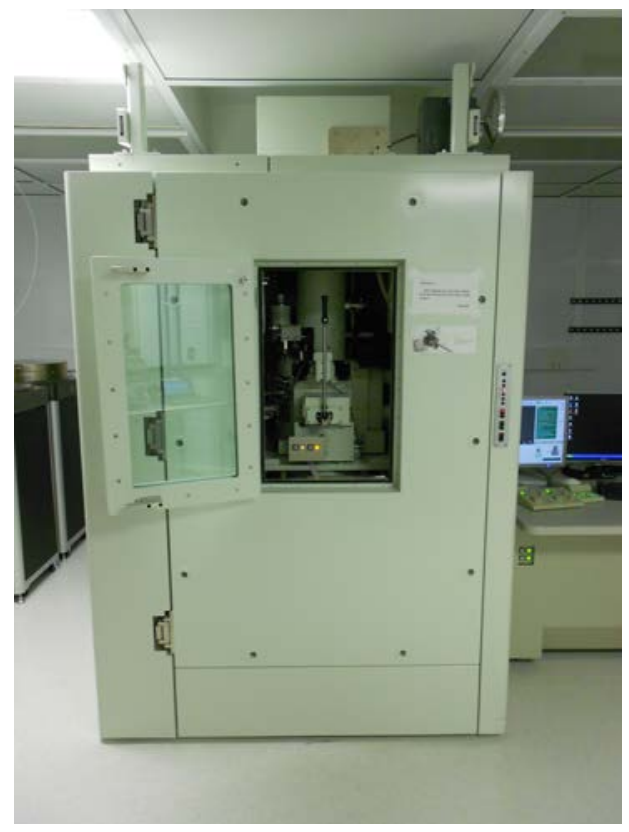

Figure 5.4 WVU' Shared Research Facility's JEOL JSM 7600F Scanning Electron Microscope

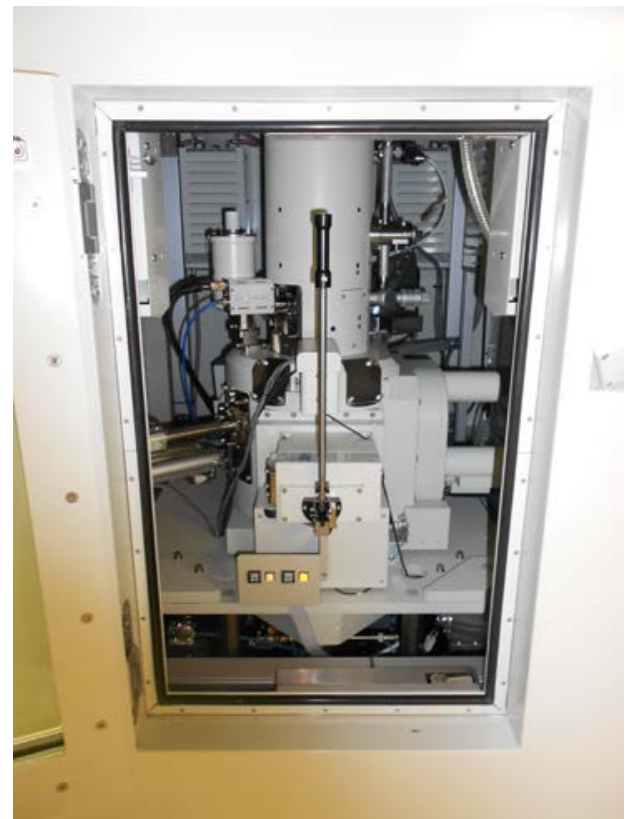

Figure 5.5 A closer view of the JEOL JSM 7600F Scanning Electron Microscope

Photographs were taken of every sample at a magnification of 800X and 5000X. Viewing the sample at 800X provided and excellent image of a larger surface area, and by zooming in at 5000X it 
was possible to examine the pore structures and unique layering of the shale. If an imbedded mineral was observed, a photograph was taken at an even higher magnification to view more detail in the composition.

After each sample had been photographed, a quantitative material composition analysis was completed on the INCA X-Ray Microanalysis System. EDX works in conjunction with the SEM to measure the amount of energy present in X-rays being released from the sample while the sample is focused under the electron beam. An analytical working distance of $15 \mathrm{~mm}$ is required for this particular machine.

After the photograph is taken of the individual sample at 800X, the EDX spectrum was collected from shale specimen. The spectrum acquisition time was set to 120 seconds and the spectrum range was set to $0-20 \mathrm{keV}$ for each specimen. Figure 5.6 is an example of the spectrum the INCA software output for the control sample from the first depth interval of Wetzel County Well B. This spectrum was created simultaneously as the data was been collected during the 120 second acquisition time. Table 5.1 is the quantitative results provided from the INCA software for this same sample.

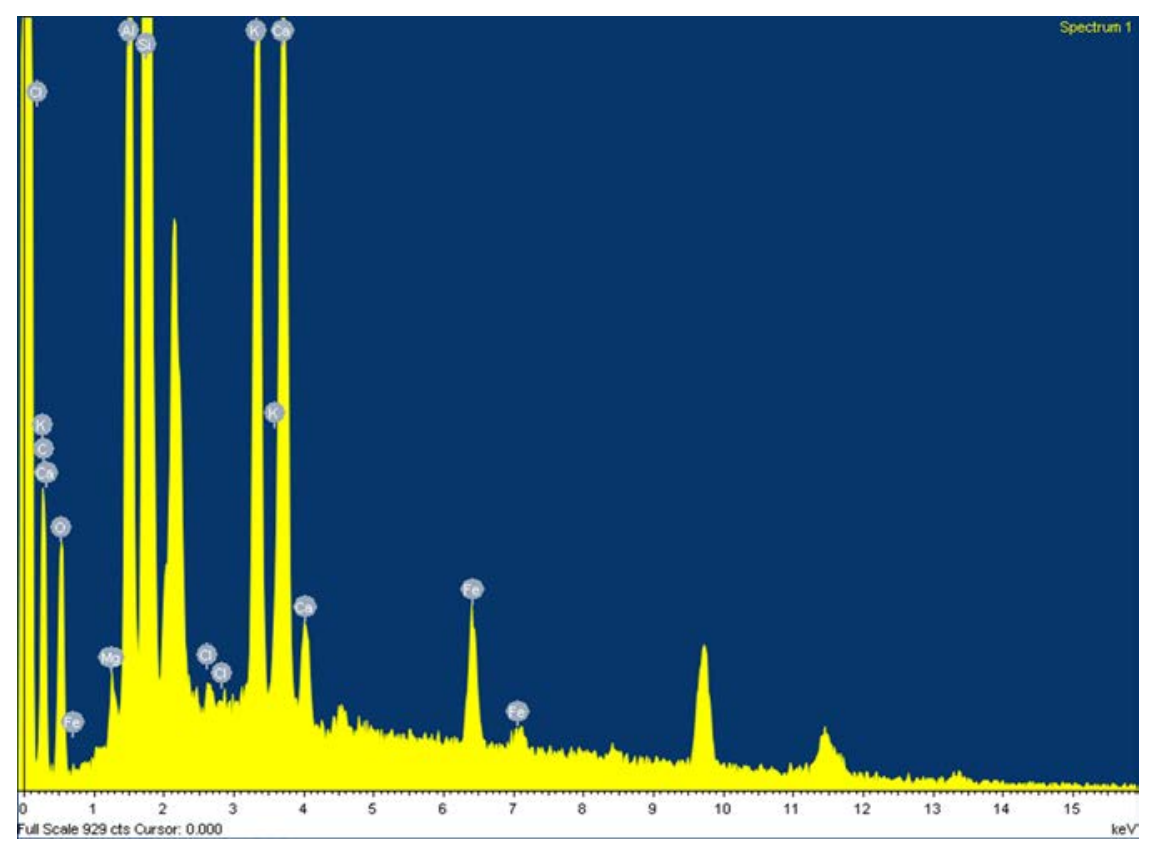

Figure 5.6 Wetzel County Well Sample 1B (No Alteration) X-ray spectrum 


\begin{tabular}{l|lllll}
\hline Element & App & Intensity & Weight\% & Weight\% & Atomic\% \\
& Conc. & Corn. & & Sigma & \\
C K & 114.58 & 0.2998 & 30.96 & 2.10 & 48.88 \\
O K & 73.71 & 0.3438 & 17.37 & 0.83 & 20.59 \\
Mg K & 3.80 & 0.7741 & 0.40 & 0.06 & 0.31 \\
Al K & 76.20 & 0.8826 & 6.99 & 0.25 & 4.92 \\
Si K & 250.55 & 0.8587 & 23.63 & 0.76 & 15.96 \\
Cl K & 3.00 & 0.7130 & 0.34 & 0.08 & 0.18 \\
K K & 93.90 & 1.0016 & 7.59 & 0.27 & 3.68 \\
Ca K & 98.98 & 0.9163 & 8.75 & 0.31 & 4.14 \\
Fe K & 39.66 & 0.8108 & 3.96 & 0.22 & 1.35 \\
\hline & & & 100.00 & & \\
\hline
\end{tabular}

Table 5.1 Quantitative analysis of the Wetzel County Well Sample 1B (No Alteration) calculated from the spectra in Figure 5.6 


\section{Chapter 6 - Discussion of Results}

\section{General Discussion}

There is extreme variability among sedimentary rocks in chemical composition, mineral crystalinity, and the effects of diagenesis. Most black shales contain 1\% or more organic carbon; between $2 \%$ and $10 \%$ is a common range; and some contain over $20 \%$ organic carbon (Tourtelot, 1979). The presence of some elements directly relates to other occurring elements in black shales. For example, silicon and aluminum are related to the abundance of detrital materials (Tourtelot $\&$ Vine, 1976). Shale has a very complex chemical composition, and this can be attributed to the depositional mixing that occurred during formation.

Variability of the samples was obvious after SEM analysis concluded. While trends were identified between the presence (or lack of presence in some cases) of certain elements, it was difficult to make a definite assumption as to what causes the elemental changes. Differences in composition can occur within every millimeter of lithology within the Marcellus shale. The black shale was interbedded with limestone layers and thin laminations of other minerals such as calcite, iron, and quartz. It was noted in some of the photographs taken on the SEM that certain minerals coalesced to form deposits. Regional variations of the Marcellus shale could also be responsible for the different trends found in Monongalia County Well A samples versus those found in Wetzel County Well B. Additionally, part of the specimen could be left behind in the solution after undergoing the alteration test. When compounds formed in distilled water and clay suspensions, they remove elements from the shale specimens. The shale specimens also removed elements from the distilled water and clay suspensions, causing alterations in the elemental composition. 


\section{Monongalia County Well Sample Analysis By Alteration}

\section{Monongalia County Well A No Alteration}

A set of samples from every depth interval was taken from Monongalia County Well A to be used as control samples. These samples did not undergo any alteration. The elemental composition was evaluated using EDX, and the ranges in weight percent for each element found in the control samples are listed in Table 6.1.

Monongalia County Well A

(No Alteration)

\begin{tabular}{|c|c|c|c|}
\hline Element & Weight\% & Sample & Range \\
\hline \multirow{2}{*}{ Al } & 0.48 & $2 \mathrm{~A}$ & \multirow{2}{*}{11.67} \\
\hline & 12.15 & $9 \mathrm{~A}$ & \\
\hline \multirow{2}{*}{ C } & 7.48 & $2 A$ & \multirow{2}{*}{22.35} \\
\hline & 29.83 & $1 \mathrm{~A}$ & \\
\hline \multirow{2}{*}{$\mathrm{Ca}$} & 0.62 & $6 \mathrm{~A}$ & \multirow{2}{*}{16.22} \\
\hline & 16.84 & $2 A$ & \\
\hline \multirow{2}{*}{$\mathrm{Fe}$} & 1.01 & $4 \mathrm{~A}$ & \multirow{2}{*}{28.62} \\
\hline & 29.63 & $3 \mathrm{~A}$ & \\
\hline \multirow{2}{*}{ K } & 2.03 & $4 \mathrm{~A}$ & \multirow{2}{*}{9.44} \\
\hline & 11.47 & $9 \mathrm{~A}$ & \\
\hline \multirow{2}{*}{$\mathrm{Mg}$} & 0.53 & $7 \mathrm{~A}$ & \multirow{2}{*}{0.39} \\
\hline & 0.92 & $6 \mathrm{~A}$ & \\
\hline \multirow{2}{*}{0} & 11.61 & $9 A$ & \multirow{2}{*}{49.49} \\
\hline & 61.10 & $2 \mathrm{~A}$ & \\
\hline \multirow{2}{*}{$S$} & 12.70 & $2 A$ & \multirow{2}{*}{1.23} \\
\hline & 13.93 & $3 \mathrm{~A}$ & \\
\hline \multirow{2}{*}{ Si } & 1.39 & $2 A$ & \multirow{2}{*}{68.54} \\
\hline & 69.93 & $5 A$ & \\
\hline $\mathrm{Ti}$ & 6.39 & $1 \mathrm{~A}$ & 6.39 \\
\hline
\end{tabular}

Table 6.1 Weight percent ranges for each element found in the Monongalia County Well A control samples

Every element found in the control samples was plotted against the corresponding depth in Figure 6.1. After evaluating these composition charts, it was obvious certain elemental trends occurred within the well. The elements with similar trends were overlain with a red circle and designated by 
different outline patterns. Aluminum and potassium followed a very similar trend. The line indicating the weight percent of these elements was created on the same scale, and they both increased and decreased with weight percent at corresponding depths. Similarly, carbon and magnesium followed a parallel trend line. While the elements were plotted on different scales due to the magnitude of carbon present, the shape of the entire line was extremely similar. Finally, calcium, iron, and sulfur produced comparable curves. The weight percent dramatically increased in shallower depths and remained close to zero until the last depth interval where calcium and iron increased again.

Photographs of the control samples taken using the SEM are seen below in Figure 6.2 through Figure 6.19. Each image was taken at a magnification of $800 \mathrm{X}$ and 5000X. While the EDX produced results showing a variation in elemental composition with depth, the photographs remained consistent. Simply, the results of varying elemental composition was difficult to see with the human eye. SEM images showed a layered clay morphology. Countless layers and flakes were seen in these images, and they all appeared to be easily separated. Numerous small pores, where oil and gas can be stored, were visible in the images. The gray color scale of the images also remained constant. While the EDX results indicate there is a larger percentage of organic content at depths 4A and $8 \mathrm{~A}$, the images did not appear to be darker at these corresponding depths. 


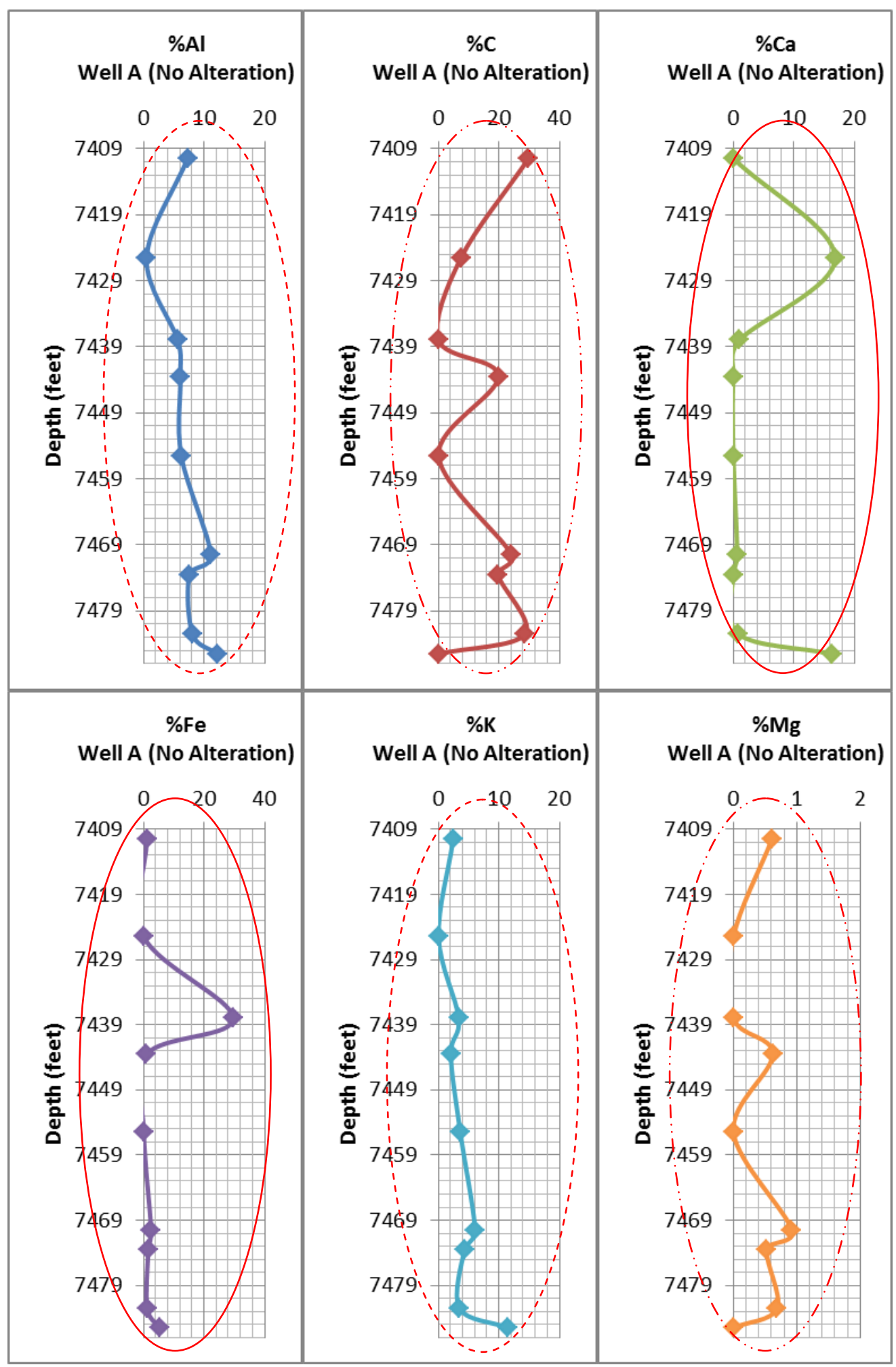




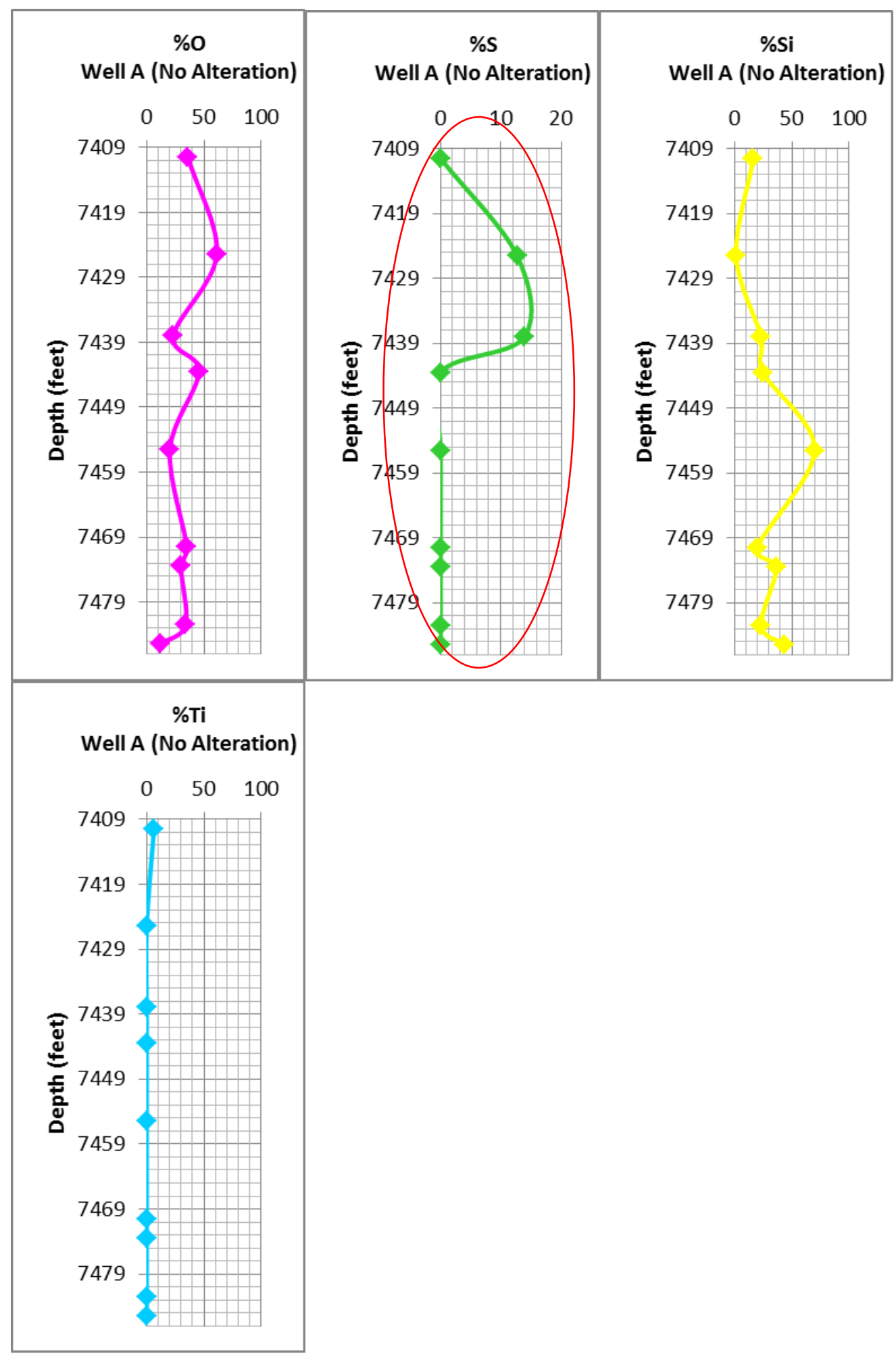

Figure 6.1 Weight percent of each element found in Monongalia County Well A control samples plotted against the corresponding depth 
Monongalia County Well A No Alteration SEM Photographs

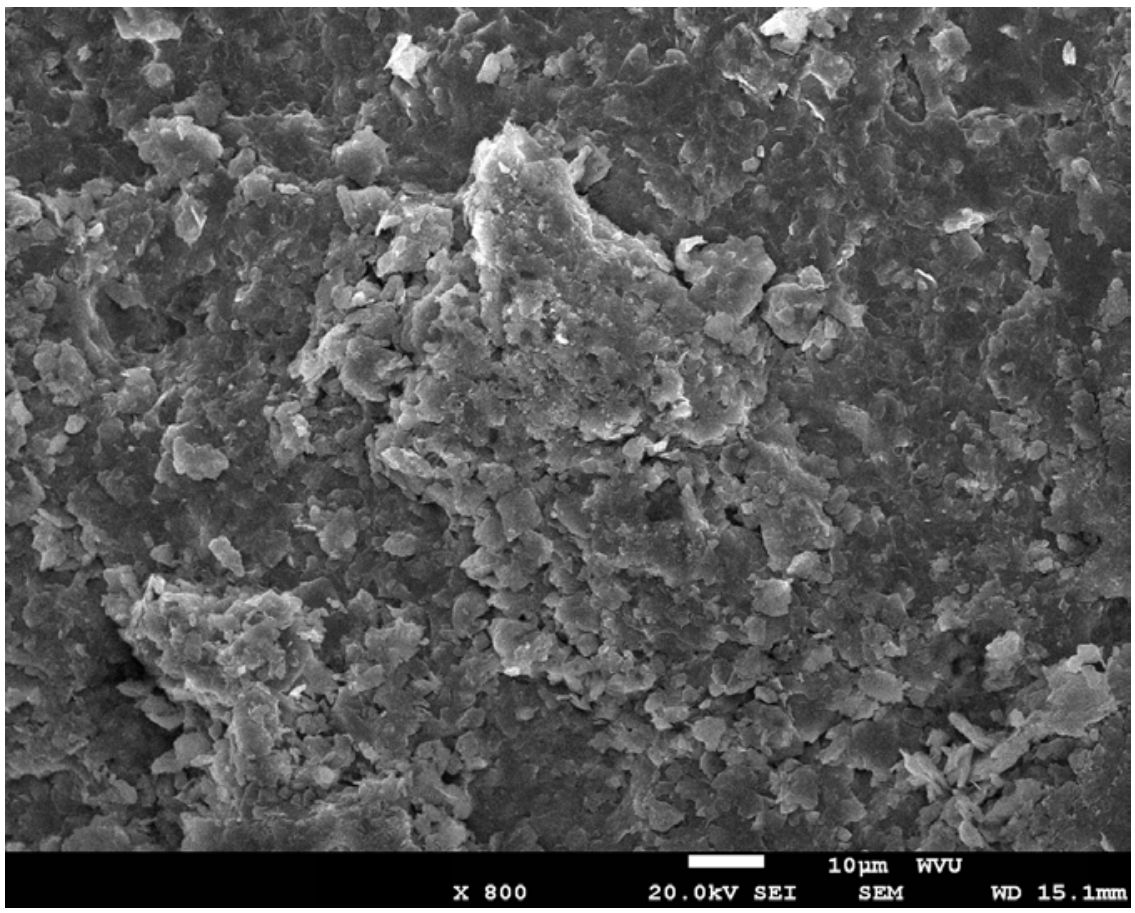

Figure 6.2 SEM image of the control specimen for the first depth interval of Well $\mathrm{A}$ at $800 \mathrm{X}$

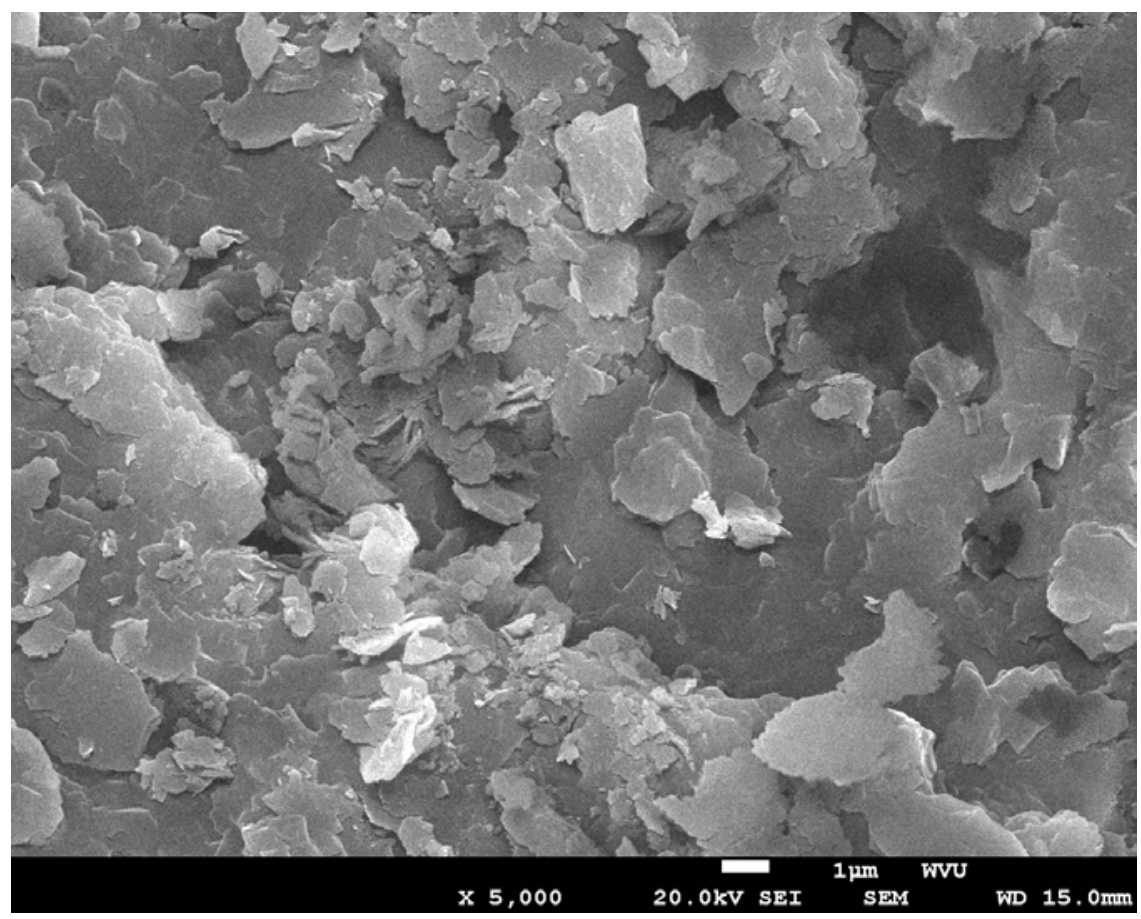

Figure 6.3 SEM image of the control specimen for the first depth interval of Well $A$ at $5000 X$ 


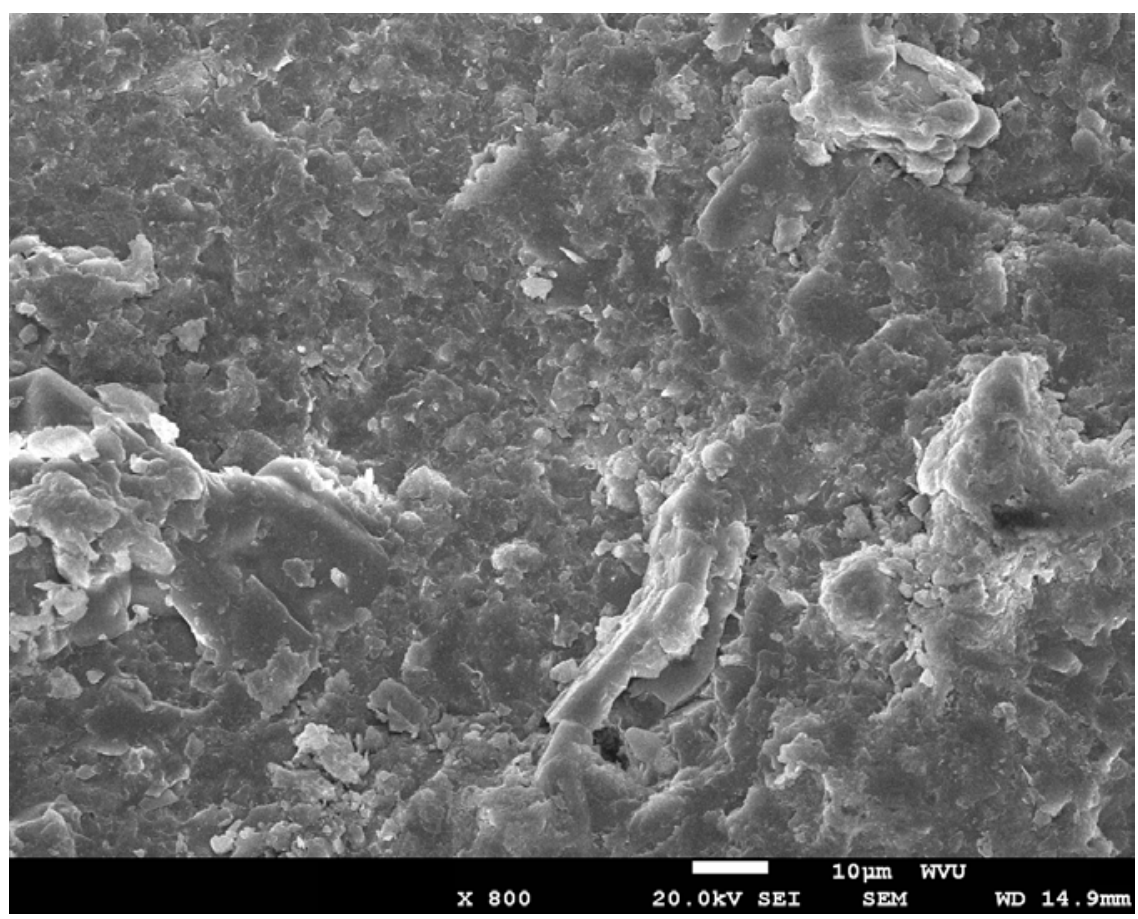

Figure 6.4 SEM image of the control specimen for the second depth interval of Well $\mathrm{A}$ at $800 \mathrm{X}$

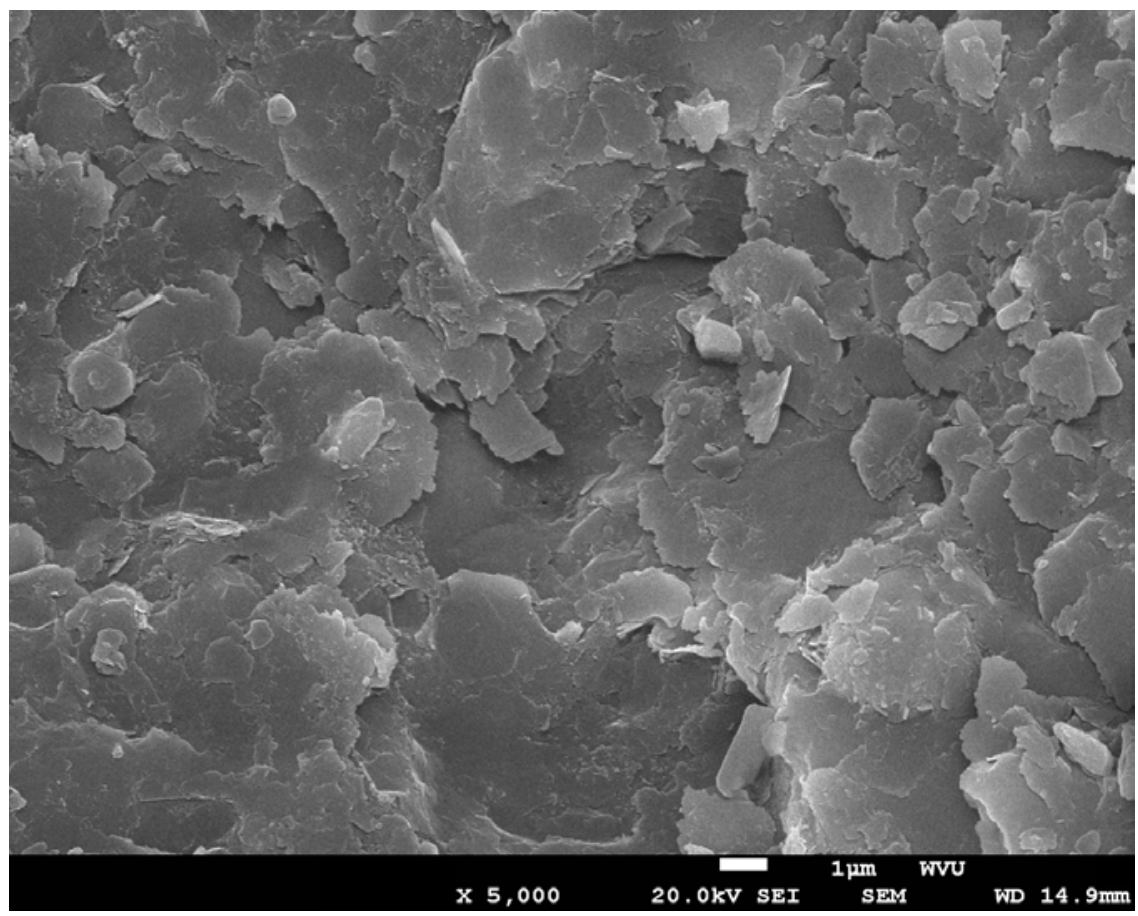

Figure 6.5 SEM image of the control specimen for the second depth interval of Well A at 5000X 


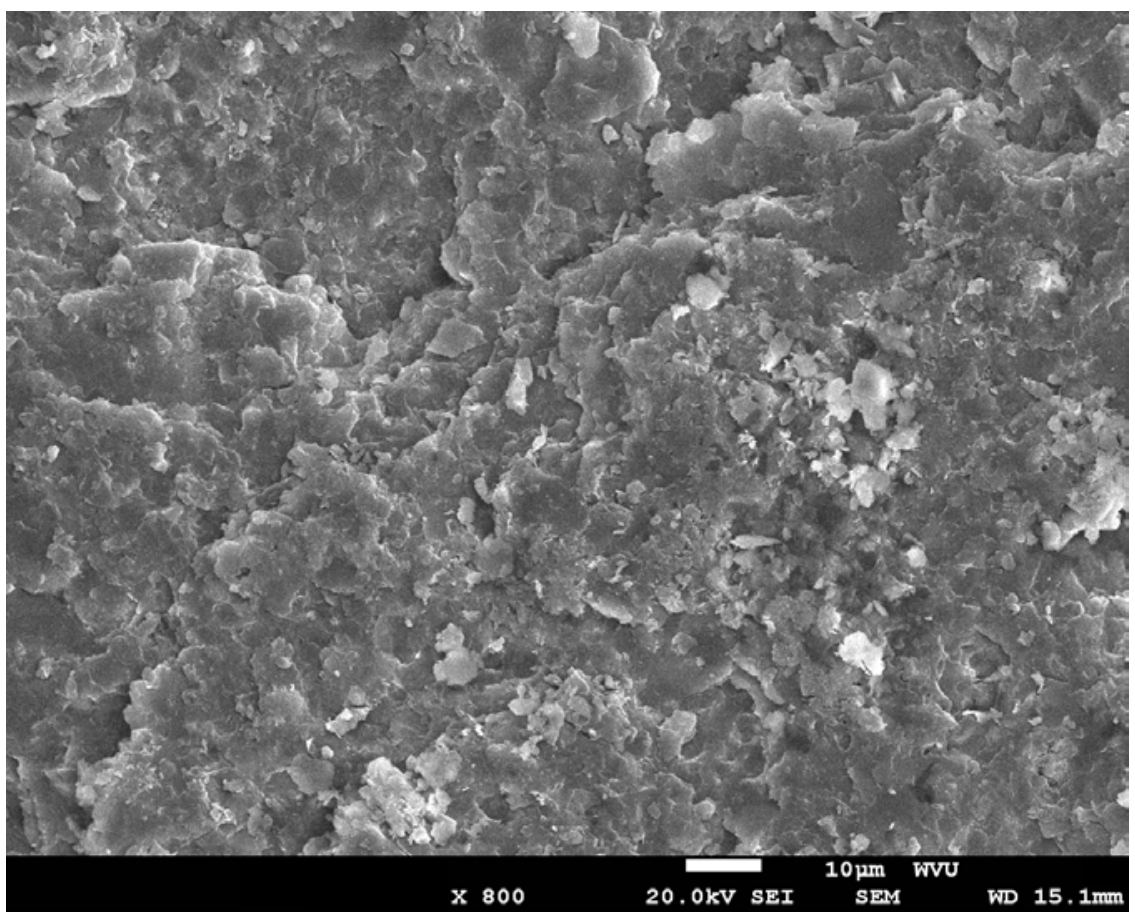

Figure 6.6 SEM image of the control specimen for the third depth interval of Well $\mathrm{A}$ at $800 \mathrm{X}$

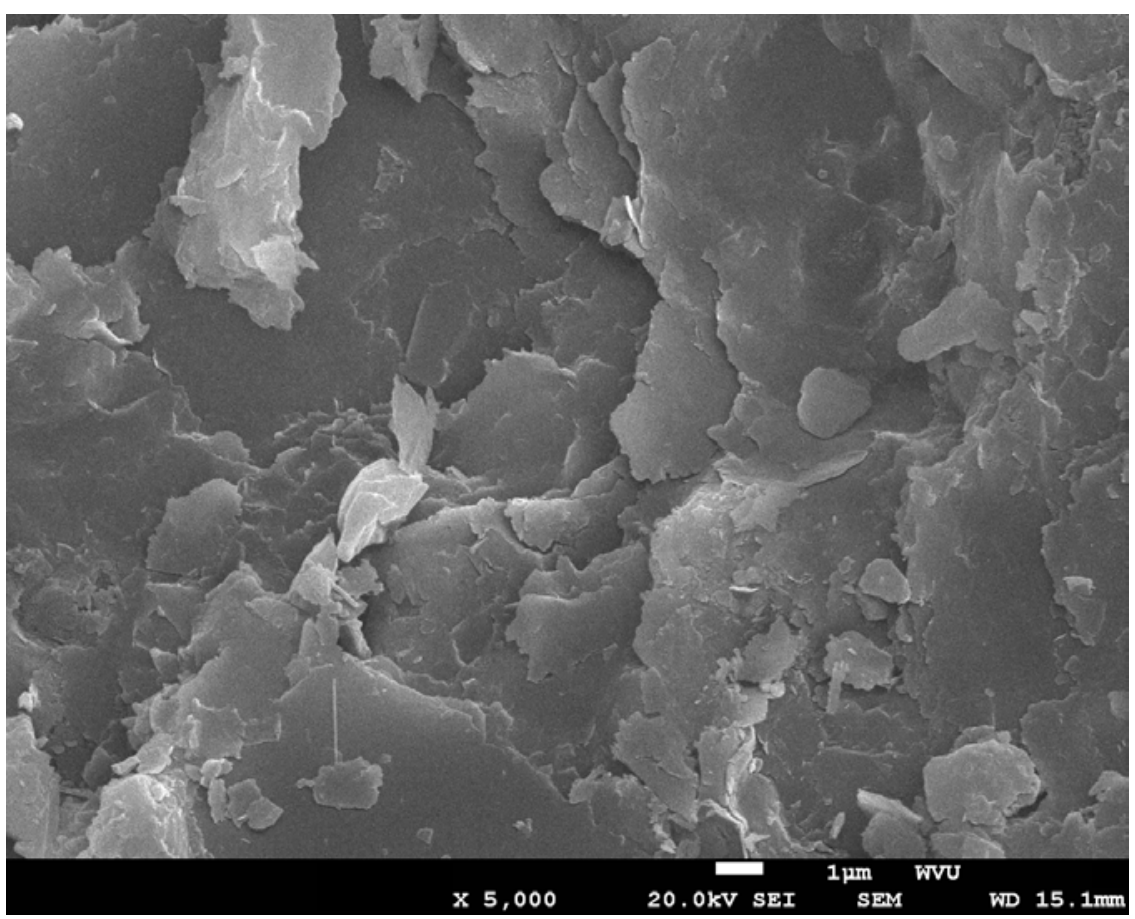

Figure 6.7 SEM image of the control specimen for the third depth interval of Well $A$ at 5000X 


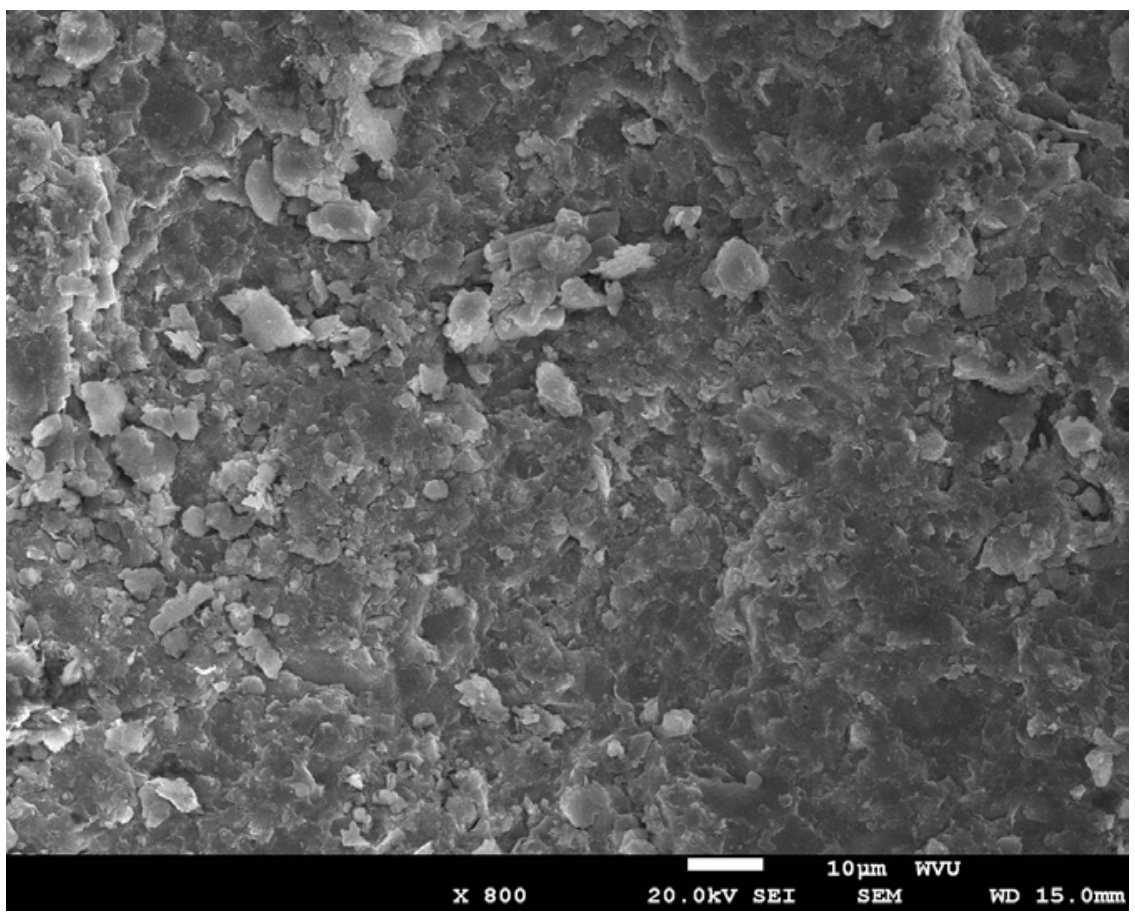

Figure 6.8 SEM image of the control specimen for the fourth depth interval of Well $\mathrm{A}$ at $800 \mathrm{X}$

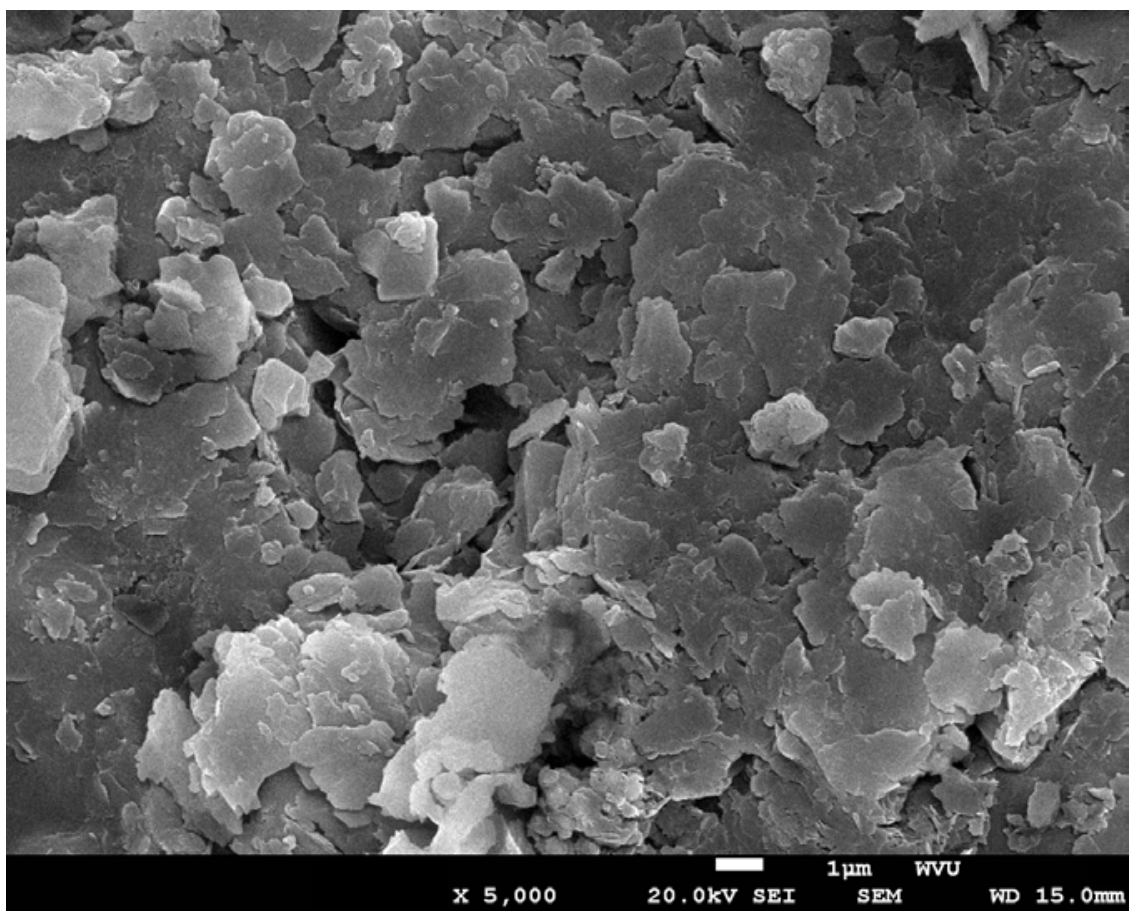

Figure 6.9 SEM image of the control specimen for the fourth depth interval of Well $A$ at 5000X 


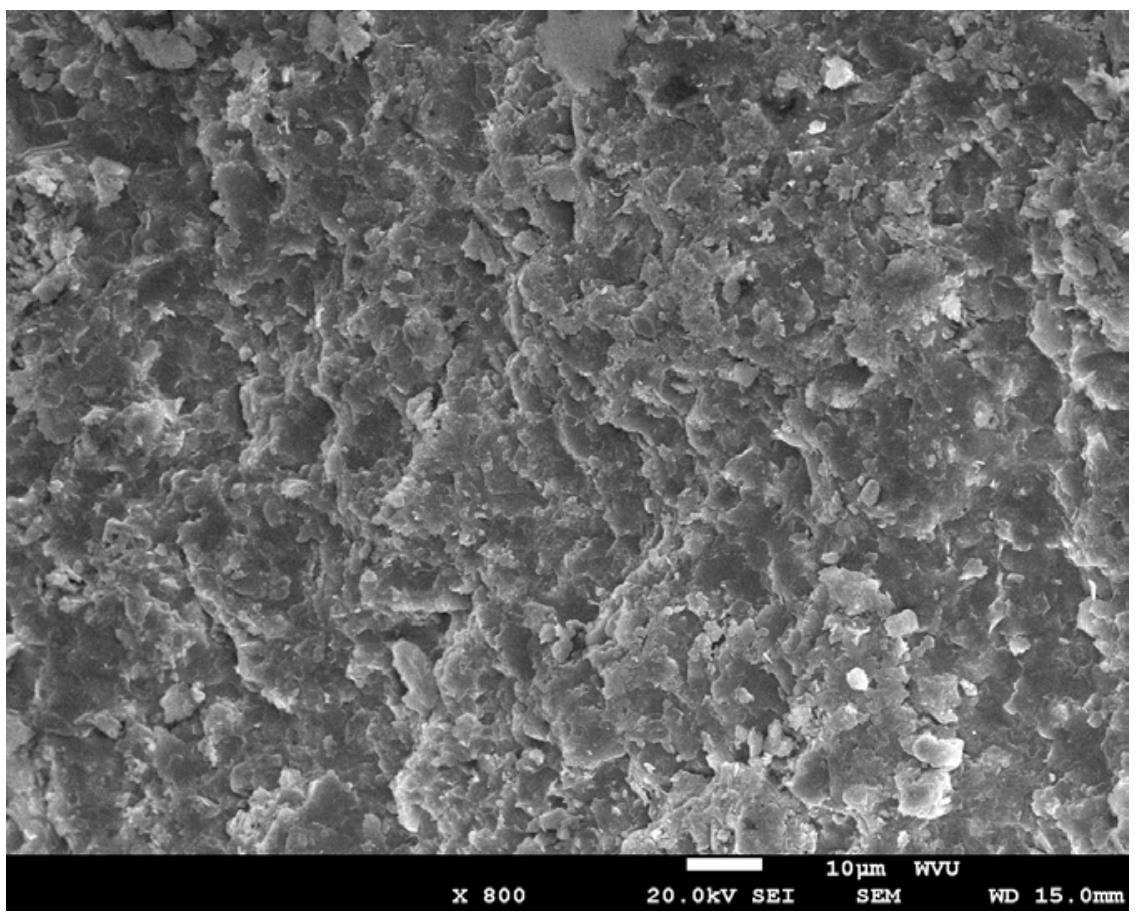

Figure 6.10 SEM image of the control specimen for the fifth depth interval of Well $\mathrm{A}$ at $800 \mathrm{X}$

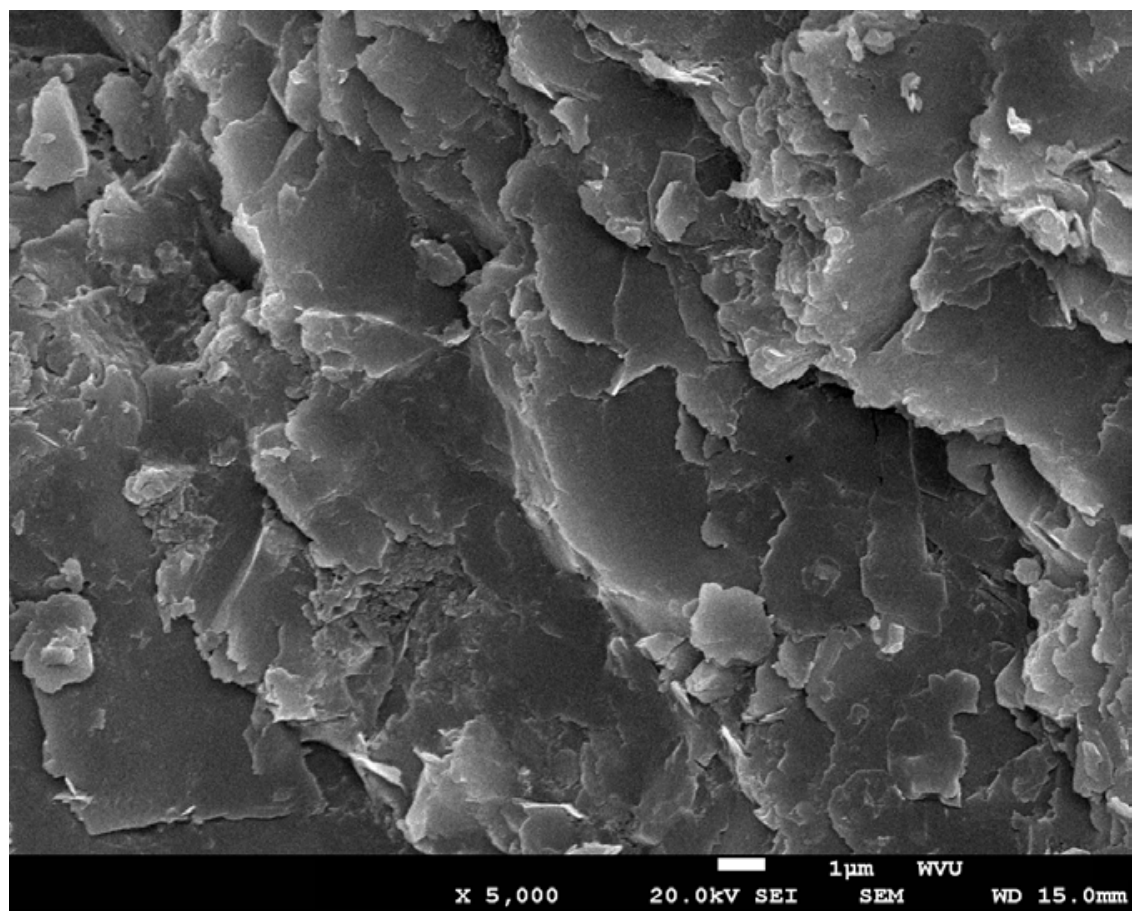

Figure 6.11 SEM image of the control specimen for the fifth depth interval of Well $A$ at 5000X 


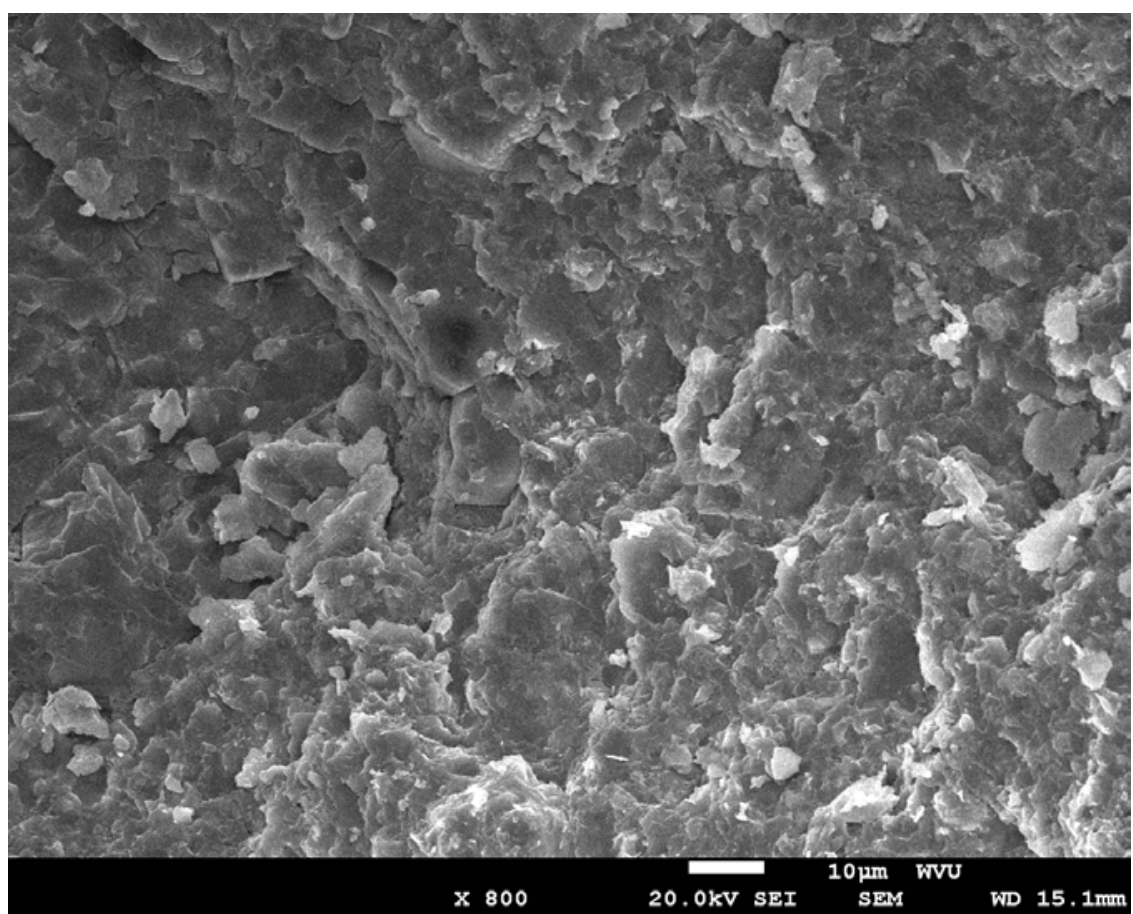

Figure 6.12 SEM image of the control specimen for the sixth depth interval of Well $\mathrm{A}$ at $800 \mathrm{X}$

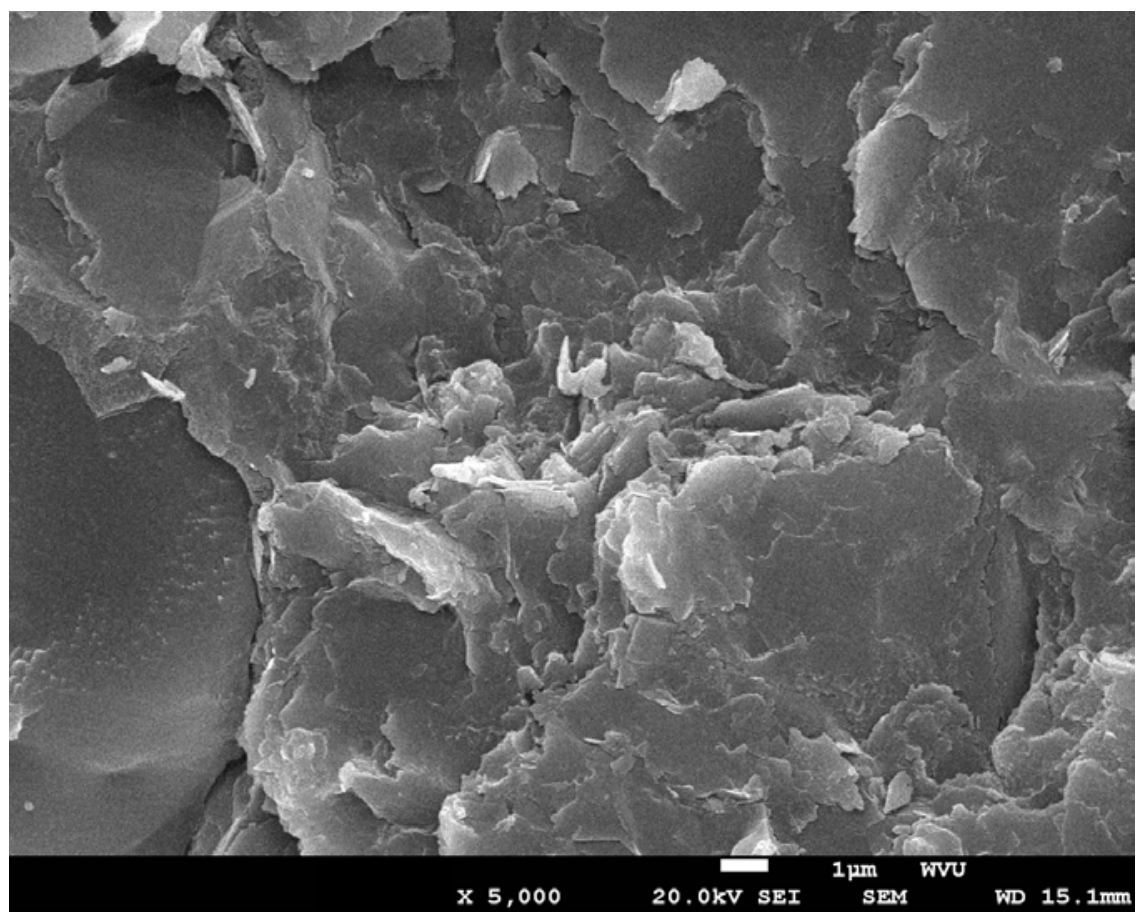

Figure 6.13 SEM image of the control specimen for the sixth depth interval of Well $A$ at 5000X 


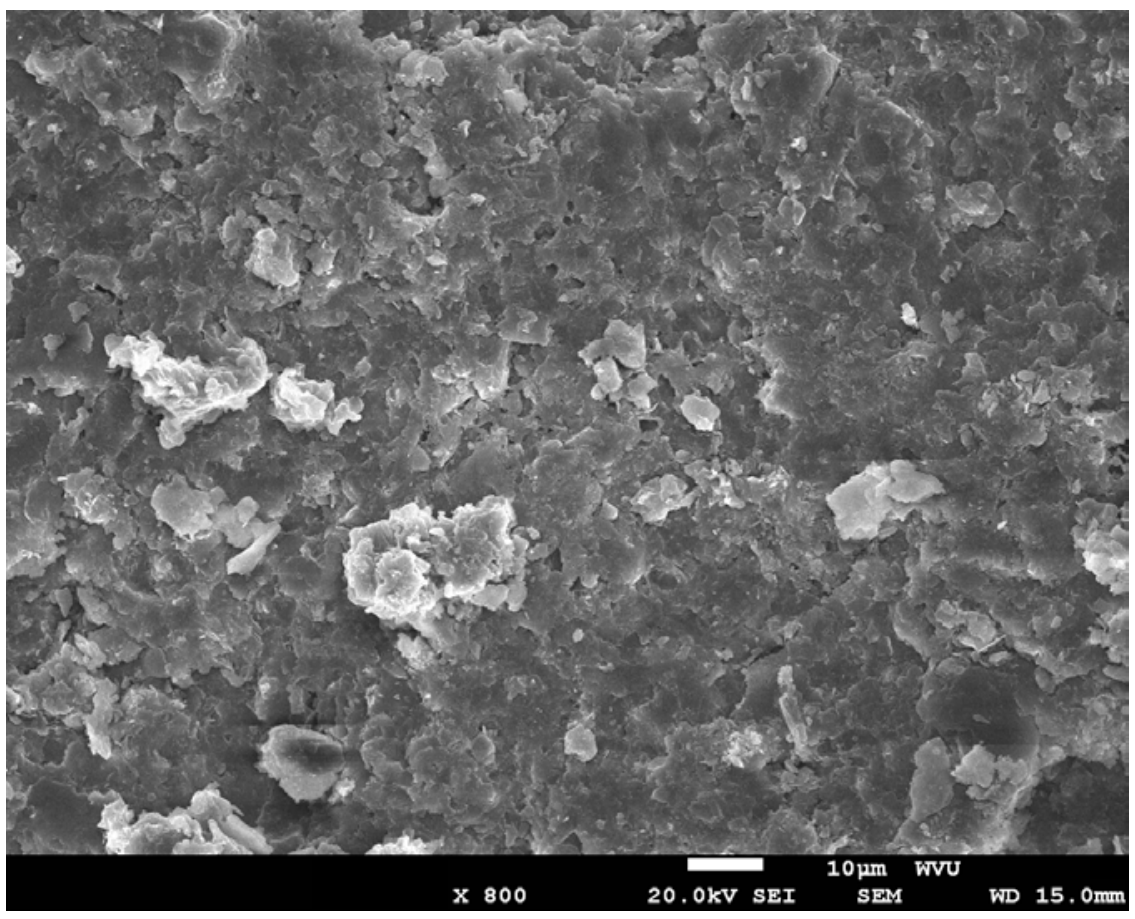

Figure 6.14 SEM image of the control specimen for the seventh depth interval of Well $A$ at 800X

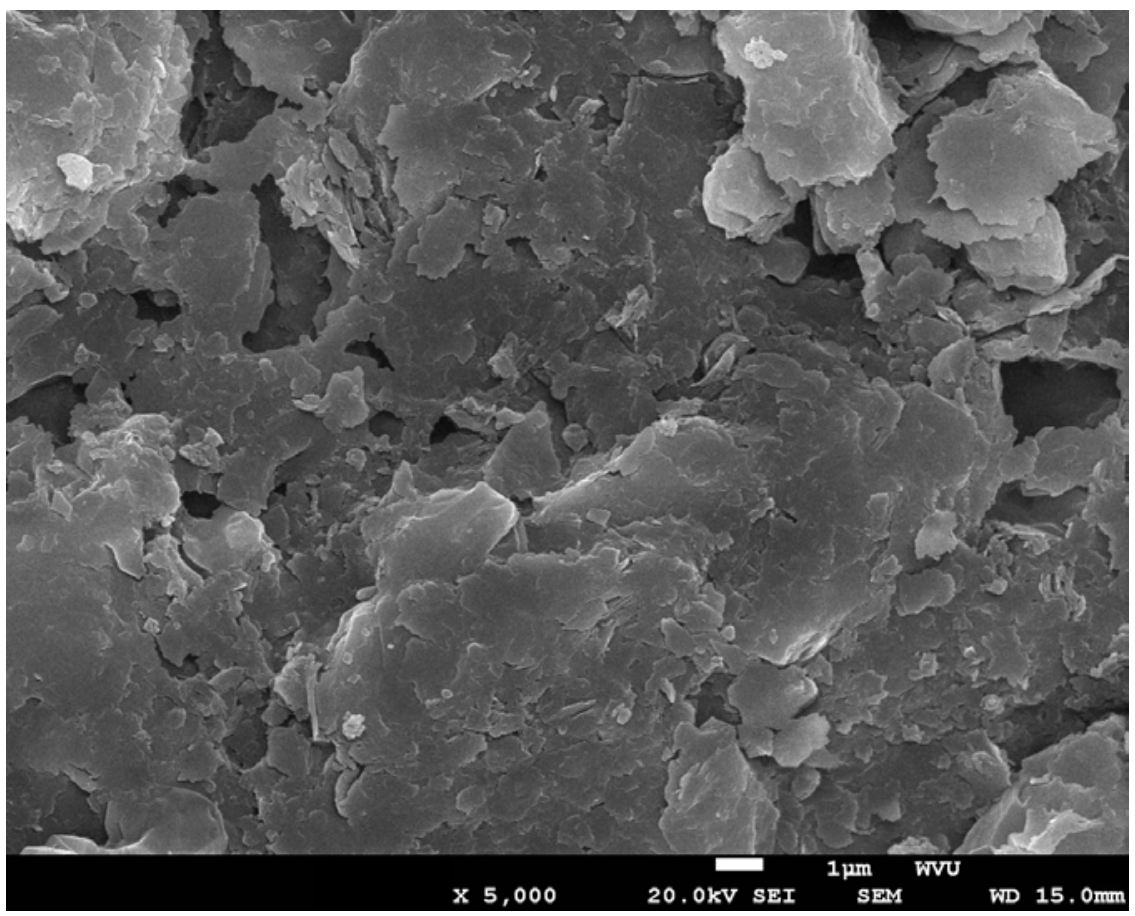

Figure 6.15 SEM image of the control specimen for the seventh depth interval of Well $A$ at 5000X 


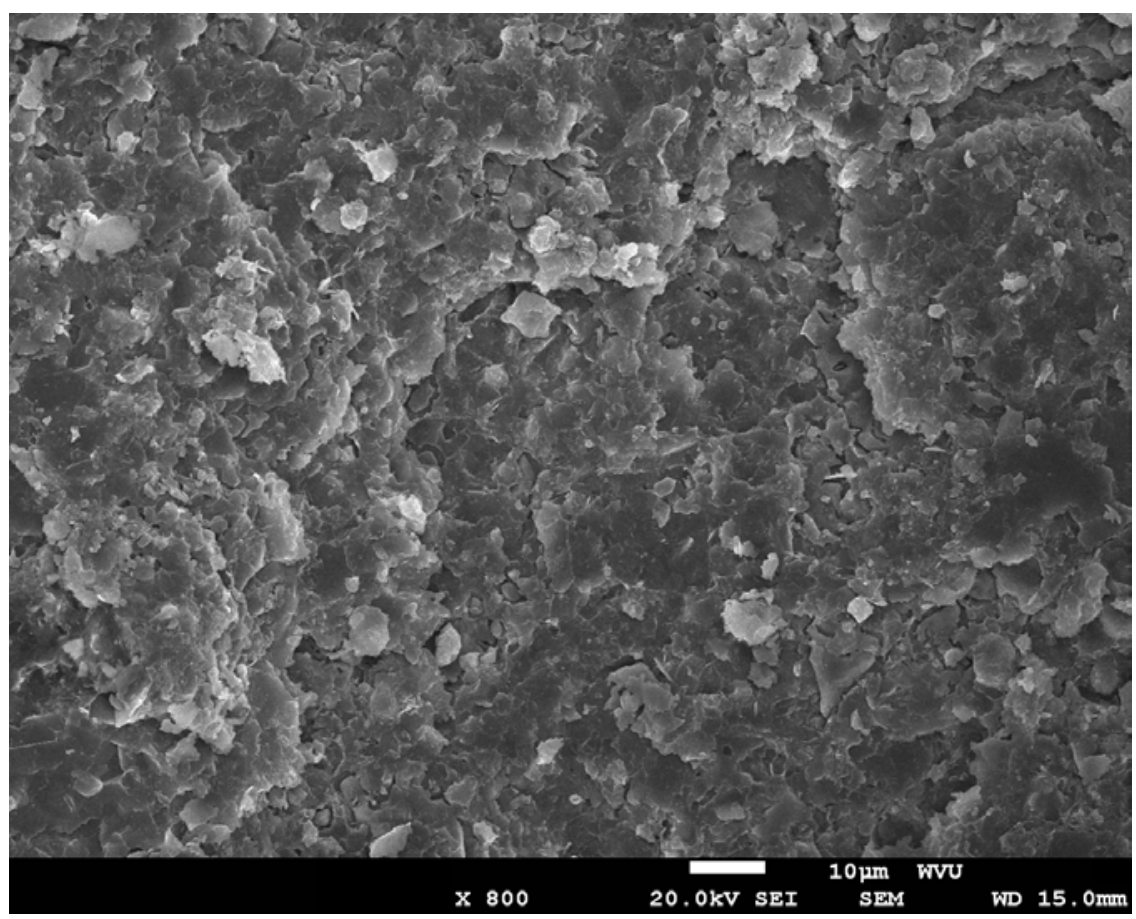

Figure 6.16 SEM image of the control specimen for the eighth depth interval of Well $\mathrm{A}$ at $800 \mathrm{X}$

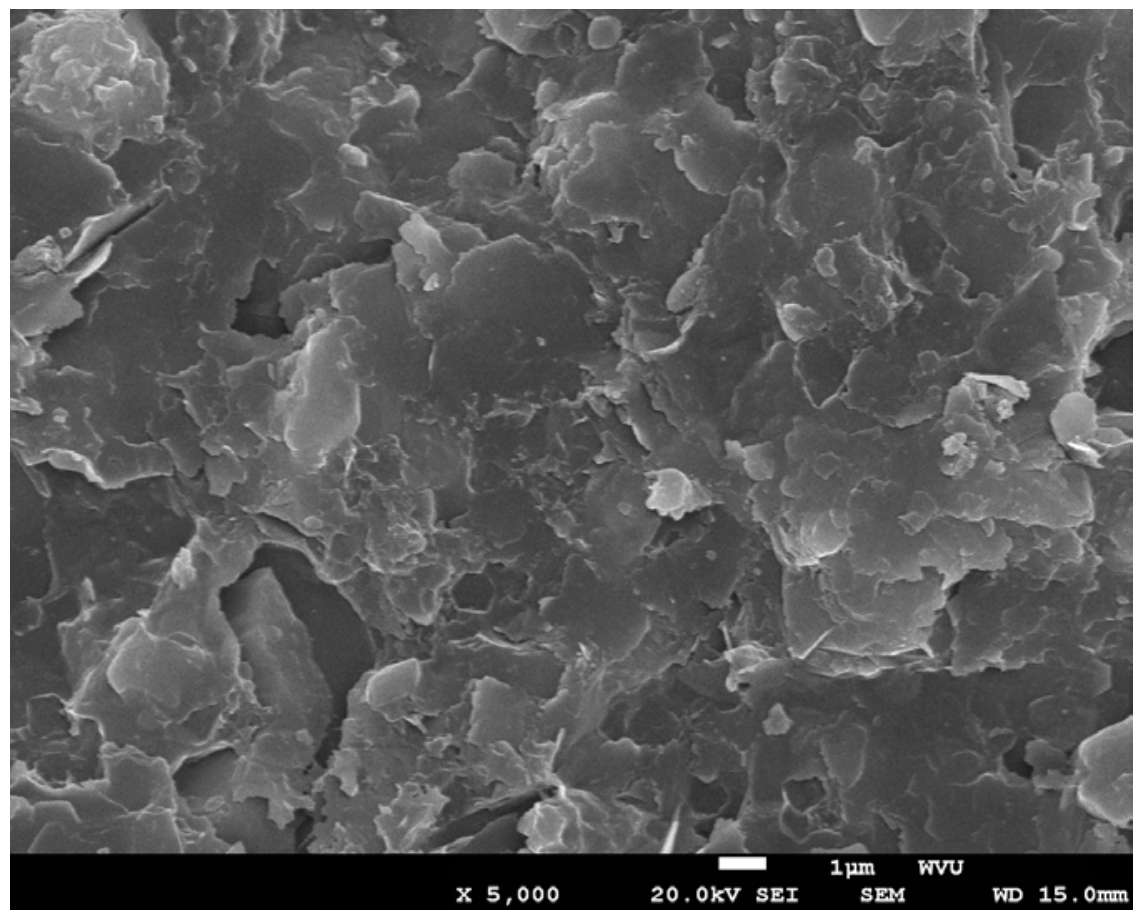

Figure 6.17 SEM image of the control specimen for the eighth depth interval of Well A at 5000X 


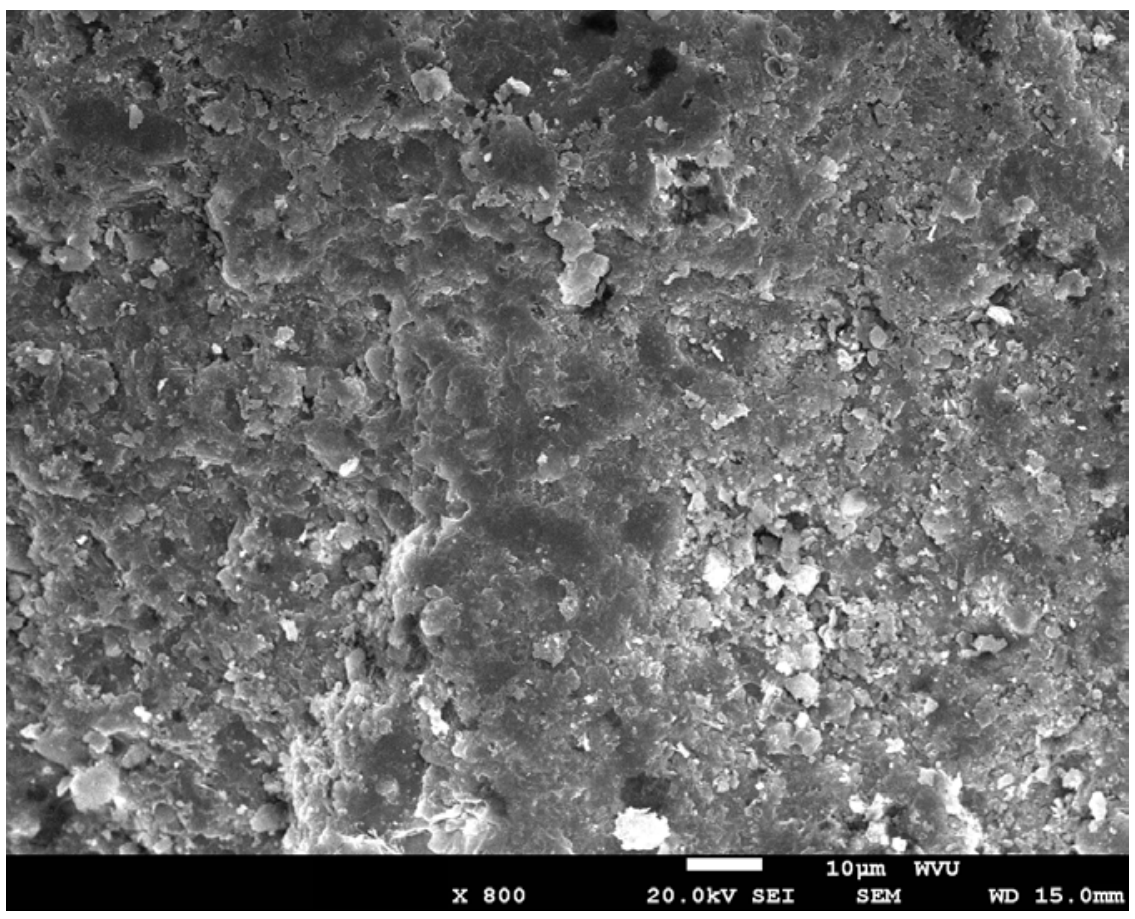

Figure 6.18 SEM image of the control specimen for the ninth depth interval of Well $A$ at $800 \mathrm{X}$

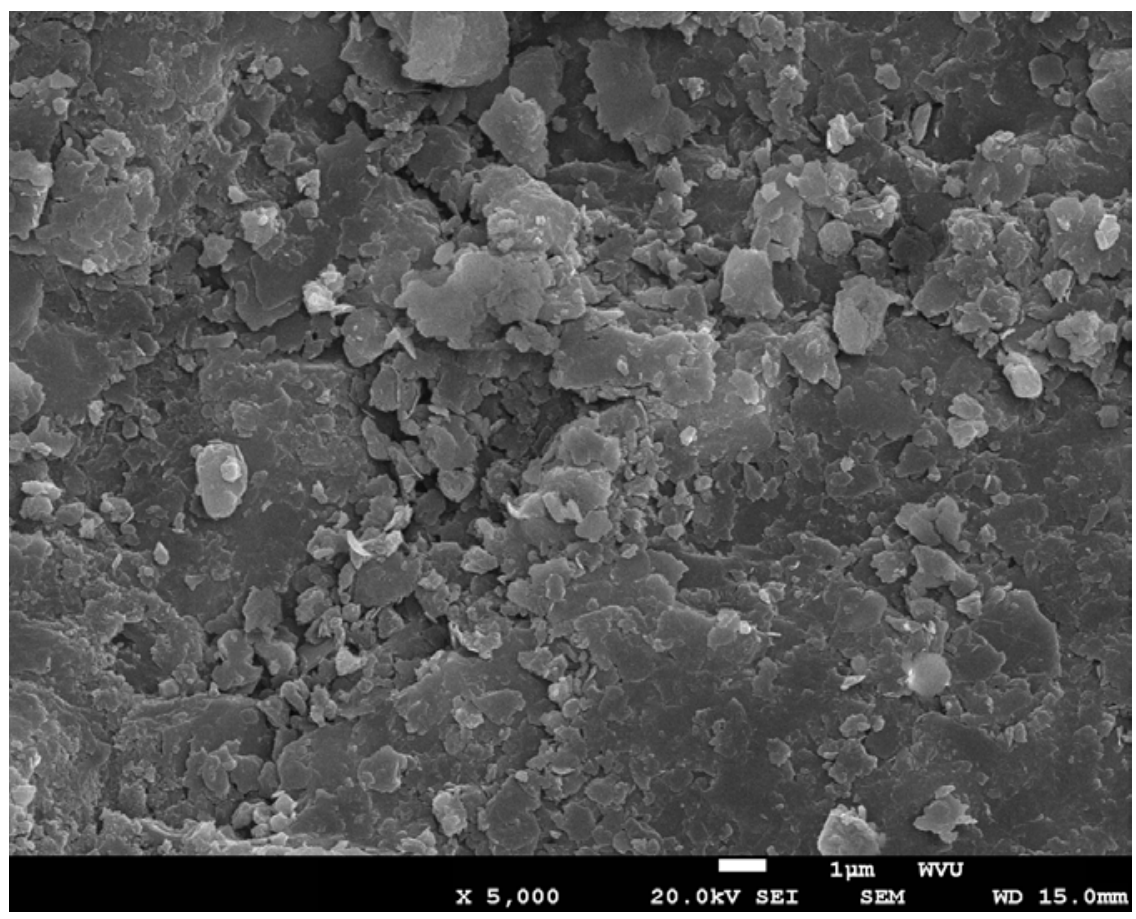

Figure 6.19 SEM image of the control specimen for the ninth depth interval of Well A at 5000X 


\section{Monongalia County Well $\mathrm{A}_{2} \mathrm{O}$ Alteration}

The samples discussed in this section underwent a water treatment alteration test. Samples from every depth interval of Monongalia County Well A soaked for two hours in distilled water. The purpose of this test was to observe the effect of water on the elemental composition of the Marcellus shale. Water is a constituent of most drilling muds, therefore it is the primary ingredient in the clay suspensions used in this project. The elemental composition was evaluated using EDX, and the ranges in weight percent for each element found in the water treatment test samples are listed in Table 6.2.

\begin{tabular}{|c|c|c|c|}
\hline \multicolumn{4}{|c|}{ Monongalia County Well $\mathrm{A}\left(\mathrm{H}_{2} \mathrm{O}\right)$} \\
\hline Element & Weight\% & Sample & Range \\
\hline \multirow{2}{*}{ Al } & 1.89 & $1 \mathrm{~A}$ & \multirow{2}{*}{7.32} \\
\hline & 9.21 & $7 \mathrm{~A}$ & \\
\hline \multirow{2}{*}{ C } & 14.45 & $7 A$ & \multirow{2}{*}{22.47} \\
\hline & 36.92 & $3 \mathrm{~A}$ & \\
\hline $\mathrm{Ca}$ & 3.89 & $8 \mathrm{~A}$ & 3.89 \\
\hline \multirow{2}{*}{$\mathrm{Fe}$} & 0.31 & $4 \mathrm{~A}$ & \multirow{2}{*}{38.78} \\
\hline & 39.09 & $1 \mathrm{~A}$ & \\
\hline \multirow{2}{*}{$\mathrm{K}$} & 0.61 & $4 \mathrm{~A}$ & \multirow{2}{*}{3.38} \\
\hline & 3.99 & $7 \mathrm{~A}$ & \\
\hline \multirow{2}{*}{$\mathrm{Mg}$} & 0.31 & $4 \mathrm{~A}$ & \multirow{2}{*}{0.47} \\
\hline & 0.78 & $7 \mathrm{~A}$ & \\
\hline $\mathrm{Na}$ & 2.74 & $1 \mathrm{~A}$ & 2.74 \\
\hline \multirow{2}{*}{$\mathrm{O}$} & 26.10 & $9 A$ & \multirow{2}{*}{22.24} \\
\hline & 48.34 & $5 \mathrm{~A}$ & \\
\hline \multirow{2}{*}{$\mathrm{S}$} & 2.06 & $9 A$ & \multirow{2}{*}{6.80} \\
\hline & 8.86 & $1 \mathrm{~A}$ & \\
\hline \multirow{2}{*}{$\mathrm{Si}$} & 1.92 & $1 \mathrm{~A}$ & \multirow{2}{*}{44.46} \\
\hline & 46.38 & $8 \mathrm{~A}$ & \\
\hline $\mathrm{Ti}$ & 0.57 & $5 \mathrm{~A}$ & 0.57 \\
\hline
\end{tabular}

Table 6.2 Weight percent ranges for each element found in the Monongalia County Well A water treatment samples

All the elements found in the samples that underwent the water treatment test from Monongalia County Well A were plotted against the corresponding depth in Figure 6.20. Two elemental trends were observed in these particular samples. Just as in the control samples, aluminum and potassium 
followed similar trends. While the weight percent of aluminum was greater in more shallow depths, the shape of the line was alike for the majority of the chart. Iron and sulfur also had parallel data lines. While the increase in weight percent was greater in the first depth interval, the remaining eight intervals remained relatively consistent in the increases and decreases in weight percent.

Photographs were taken of the samples that underwent the water treatment test using the SEM, and they are seen below in Figure 6.21 through Figure 6.38. Each sample was taken at a magnification of $800 \mathrm{X}$ and 5000X. Tiny pores and a countless layers are visible in the water treatment samples as they are in the control samples. Organic rich areas are indicated by red circles in Figure 6.27. These circles are identifying the small dark areas with a higher carbon content. The surface of the specimen in Figure 6.36 takes on a different appearance than the other samples from the water treatment test. The shape of the crystals resemble a quartz structure, further supporting the increase of silicon in the eighth depth interval. 


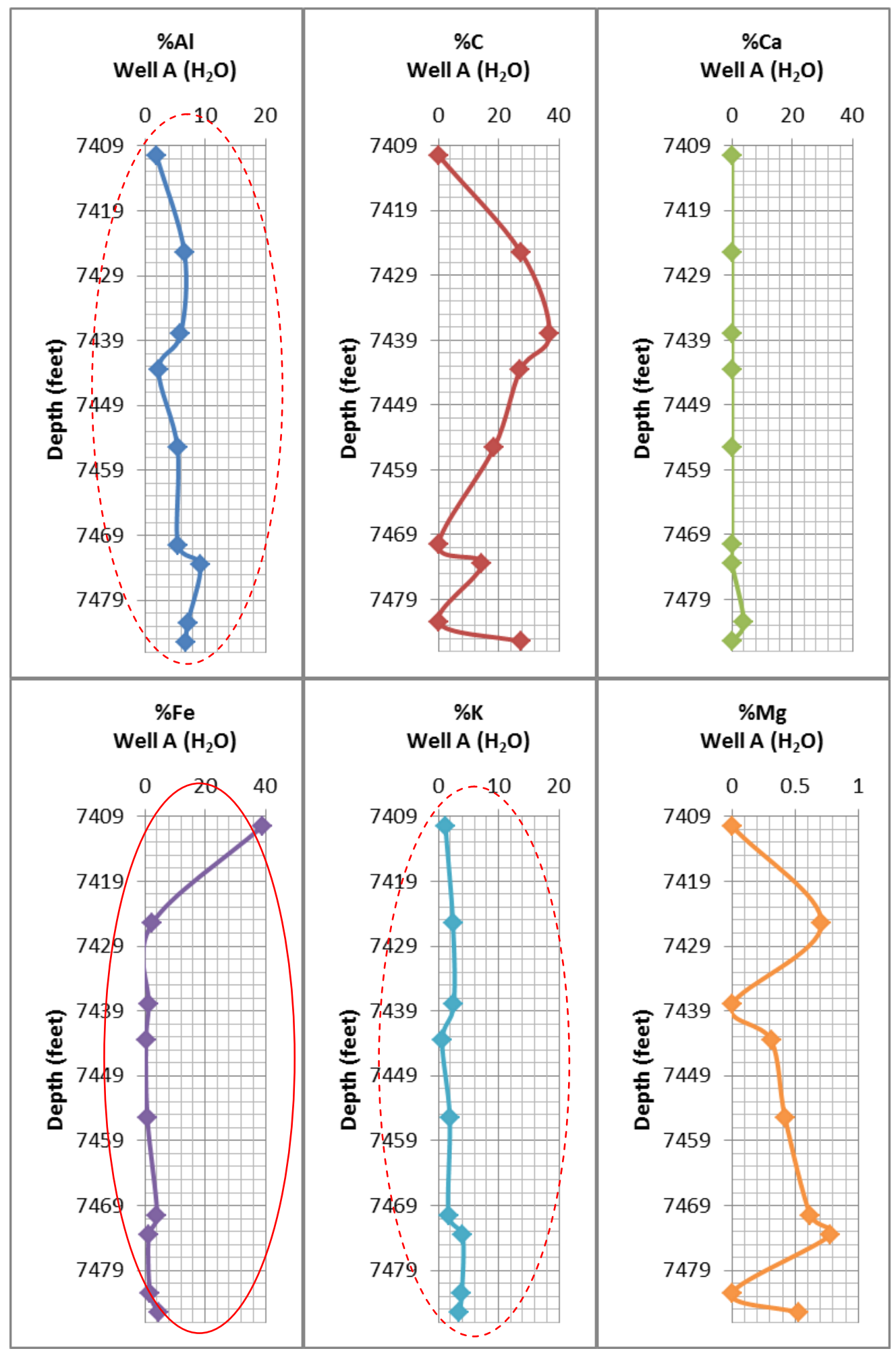




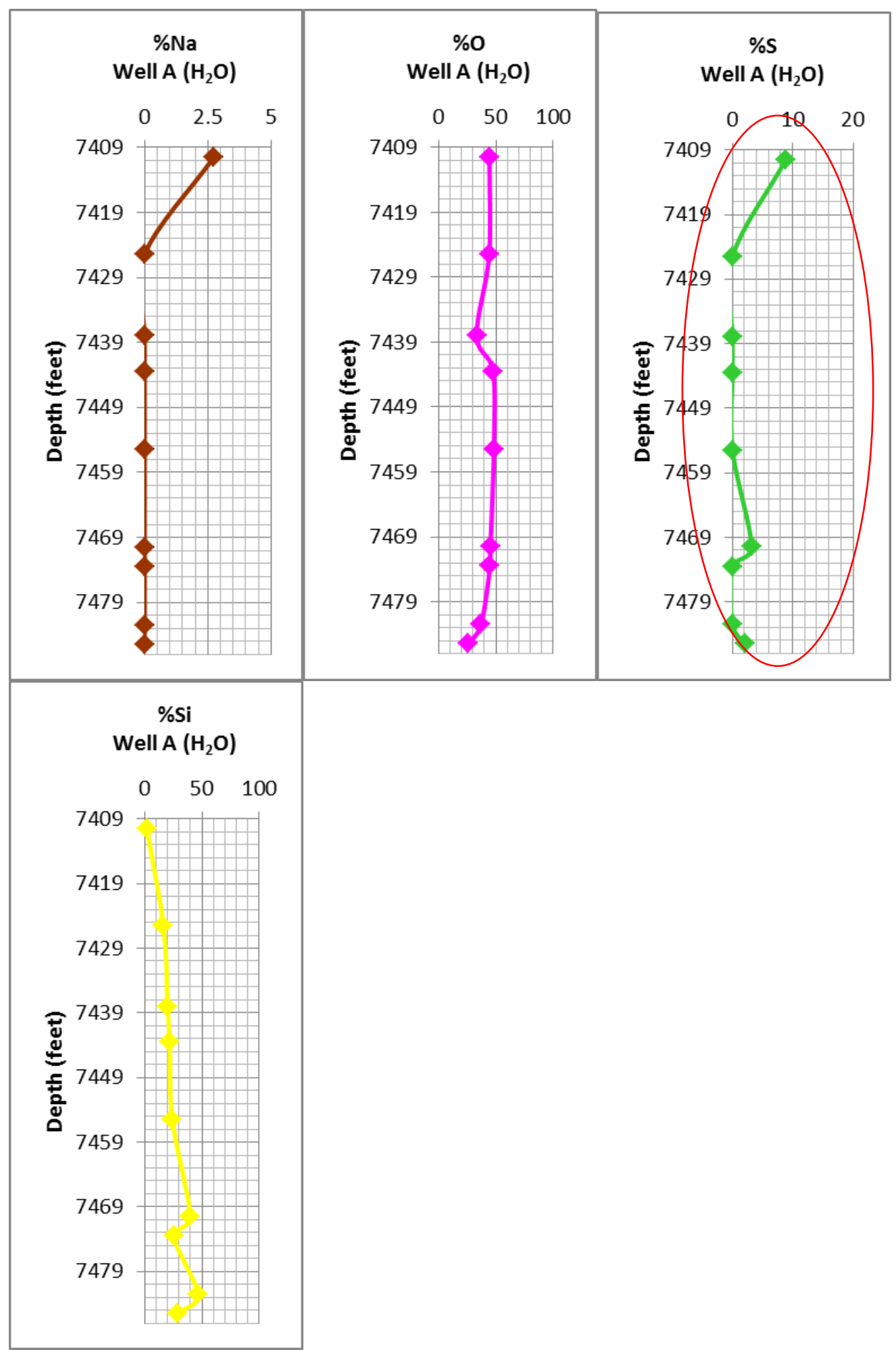

Figure 6.20 Weight percent of each element found in Monongalia County Well A water treatment sampled plotted against the corresponding depth 
Monongalia County Well $\mathrm{A} \mathrm{H}_{2} \mathrm{O}$ Alteration SEM Photographs

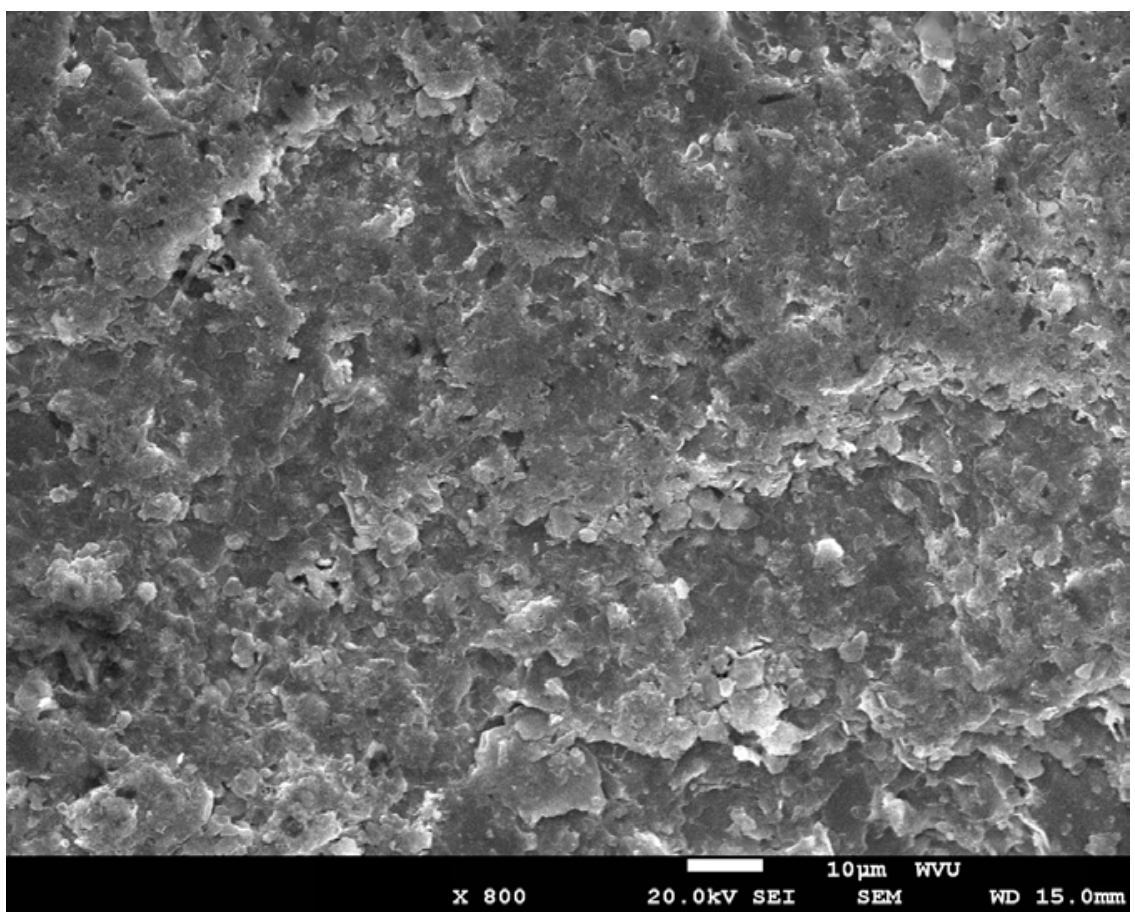

Figure 6.21 SEM image of the water treatment specimen for the first depth interval of Well $A$ at $800 \mathrm{X}$

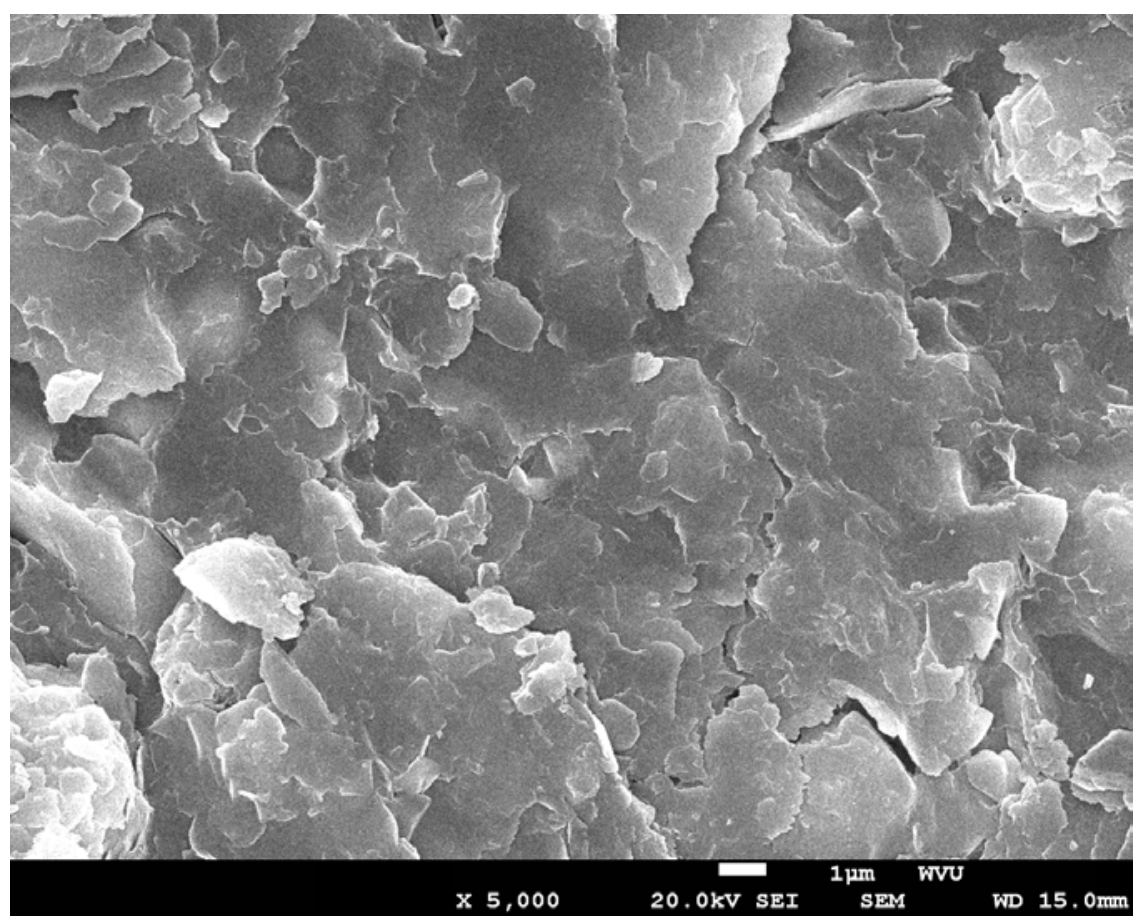

Figure 6.22 SEM image of the water treatment specimen for the first depth interval of Well A at 5000X 


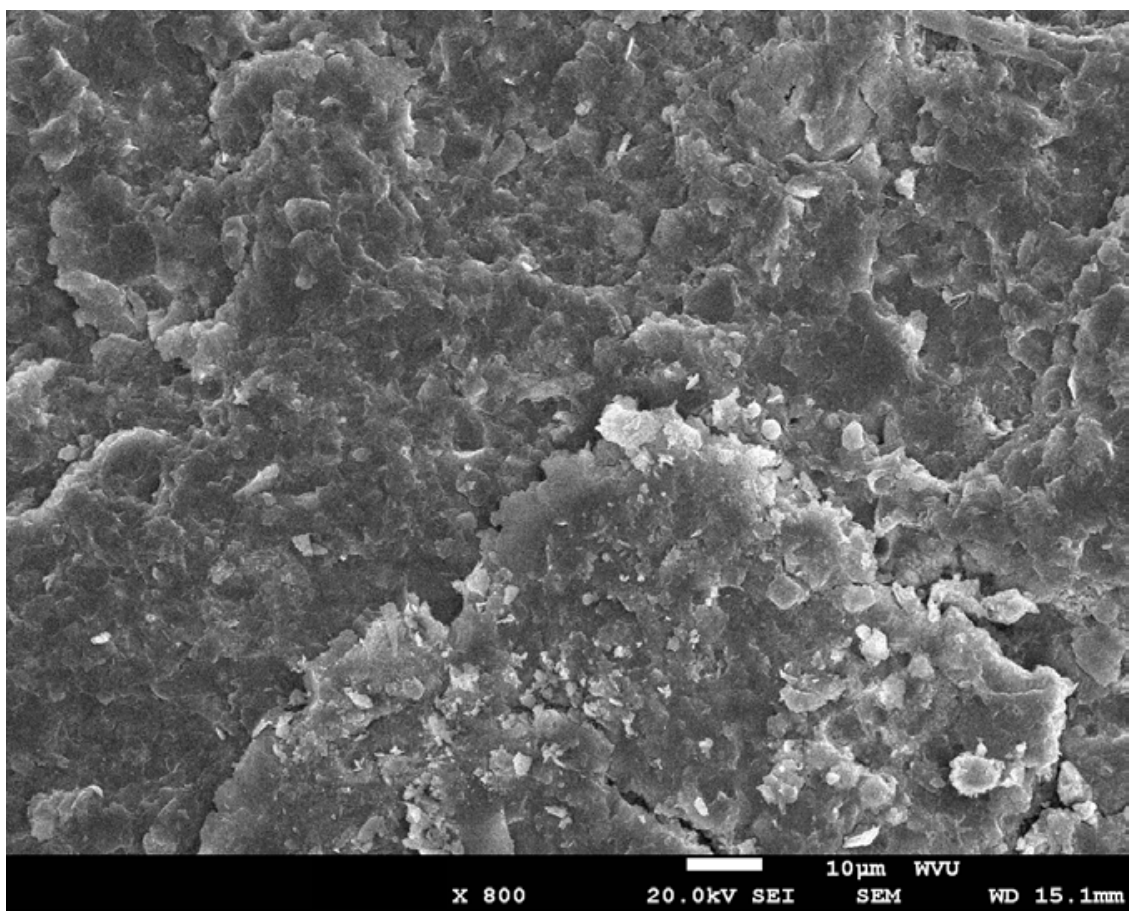

Figure 6.23 SEM image of the water treatment specimen for the second depth interval of Well $\mathrm{A}$ at $800 \mathrm{X}$

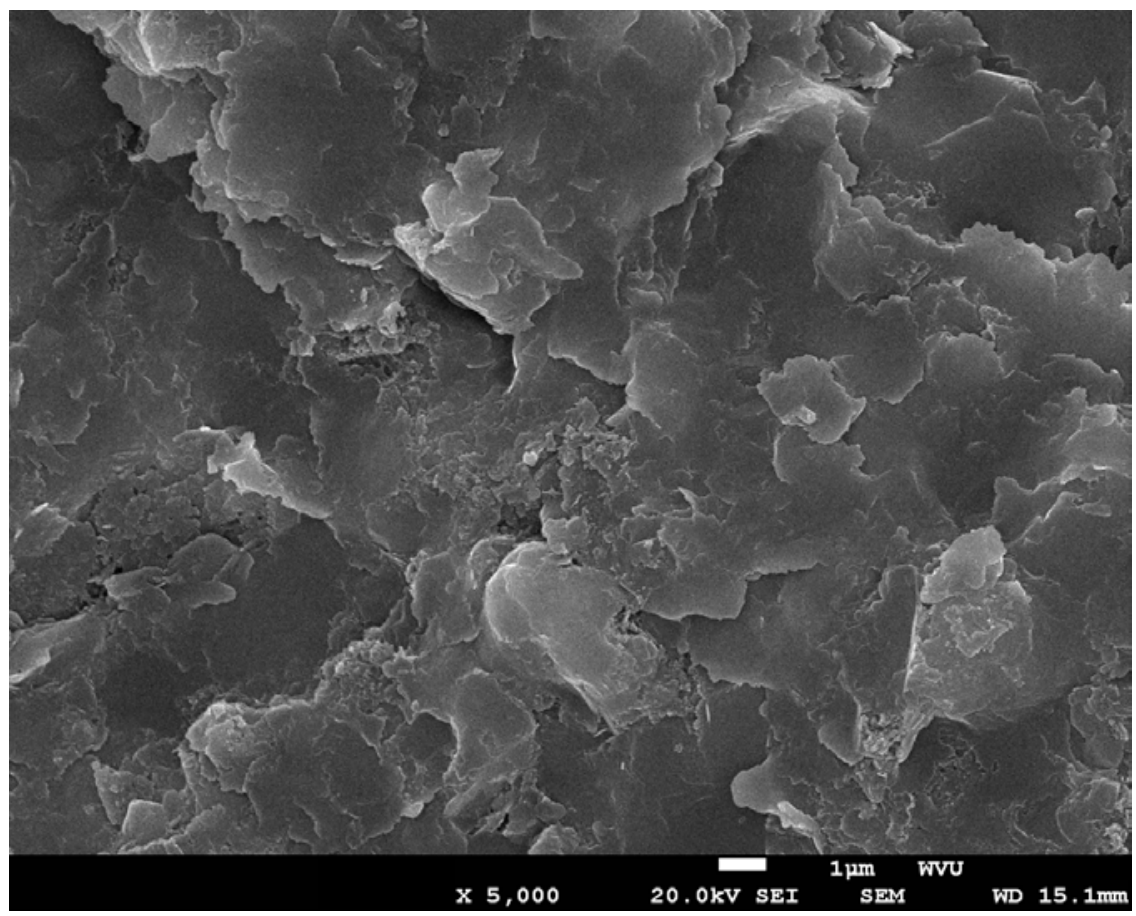

Figure 6.24 SEM image of the water treatment specimen for the second depth interval of Well $A$ at 5000X 


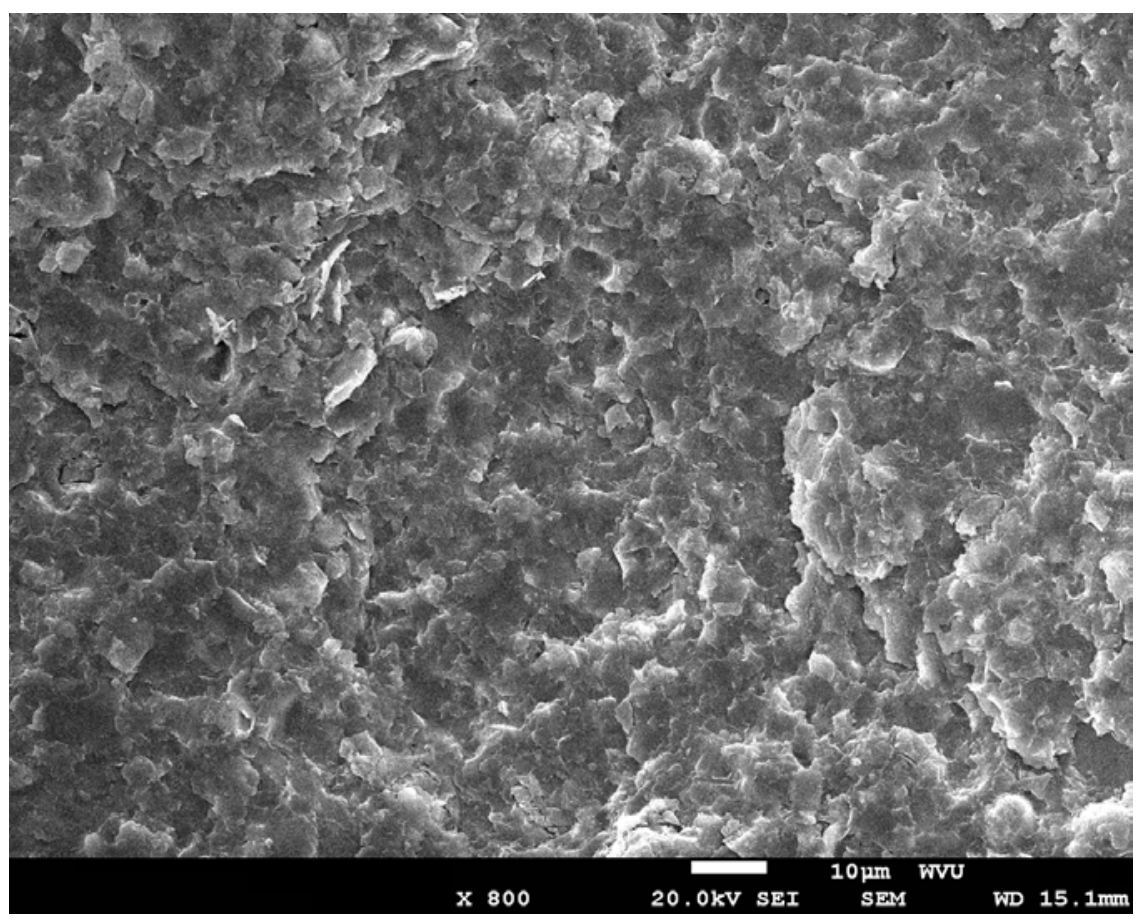

Figure 6.25 SEM image of the water treatment specimen for the third depth interval of Well A at 800X

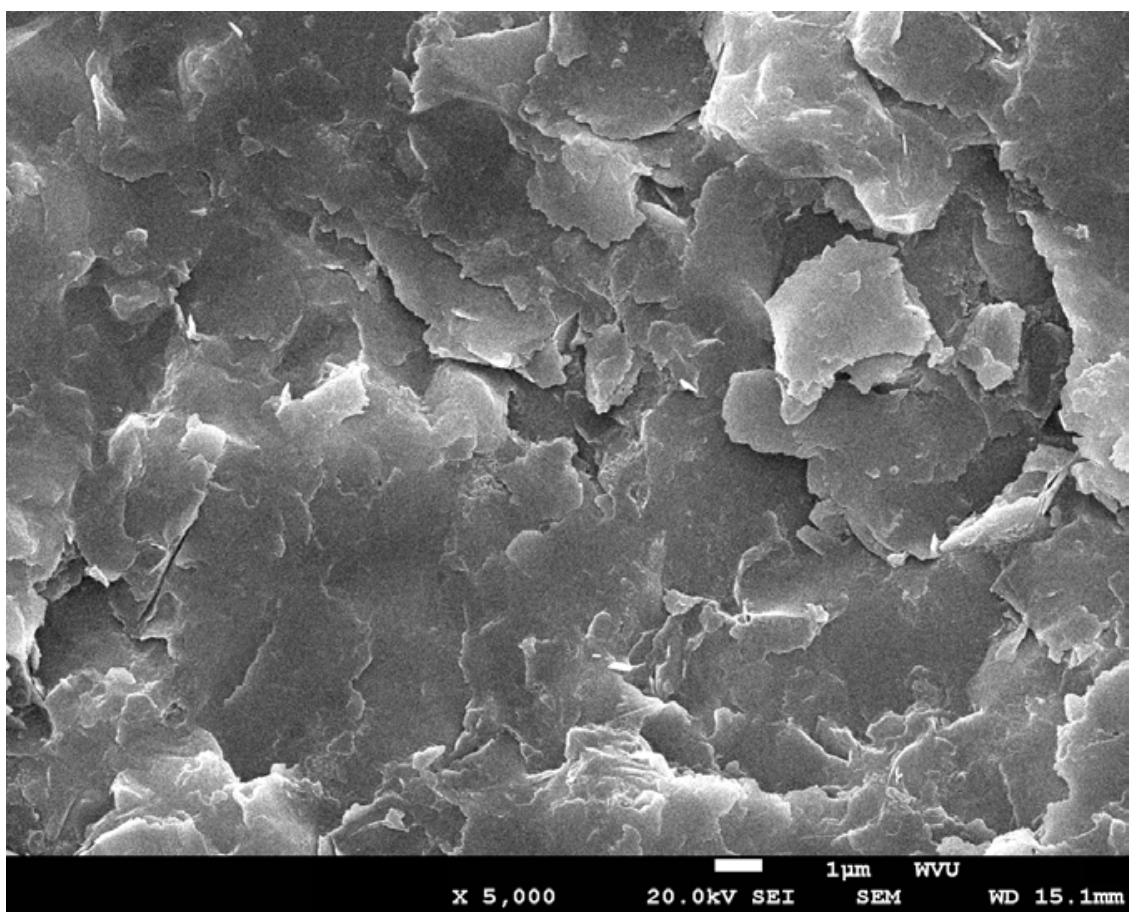

Figure 6.26 SEM image of the water treatment specimen for the third depth interval of Well $A$ at 5000X 


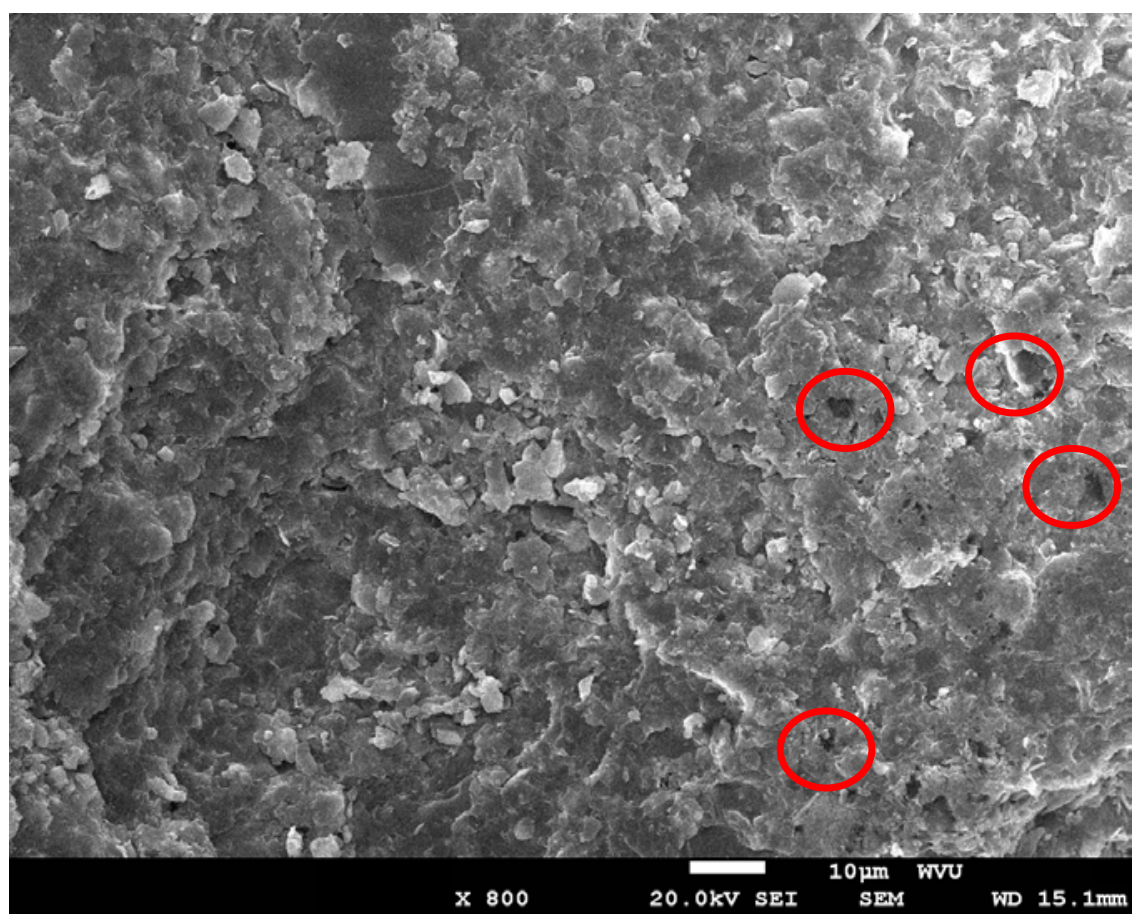

Figure 6.27 SEM image of the water treatment specimen for the fourth depth interval of Well A at $800 \mathrm{X}$

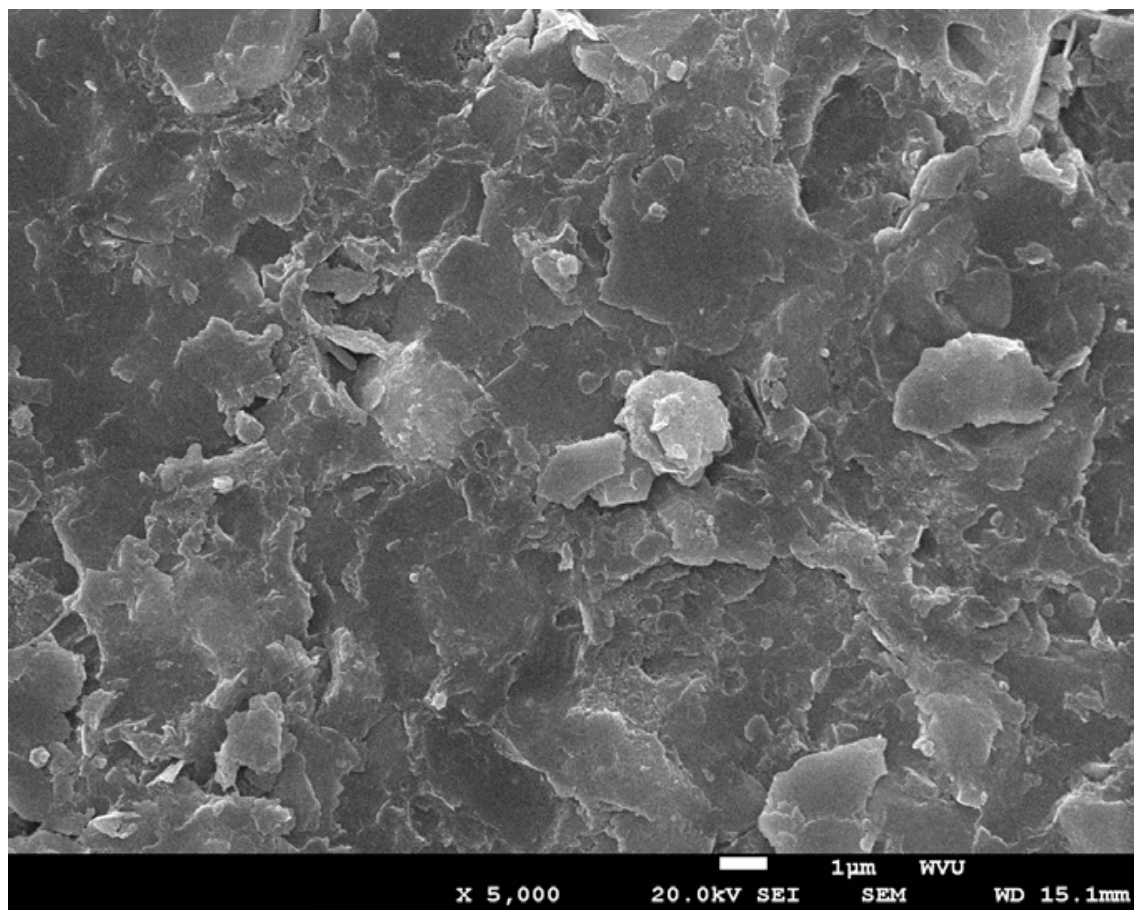

Figure 6.28 SEM image of the water treatment specimen for the fouth depth interval of Well A at 5000X 


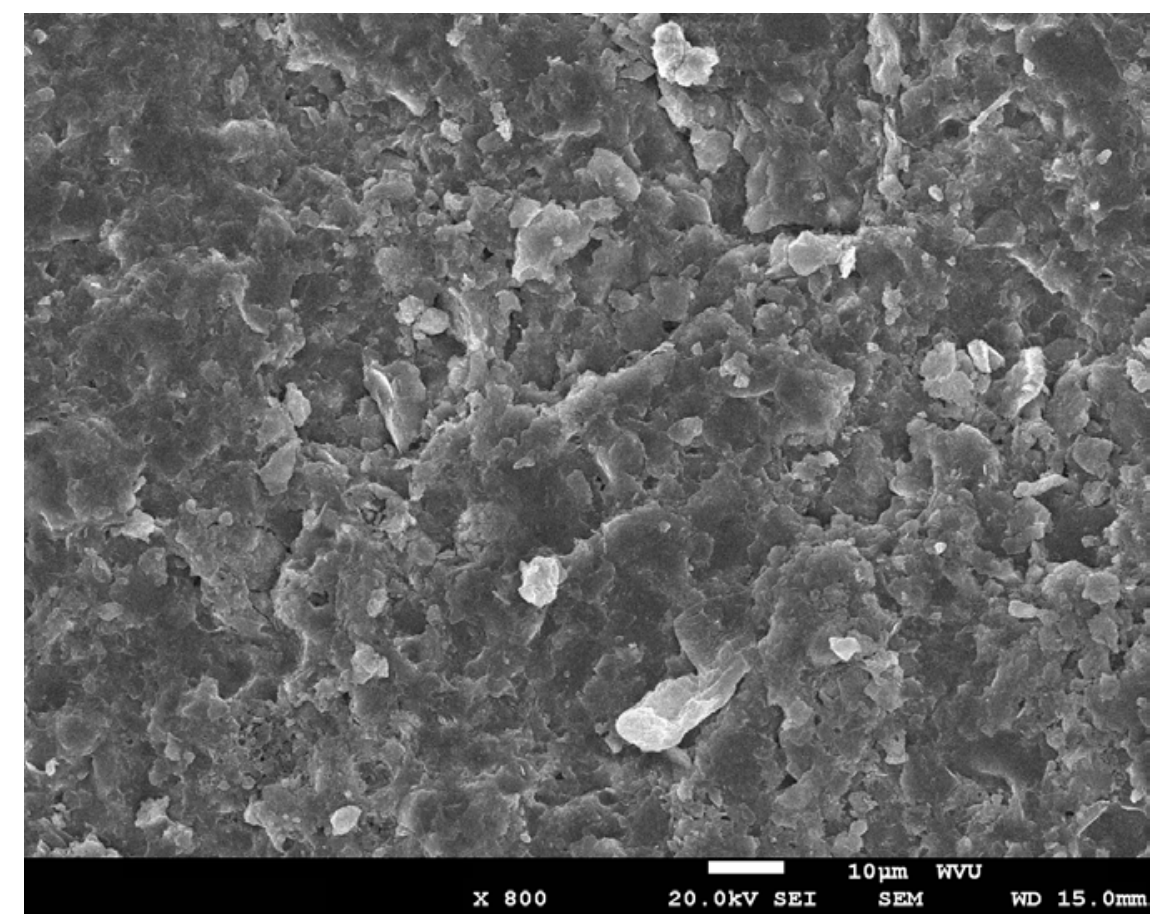

Figure 6.29 SEM image of the water treatment specimen for the fifth depth interval of Well A at 800X

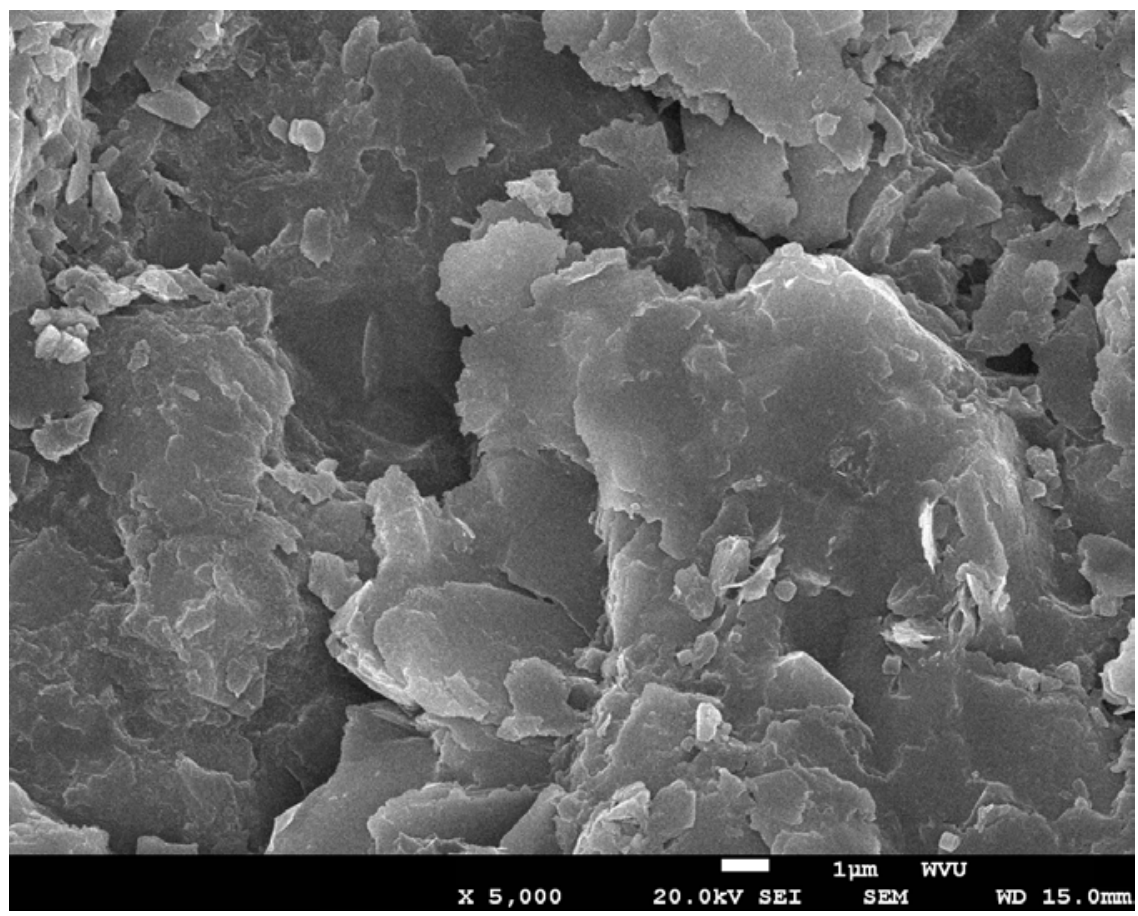

Figure 6.30 SEM image of the water treatment specimen for the fifth depth interval of Well A at 5000X 


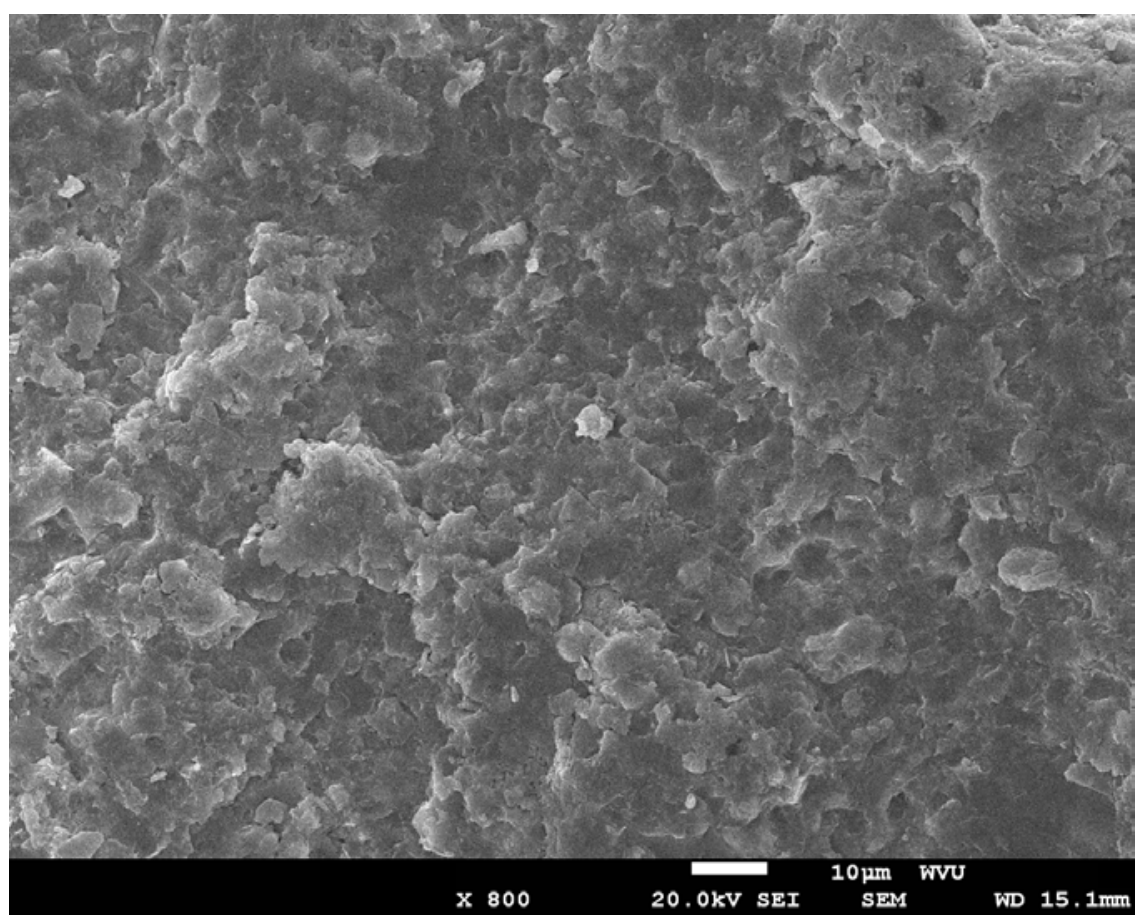

Figure 6.31 SEM image of the water treatment specimen for the sixth depth interval of Well A at 800X

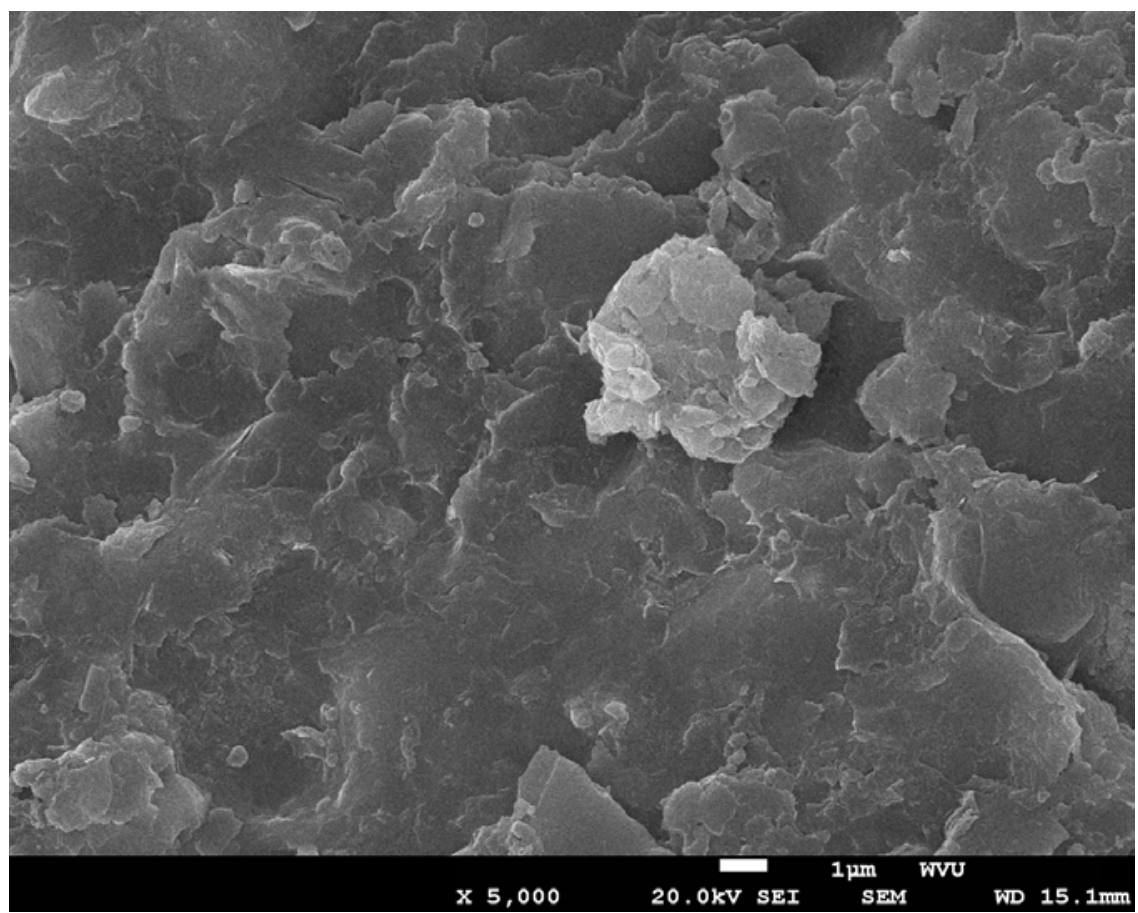

Figure 6.32 SEM image of the water treatment specimen for the sixth depth interval of Well A at 5000X 


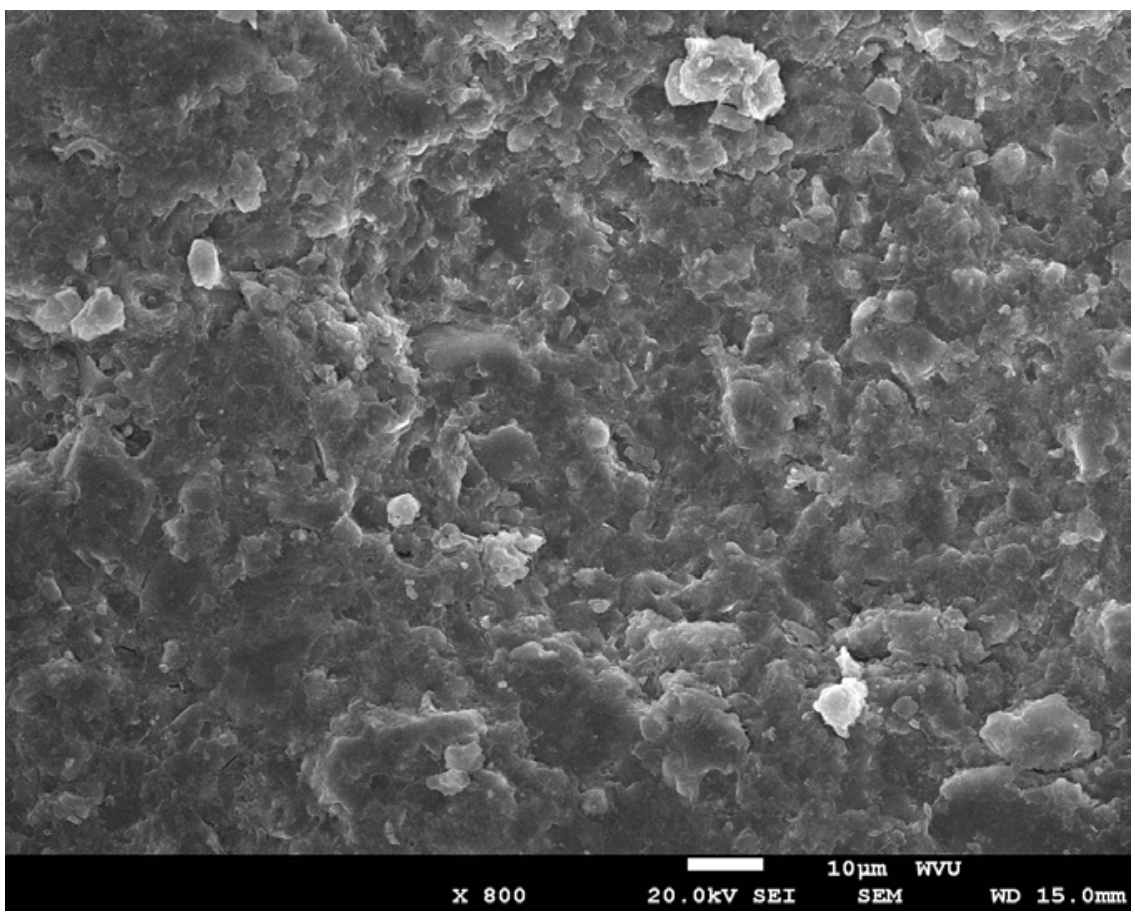

Figure 6.33 SEM image of the water treatment specimen for the seventh depth interval of Well $A$ at $800 \mathrm{X}$

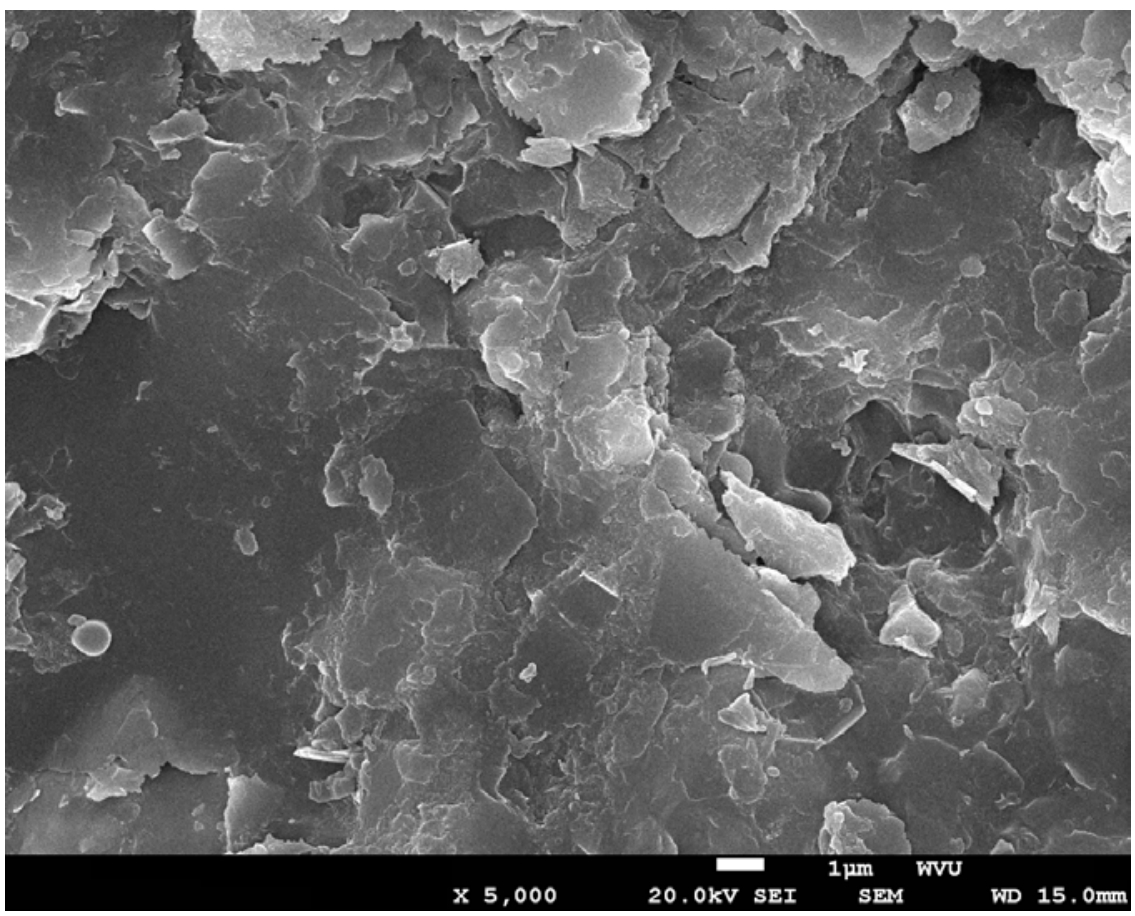

Figure 6.34 SEM image of the water treatment specimen for the seventh depth interval of Well A at 5000X 


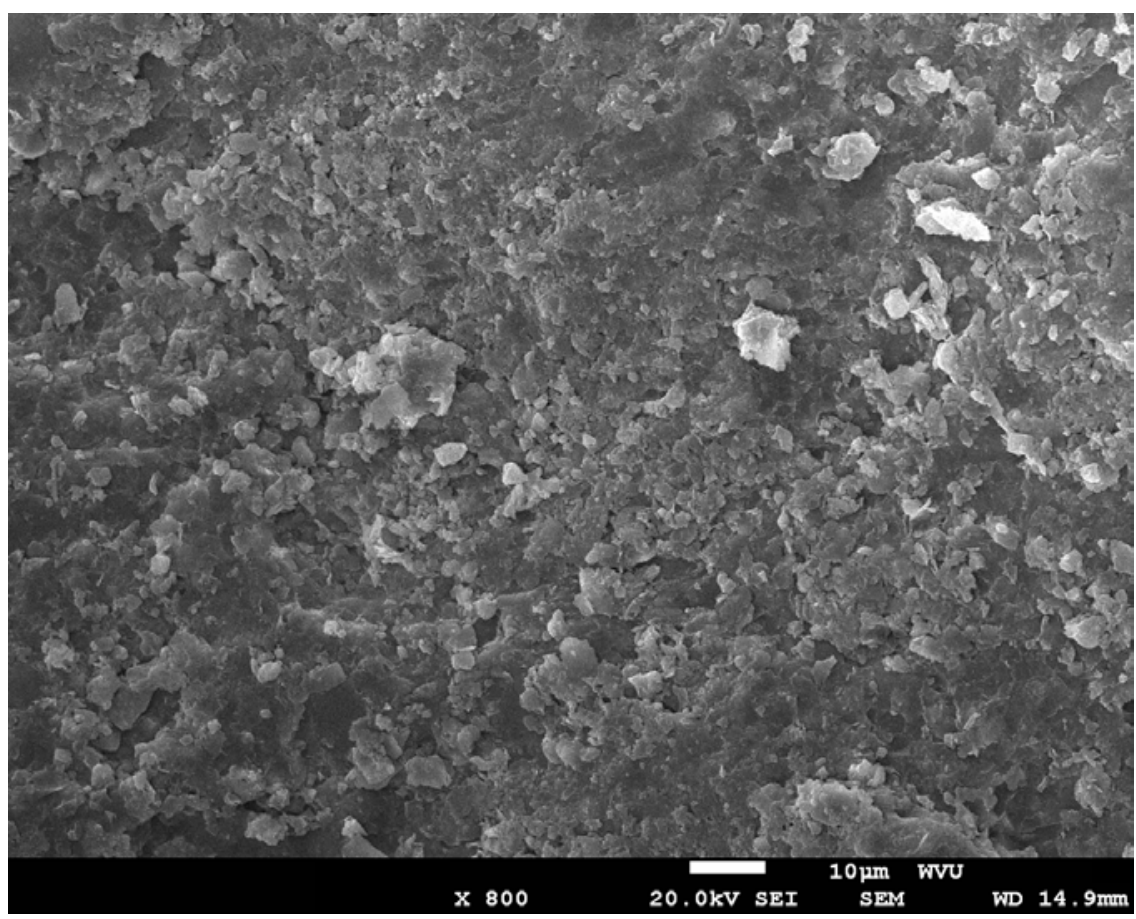

Figure 6.35 SEM image of the water treatment specimen for the eighth depth interval of Well A at 800X

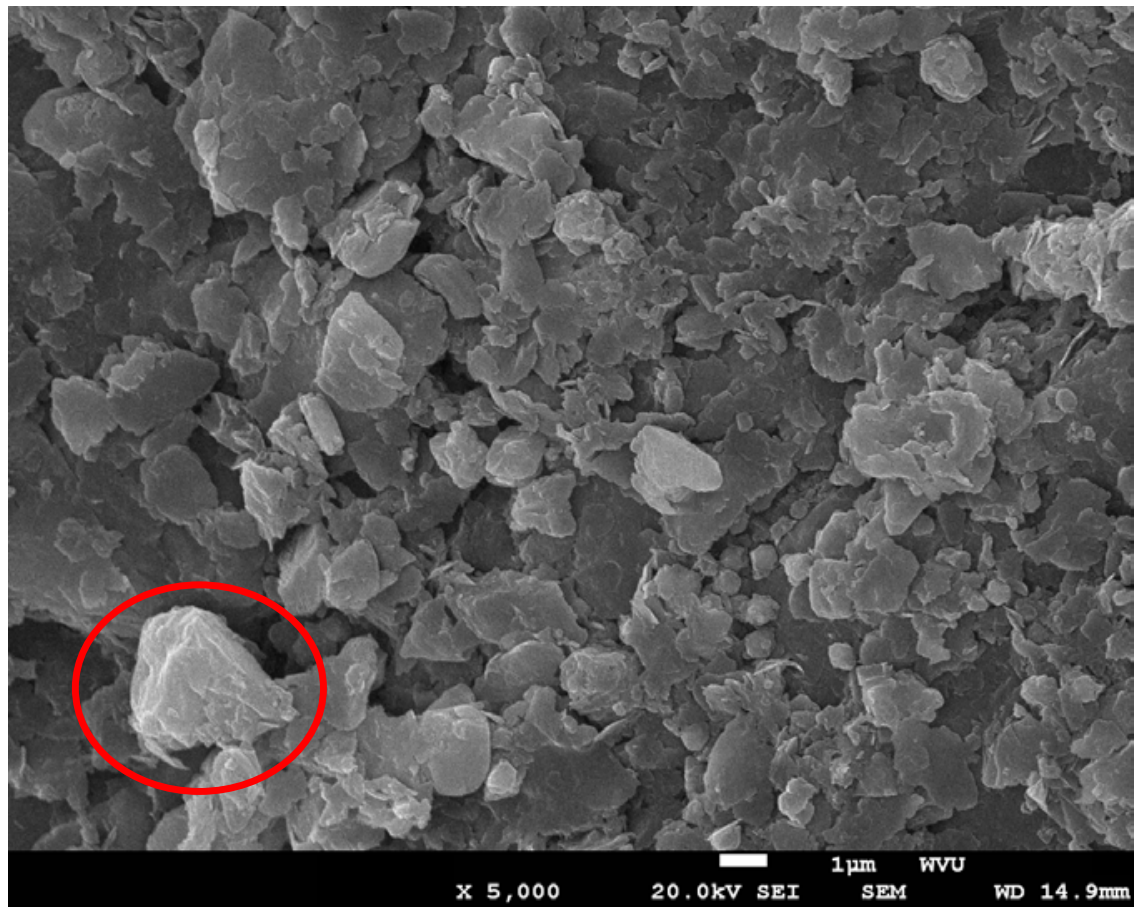

Figure 6.36 SEM image of the water treatment specimen for the eighth depth interval of Well A at 5000X 


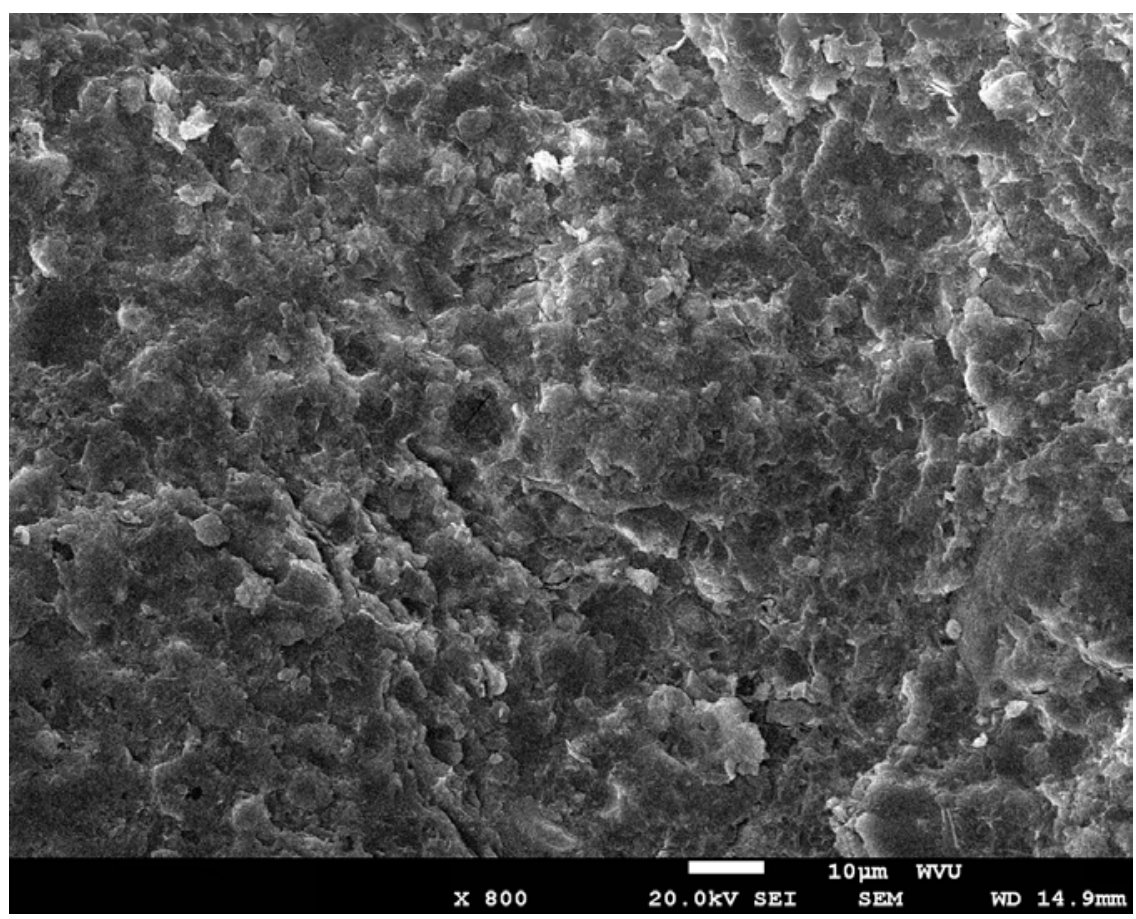

Figure 6.37 SEM image of the water treatment specimen for the ninth depth interval of Well A at 800X

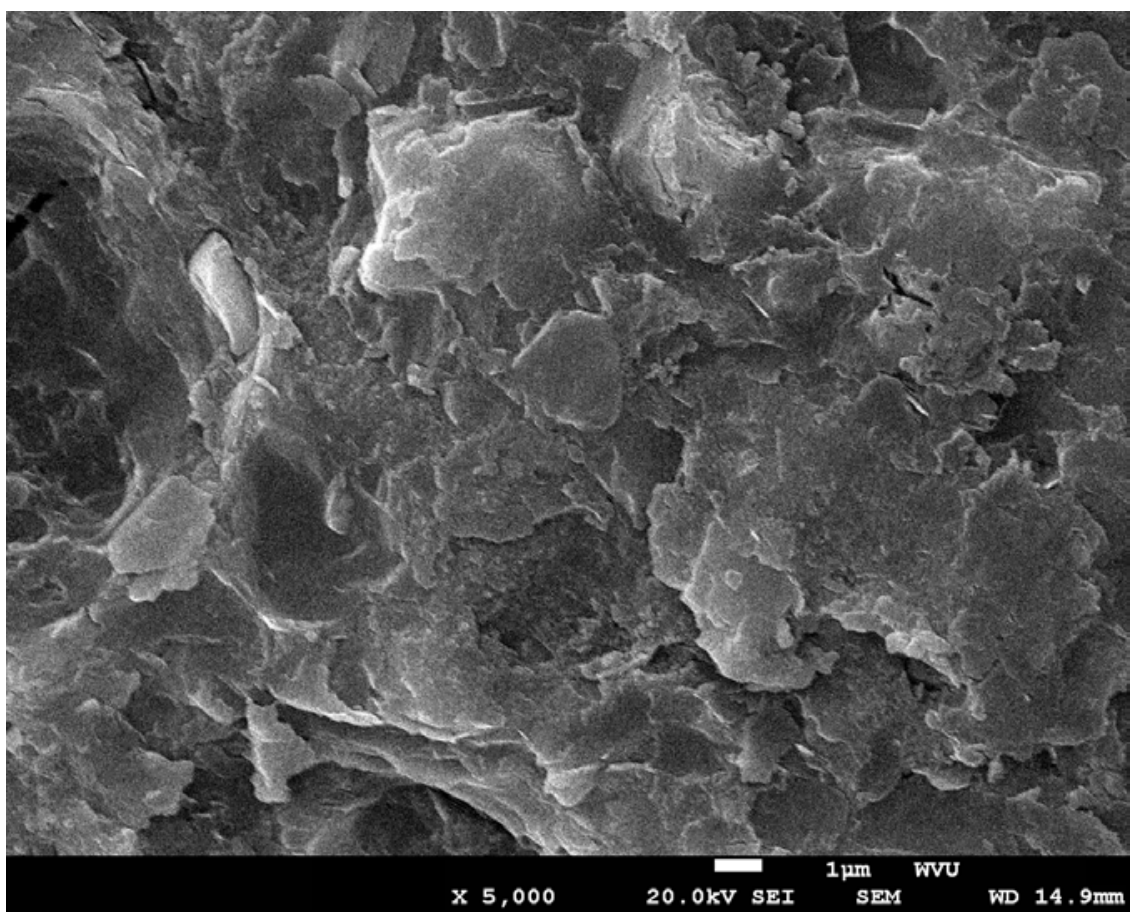

Figure 6.38 SEM image of the water treatment specimen for the ninth depth interval of Well A at 5000X 


\section{Monongalia County Well A Aquagel@ Alteration}

The samples discussed in this section underwent an Aquagel® treatment test. Samples from nine depth intervals of Monongalia County Well A soaked overnight in an Aquagel ${ }^{\circledR}$ and distilled water suspension. The purpose of this test was to observe the effect the clay additive on the elemental composition of the Marcellus shale. Aquagel ${ }^{\circledR}$ is added to many drilling muds used in the oil and natural gas industry. The elemental composition was evaluated using EDX, and the ranges in weight percent for each element found in the Aquagel® treatment test samples are listed in Table 6.3.

\begin{tabular}{|c|c|c|c|}
\hline \multicolumn{4}{|c|}{ Monongalia County Well A (Aquagel $\left.{ }^{\circledR}\right)$} \\
\hline Element & Weight\% & Sample & Range \\
\hline \multirow{2}{*}{ Al } & 0.54 & $3 A$ & \multirow{2}{*}{13.18} \\
\hline & 13.72 & $2 \mathrm{~A}$ & \\
\hline \multirow{2}{*}{ C } & 14.40 & $3 A$ & \multirow{2}{*}{14.41} \\
\hline & 28.81 & $5 A$ & \\
\hline \multirow{2}{*}{$\mathrm{Ca}$} & 0.63 & $6 \mathrm{~A}$ & \multirow{2}{*}{8.21} \\
\hline & 8.84 & $1 \mathrm{~A}$ & \\
\hline \multirow{2}{*}{$\mathrm{Fe}$} & 0.80 & $7 A$ & \multirow{2}{*}{32.86} \\
\hline & 33.66 & $3 A$ & \\
\hline \multirow{2}{*}{ K } & 1.79 & $2 \mathrm{~A}$ & \multirow{2}{*}{3.44} \\
\hline & 5.23 & $4 \mathrm{~A}$ & \\
\hline \multirow{2}{*}{ Mg } & 0.59 & $8 \mathrm{~A}$ & \multirow{2}{*}{4.72} \\
\hline & 5.31 & $2 A$ & \\
\hline \multirow{2}{*}{$\mathrm{Na}$} & 0.43 & $8 \mathrm{~A}$ & \multirow{2}{*}{1.46} \\
\hline & 1.89 & $4 \mathrm{~A}$ & \\
\hline \multirow{2}{*}{0} & 14.40 & $3 A$ & \multirow{2}{*}{38.76} \\
\hline & 53.16 & $1 \mathrm{~A}$ & \\
\hline$P$ & 3.67 & $1 \mathrm{~A}$ & 3.67 \\
\hline \multirow{2}{*}{$\mathrm{S}$} & 1.99 & $8 \mathrm{~A}$ & \multirow{2}{*}{33.14} \\
\hline & 35.13 & $3 A$ & \\
\hline \multirow{2}{*}{ Si } & 1.87 & $3 A$ & \multirow{2}{*}{42.14} \\
\hline & 44.01 & $4 \mathrm{~A}$ & \\
\hline \multirow{2}{*}{$\mathrm{Ti}$} & 0.33 & $9 A$ & \multirow{2}{*}{0.69} \\
\hline & 1.02 & $1 \mathrm{~A}$ & \\
\hline
\end{tabular}

Table 6.3 Weight percent ranges for each element found in the Monongalia County Well A Aquagel ${ }^{\circledR}$ treatment samples 


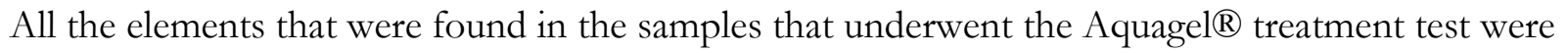
plotted against the corresponding depth in Figure 6.39. In both the control samples and the water treatment samples, aluminum and potassium followed a similar trend line. This similarity was present again in the Aquagel ${ }^{\circledR}$ treatment samples, and silicon produced a similar weight percent curve as well. Another set of parallel elemental weight percent data included iron and sulfur. This is a clear indication this set of samples obtained the mineral pyrite $\left(\mathrm{FeS}_{2}\right)$ in the third depth interval. The weight percent data for magnesium was similar to iron and sulfur also. The weight percent values for sodium and titanium wre complimentary, as the weights of the elements increased at the same depth intervals.

Samples that underwent the Aquagel ${ }^{\circledR}$ treatment test were photographed using the SEM, and they are seen below in Figure 6.40 through Figure 6.57. Each image was taken at a magnification of 800X and 5000X. The images for this set of samples remained consistent with the control samples and water treatments samples concerning the presence of many tiny pores and a layered surface. A large quartz structure was identified in Figure 6.49. The presence of quartz $\left(\mathrm{SiO}_{2}\right)$ at fifth depth interval was supported by the silicon and oxygen trends in Figure 6.39. Calcite structures were circled in the two images for the eighth depth interval. They can be seen at $800 \mathrm{X}$ and $5000 \mathrm{X}$ in Figure 6.54 and Figure 6.55 respectively. The weight percent data line showed that calcium reappeared in the eighth depth interval. This further supported the mineral identification in the corresponding images. 


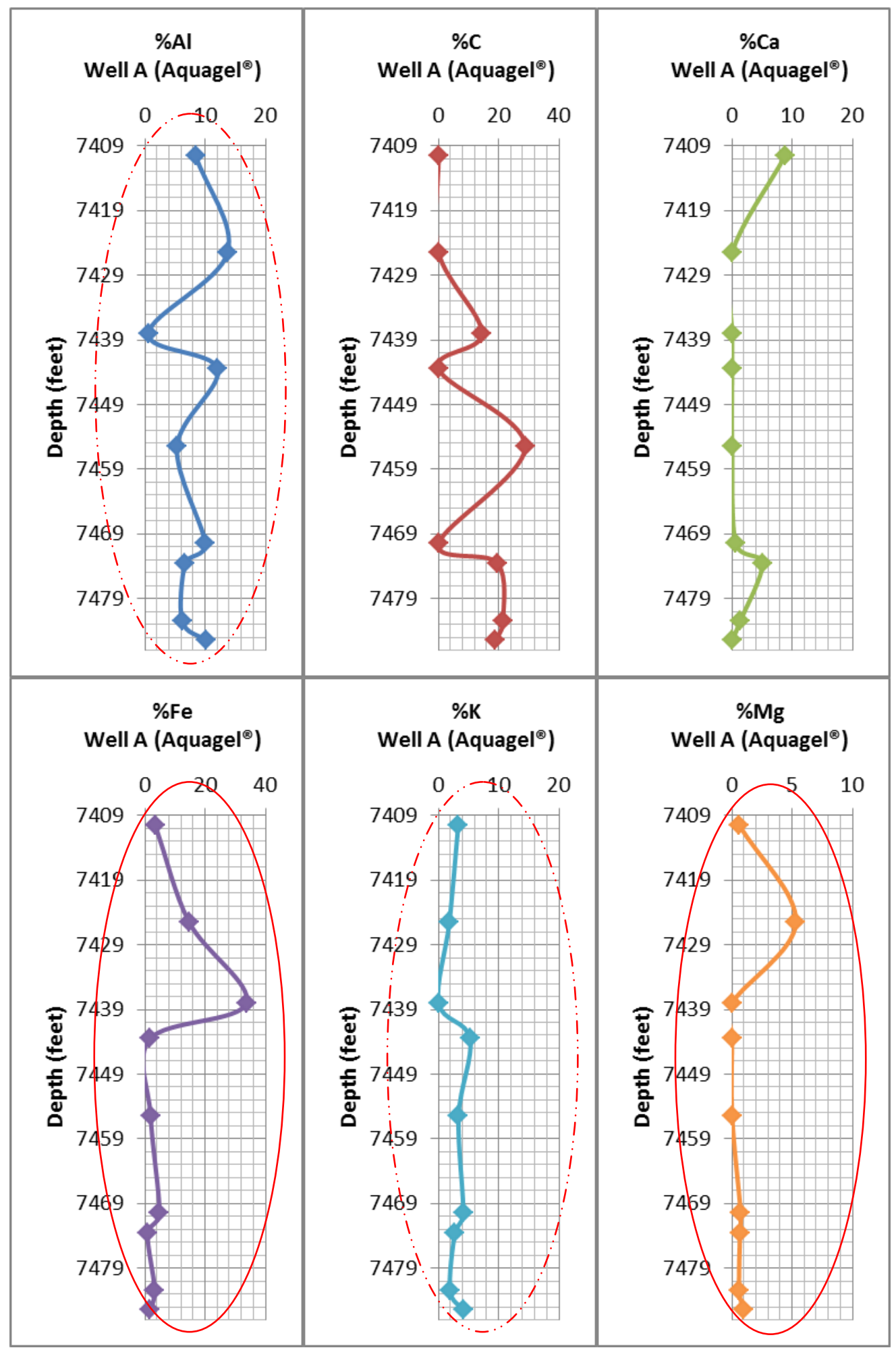




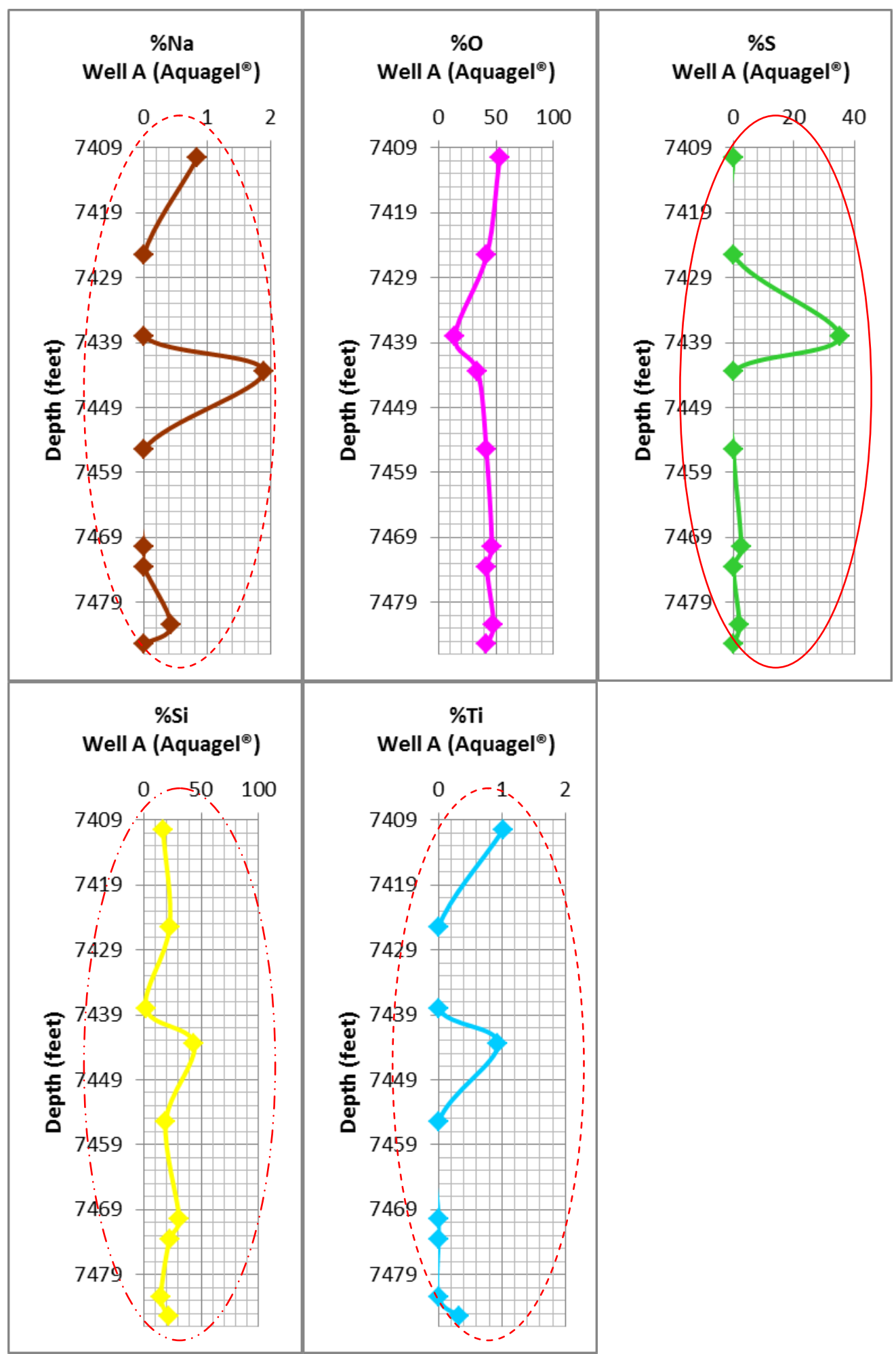

Figure 6.39 Weight percent of each element found in Monongalia County Well A Aquagel ${ }^{\circledR}$ treatment samples plotted against the corresponding depth 
Monongalia County Well A Aquagel@ Alteration SEM Photographs

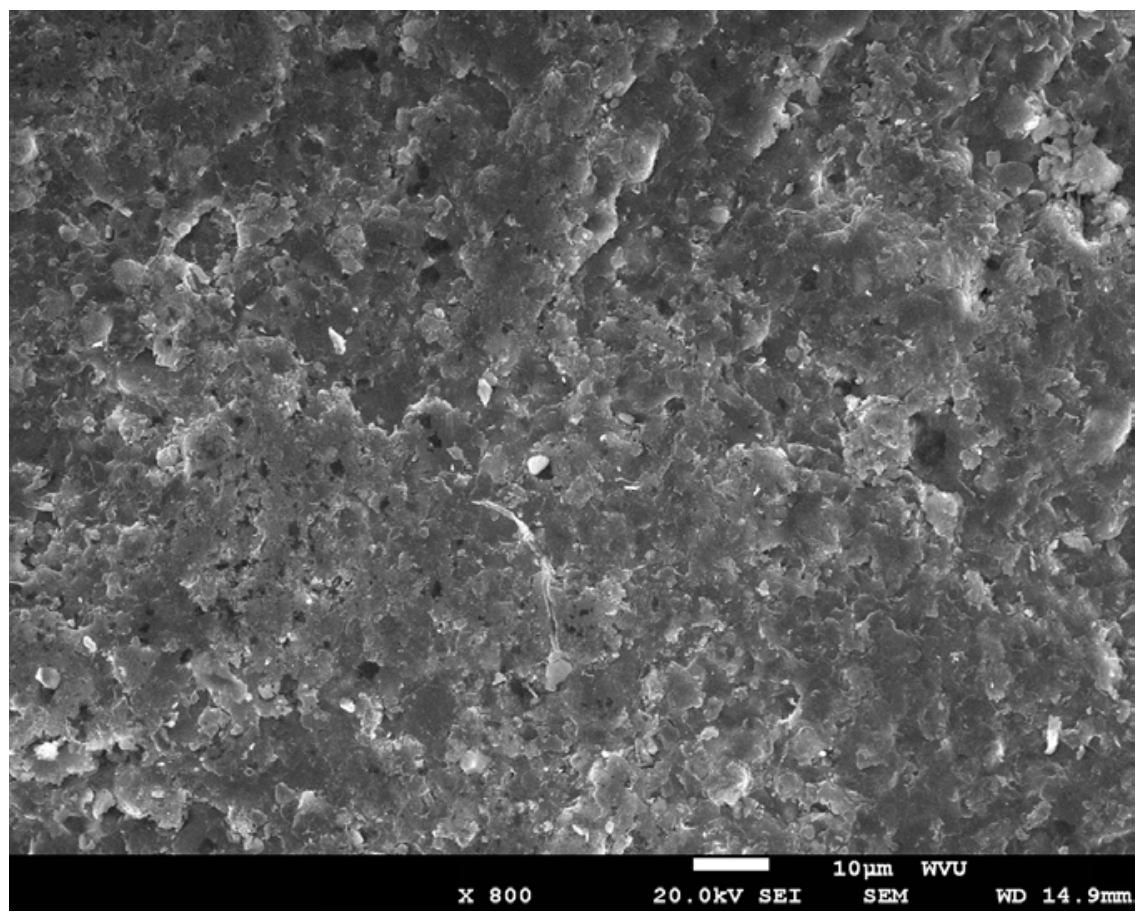

Figure 6.40 SEM image of the Aquagel ${ }^{\circledR}$ treatment sample for the first depth interval of Well $A$ at $800 \mathrm{X}$

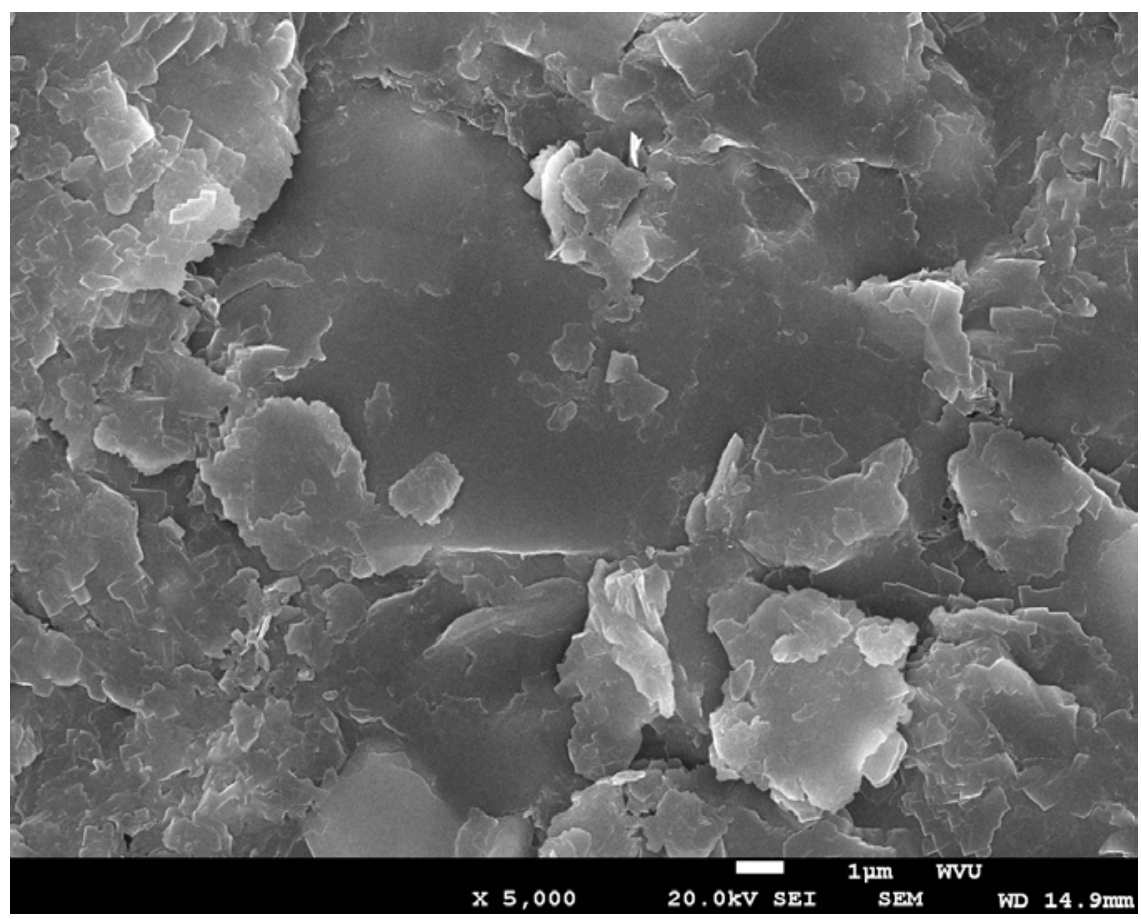

Figure 6.41 SEM image of the Aquagel ${ }^{\circledR}$ treatment sample for the first depth interval of Well $\mathrm{A}$ at $5000 \mathrm{X}$ 


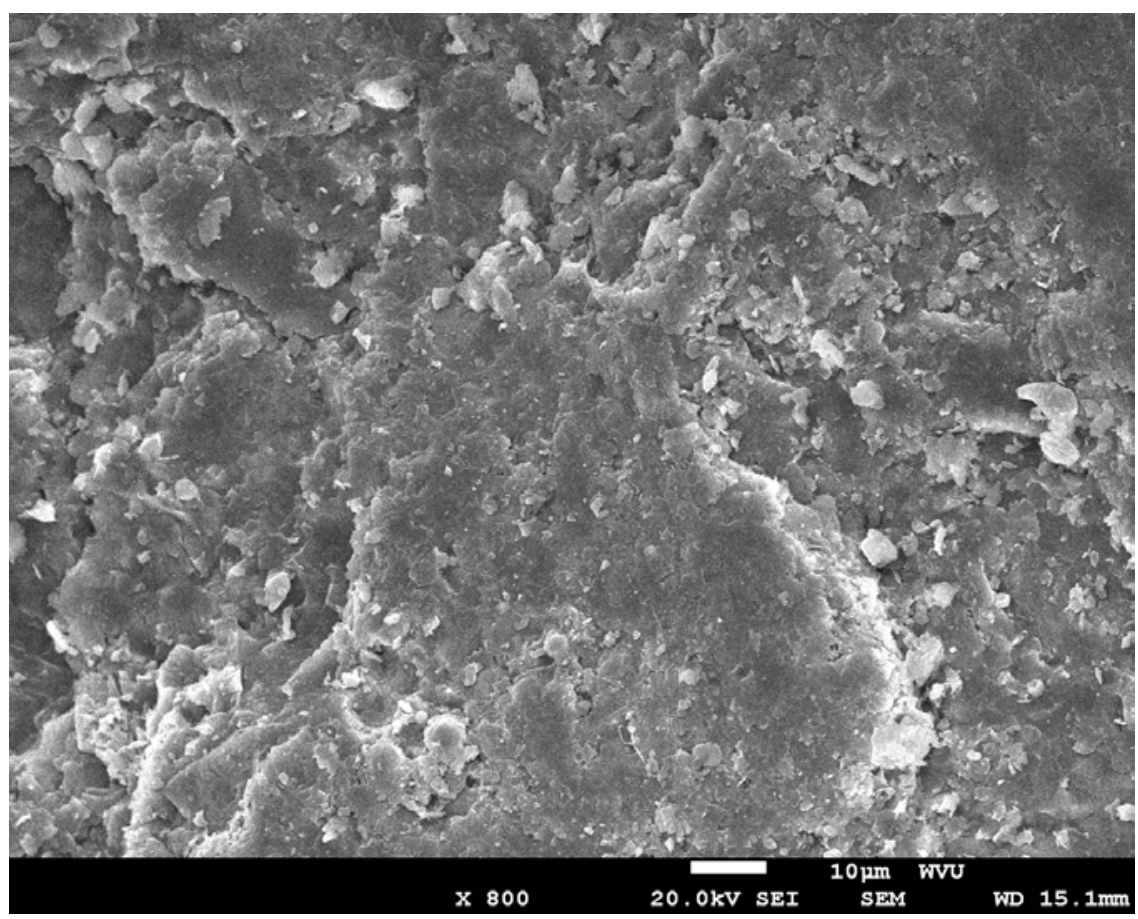

Figure 6.42 SEM image of the Aquagel® treatment sample for the second depth interval of Well $\mathrm{A}$ at $800 \mathrm{X}$

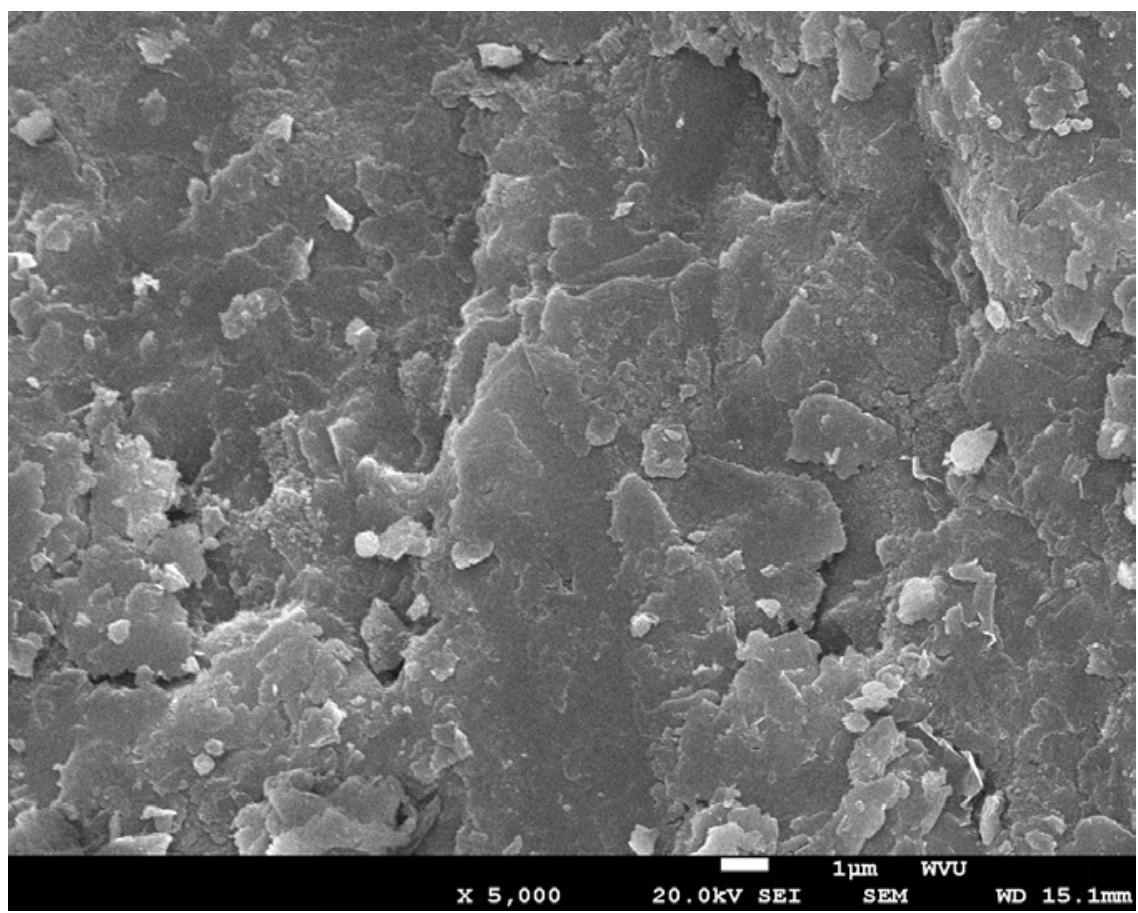

Figure 6.43 SEM image of the Aquagel® treatment sample for the second depth interval of Well A at 5000X 


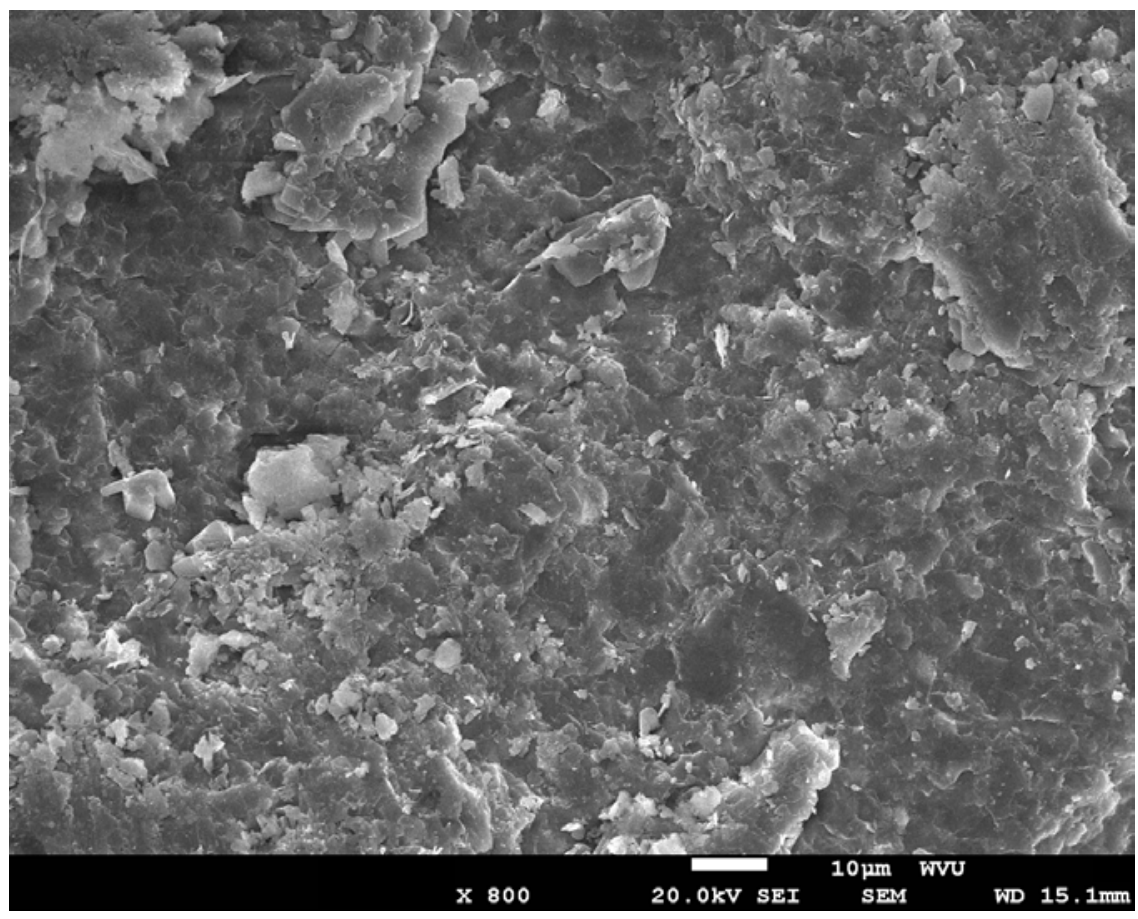

Figure 6.44 SEM image of the Aquagel ${ }^{\circledR}$ treatment sample for the third depth interval of Well $\mathrm{A}$ at $800 \mathrm{X}$

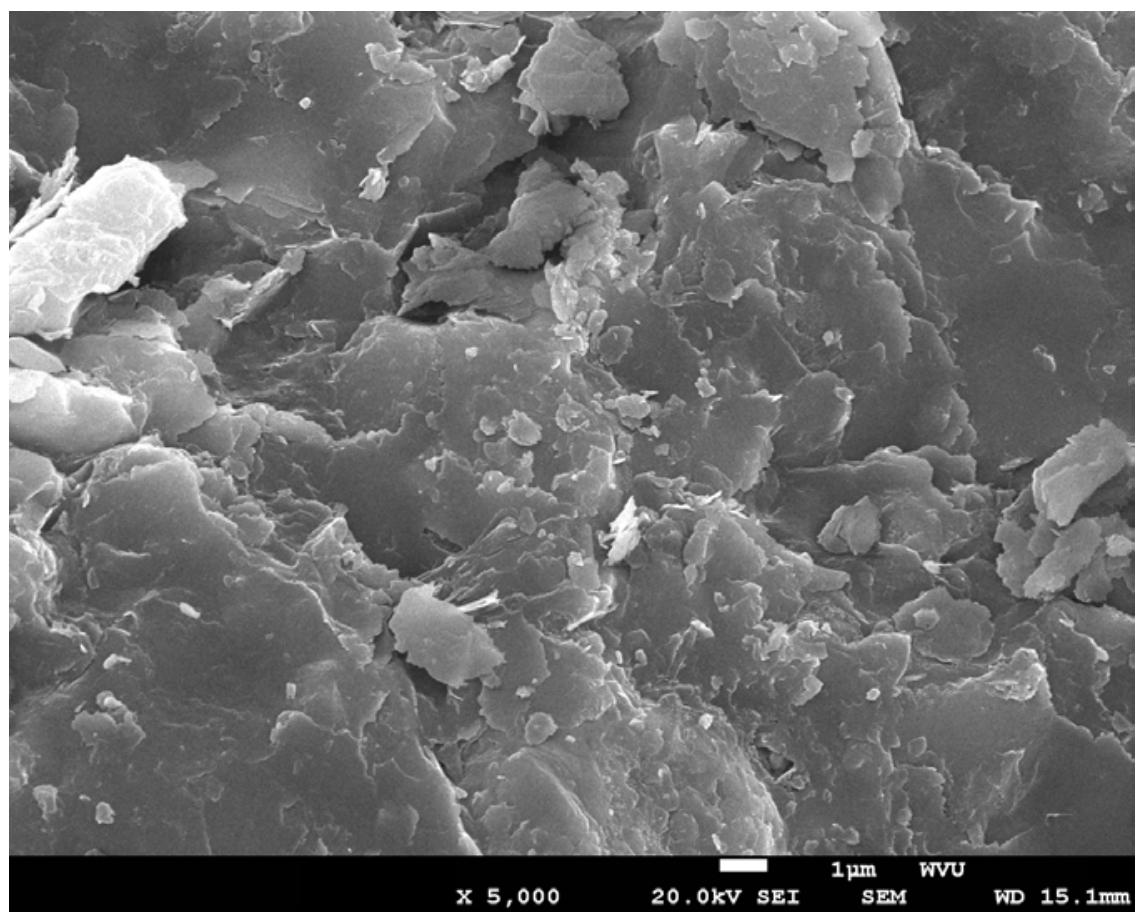

Figure 6.45 SEM image of the Aquagel ${ }^{\circledR}$ treatment sample for the third depth interval of Well A at 5000X 


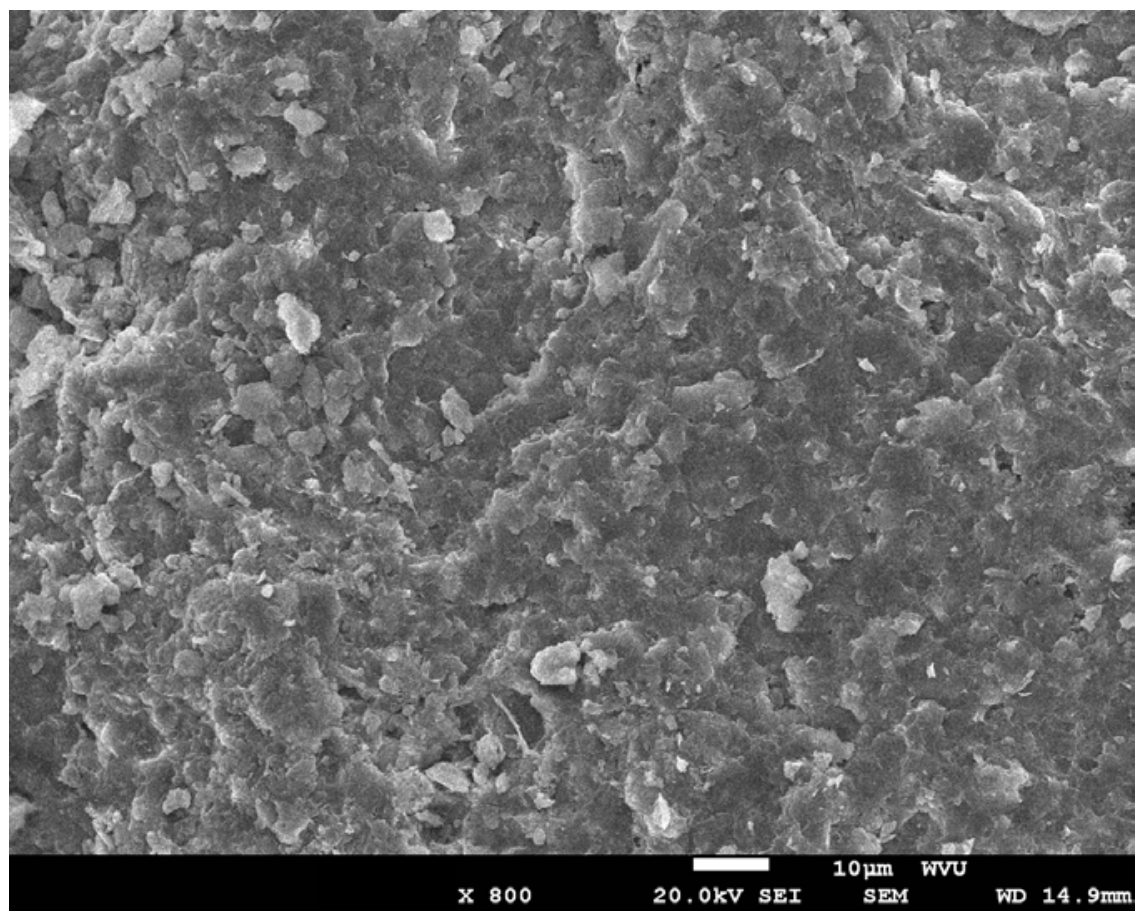

Figure 6.46 SEM image of the Aquagel ${ }^{\circledR}$ treatment sample for the fourth depth interval of Well $A$ at $800 X$

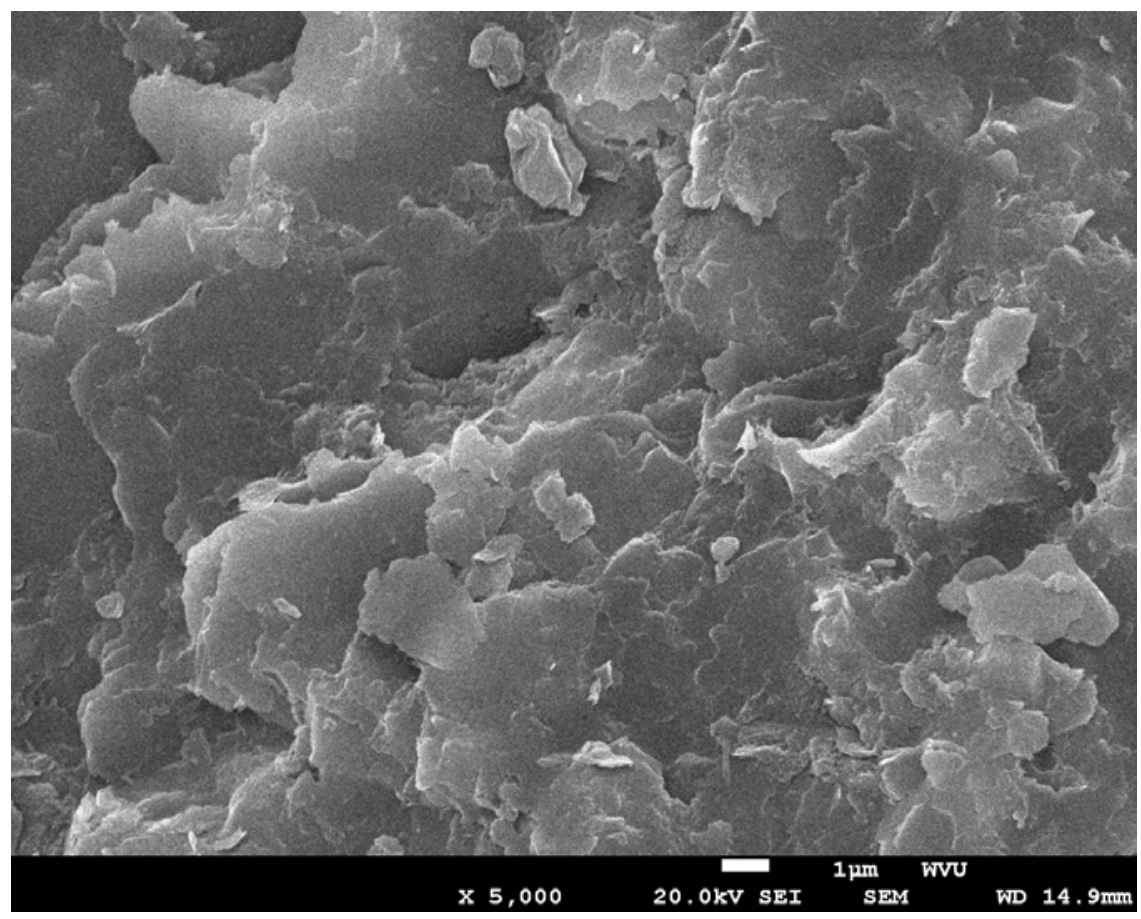

Figure 6.47 SEM image of the Aquagel ${ }^{\circledR}$ treatment sample for the fourth depth interval of Well A at 5000X 


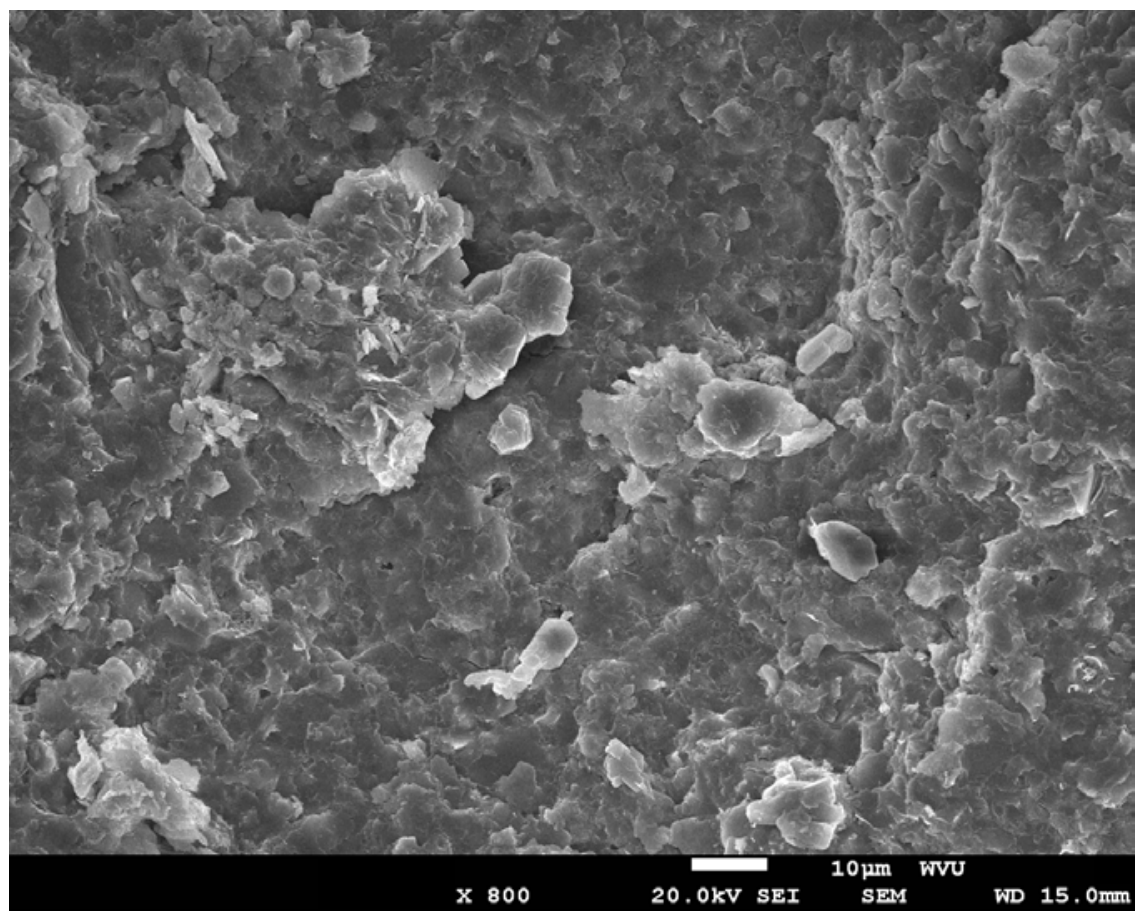

Figure 6.48 SEM image of the Aquagel ${ }^{\circledR}$ treatment sample for the fifth depth interval of Well A at 800X.

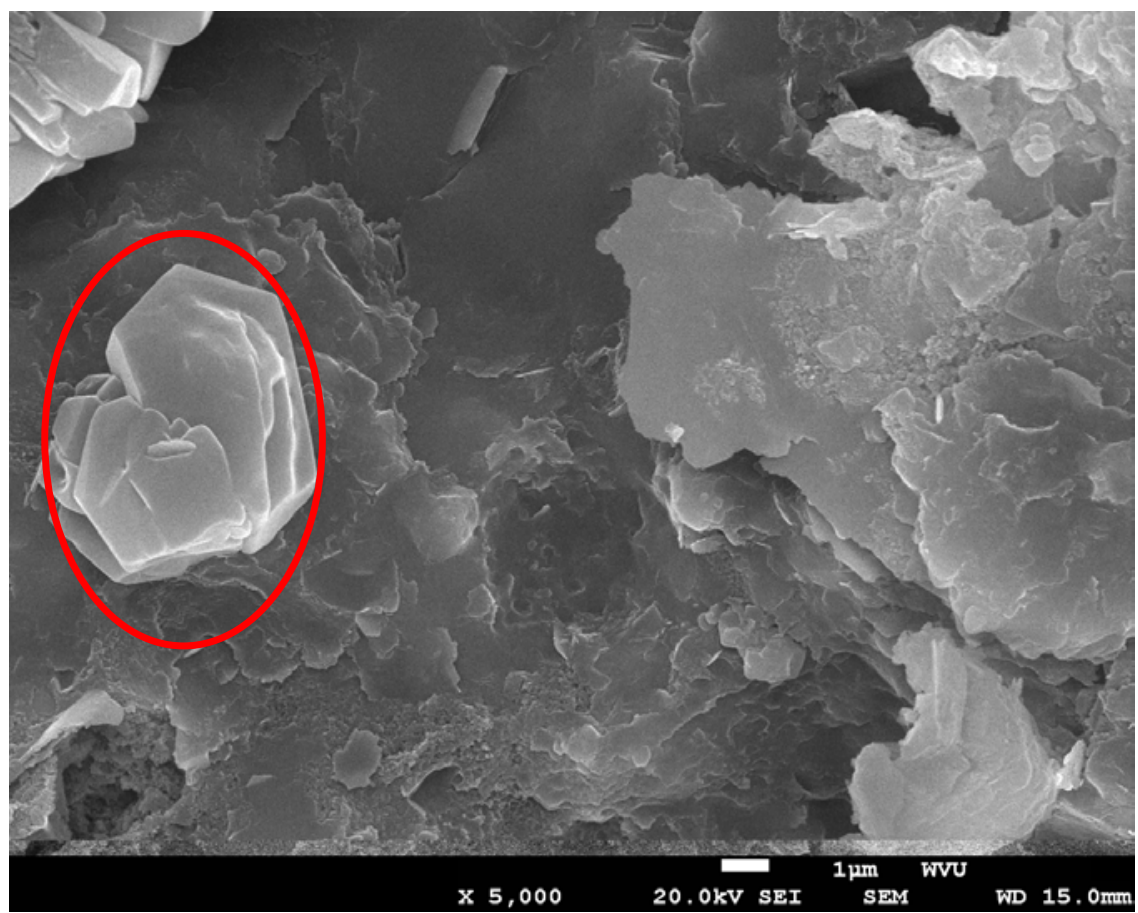

Figure 6.49 SEM image of the Aquagel® treatment sample for the fifth depth interval of Well A at 5000X 


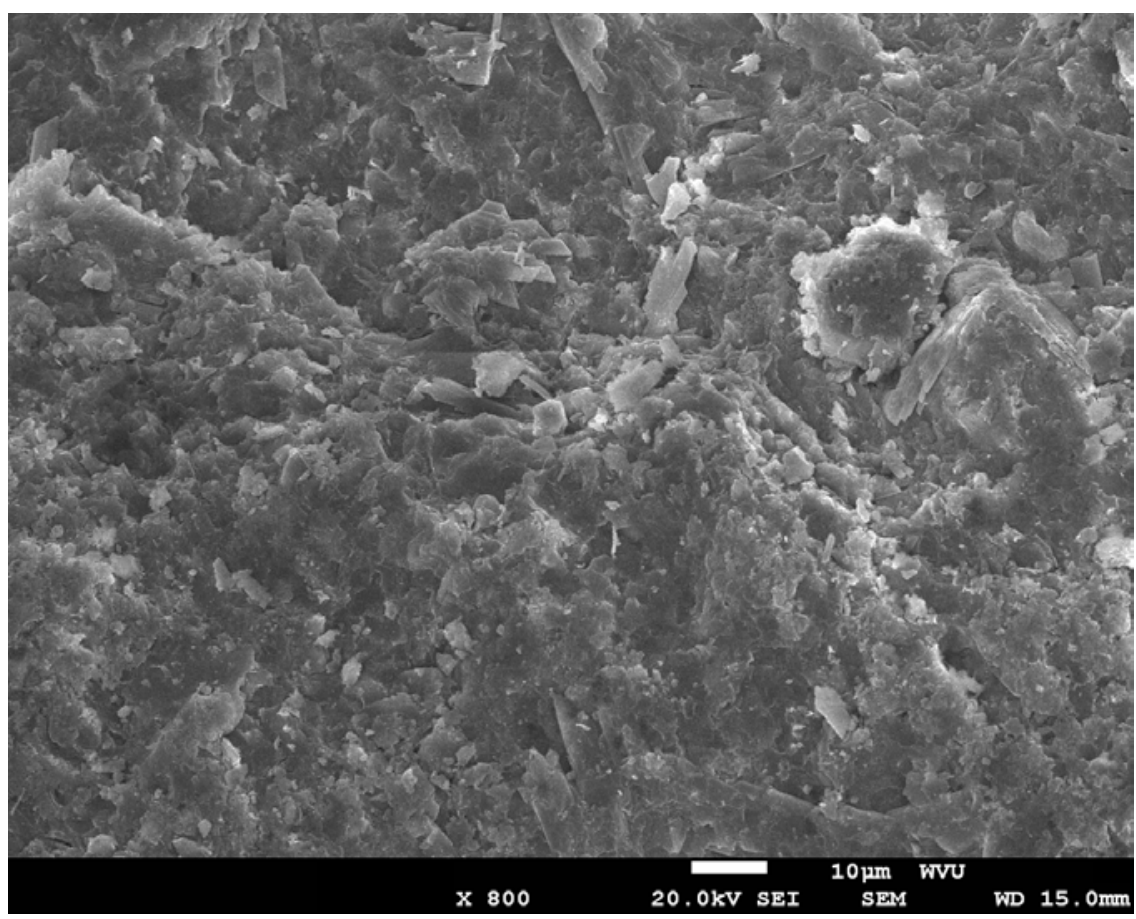

Figure 6.50 SEM image of the Aquagel ${ }^{\circledR}$ treatment sample for the sixth depth interval of Well $A$ at $800 \mathrm{X}$

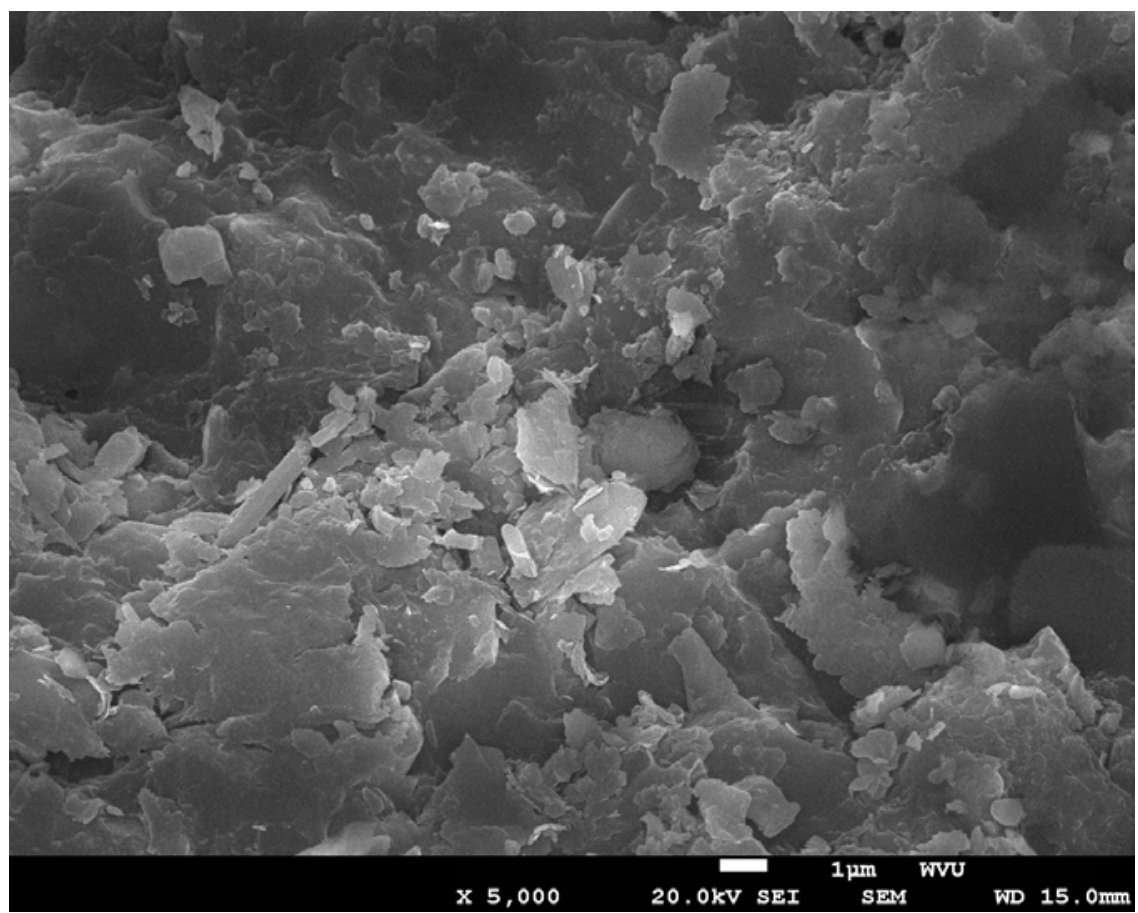

Figure 6.51 SEM image of the Aquagel ${ }^{\circledR}$ treatment sample for the sixth depth interval of Well A at 5000X 


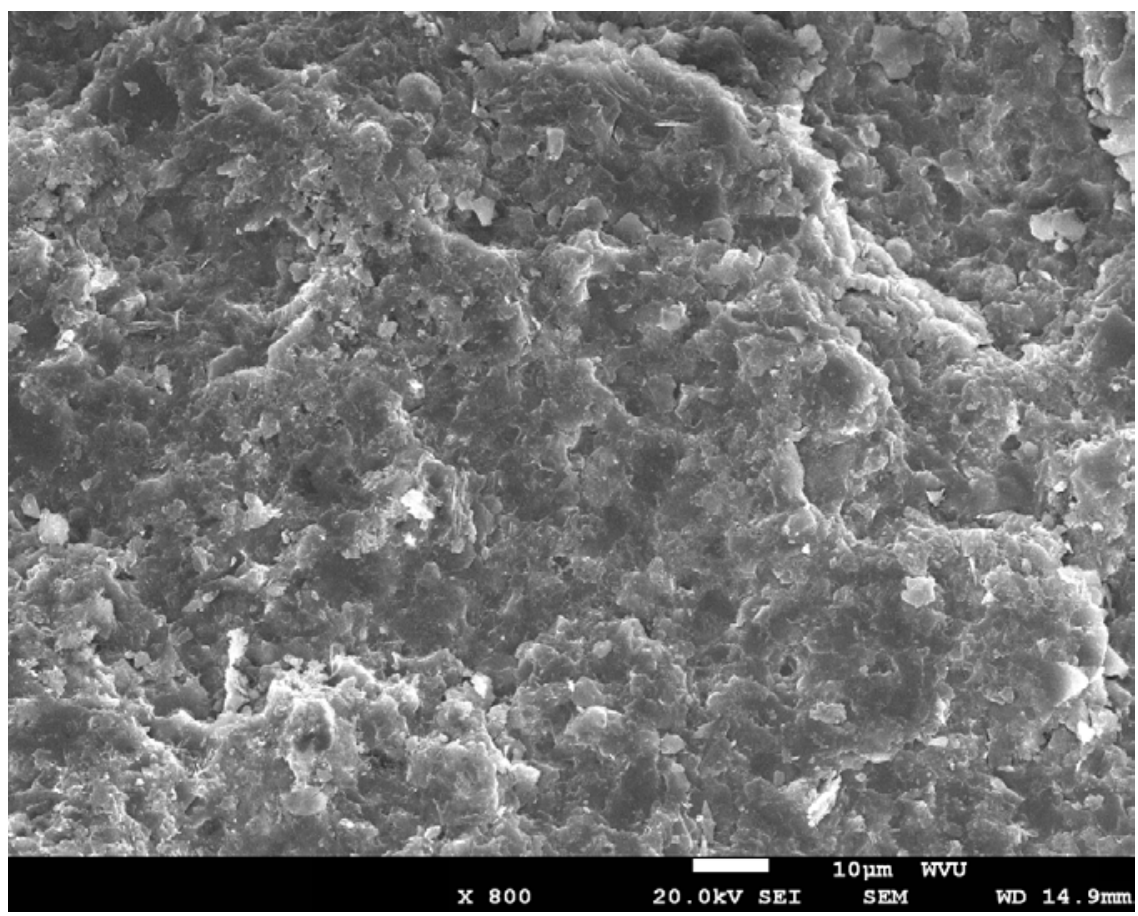

Figure 6.52 SEM image of the Aquagel ${ }^{\circledR}$ treatment sample for the seventh depth interval of Well A at 800X.

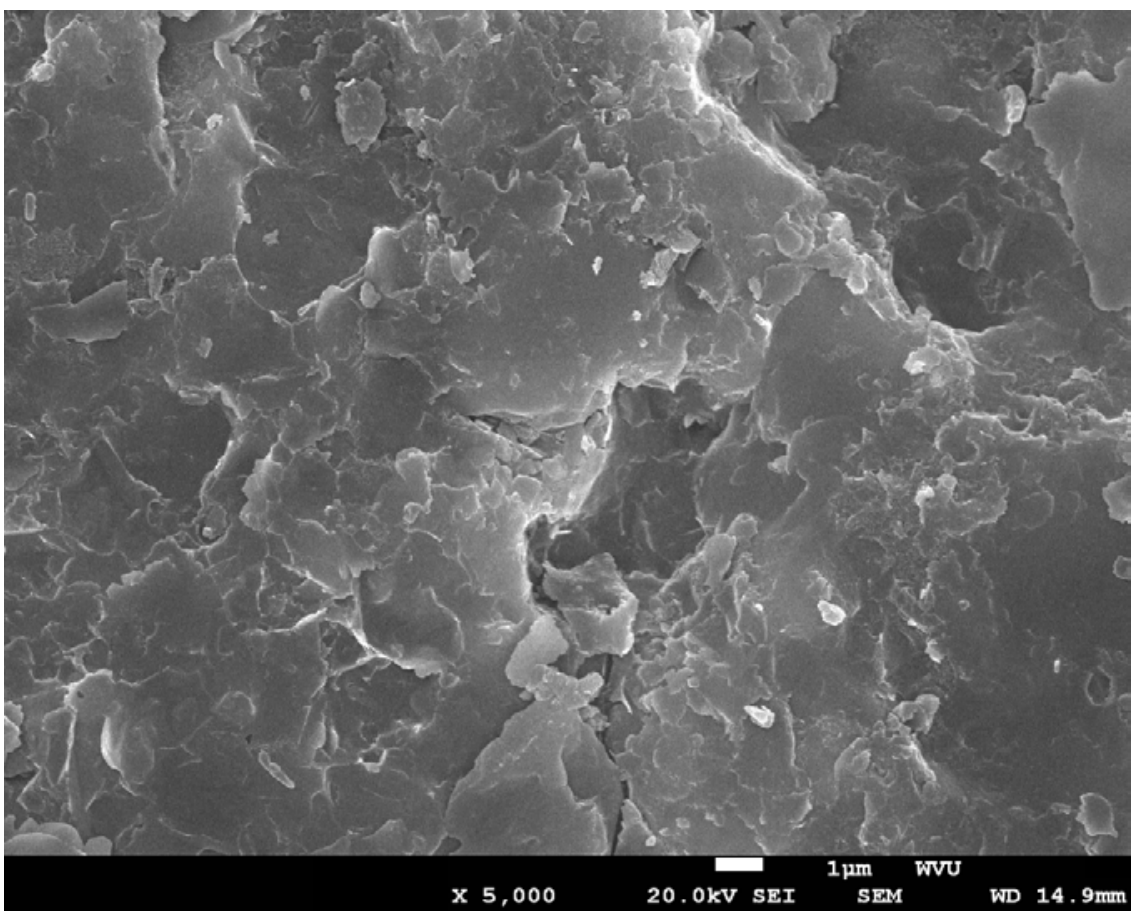

Figure 6.53 SEM image of the Aquagel ${ }^{\circledR}$ treatment sample for the seventh depth interval of Well $A$ at 5000X 


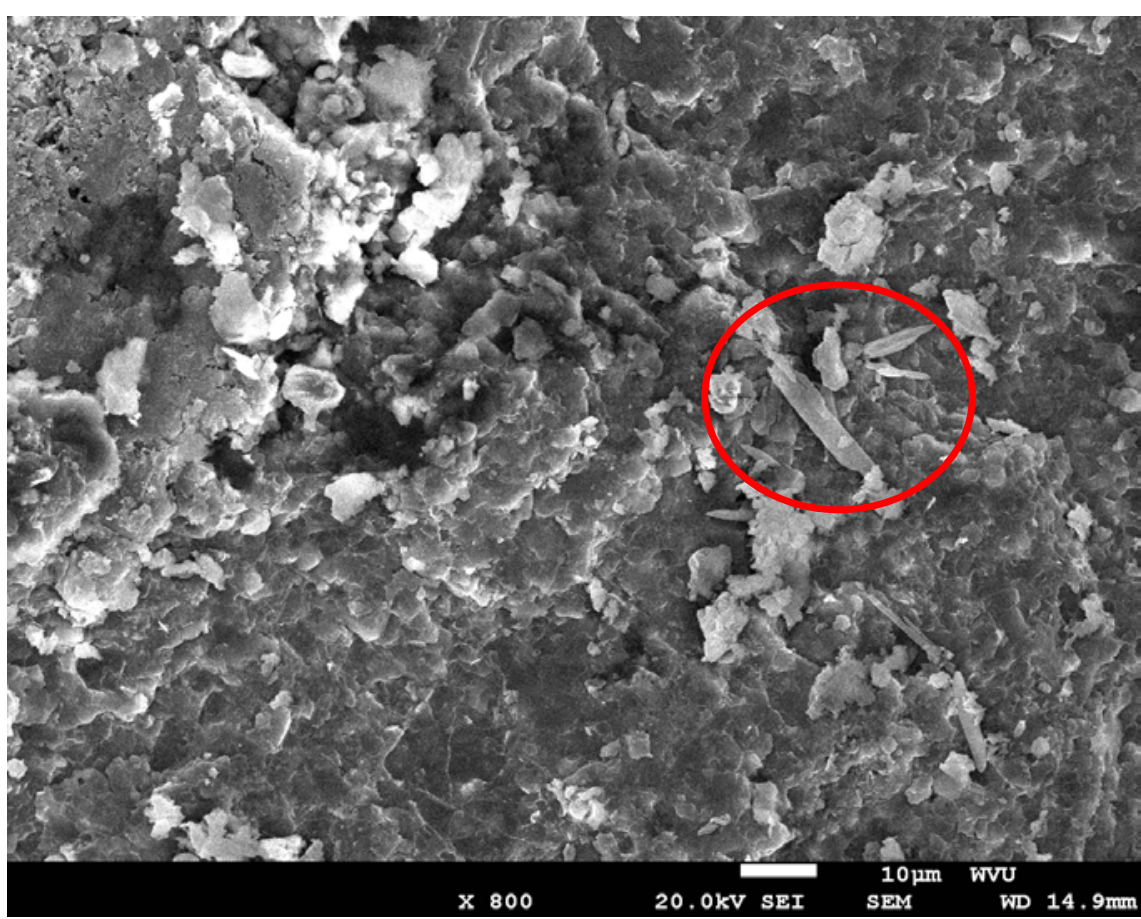

Figure 6.54 SEM image of the Aquagel ${ }^{\circledR}$ treatment sample for the eighth depth interval of Well $A$ at $800 \mathrm{X}$

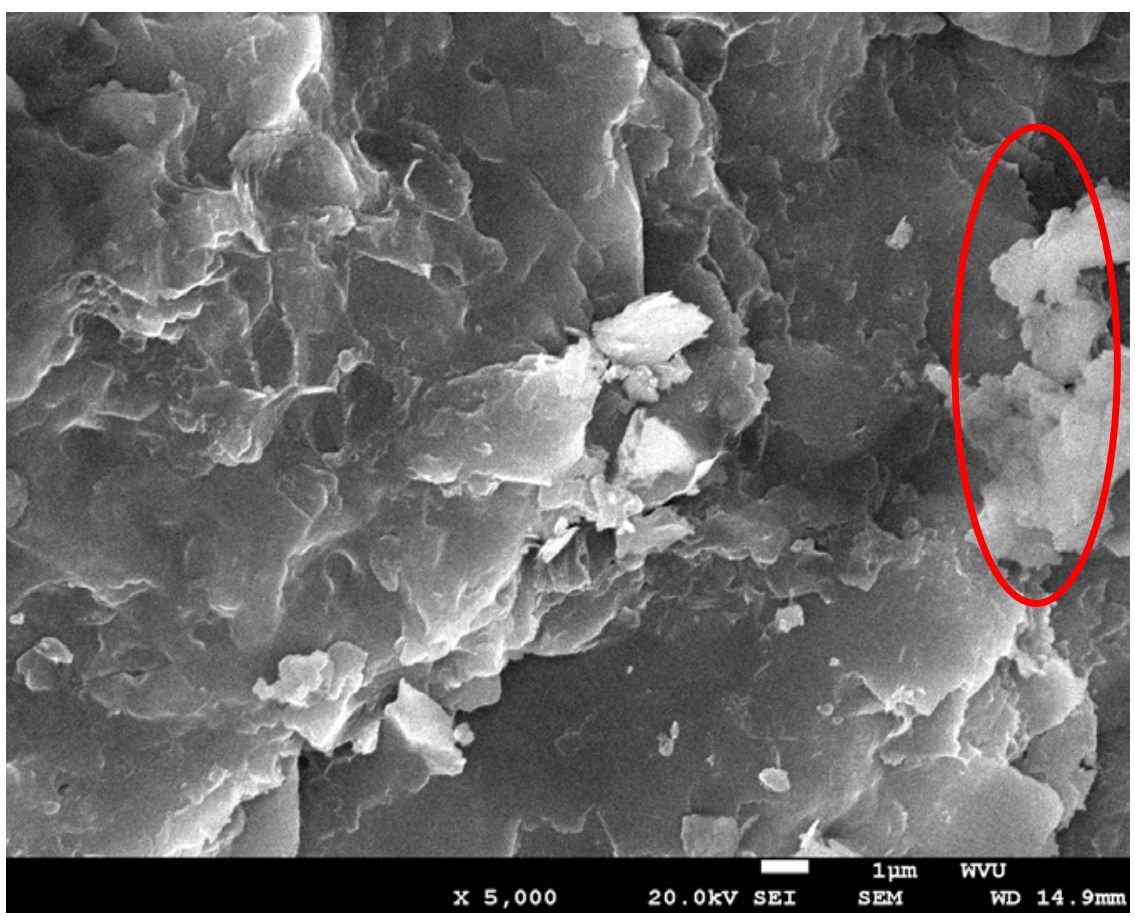

Figure 6.55 SEM image of the Aquagel ${ }^{\circledR}$ treatment sample for the eighth depth interval of Well $A$ at 5000X 


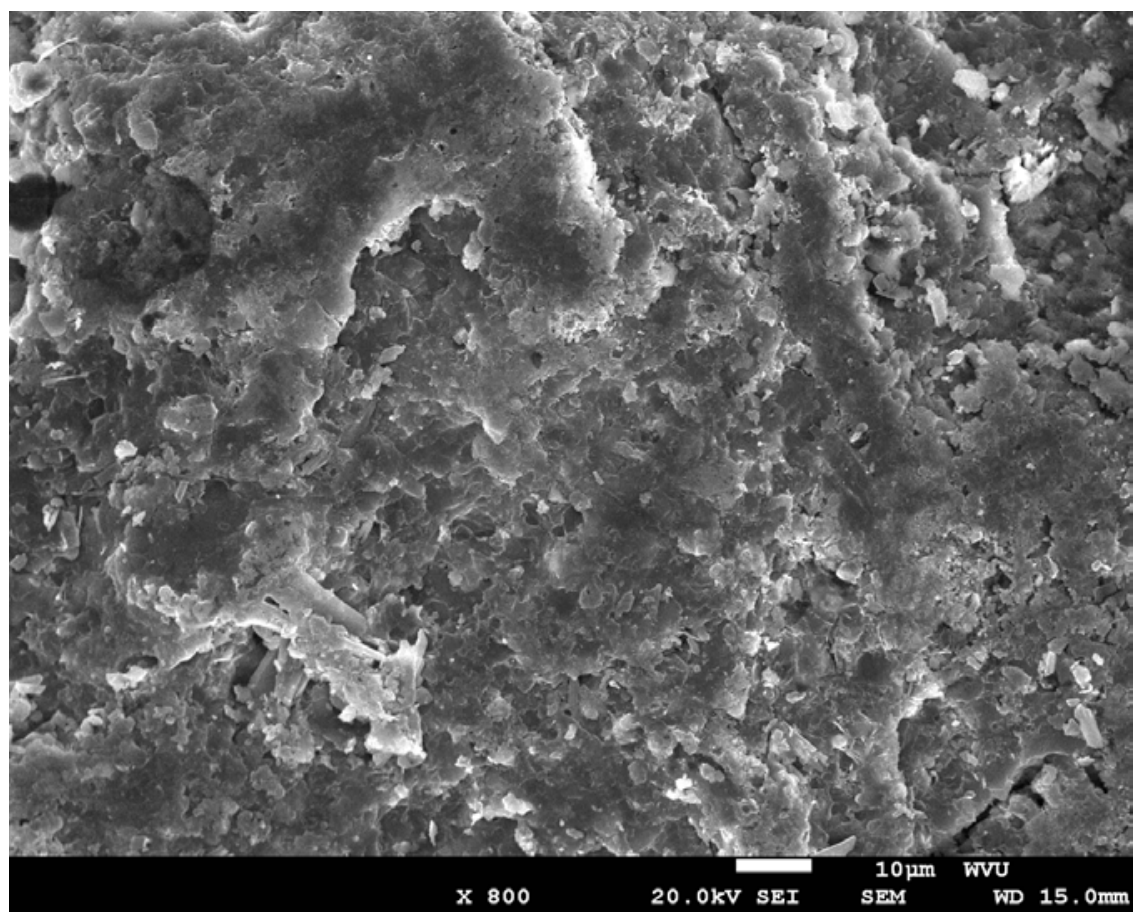

Figure 6.56 SEM image of the Aquagel ${ }^{\circledR}$ treatment sample for the ninth depth interval of Well $A$ at $800 \mathrm{X}$

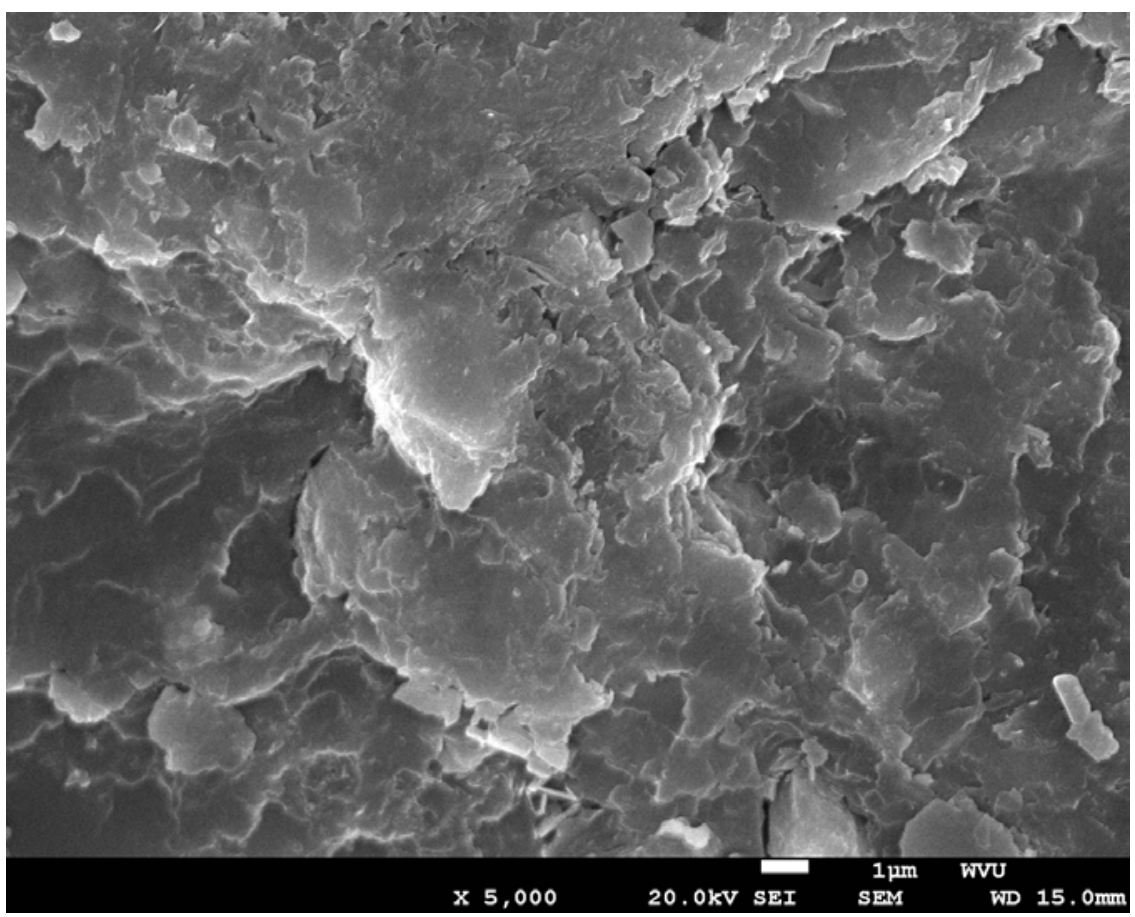

Figure 6.57 SEM image of the Aquagel ${ }^{\circledR}$ treatment sample for the ninth depth interval of Well $A$ at 5000X 


\section{Monongalia County Well A Quik-Gel@ Alteration}

The samples discussed in this section underwent a Quik-Gel® treatment test. Samples from nine depth intervals of Monongalia County Well A soaked overnight in a Quik-Gel® and distilled water suspension. The purpose of this test was to observe the effect the clay additive on the elemental composition of the Marcellus shale. Quik-Gel® is added to many drilling muds used in the oil and natural gas industry. The elemental composition was evaluated using EDX, and the ranges in weight percent for each element found in the Quik-Gel® treatment test samples are listed in Table 6.4.

\begin{tabular}{|c|c|c|c|}
\hline \multicolumn{4}{|c|}{ Monongalia County Well A (Quik-Gel $\left.{ }^{\circledR}\right)$} \\
\hline Element & Weight\% & Sample & Range \\
\hline \multirow{2}{*}{ Al } & 3.87 & $9 A$ & \multirow{2}{*}{8.96} \\
\hline & 12.83 & $8 \mathrm{~A}$ & \\
\hline \multirow{2}{*}{ C } & 8.91 & $2 \mathrm{~A}$ & \multirow{2}{*}{22.41} \\
\hline & 31.32 & $1 \mathrm{~A}$ & \\
\hline \multirow{2}{*}{$\mathrm{Ca}$} & 0.29 & $7 A$ & \multirow{2}{*}{29.74} \\
\hline & 30.03 & $9 A$ & \\
\hline \multirow{2}{*}{$\mathrm{Fe}$} & 0.58 & $3 A$ & \multirow{2}{*}{11.32} \\
\hline & 11.90 & $2 \mathrm{~A}$ & \\
\hline \multirow{2}{*}{ K } & 0.51 & $7 A$ & \multirow{2}{*}{6.94} \\
\hline & 7.45 & $6 \mathrm{~A}$ & \\
\hline \multirow{2}{*}{ Mg } & 0.48 & $2 \mathrm{~A}$ & \multirow{2}{*}{9.97} \\
\hline & 10.45 & $9 A$ & \\
\hline \multirow{2}{*}{$\mathrm{Na}$} & 0.37 & $4 \mathrm{~A}$ & \multirow{2}{*}{0.08} \\
\hline & 0.45 & $2 \mathrm{~A}$ & \\
\hline \multirow{2}{*}{0} & 14.64 & $1 \mathrm{~A}$ & \multirow{2}{*}{44.71} \\
\hline & 59.35 & $7 \mathrm{~A}$ & \\
\hline \multirow{2}{*}{$S$} & 1.56 & $1 \mathrm{~A}$ & \multirow{2}{*}{3.99} \\
\hline & 5.55 & $2 \mathrm{~A}$ & \\
\hline \multirow{2}{*}{ Si } & 8.84 & $9 A$ & \multirow{2}{*}{44.43} \\
\hline & 53.27 & $3 \mathrm{~A}$ & \\
\hline \multirow{2}{*}{$\mathrm{Ti}$} & 0.58 & $8 \mathrm{~A}$ & \multirow{2}{*}{1.13} \\
\hline & 1.71 & $1 \mathrm{~A}$ & \\
\hline
\end{tabular}

Table 6.4 Weight percent ranges for each element found in the Monongalia County Well A Quik-Gel® treatment samples

All the elements that were found in the samples that underwent the Quik-Gel® treatment test were plotted against the corresponding depth in Figure 6.58. In the control samples, the water treatment 
test samples, and the Aquagel ${ }^{\circledR}$ treatment samples, aluminum and potassium followed a similar trend line, and this characteristic appeared again in this set of samples. Calcium and magnesium are both absent in every depth interval except for the ninth depth interval where the weight percent dramatically jumped. Sodium and oxygen increased and decreased in weight percent at the same depth intervals. Pyrite was present in the second depth interval as both the iron and sulfur data points increased at this particular segment.

All the samples subjected to the Quik-Gel® treatment test were studied in more detail in the photographs taken in the SEM (Figure 6.59 through Figure 6.76). Each image was taken at a magnification of $800 \mathrm{X}$ and 5000X. All the images showed a surface containing tiny pores and many layers; however, the samples from deeper depth intervals has a smoother surface when observed at a magnification of 5000X (Figure 6.72, Figure 6.74, and Figure 6.76). Calcite minerals were identified in the sixth and eighth depth interval as seen in Figure 6.69 and Figure 6.74 respectively. 


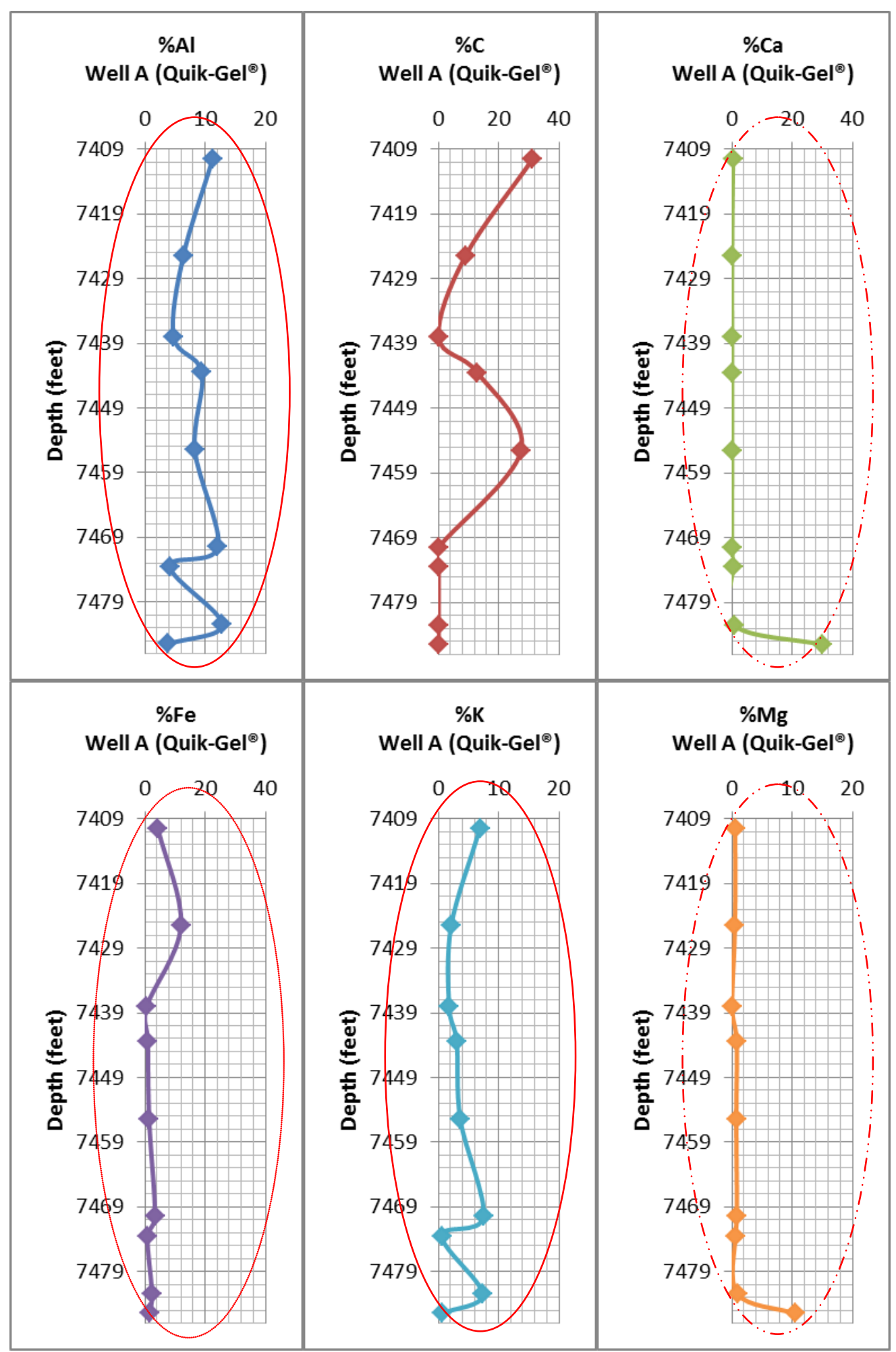




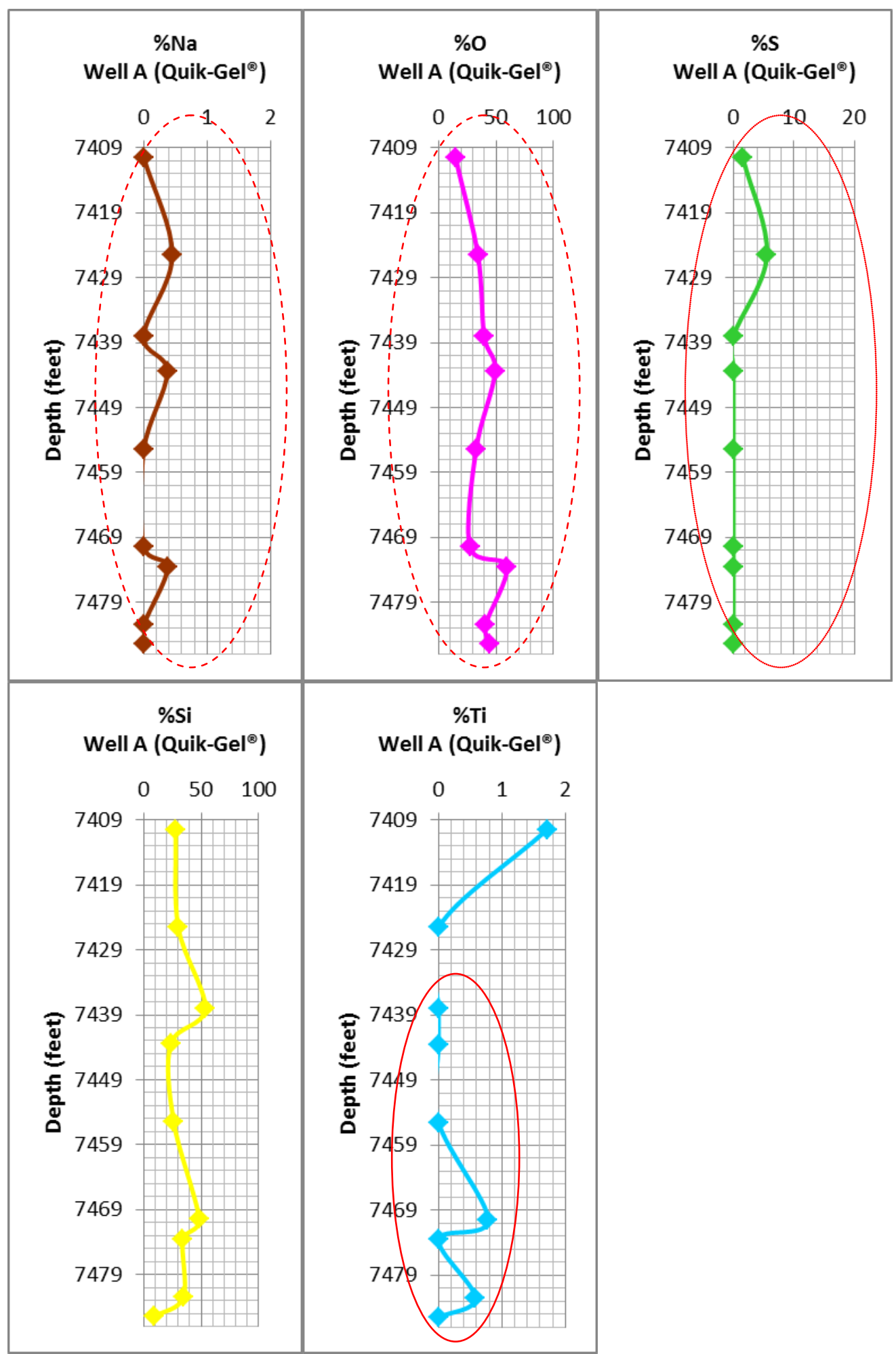

Figure 6.58 Weight percent of each element found in Monongalia County Well A Quik$\mathrm{Gel}{ }^{\circledR}$ treatment samples plotted against the corresponding depth 
Monongalia County Well A Quik-Gel@ Alteration SEM Photographs

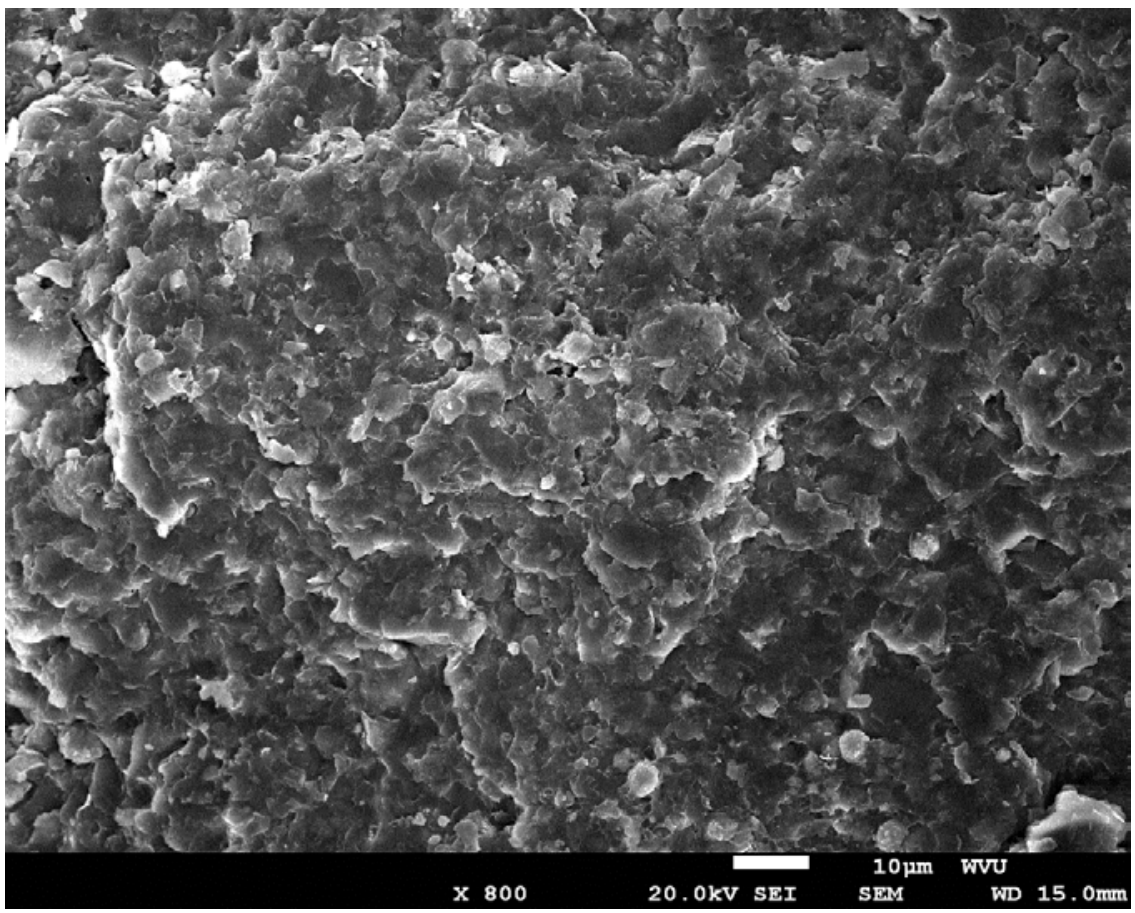

Figure 6.59 SEM image of the Quik-Gel® treatment sample for the first depth interval of Well $\mathrm{A}$ at $800 \mathrm{X}$

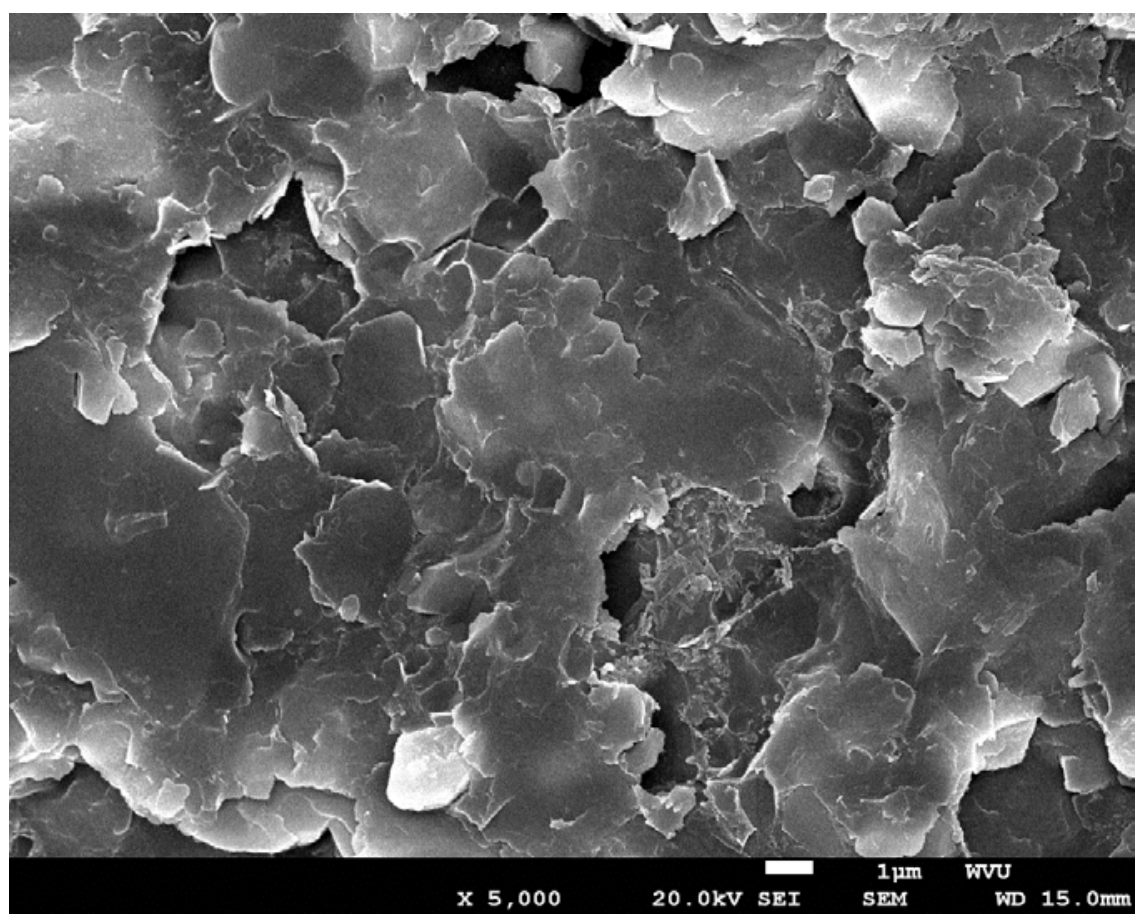

Figure 6.60 SEM image of the Quik-Gel® treatment sample for the first depth interval of Well $A$ at 5000X 


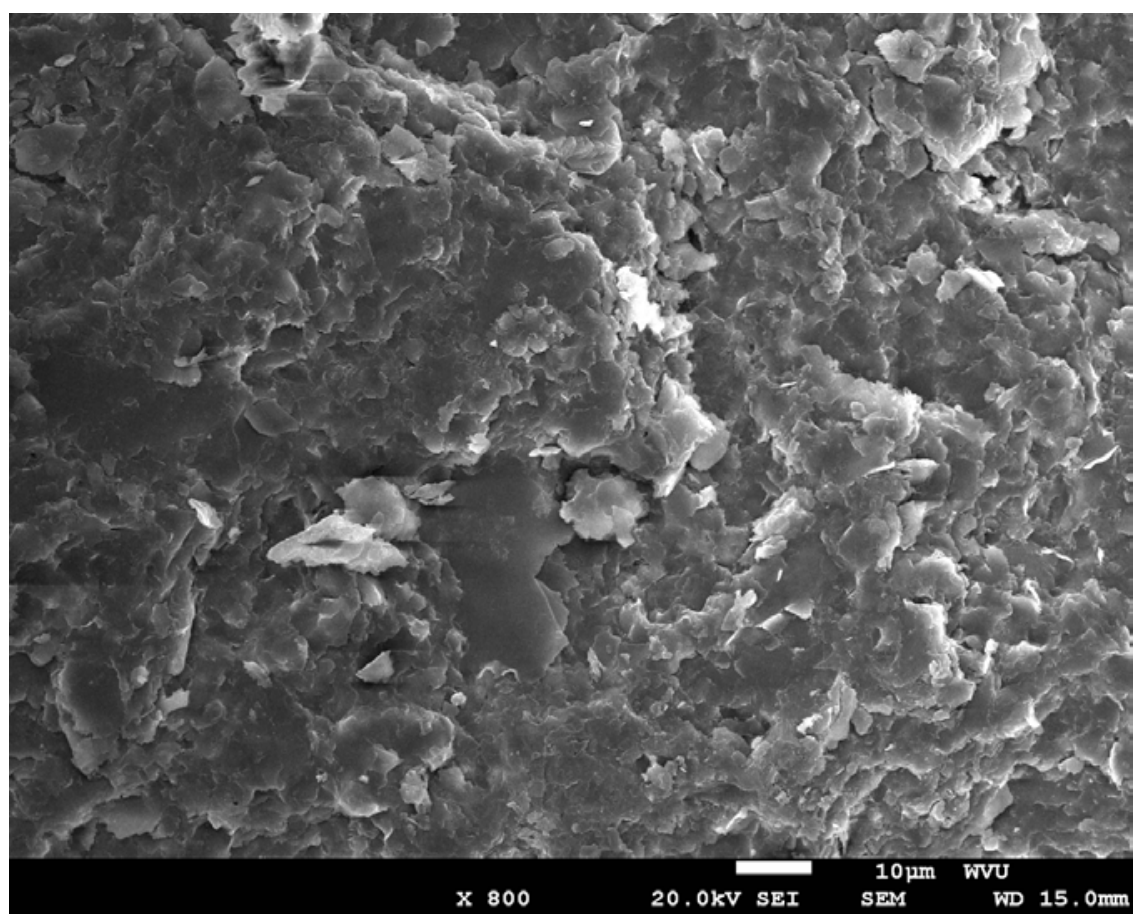

Figure 6.61 SEM image of the Quik-Gel® treatment sample for the second depth interval of Well $A$ at $800 X$

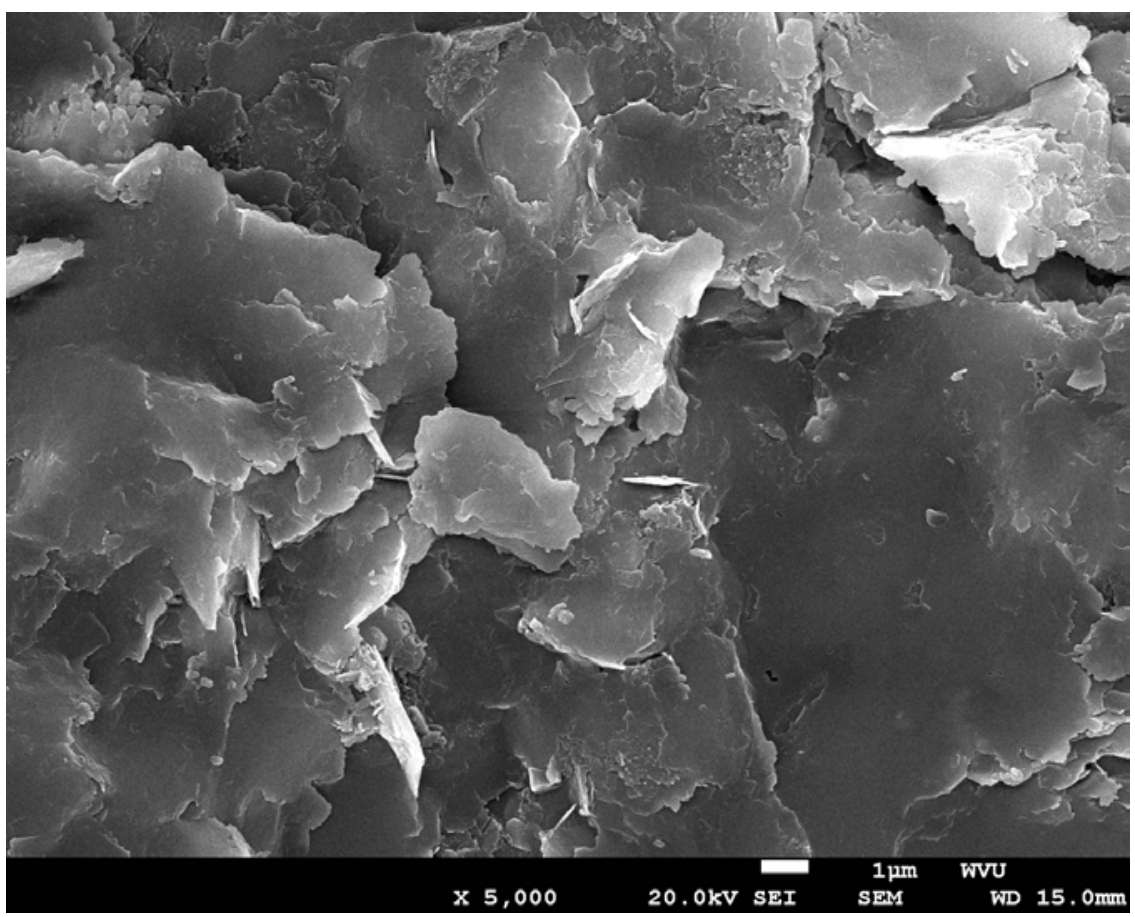

Figure 6.62 SEM image of the Quik-Gel® treatment sample for the second depth interval of Well A at 5000X 


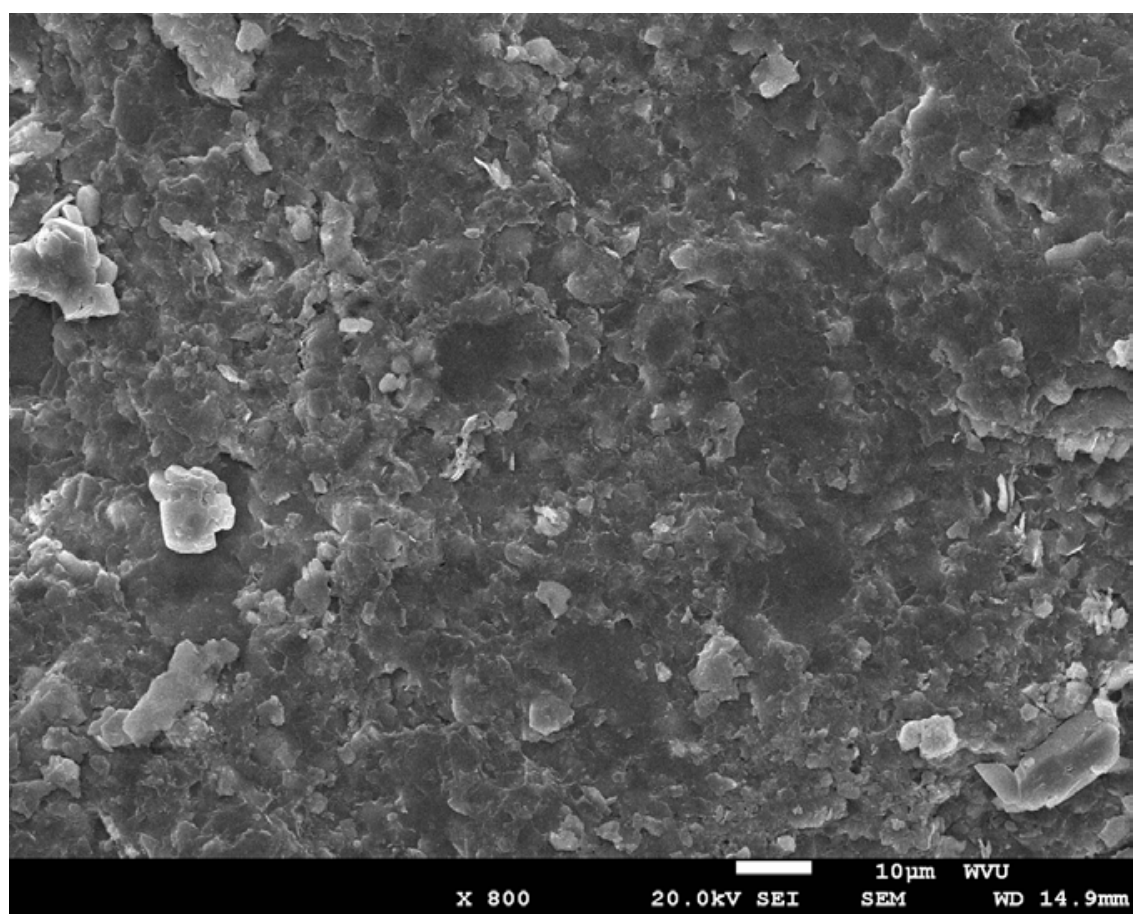

Figure 6.63 SEM image of the Quik-Gel® treatment sample for the third depth interval of Well A at 800X.

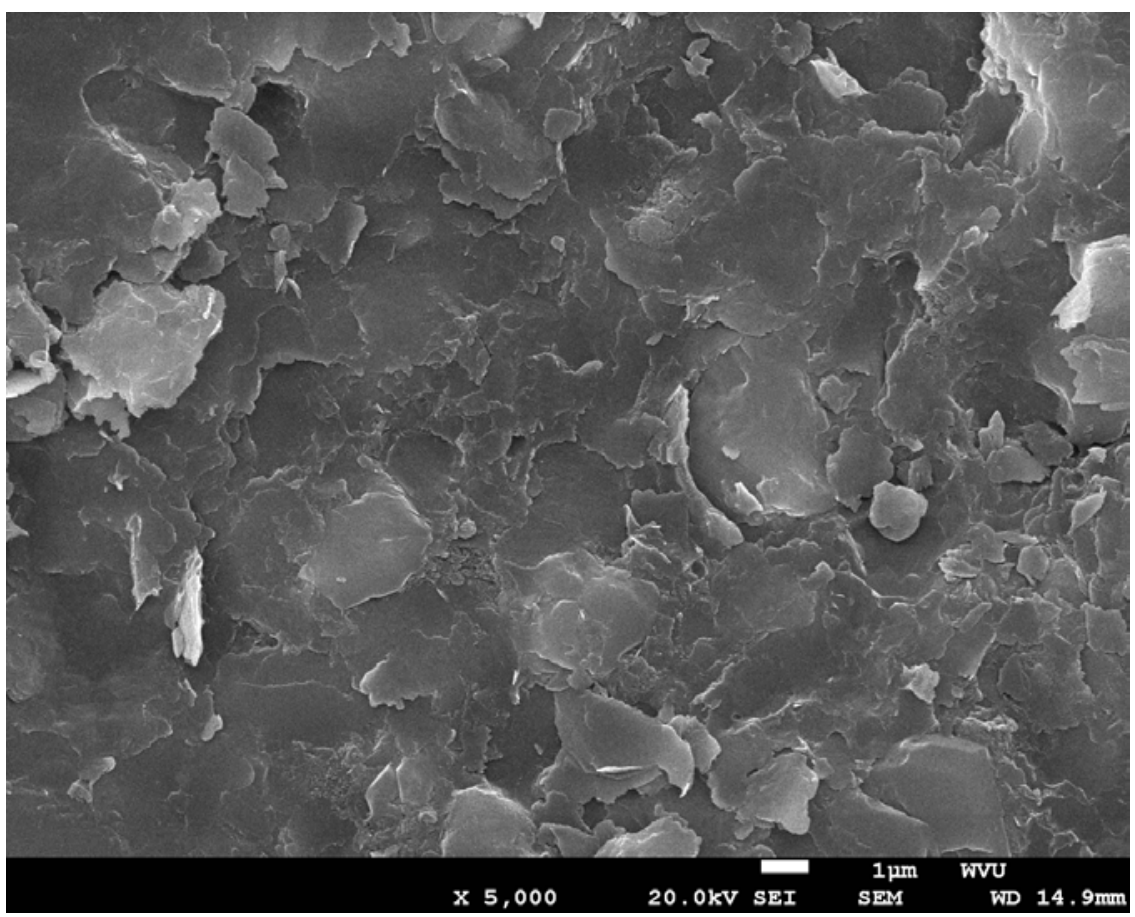

Figure 6.64 SEM image of the Quik-Gel® treatment sample for the third depth interval of Well A at 5000X 


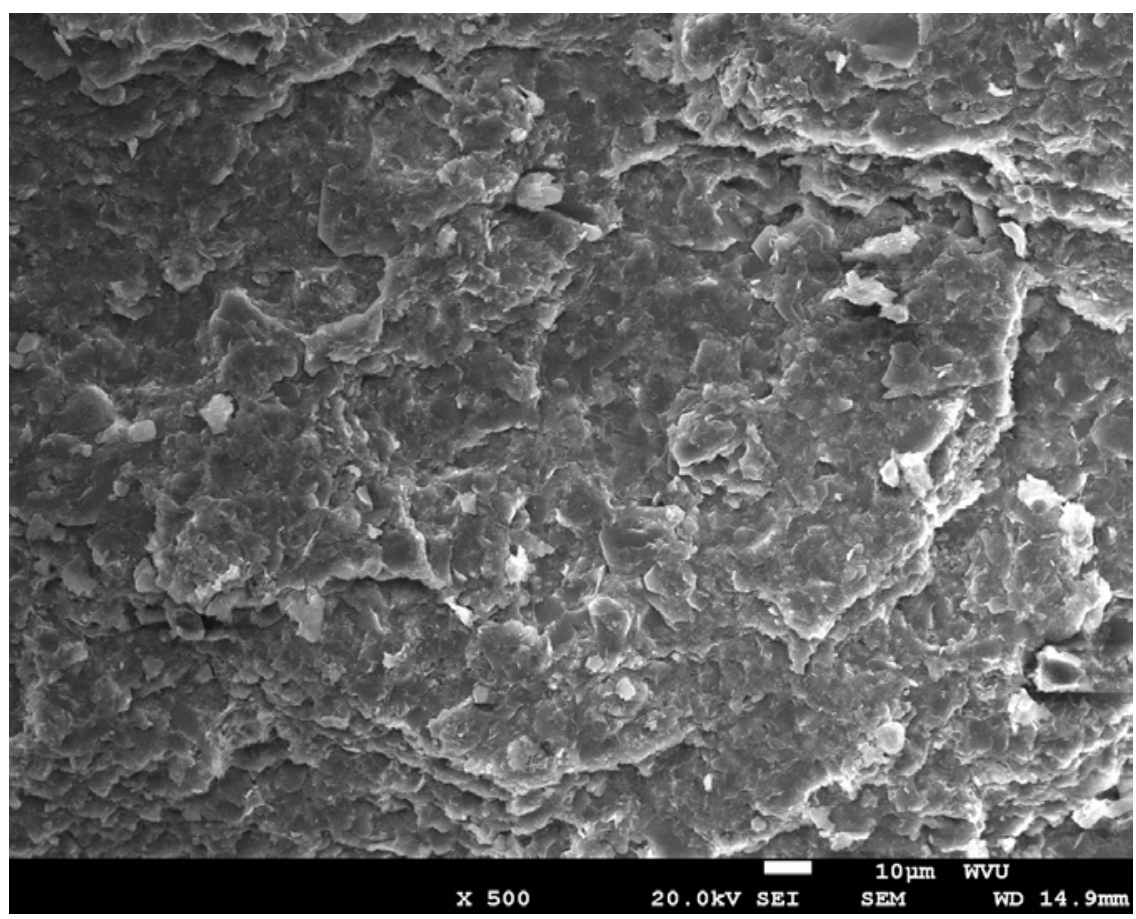

Figure 6.65 SEM image of the Quik-Gel® treatment sample for the fourth depth interval of Well $A$ at $800 X$

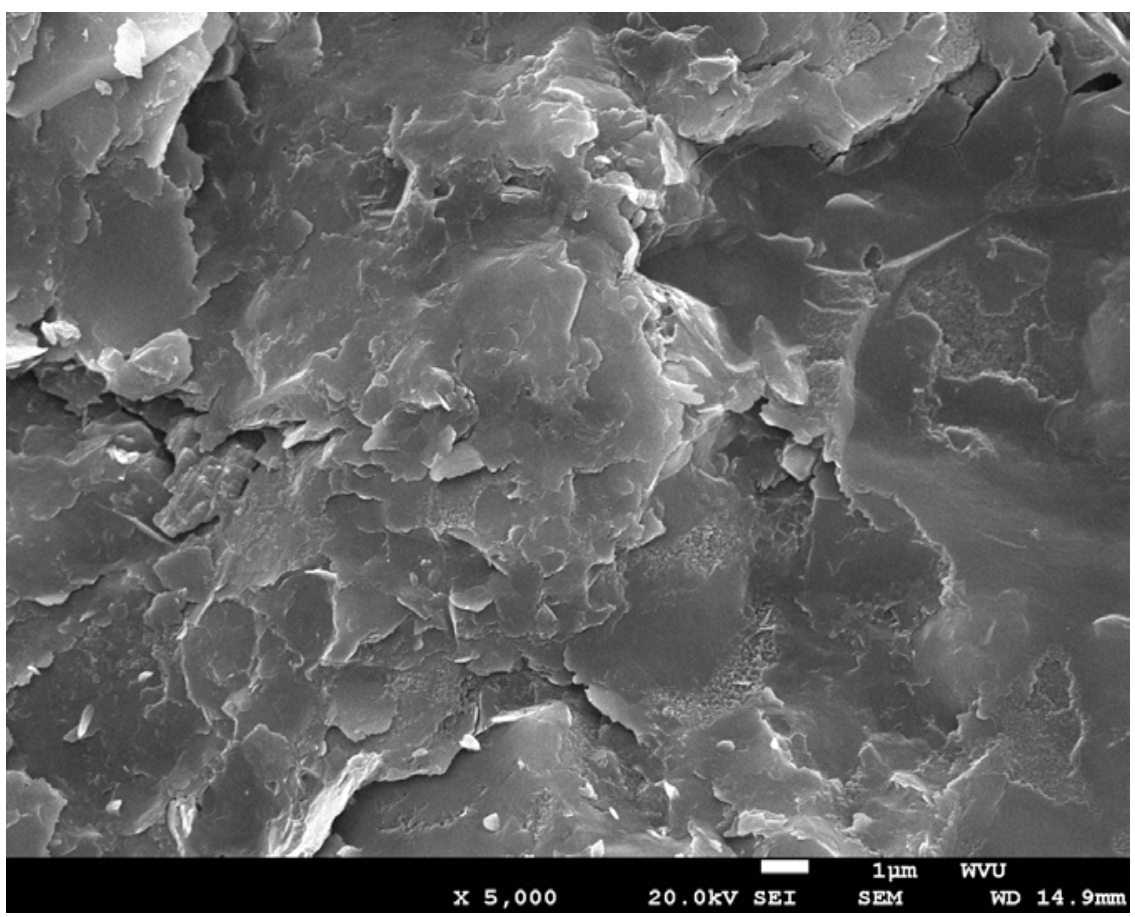

Figure 6.66 SEM image of the Quik-Gel® treatment sample for the fourth depth interval of Well A at 5000X 


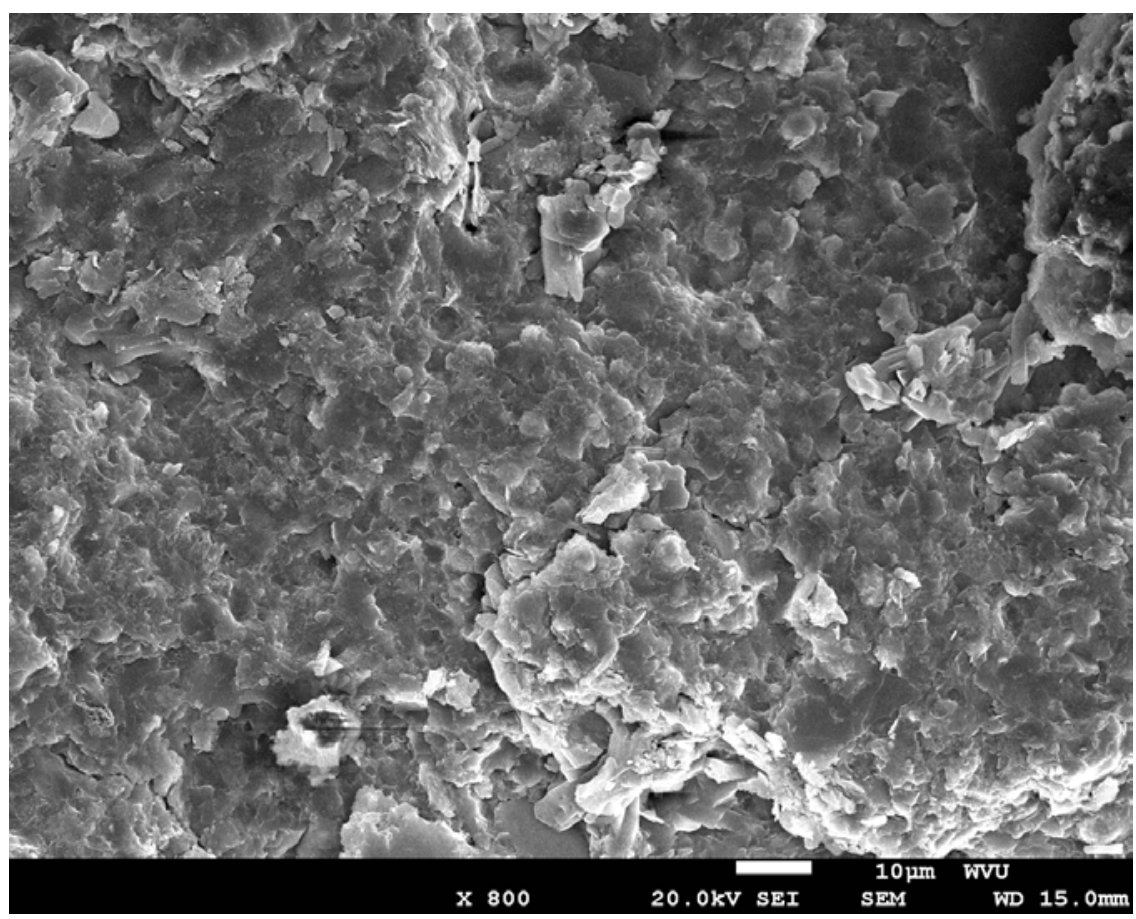

Figure 6.67 SEM image of the Quik-Gel® treatment sample for the fifth depth interval of Well $A$ at $800 X$

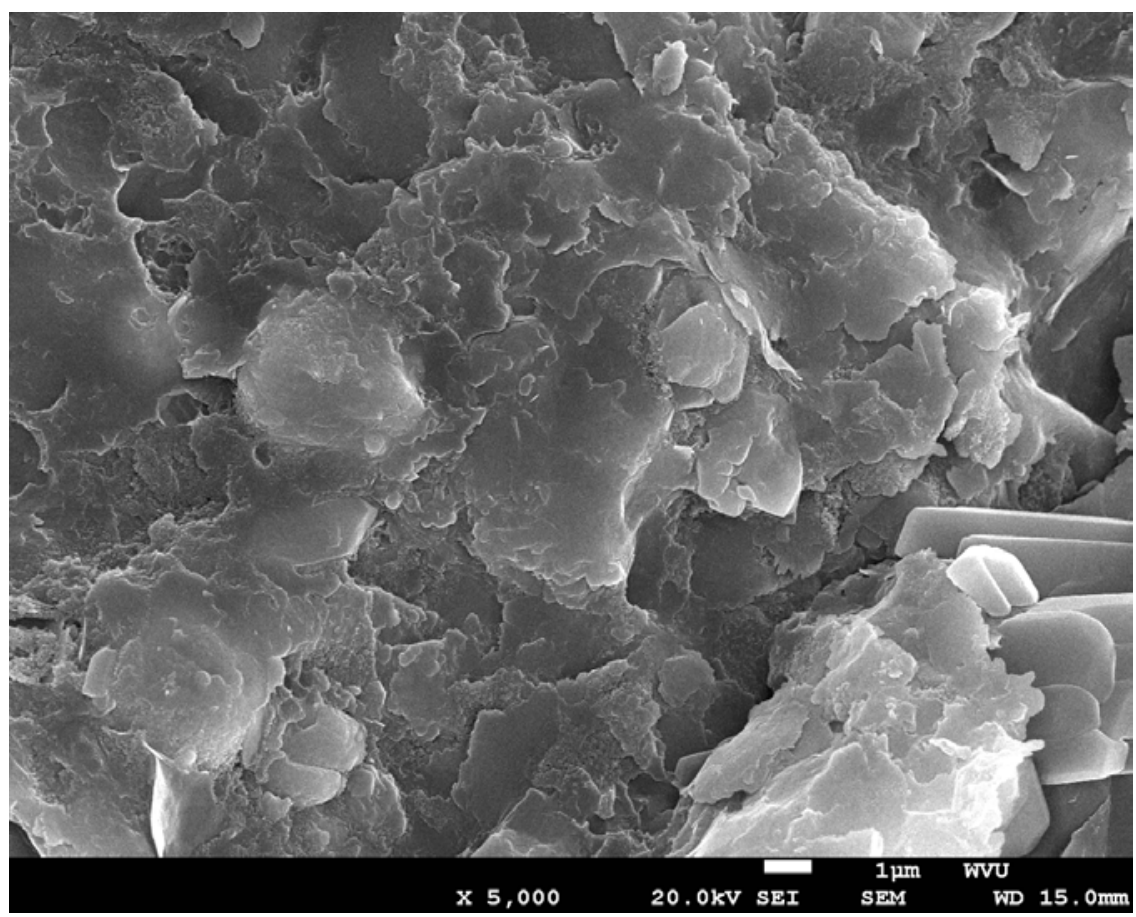

Figure 6.68 SEM image of the Quik-Gel® treatment sample for the fifth depth interval of Well A at 5000X 


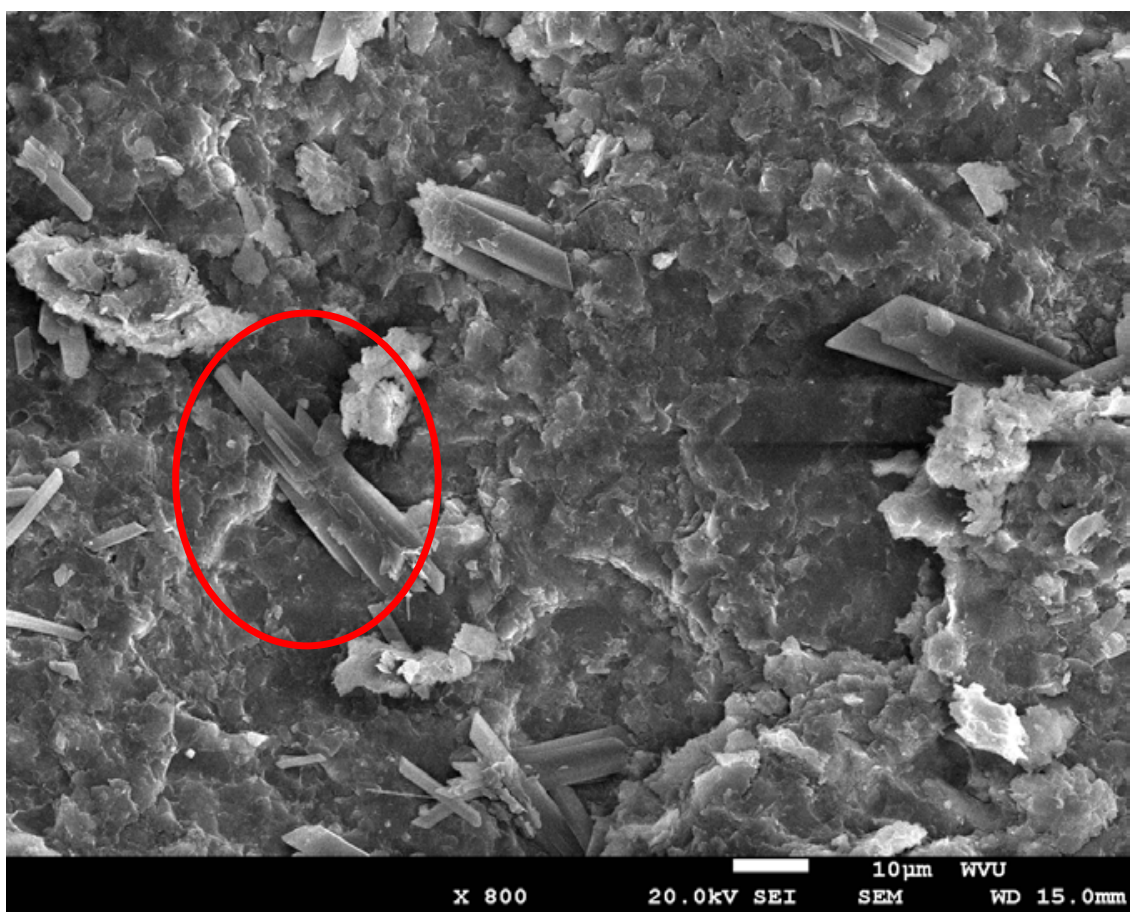

Figure 6.69 SEM image of the Quik-Gel® treatment sample for the sixth depth interval of Well $A$ at $800 X$

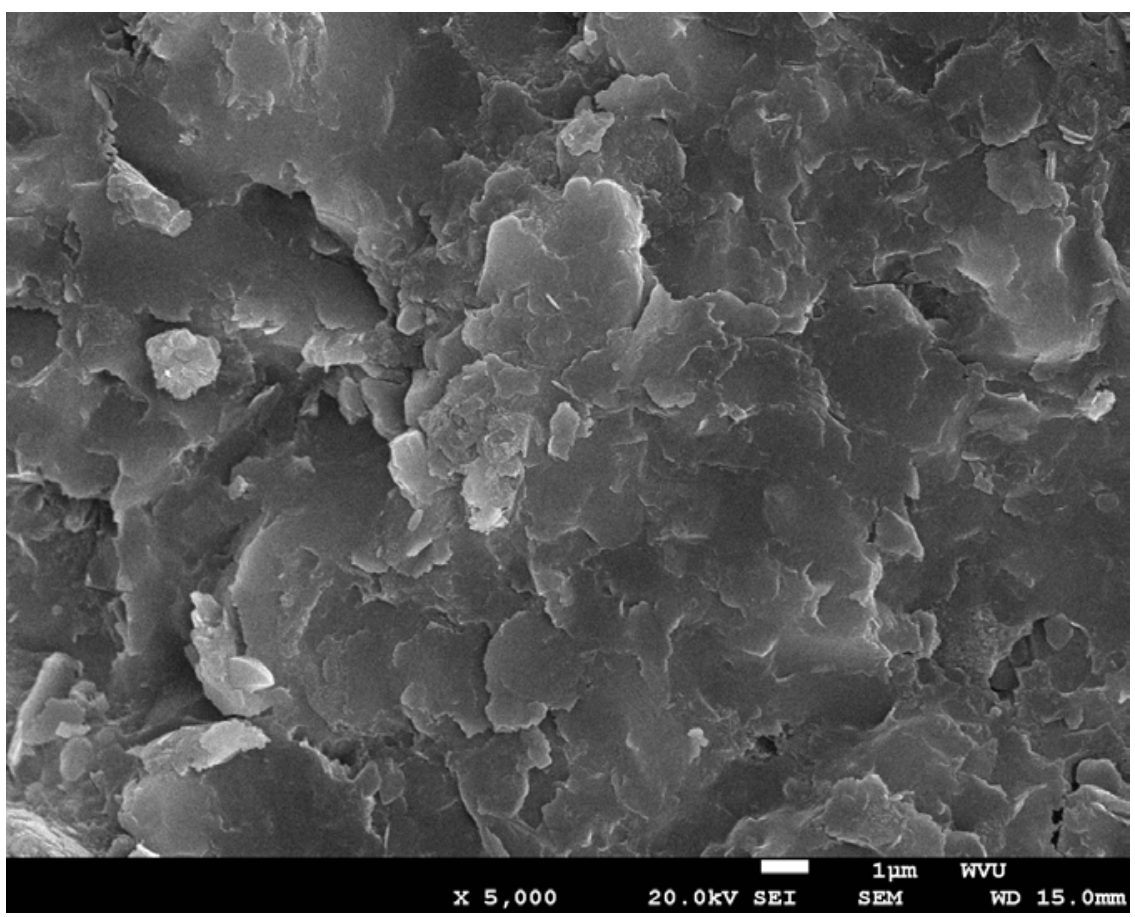

Figure 6.70 SEM image of the Quik-Gel® treatment sample for the sixth depth interval of Well A at 5000X 


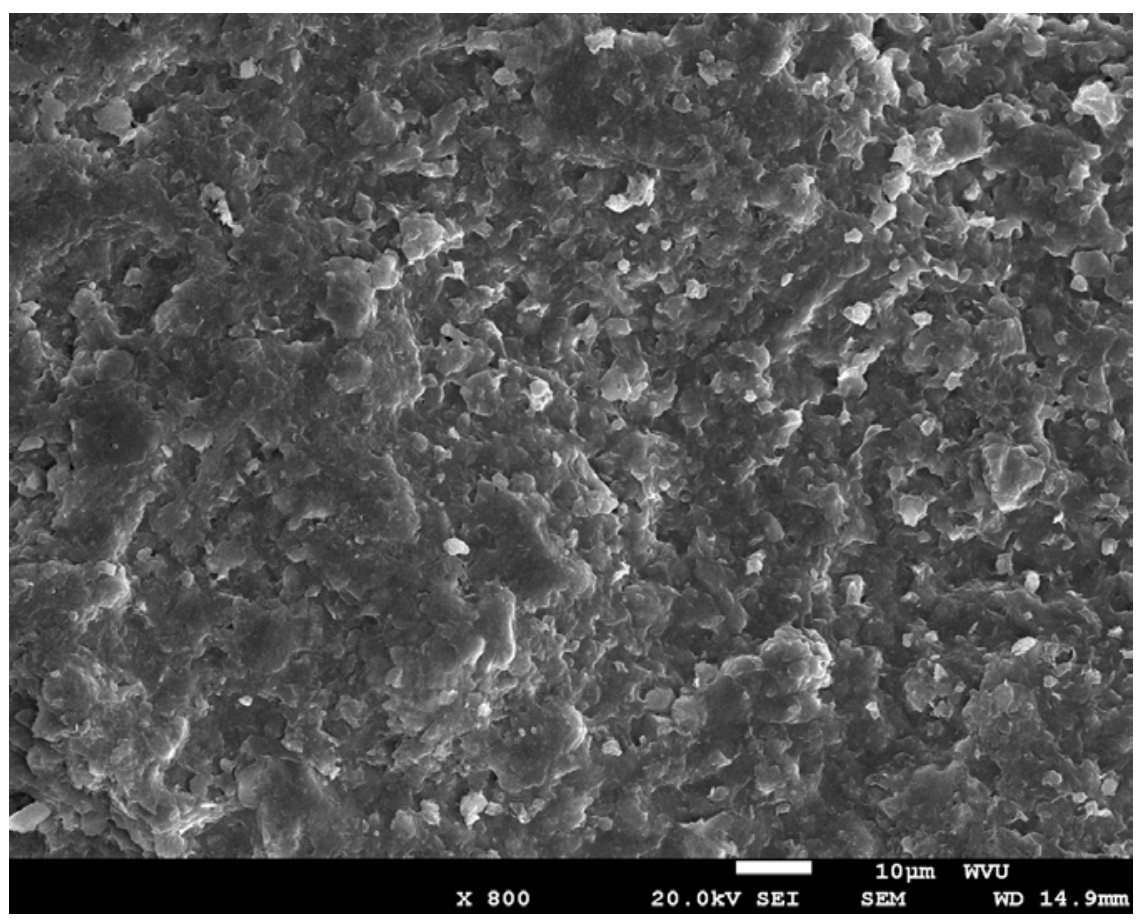

Figure 6.71 SEM image of the Quik-Gel® treatment sample for the seventh depth interval of Well $A$ at $800 X$

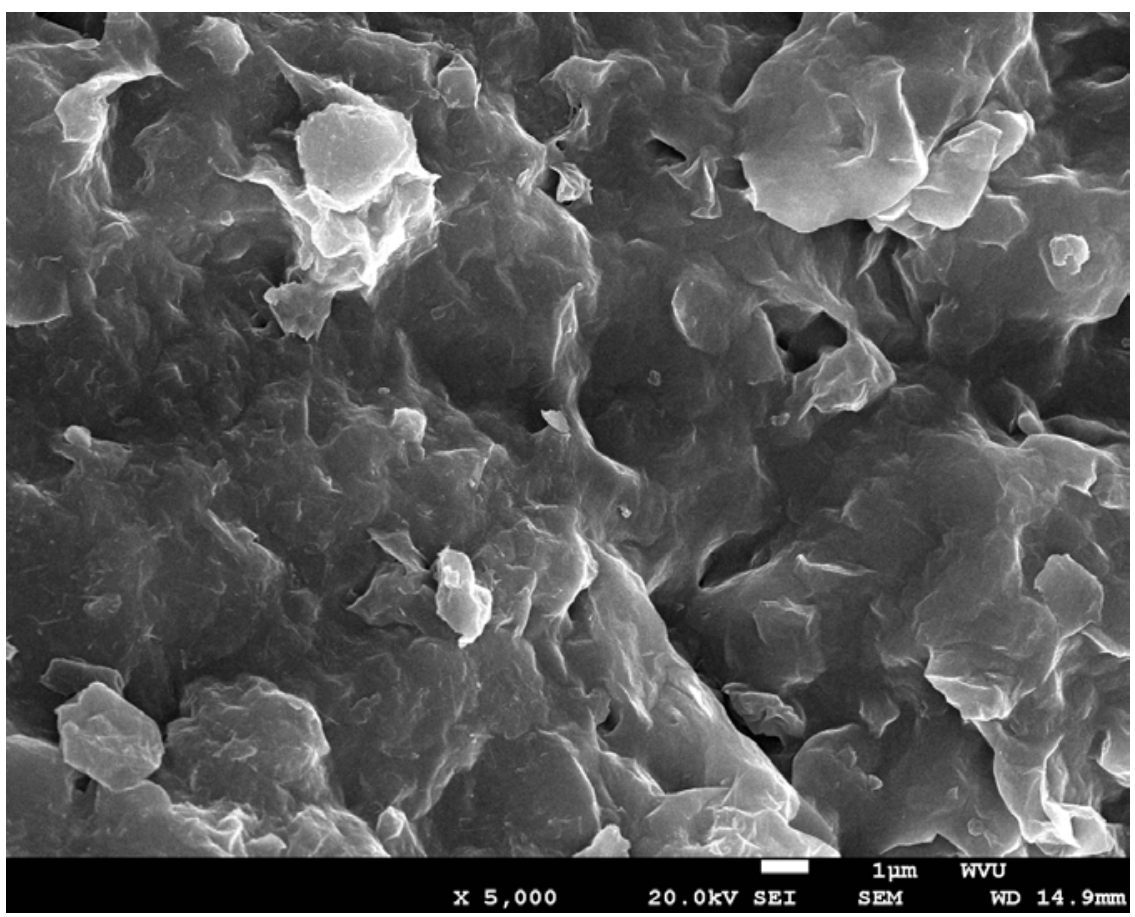

Figure 6.72 SEM image of the Quik-Gel ${ }^{\circledR}$ treatment sample for the seventh depth interval of Well A at 5000X 


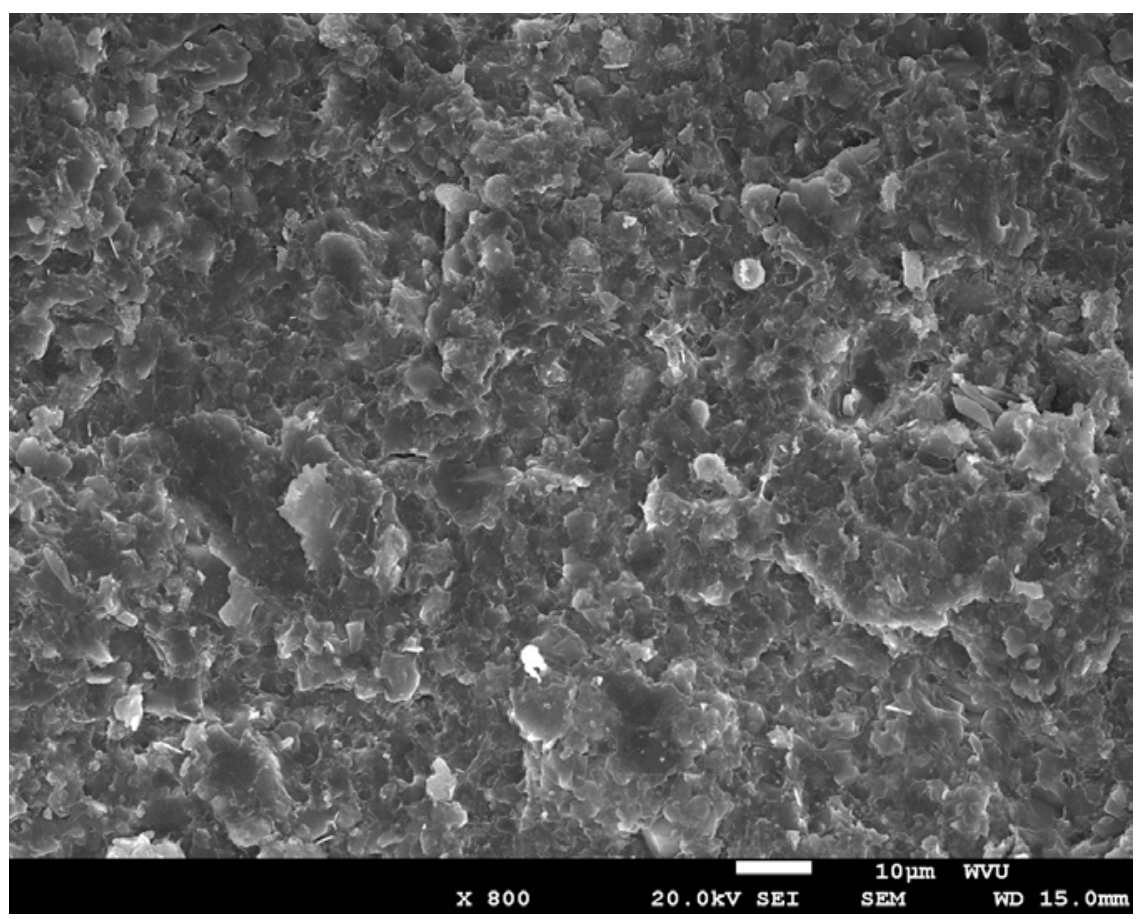

Figure 6.73 SEM image of the Quik-Gel® treatment sample for the eighth depth interval of Well $A$ at $800 X$

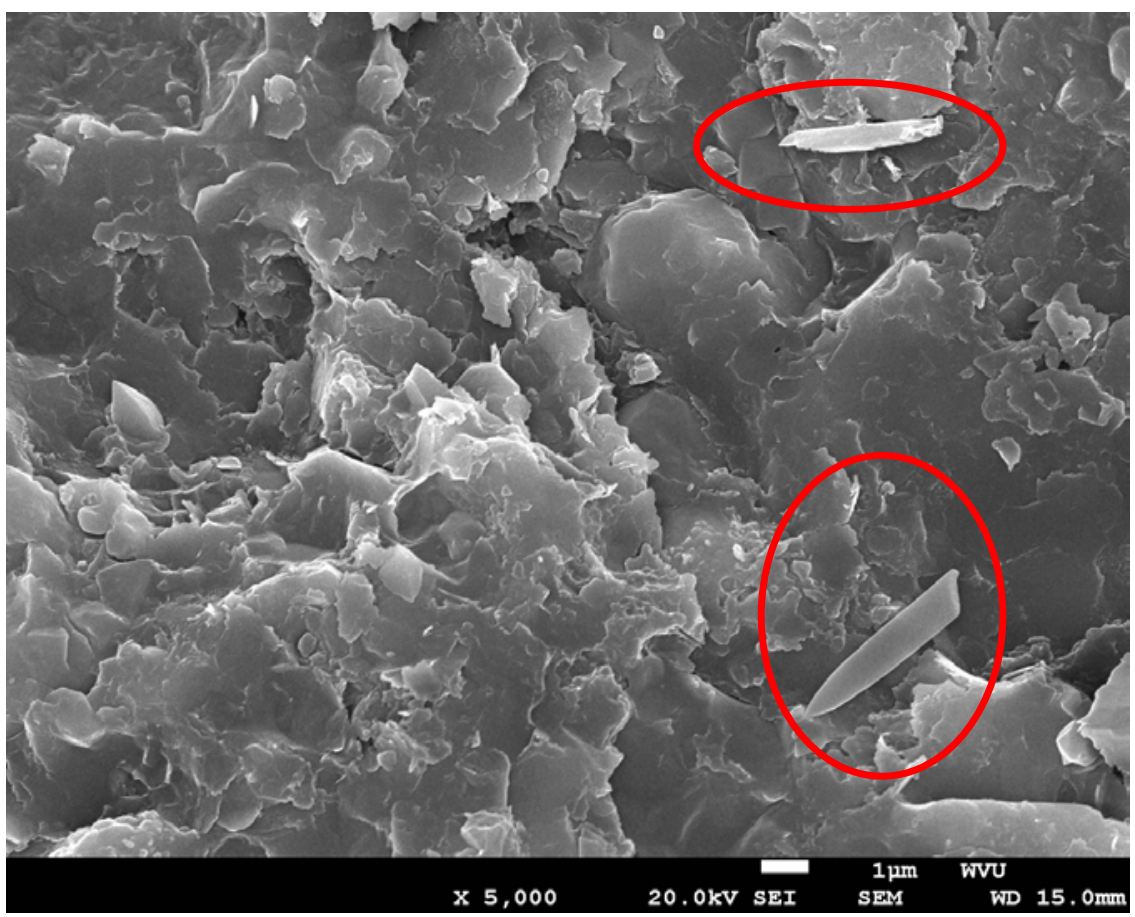

Figure 6.74 SEM image of the Quik-Gel ${ }^{\circledR}$ treatment sample for the eighth depth interval of Well A at 5000X 


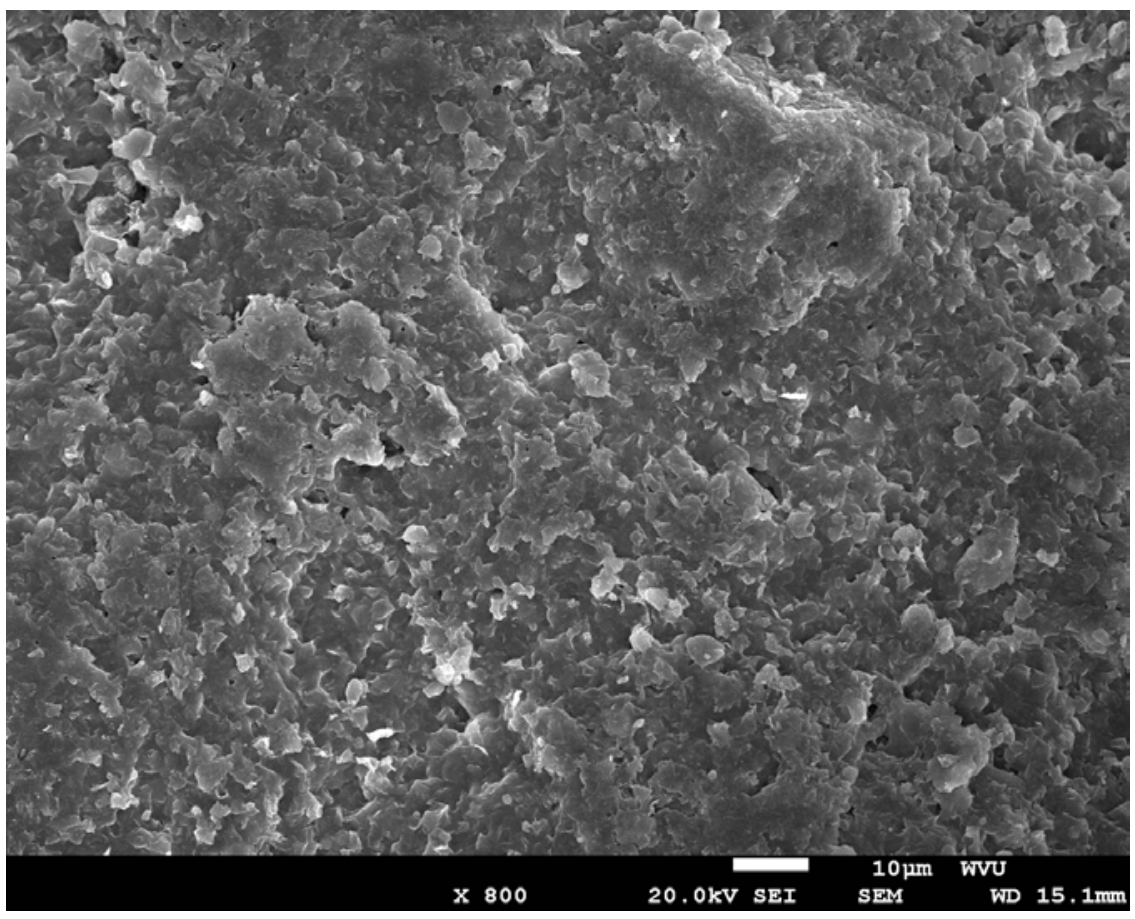

Figure 6.75 SEM image of the Quik-Gel ${ }^{\circledR}$ treatment sample for the ninth depth interval of Well $A$ at $800 X$

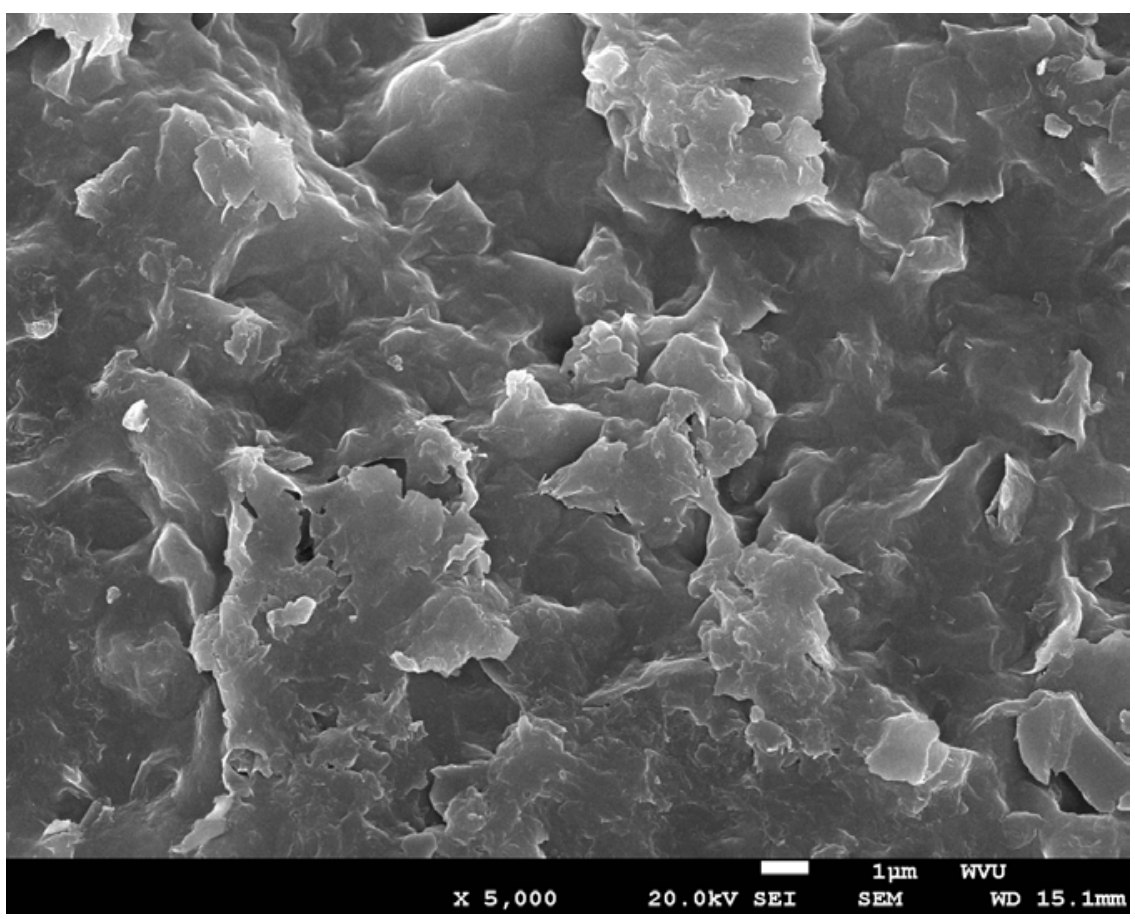

Figure 6.76 SEM image of the Quik-Gel ${ }^{\circledR}$ treatment sample for the ninth depth interval of Well A at 5000X 


\section{Monongalia County Well A Zeogel@ Alteration}

The samples discussed in this section underwent a Zeogel ${ }^{\circledR}$ treatment test. Samples from nine depth intervals of Monongalia County Well A soaked overnight in a Zeogel ${ }^{\circledR}$ and distilled water suspension. The purpose of this test was to observe the effect the clay additive on the elemental composition of the Marcellus shale. Zeogel ${ }^{\circledR}$ is added to many drilling muds used in the oil and natural gas industry. The elemental composition was evaluated using EDX, and the ranges in weight percent for each element found in the Zeogel ${ }^{\circledR}$ alteration treatment samples are listed in Table 6.5.

\begin{tabular}{|c|c|c|c|}
\hline \multicolumn{4}{|c|}{ Monongalia County Well A (Zeoge $\left.{ }^{\circledR}\right)$} \\
\hline Element & Weight\% & Sample & Range \\
\hline \multirow{2}{*}{ Al } & 2.97 & $8 \mathrm{~A}$ & \multirow{2}{*}{12.01} \\
\hline & 14.98 & $4 \mathrm{~A}$ & \\
\hline \multirow{2}{*}{$\mathrm{Ca}$} & 6.40 & $3 A$ & \multirow{2}{*}{14.76} \\
\hline & 21.16 & $9 \mathrm{~A}$ & \\
\hline \multirow{2}{*}{ Fe } & 0.81 & $2 \mathrm{~A}$ & \multirow{2}{*}{6.38} \\
\hline & 7.19 & $5 A$ & \\
\hline \multirow{2}{*}{ K } & 1.23 & $8 \mathrm{~A}$ & \multirow{2}{*}{8.76} \\
\hline & 9.99 & $4 \mathrm{~A}$ & \\
\hline \multirow{2}{*}{ Mg } & 0.45 & $2 \mathrm{~A}$ & \multirow{2}{*}{0.66} \\
\hline & 1.11 & $7 \mathrm{~A}$ & \\
\hline $\mathrm{Na}$ & 4.58 & $1 \mathrm{~A}$ & 4.58 \\
\hline \multirow{2}{*}{0} & 28.81 & $4 \mathrm{~A}$ & \multirow{2}{*}{23.74} \\
\hline & 52.55 & $2 \mathrm{~A}$ & \\
\hline \multirow{2}{*}{$S$} & 4.11 & $5 A$ & \multirow{2}{*}{10.54} \\
\hline & 14.65 & $9 A$ & \\
\hline \multirow{2}{*}{$\mathrm{Si}$} & 16.60 & $9 A$ & \multirow{2}{*}{22.80} \\
\hline & 39.40 & $2 \mathrm{~A}$ & \\
\hline \multirow{2}{*}{$\mathrm{Ti}$} & 0.60 & $9 A$ & \multirow{2}{*}{0.79} \\
\hline & 1.39 & $6 \mathrm{~A}$ & \\
\hline
\end{tabular}

Table 6.5 Weight percent ranges for each element found in the Monongalia County Well A Zeogel® treatment samples

All the elements found in the samples that underwent the Zeogel ${ }^{\circledR}$ treatment test were plotted against the corresponding depth in Figure 6.77. Two elemental trends were observed in these

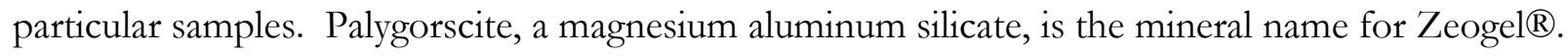
Generally, the weight percent for these four elements (magnesium, aluminum, silicon, and oxygen) 
increased when compared to the control samples. Iron and potassium followed nearly identical data trends, and they were plotted on the same scale. While the data line for sulfur did not follow as closely to iron as potassium, there was still an indication of the presence of pyrite since the weight percent of the elements both increased at the fifth depth interval. Magnesium also followed this trend from the fourth depth interval to the eighth depth interval. The data curves for aluminum and oxygen were parallel after the second depth interval. The samples that underwent the Zeogel® alteration test were the only samples that did not produce parallel data curves for iron and sulfur.

Photographs were taken of the samples that underwent the Zeogel® treatment test using the SEM, and they are seen below in Figure 6.78 through Figure 6.95. Each image was photographed at a magnification of $800 \mathrm{X}$ and 5000X. Organic rich areas, tiny pores, and countless layers were visible in the Zeogel ${ }^{\circledR}$ treatment samples as they were in the control samples. Images taken at a magnification of $5000 \mathrm{X}$ for the depth intervals $3 \mathrm{~A}, 7 \mathrm{~A}$, and $9 \mathrm{~A}$ had a unique surface texture that can be observed in Figure 6.83, Figure 6.91, and Figure 6.95 respectively. Because these hair-like fibers have only been observed in samples that were subjected to the Zeogel ${ }^{\circledR}$ treatment test, it can be assumed there is a direct relation between the magnesium aluminum silicate mineral and the Marcellus shale. 


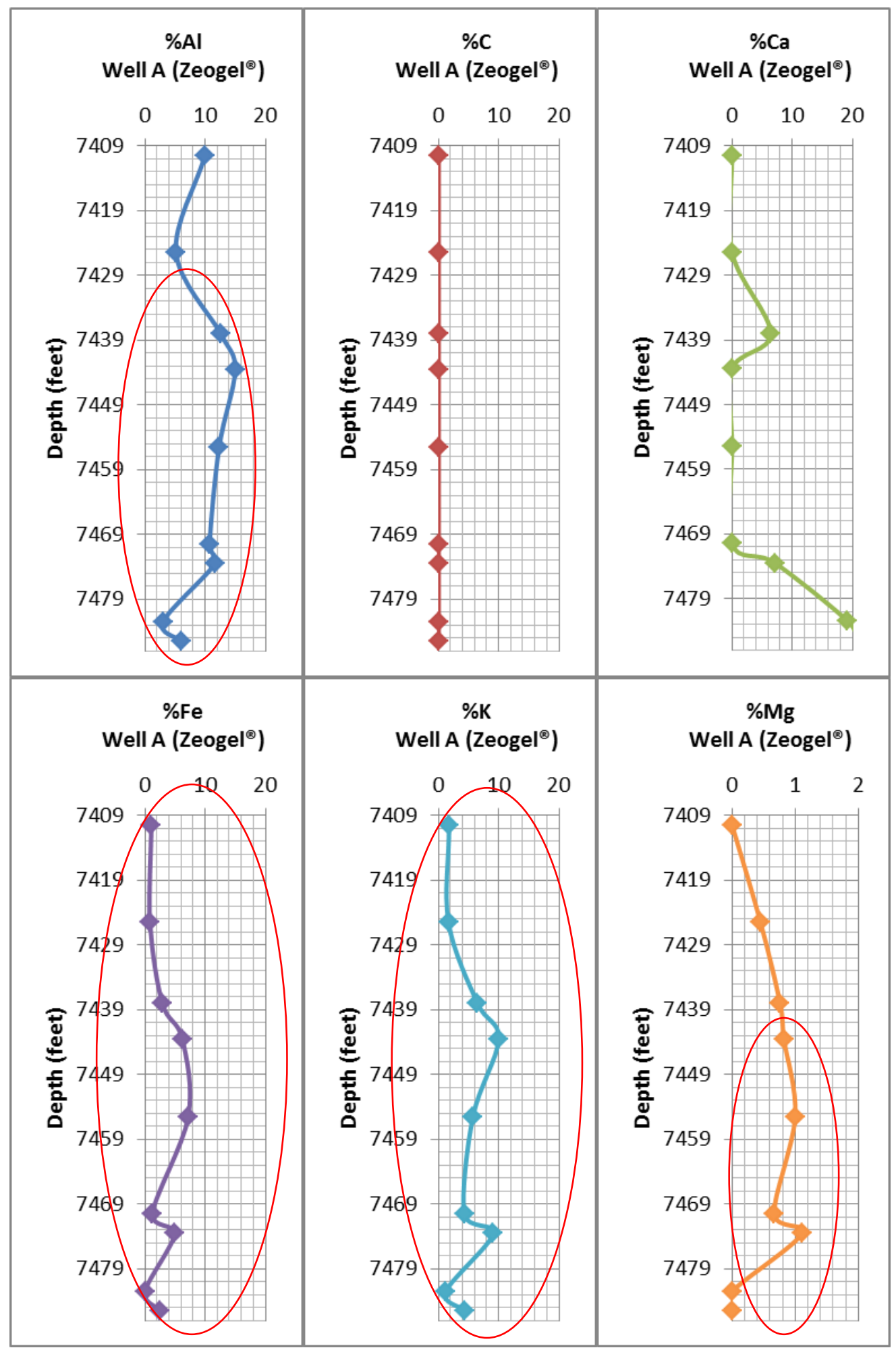




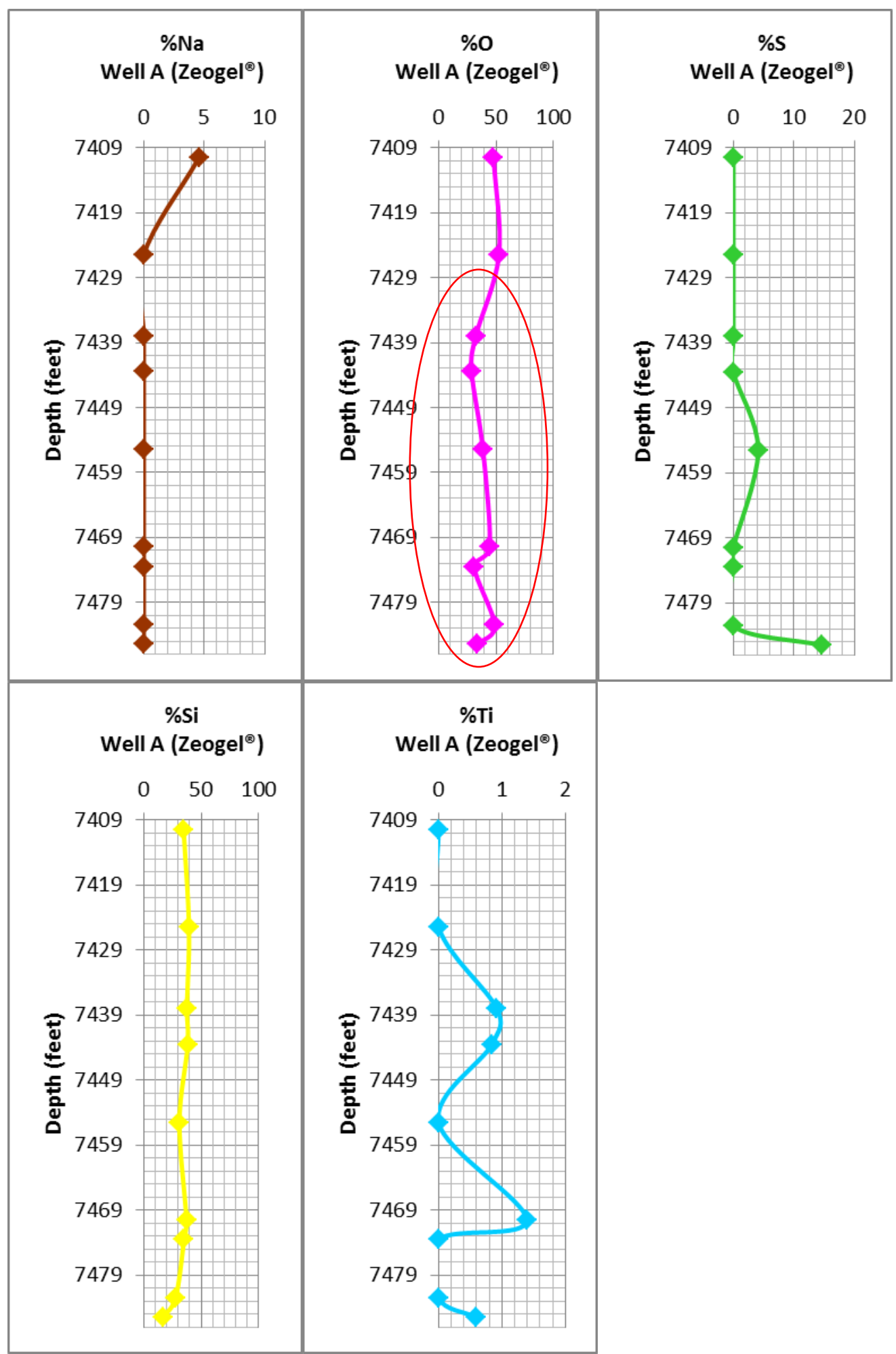

Figure 6.77 Weight percent of each element found in Monongalia County Well A Zeogel® treatment samples plotted against the corresponding depth 
Monongalia County Well A Zeogel@ Alteration SEM Photographs

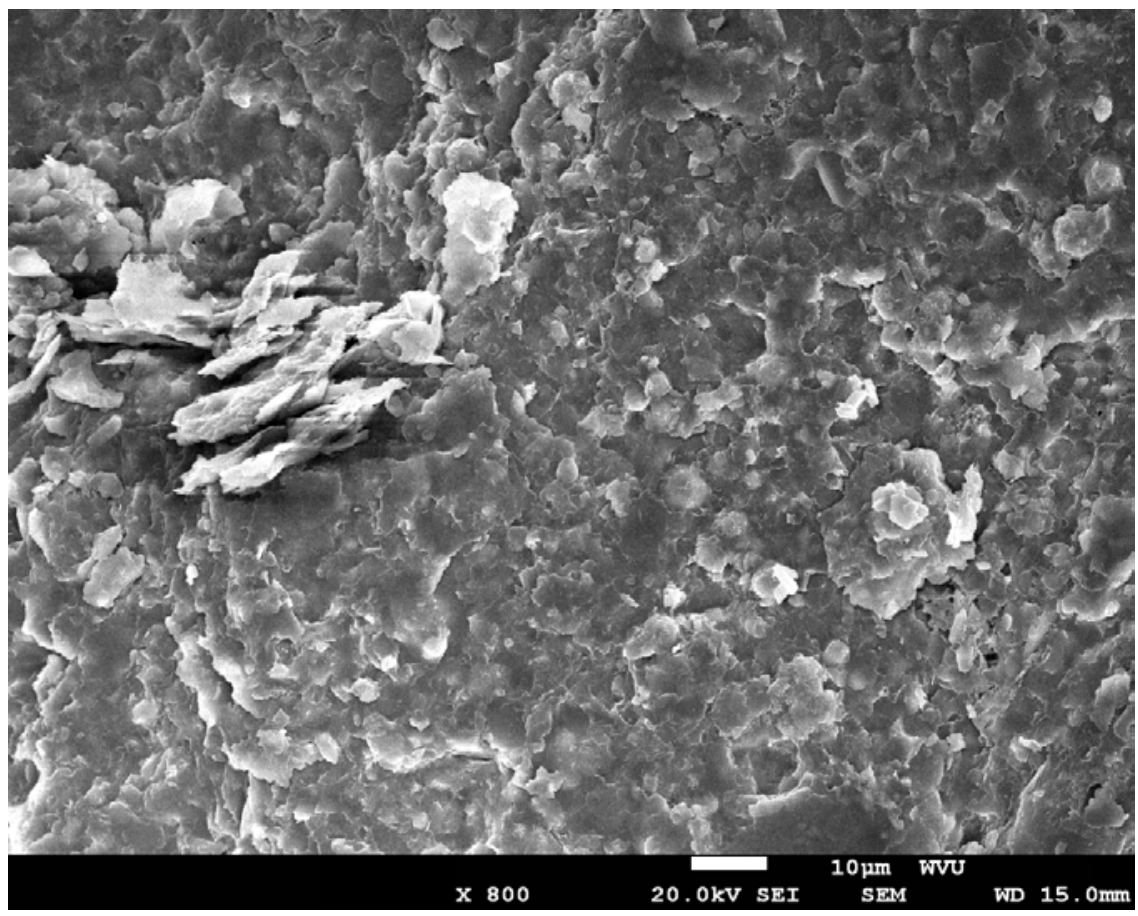

Figure 6.78 SEM image of the Zeogel ${ }^{\circledR}$ treatment sample for the first depth interval of Well A at 800X

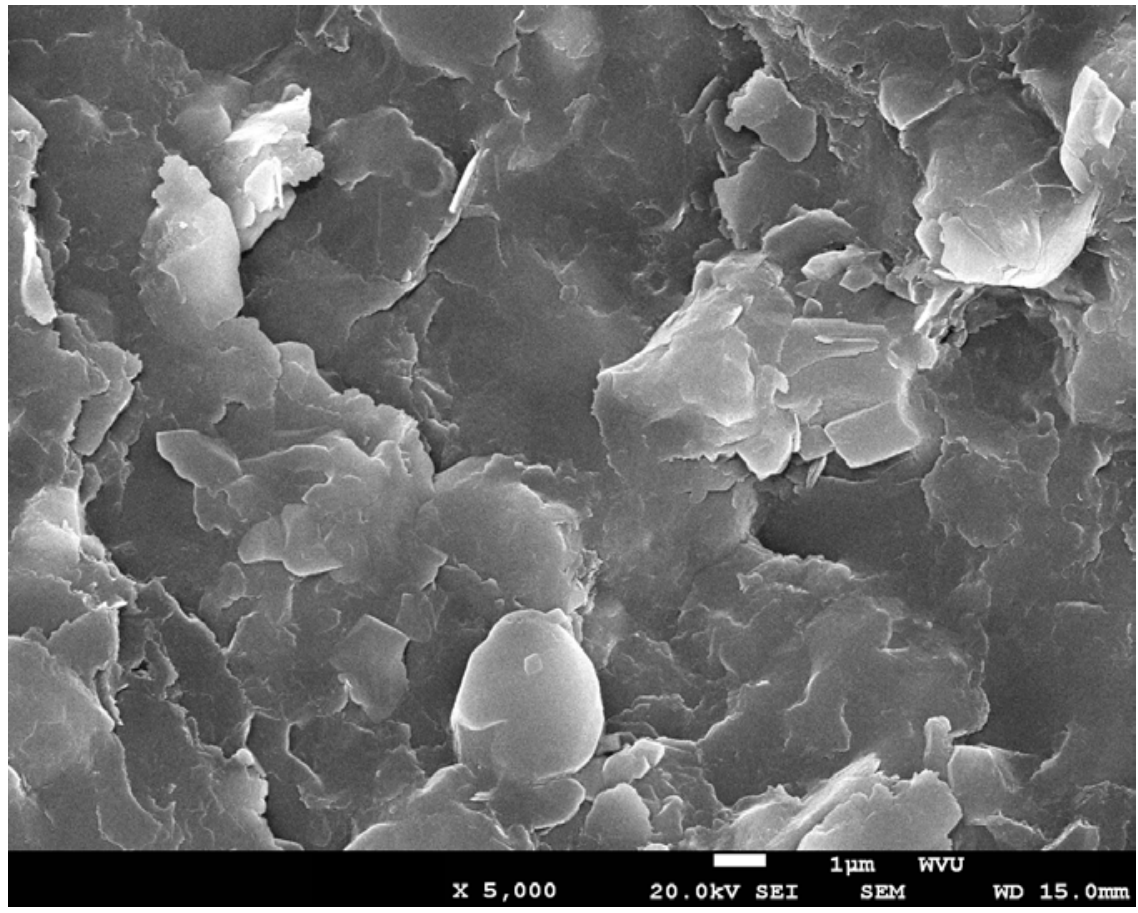

Figure 6.79 SEM image of the Zeogel® treatment sample for the first depth interval of Well A at 5000X 


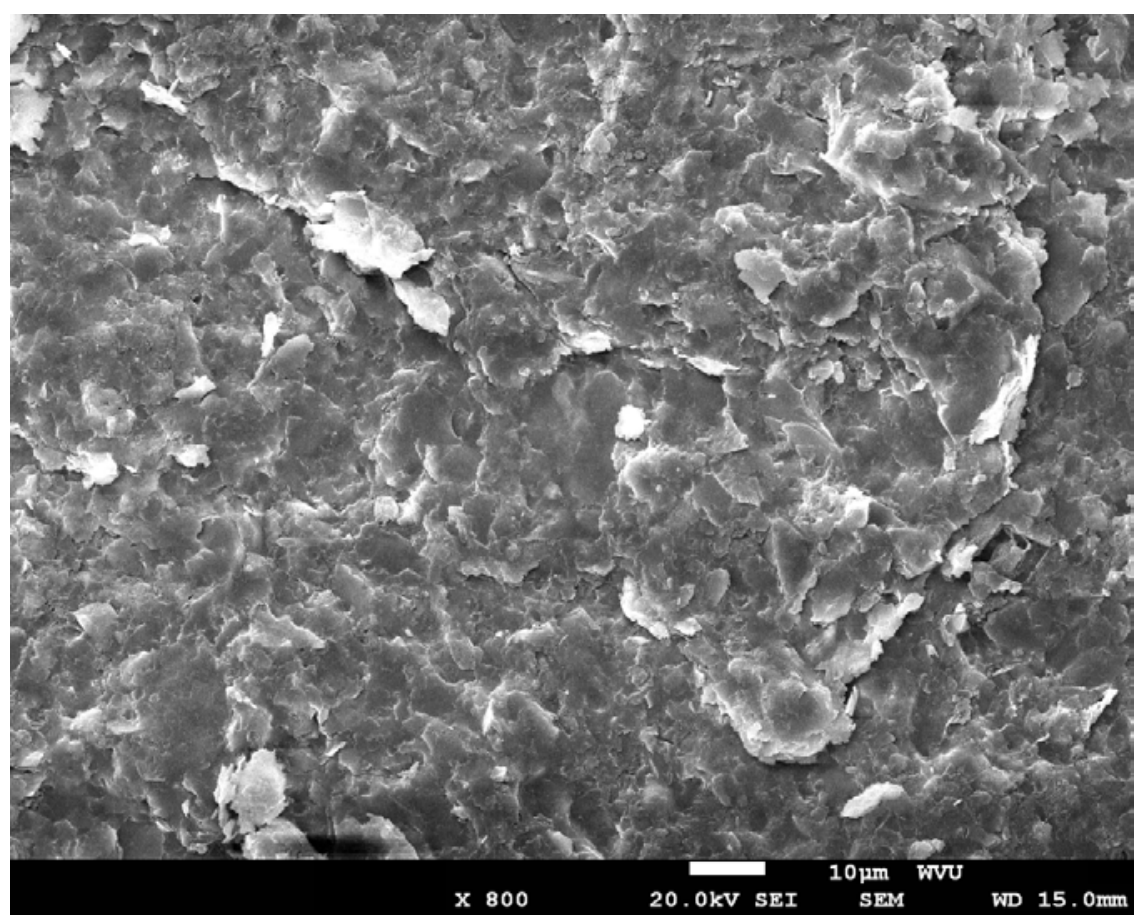

Figure 6.80 SEM image of the Zeogel ${ }^{\circledR}$ treatment sample for the second depth interval of Well $\mathrm{A}$ at $800 \mathrm{X}$

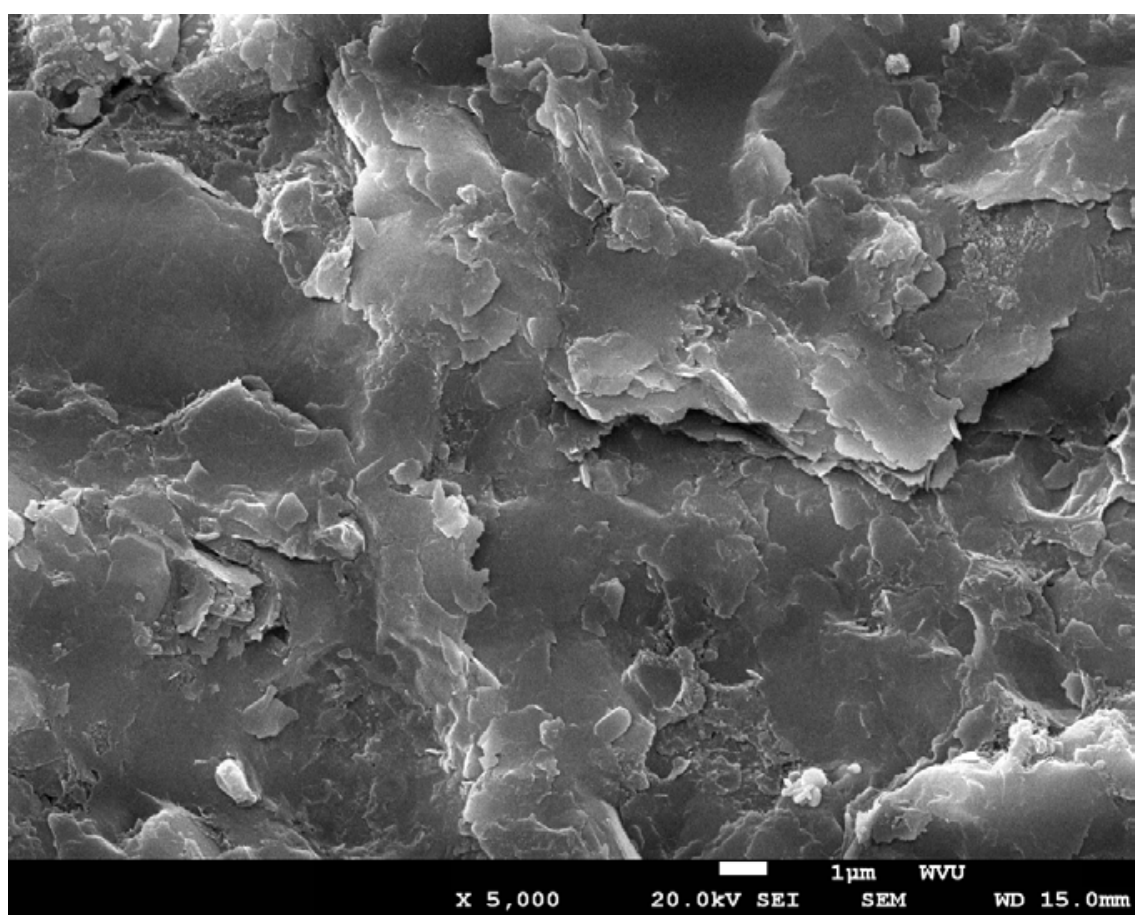

Figure 6.81 SEM image of the Zeogel ${ }^{\circledR}$ treatment sample for the second depth interval of Well $A$ at 5000X 


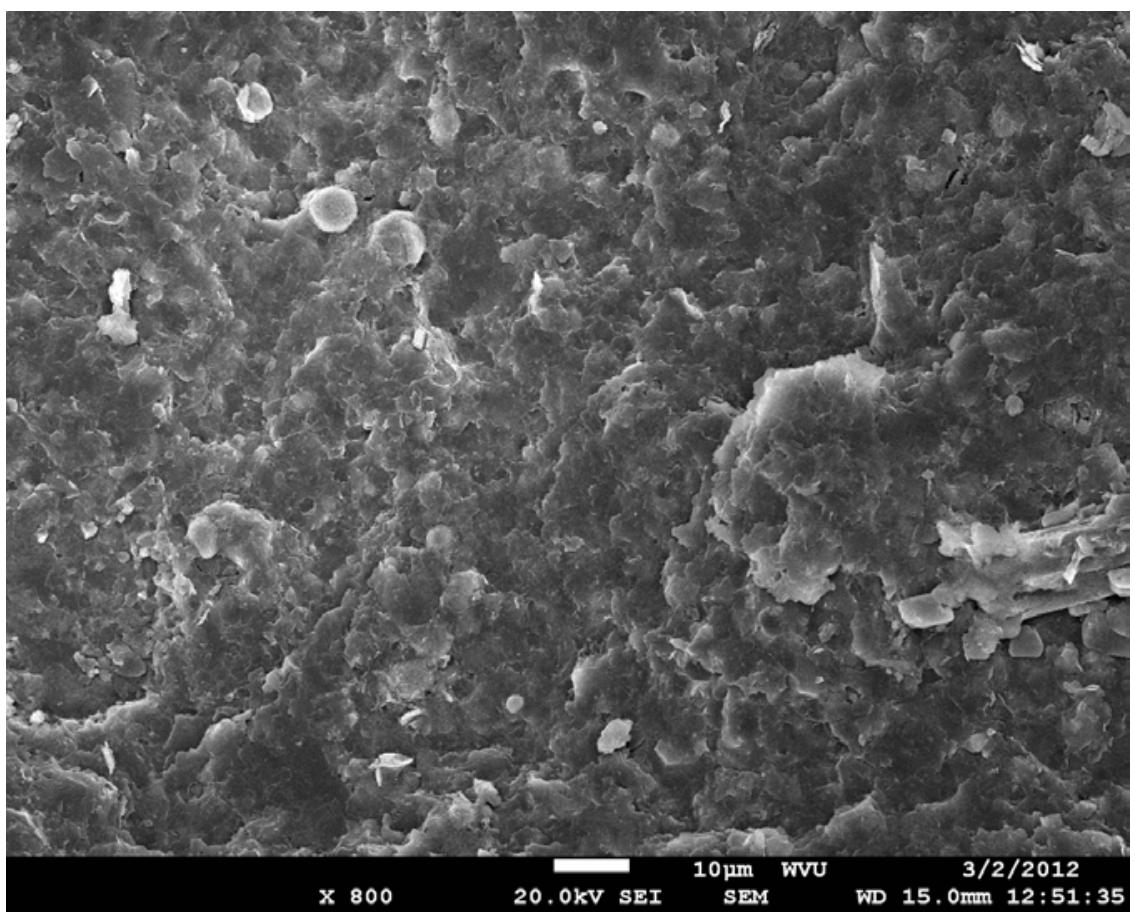

Figure 6.82 SEM image of the Zeogel ${ }^{\circledR}$ treatment sample for the third depth interval of Well A at 800X.

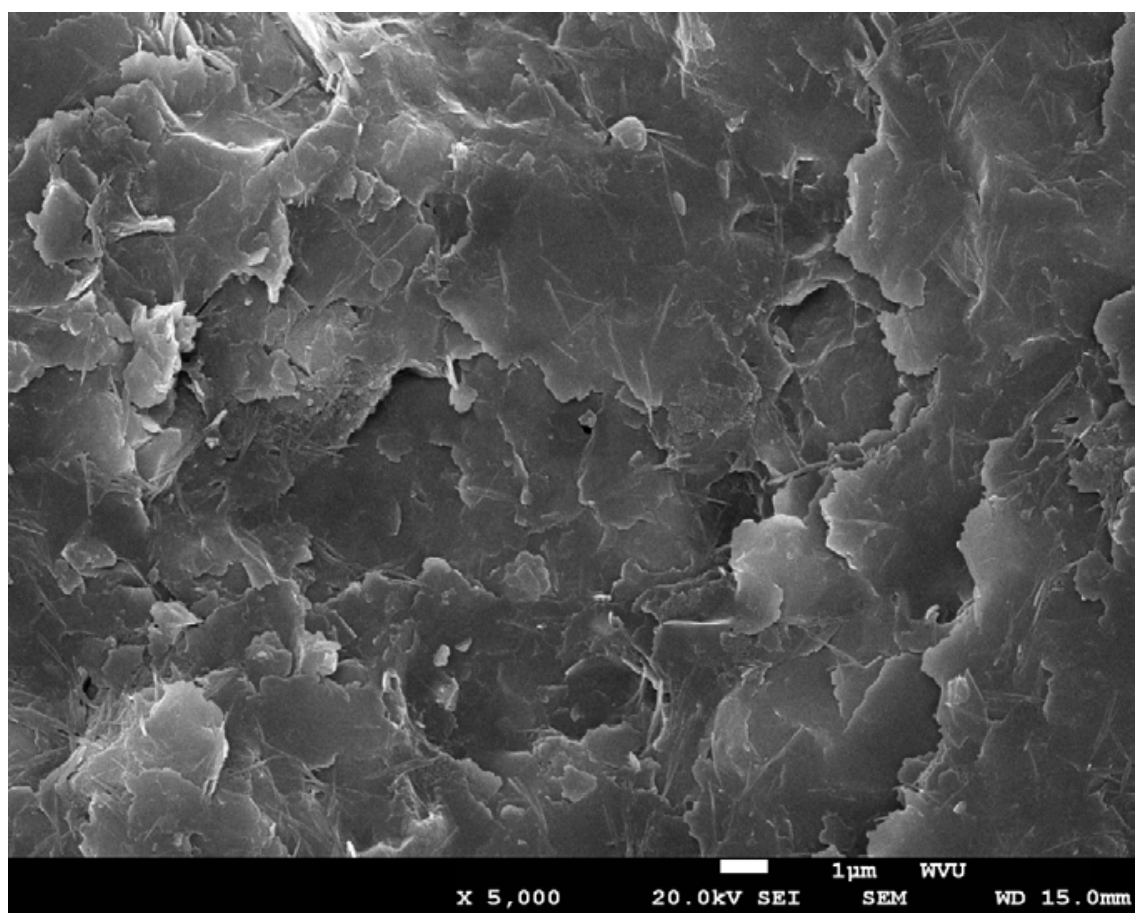

Figure 6.83 SEM image of the Zeogel ${ }^{\circledR}$ treatment sample for the third depth interval of Well A at 5000X 


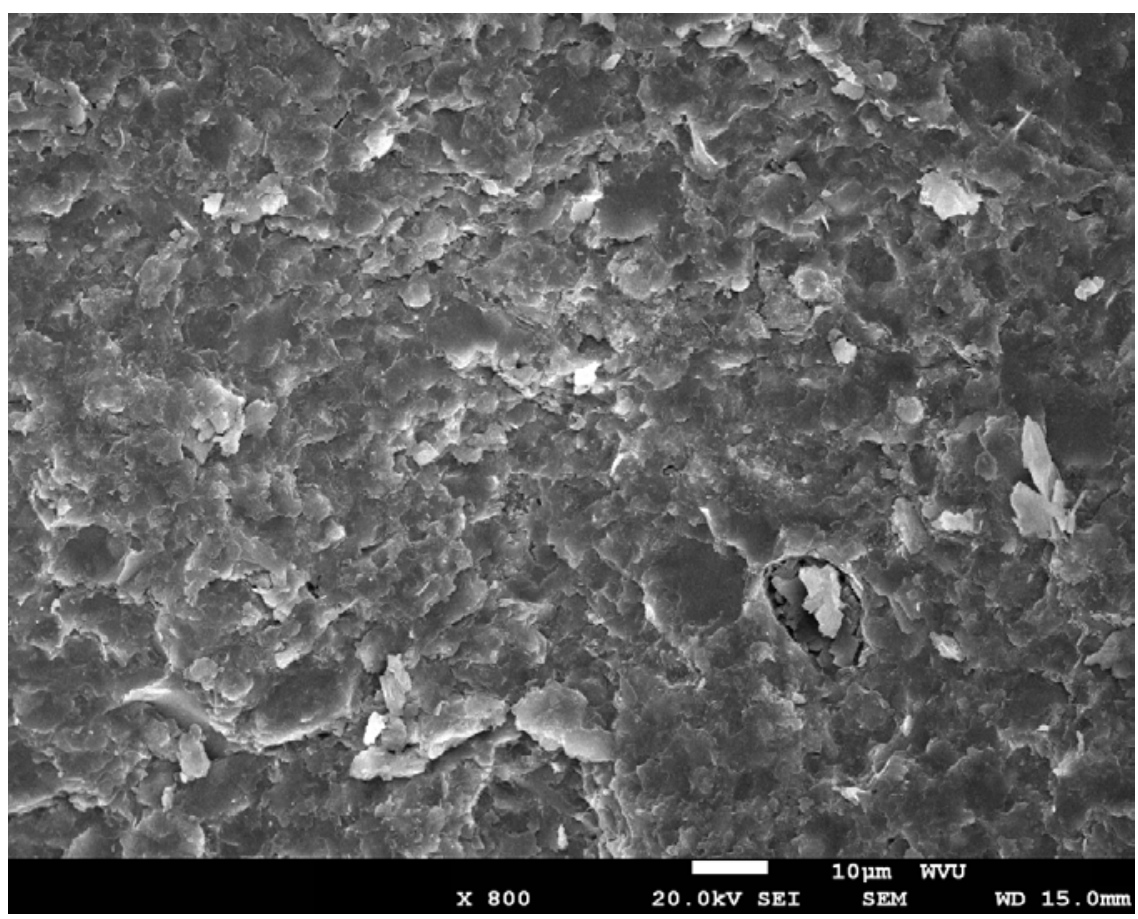

Figure 6.84 SEM image of the Zeogel ${ }^{\circledR}$ treatment sample for the fourth depth interval of Well A at 800X

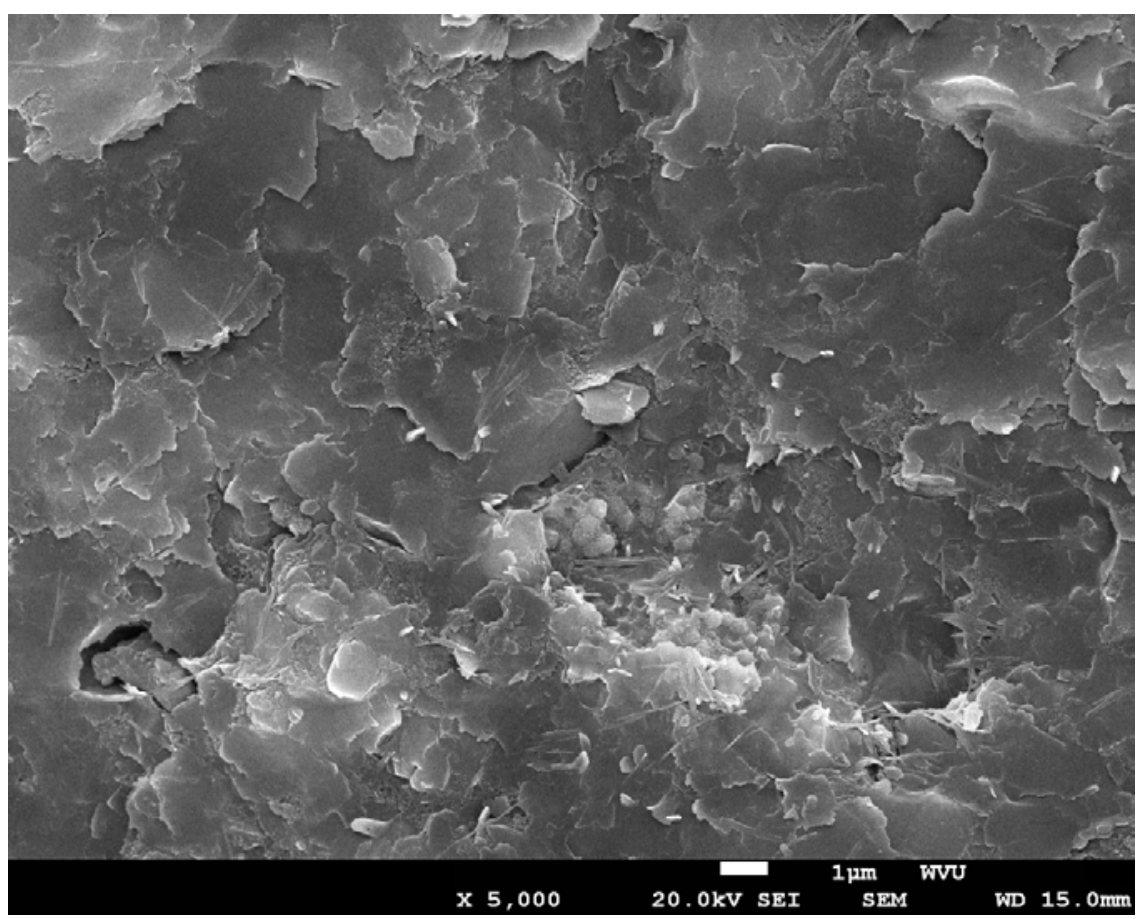

Figure 6.85 SEM image of the Zeogel ${ }^{\circledR}$ treatment sample for the fourth depth interval of Well A at 5000X 


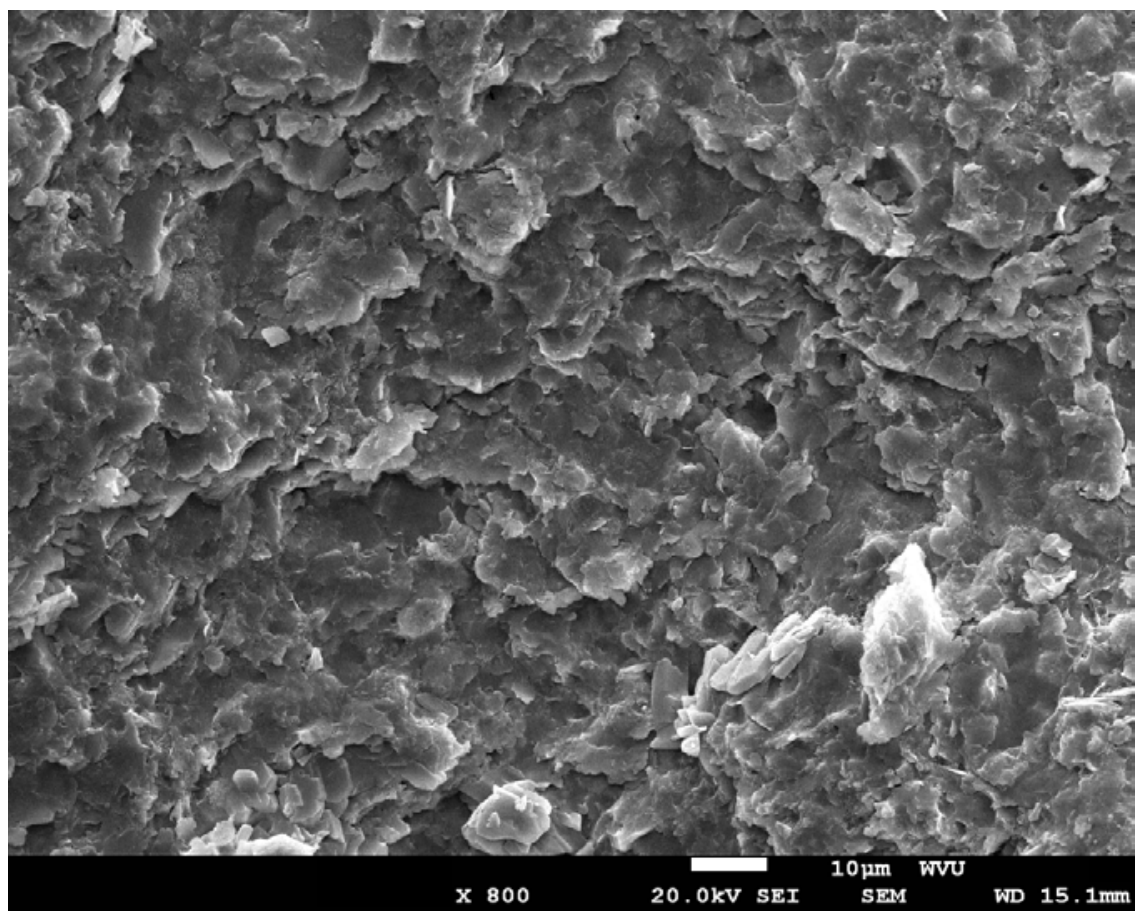

Figure 6.86 SEM image of the Zeogel ${ }^{\circledR}$ treatment sample for the fifth depth interval of Well A at $800 \mathrm{X}$.

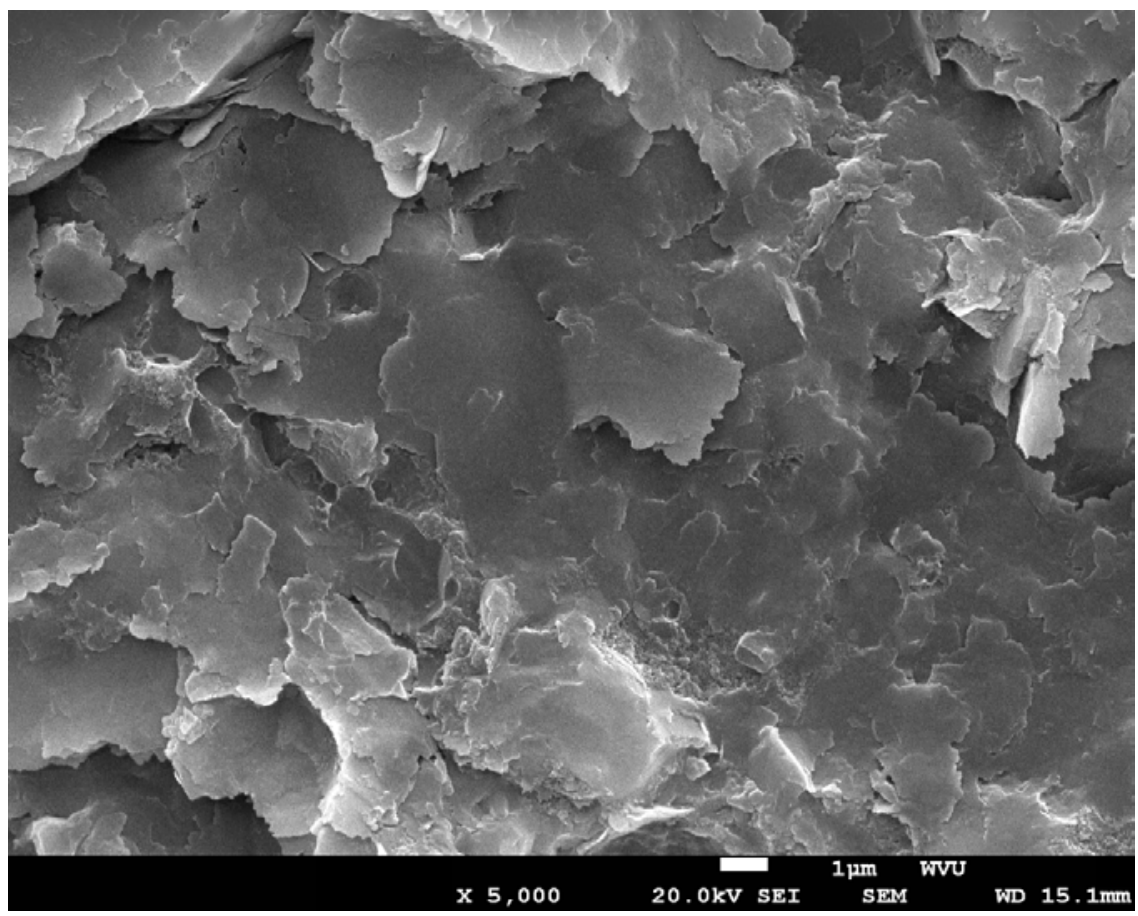

Figure 6.87 SEM image of the Zeogel ${ }^{\circledR}$ treatment sample for the fifth depth interval of Well A at 5000X 


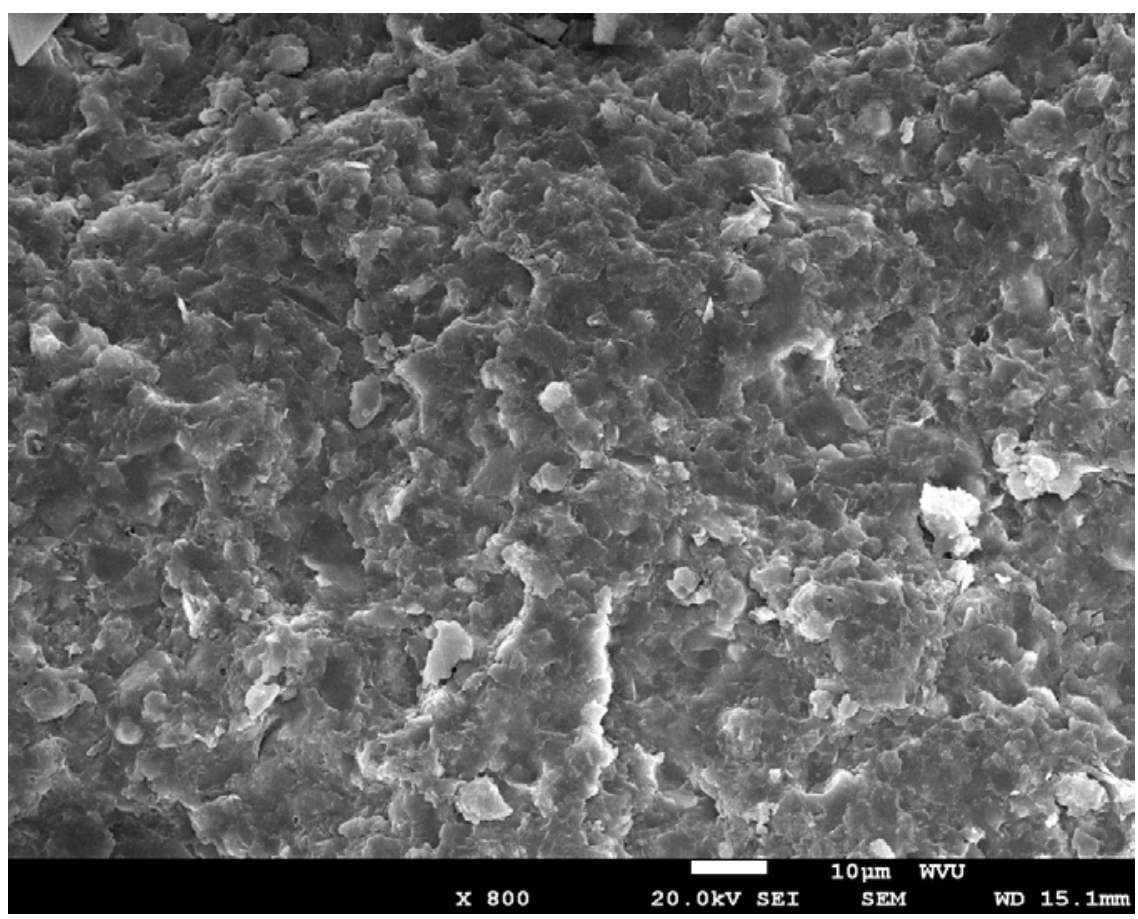

Figure 6.88 SEM image of the Zeogel ${ }^{\circledR}$ treatment sample for the sixth depth interval of Well A at 800X

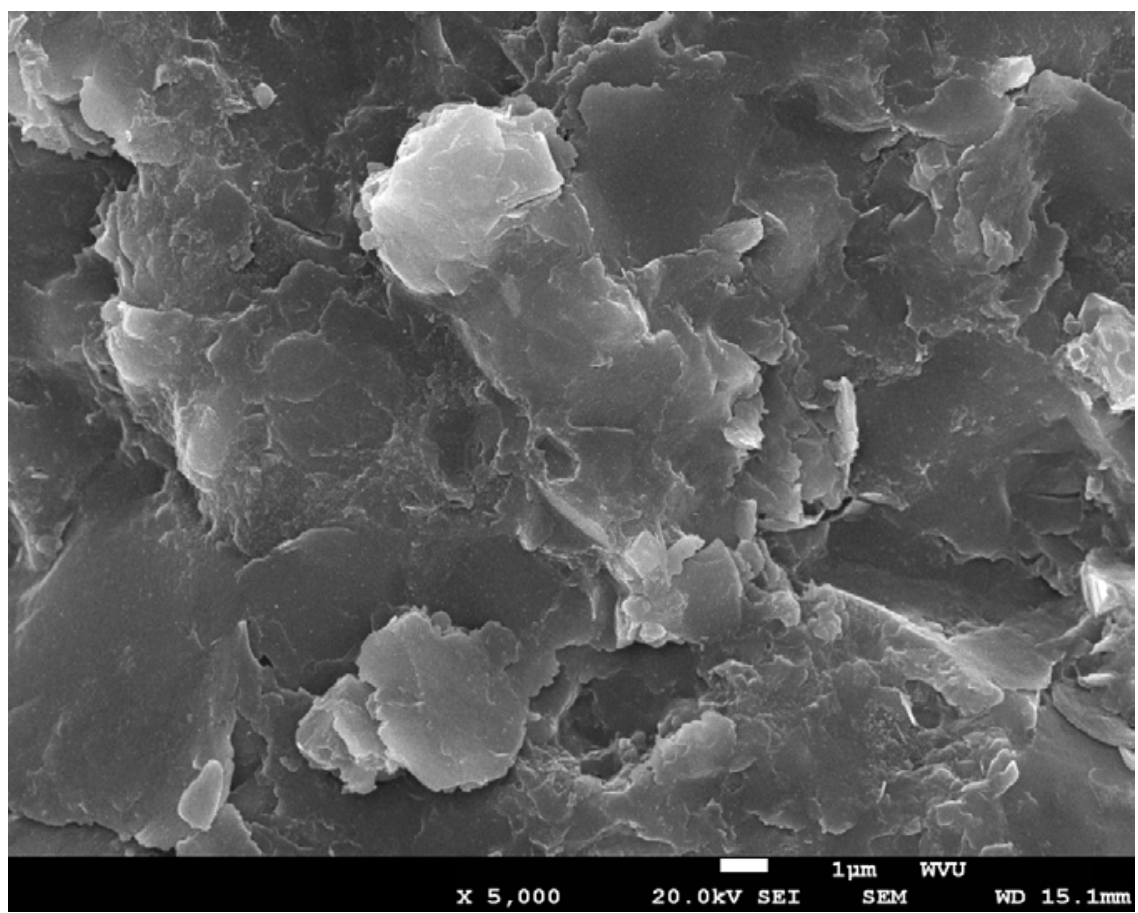

Figure 6.89 SEM image of the Zeogel ${ }^{\circledR}$ treatment sample for the sixth depth interval of Well A at 5000X 


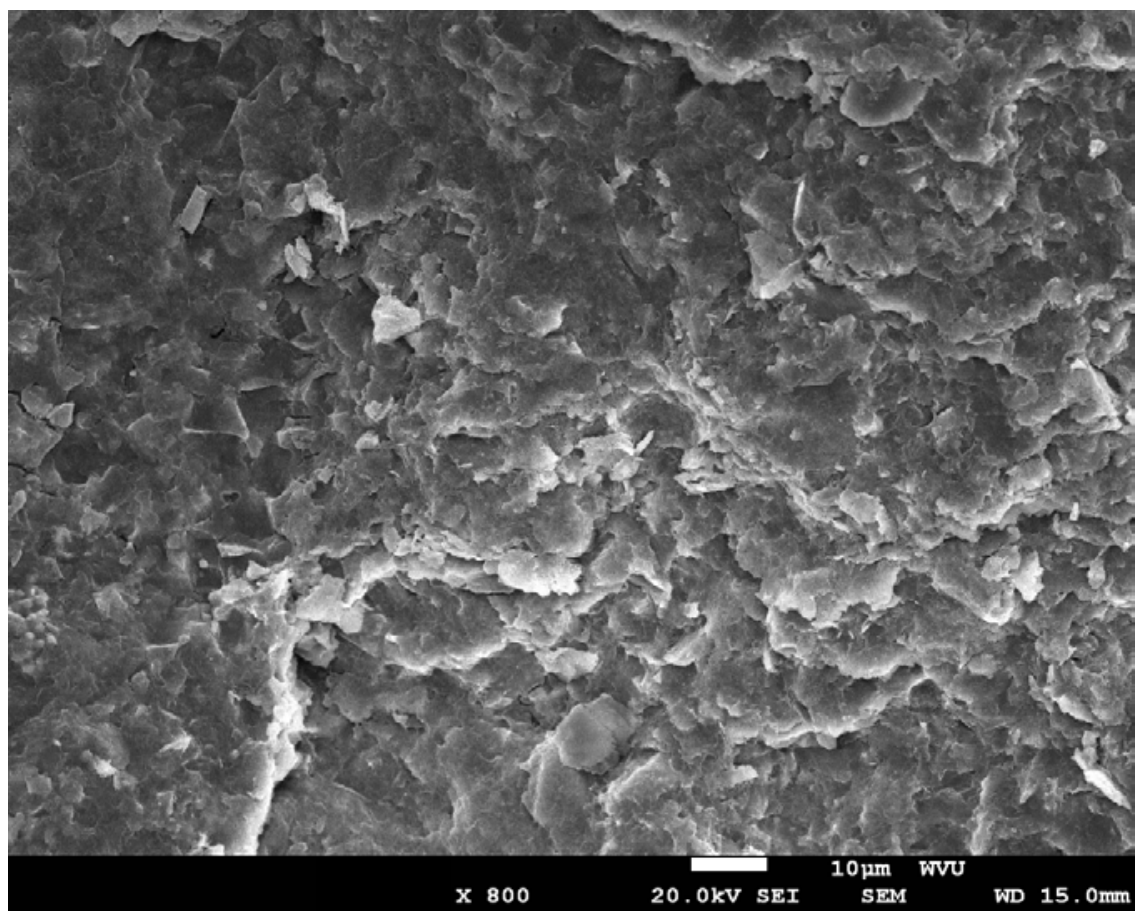

Figure 6.90 SEM image of the Zeogel ${ }^{\circledR}$ treatment sample for the seventh depth interval of Well $\mathrm{A}$ at $800 \mathrm{X}$

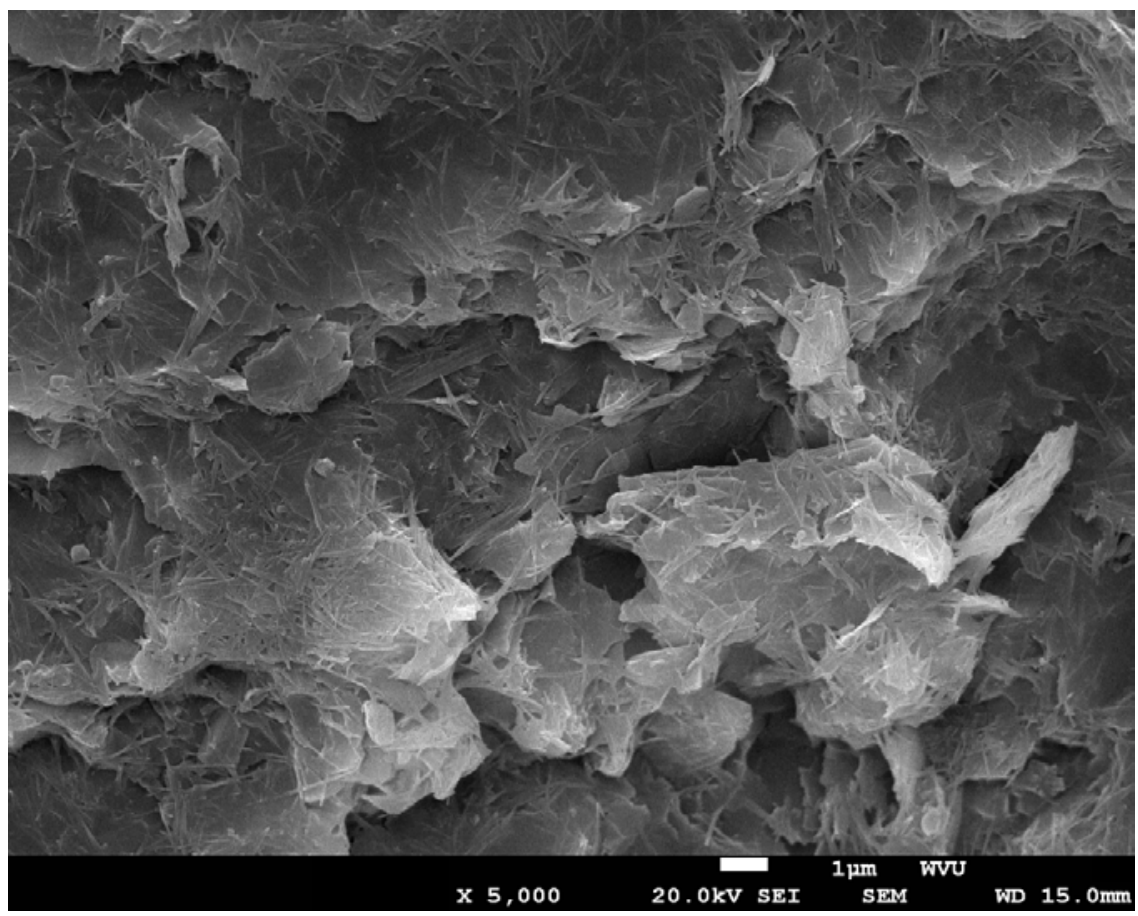

Figure 6.91 SEM image of the Zeogel ${ }^{\circledR}$ treatment sample for the seventh depth interval of Well A at 5000X 


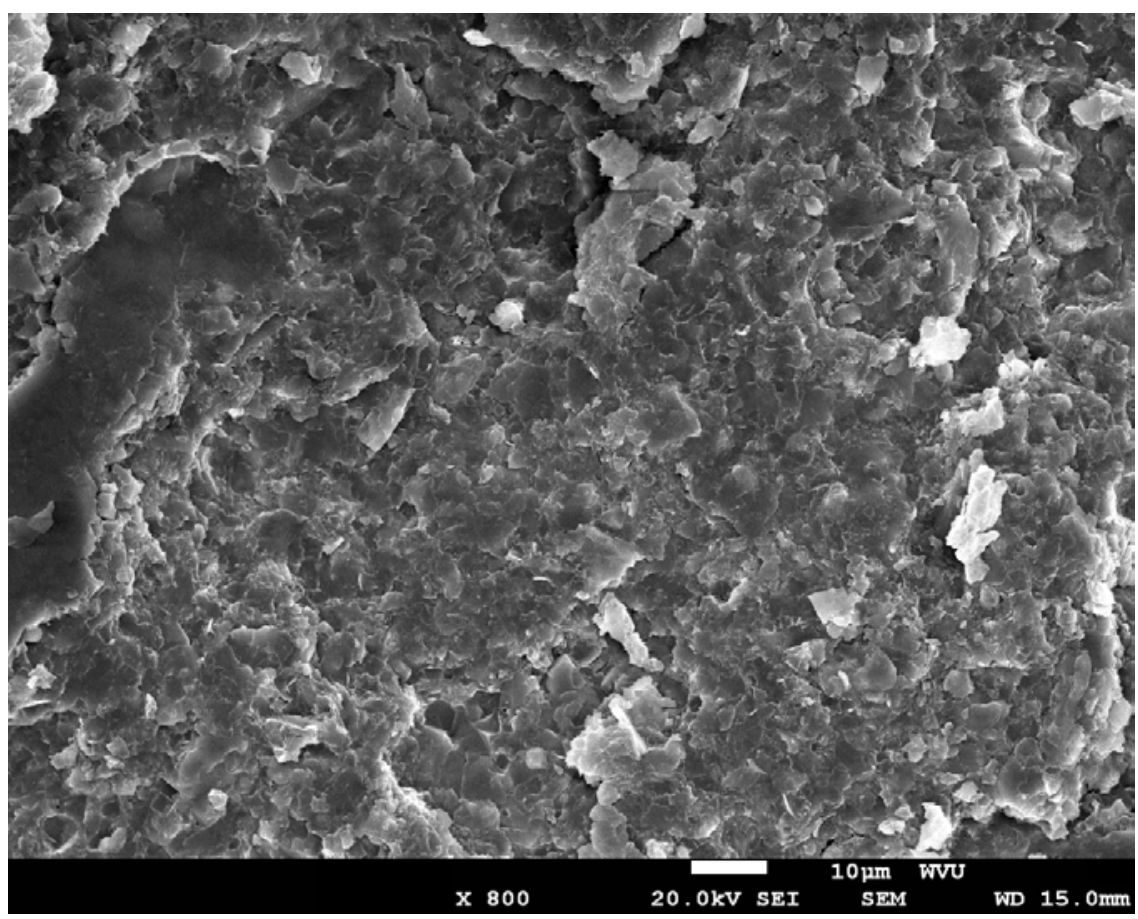

Figure 6.92 SEM image of the Zeogel® treatment sample for the eighth depth interval of Well $A$ at $800 X$

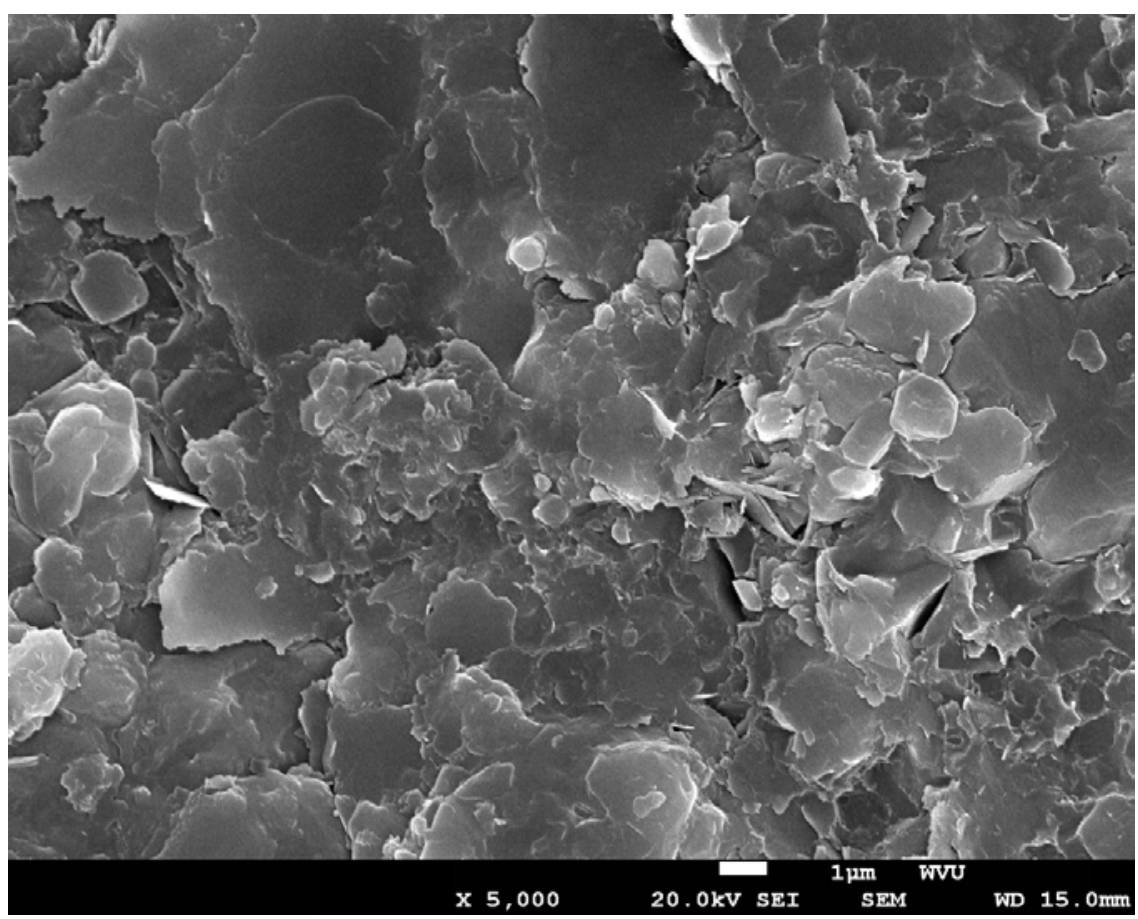

Figure 6.93 SEM image of the Zeogel ${ }^{\circledR}$ treatment sample for the eighth depth interval of Well A at 5000X 


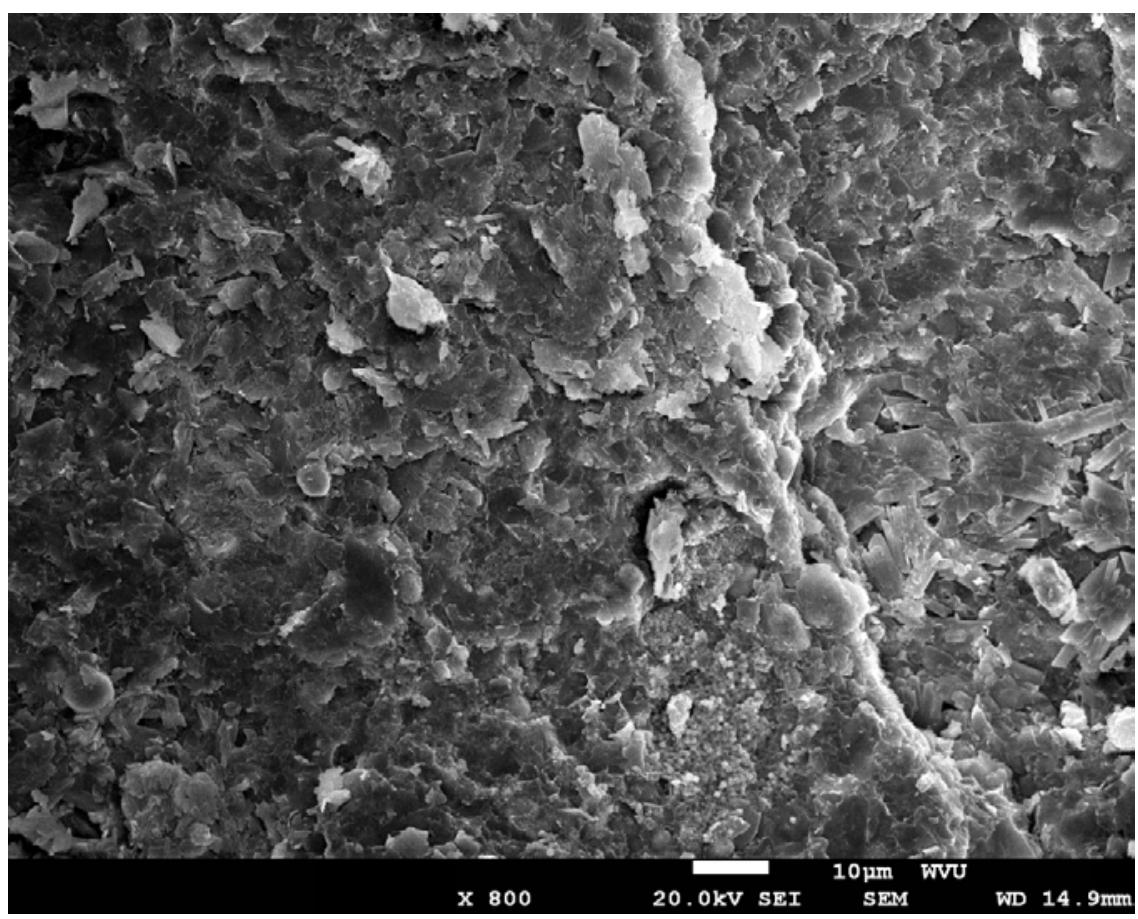

Figure 6.94 SEM image of the Zeogel ${ }^{\circledR}$ treatment sample for the ninth depth interval of Well A at 800X

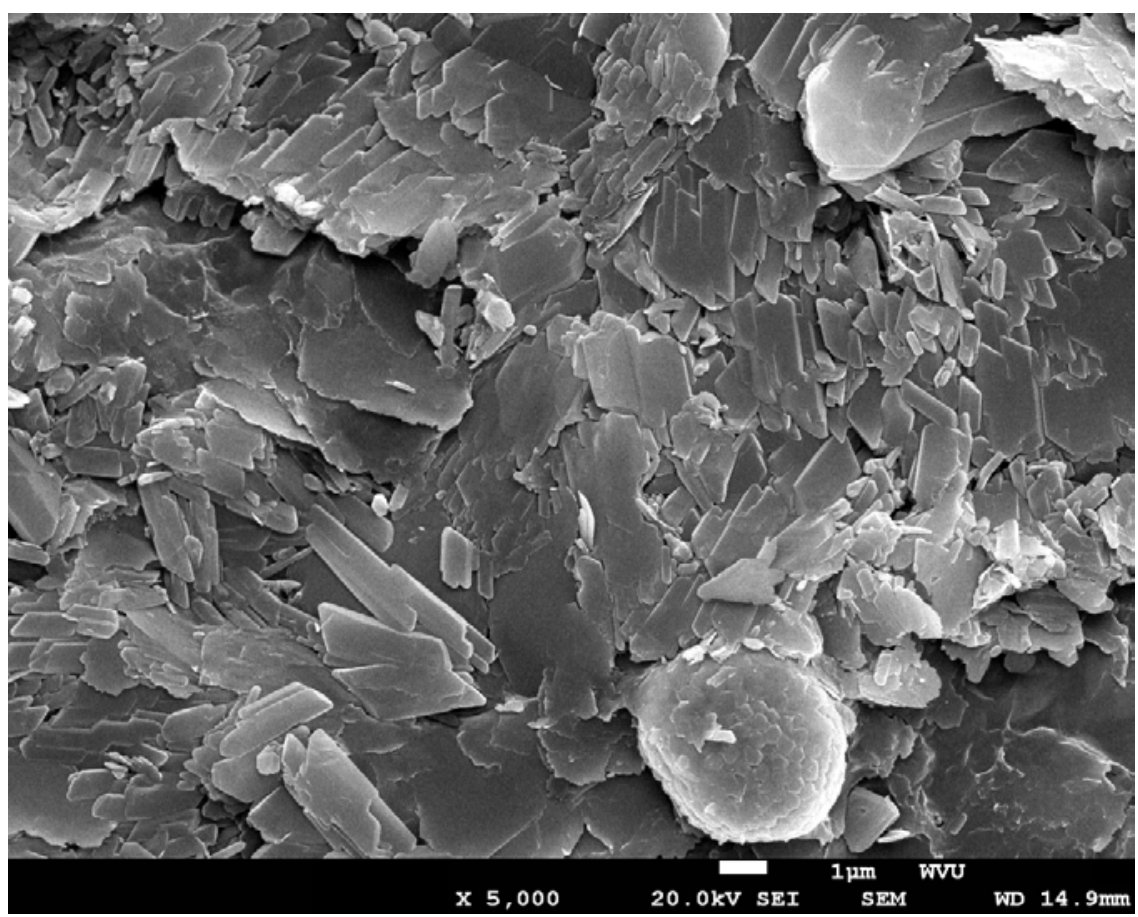

Figure 6.95 SEM image of the Zeogel ${ }^{\circledR}$ treatment sample for the ninth depth interval of Well A at 5000X 


\title{
Wetzel County Well Sample Analysis By Alteration
}

\author{
Wetzel County Well B No Alteration
}

A set of samples from every depth interval was taken from Wetzel County Well B to be used as control samples. These samples did not undergo any alteration. The elemental composition was evaluated using EDX, and the ranges in weight percent for each element found in the control samples are listed in Table 6.6.

\begin{tabular}{|c|c|c|c|}
\hline \multicolumn{4}{|c|}{ Wetzel County Well B (No Alteration) } \\
\hline Element & Weight $\%$ & Sample & Range \\
\hline \multirow{2}{*}{ Al } & 6.83 & $2 B$ & \multirow{2}{*}{6.92} \\
\hline & 13.75 & $5 B$ & \\
\hline \multirow{2}{*}{ C } & 4.66 & $2 B$ & \multirow{2}{*}{26.30} \\
\hline & 30.96 & 1B & \\
\hline \multirow{2}{*}{$\mathrm{Ca}$} & 0.64 & $5 B$ & \multirow{2}{*}{13.15} \\
\hline & 13.79 & $4 B$ & \\
\hline $\mathrm{Cl}$ & 0.34 & $1 \mathrm{~B}$ & 0.34 \\
\hline \multirow{2}{*}{$\mathrm{Fe}$} & 1.09 & $2 \mathrm{~B}$ & \multirow{2}{*}{3.51} \\
\hline & 4.60 & $4 \mathrm{~B}$ & \\
\hline \multirow{2}{*}{$\mathrm{K}$} & 2.51 & $2 B$ & \multirow{2}{*}{5.84} \\
\hline & 8.35 & $4 B$ & \\
\hline \multirow{2}{*}{$\mathrm{Mg}$} & 0.40 & $1 \mathrm{~B}$ & \multirow{2}{*}{1.17} \\
\hline & 1.57 & $5 B$ & \\
\hline $\mathrm{Na}$ & 0.31 & $2 \mathrm{~B}$ & 0.31 \\
\hline \multirow{2}{*}{0} & 17.37 & 1B & \multirow{2}{*}{41.63} \\
\hline & 59.00 & $3 B$ & \\
\hline \multirow{2}{*}{ Si } & 15.27 & $3 B$ & \multirow{2}{*}{22.71} \\
\hline & 37.98 & $4 B$ & \\
\hline \multirow{2}{*}{$\mathrm{Ti}$} & 0.34 & $2 B$ & \multirow{2}{*}{0.04} \\
\hline & 0.38 & $3 B$ & \\
\hline
\end{tabular}

Table 6.6 Weight percent ranges for each element found in the Wetzel County Well B control samples

Every element found in the Wetzel County Well B control samples was plotted against the corresponding depth in Figure 6.36. There were two sets of trending data trends for this particular set of samples. Iron and potassium had parallel trend lines, and this similarity was noted in the samples that underwent the Zeogel ${ }^{\circledR}$ treatment test in Well A. While oxygen and magnesium were 
plotted on two different scales, the two elements still increased in weight percent at similar depth intervals.

Photographs of the control sample taken using the SEM can be seen below in Figure 6.97 through Figure 6.106. Each sample's photograph was taken at a magnification of $800 \mathrm{X}$ and 5000X. The photographs indicated a layered morphology. Countless layers and flakes were seen in these images, and they all appeared to be easily separated. Numerous small pores where oil and gas can be stored were visible in the images. These samples also contained occasional larger and deeper pores such as the one in Figure 6.100. Calcite flakes were identified in the third depth interval (Figure 6.102), and the weight percent of calcium increased in the third depth interval in Figure 6.96 as well. Pyrite crystals were circled in an image taken of the sample from the fourth depth interval (Figure 6.103), and quartz crystals were noted in both images for the fifth depth interval (Figure 6.105 and Figure 6.106). Silicon and oxygen remained relatively constant in weight percent throughout the core, but the images from $5 \mathrm{~B}$ provided obvious examples of the quartz mineral. 


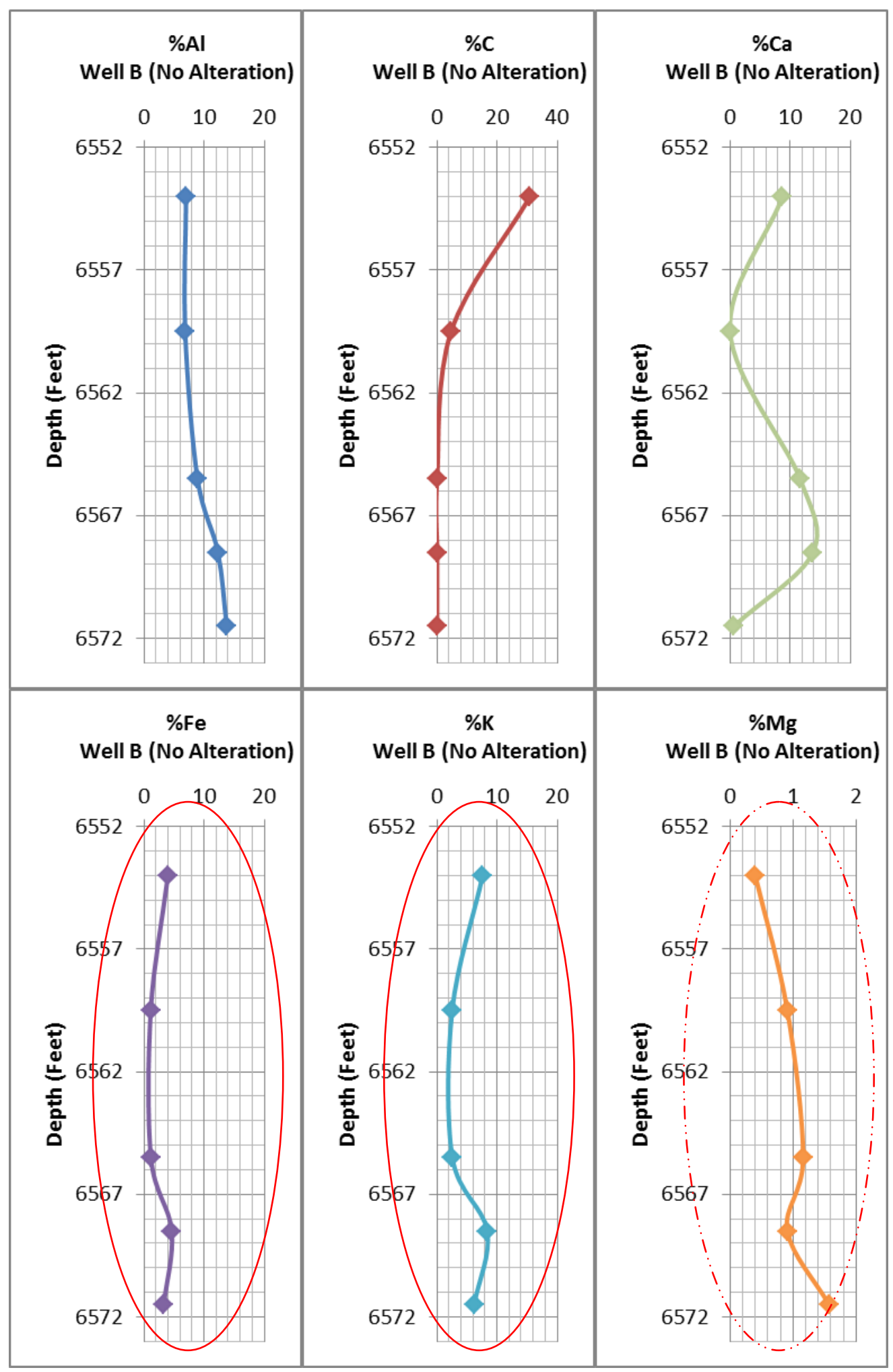




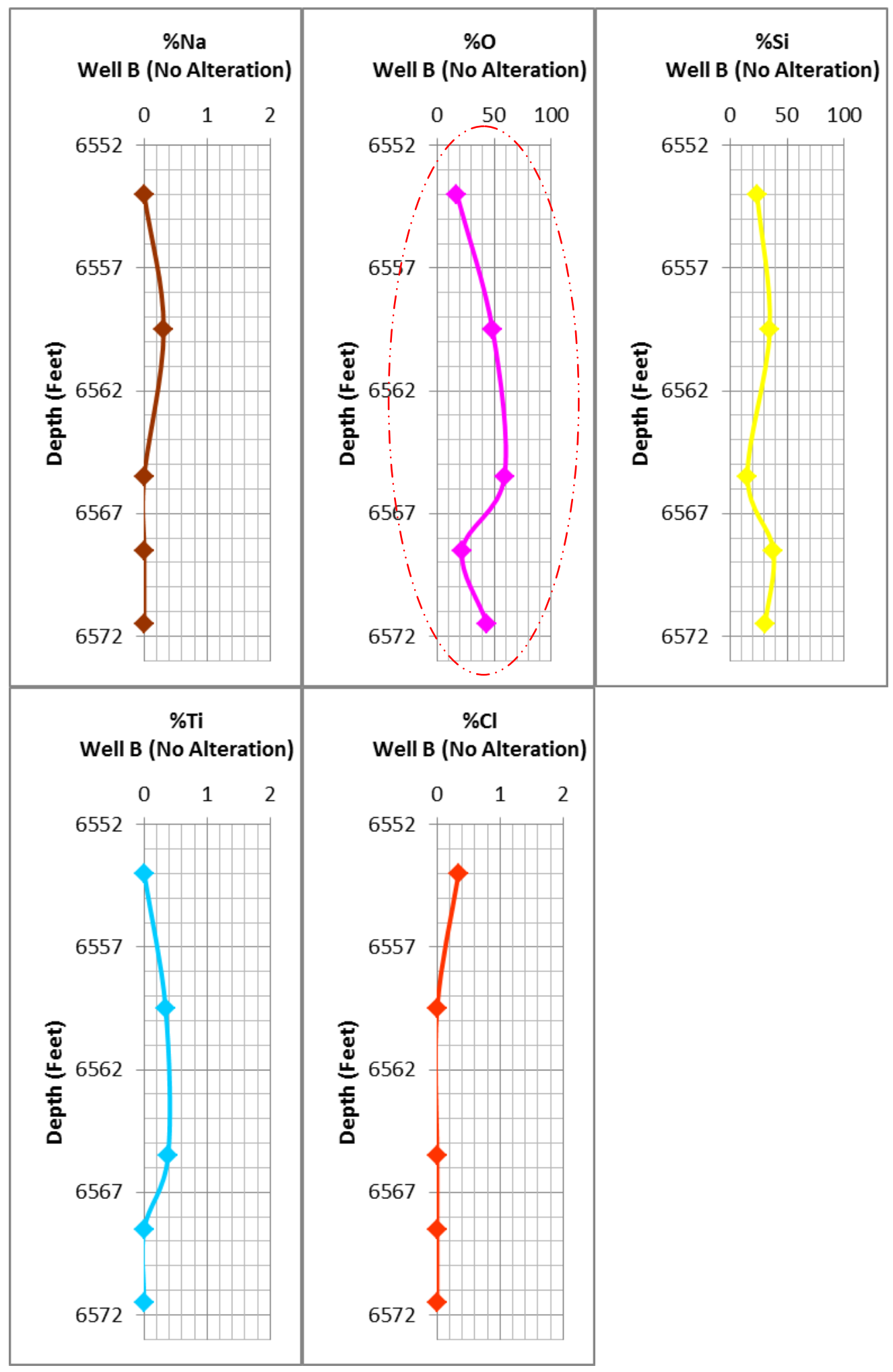

Figure 6.96 Weight percent of each element found in Wetzel County Well B control samples plotted against the corresponding depth 
Wetzel County Well B No Alteration SEM Photographs

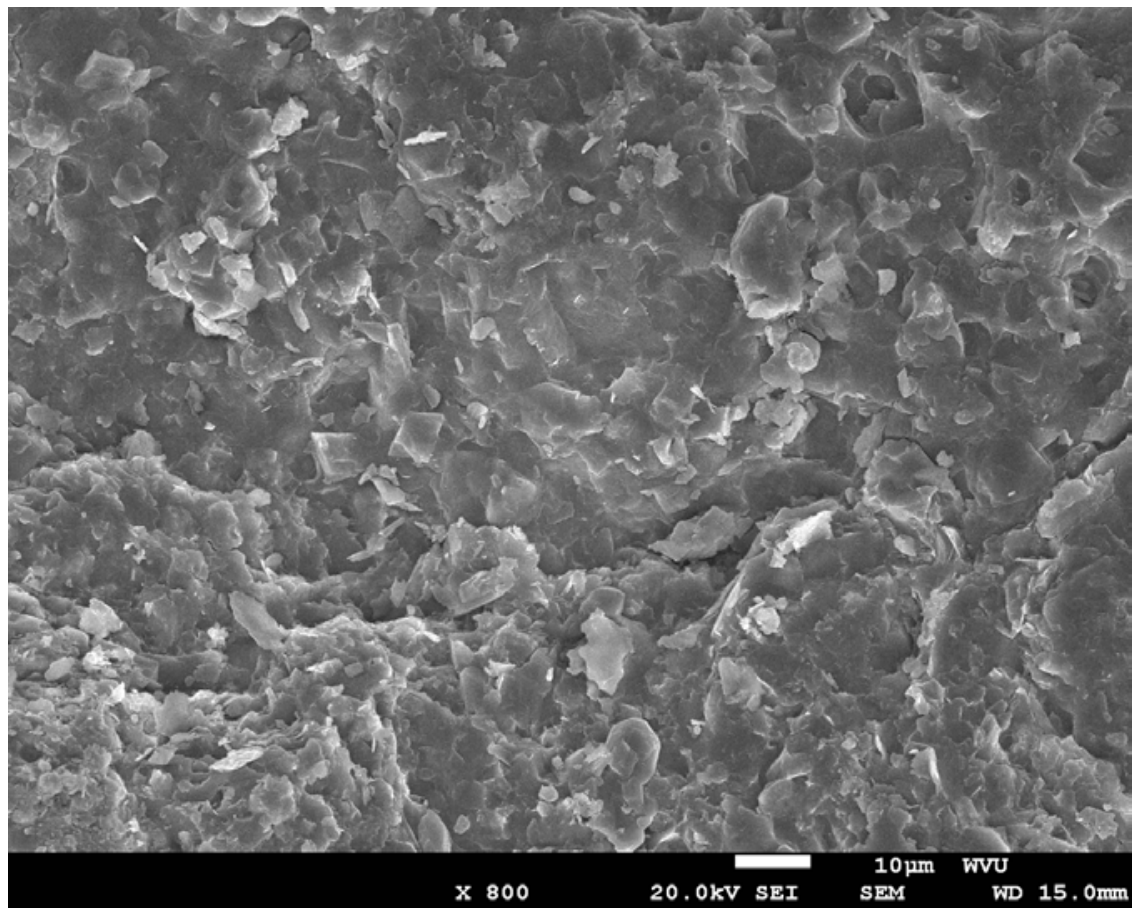

Figure 6.97 SEM image of the control specimen for the first depth interval of Well $\mathrm{B}$ at $800 \mathrm{X}$

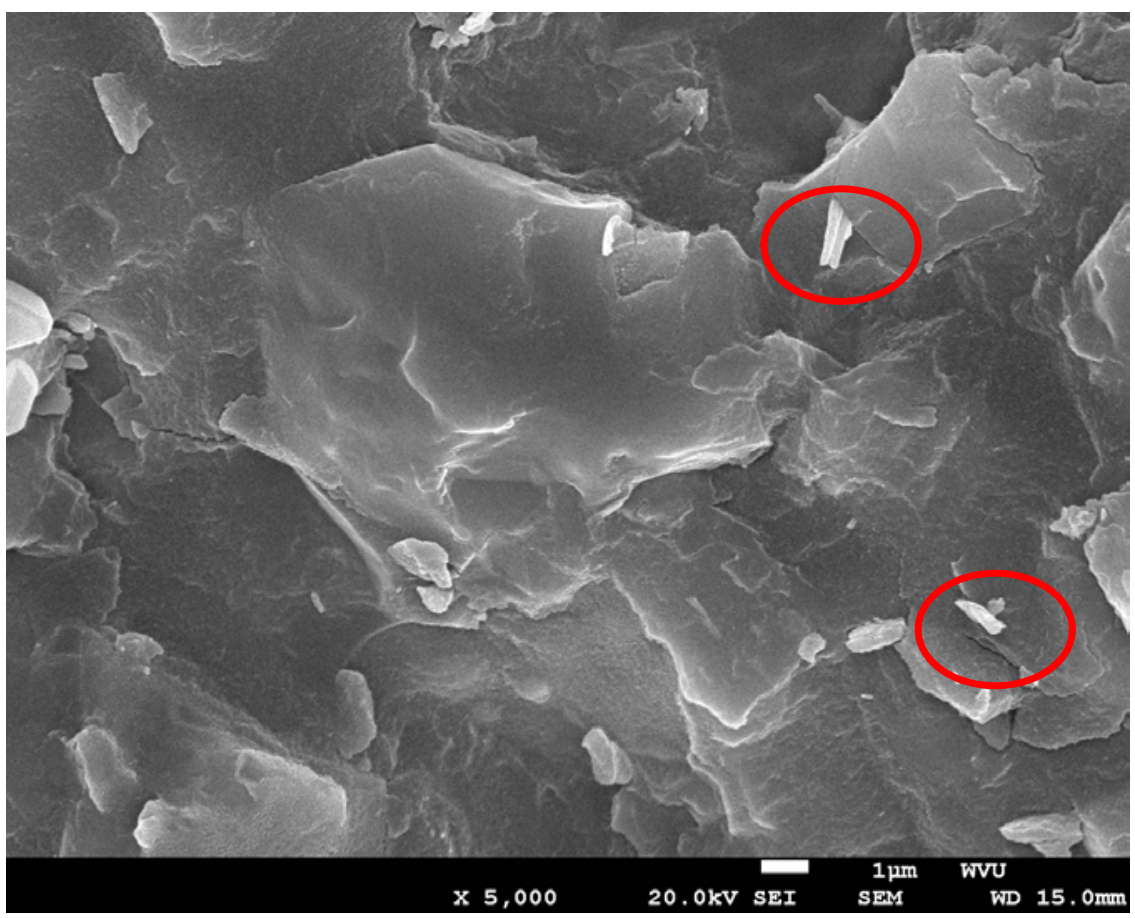

Figure 6.98 SEM image of the control specimen for the first depth interval of Well B at 5000X 


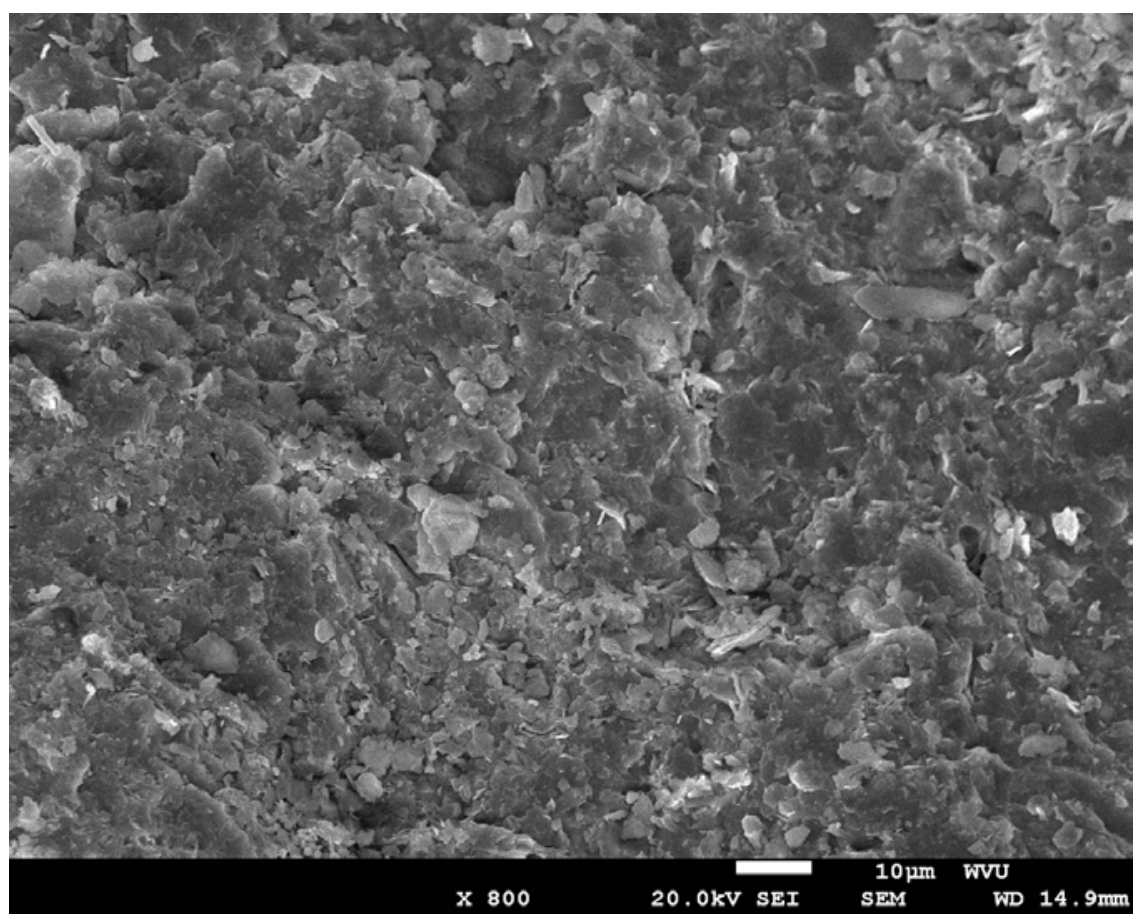

Figure 6.99 SEM image of the control specimen for the second depth interval of Well B at 800X

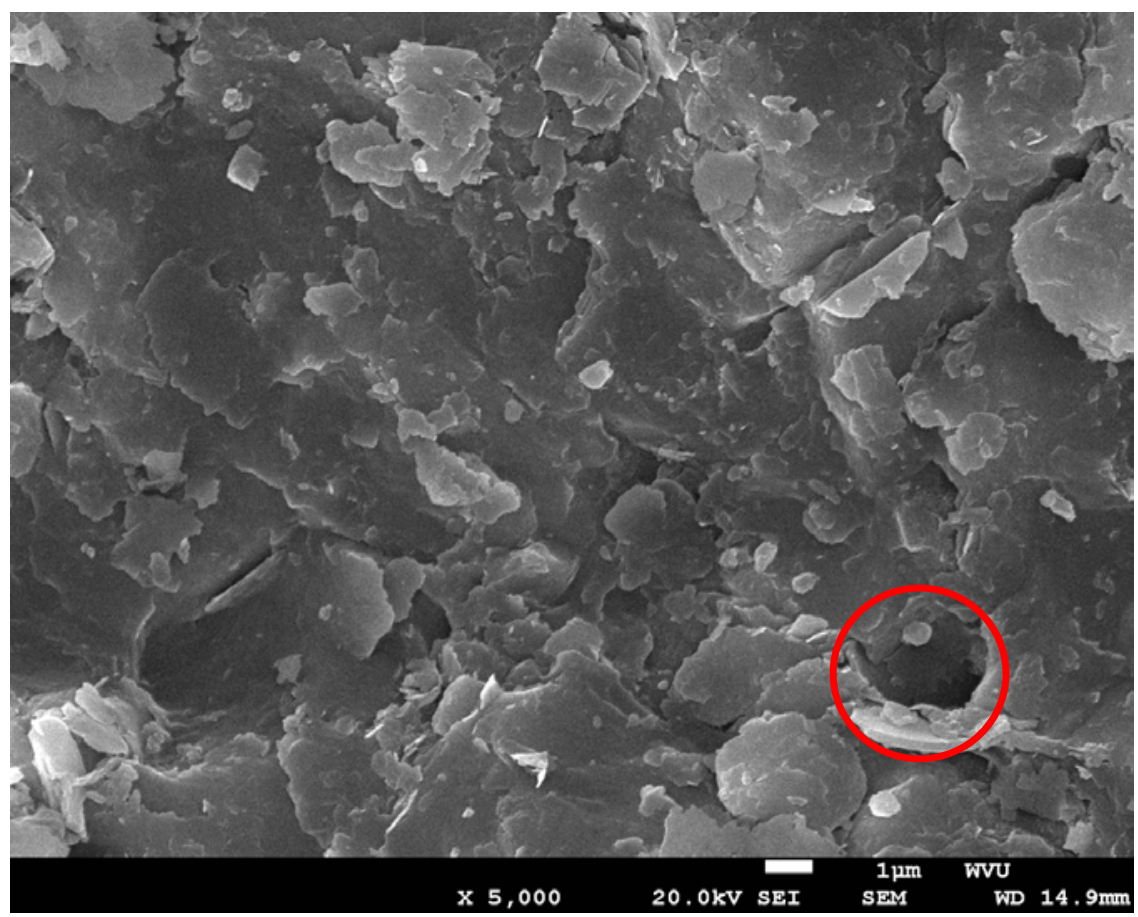

Figure 6.100 SEM image of the control specimen for the second depth interval of Well B at 5000X 


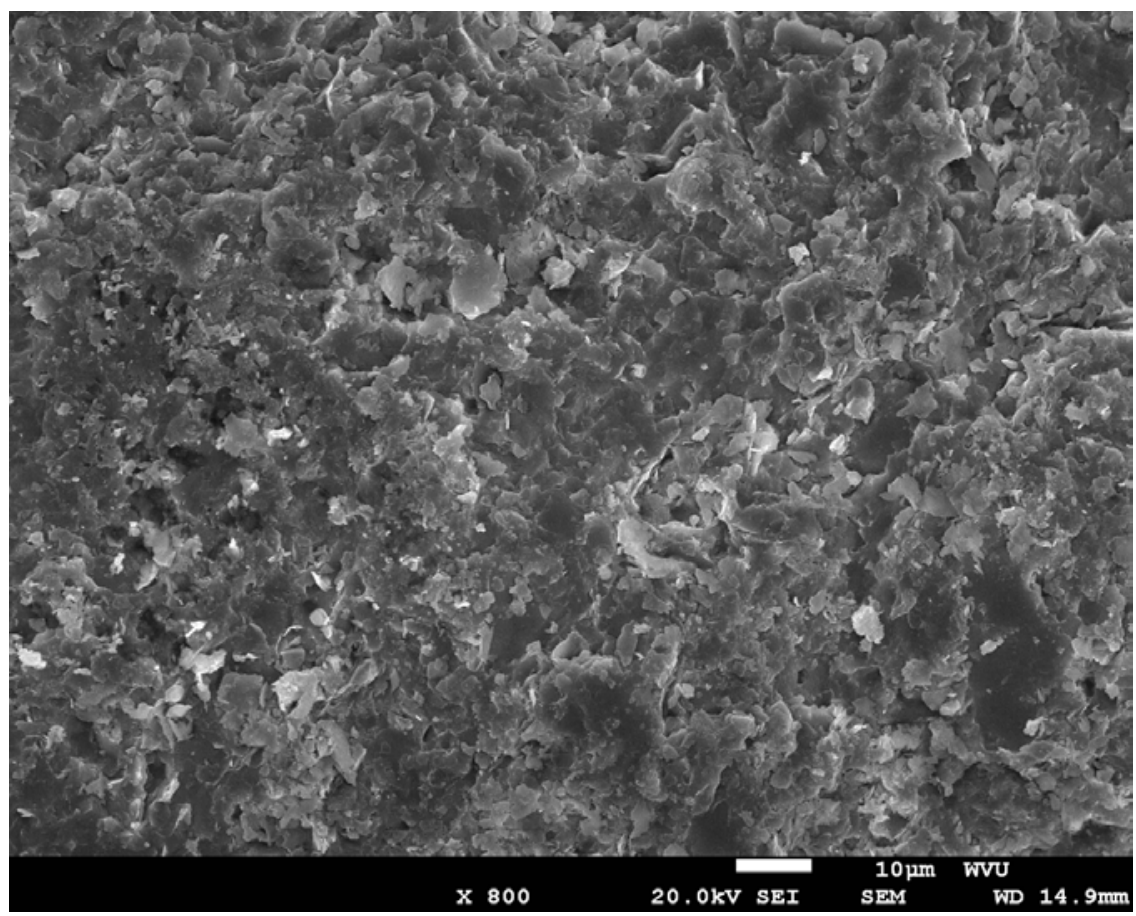

Figure 6.101 SEM image of the control specimen for the third depth interval of Well B at 800X

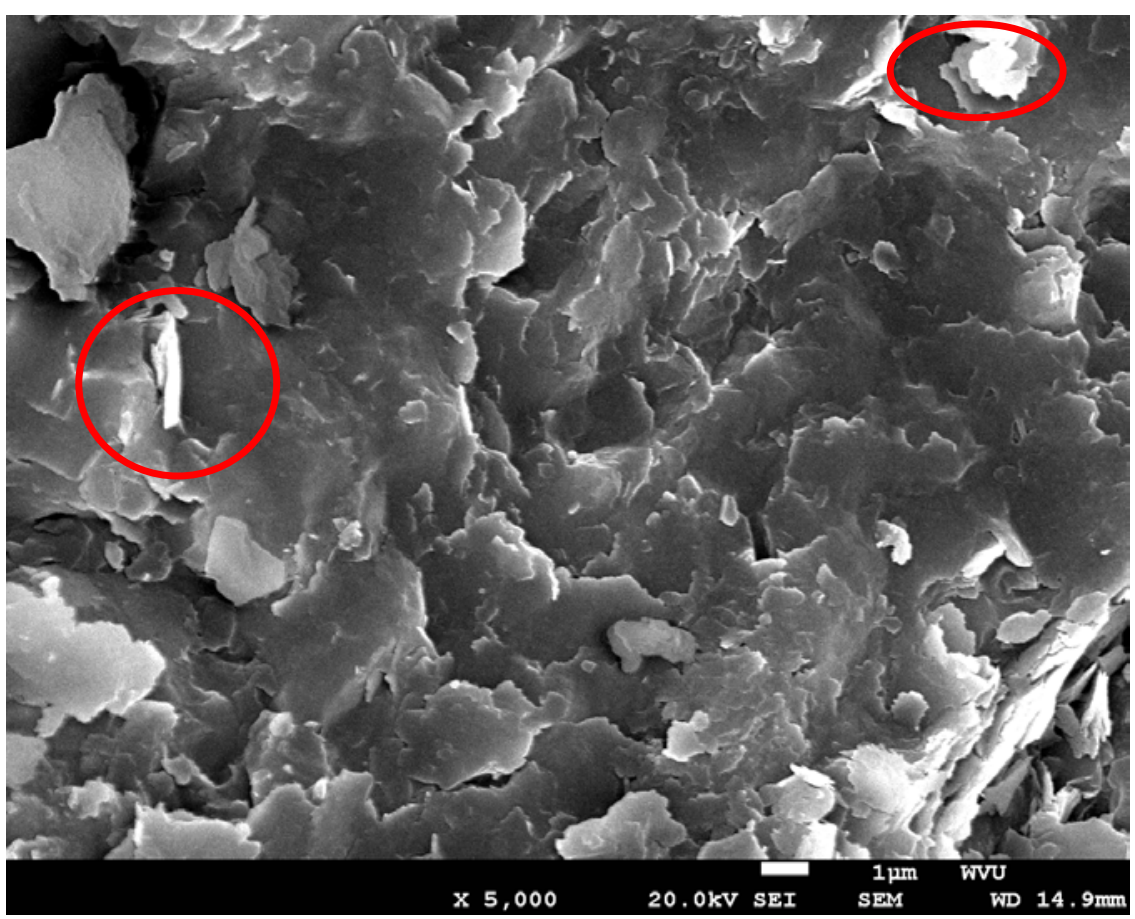

Figure 6.102 SEM image of the control specimen for the third depth interval of Well B at 5000X 


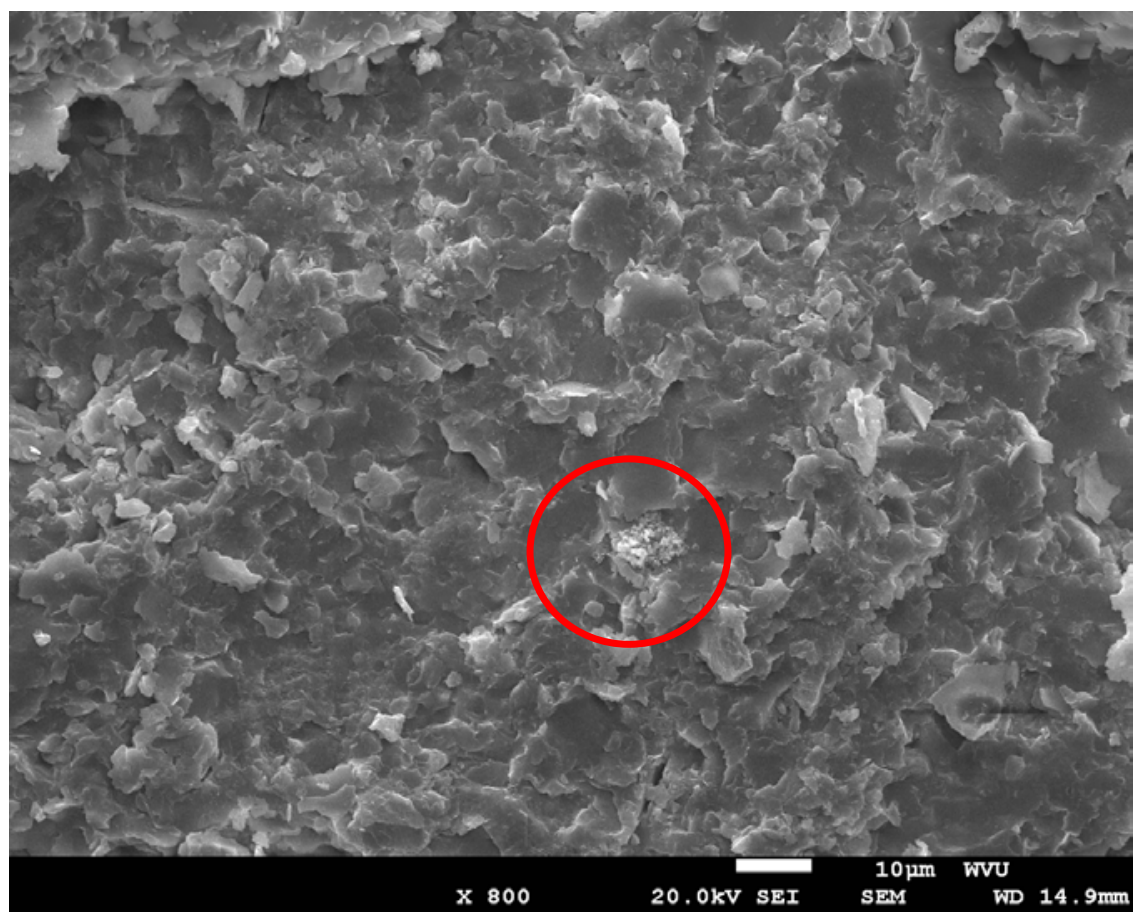

Figure 6.103 SEM image of the control specimen for the fourth depth interval of Well $B$ at $800 \mathrm{X}$

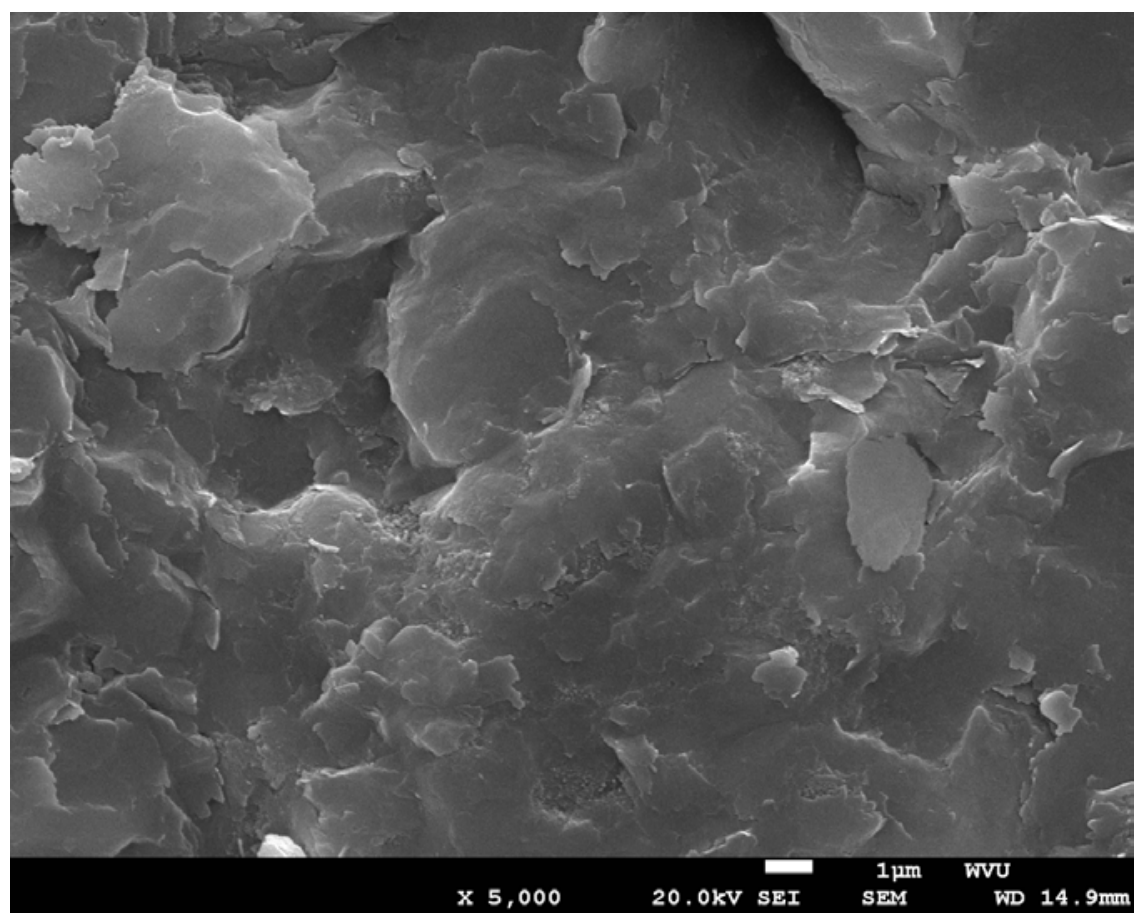

Figure 6.104 SEM image of the control specimen for the fourth depth interval of Well B at 5000X 


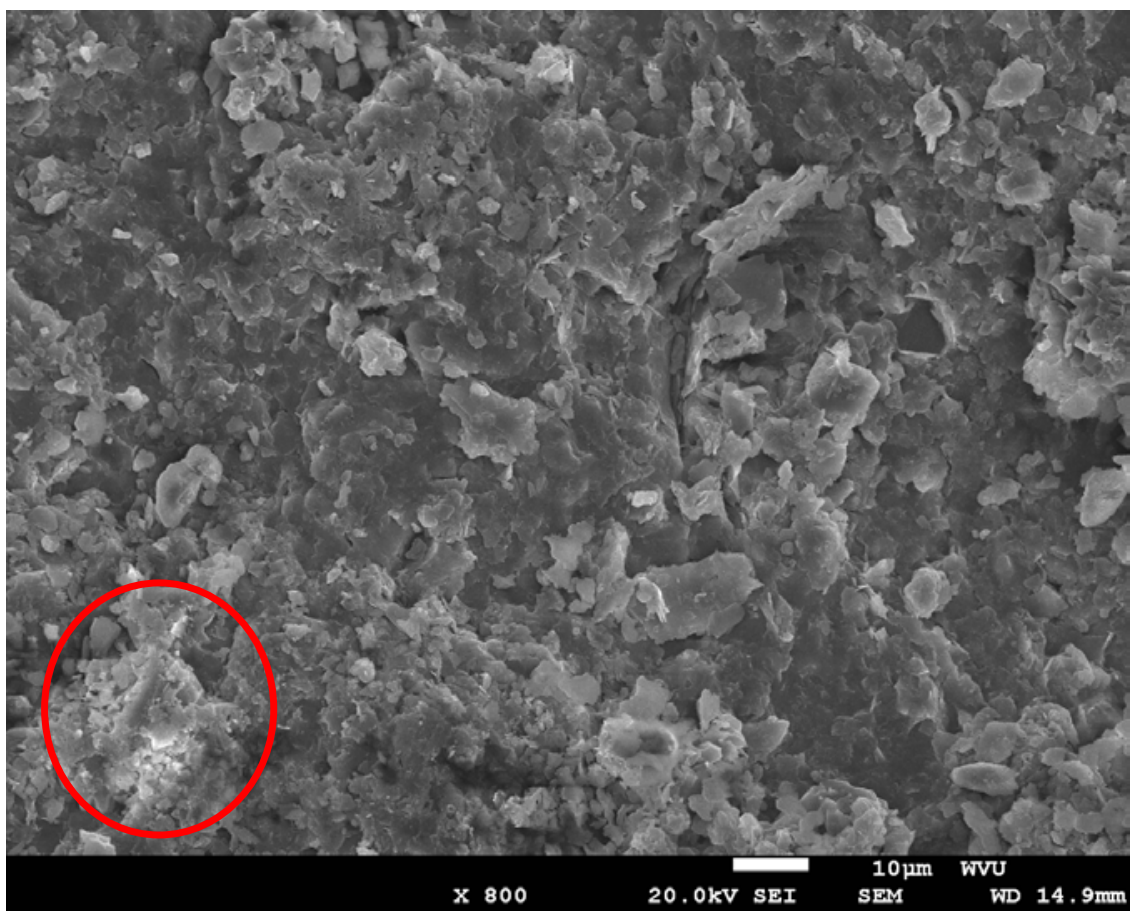

Figure 6.105 SEM image of the control specimen for the fifth depth interval of Well B at 800X

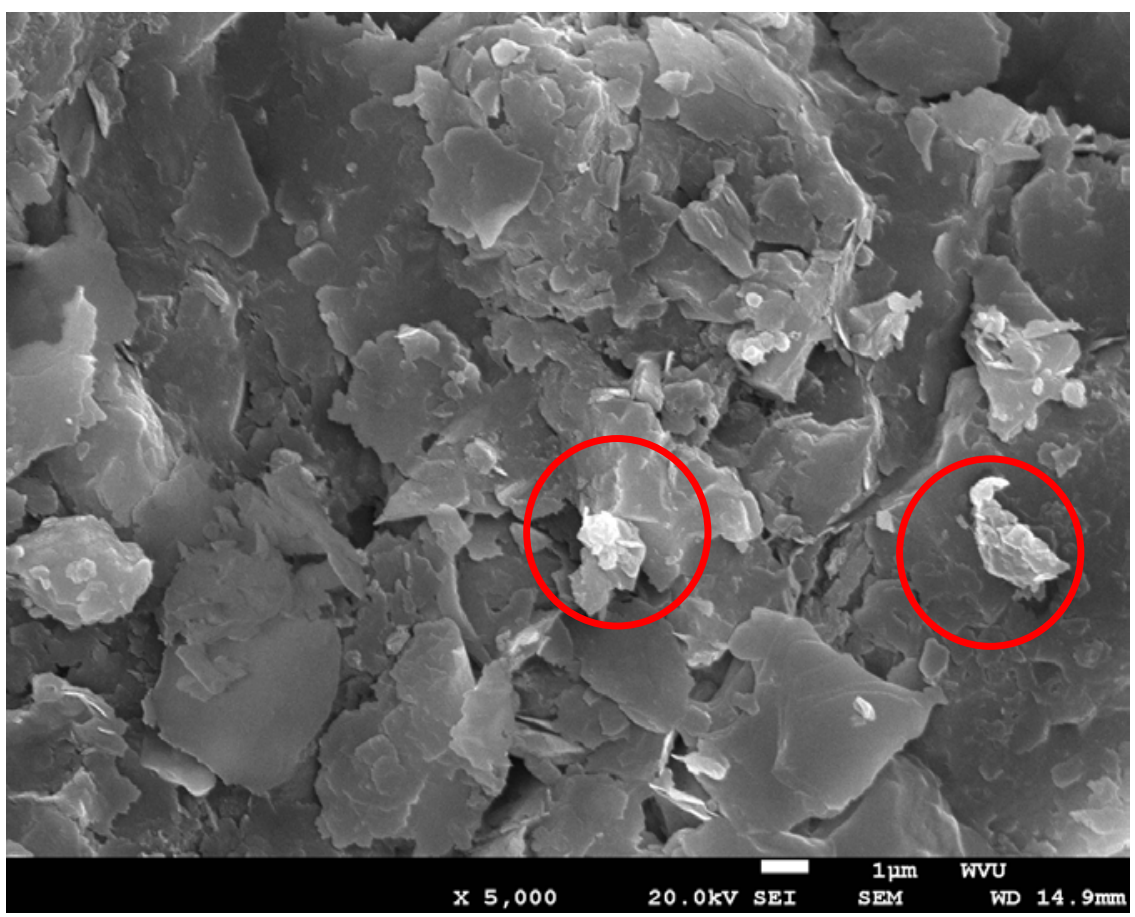

Figure 6.106 SEM image of the control specimen for the fifth depth interval of Well B at 5000X 


\section{Wetzel County Well $\mathrm{B} \mathrm{H}_{2} \mathrm{O}$ Alteration}

The samples discussed in this section underwent a water treatment alteration test. Samples were taken at every depth interval of Wetzel County Well B and soaked for two hours in distilled water. The purpose of this test was to observe the effect water on the elemental composition of the Marcellus Shale. Water is the major constituent of most drilling muds, and thus the clay suspensions in the following tests on Well B. The elemental composition was evaluated using EDX, and the ranges in weight percent for each element found in the water treatment test samples are listed in Table 6.7.

Wetzel County Well B $\left(\mathrm{H}_{2} \mathrm{O}\right)$

\begin{tabular}{|c|c|c|c|}
\hline Element & Weight\% & Sample & Range \\
\hline \multirow{2}{*}{ Al } & 4.23 & 1B & \multirow{2}{*}{8.00} \\
\hline & 12.23 & $5 B$ & \\
\hline \multirow{2}{*}{ C } & 5.01 & $3 B$ & \multirow{2}{*}{11.19} \\
\hline & 16.20 & $4 B$ & \\
\hline \multirow{2}{*}{$\mathrm{Ca}$} & 0.93 & 1B & \multirow{2}{*}{17.31} \\
\hline & 18.24 & $2 B$ & \\
\hline \multirow{2}{*}{$\mathrm{Fe}$} & 1.52 & $3 B$ & \multirow{2}{*}{13.02} \\
\hline & 14.54 & $2 B$ & \\
\hline \multirow{2}{*}{ K } & 1.39 & 1B & \multirow{2}{*}{11.47} \\
\hline & 12.86 & $2 B$ & \\
\hline \multirow{2}{*}{$\mathrm{Mg}$} & 0.45 & 1B & \multirow{2}{*}{0.37} \\
\hline & 0.82 & 4B & \\
\hline $\mathrm{Na}$ & 0.41 & 4B & 0.41 \\
\hline \multirow{2}{*}{$\mathrm{O}$} & 23.80 & $2 B$ & \multirow{2}{*}{22.49} \\
\hline & 46.29 & $3 B$ & \\
\hline \multirow{2}{*}{$\mathrm{Si}$} & 21.84 & $2 B$ & \multirow{2}{*}{23.09} \\
\hline & 44.93 & 1B & \\
\hline $\mathrm{Ti}$ & 1.97 & $5 B$ & 1.97 \\
\hline
\end{tabular}

Table 6.7 Weight percent ranges for each element found in the Wetzel County Well B water treatment samples

All the elements found in the samples that underwent the water treatment test from Wetzel County Well B were plotted against the corresponding depth in Figure 6.107. Three elemental trends were observed in these particular samples. Just as in the control samples, iron and potassium weight percent data lines were complimentary, and aluminum followed a similar curve as well. Weight percent data curves for aluminum and potassium were parallel in the water treatment test samples 
from Well A. Carbon and sodium produced similar data points, with a slightly higher weight percent of carbon in the fourth depth interval. The weight percent values were parallel for oxygen and silicon. The data points were plotted on the same scale and follow nearly the exact same trend. These values could be used to determine the magnitude of quartz present within the core.

Photographs were taken using the SEM of the samples that underwent the water treatment test, and they are seen below in Figure 6.108 through Figure 6.117. Each sample's image was taken at a magnification of $800 \mathrm{X}$ and 5000X, and the surface of the samples remained consistent with the control samples. Characteristic layers and pores were present in all the images. The increase in weight percent for calcium supports the validity of the calcite crystals circled in the images taken at a magnification of 5000X for the third depth interval (Figure 6.111). 


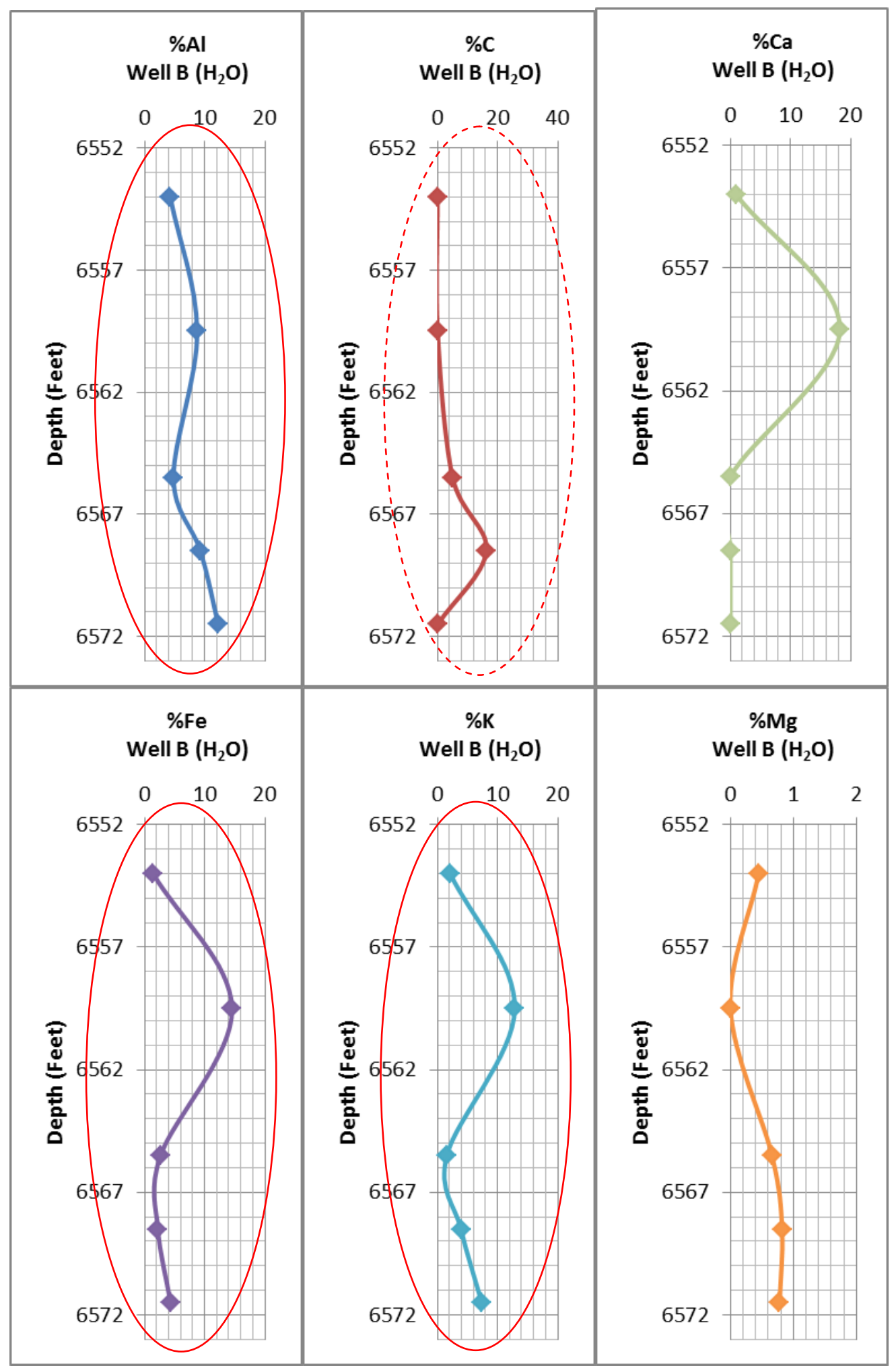




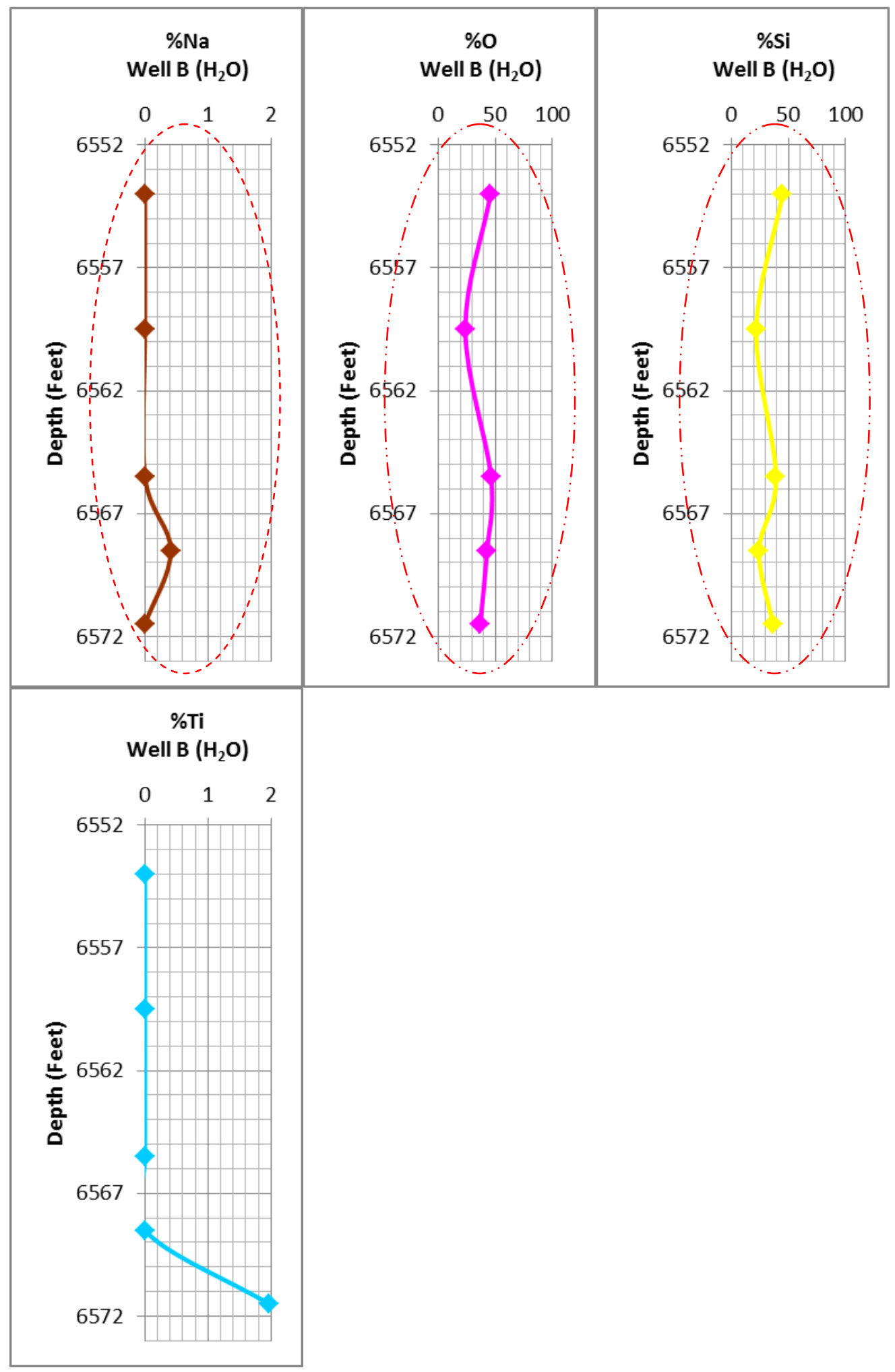

Figure 6.107 Weight percent of each element found in Wetzel County Well B water treatment samples plotted against the corresponding depth 
Wetzel County Well $\mathrm{B} \mathrm{H}_{2} \mathrm{O}$ Alteration SEM Photographs

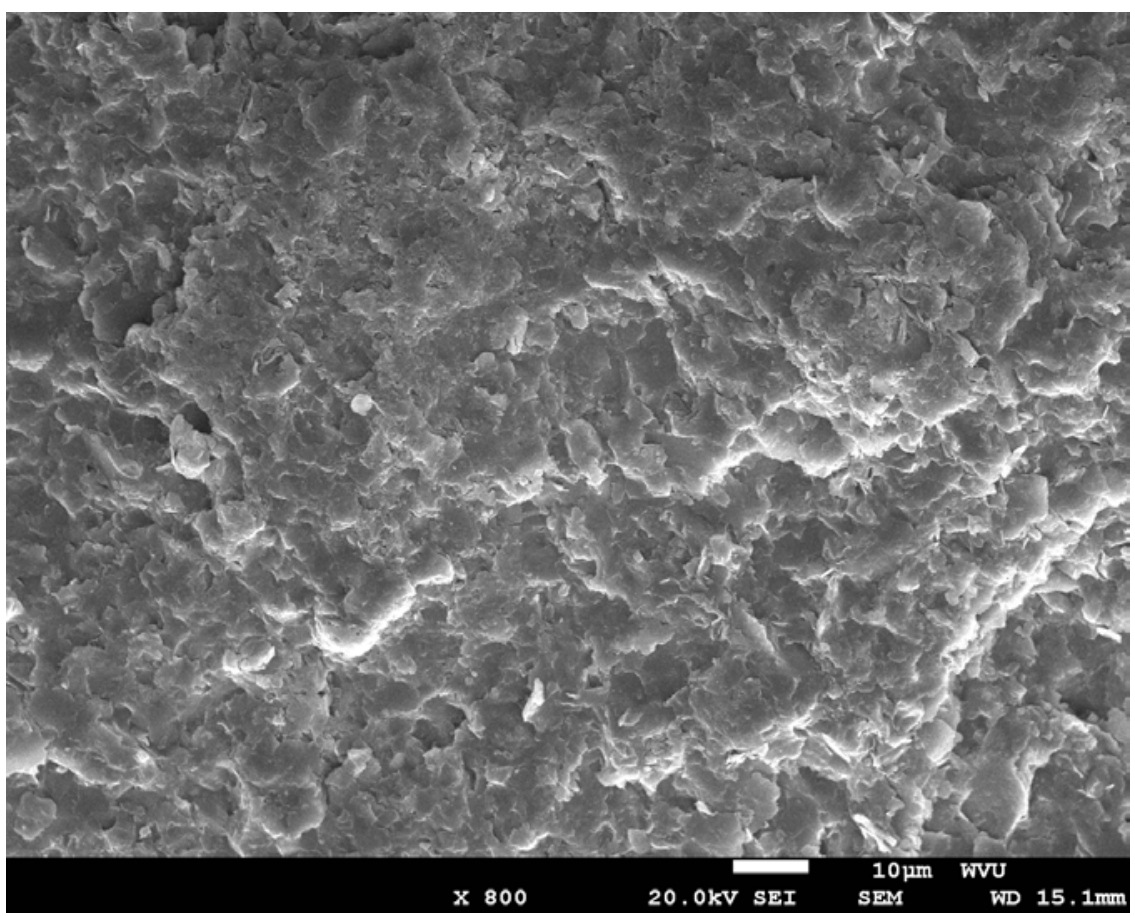

Figure 6.108 SEM image of the water treatment specimen for the first depth interval of Well B at $800 \mathrm{X}$

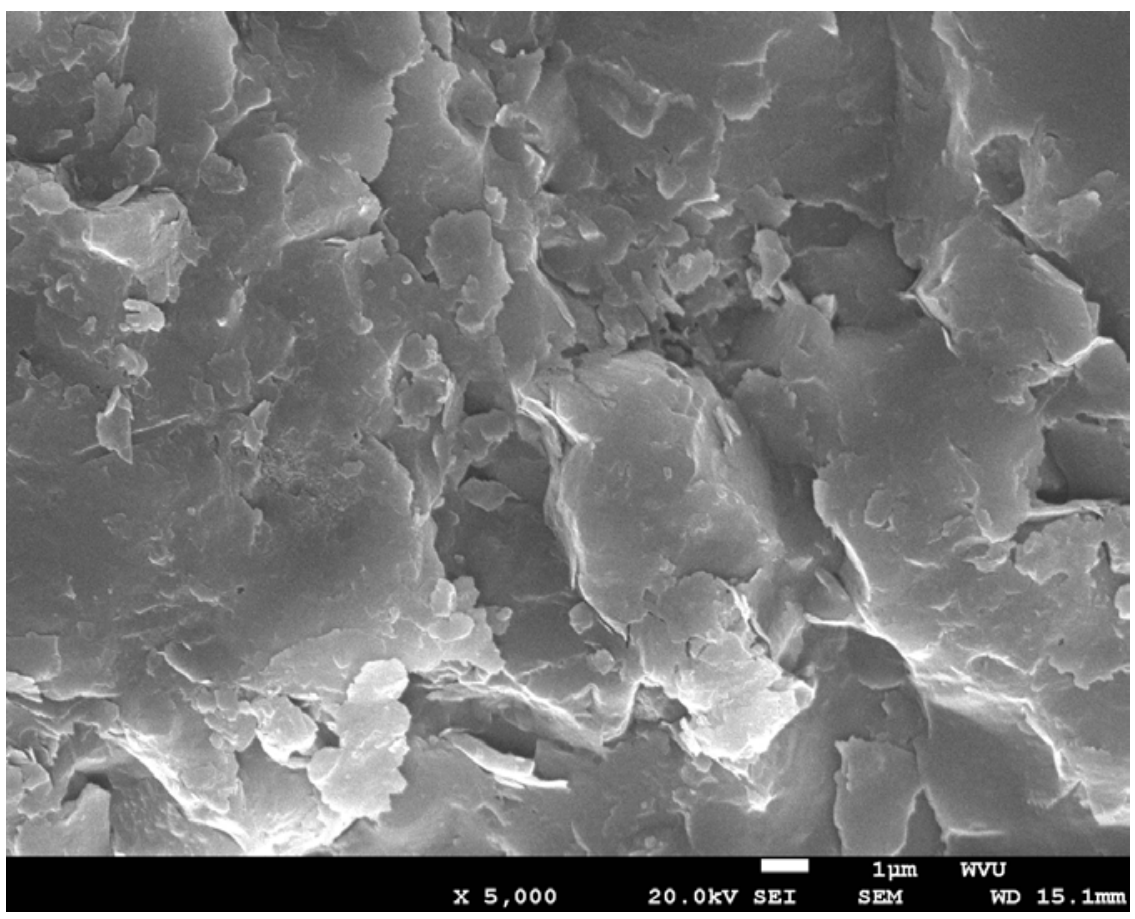

Figure 6.109 SEM image of the water treatment specimen for the first depth interval of Well B at 5000X 


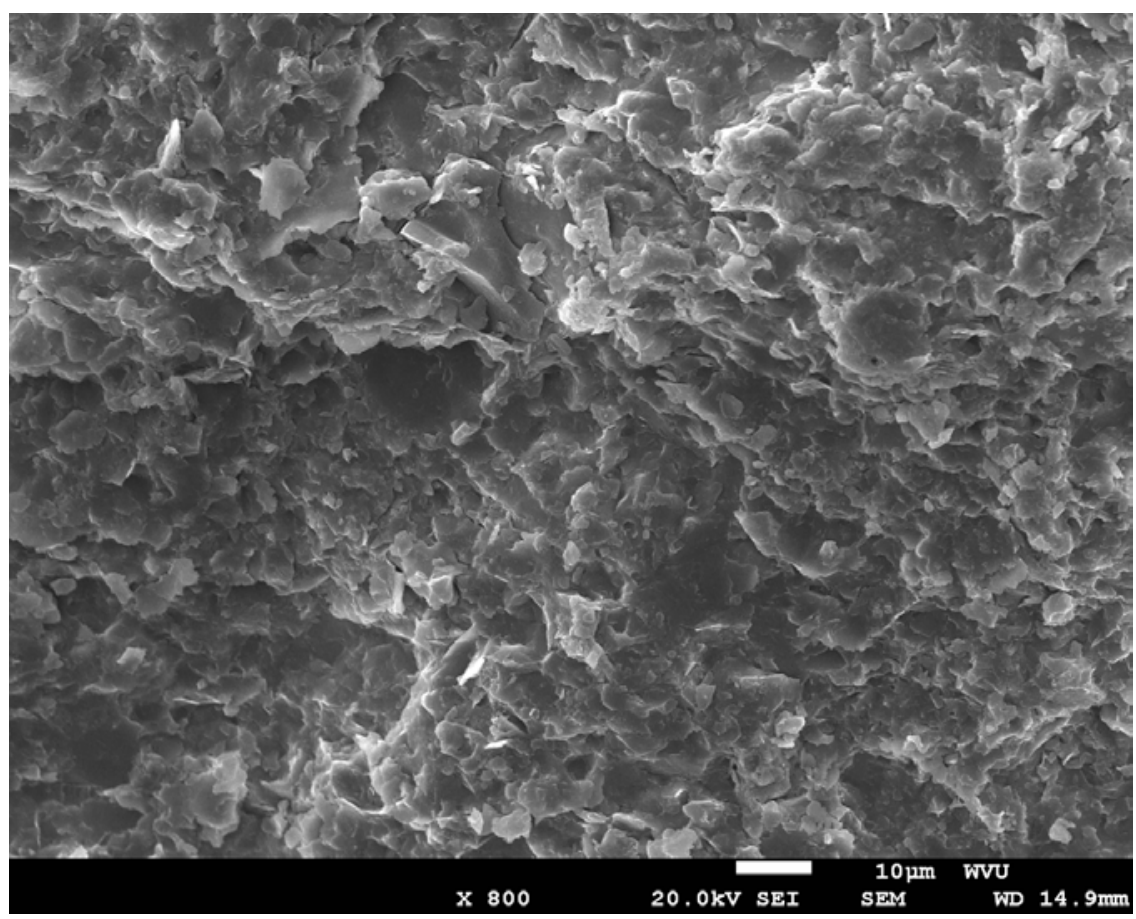

Figure 6.110 SEM image of the water treatment specimen for the second depth interval of Well $B$ at $800 X$

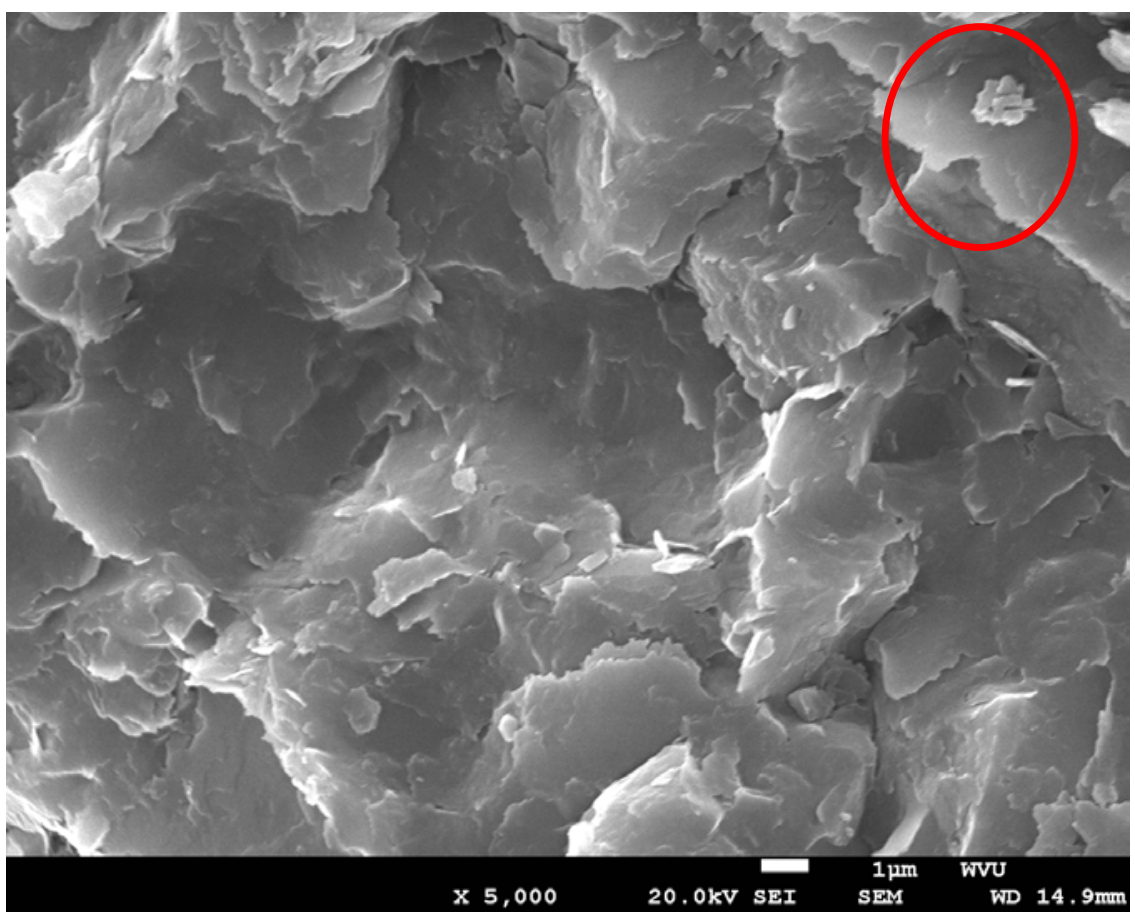

Figure 6.111 SEM image of the water treatment specimen for the second depth interval of Well B at 5000X 


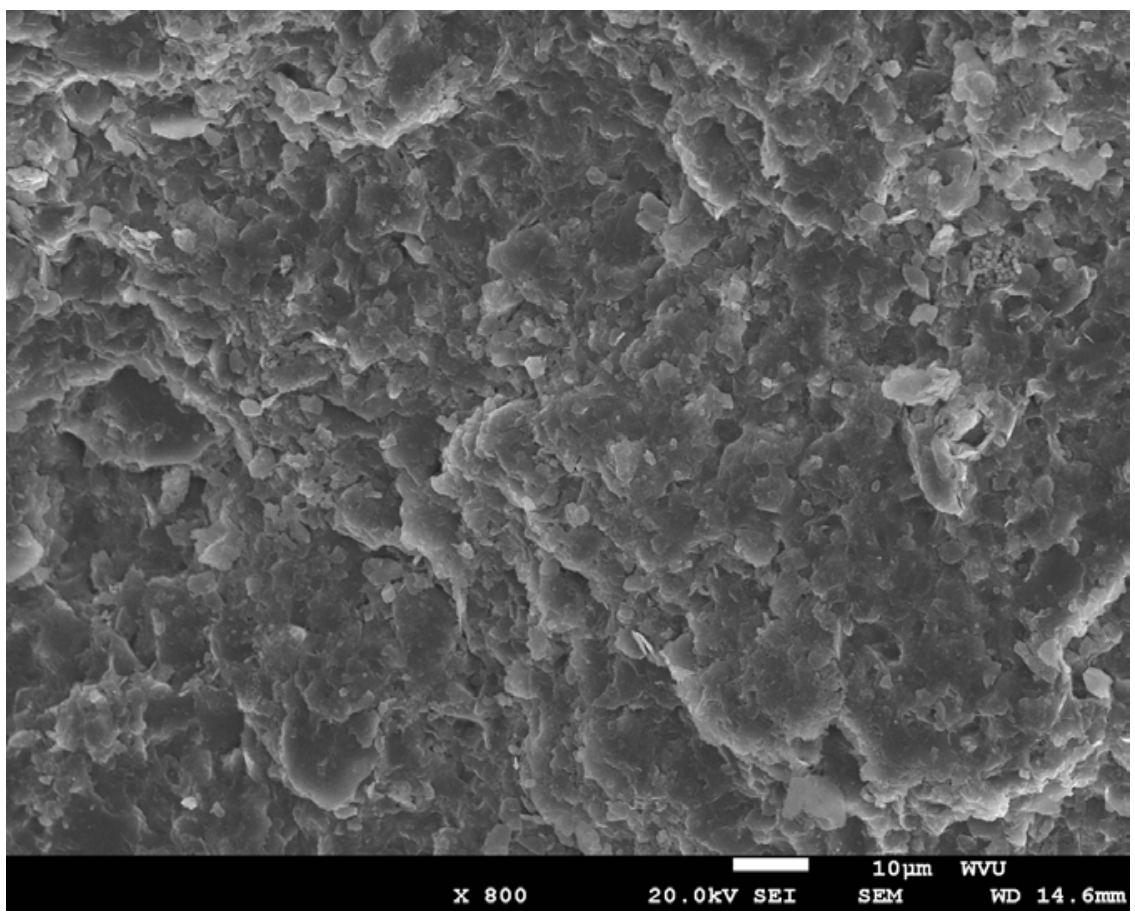

Figure 6.112 SEM image of the water treatment specimen for the third depth interval of Well B at $800 \mathrm{X}$

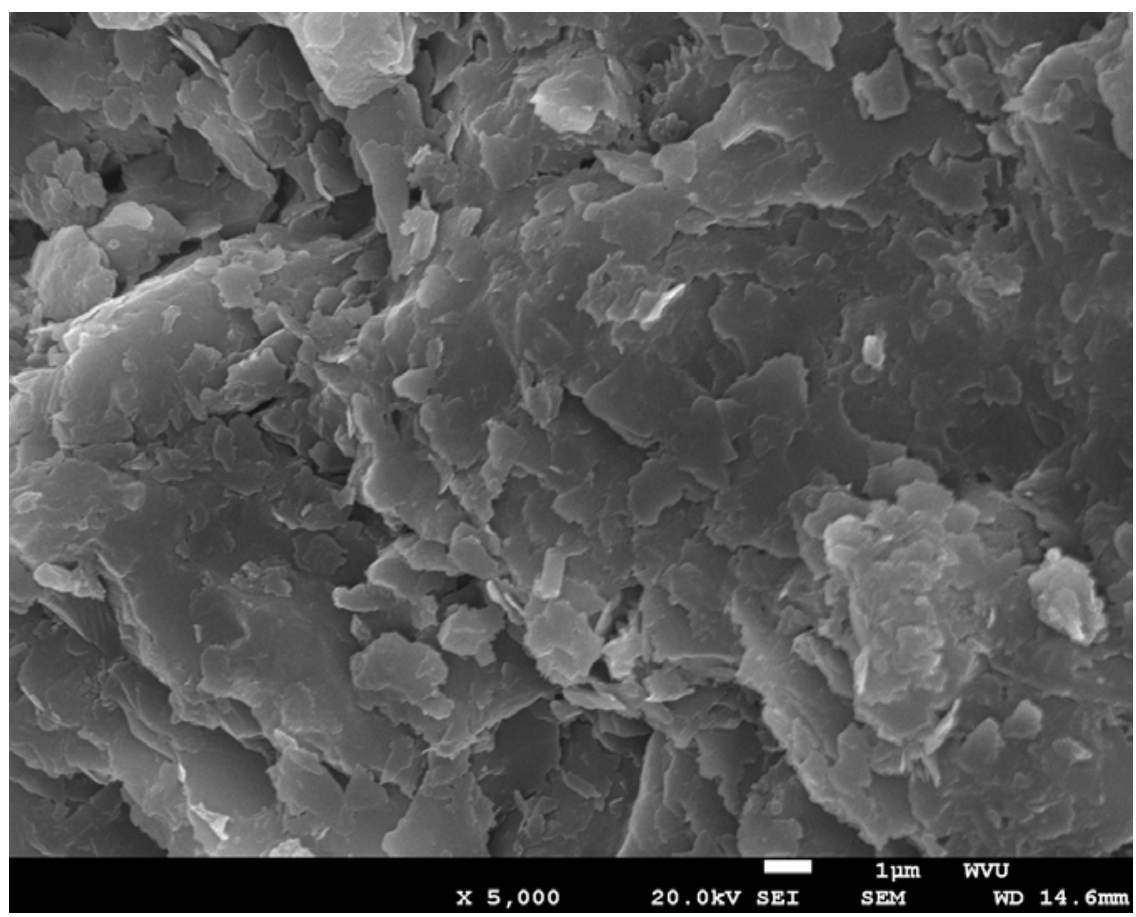

Figure 6.113 SEM image of the water treatment specimen for the third depth interval of Well B at 5000X 


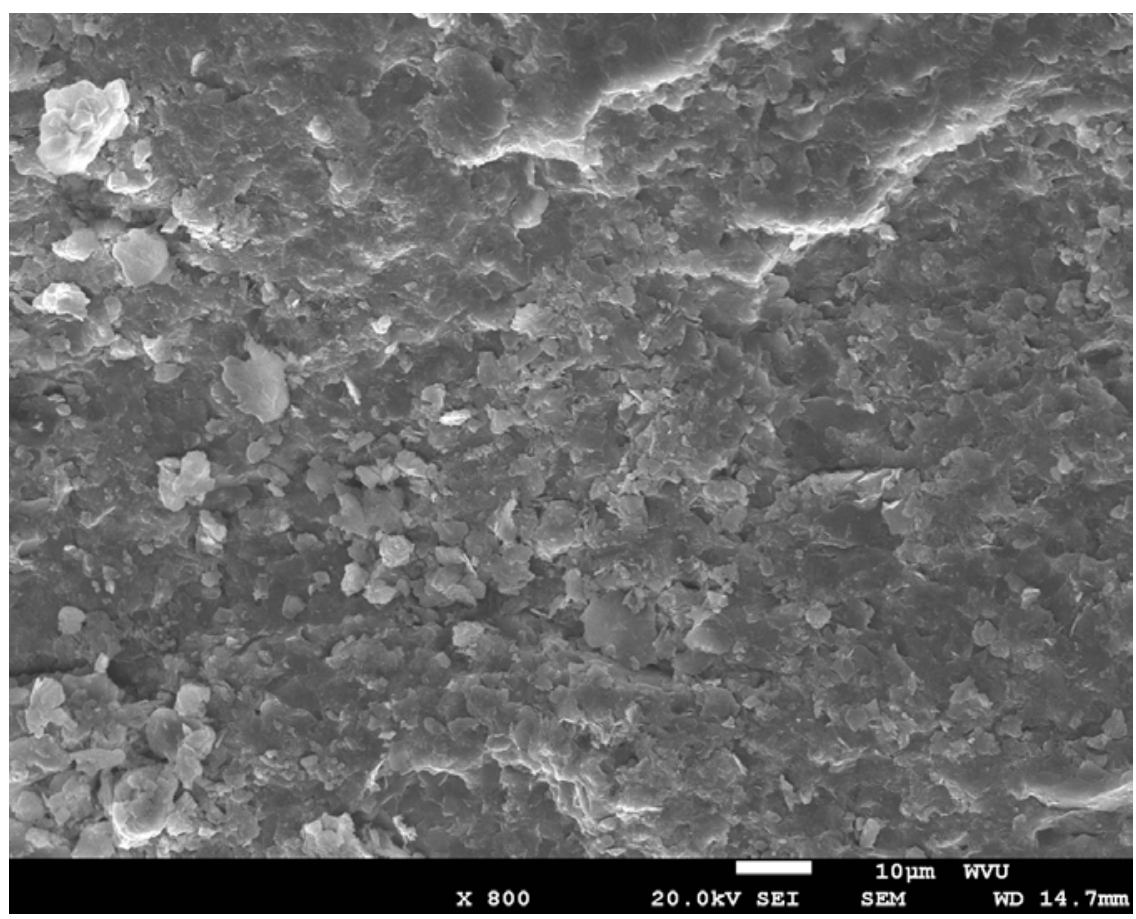

Figure 6.114 SEM image of the water treatment specimen for the fourth depth interval of Well B at 800X

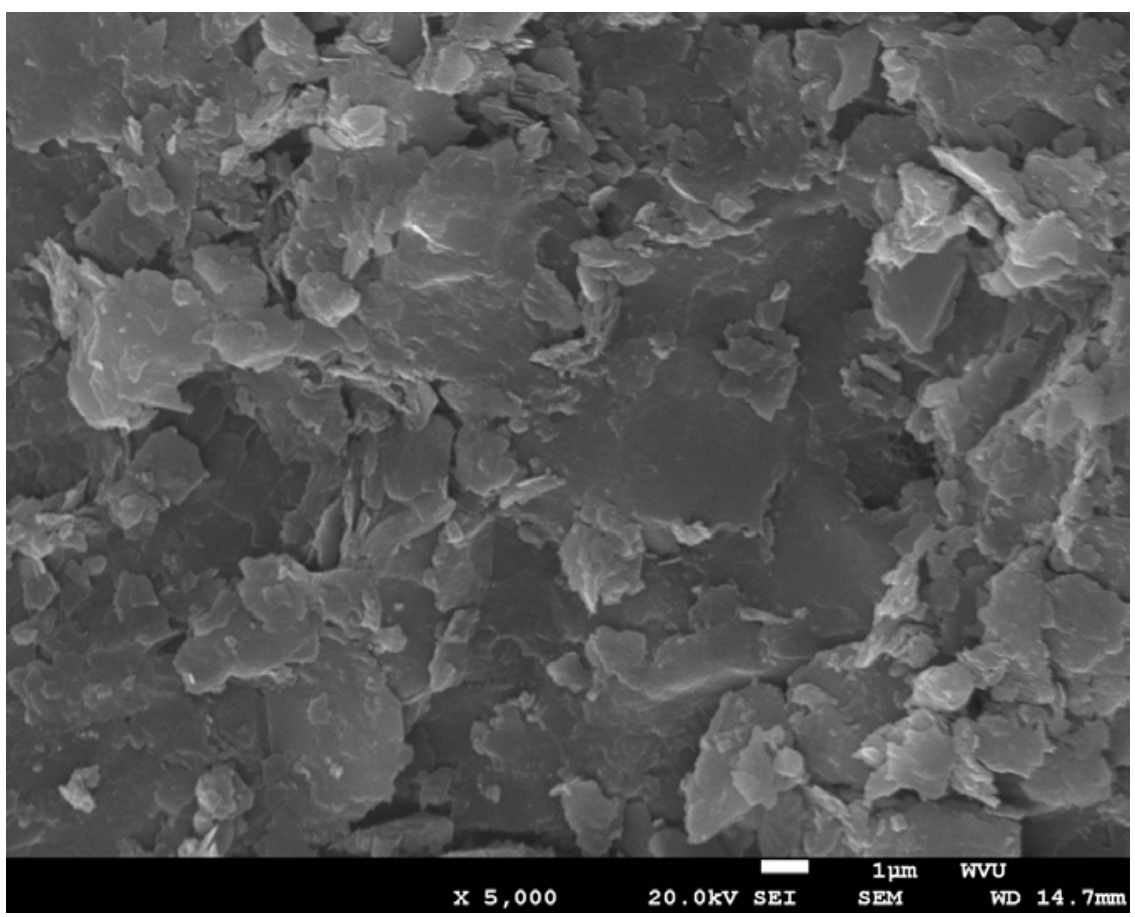

Figure 6.115 SEM image of the water treatment specimen for the fourth depth interval of Well B at 5000X 


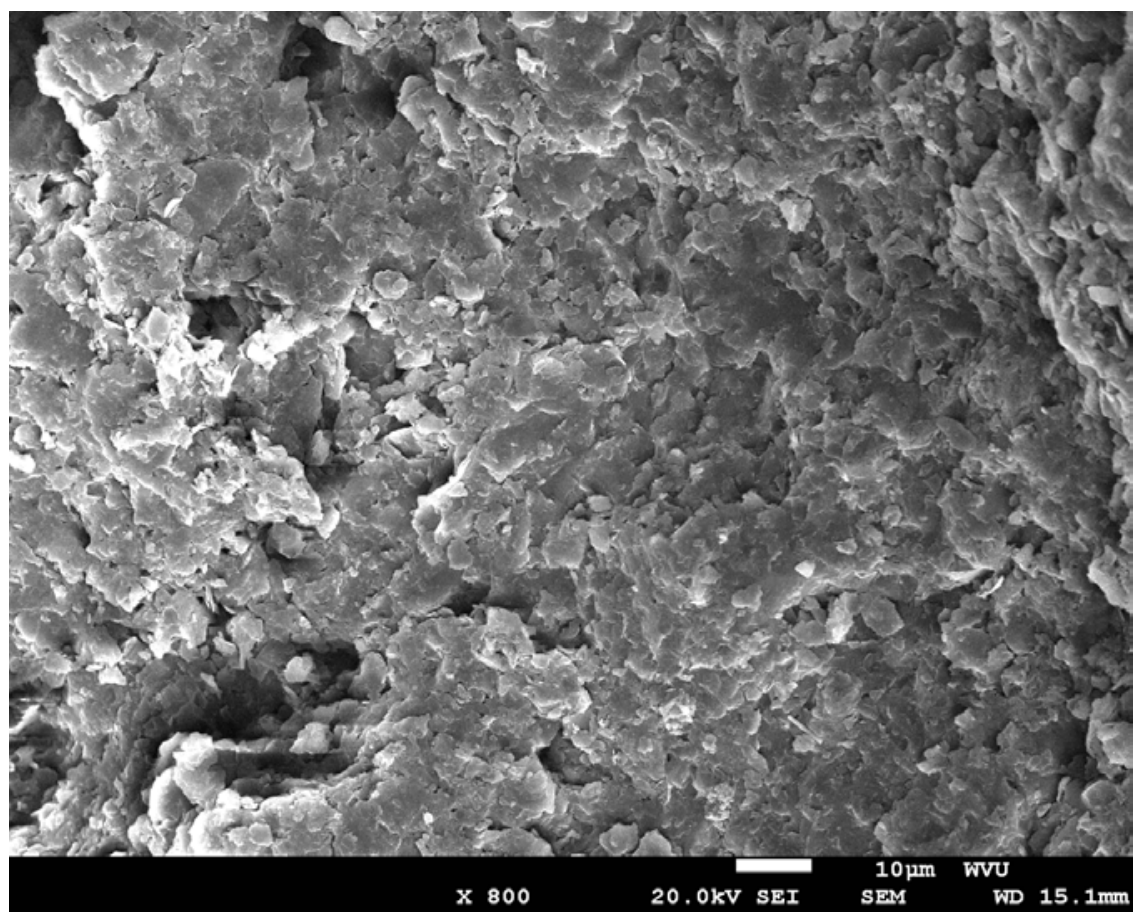

Figure 6.116 SEM image of the water treatment specimen for the fifth depth interval of Well B at $800 \mathrm{X}$

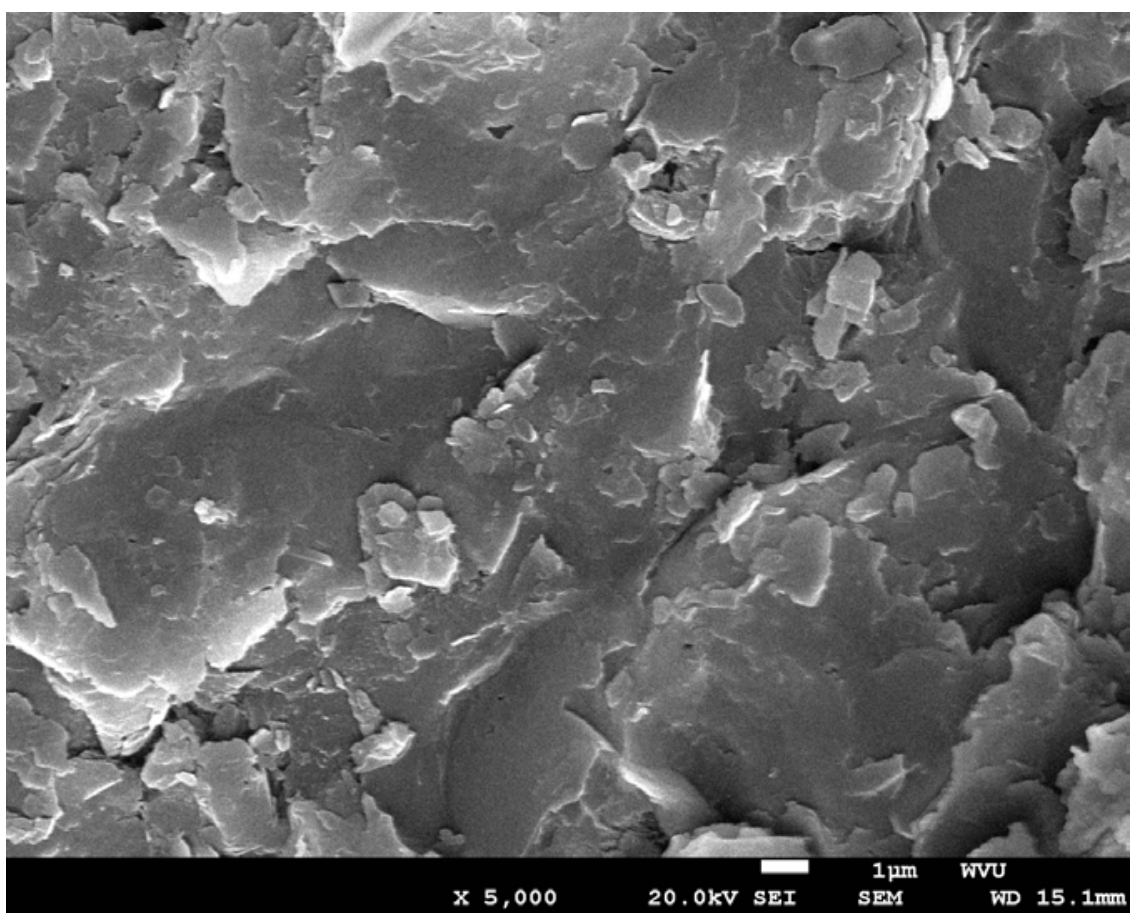

Figure 6.117 SEM image of the water treatment specimen for the fifth depth interval of Well B at 5000X 


\section{Wetzel County Well B Aquagel@ Alteration}

The samples discussed in this section underwent an Aquagel ${ }^{\circledR}$ treatment test. Samples from nine depth intervals of Wetzel County Well B soaked overnight in an Aquagel® and distilled water suspension. The purpose of this test was to observe the effect the clay additive on the elemental composition of the Marcellus shale. Aquagel ${ }^{\circledR}$ is added to many drilling muds used in the oil and natural gas industry. The elemental composition was evaluated using EDX, and the ranges in weight percent for each element found in the Aquagel ${ }^{\circledR}$ treatment test samples are listed in Table 6.8.

Wetzel County Well B (Aquagel ${ }^{\circledR}$ )

\begin{tabular}{c|r|r|c}
\hline Element & Weight\% & Sample & Range \\
\hline \multirow{2}{*}{$\mathrm{Al}$} & 3.14 & $5 \mathrm{~B}$ & \multirow{2}{*}{11.79} \\
& 14.93 & $4 \mathrm{~B}$ & \\
\hline $\mathrm{Ca}$ & 1.70 & $4 \mathrm{~B}$ & \multirow{2}{*}{33.54} \\
& 35.24 & $1 \mathrm{~B}$ & \\
\hline \multirow{2}{*}{$\mathrm{Fe}$} & 0.64 & $5 \mathrm{~B}$ & \multirow{2}{*}{5.64} \\
& 6.28 & $3 \mathrm{~B}$ & \\
\hline \multirow{2}{*}{$\mathrm{K}$} & 0.94 & $1 \mathrm{~B}$ & \multirow{2}{*}{6.05} \\
& 6.99 & $4 \mathrm{~B}$ & \\
\hline \multirow{2}{*}{$\mathrm{Mg}$} & 0.40 & $5 \mathrm{~B}$ & \multirow{2}{*}{0.71} \\
\hline \multirow{2}{*}{$\mathrm{O}$} & 1.11 & $2 \mathrm{~B}$ & \\
\hline \multirow{2}{*}{$\mathrm{Si}$} & 43.08 & $3 \mathrm{~B}$ & \multirow{2}{*}{10.44} \\
\hline $\mathrm{Ti}$ & 53.52 & $1 \mathrm{~B}$ & \\
\hline & 45.31 & $1 \mathrm{~B}$ & \multirow{2}{*}{40.19} \\
\hline $\mathrm{Ta}$ & 1.92 & $3 \mathrm{~B}$ & \multirow{2}{*}{1.92}
\end{tabular}

Table 6.8 Weight percent ranges for each element found in Wetzel County Well B Aquagel ${ }^{\circledR}$ treatment samples

All the elements that were found in the samples that underwent the Aquagel $\mathbb{R}$ treatment test were plotted against the corresponding depth in Figure 6.118. Aluminum, iron and potassium followed a similar trend line in the water treatment and this similarity was present in this particular set of samples as well. Magnesium also followed this curve after the first depth interval, and silicon followed the pattern until the last depth interval. It is important to note, aluminum, potassium, and silicon produced similar data trends in the samples from Monongalia County Well A that underwent 
the Aquagel ${ }^{\circledR}$ treatment test. Additionally, the increases in weight percent for oxygen and silicon were parallel in the bottom four depth intervals.

Samples that underwent the Aquagel ${ }^{\circledR}$ treatment test were photographed using the SEM, and they are seen below in Figure 6.119 through Figure 6.128. All the samples were photographed at a magnification of $800 \mathrm{X}$ and 5000X. Every image portrayed areas of high organic content. The areas were darker in color than the light gray clay material. Red circles were been used to identify calcite material on the surface of the samples from the first depth interval, as well as quartz crystals on the surface of the samples from second and third depth interval. There was an increase in calcium, oxygen, and silicon at these particular depth intervals, supporting the identity of the calcite $\left(\mathrm{CaCO}_{3}\right)$ and quartz $\left(\mathrm{SiO}_{2}\right)$. 


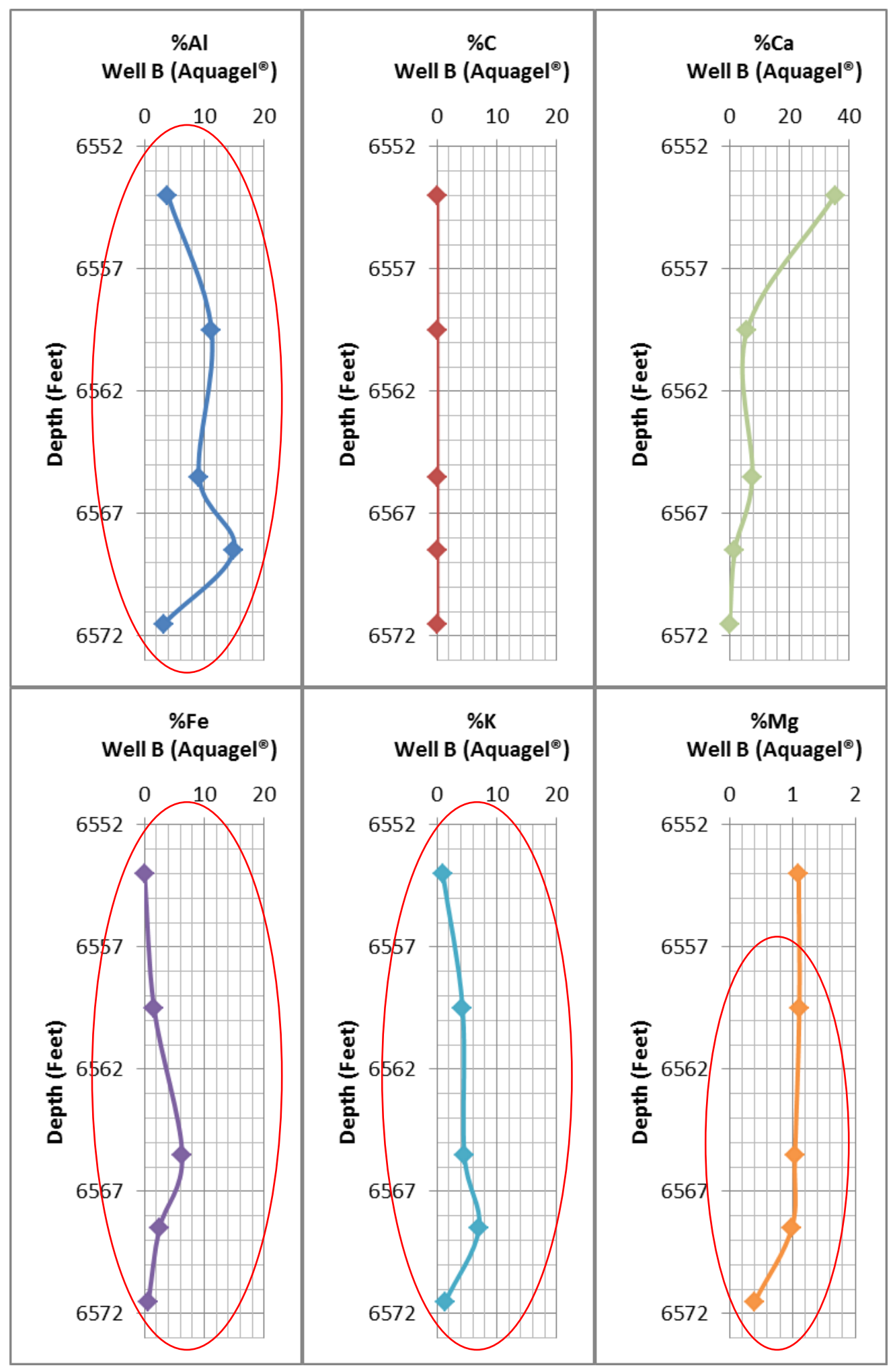




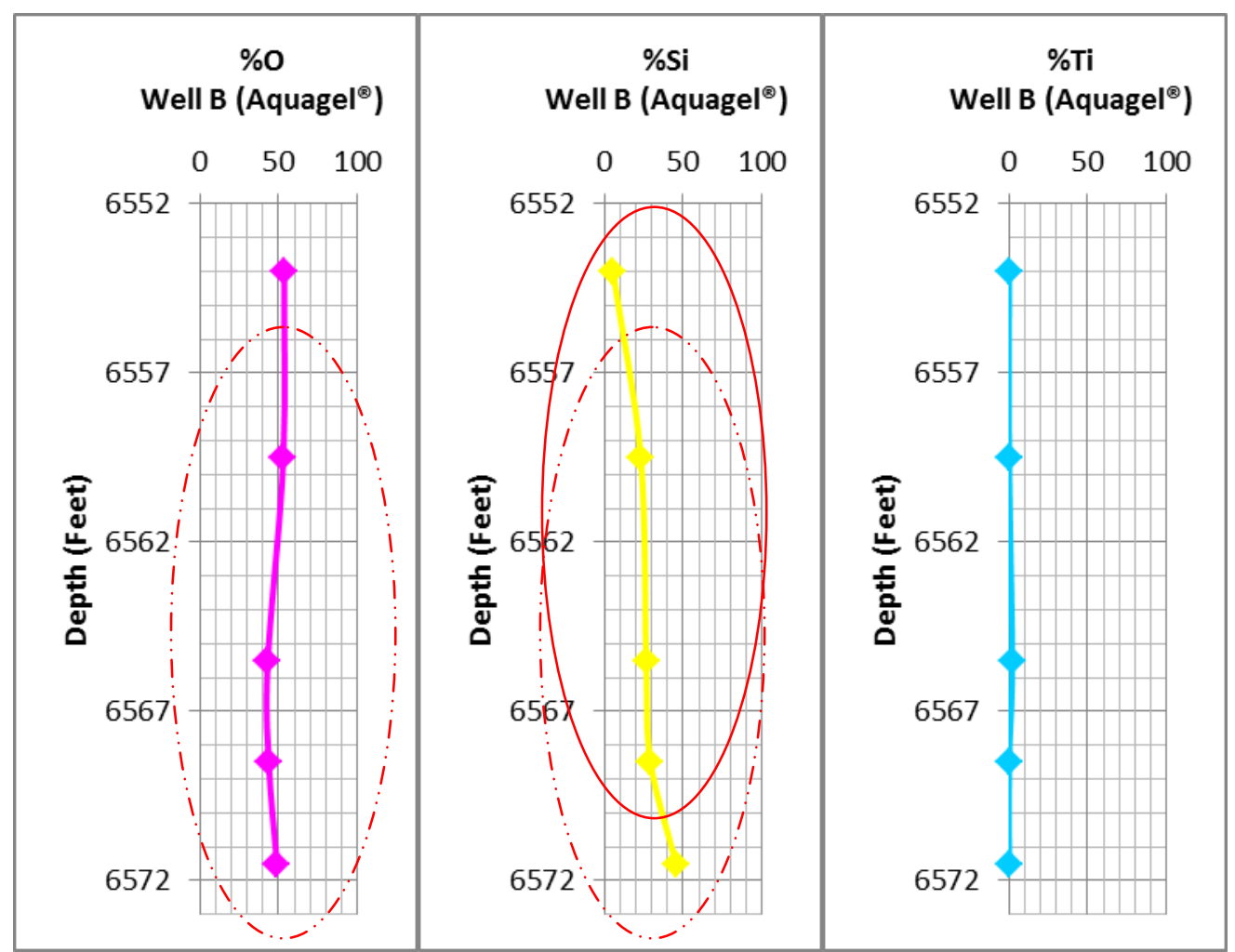

Figure 6.118 Weight percent of each element found in Wetzel County Well B Aquagel® treatment samples plotted against the corresponding depth 
Wetzel County Well B Aquagel囚 Alteration SEM Photographs

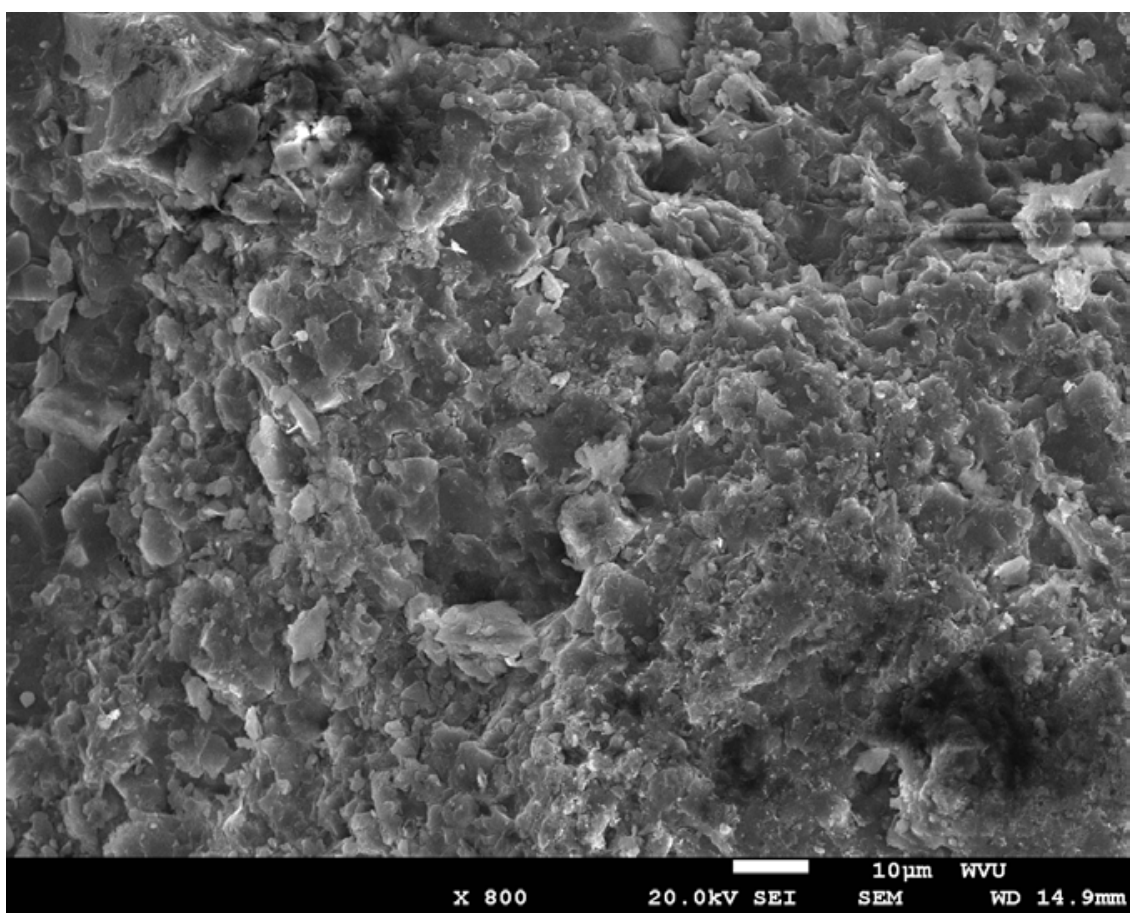

Figure 6.119 SEM image of the Aquagel ${ }^{\circledR}$ treatment sample for the first depth interval of Well B at 800X.

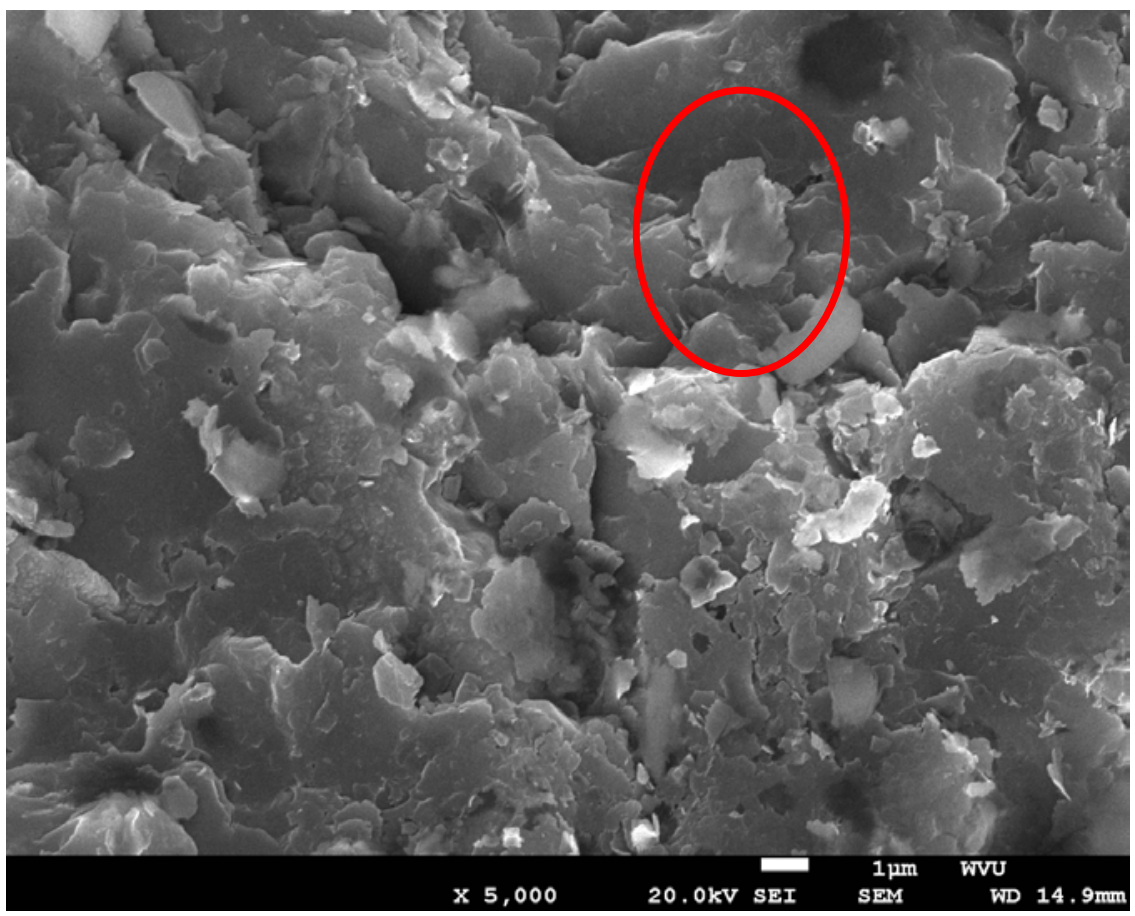

Figure 6.120 SEM image of the Aquagel ${ }^{\circledR}$ treatment sample for the first depth interval of Well B at 5000X 


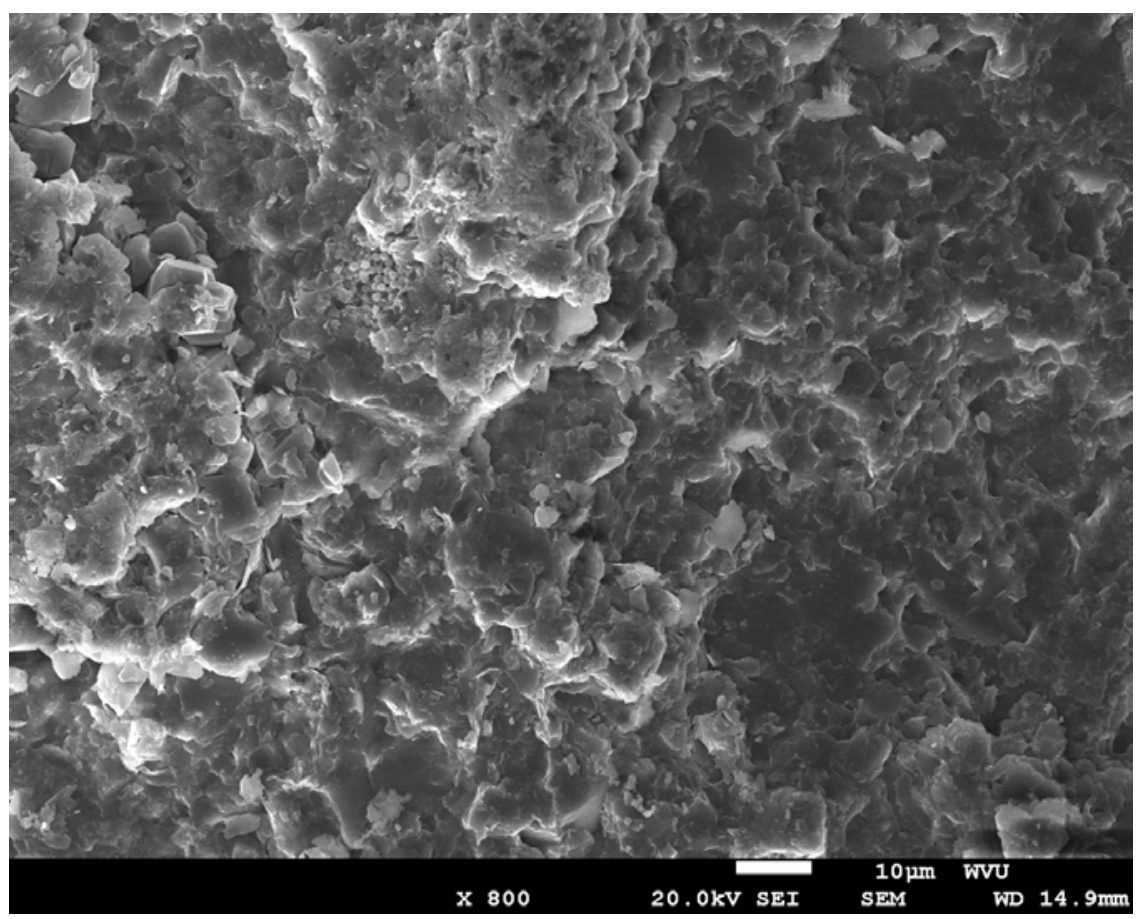

Figure 6.121 SEM image of the Aquagel ${ }^{\circledR}$ treatment sample for the second depth interval of Well $B$ at $800 X$

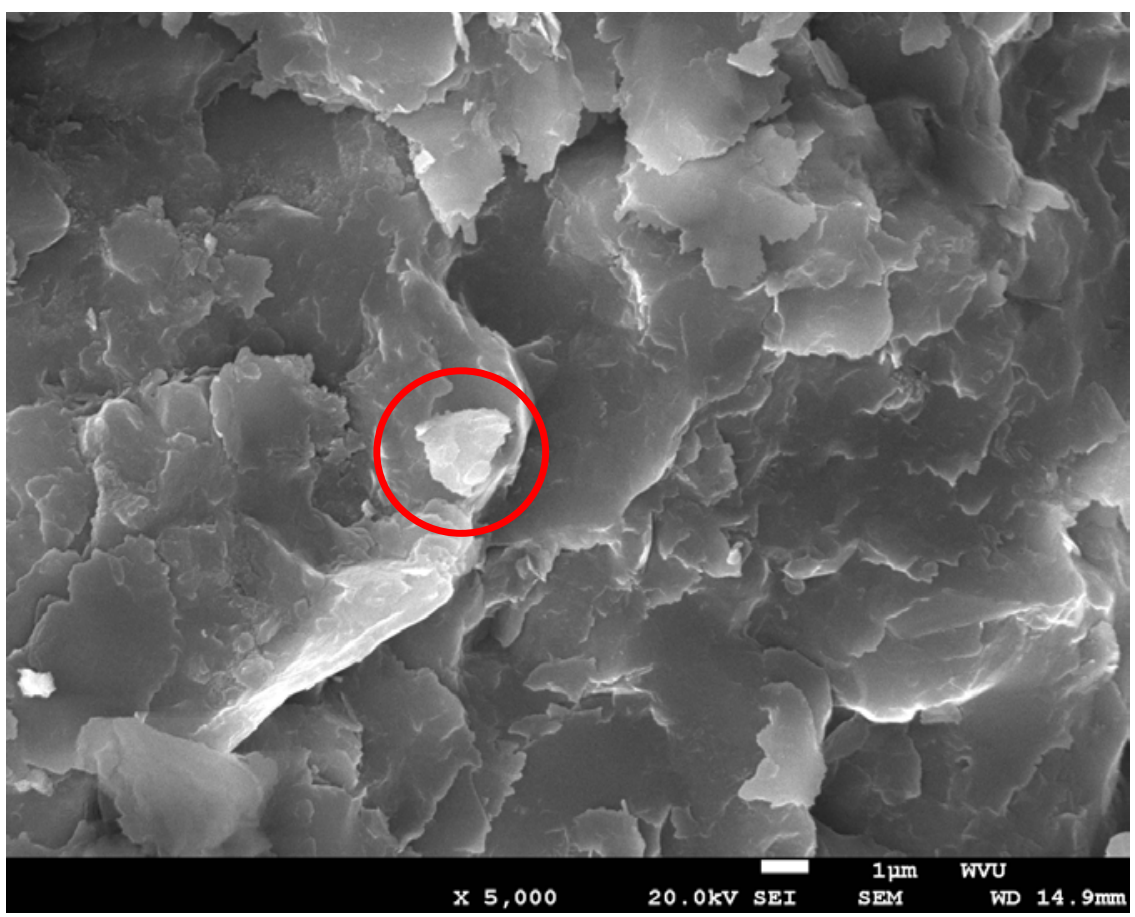

Figure 6.122 SEM image of the Aquagel ${ }^{\circledR}$ treatment sample for the second depth interval of Well $B$ at 5000X 


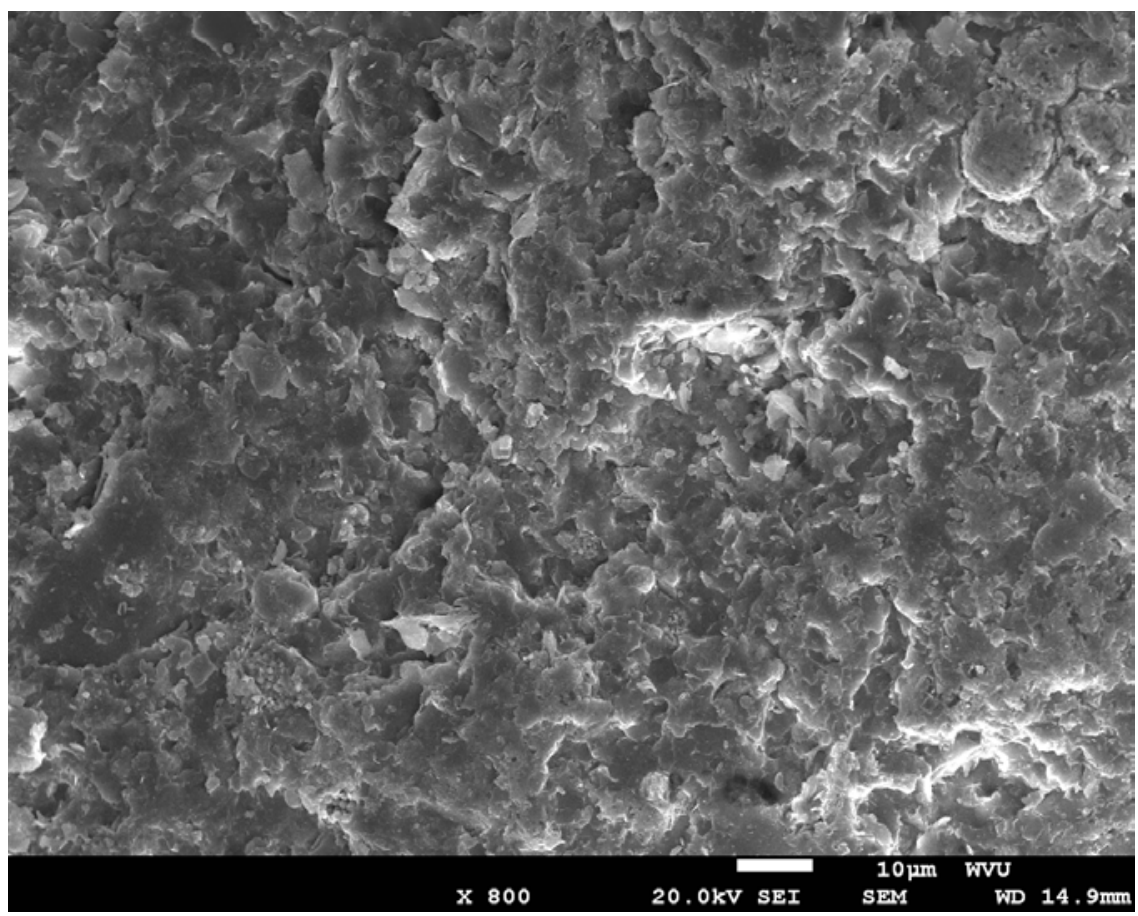

Figure 6.123 SEM image of the Aquagel® treatment sample for the third depth interval of Well $B$ at $800 \mathrm{X}$

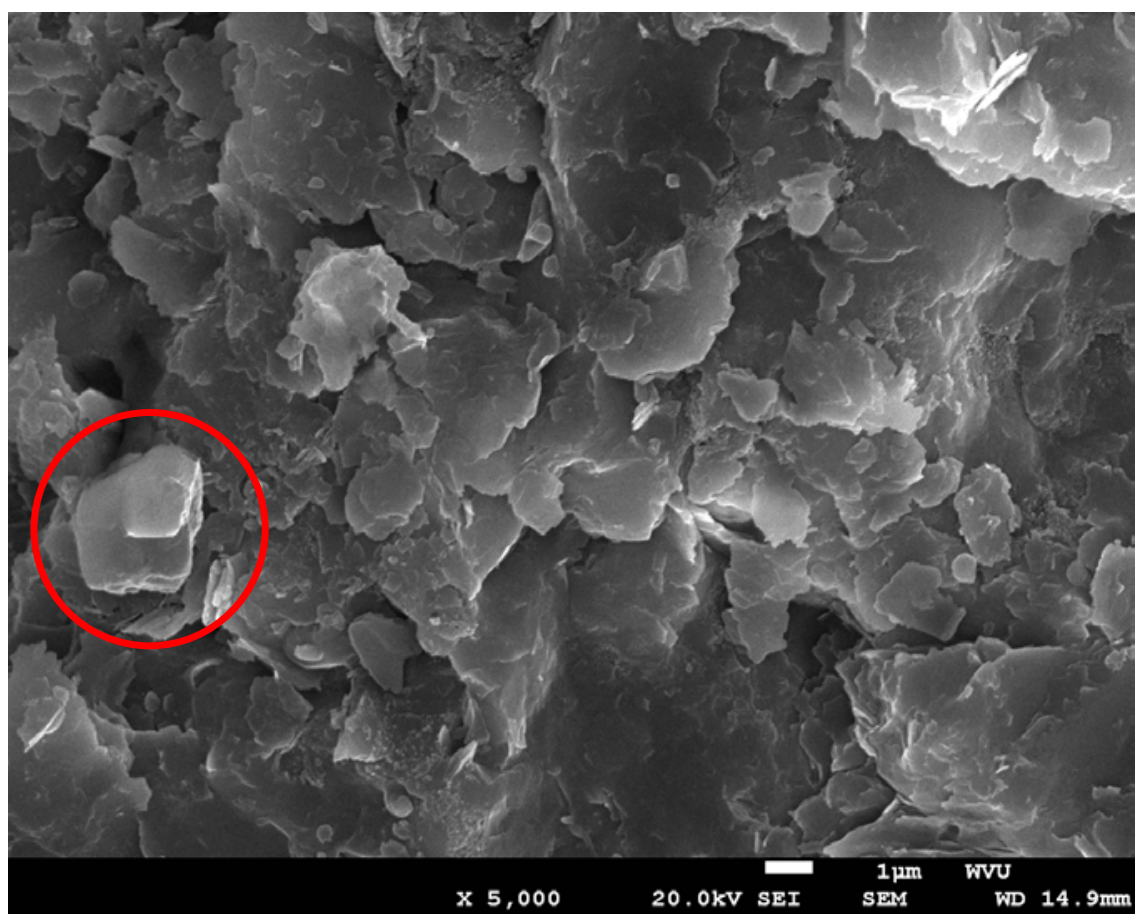

Figure 6.124 SEM image of the Aquagel ${ }^{\circledR}$ treatment sample for the third depth interval of Well B at 5000X 


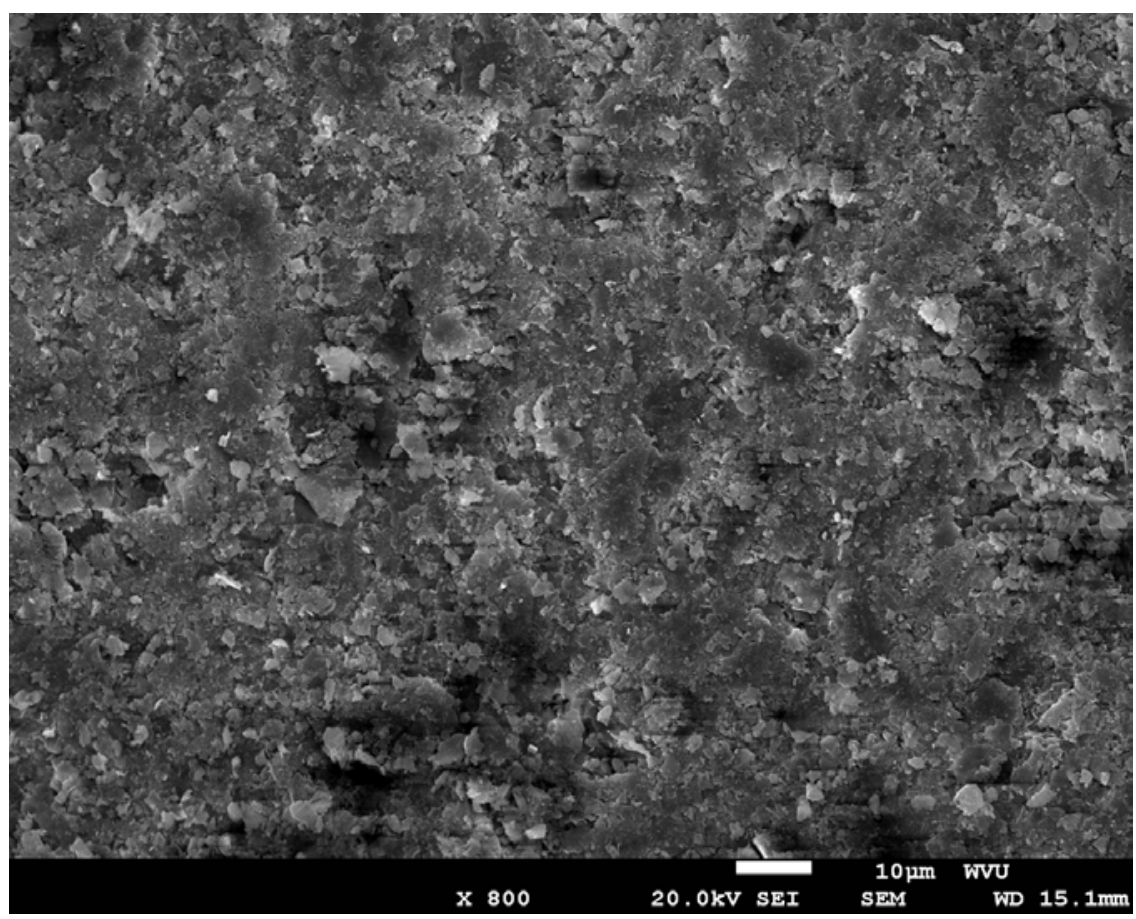

Figure 6.125 SEM image of the Aquagel ${ }^{\circledR}$ treatment sample for the fourth depth interval of Well $B$ at $800 \mathrm{X}$

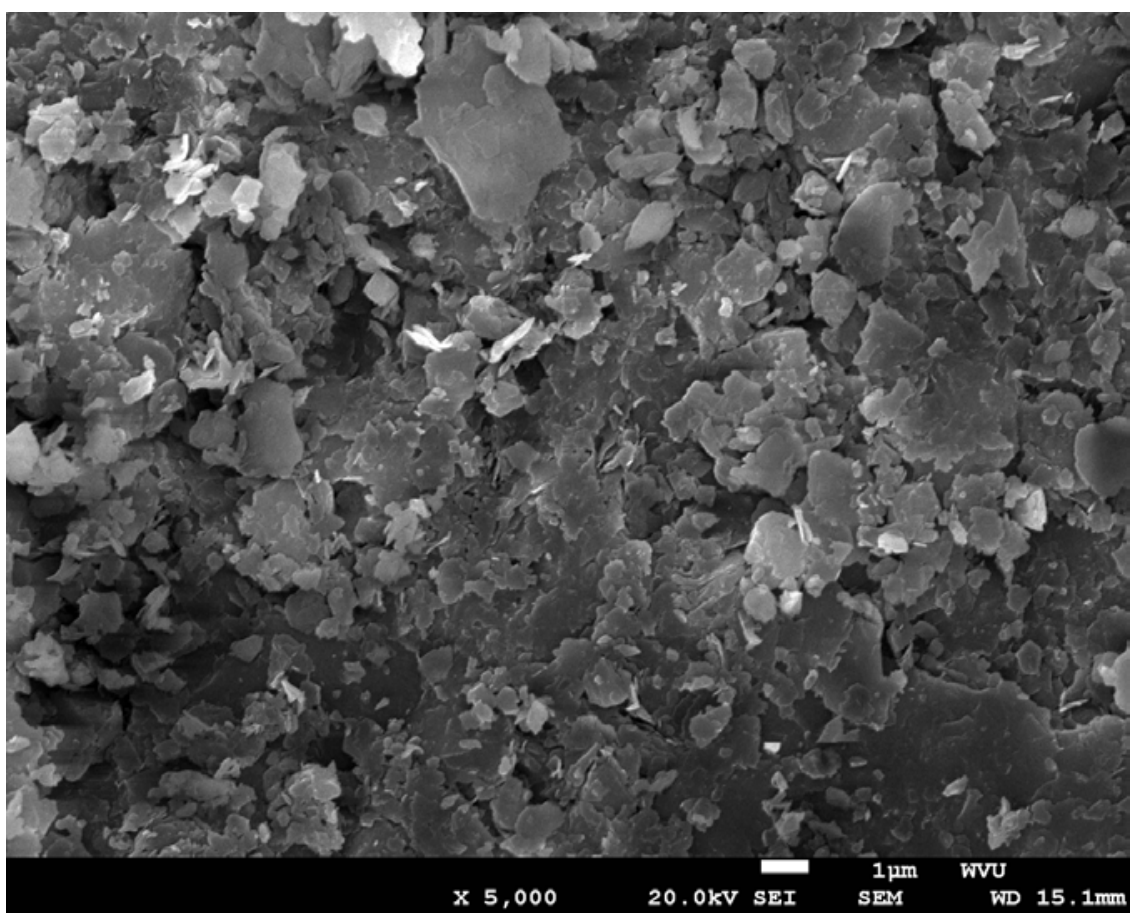

Figure 6.126 SEM image of the Aquagel ${ }^{\circledR}$ treatment sample for the fourth depth interval of Well $B$ at 5000X 


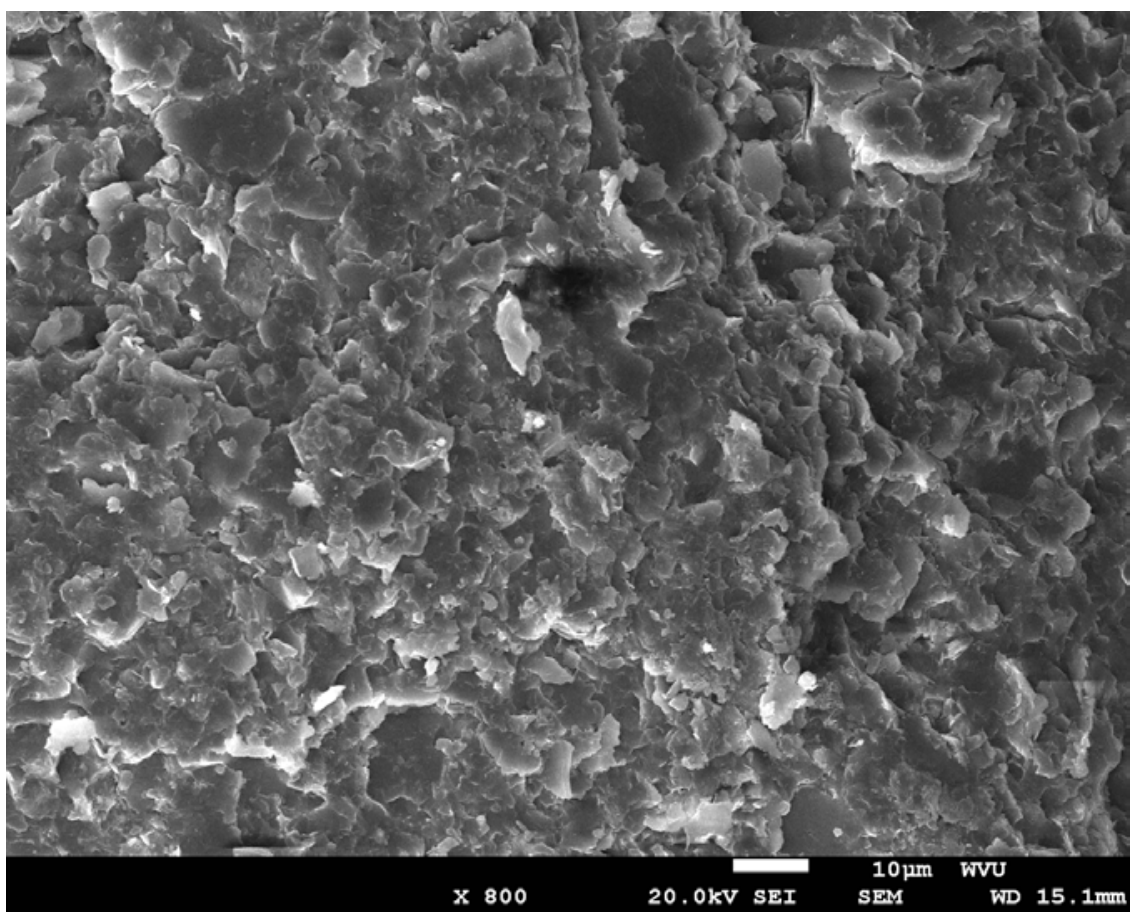

Figure 6.127 SEM image of the Aquagel® treatment sample for the fifth depth interval of Well $B$ at $800 \mathrm{X}$

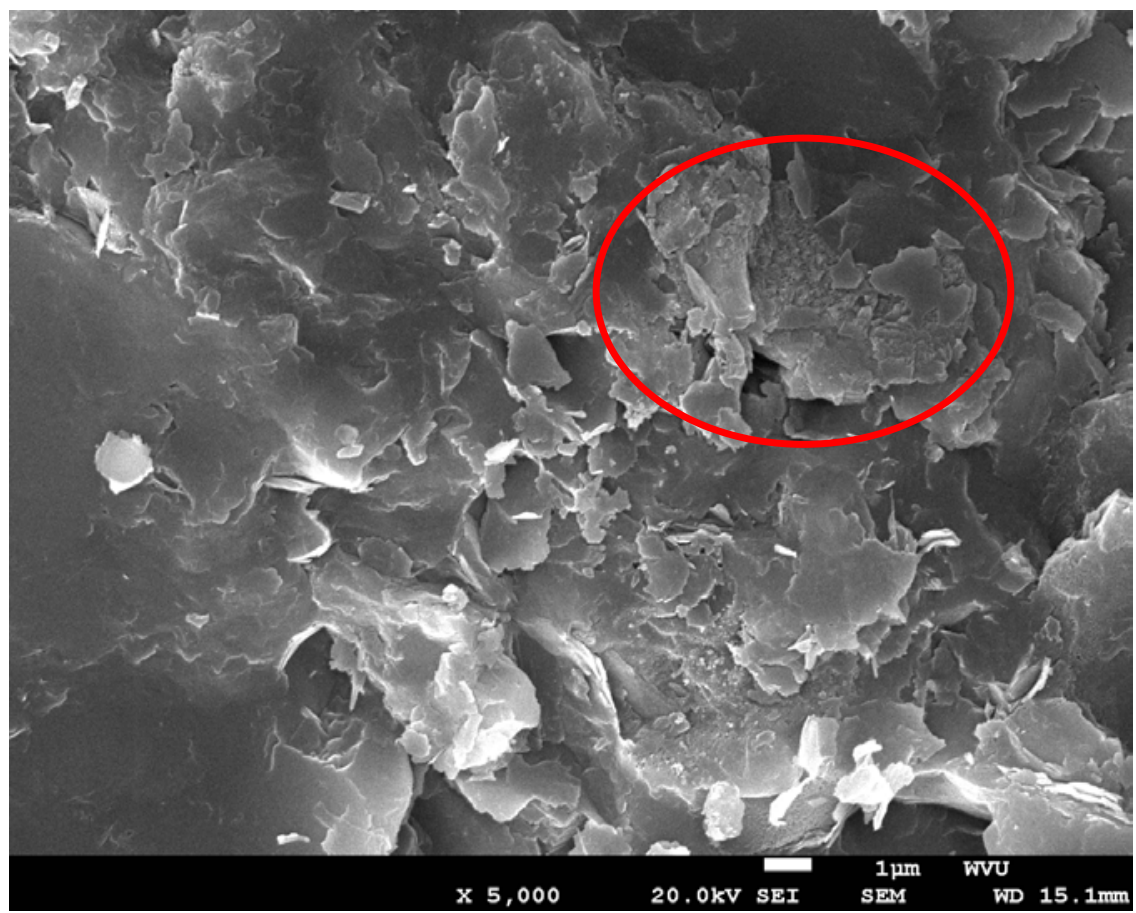

Figure 6.128 SEM image of the Aquagel ${ }^{\circledR}$ treatment sample for the fifth depth interval of Well $\mathrm{B}$ at $800 \mathrm{X}$ 


\section{Wetzel County Well B Quik-Gel@ Alteration}

The samples discussed in this section underwent a Quik-Gel® treatment test. Samples from nine depth intervals of Wetzel County Well B soaked overnight in a Quik-Gel® and distilled water suspension. The purpose of this test was to observe the effect the clay additive on the elemental composition of the Marcellus shale. Quik-Gel® is added to many drilling muds used in the oil and natural gas industry. The elemental composition was evaluated using EDX, and the ranges in weight percent for each element found in the Quik-Gel® treatment test samples are listed in Table 6.9.

Wetzel County Well B (Quik-Gel ${ }^{\circledR}$ )

\begin{tabular}{|c|c|c|c|}
\hline Element & Weight\% & Sample & Range \\
\hline \multirow{2}{*}{ Al } & 1.09 & $2 B$ & \multirow{2}{*}{17.95} \\
\hline & 19.04 & $4 B$ & \\
\hline \multirow{2}{*}{ C } & 19.72 & $2 B$ & \multirow{2}{*}{8.49} \\
\hline & 28.21 & $5 B$ & \\
\hline \multirow{2}{*}{$\mathrm{Ca}$} & 0.82 & $1 \mathrm{~B}$ & \multirow{2}{*}{21.10} \\
\hline & 21.92 & $2 B$ & \\
\hline $\mathrm{Cl}$ & 0.15 & $1 \mathrm{~B}$ & 0.15 \\
\hline \multirow{2}{*}{$\mathrm{Fe}$} & 0.47 & $5 B$ & \multirow{2}{*}{3.42} \\
\hline & 3.89 & $3 B$ & \\
\hline \multirow{2}{*}{ K } & 0.27 & $2 B$ & \multirow{2}{*}{9.51} \\
\hline & 9.78 & $3 B$ & \\
\hline \multirow{2}{*}{$\mathrm{Mg}$} & 0.34 & 1B & \multirow{2}{*}{0.94} \\
\hline & 1.28 & $3 B$ & \\
\hline \multirow{2}{*}{$\mathrm{Na}$} & 0.31 & 1B & \multirow{2}{*}{0.33} \\
\hline & 0.64 & 4B & \\
\hline \multirow{2}{*}{$\mathrm{O}$} & 33.18 & $3 B$ & \multirow{2}{*}{18.68} \\
\hline & 51.86 & $2 B$ & \\
\hline \multirow{2}{*}{$\mathrm{Si}$} & 3.97 & $2 B$ & \multirow{2}{*}{27.67} \\
\hline & 31.64 & $3 B$ & \\
\hline $\mathrm{Ti}$ & 0.78 & 1B & 0.78 \\
\hline
\end{tabular}

Table 6.9 Weight percent ranges for each element found in Wetzel County Well B QuikGel® treatment samples

All the elements that were found in the samples that underwent the Quik-Gel® treatment test were plotted against the corresponding depth in Figure 6.140. Aluminum, iron, and potassium followed a similar trend line in the water treatment samples, the Aquagel ${ }^{\circledR}$ treatment samples, and the QuikGel ${ }^{\circledR}$ treatment samples from Well B. Magnesium also followed this weight percent curve just as 
the element did in the Aquagel ${ }^{\circledR}$ treatment samples from this same well. The weight percent data trends for the Quik-Gel® treatment samples from Well B were similar to the trends found in the Quik-Gel® treatment samples from Well A, as aluminum and potassium produced parallel weight percent curves for Quik-Gel@ treatment samples in both wells. Additionally, sodium and oxygen followed similar curves in both sets of samples that underwent the Quik-Gel® alteration test.

All the samples subjected to the Quik-Gel@ treatment test were studied in more detail in the photographs taken in the SEM (Figure 6.130 through Figure 6.139). Each image was taken at a magnification of $800 \mathrm{X}$ and 5000X. All the images showed a surface containing tiny pores and many layers. Calcite minerals were identified in second depth interval as seen in Figure 6.132 and Figure 6.133 respectively. 


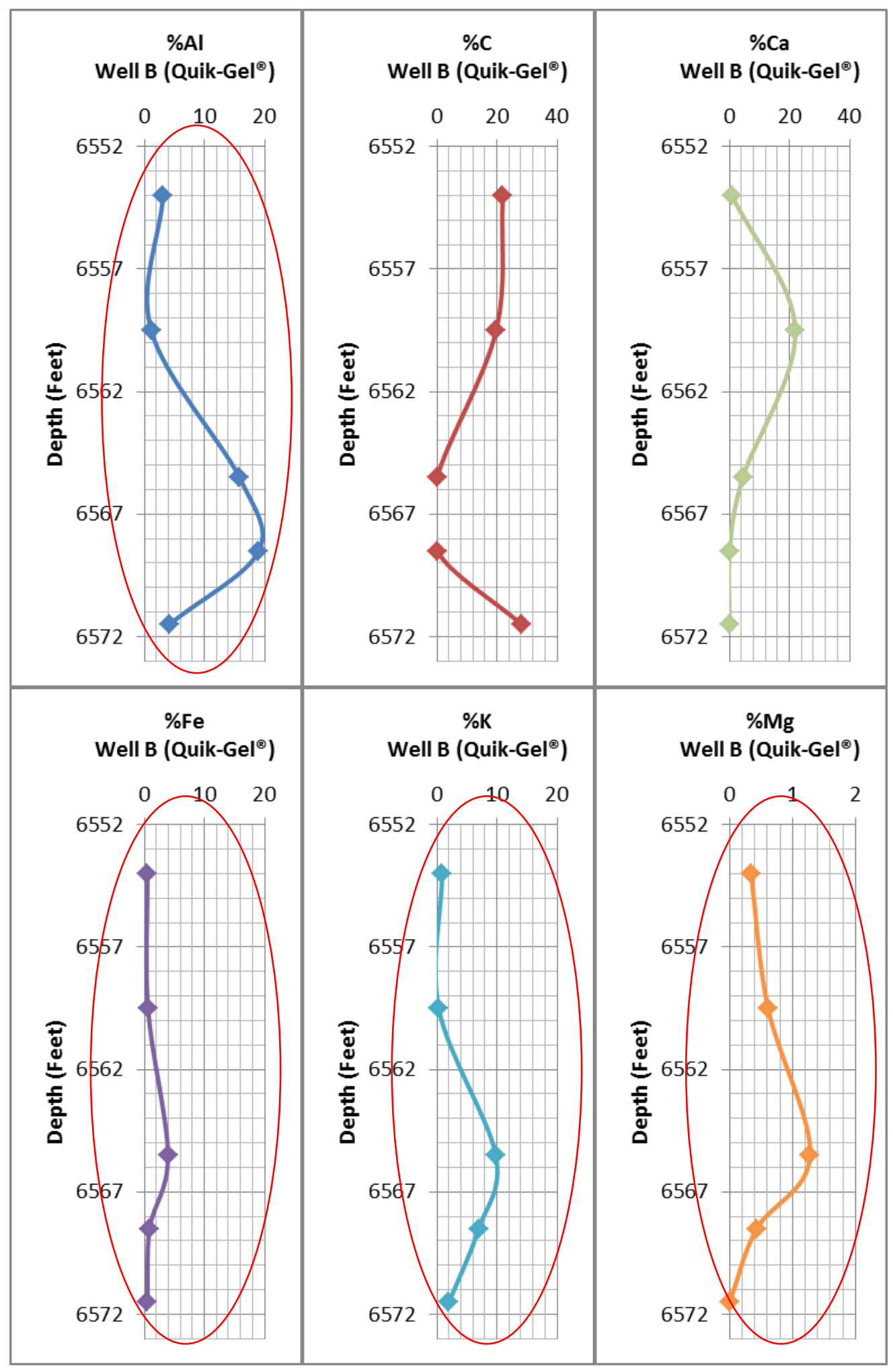




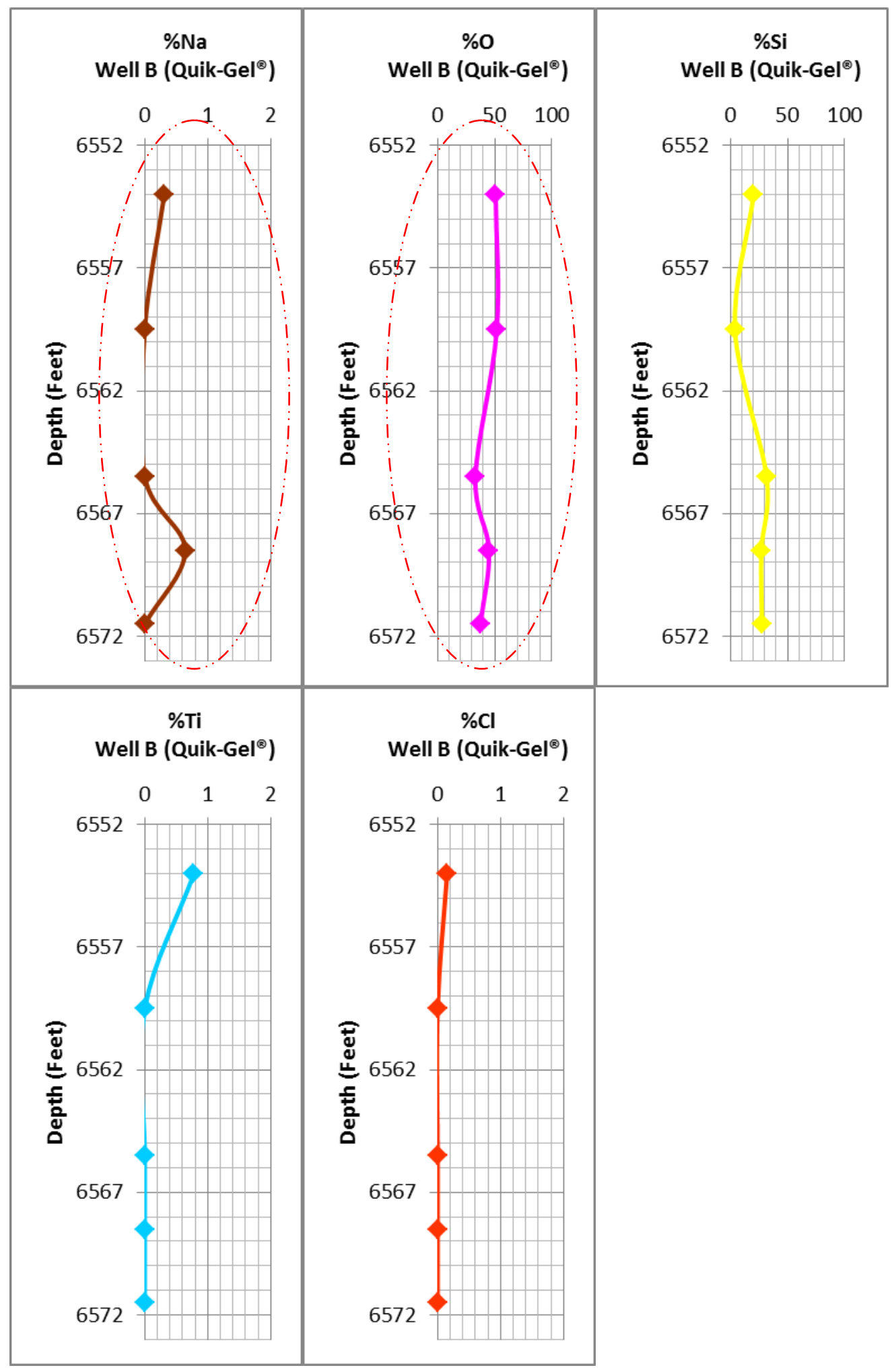

Figure 6.129 Weight percent of each element found in Wetzel County Well B Quik-Gel® treatment samples plotted against the corresponding depth 
Wetzel County Well B Quik-Gel囚 Alteration Photographs

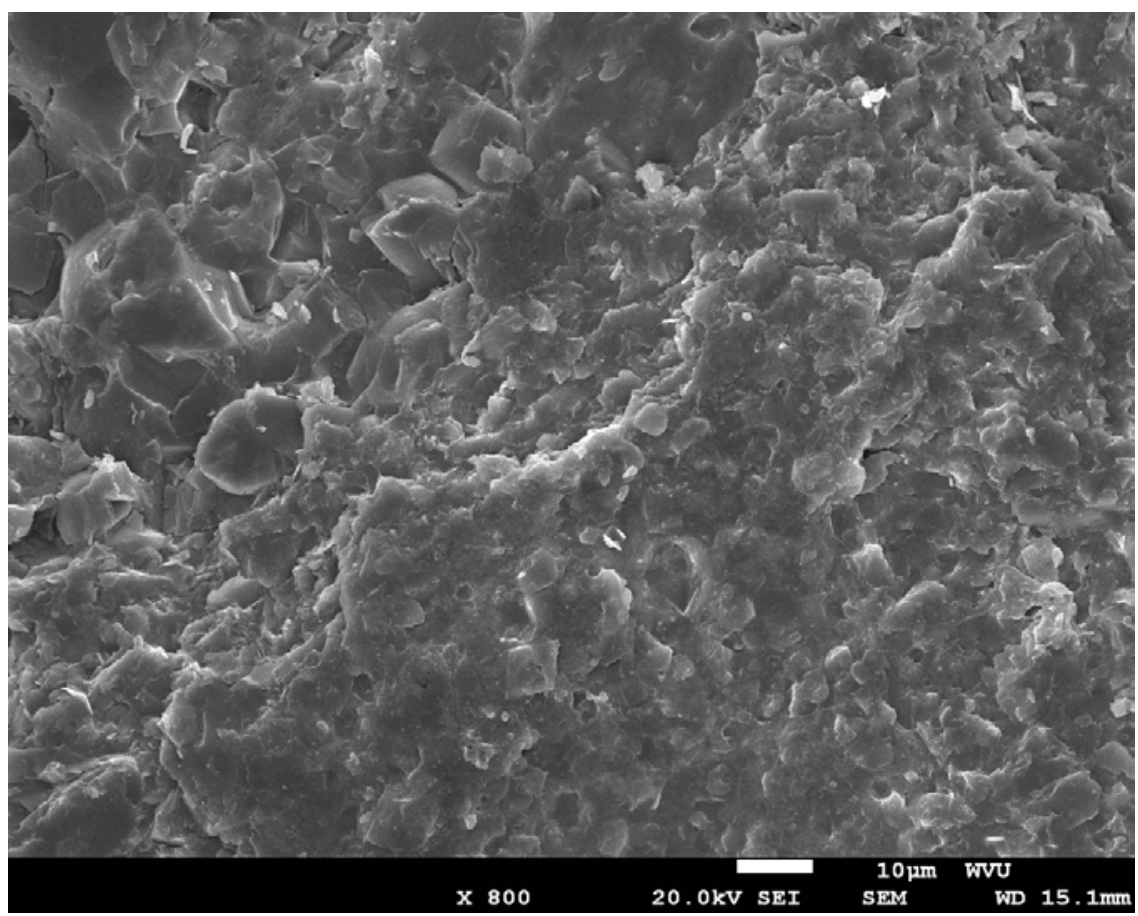

Figure 6.130 SEM image of the Quik-Gel® treatment sample for the first depth interval of Well $\mathrm{B}$ at $800 \mathrm{X}$

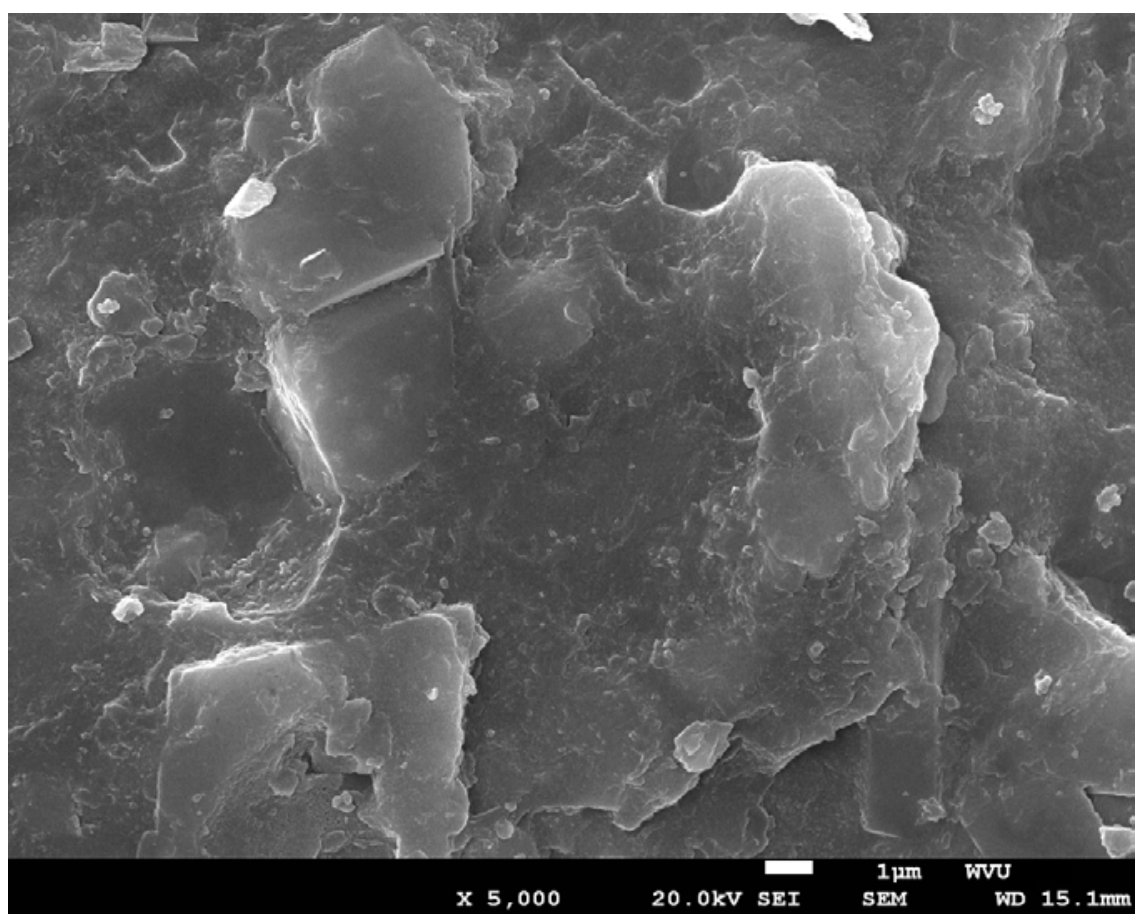

Figure 6.131 SEM image of the Quik-Gel® treatment sample for the first depth interval of Well B at 5000X 


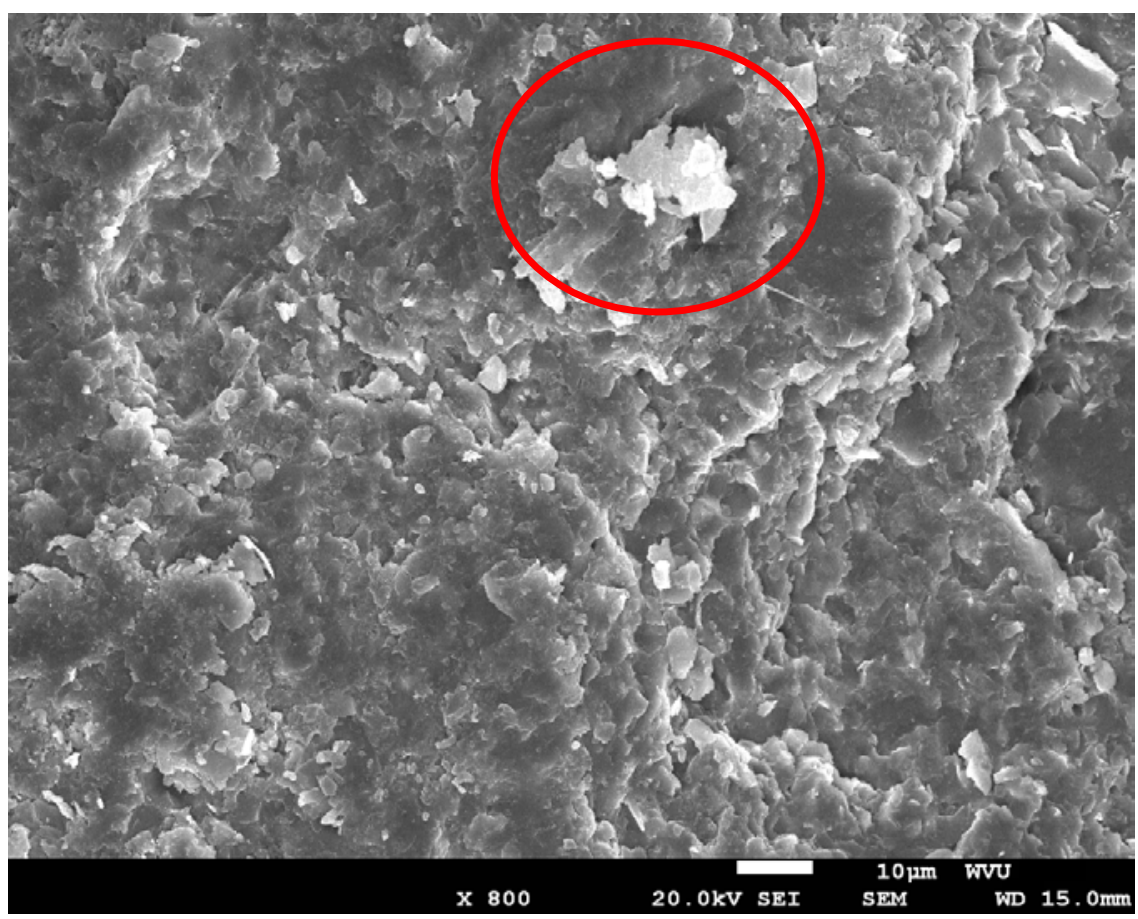

Figure 6.132 SEM image of the Quik-Gel® treatment sample for the second depth interval of Well $B$ at $800 \mathrm{X}$

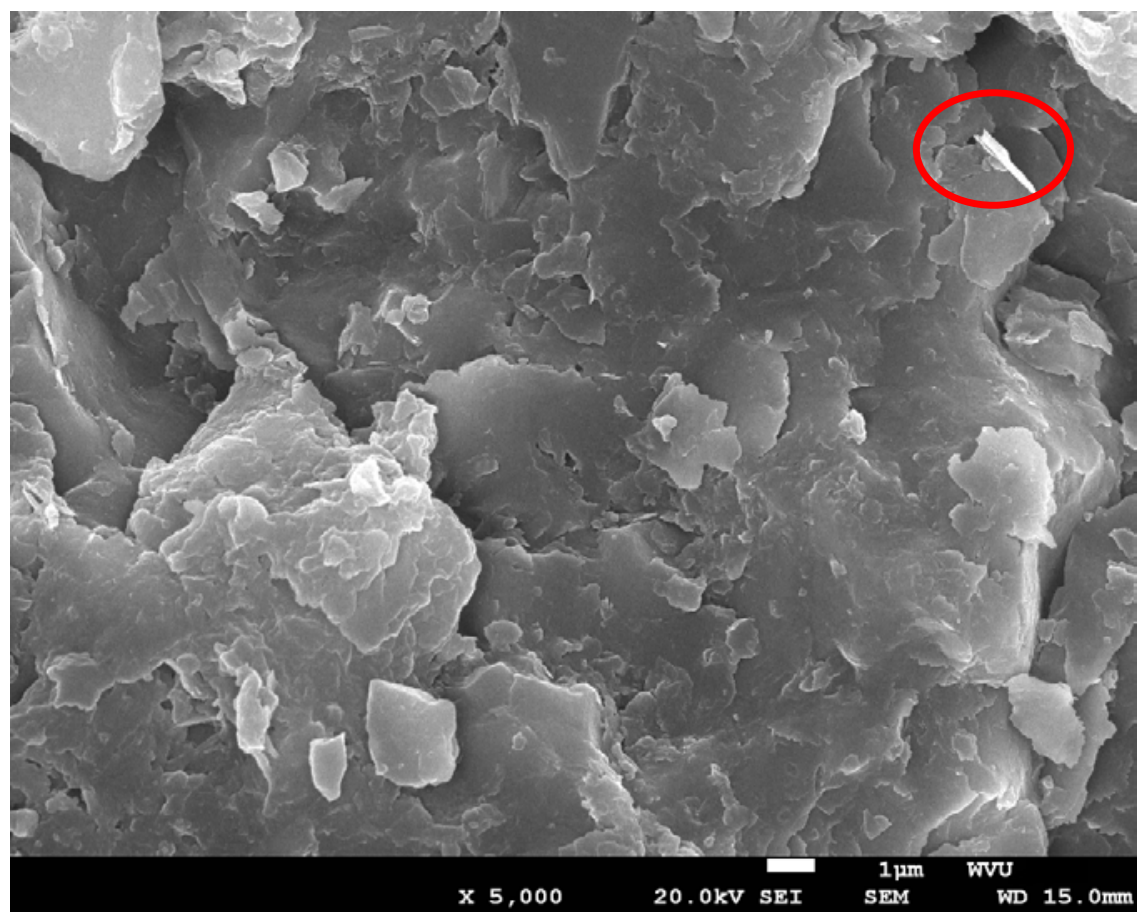

Figure 6.133 SEM image of the Quik-Gel ${ }^{\circledR}$ treatment sample for the second depth interval of Well $B$ at 5000X 


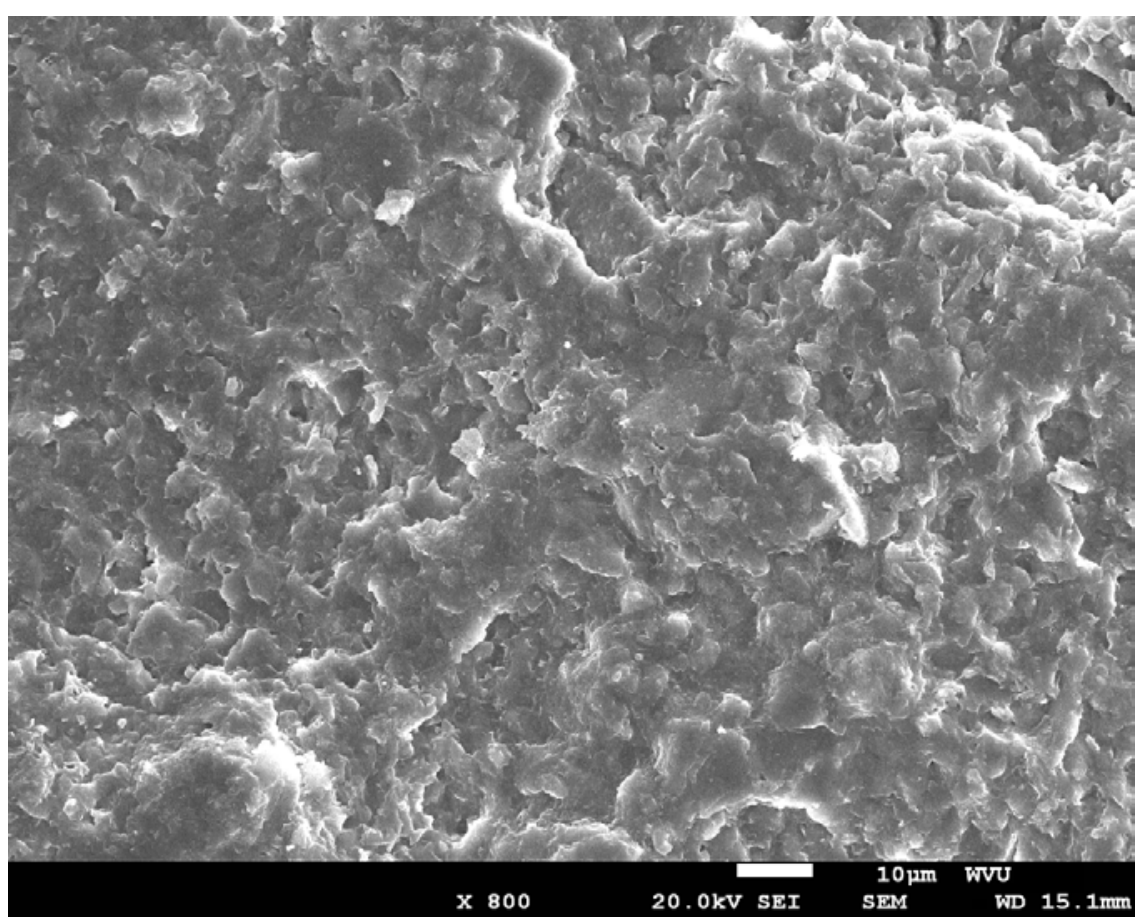

Figure 6.134 SEM image of the Quik-Gel® treatment sample for the third depth interval of Well $B$ at $800 \mathrm{X}$

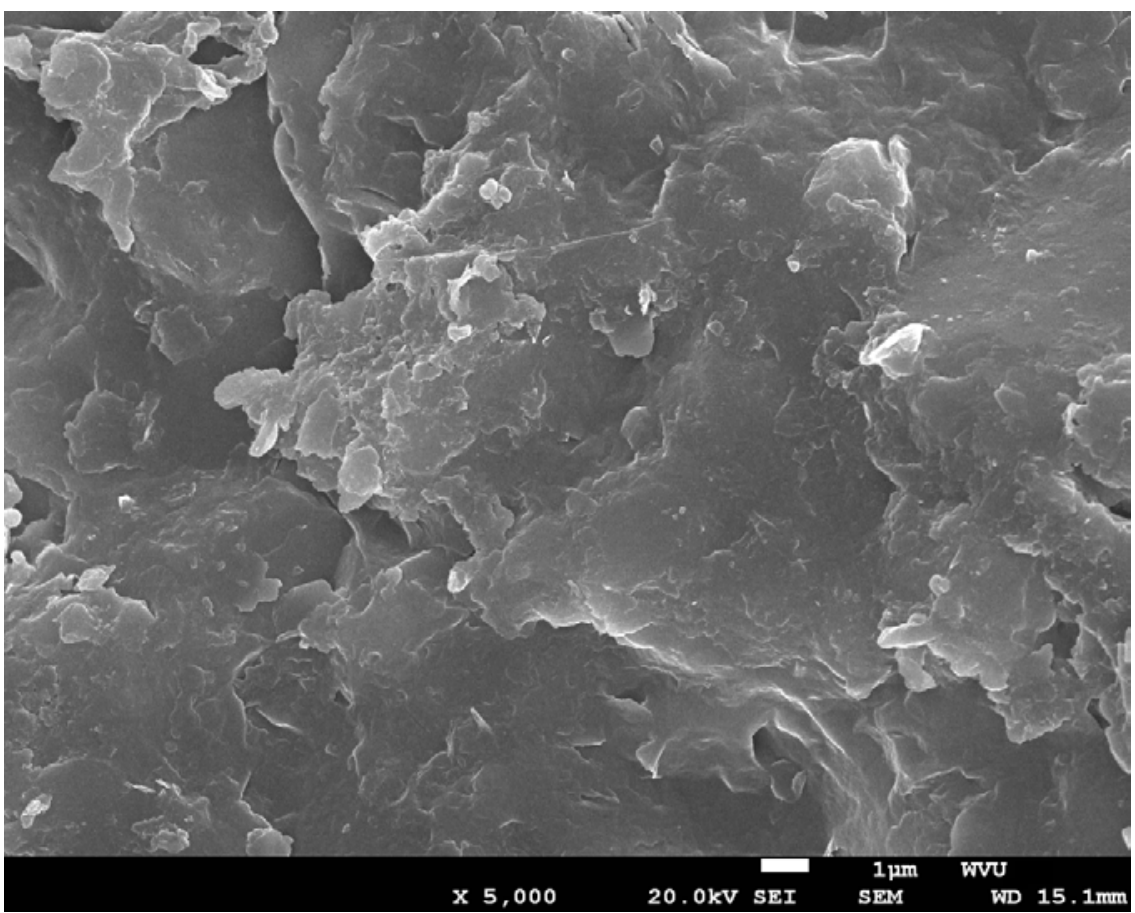

Figure 6.135 SEM image of the Quik-Gel® treatment sample for the third depth interval of Well $B$ at 5000X 


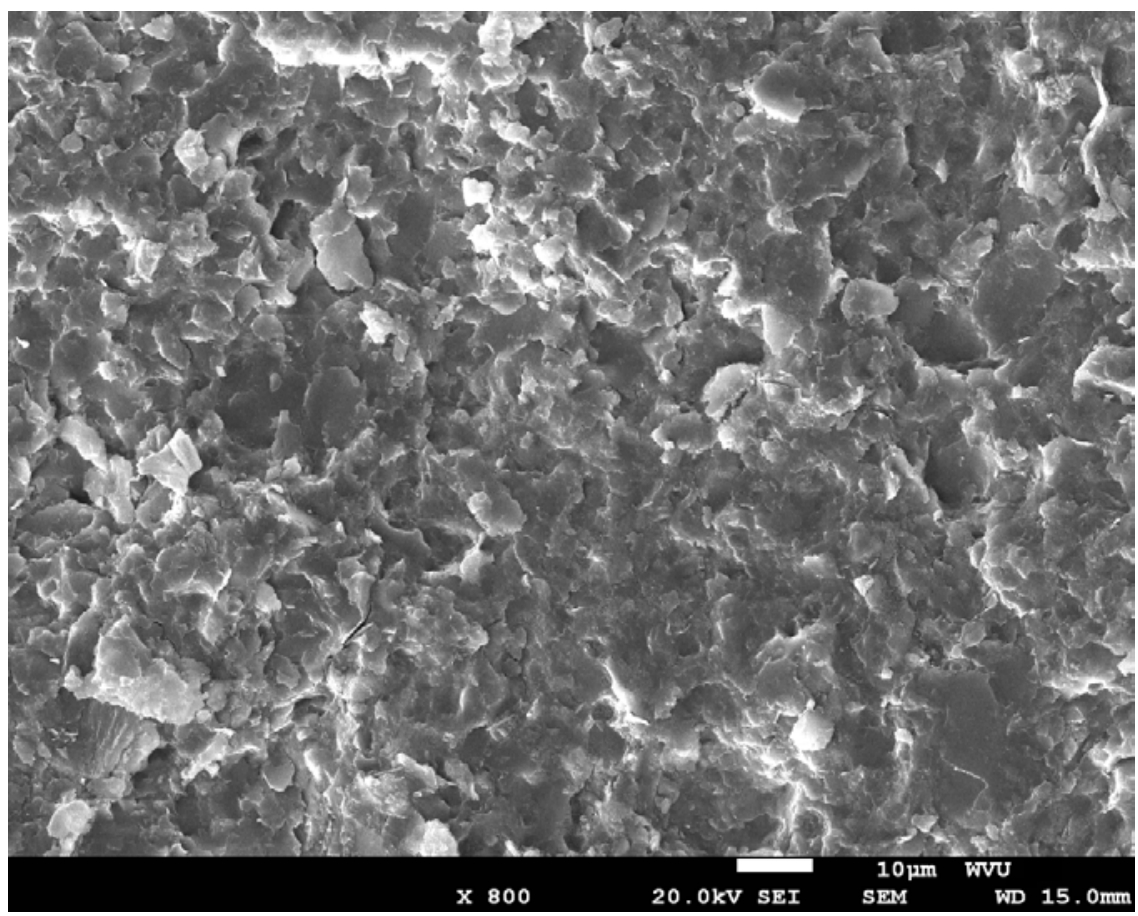

Figure 6.136 SEM image of the Quik-Gel® treatment sample for the fourth depth interval of Well $B$ at $800 \mathrm{X}$

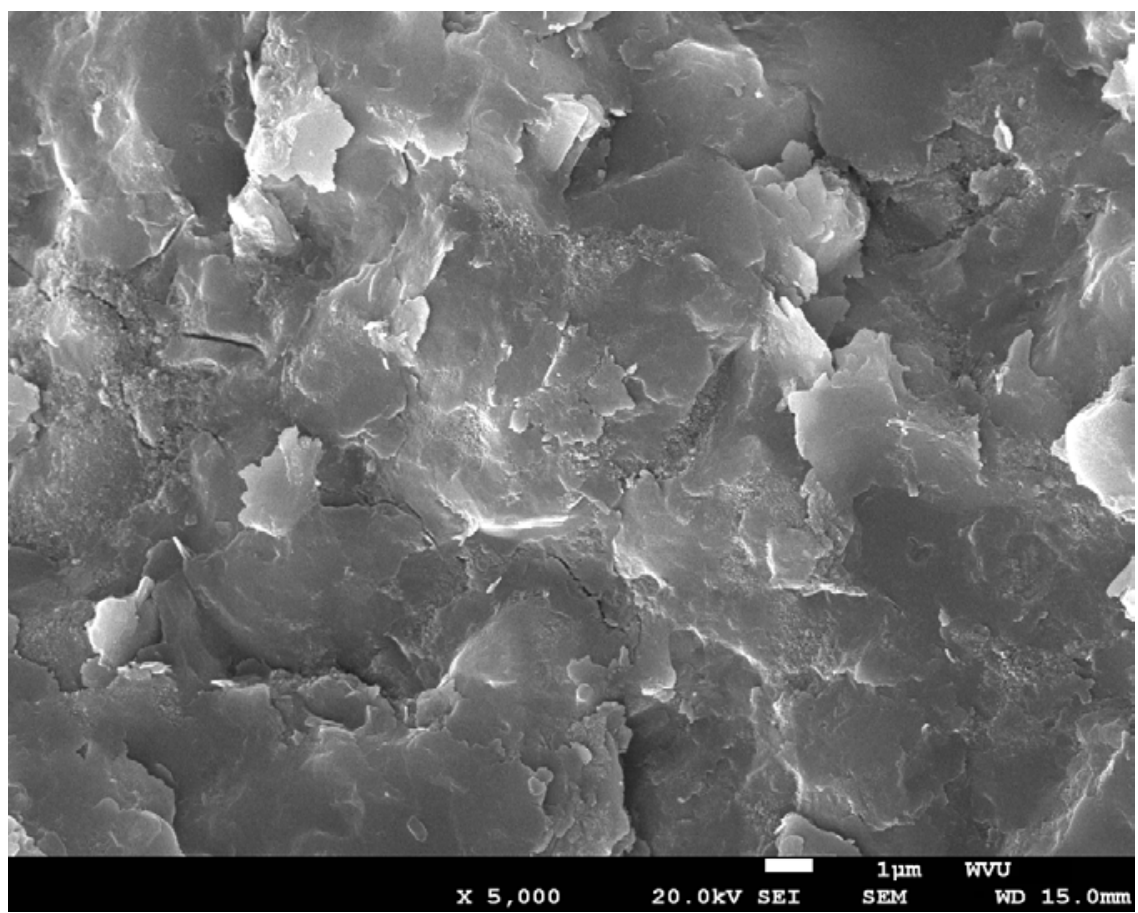

Figure 6.137 SEM image of the Quik-Gel® treatment sample for the fourth depth interval of Well B at 5000X 


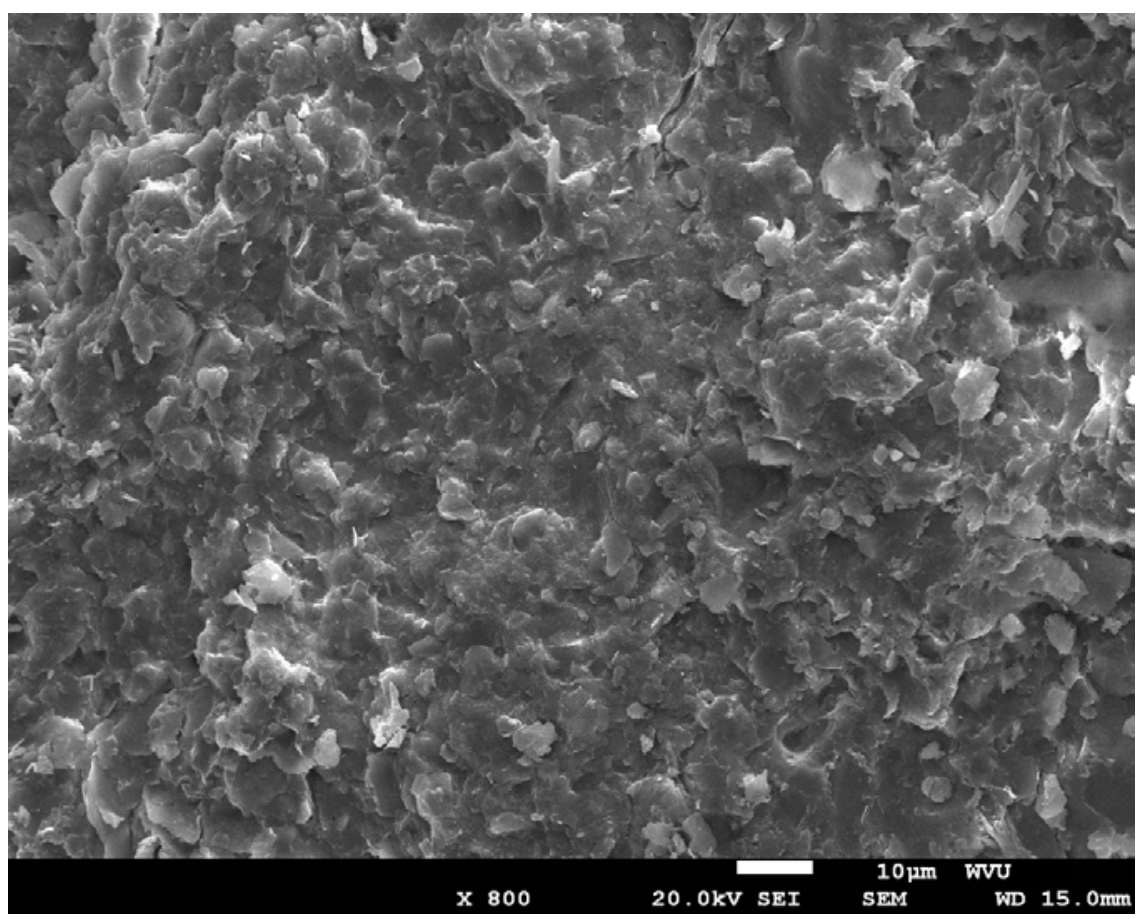

Figure 6.138 SEM image of the Quik-Gel ${ }^{\circledR}$ treatment sample for the fifth depth interval of Well $\mathrm{B}$ at $800 \mathrm{X}$

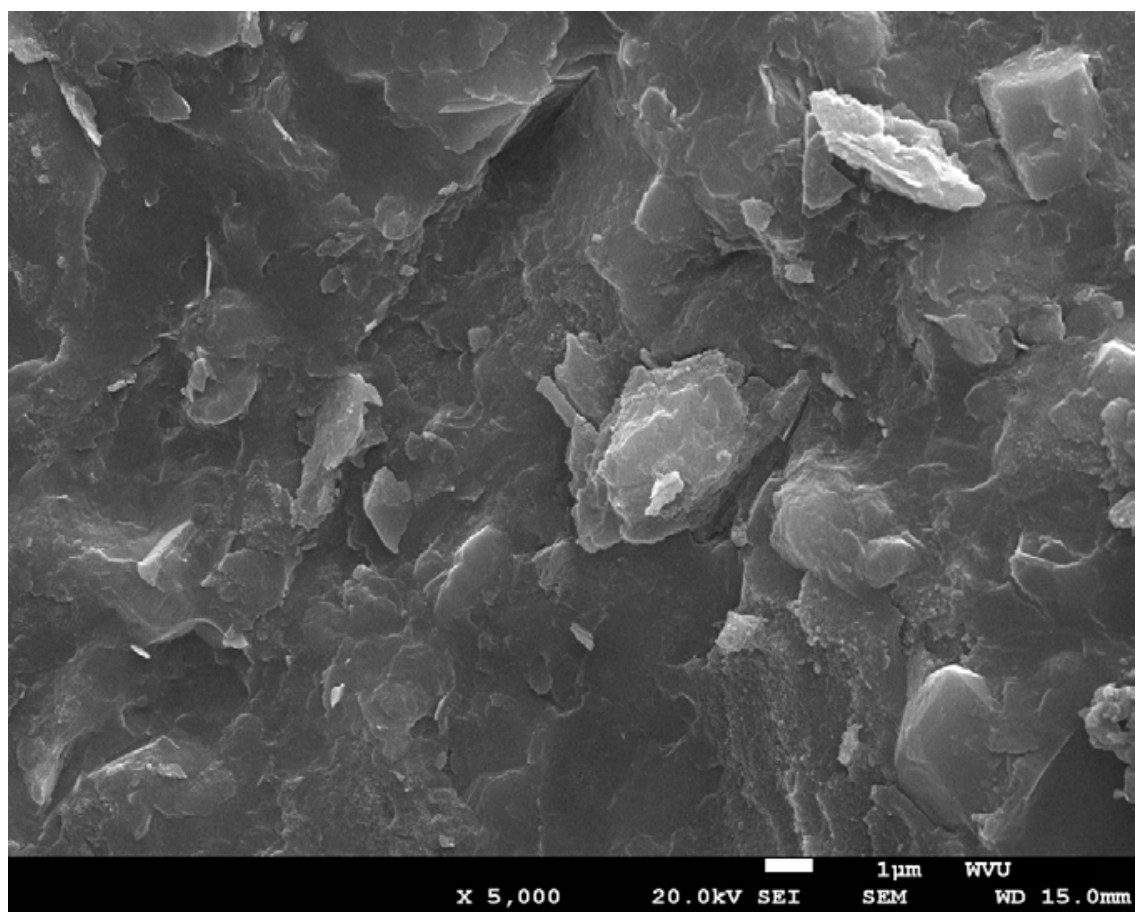

Figure 6.139 SEM image of the Quik-Gel ${ }^{\circledR}$ treatment sample for the fifth depth interval of Well $B$ at 5000X 


\section{Wetzel County Well B Zeogel@ Alteration}

The samples discussed in this section underwent a Zeogel® treatment test. Samples from nine depth intervals of Wetzel County Well B soaked overnight in Zeogel® and distilled water suspension. The purpose of this test was to observe the effect the clay additive on the elemental composition of the Marcellus Shale. Zeogel ${ }^{\circledR}$ is added to many drilling muds used in the oil and natural gas industry. The elemental composition was evaluated using EDX, and the ranges in weight percent for each element found in the Zeogel ${ }^{\circledR}$ treatment test samples are listed in Table 6.10.

Wetzel County Well B (Zeogel $\left.{ }^{\circledR}\right)$

\begin{tabular}{c|r|r|c}
\hline Element & Weight\% & Sample & Range \\
\hline \multirow{2}{*}{$\mathrm{Al}$} & 0.44 & $5 \mathrm{~B}$ & \multirow{2}{*}{16.35} \\
& 16.79 & $4 \mathrm{~B}$ & \\
\hline \multirow{2}{*}{$\mathrm{C}$} & 6.24 & $5 \mathrm{~B}$ & \multirow{2}{*}{36.16} \\
& 42.40 & $1 \mathrm{~B}$ & \\
\hline \multirow{2}{*}{$\mathrm{Ca}$} & 1.48 & $3 \mathrm{~B}$ & \multirow{2}{*}{19.66} \\
\hline \multirow{2}{*}{$\mathrm{Fe}$} & 21.14 & $5 \mathrm{~B}$ & \\
\hline \multirow{2}{*}{$\mathrm{K}$} & 1.72 & $1 \mathrm{~B}$ & \multirow{2}{*}{3.21} \\
& 4.93 & $3 \mathrm{~B}$ & \\
\hline \multirow{2}{*}{$\mathrm{Mg}$} & 3.86 & $1 \mathrm{~B}$ & \multirow{2}{*}{5.44} \\
& 9.30 & $4 \mathrm{~B}$ & \\
\hline \multirow{2}{*}{$\mathrm{O}$} & 0.53 & $1 \mathrm{~B}$ & \multirow{2}{*}{0.27} \\
& 19.49 & $3 \mathrm{~B}$ & \\
\hline \multirow{2}{*}{$\mathrm{S}$} & 53.55 & $5 \mathrm{~B}$ & \multirow{2}{*}{34.06} \\
& 1.64 & $3 \mathrm{~B}$ & \multirow{2}{*}{16.35} \\
\hline \multirow{2}{*}{$\mathrm{Si}$} & 17.99 & $5 \mathrm{~B}$ & \\
\hline & 0.64 & $5 \mathrm{~B}$ & \multirow{2}{*}{34.83} \\
\end{tabular}

Table 6.10 Weight percent ranges for each element found in Wetzel County Well B Zeogel® treatment samples

All the elements found in the samples that underwent the Zeogel® treatment test are plotted against the corresponding depth in Figure 6.140. Iron and potassium follow parallel weight percent data trends in this the control sample and every alteration test for this well. Silicon followed a similar data pattern as iron and potassium, and oxygen also follows this trend from the first depth interval to the fourth depth interval. Oxygen and silicon follow complimentary weight percent curves in the samples from the water treatment test and Aquagel ${ }^{\circledR}$ treatment test as well. 
Another elemental trend is also observed in these particular samples. Aluminum and potassium are plotted on the same scale, and they follow very similar data curves for the bottom three depth intervals. These two elements produced parallel weight percent curves in every alteration test for Well B. The similar weight percent values of iron, aluminum, and potassium are found in the Zeogel ${ }^{\circledR}$ treatment samples from Monongalia County Well A.

Photographs were taken of the samples that underwent the Zeogel ${ }^{\circ}$ treatment test using the SEM, and they are seen below in Figure 6.141 throughFigure 6.150. Each image was photographed at a magnification of 800X and 5000X. Organic rich areas, tiny pores, and countless layers were visible in the Zeogel ${ }^{\circledR}$ samples as they were in the control samples. Images taken at a magnification of $5000 \mathrm{X}$ for the depth intervals $4 \mathrm{~B}$ and $5 \mathrm{~B}$ had a unique surface texture that can be observed in Figure 6.148 and Figure 6.150. Because these hair-like fibers have only been observed in samples that were subjected to the Zeogel ${ }^{\circledR}$ treatment test, it can be assumed there is a direct relation between the magnesium aluminum silicate mineral and the Marcellus shale. The same characteristic was observed in the Zeogel ${ }^{\circledR}$ treatment samples from Well A. 


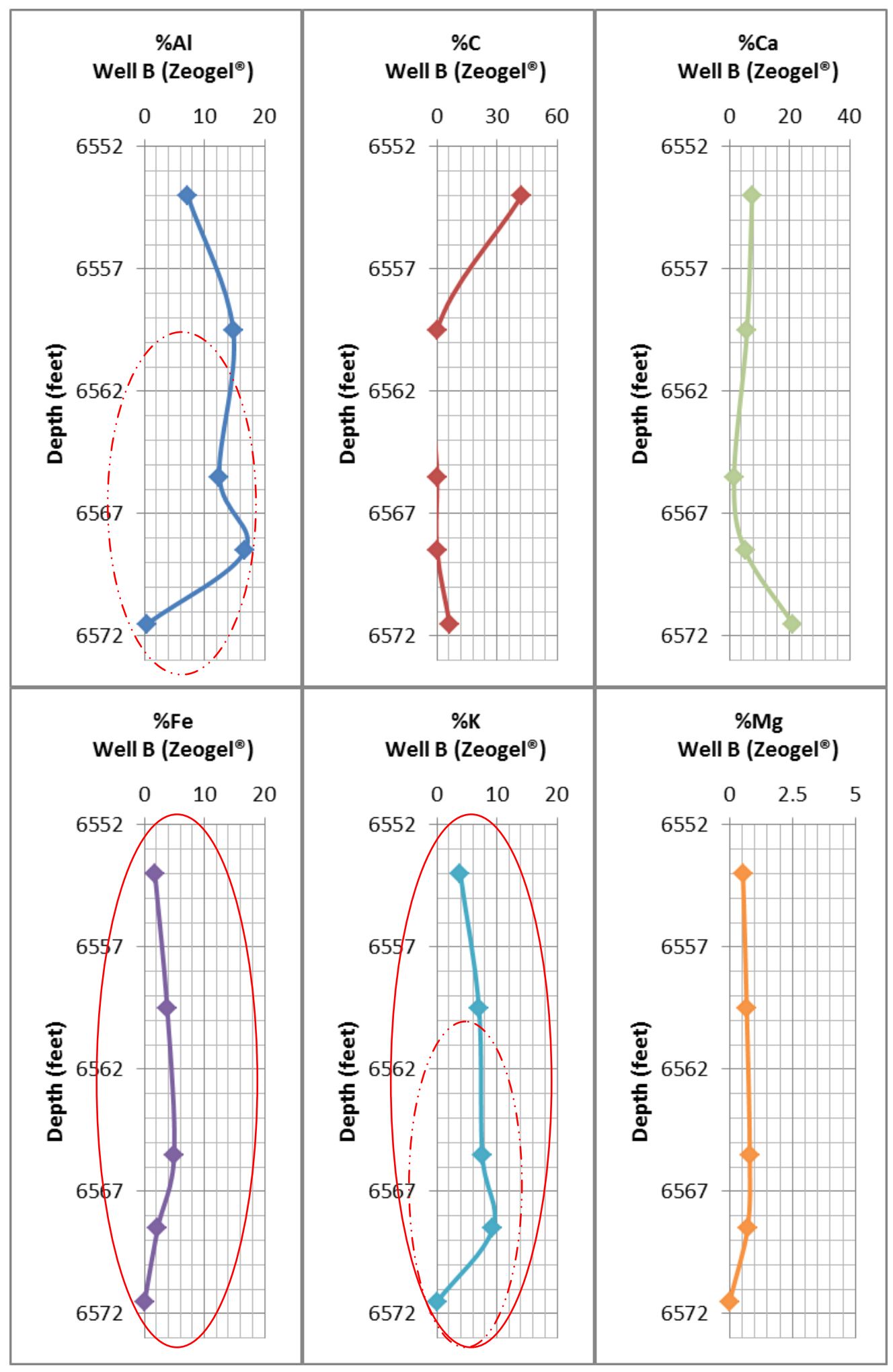




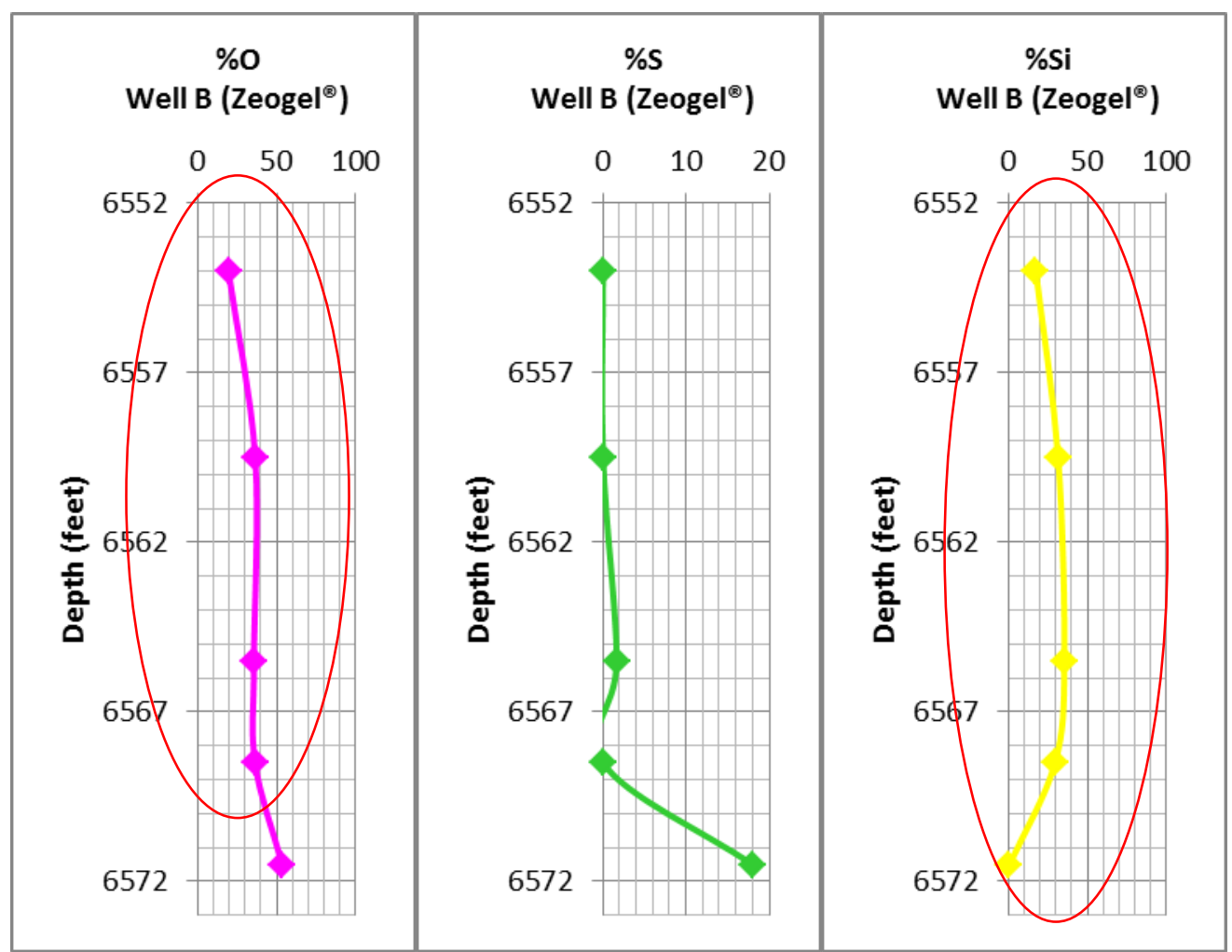

Figure 6.140 Weight percent of each element found in Wetzel County Well B Zeogel® treatment samples plotted against the corresponding depth 
Wetzel County Well B Zeogel@ Alteration Photographs

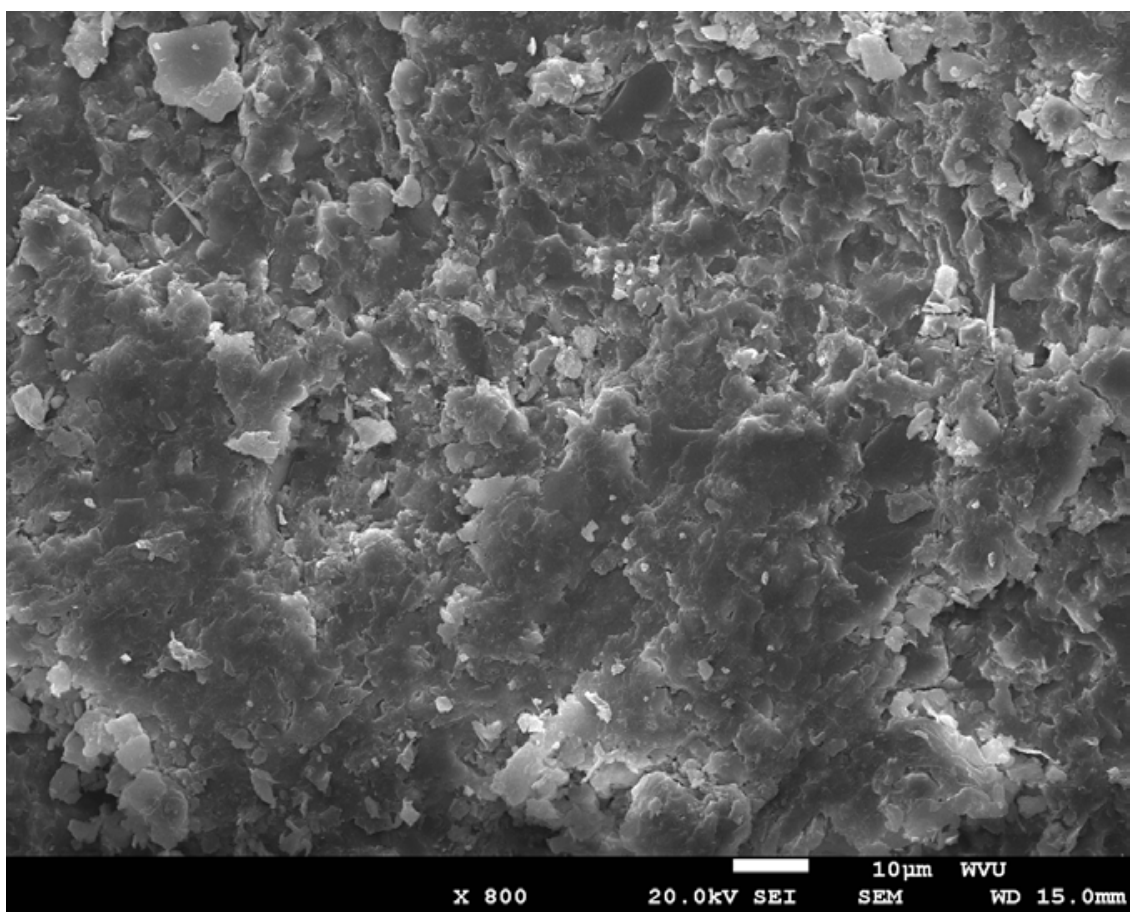

Figure 6.141 SEM image of the Zeogel ${ }^{\circledR}$ treatment sample for the first depth interval of Well B at 800X

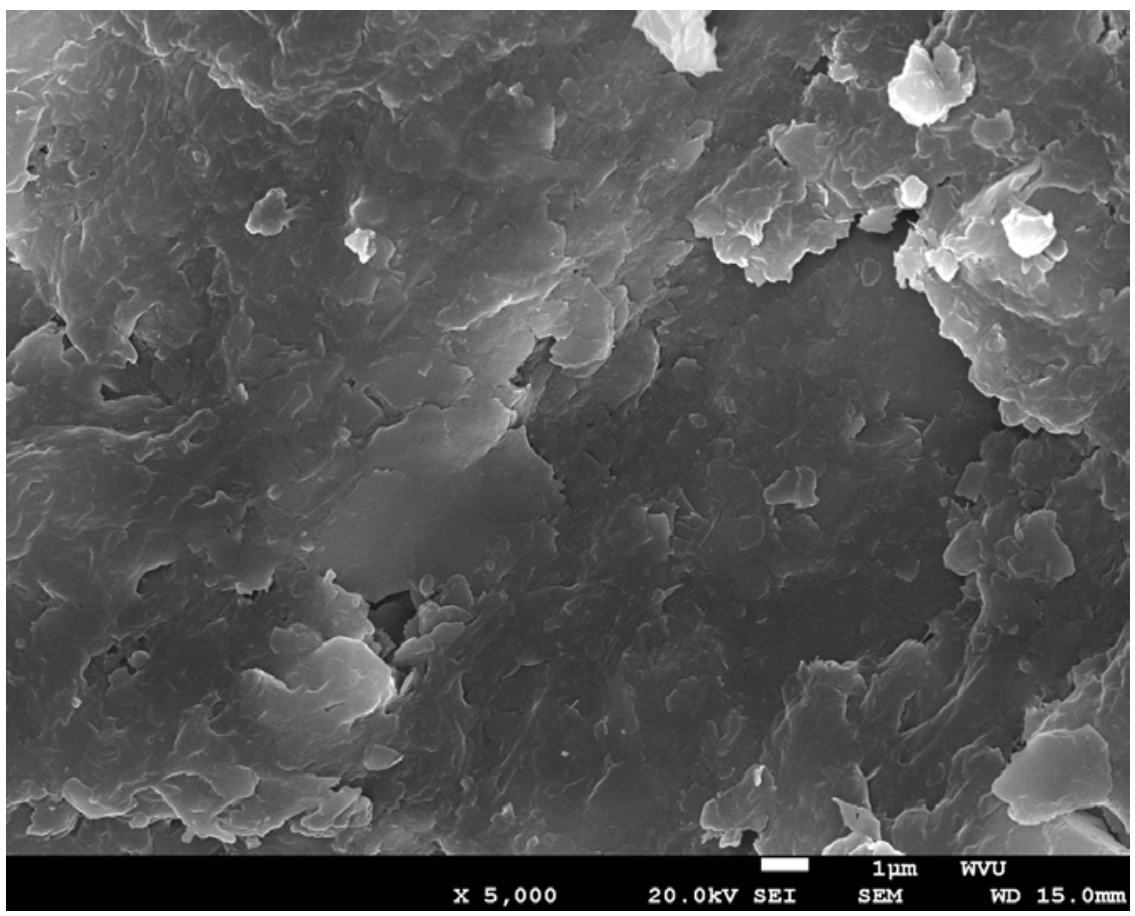

Figure 6.142 SEM image of the Zeogel ${ }^{\circledR}$ treatment sample for the first depth interval of Well B at 5000X 


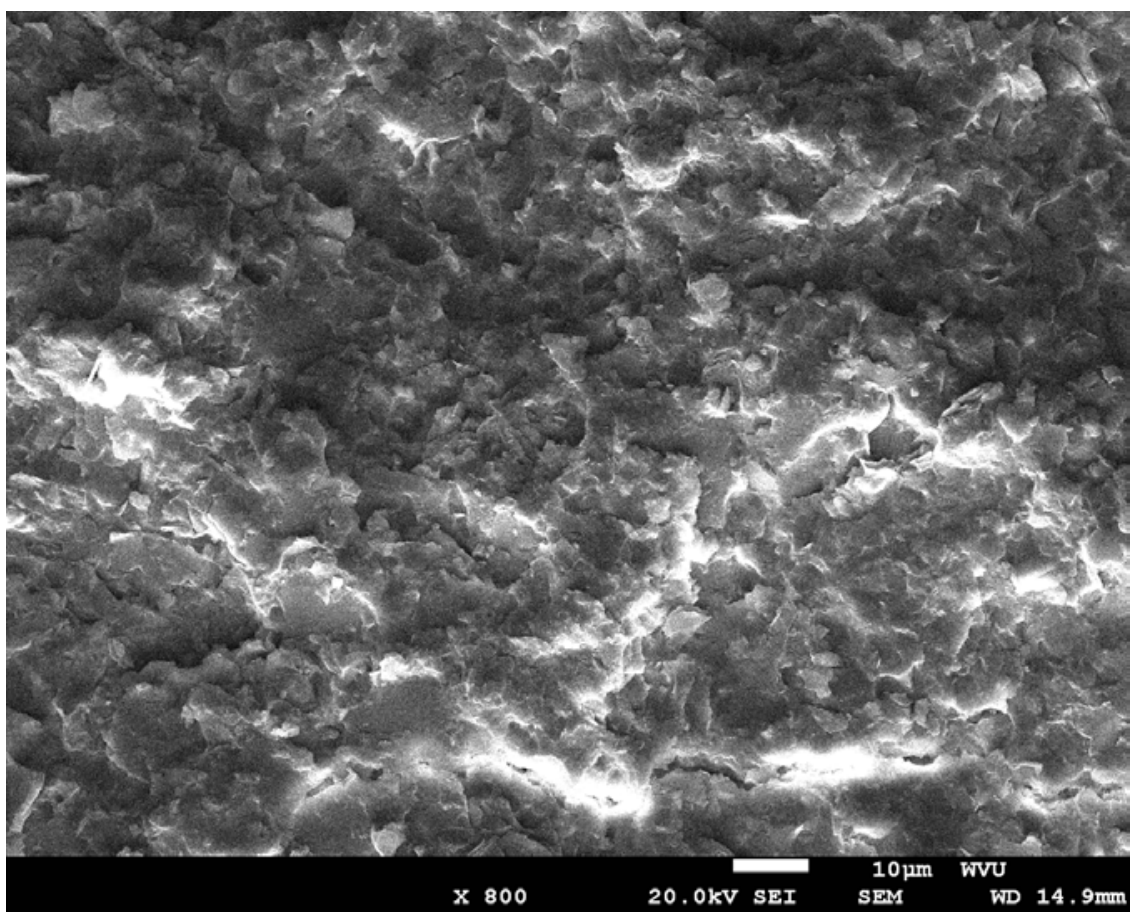

Figure 6.143 SEM image of the Zeogel ${ }^{\circledR}$ treatment sample for the second depth interval of Well $B$ at $800 X$

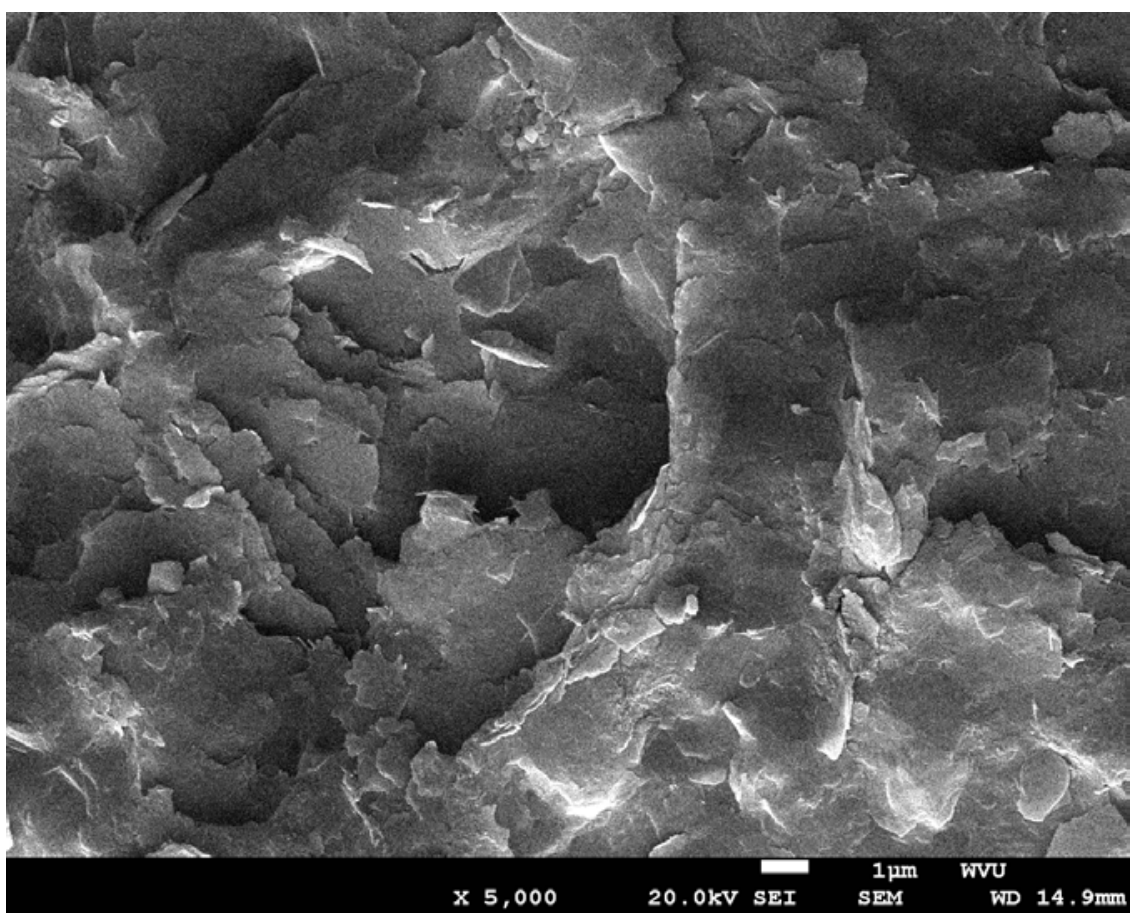

Figure 6.144 SEM image of the Zeogel ${ }^{\circledR}$ treatment sample for the second depth interval of Well B at 5000X 


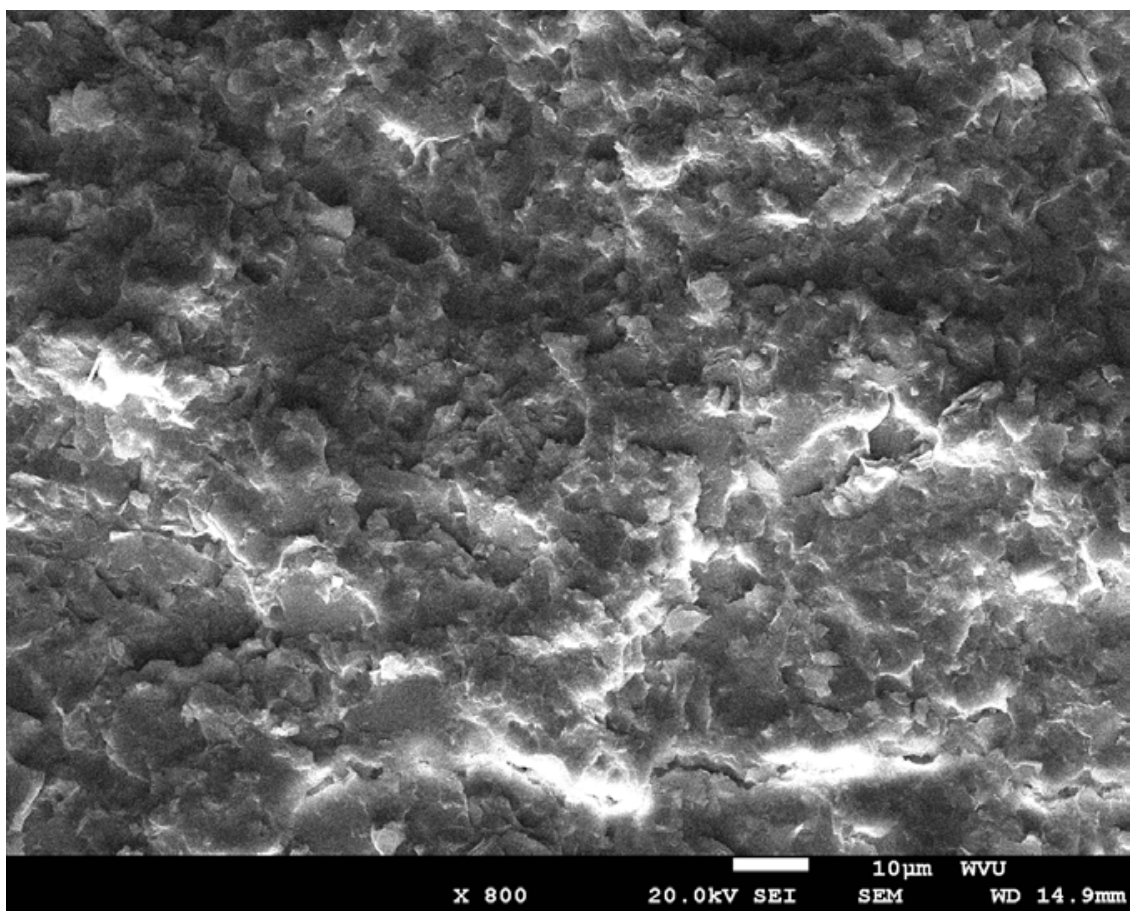

Figure 6.145 SEM image of the Zeogel ${ }^{\circledR}$ treatment sample for the third depth interval of Well B at $800 \mathrm{X}$

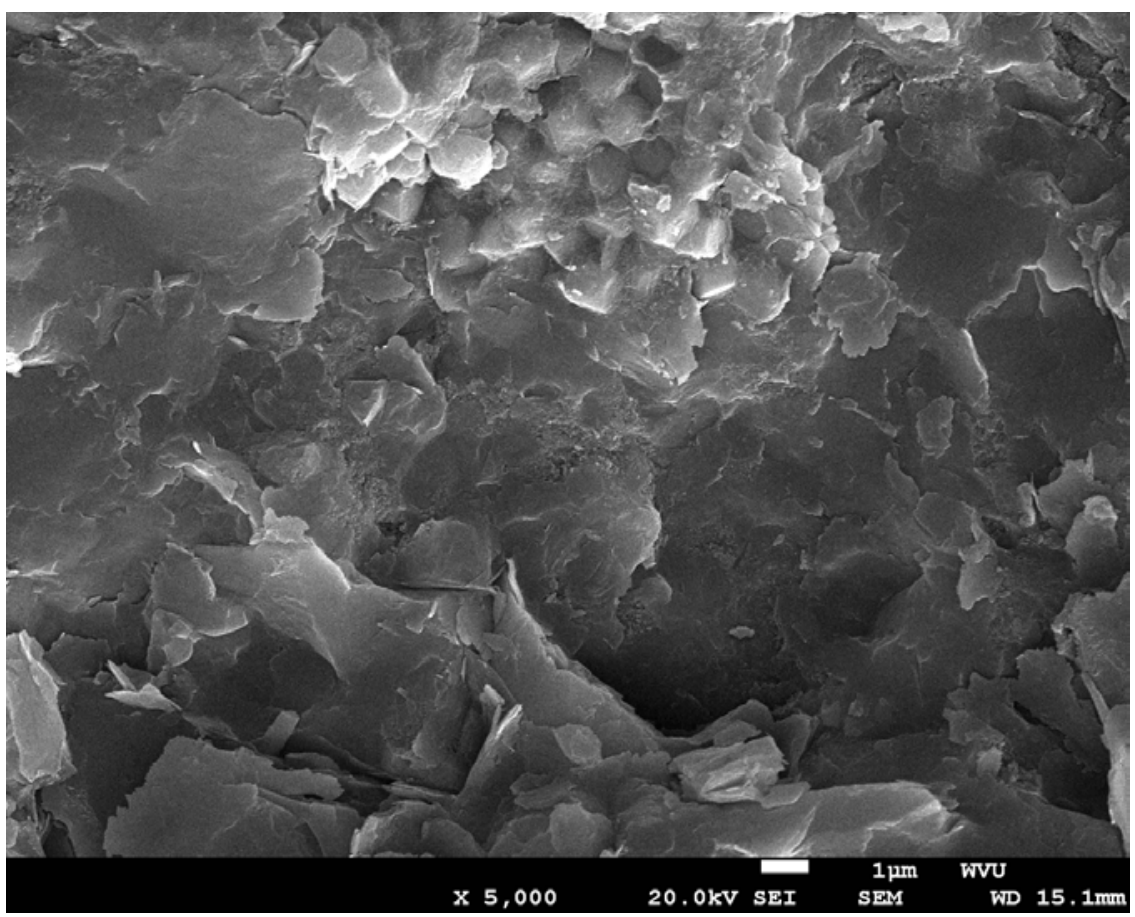

Figure 6.146 SEM image of the Zeogel ${ }^{\circledR}$ treatment sample for the third depth interval of Well B at 5000X 


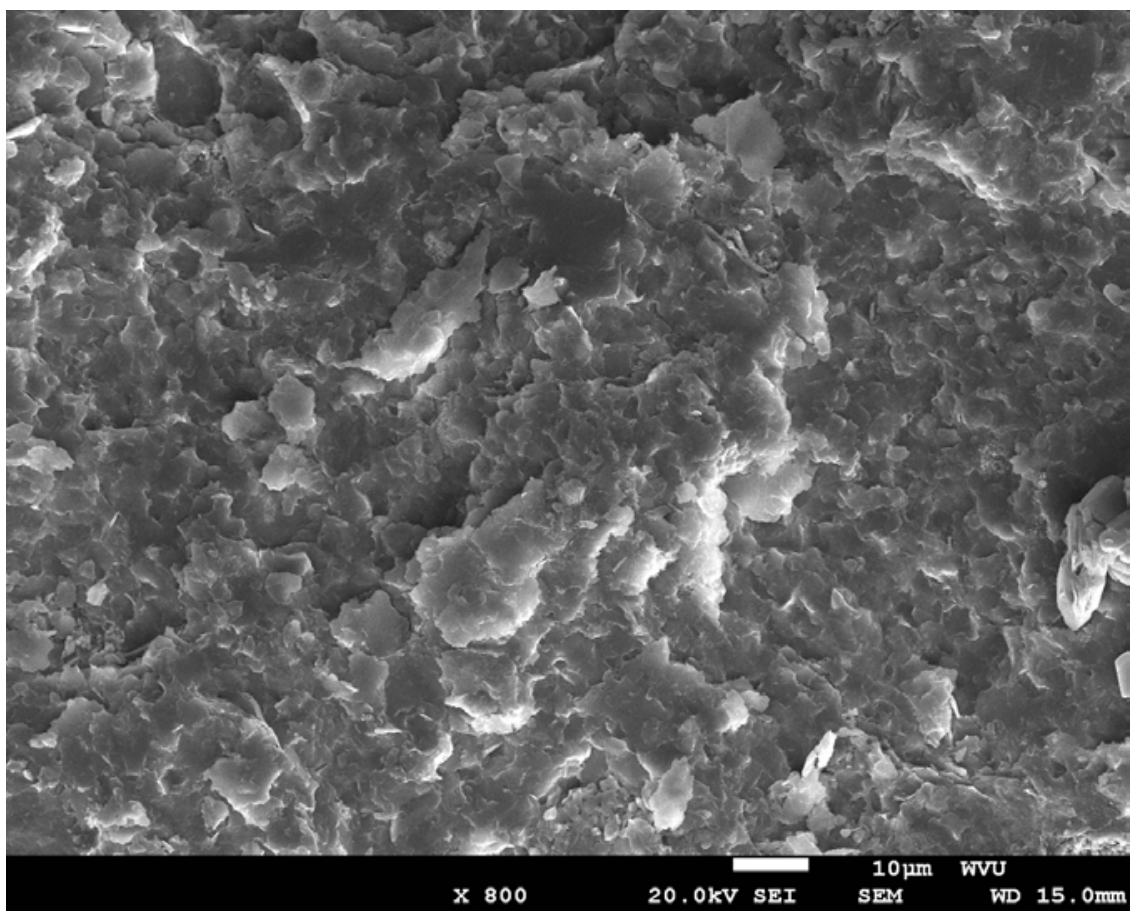

Figure 6.147 SEM image of the Zeogel® treatment sample for the fourth depth interval of Well $B$ at $800 X$

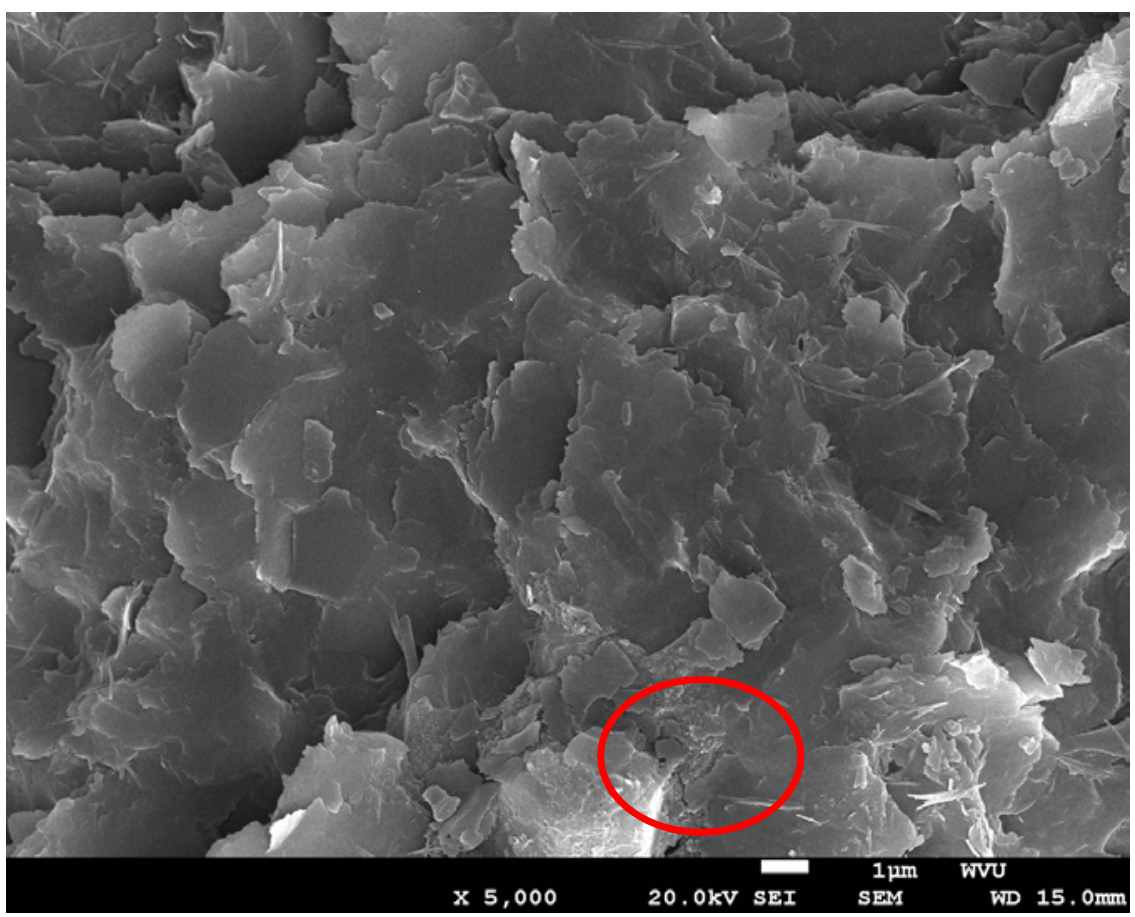

Figure 6.148 SEM image of the Zeogel ${ }^{\circledR}$ treatment sample for the fourth depth interval of Well B at 5000X 


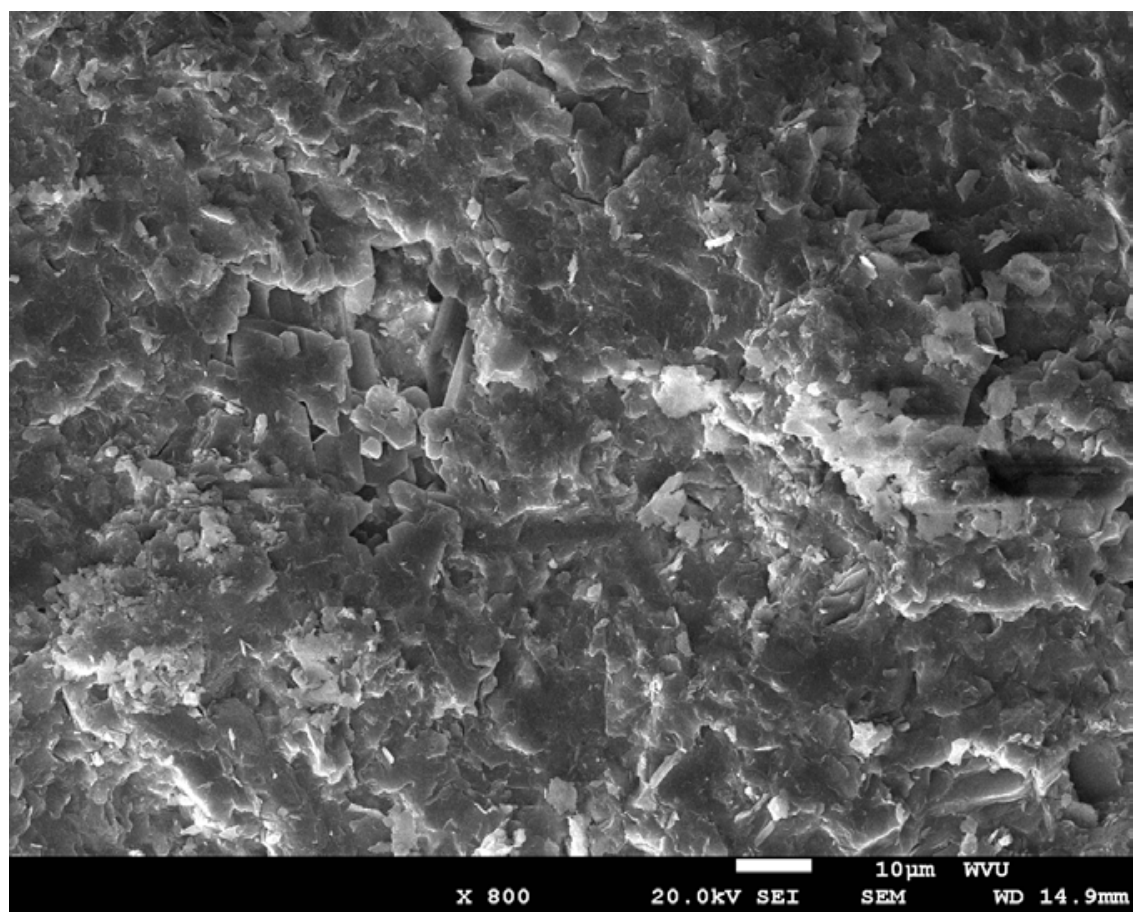

Figure 6.149 SEM image of the Zeogel ${ }^{\circledR}$ treatment sample for the fifth depth interval of Well B at $800 \mathrm{X}$

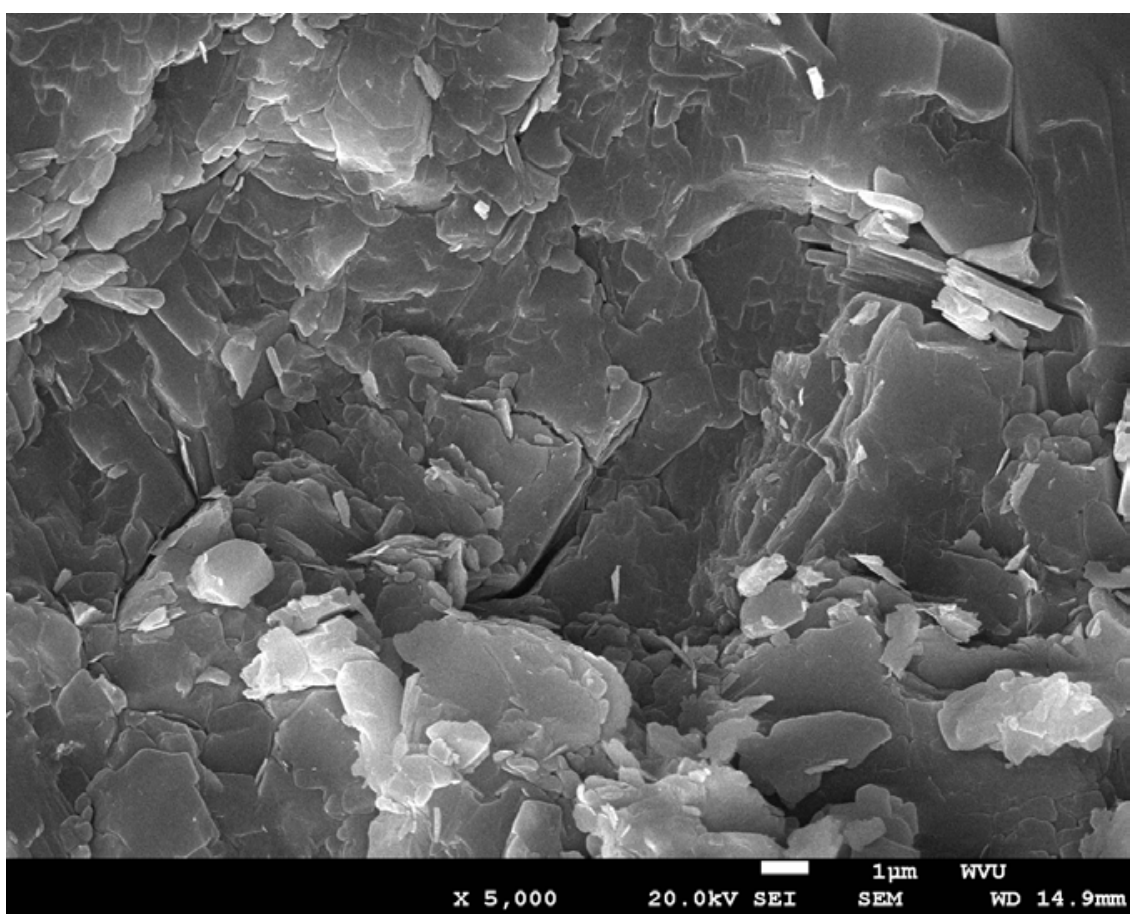

Figure 6.150 SEM image of the Zeogel ${ }^{\circledR}$ treatment sample for the fifth depth interval of Well B at 5000X 


\section{Overall Elemental Trends}

After analyzing the elemental data from both the control samples and the samples that underwent alteration, it is important to note the trends present within these samples from Monongalia County Well A and Wetzel County Well B. While the EDX analysis produced both atomic and elemental weight percent for every specimen, it was difficult to determine the exact mineral composition of each of these specimens. These elements can combined in unique ways, both breaking down and forming new minerals. When looking at the data trends it was occasionally obvious when minerals such as pyrite and quartz formed; however, it could also be very difficult to identify other minerals present in the Marcellus shale such as gypsum and limestone.

Monongalia County Well A produced four overall trends among the samples that underwent alteration. In Figure 6.151 it was observed that every specimen but one increased in oxygen in the same set of samples that were submitted to the water treatment test. This increase in elemental weight could be attributed to the addition of the $\mathrm{H}_{2} \mathrm{O}$ molecules. There was a general increase in weight percent in iron for the Aquagel® treatment samples Figure 6.152. There was not general trend in the changes of the weight percent values for the elements that underwent the Quik-Gel® treatment test. Due to the fact carbon was not measured in the samples from the Zeogel@ treatment test, there was a dramatic overall decrease in this element (Figure 6.153). It is probable the aluminum silicate minerals that comprise palygorscite was masking carbon elements after the alteration test. 


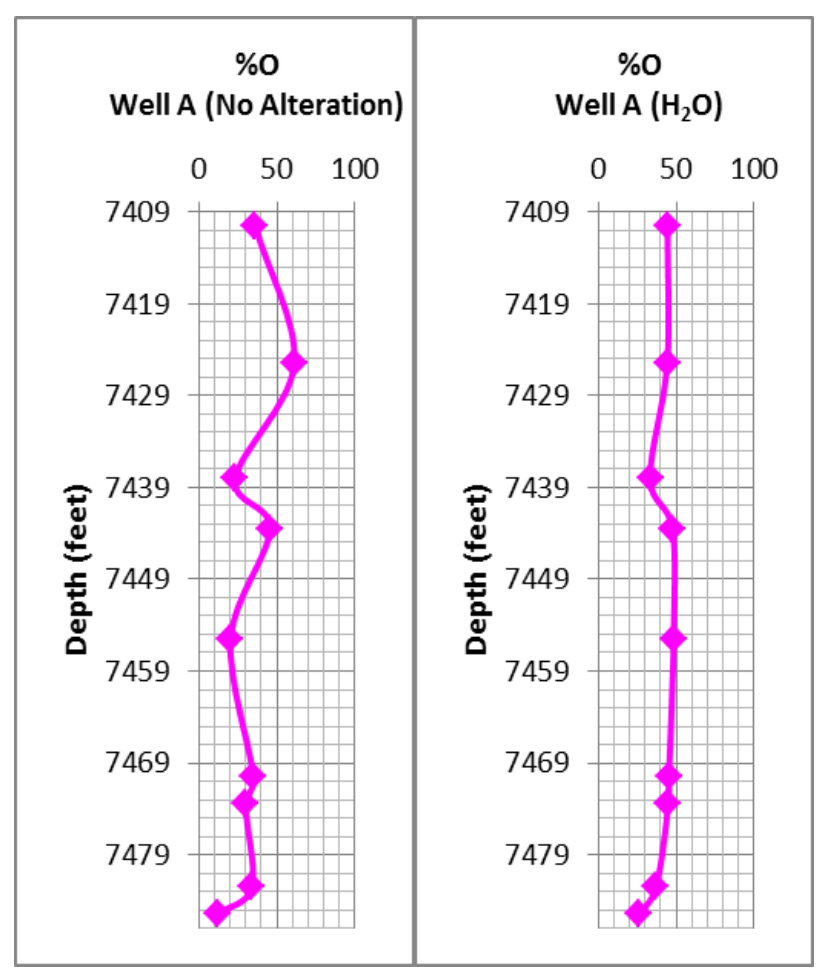

Figure 6.151 Comparison of the weight percent data for oxygen found in the control samples and the water treatment samples for Monongalia County Well A

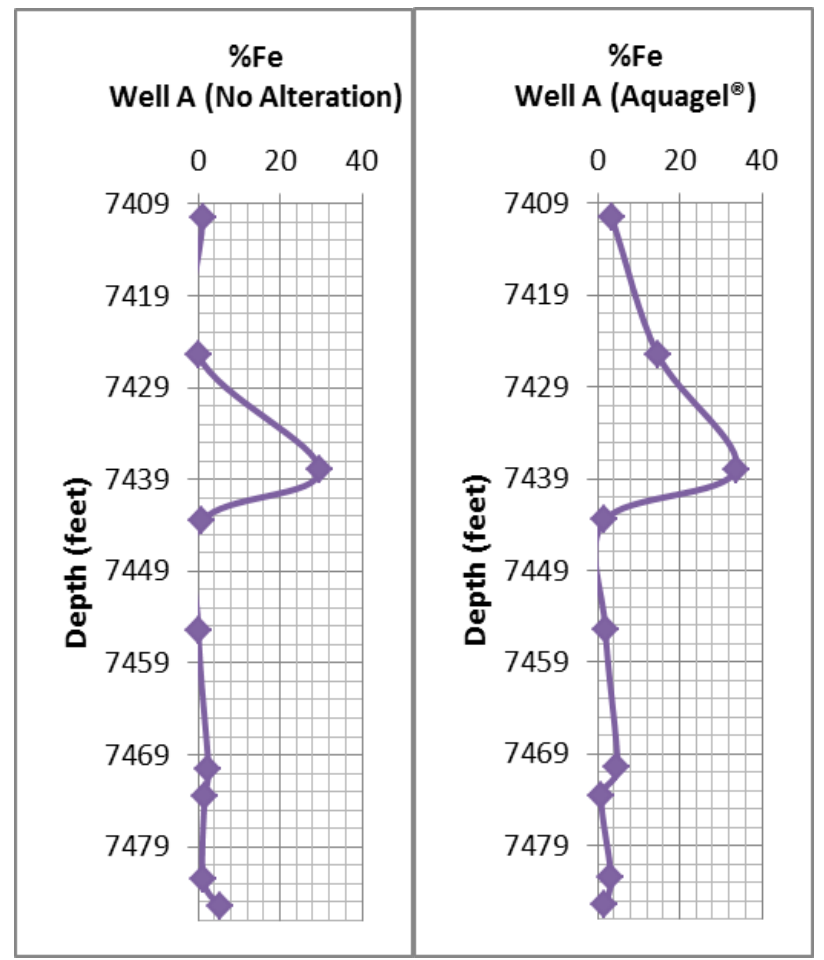

Figure 6.152 Comparison of the weight percent data for iron found in the control samples and the Aquagel® treatment samples for Monongalia County Well A 


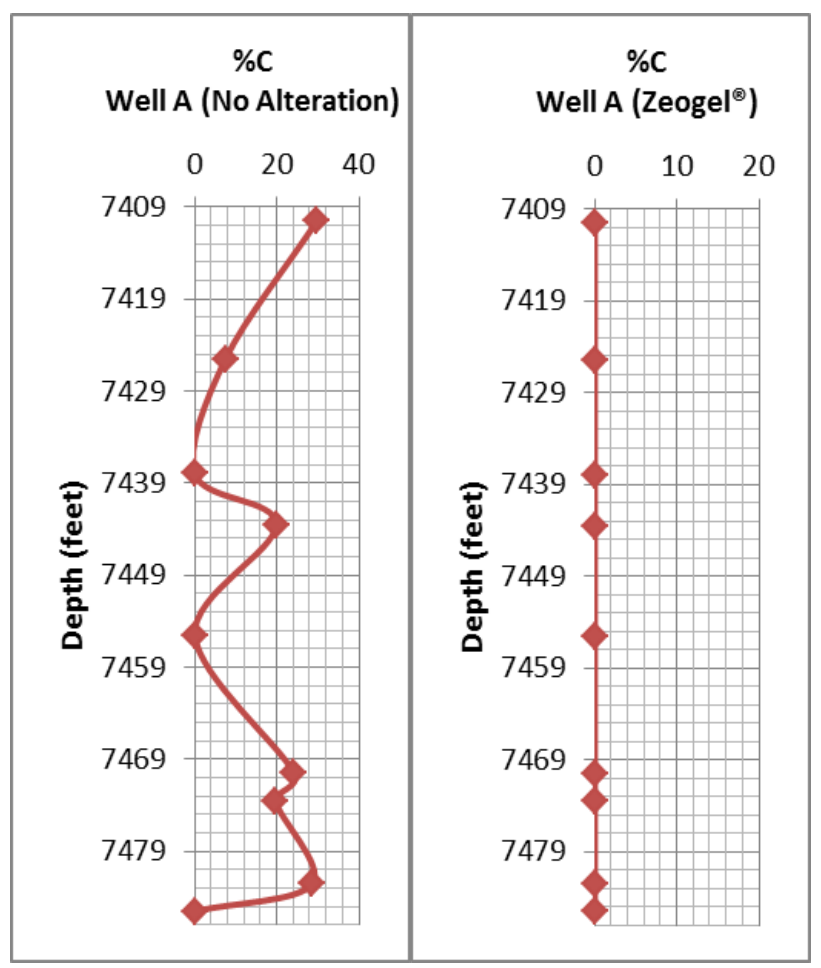

Figure 6.153 Comparison of the weight percent data for carbon found in the control samples and the Zeogel® treatment samples for Monongalia County Well A

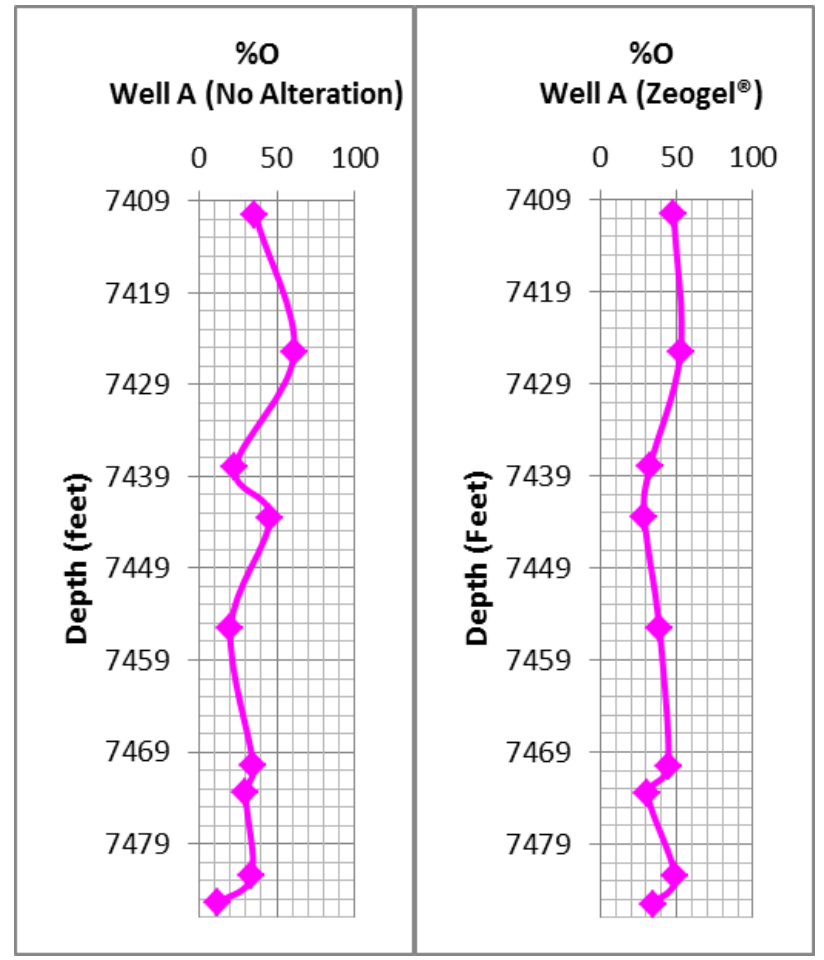

Figure 6.154 Comparison of the weight percent data for oxygen found in the control samples and the Zeogel ${ }^{\circledR}$ treatment samples for Monongalia County Well A 
Wetzel County Well B produced eight overall trends among the samples that underwent alteration The elemental weight percent of aluminum and a magnesium showed an overall decrease in the water treatment samples (Figure 6.155 and Figure 6.156). There was an overall increase in the weight percent of oxygen in the samples that were subjected to the Aquagel ${ }^{\circledR}$ treatment test. Every sample but the specimen from the third depth interval increased in oxygen as seen in Figure 6.157. The weight percent of potassium, magnesium, and aluminum generally decreased in the samples that underwent the Quik-Gel® treatment test as seen in Figure 6.158, Figure 6.159, and Figure 6.160 respectively. It should be noted, each element increased in weight percent at the third depth interval. The samples that underwent the Zeogel® treatment test produced two general trends in data. The weight percent values of magnesium and silicon decreased overall compared to the weight percent values in the control samples (Figure 6.161 and Figure 6.162).

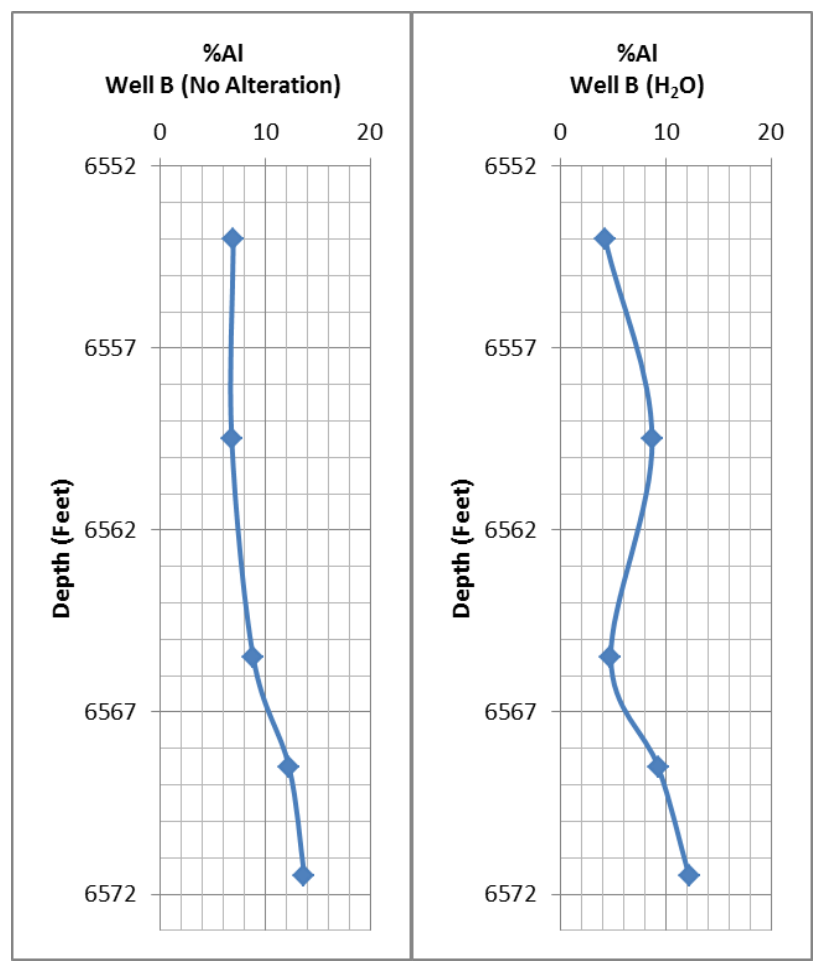

Figure 6.155 Comparison of the weight percent data for aluminum found in the control samples and the water treatment samples for Wetzel County Well B 


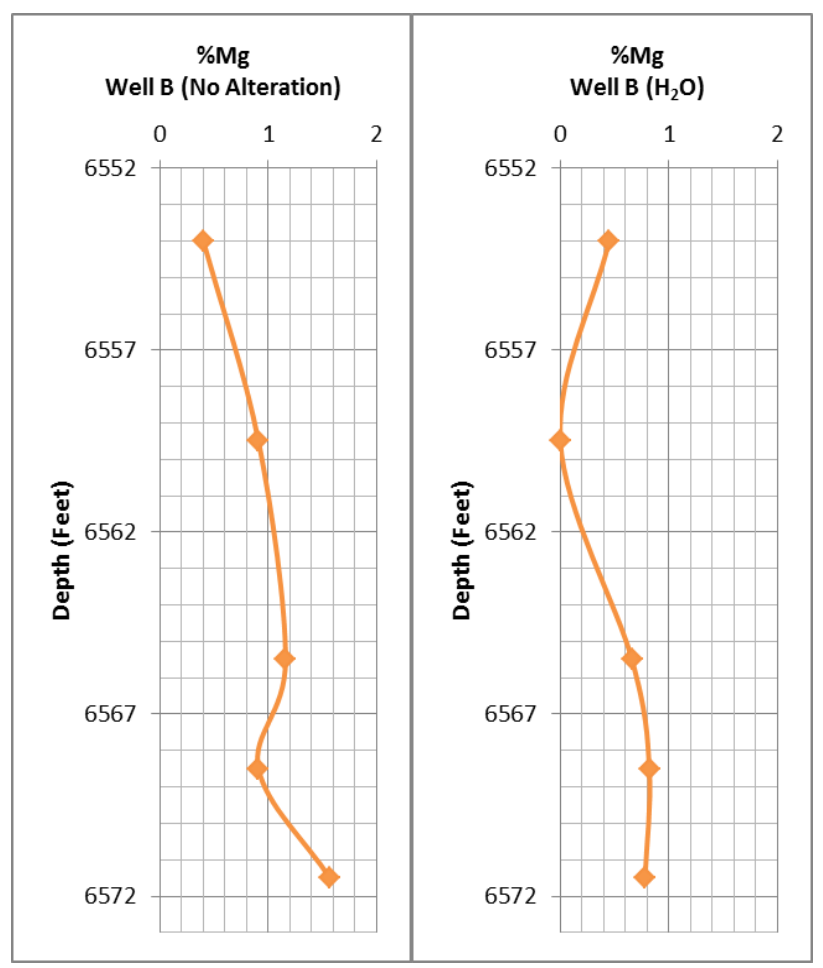

Figure 6.156 Comparison of the weight percent data for magnesium found in the control samples and the water treatment samples for Wetzel County Well B

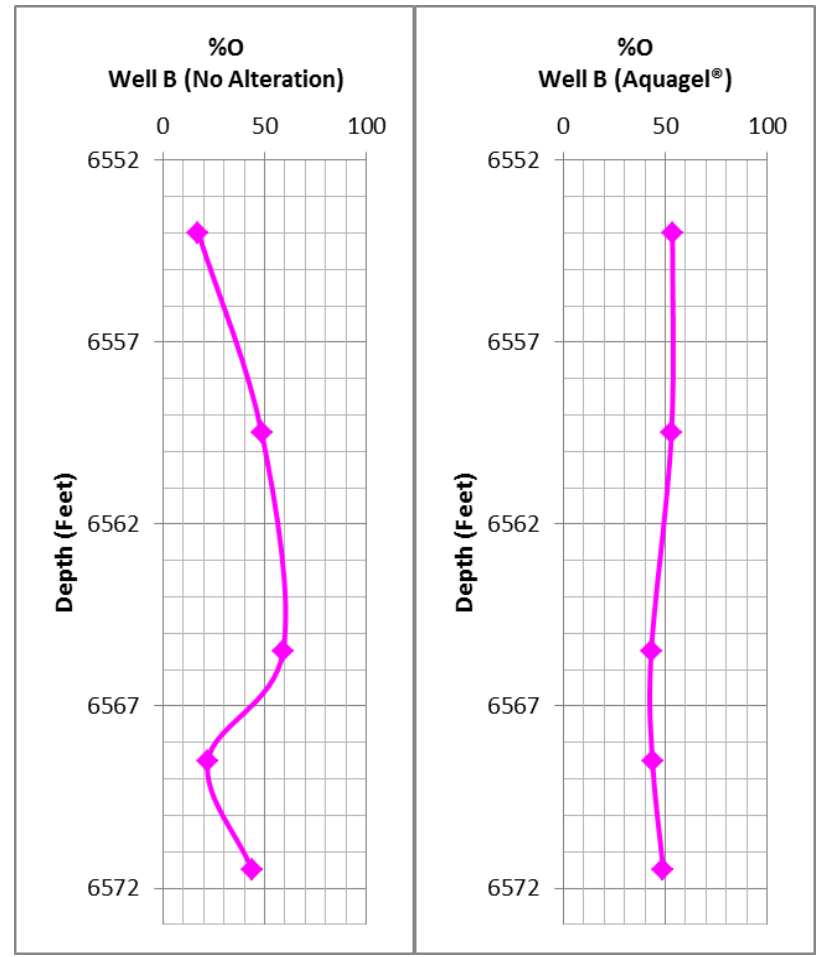

Figure 6.157 Comparison of the weight percent data for oxygen found in the control samples and the Aquagel ${ }^{\circledR}$ treatment samples for Monongalia County Well B 


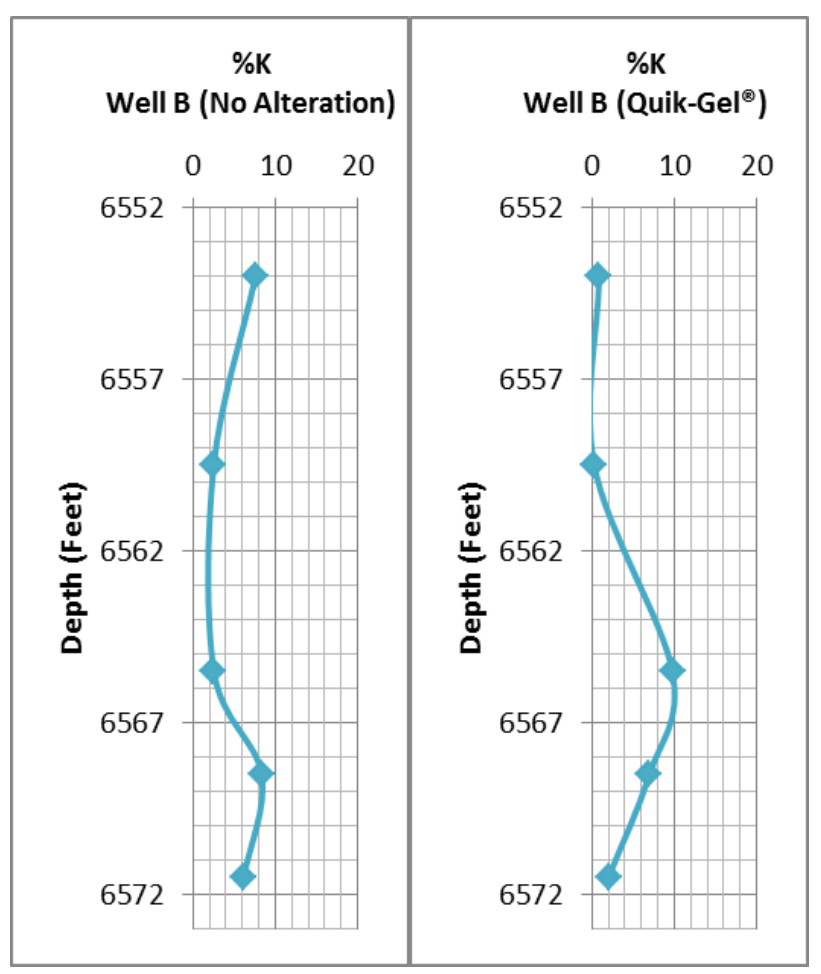

Figure 6.158 Comparison of the weight percent data for potassium found in the control samples and the Quik-Gel® treatment samples for Monongalia County Well B

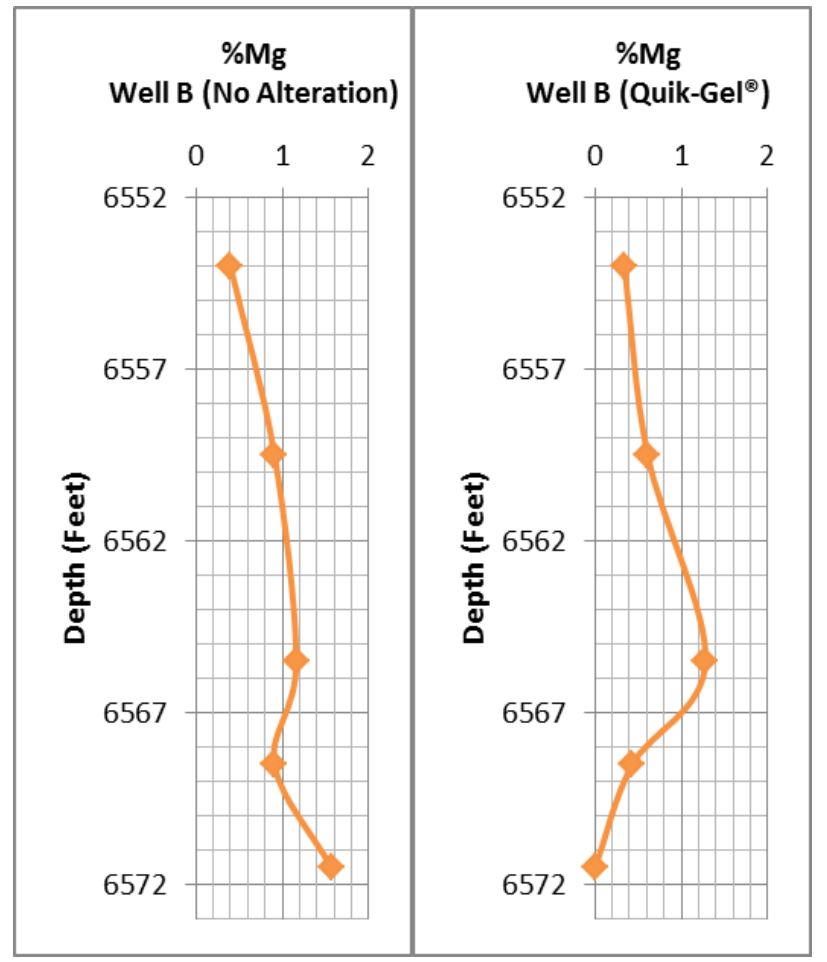

Figure 6.159 Comparison of the weight percent data for magnesium found in the control samples and the Quik-Gel ${ }^{\circledR}$ treatment samples for Monongalia County Well B 


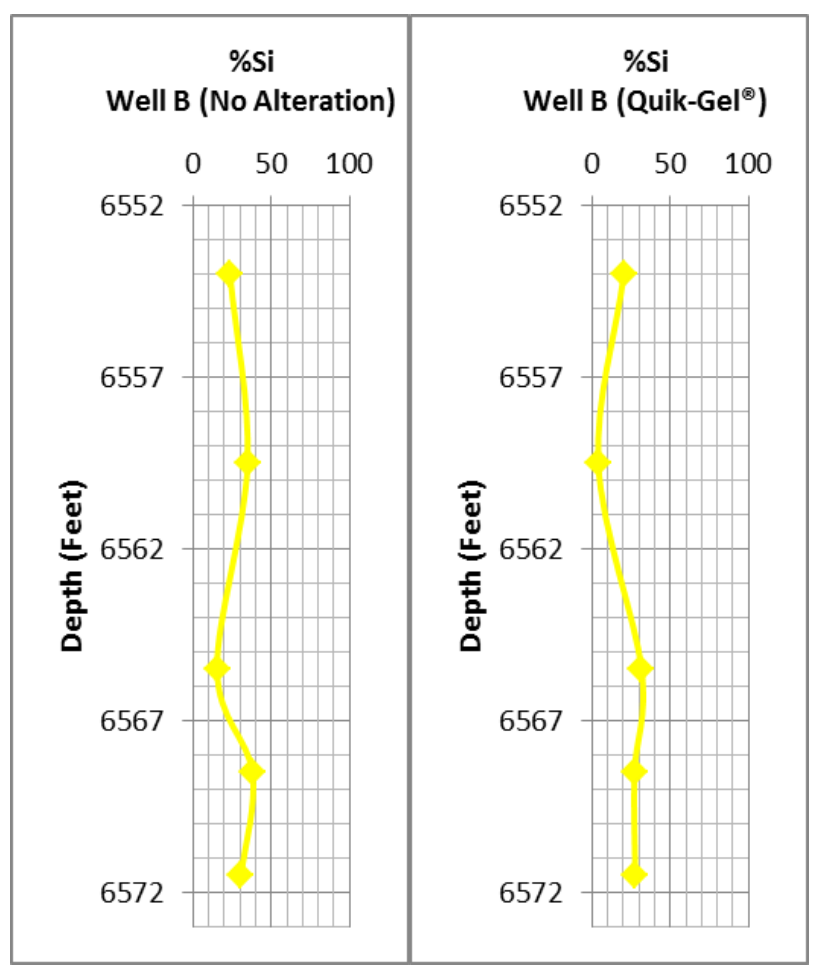

Figure 6.160 Comparison of the weight percent data for silicon found in the control samples and the Quik-Gel ${ }^{\circledR}$ treatment samples for Monongalia County Well B

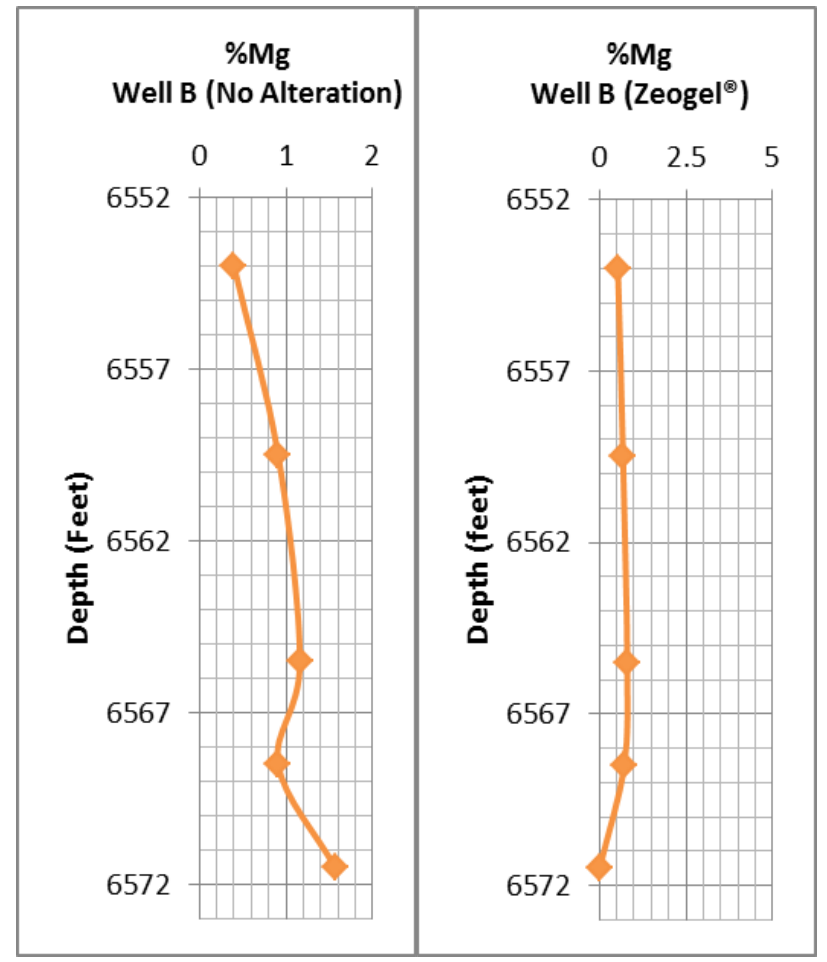

Figure 6.161 Comparison of the weight percent data for magnesium found in the control samples and the Zeogel ${ }^{\circledR}$ treatment samples for Monongalia County Well B 


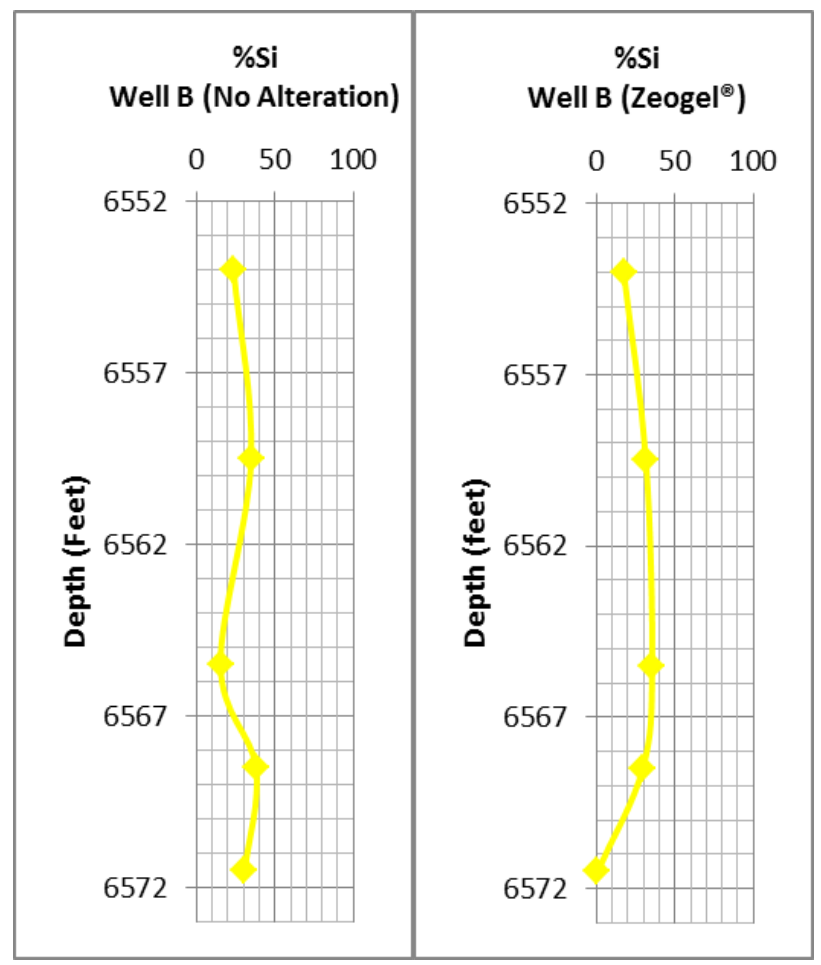

Figure 6.162 Comparison of the weight percent data for silicon found in the control samples and the Zeogel® treatment samples for Monongalia County Well B

There is large mineralogical variability among the Marcellus shale. This leads to variation among the mineral composition of the Marcellus shale as well. While trends were discovered among the control samples and those that underwent alteration, there is not enough evidence to support that subjecting a Marcellus shale sample to a particular clay suspension always results in the same elemental change in weight percent. It is important to note there were parallel data trends among the same element within the four alteration tests. While the elemental curves between Well A and Well B do not match, the samples submitted to the water treatment test produce trends among particular pairs of elements. Aluminum and potassium followed a similar weight percent trend in both Well A and Well B. In both sets of Aquagel ${ }^{\circledR}$ treatment test samples potassium, magnesium and silicon followed a similar curve. The weight percent data trends for the Quik-Gel® treatment samples from Well A are similar to the trends found in the Quik-Gel ${ }^{\circledR}$ treatment samples from Well B. Aluminum and potassium follow a similar weight percent curve as well as sodium and oxygen Finally, iron, potassium, aluminum, and oxygen produced complimentary curves in both Well A and Well B. 


\section{Chapter 7 - Conclusion}

The results from the study of the chemical interactions between the Marcellus shale and attapulgite and bentonite clays have been presented, and it was concluded:

- It was difficult to determine the exact mineral composition of each of the studied specimens. Elements combined in unique ways, both breaking down and forming new minerals.

- The ranges in weight percent values for the samples analyzed was attributed to the extreme mineralogical variability of the Marcellus shale. Whenever a shale fragment undergoes a test involving water, there was always a possibility that part of the rock would remain in the solution or suspension. Additionally, after a sample was flooded with a solution or suspension, the less durable minerals dissolved leaving the more durable ones, such as pyrite, behind.

- While trends were discovered among the control samples and those that underwent alteration, there was not enough evidence to support that subjecting a Marcellus shale sample to a particular clay suspension would always result in the same elemental change in weight percent.

- The photographs taken on the SEM showed also confirmed variability among the samples. While all the images showed many pores and layers, the size of the pores and the amount of quantity of layers varied. Areas of higher organic content could be seen for most samples when observed at $800 \mathrm{X}$ magnification. Some of the photographs taken on the SEM showed that certain minerals coalesced to form deposits. While some of the deposits may be part of the source rock, others have formed as a direct result of the alteration experiments.

- Suggested directions for future research of this topic include:

o Maintain excellent quality control of the samples throughout the entire project. Proper specimen management must occur from collecting the samples directly from the well head to performing the laboratory experiments. 
O X-Ray Diffraction Analysis should be used to determine the mineral composition.

o Treating multiple samples from each depth interval would provide more data for developing conclusions. 


\section{References}

Bohem, P., Turton, D., Raval, A., Caudle, D., French, D., Rabalais, N., et al. (2001). Deepwater Program: Literature Review, Environmental Risks of Chemical Products Used in Gulf of Mexico Deepwater Oil and Gas Operations. OCS Study MMS 2001-011. New Orleans: U.S. Department of the Interior Minerals Management Service Gulf of Mexico OCS Region.

Clem, A. G., \& Doehler, R. W. (1961). Industrial Applications of Bentonite. Clays and Clay Minerals: Tenth National Conference on Clays and Clay Minerals. 10, pp. 272-282. Austin: Pergamon Press.

Cliff Minerals, Inc. (1981). Phase III Report Summary of Laboratory Analyses and Mechanical Characterization Results. Eastern Gas Shale Project West Virginia \#6 Well - Monongalia County.

Haden Jr., W. L. (1961). Attapulgire: Properties and Uses. Clays and Clay Minerals: Tenth National Conference on Clays and Clay Minerals (pp. 284-290). Austin: Pergamon Press.

Milici, R. C., \& Swezey, C. S. (2006). Assessment of Appalachian Basin Oil and Gas Resources: Devonian Shale-Middle and Upper Paleozoic Total Petroleum System. U.S. Department of the Interior. Reston: U.S. Geological Survey.

Neff, J. M. (2005). Composition, Environmental Fates, and Biological Effect of Water Based Drilling Muds and Cuttings Discharged to the Marine Environment: A Synthesis and Annotated Bibliography. Prepared for Petroleum Environmental Research Forum (PERF) and American Petroleum Institute.

Onuoha, I. E. (2011). Study of Drilling Fluid Additives and their Impact on Smectite Inbibition, Marcellus Shale Inbibition, and Filtration and Rheological Properties of Bentonite Based Drilling Fluids. Society of Petroleum Engineers.

Santarelli, F. J., \& Carminati. (1995). Do Shales Swell? A critical Review of Available Evidence. Society of Petroleum Engineers.

Sharma, H. D., \& Sangeeta, P. L. (1994). Waste Containment Systems, Waste Stabilization, and Landfills: Design and Evaluation. New York: John Wiley \& Sons, Inc.

Sorptive Minerals Institute. (2007). Learn About Absorbent Minerals and Ores, Clay, Attapulgite, Palygorskite, Montmorillonite, Bentonite, Wyoming Bentonites, Southern Bentonites, Minerology.

Retrieved March 21, 2012, from Sorptive Minerals Institute:

http://www.sorptive.org/content/page04.shtml

Steiger, R. P., \& Leung, P. K. (1992). Quantitative Determination of the Mechanical Properties of Shales. Society of Petroleum Engineers.

Stephens, M., Gomez-Nava, S., \& Churan, M. (2009). Laboratory Methods to Assess Shale Reactivity with Drilling Fluids. American Association of Drilling Engineers. 
Swarthmore College. (2012). Natural Gas Drilling in the Marcellus Shale. Retrieved from Swarthmore College: http://www.swarthmore.edu/MarcellusShale.xml

Tourtelot, E. B., \& Vine, J. D. (1976). Copper Deposits in Sedimentary and Volcanogenic Rocks. Wasington: U.S Government Printing Office.

Tourtelot, H. A. (1979). Black Shale-Its Deposition and Diagenesis. Clays and Clay Minerals , 27 (5), 313-321.

World Oil. (1999, June). Classification of Fluid Systems. World Oil , 85-87 
Appendix A - Comparison of Elemental Composition 


\section{Monongalia County Well A}

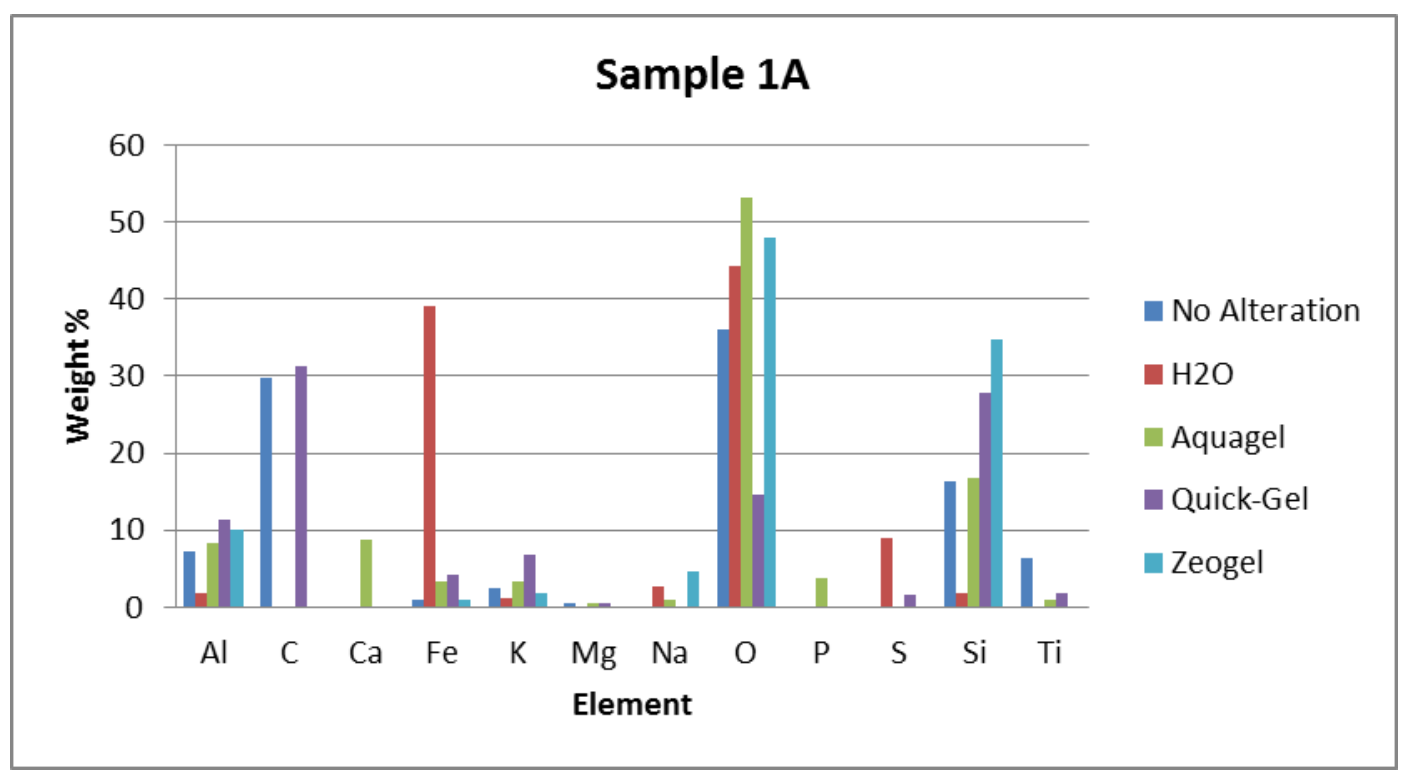

Figure A-1 Elemental weight percent values found in the Monongalia County Well A specimens from the first depth interval

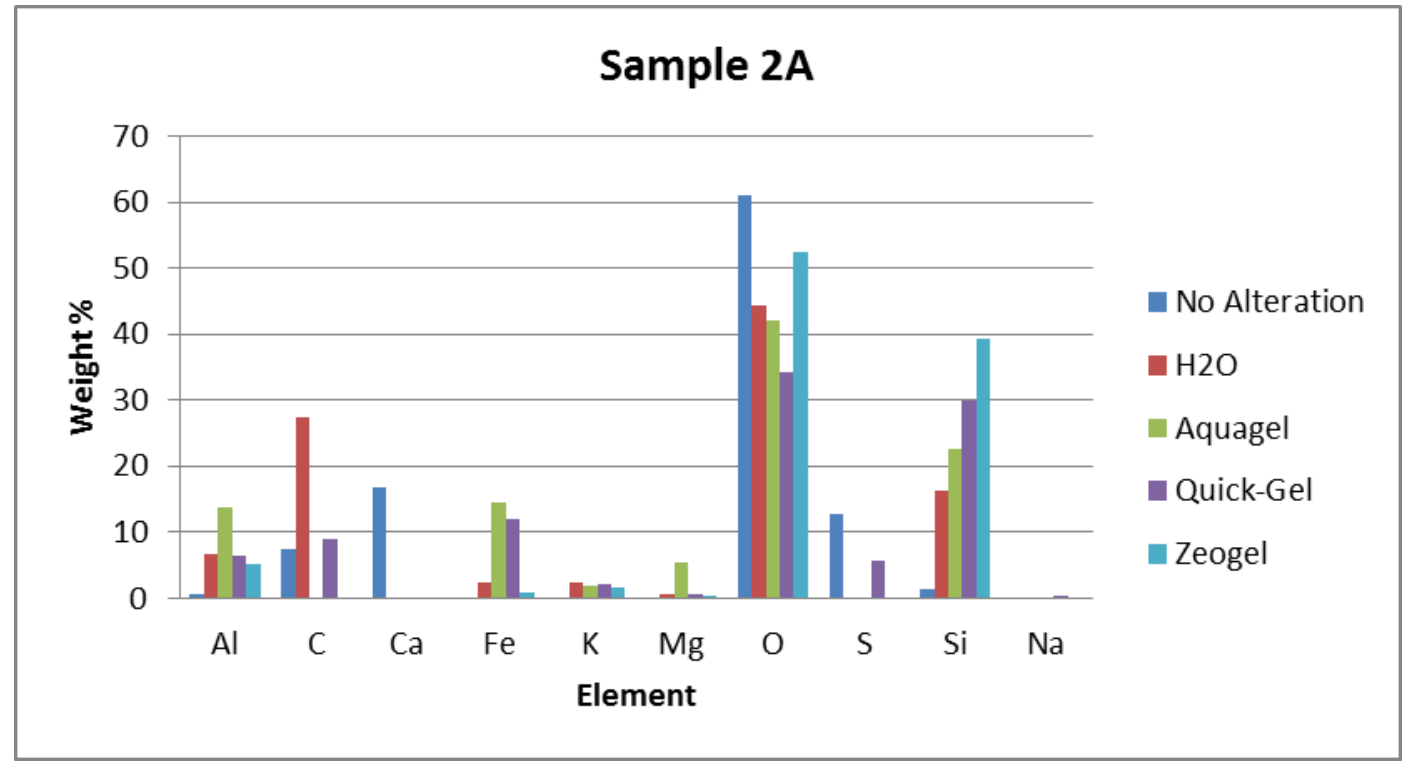

Figure A-2 Elemental weight percent values found in the Monongalia County Well A specimens from the second depth interval 


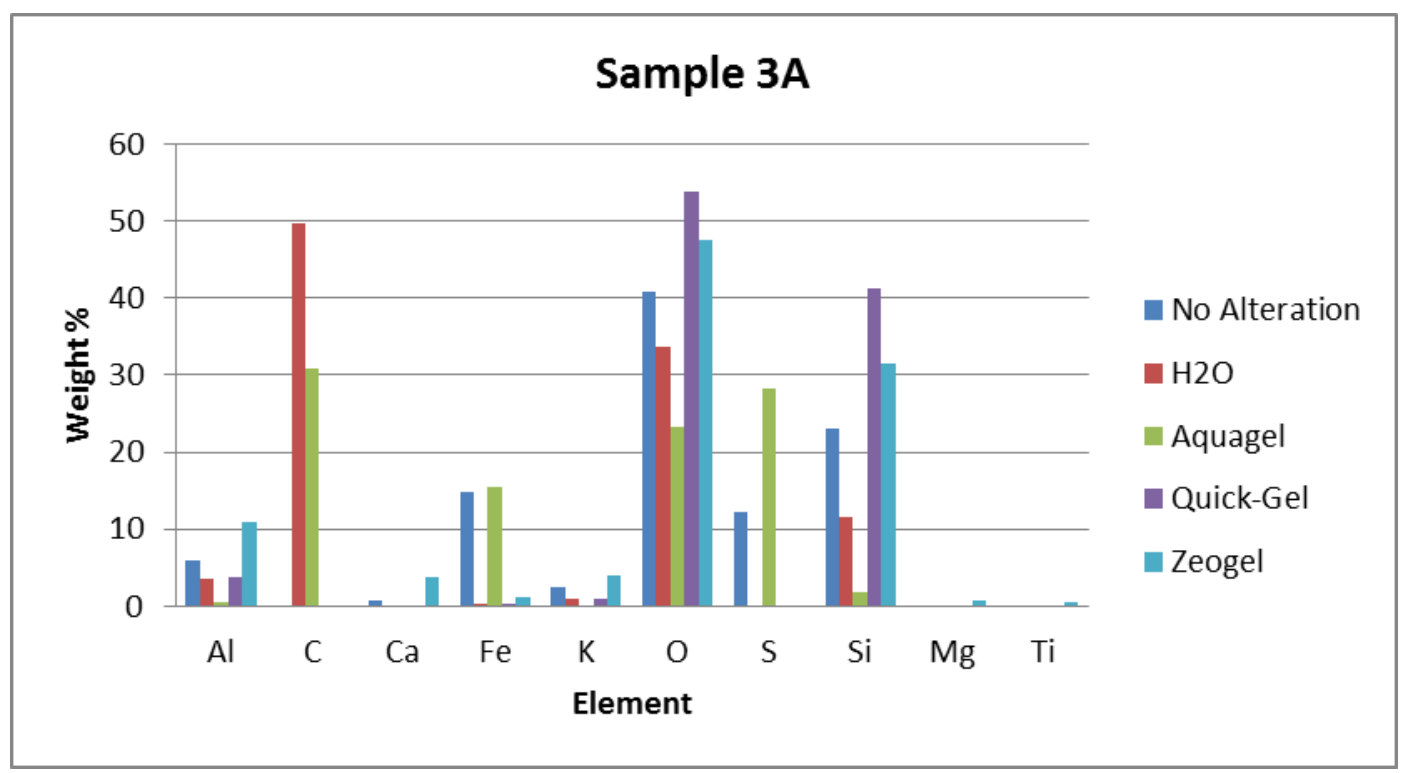

Figure A-3 Elemental weight percent values found in the Monongalia County Well A specimens from the third depth interval

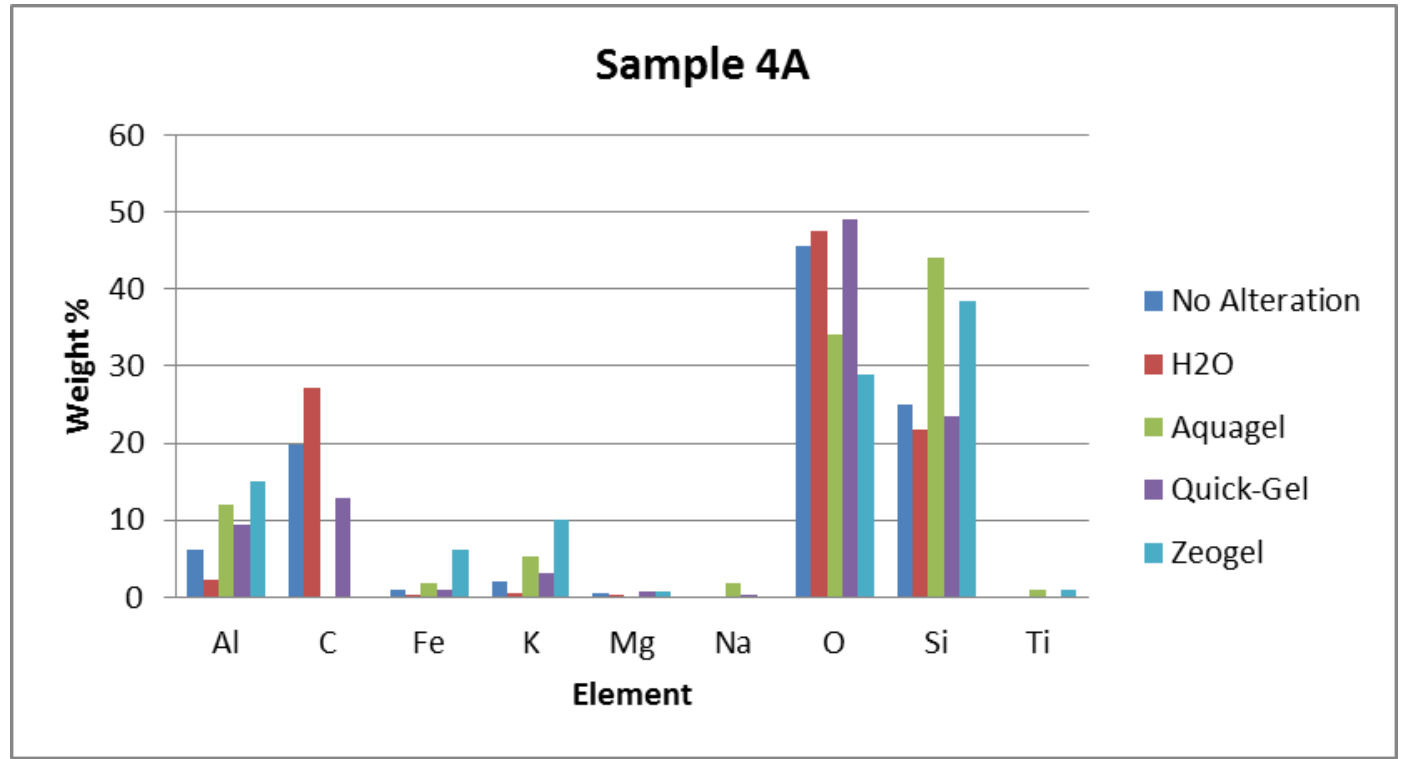

Figure A-4 Elemental weight percent values found in the Monongalia County Well A specimens from the fourth depth interval 


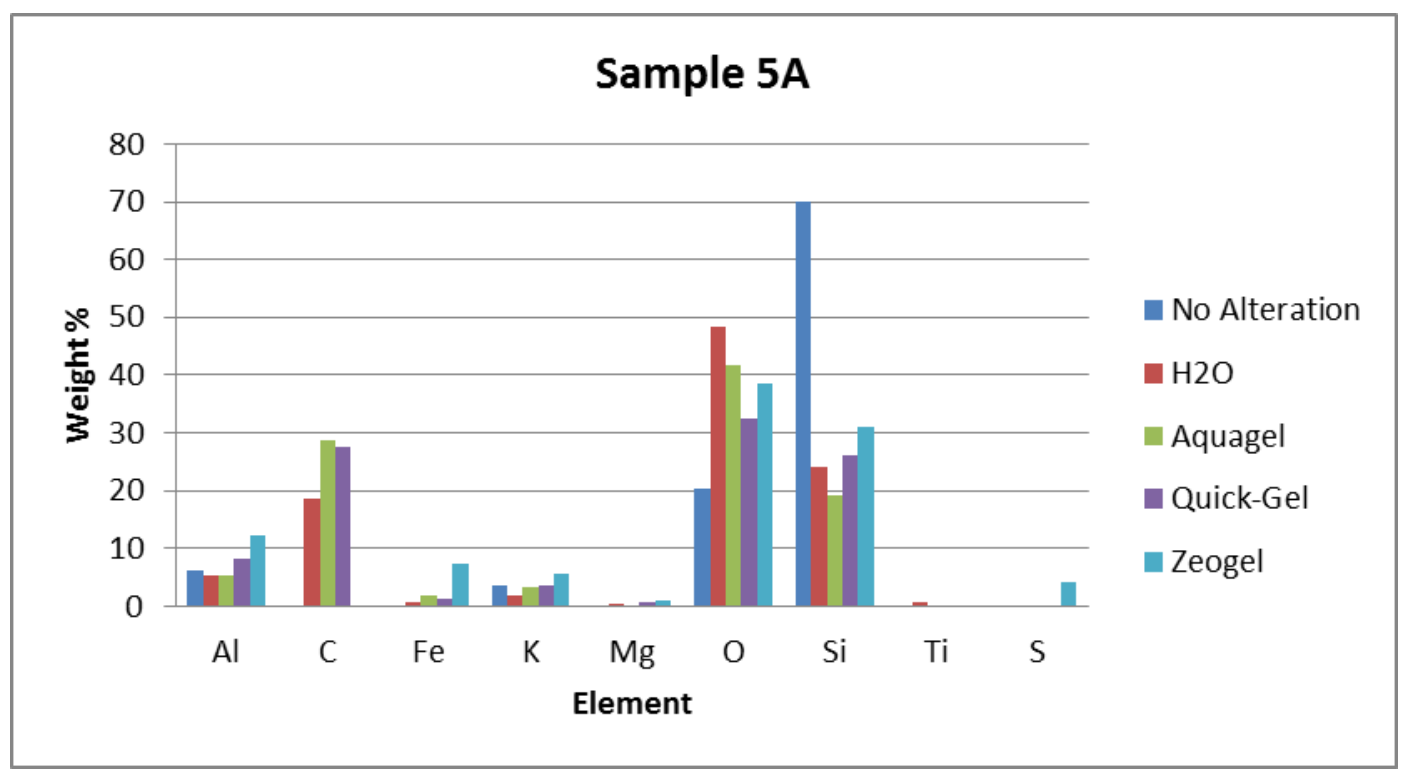

Figure A-5 Elemental weight percent values found in the Monongalia County Well A specimens from the fifth depth interval

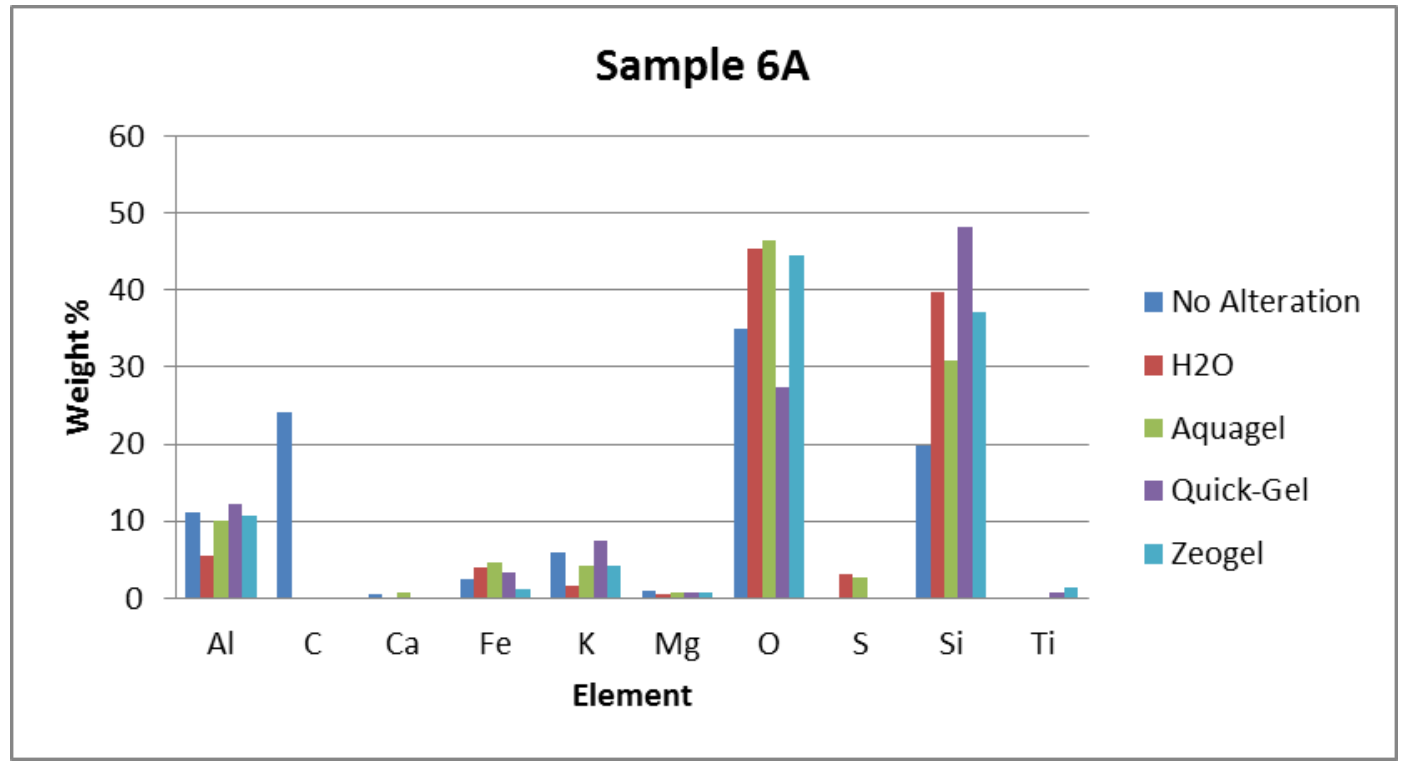

Figure A-6 Elemental weight percent values found in the Monongalia County Well A specimens from the sixth depth interval 


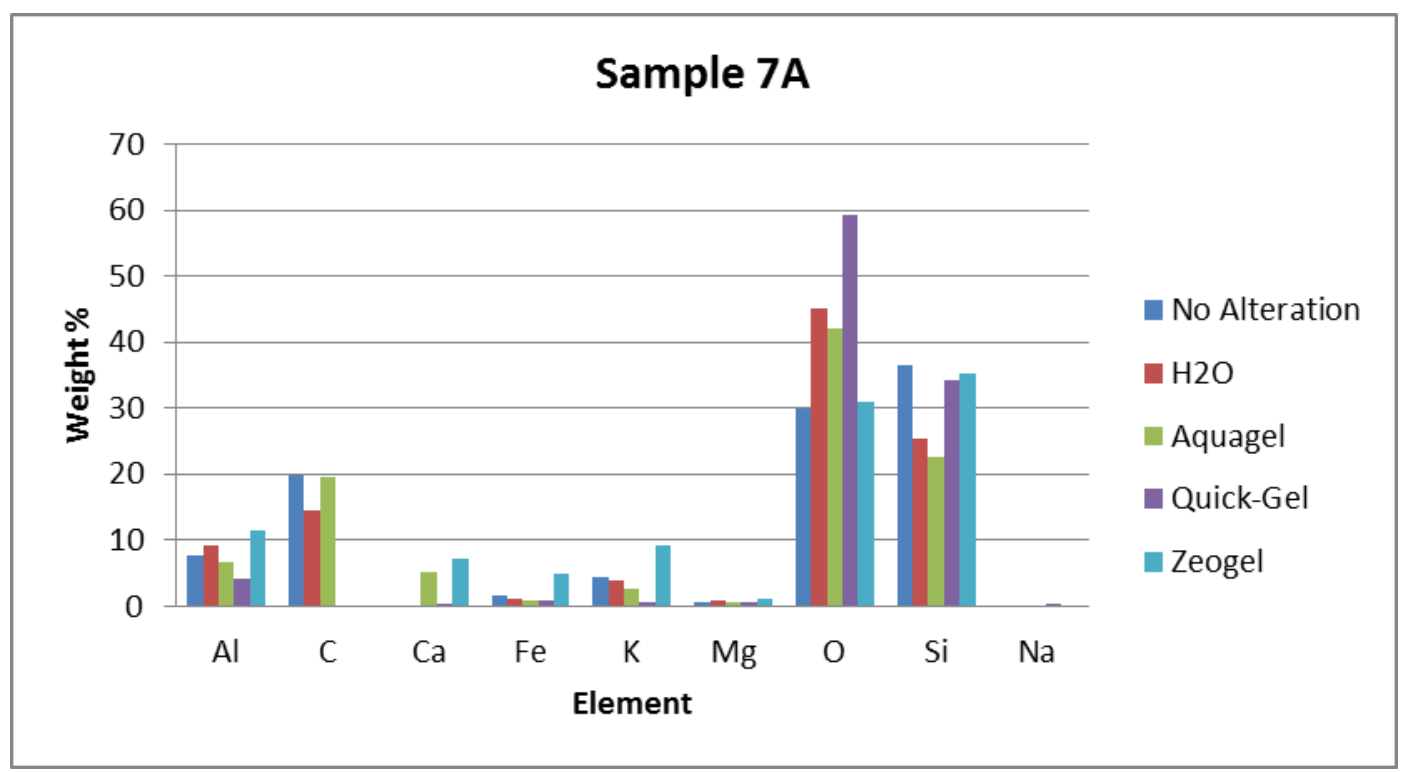

Figure A-7 Elemental weight percent values found in the Monongalia County Well A specimens from the seventh depth interval

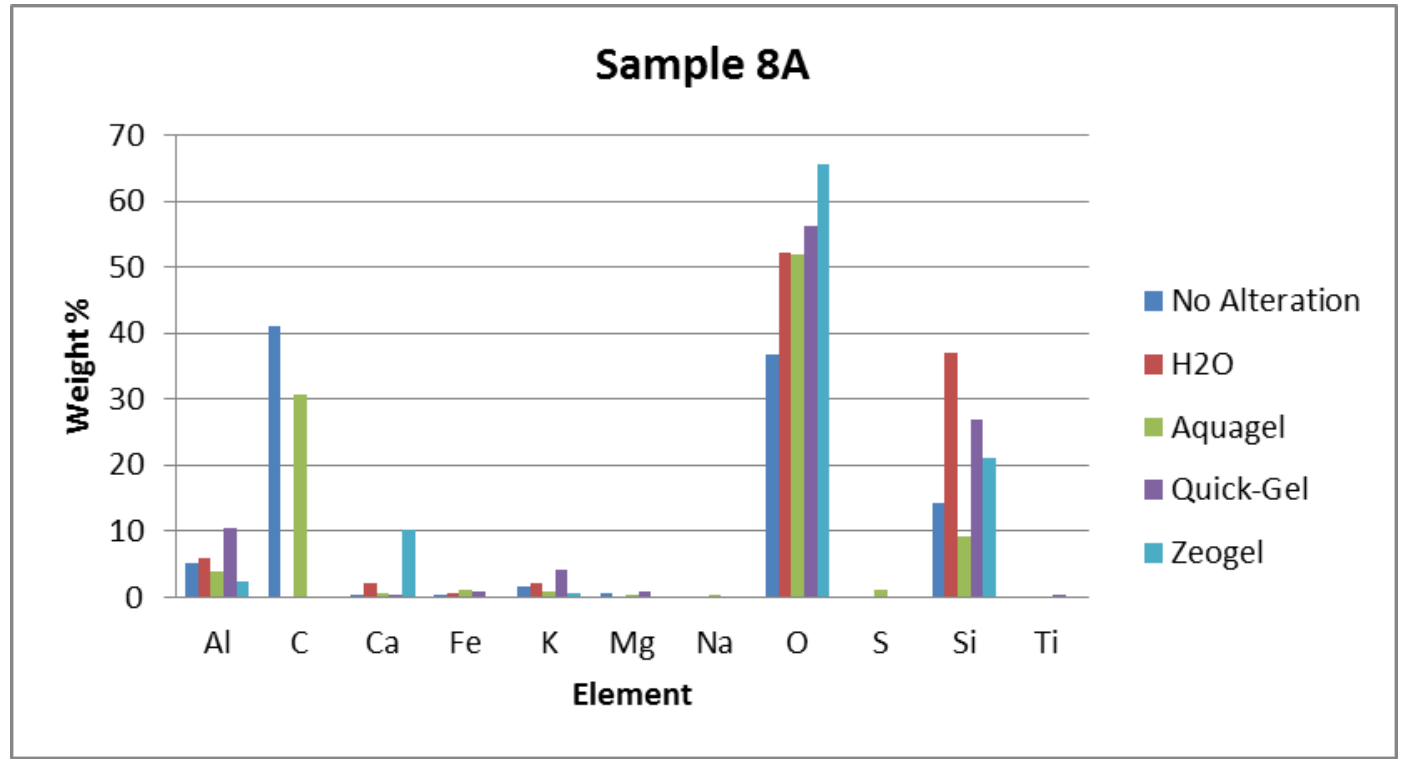

Figure A-8 Elemental weight percent values found in the Monongalia County Well A specimens from the eighth depth interval 


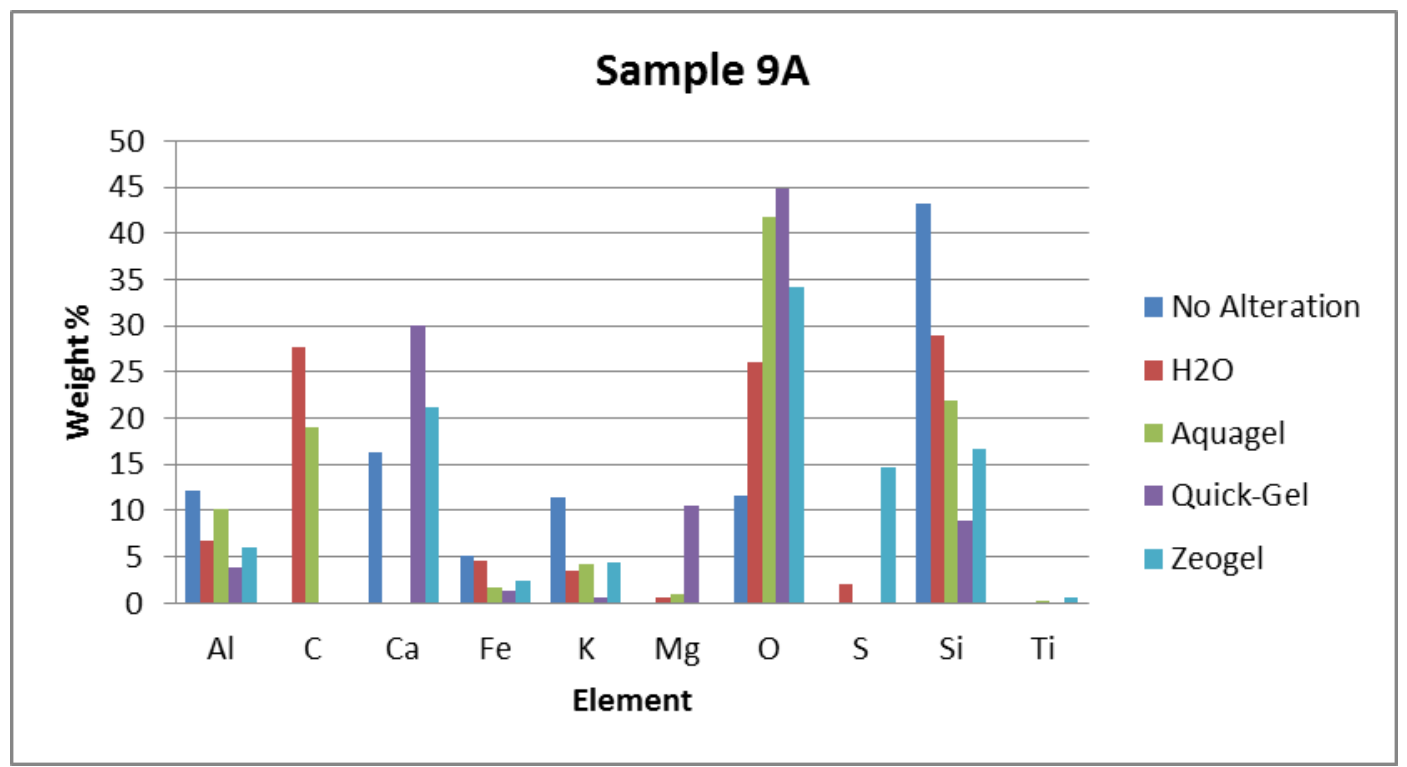

Figure A-9 Elemental weight percent values found in the Monongalia County Well A specimens from the ninth depth interval 


\section{Wetzel County Well B}

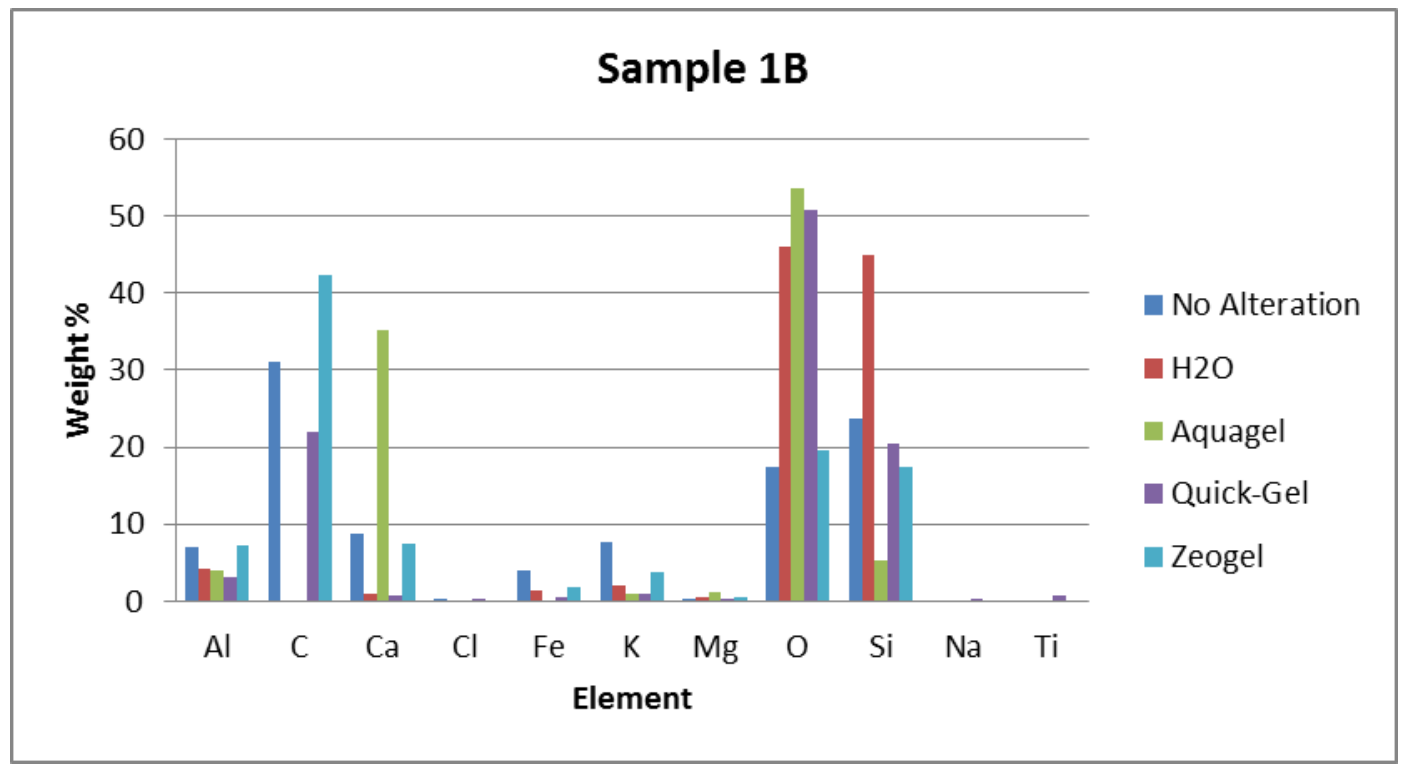

Figure A-10 Elemental weight percent values found in the Wetzel County Well B specimens from the first depth interval

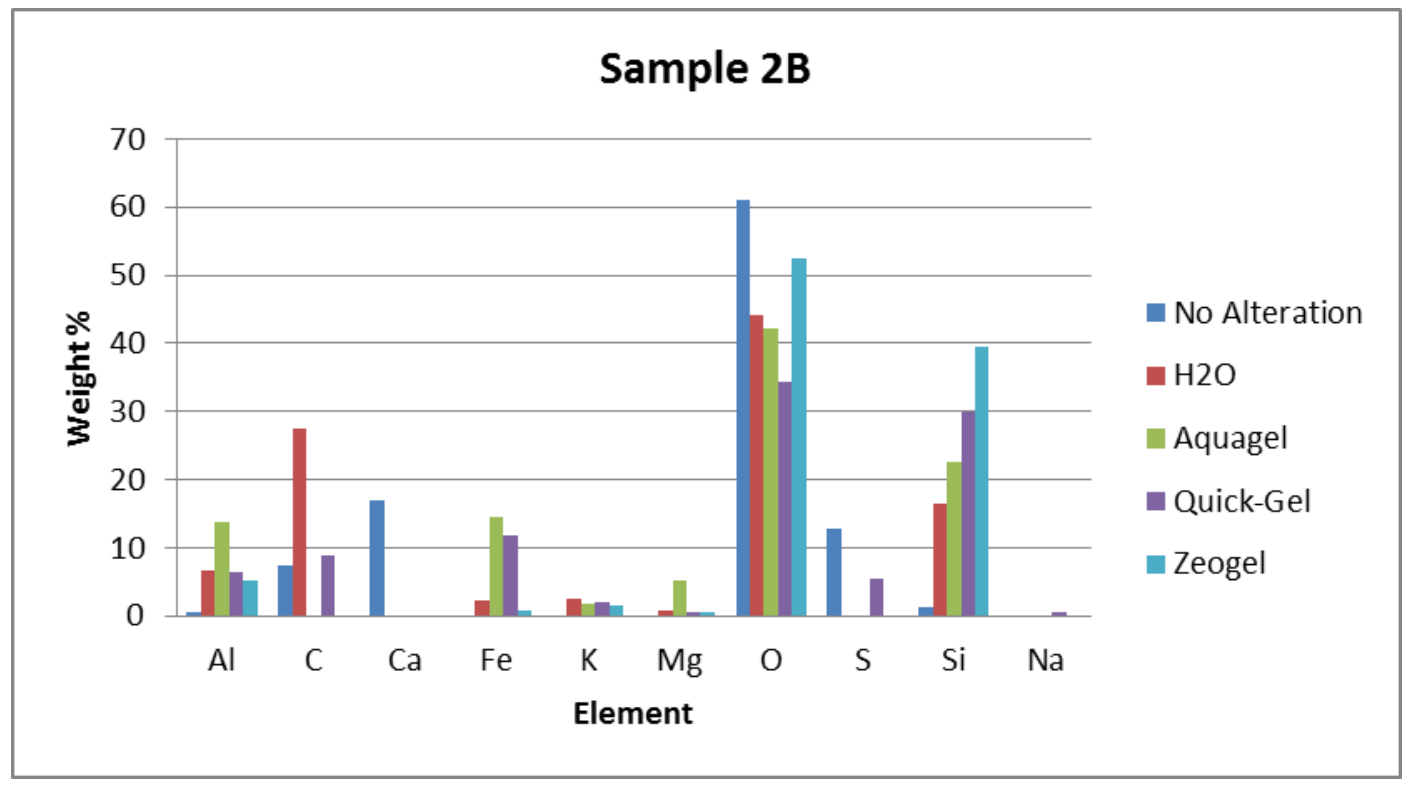

Figure A-11 Elemental weight percent values found in the Wetzel County Well B specimens from the second depth interval 


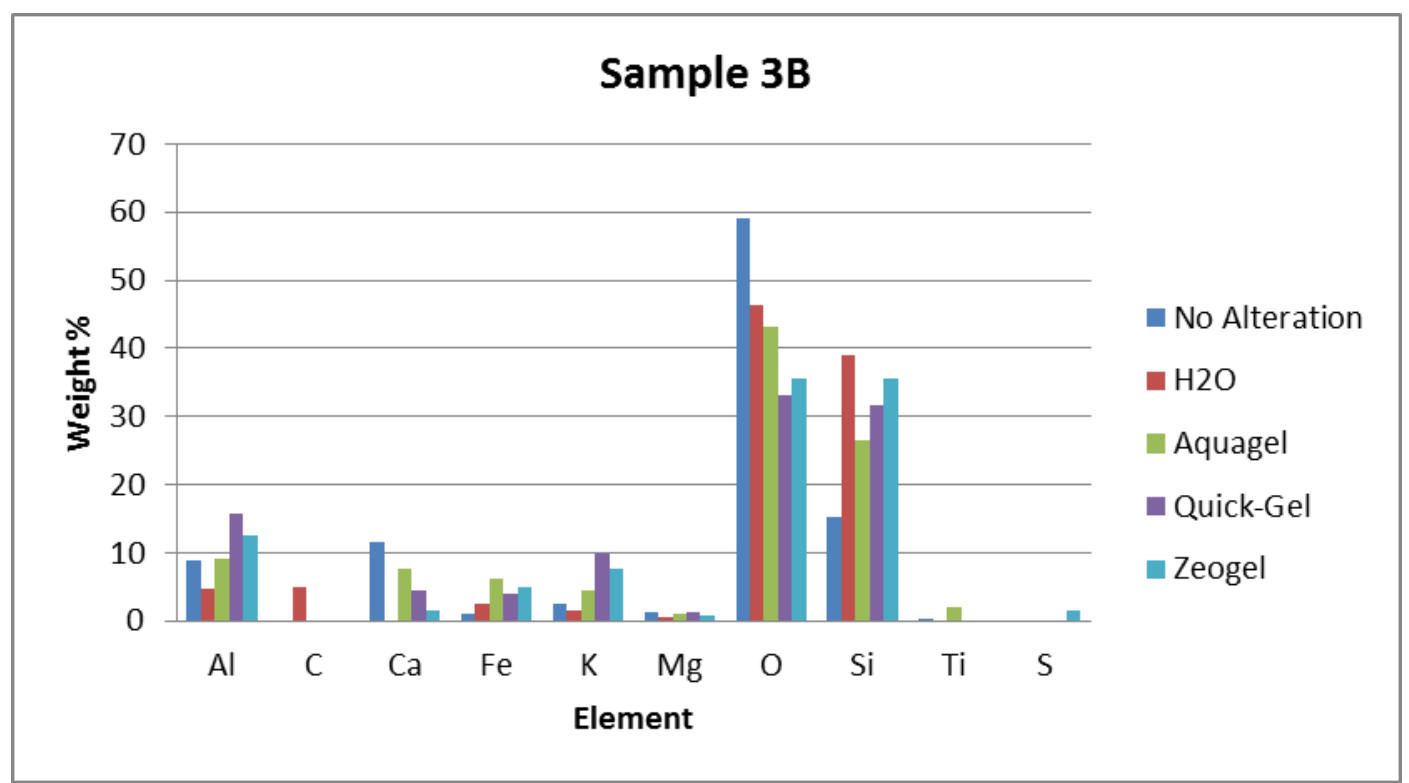

Figure A-12 Elemental weight percent values found in the Wetzel County Well B specimens from the third depth interval

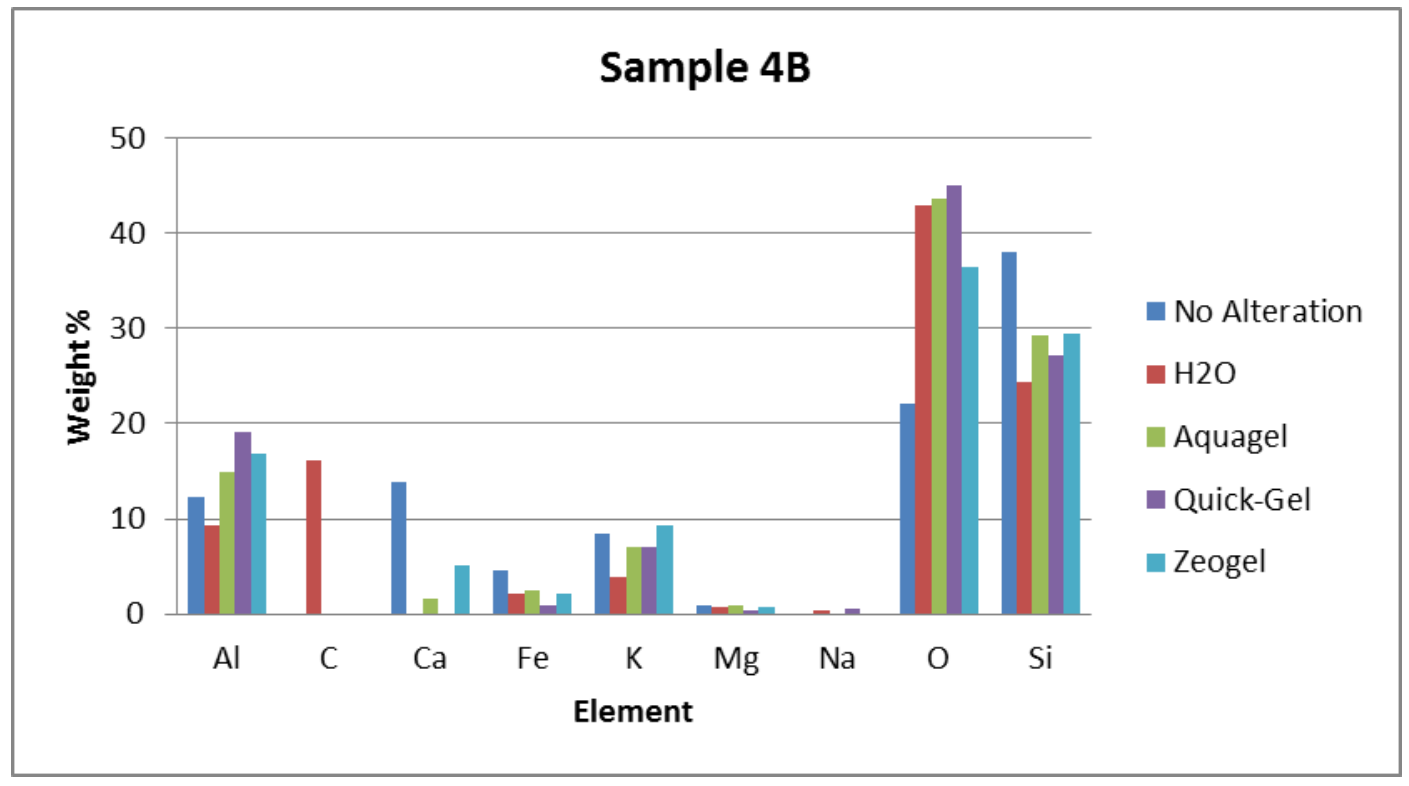

Figure A-13 Elemental weight percent values found in the Wetzel County Well B specimens from the fourth depth interval 


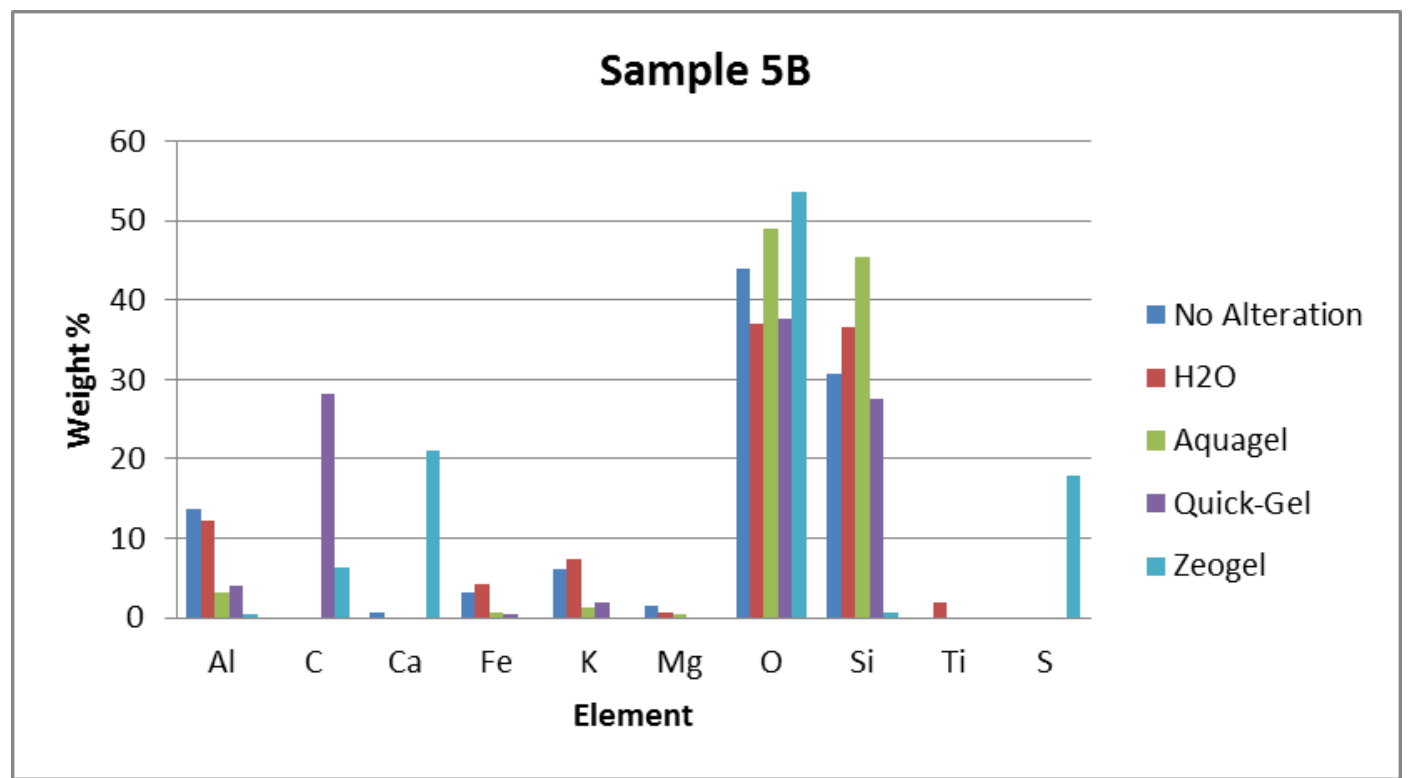

Figure A-14 Elemental weight percent values found in the Wetzel County Well B specimens from the fifth depth interval 
Appendix B - Elemental Composition Per Individual Sample 


\section{Monongalia County Well (First Depth Interval)}

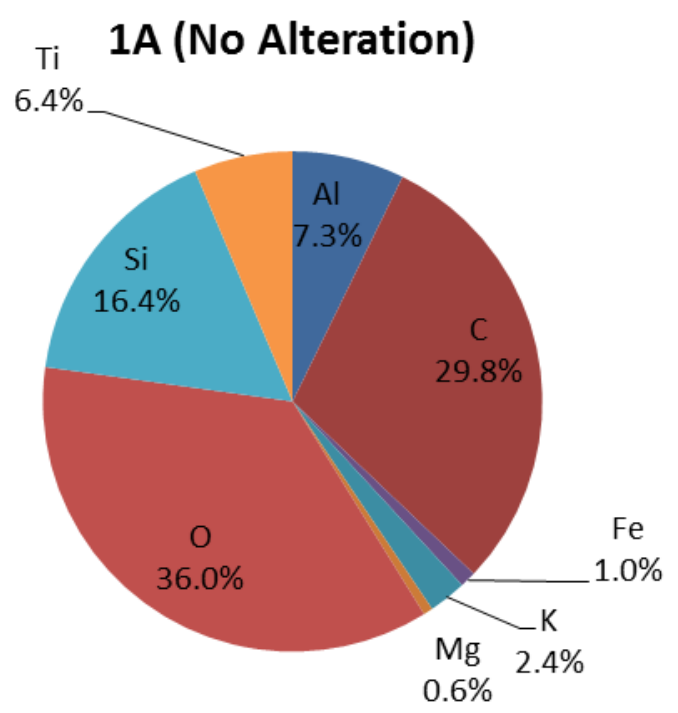

Figure B.1 Elemental composition of the control sample for the first depth interval of Well A

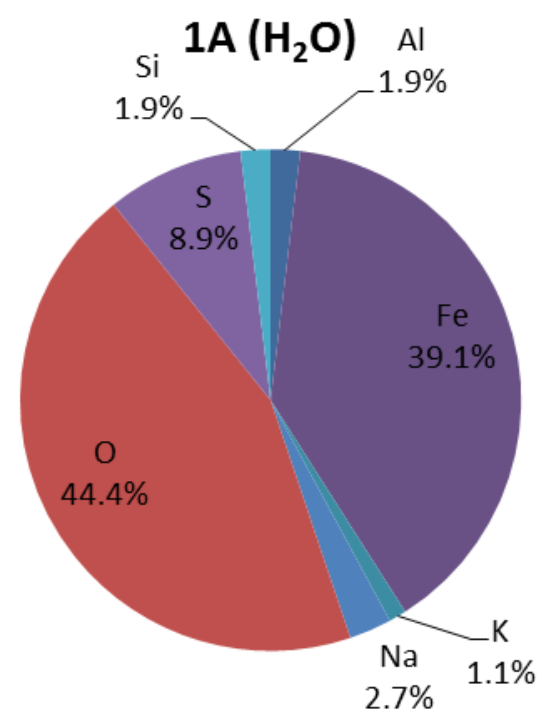

Figure B.2 Elemental composition of the water treatment sample for the first depth interval of Well A 


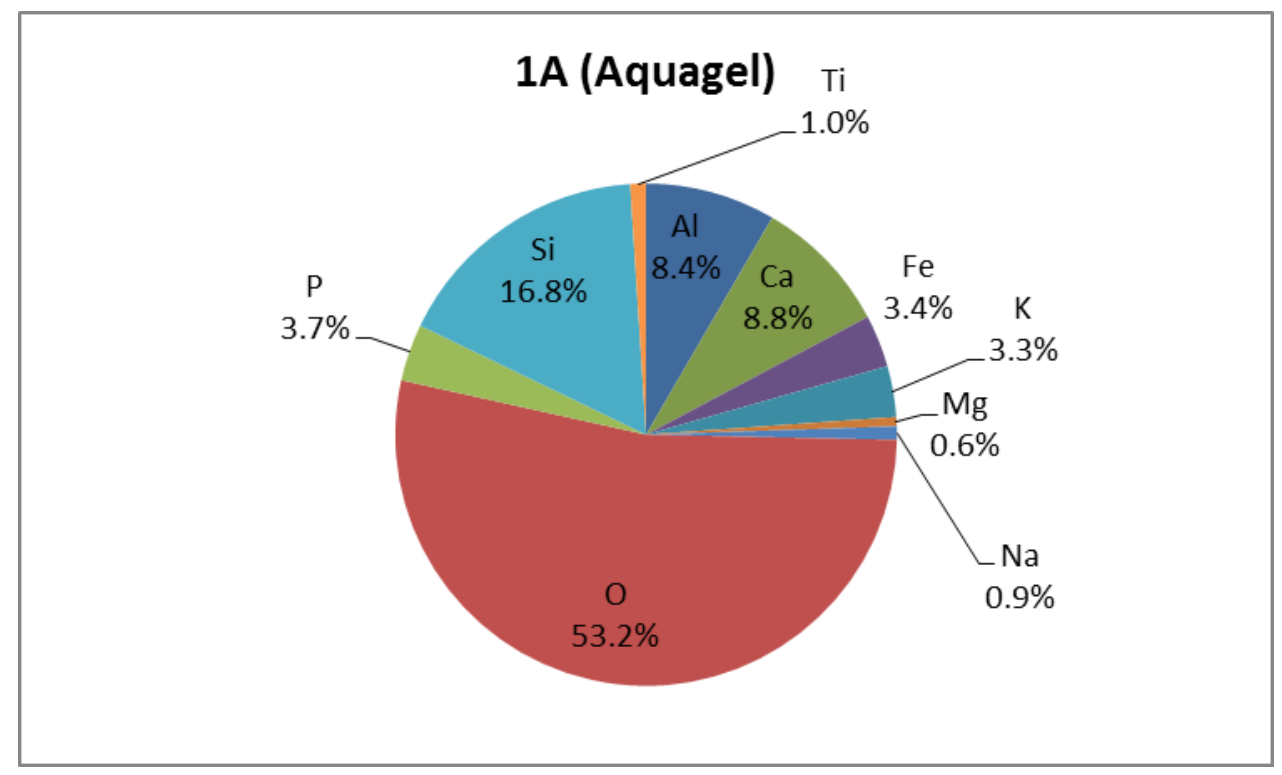

Figure B.3 Elemental composition of the Aquagel ${ }^{\circledR}$ treatment sample for the first depth interval of Well A

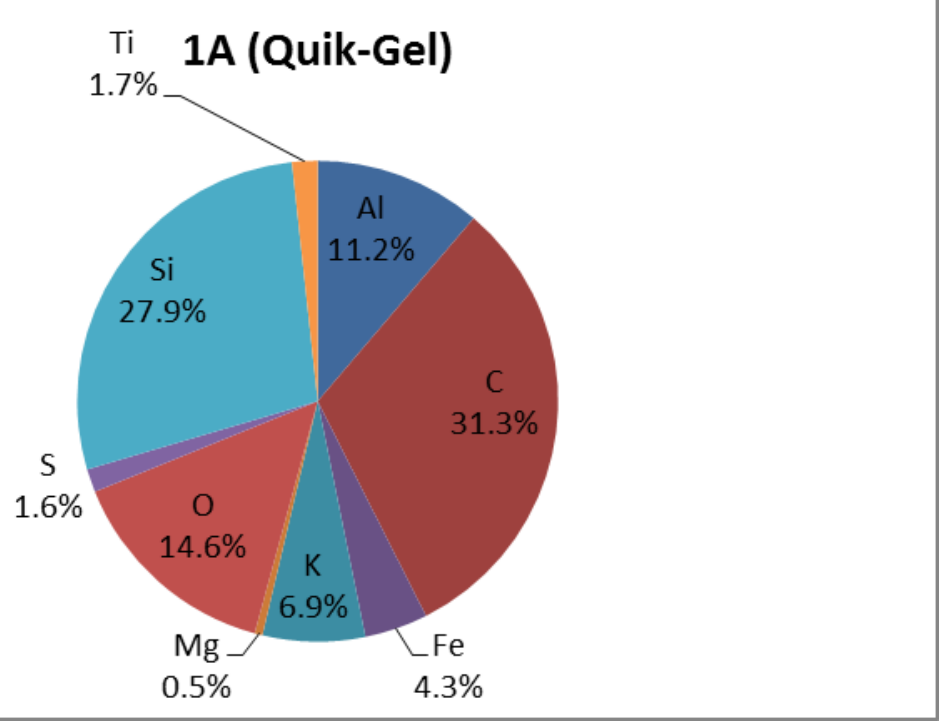

Figure B.4 Elemental composition of the Quik-Gel® treatment sample for the first depth interval of Well A 


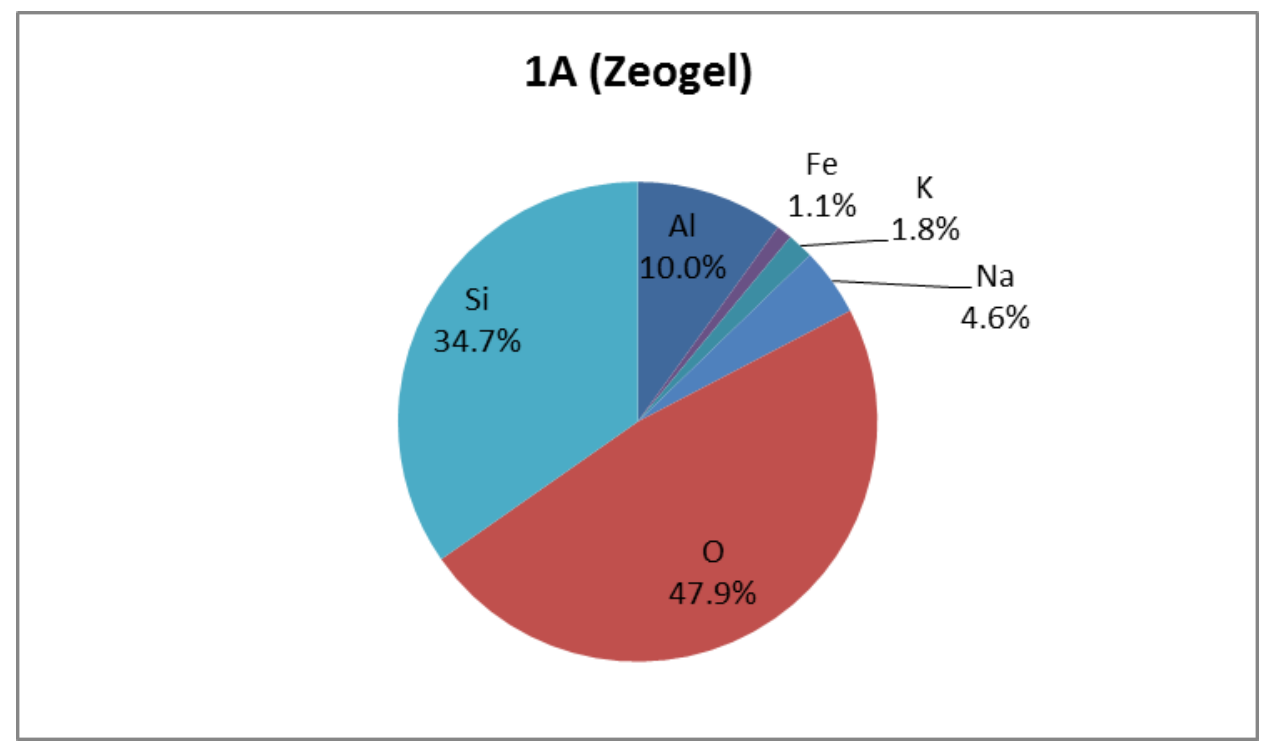

Figure B.5 Elemental composition of the Zeogel® treatment sample for the first depth interval of Well A 


\section{Monongalia County Well (Second Depth Interval)}

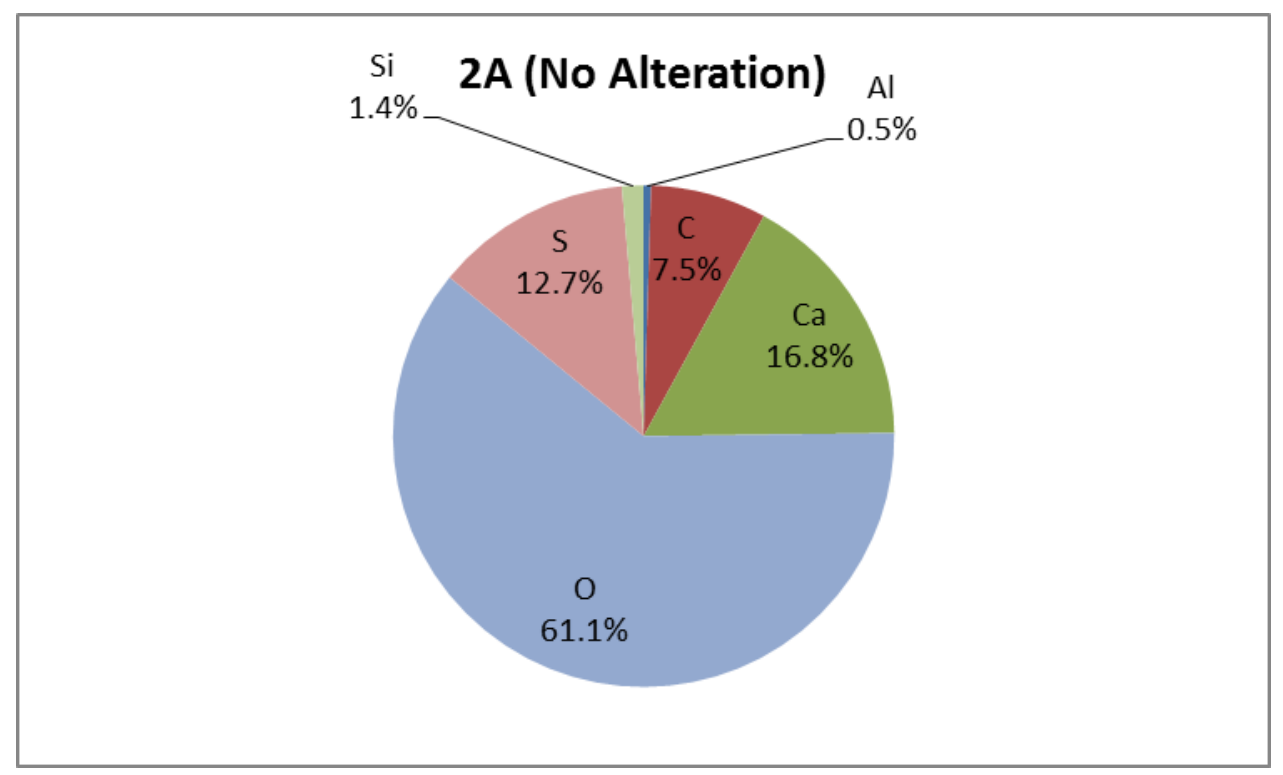

Figure B.6 Elemental composition of the control sample for the second depth interval of Well A

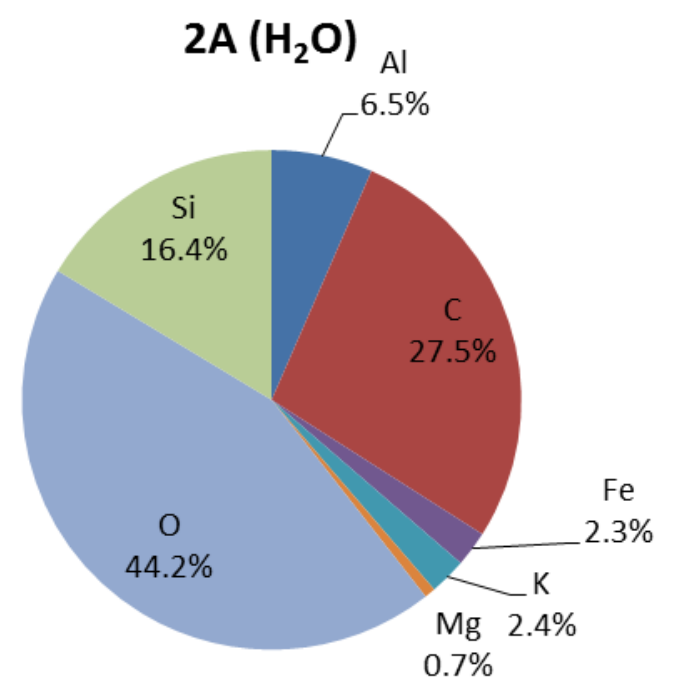

Figure B.7 Elemental composition of the water treatment sample for the second depth interval of Well A 


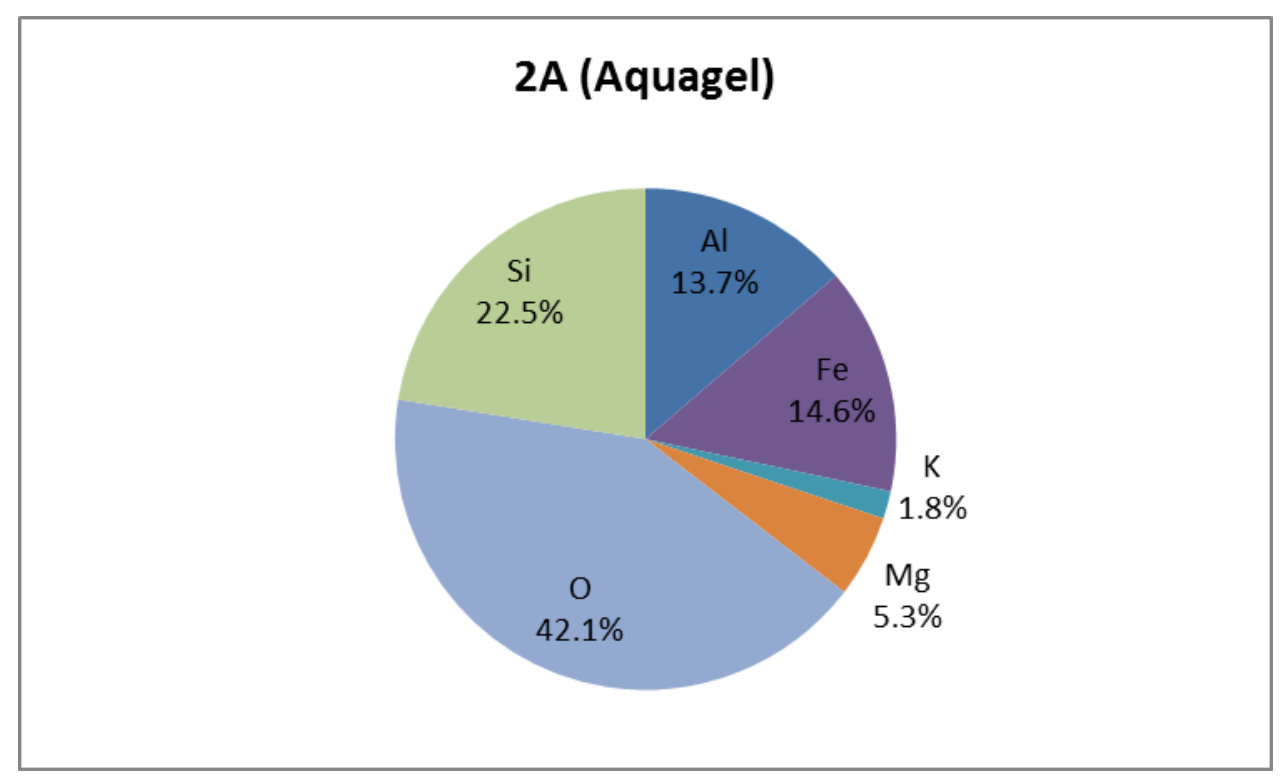

Figure B.8 Elemental composition of the Aquagel ${ }^{\circledR}$ treatment sample for the second depth interval of Well A

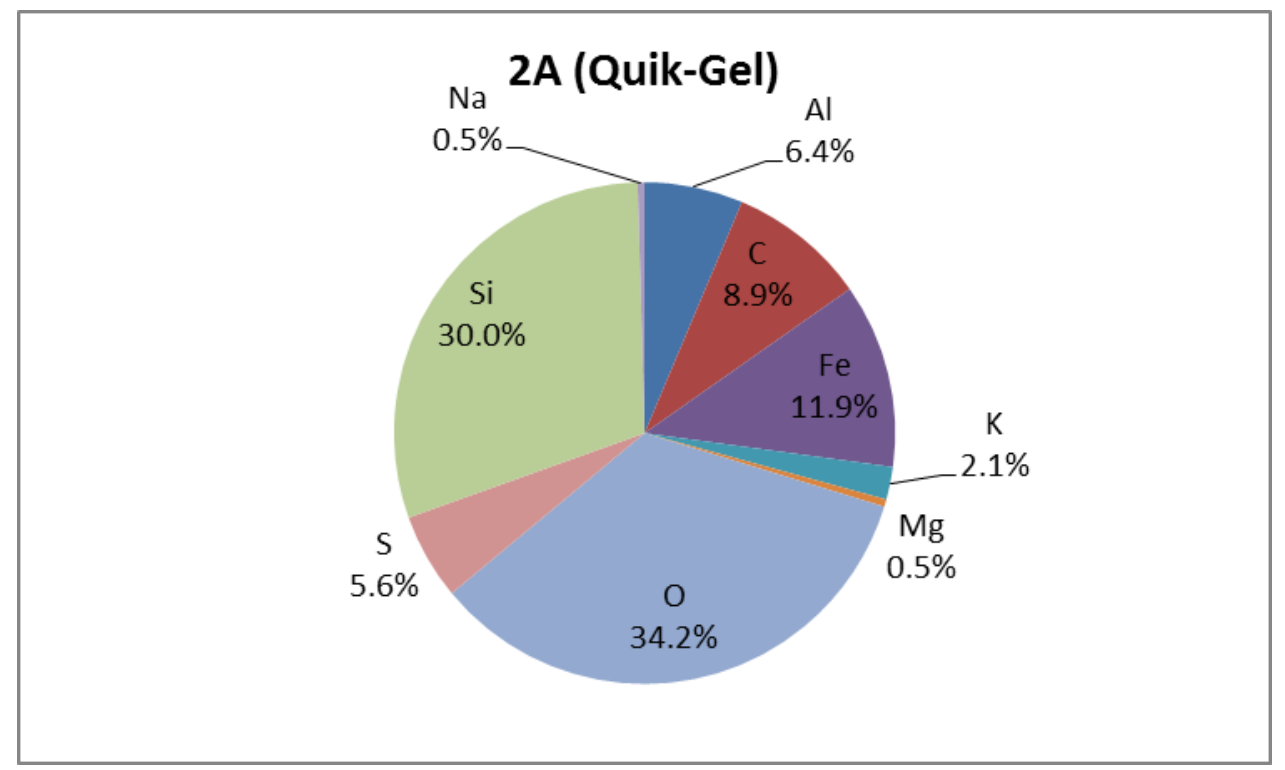

Figure B.9 Elemental composition of the Quik-Gel ${ }^{\circledR}$ treatment sample for the second depth interval of Well A 


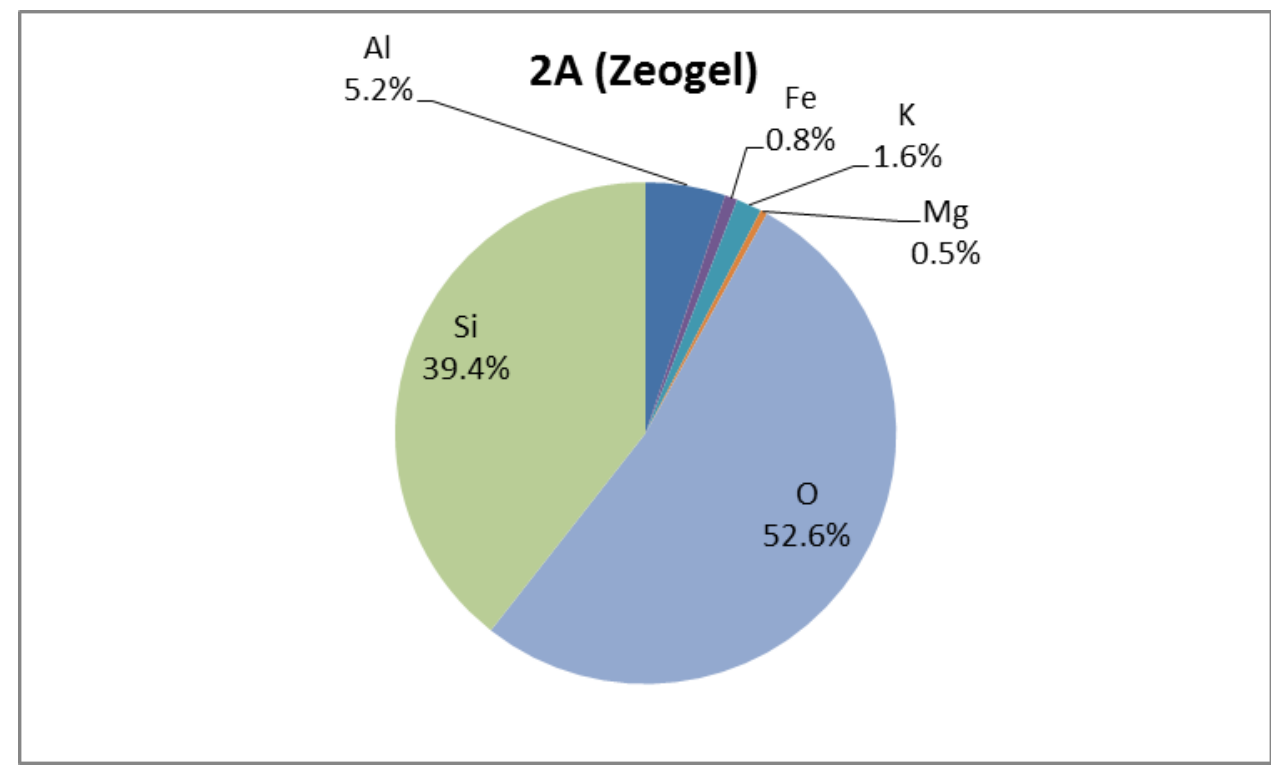

Figure B.10 Elemental composition of the Zeogel® treatment sample for the second depth interval of Well A 


\section{Monongalia County Well (Third Depth Interval)}

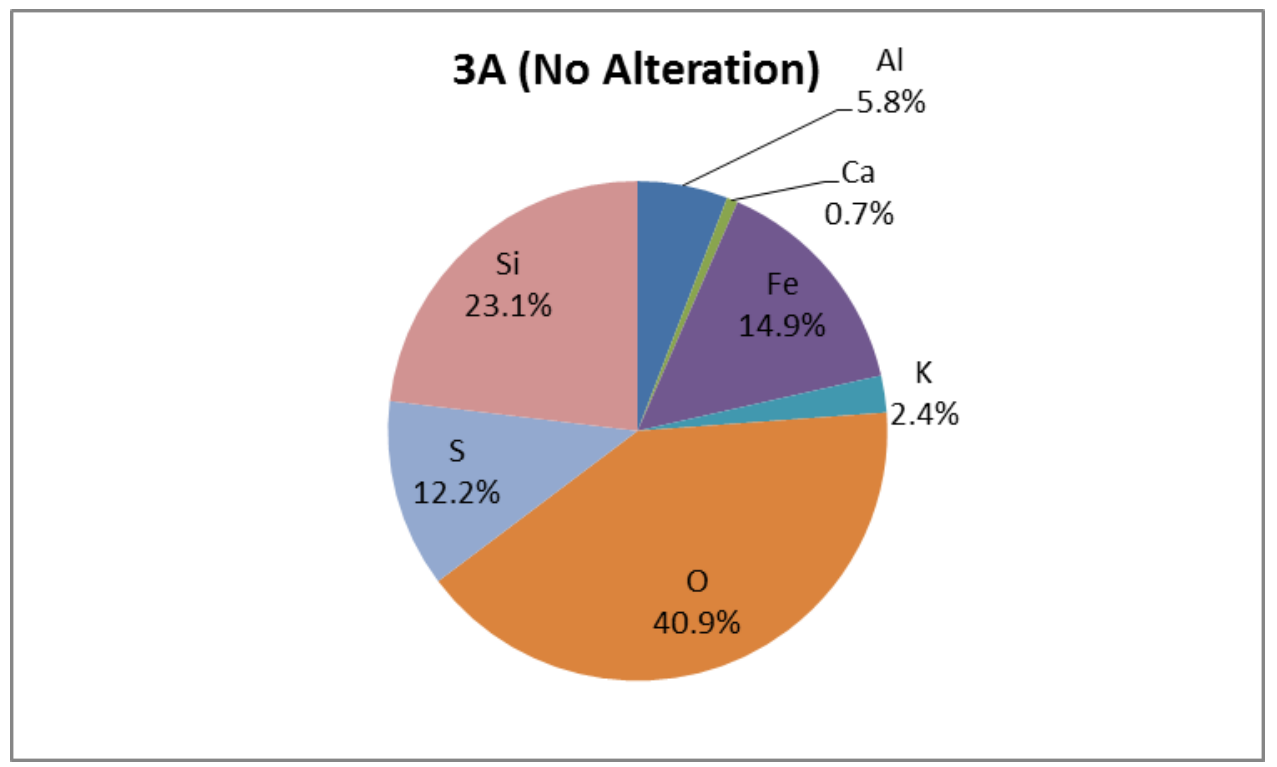

Figure B.11 Elemental composition of the control sample for the third depth interval of Well A

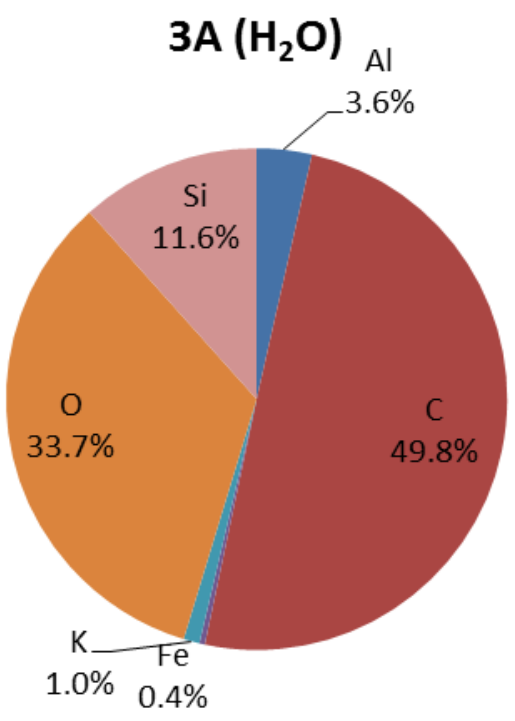

Figure B.12 Elemental composition of the water treatment sample for the third depth interval of Well A 


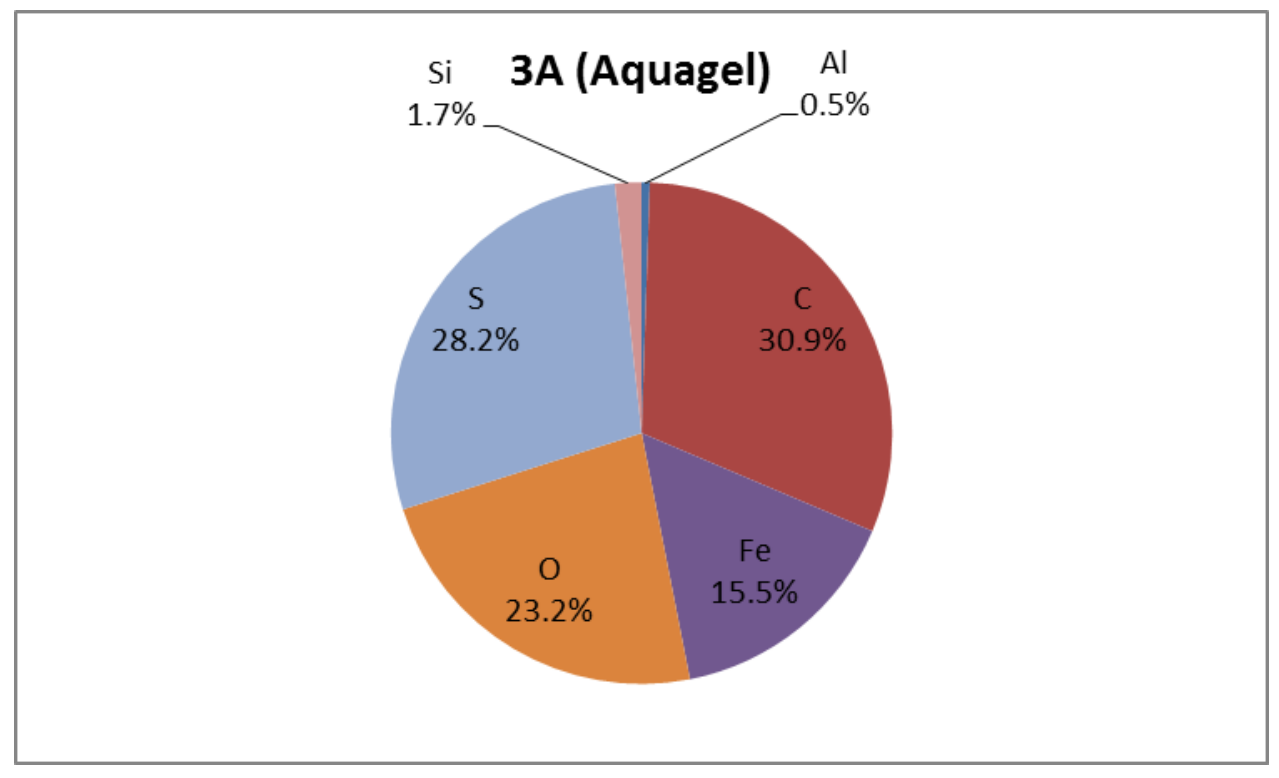

Figure B.13 Elemental composition of the Aquagel ${ }^{\circledR}$ treatment sample for the third depth interval of Well A

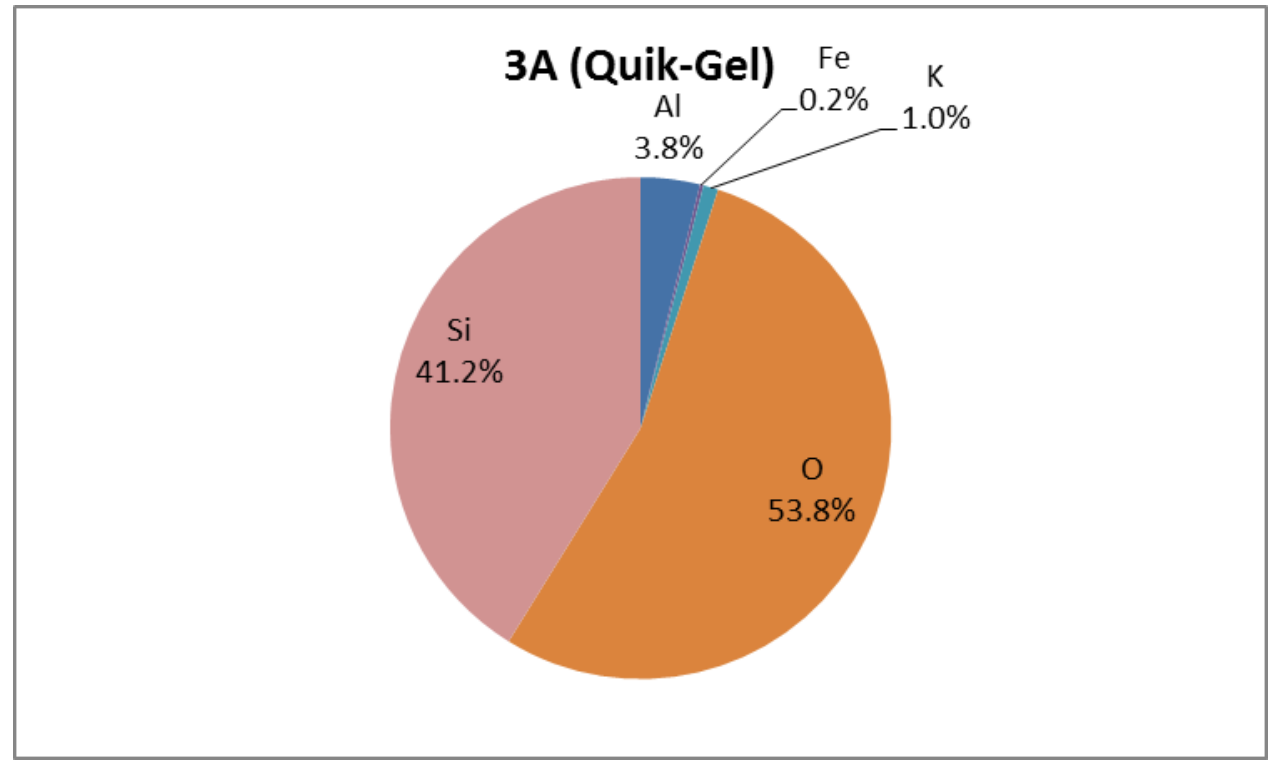

Figure B.14 Elemental composition of the Quik-Gel® treatment sample for the third depth interval of Well A 


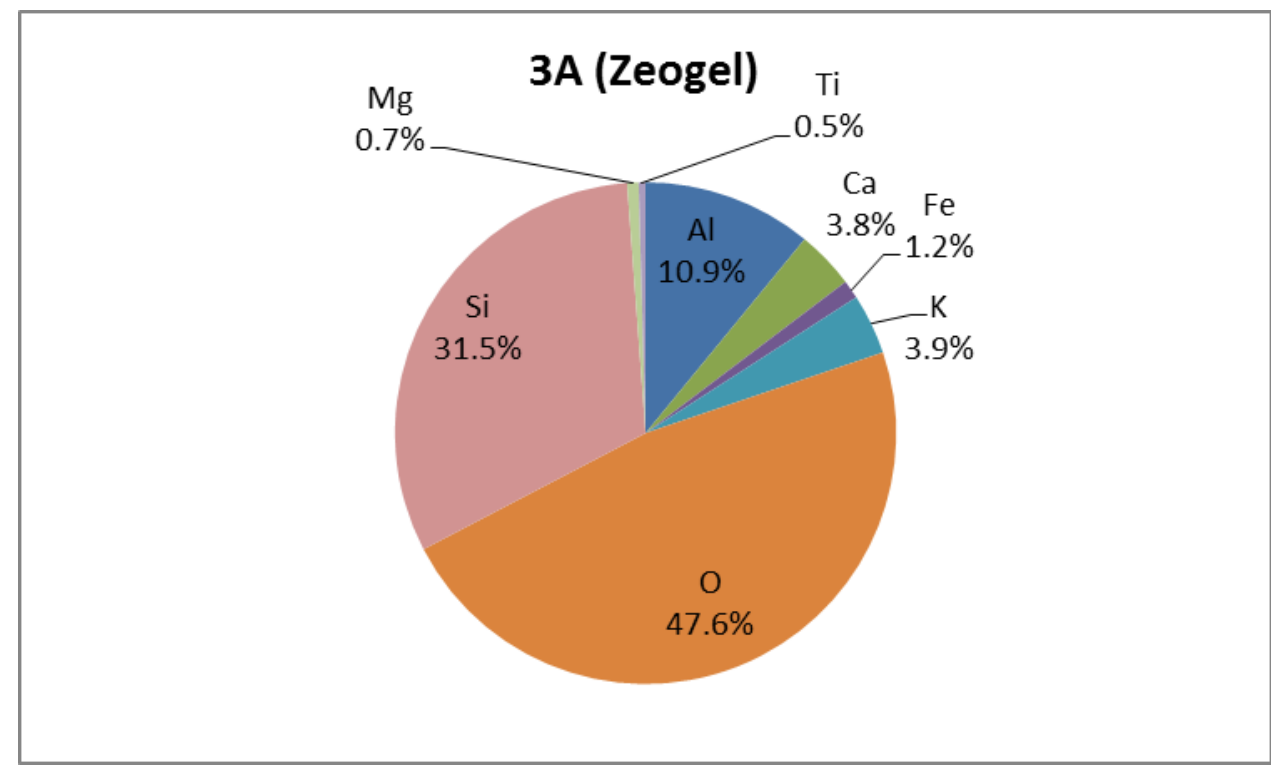

Figure B.15 Elemental composition of the Zeogel® treatment sample for the third depth interval of Well A 


\section{Monongalia County Well (Fourth Depth Interval)}

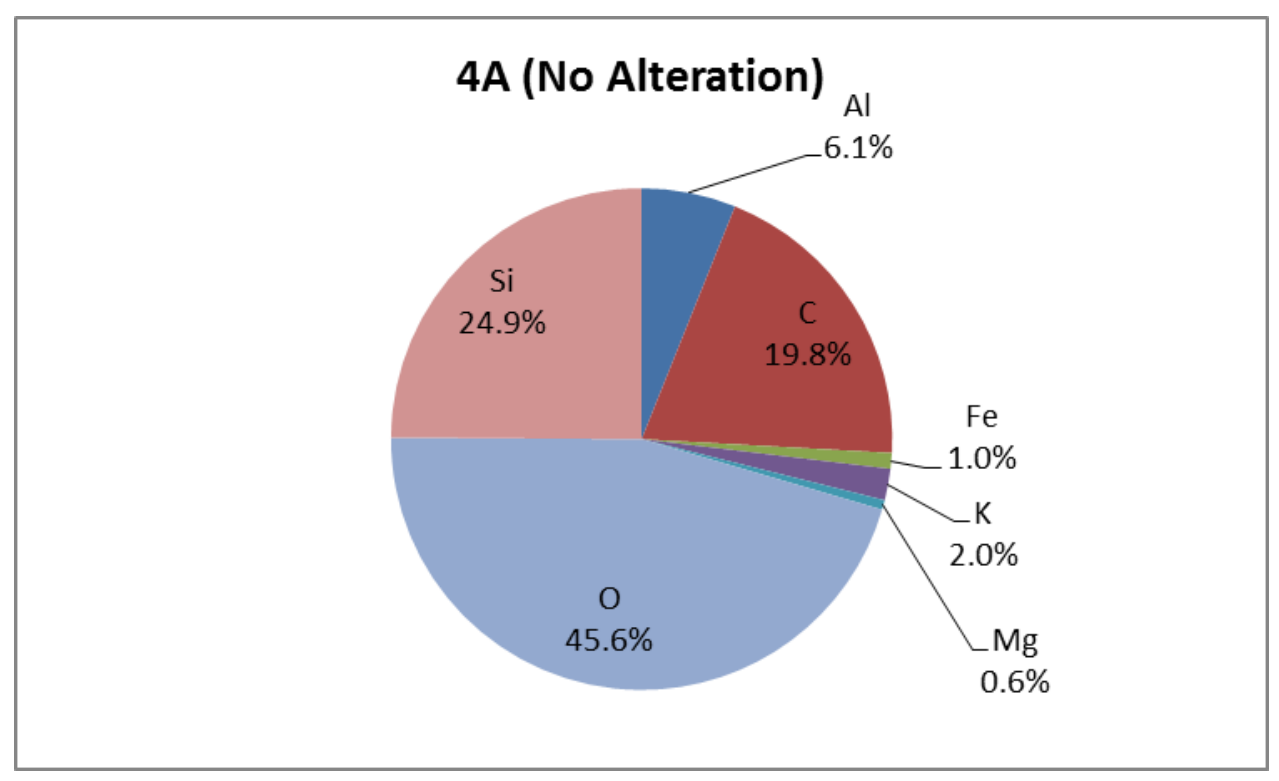

Figure B.16 Elemental composition of the control sample for the fourth depth interval of Well A

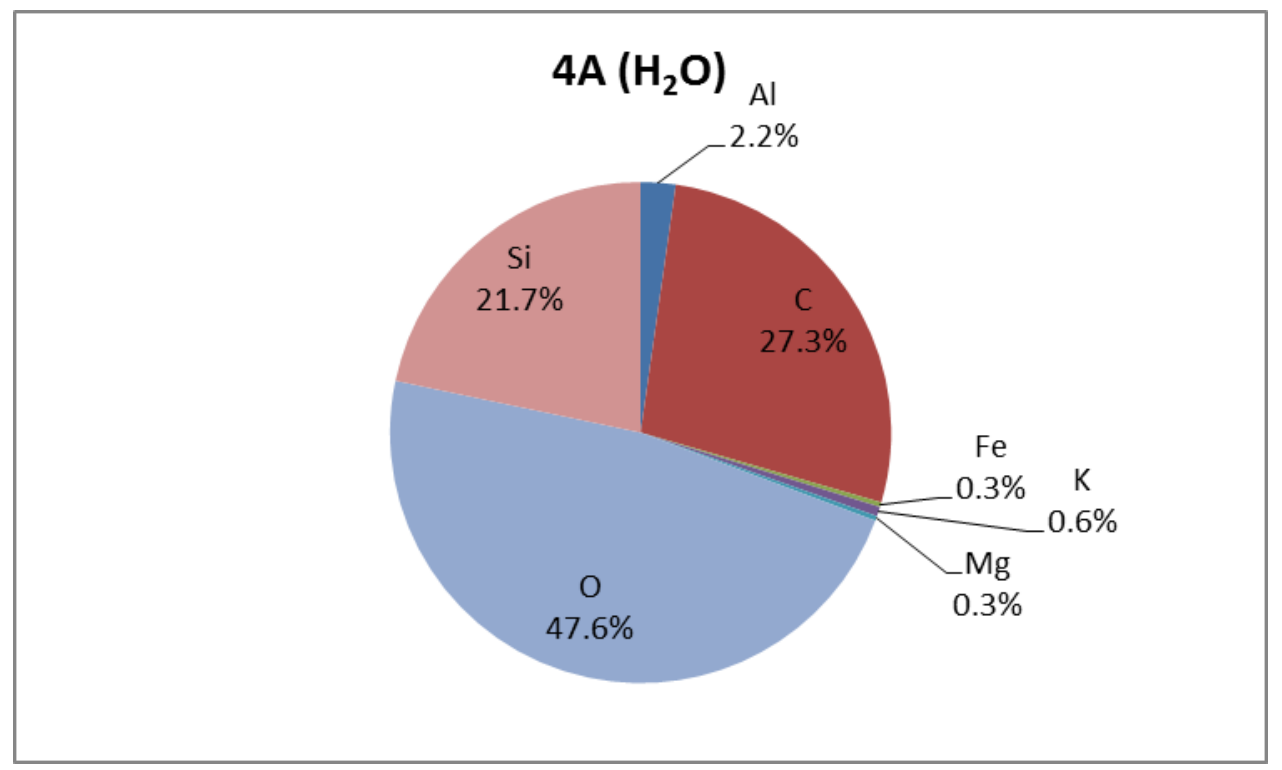

Figure B.17 Elemental composition of the water treatment sample for the fourth depth interval of Well A 


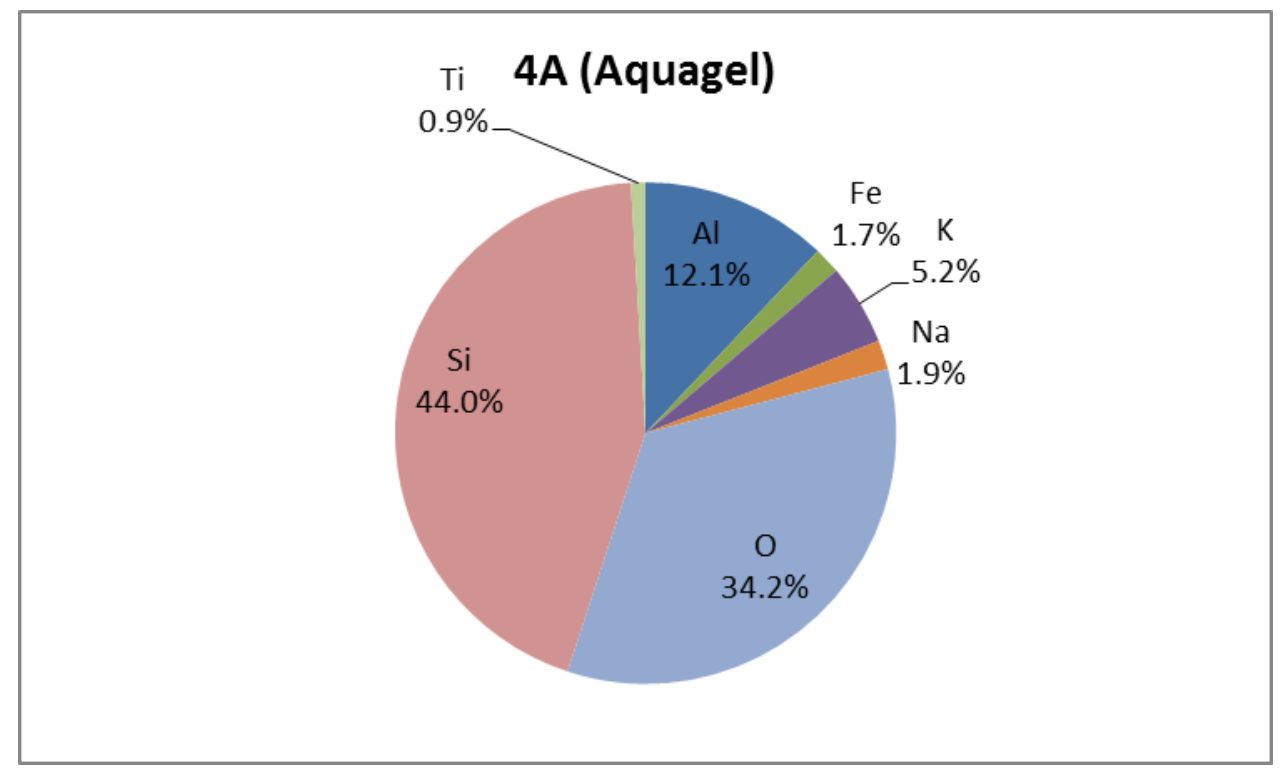

Figure B.18 Elemental composition of the Aquagel® treatment sample for the fourth depth interval of Well A

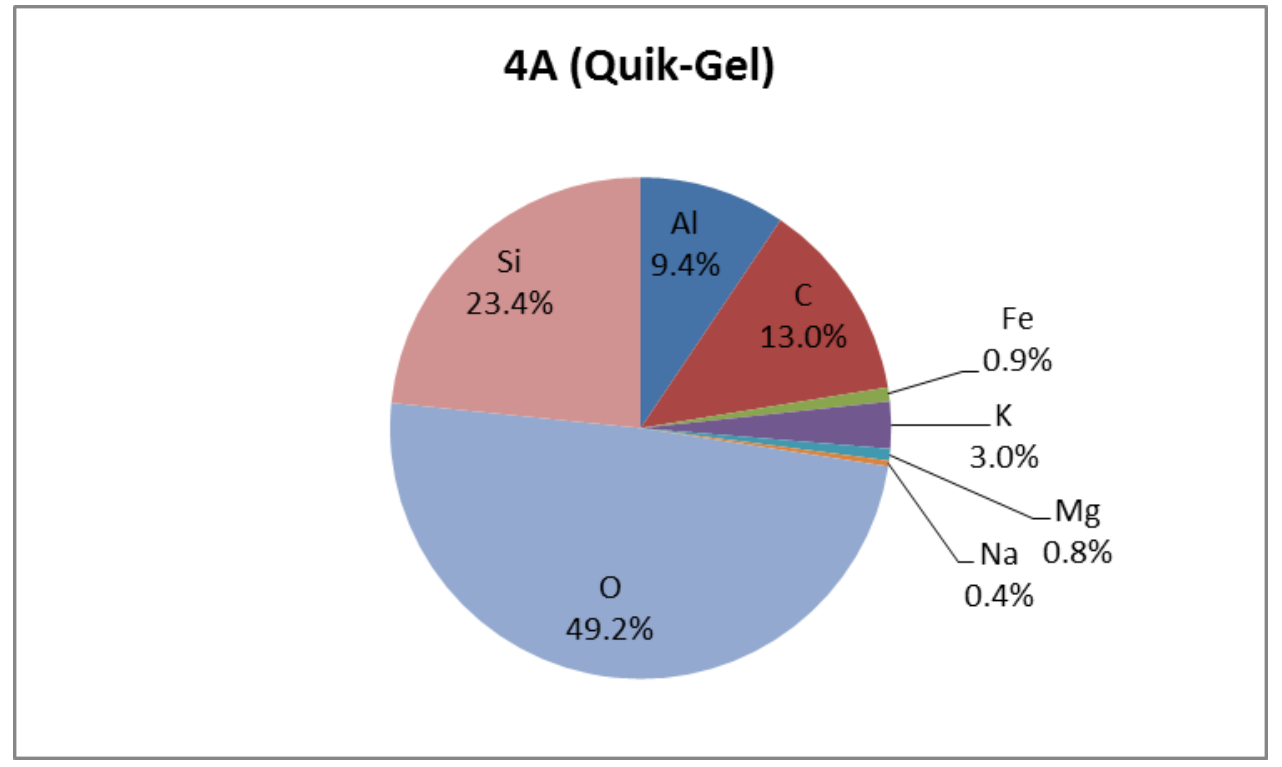

Figure B.19 Elemental composition of the Quik-Gel ${ }^{\circledR}$ treatment sample for the fourth depth interval of Well A 


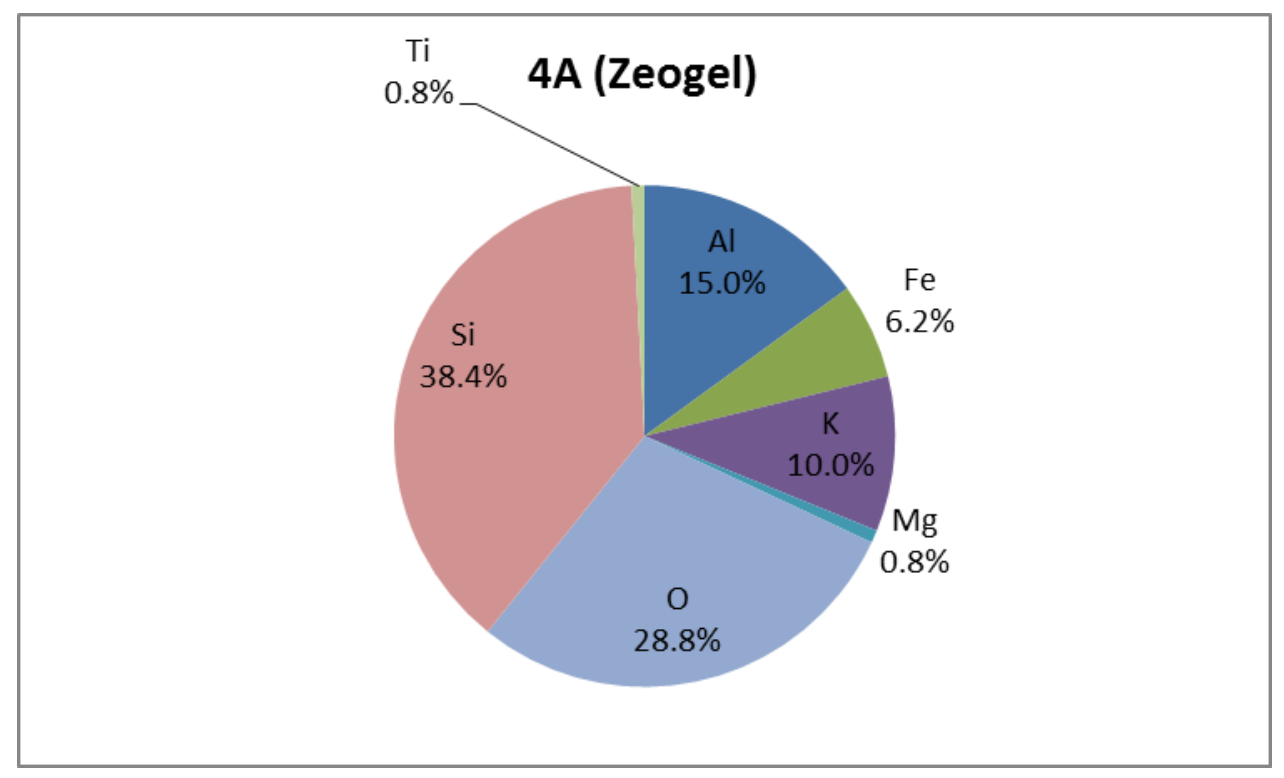

Figure B.20 Elemental composition of the Zeogel® treatment sample for the fourth depth interval of Well A 


\section{Monongalia County Well (Fifth Depth Interval)}

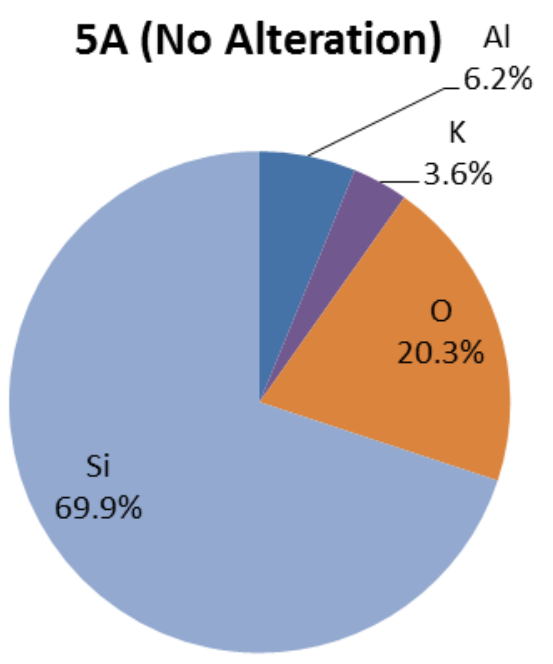

Figure B.21 Elemental composition of the control sample for the fifth depth interval of Well A

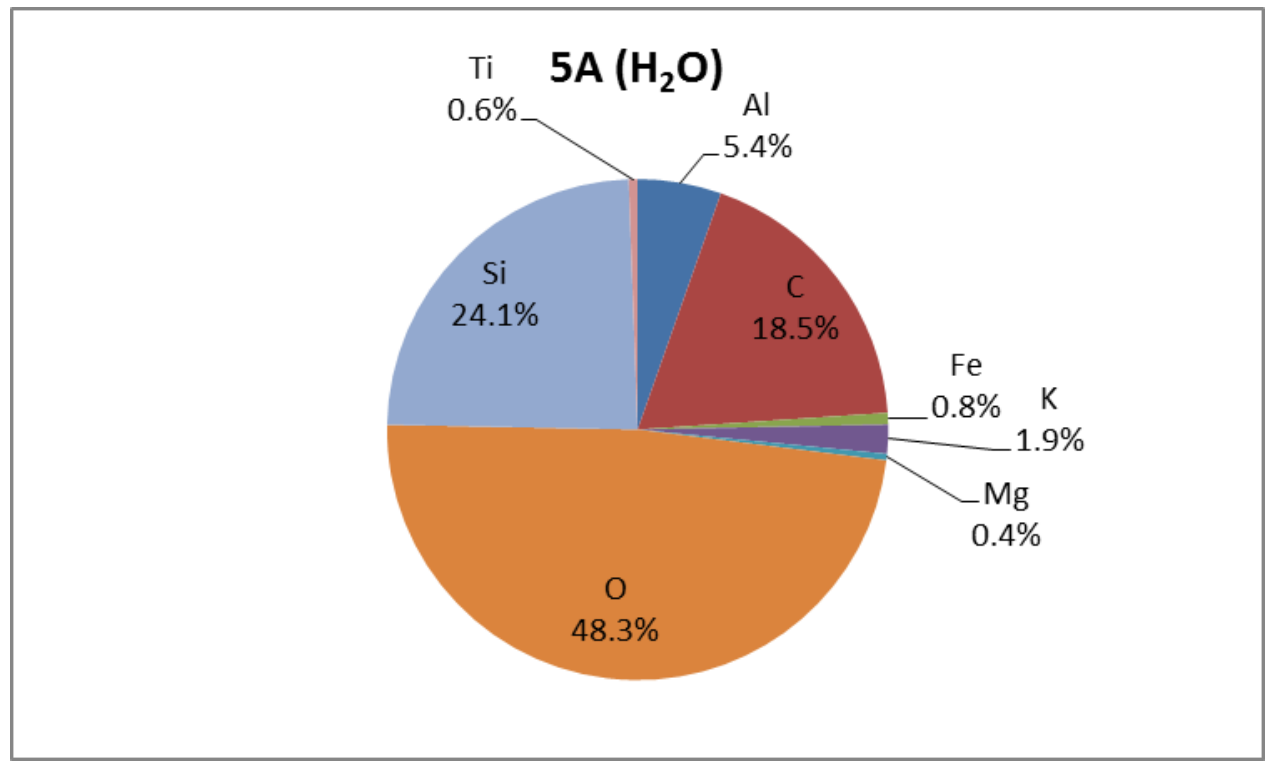

Figure B.22 Elemental composition of the water treatment sample for the fifth depth interval of Well A 


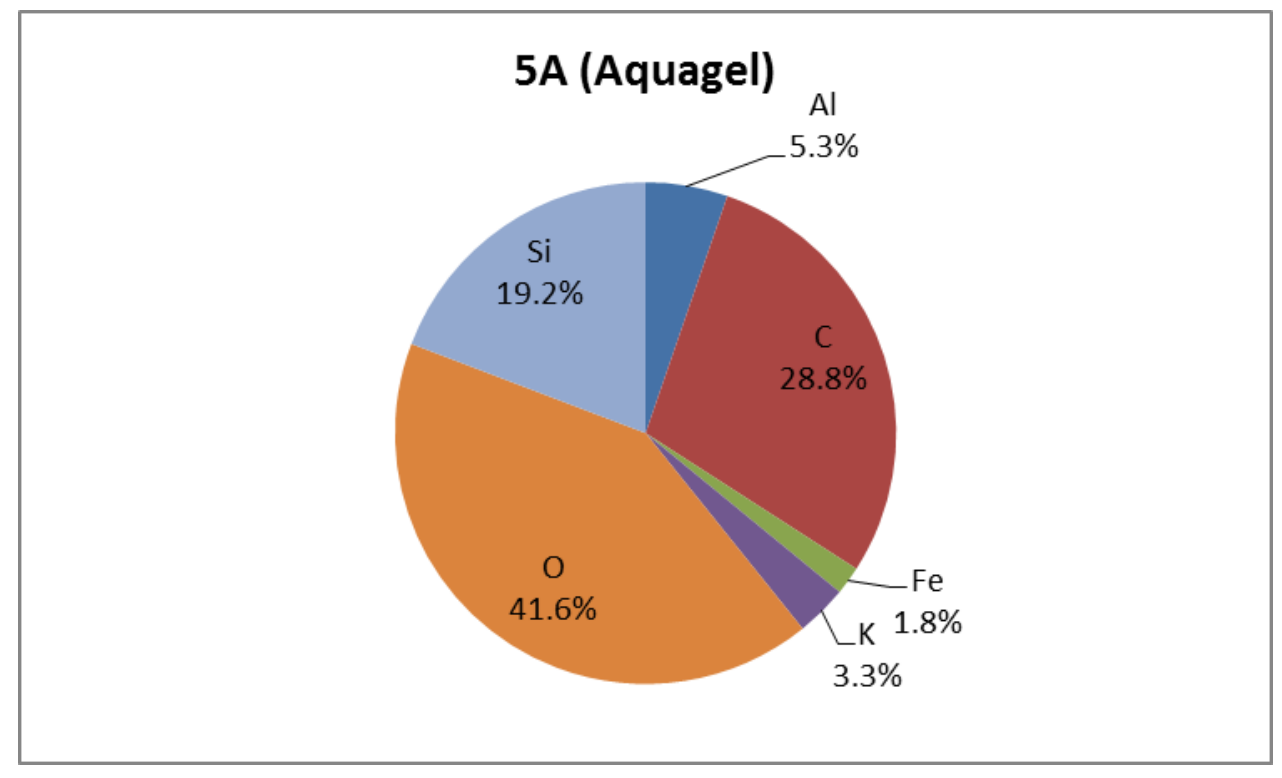

Figure B.23 Elemental composition of the Aquagel® treatment sample for the fifth depth interval of Well A

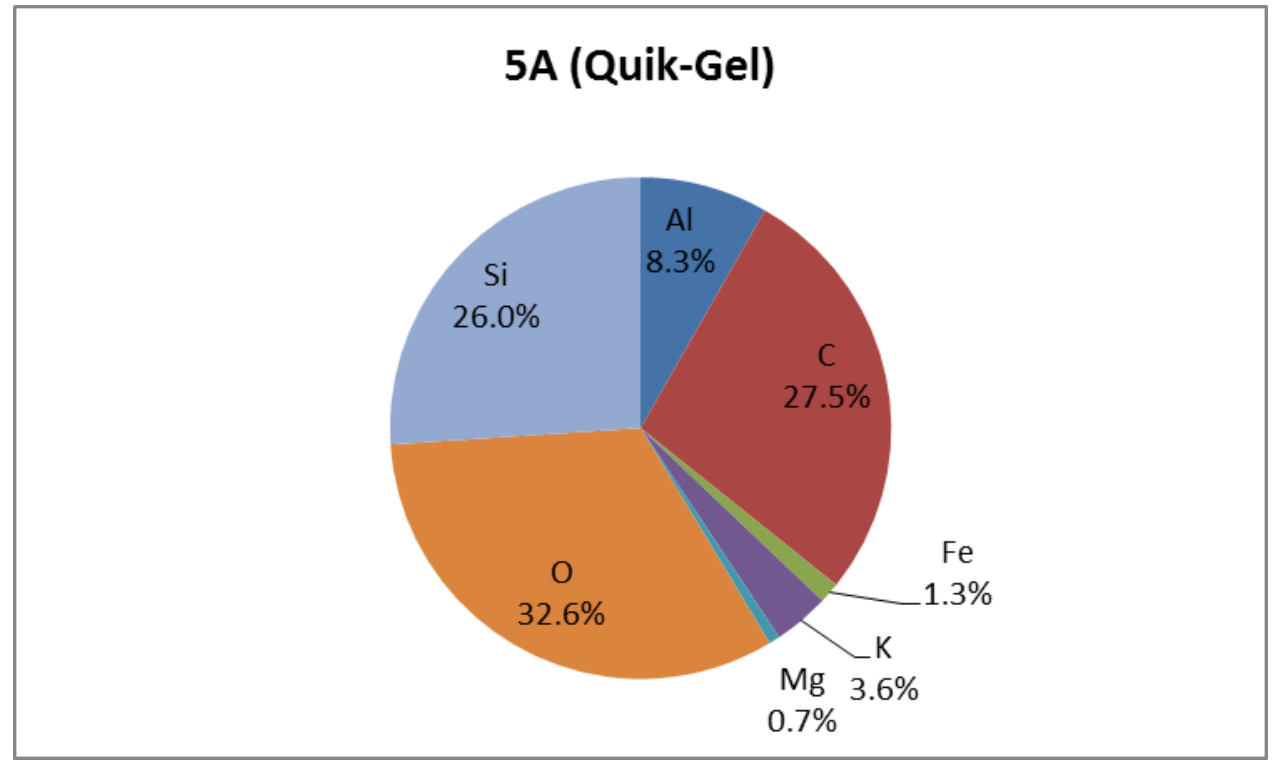

Figure B.24 Elemental composition of the Quik-Gel® treatment sample for the fifth depth interval of Well A. 


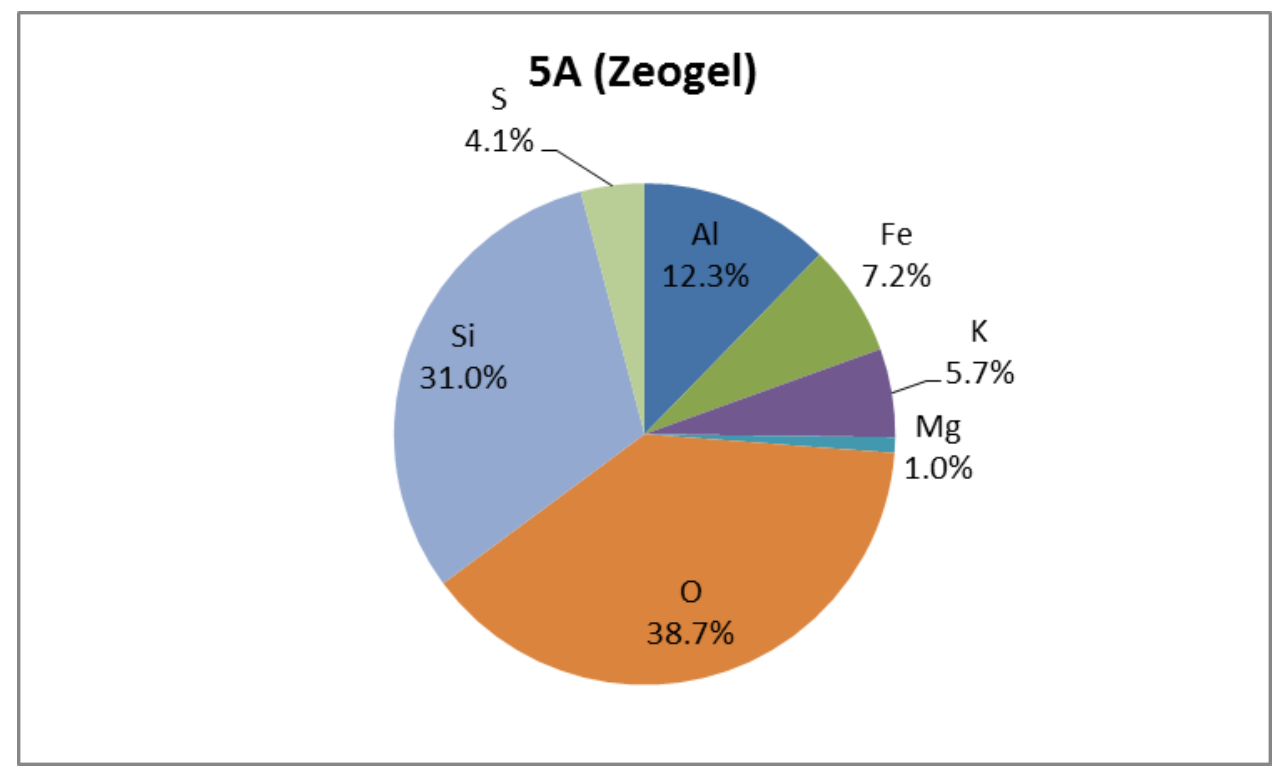

Figure B.25 Elemental composition of the Zeogel® treatment sample for the fifth depth interval of Well A 


\section{Monongalia County Well (Sixth Depth Interval)}

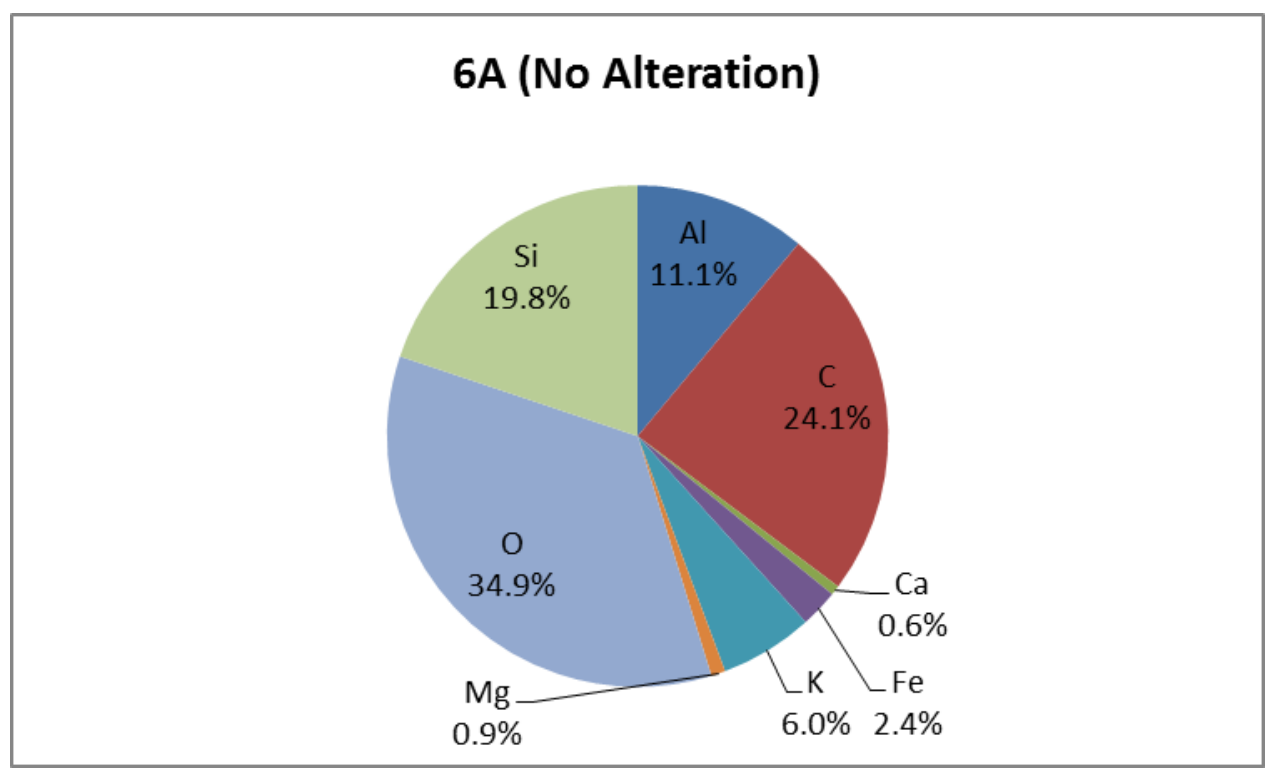

Figure B.26 Elemental composition of the control sample for the sixth depth interval of Well A

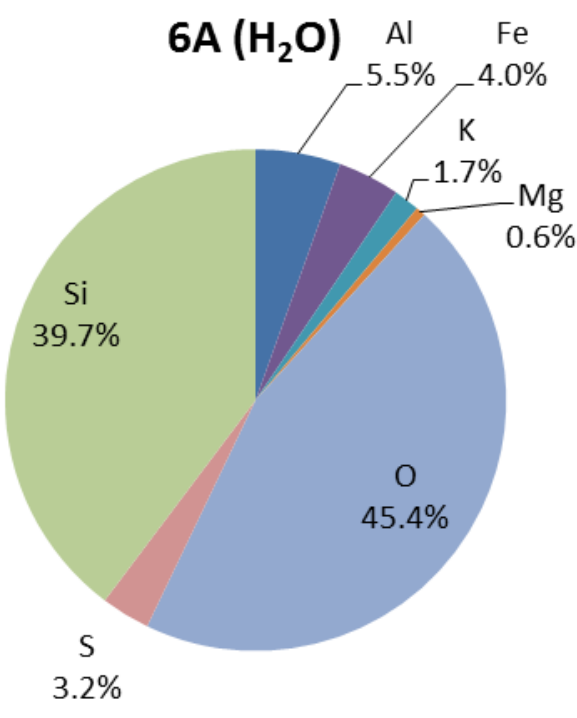

Figure B.27 Elemental composition of the water treatment sample for the sixth depth interval of Well A 


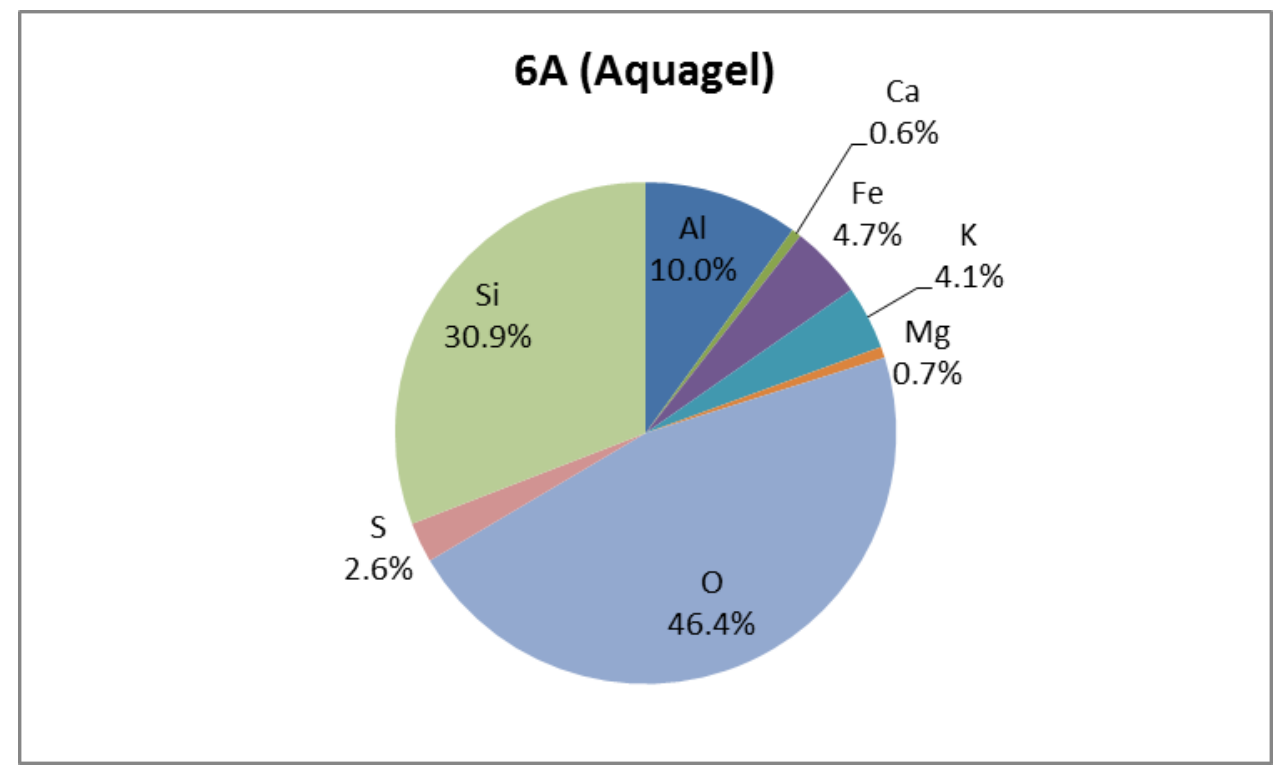

Figure B.28 Elemental composition of the Aquagel ${ }^{\circledR}$ treatment sample for the sixth depth interval of Well A

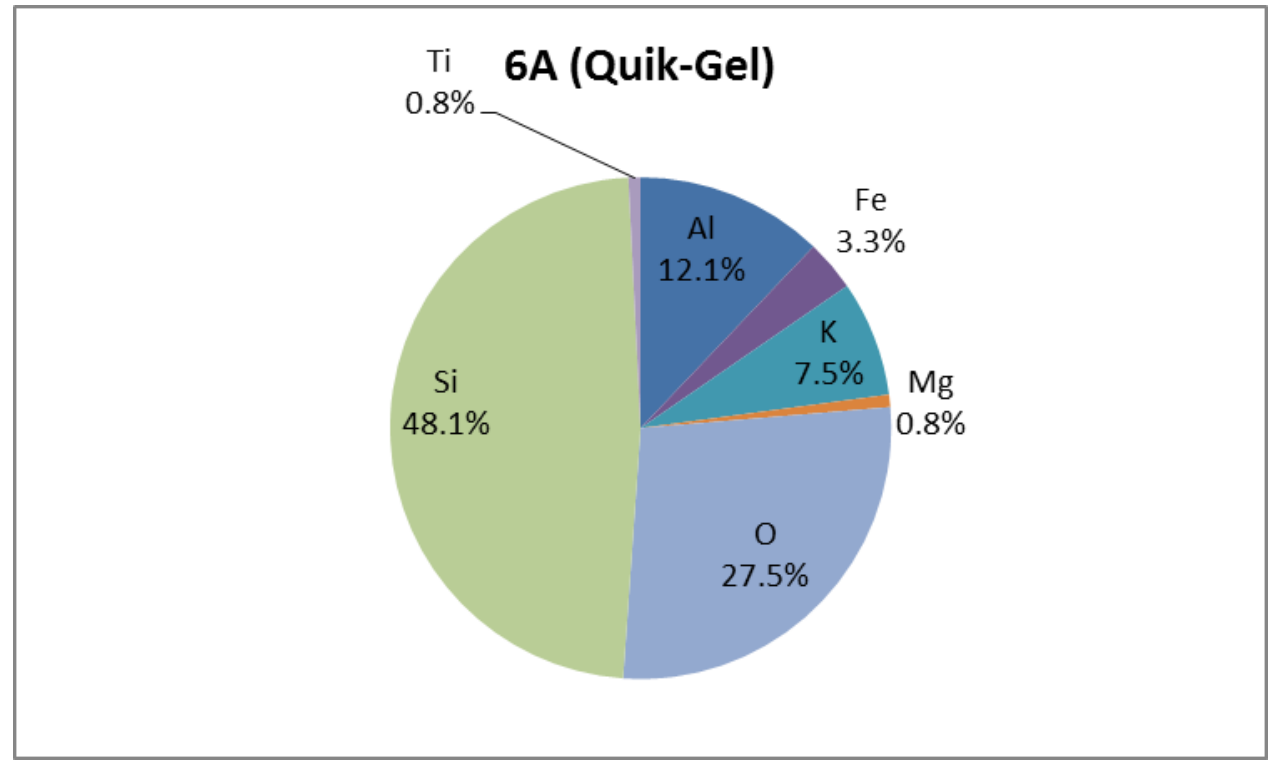

Figure B.29 Elemental composition of the Quik-Gel® treatment sample for the sixth depth interval of Well A 


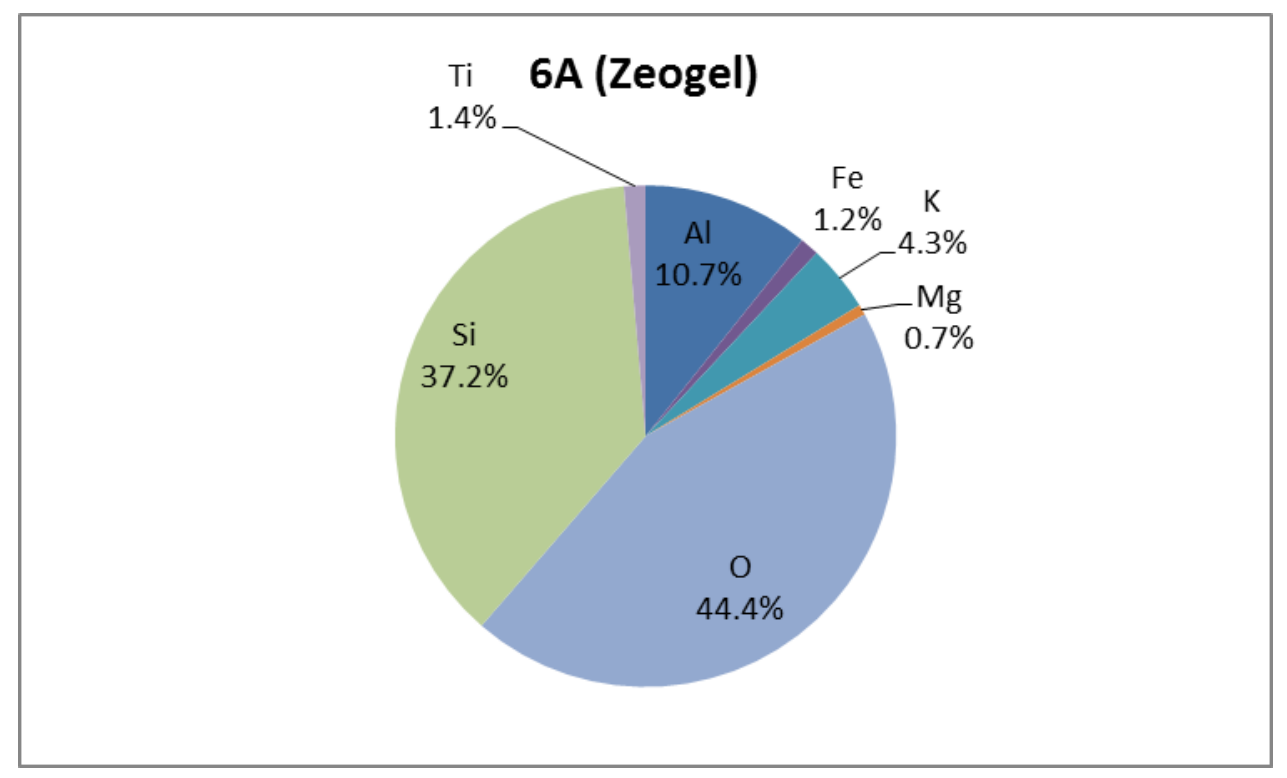

Figure B.30 Elemental composition of the Zeogel® treatment sample for the sixth depth interval of Well A 


\section{Monongalia County Well (Seventh Depth Interval)}

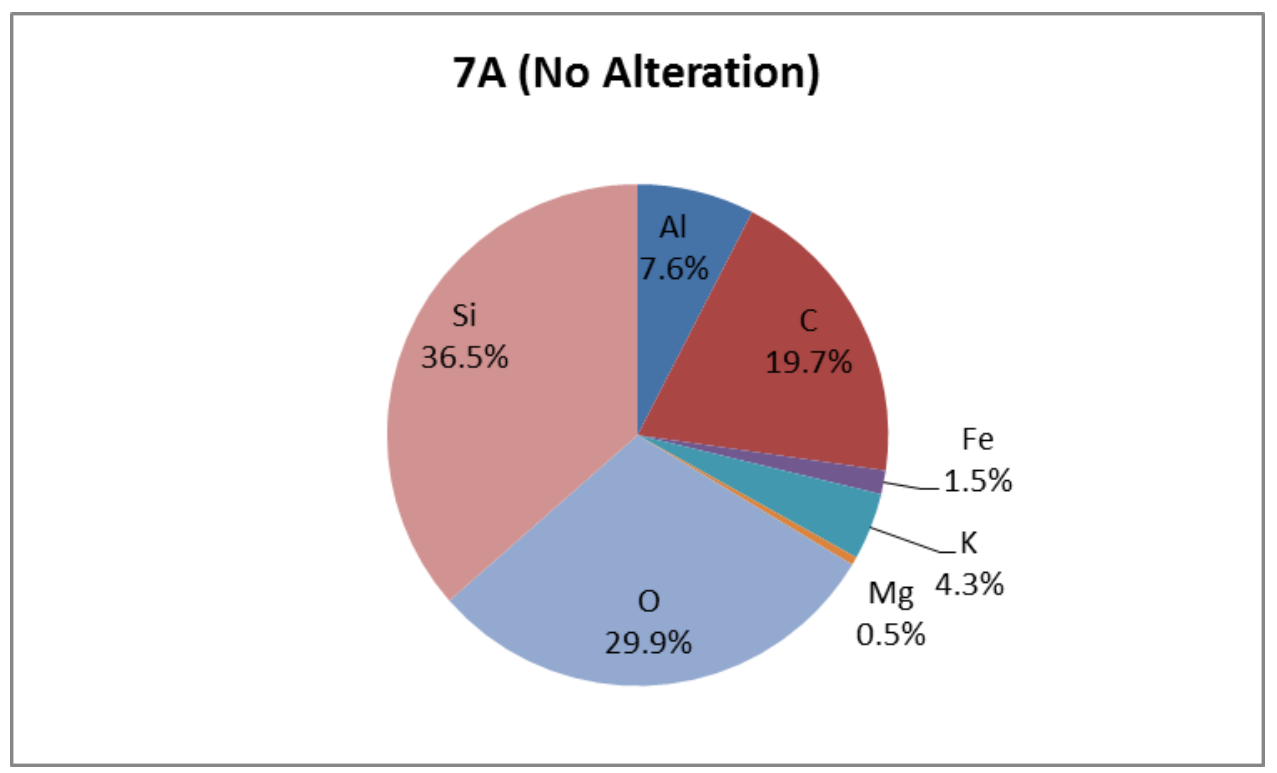

Figure B.31 Elemental composition of the control sample for the seventh depth interval of Well A

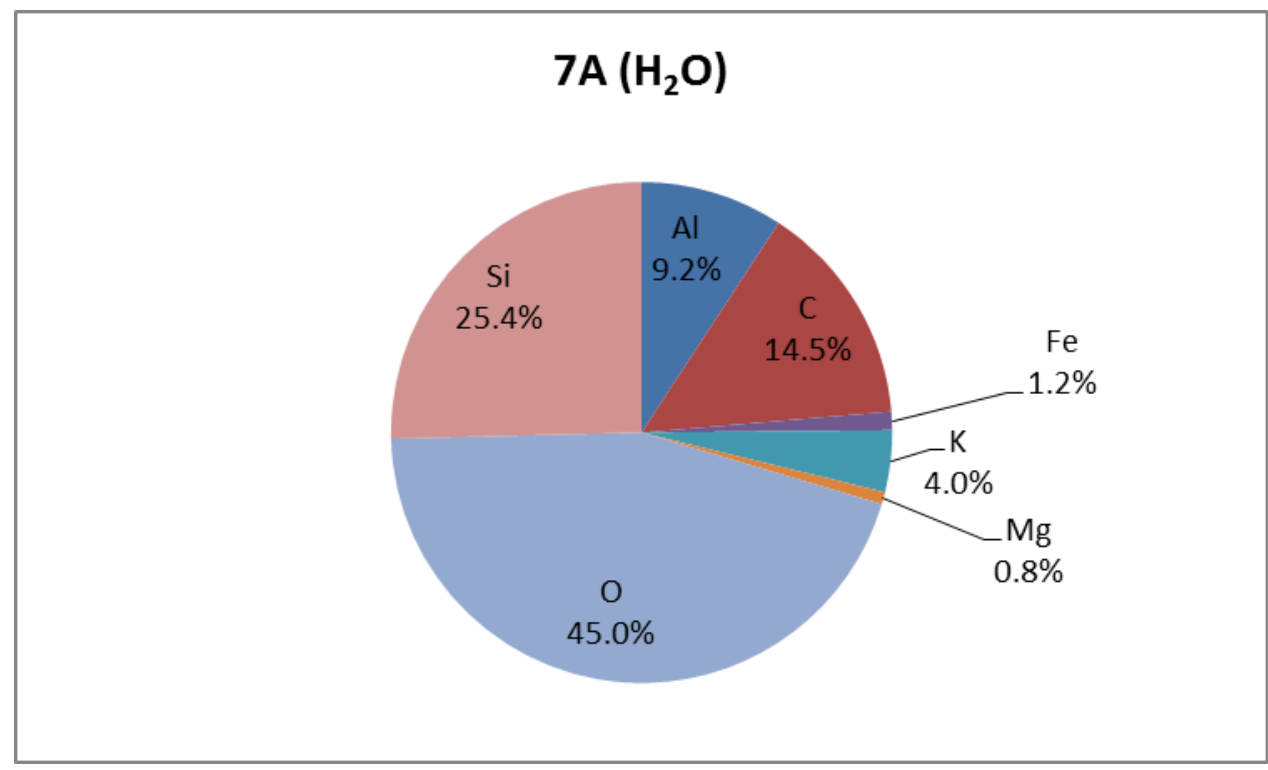

Figure B.32 Elemental composition of the water treatment sample for the seventh depth interval of Well A 


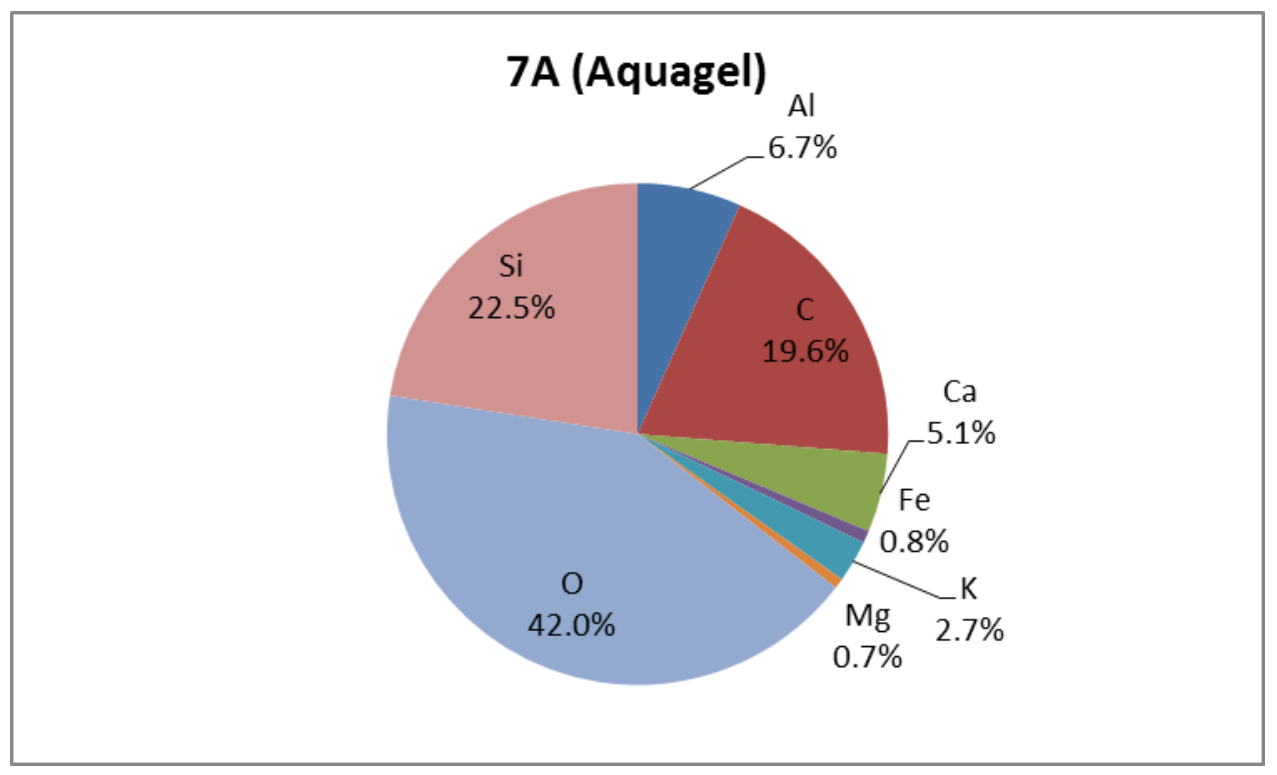

Figure B.33 Elemental composition of the Aquagel ${ }^{\circledR}$ treatment sample for the seventh depth interval of Well A

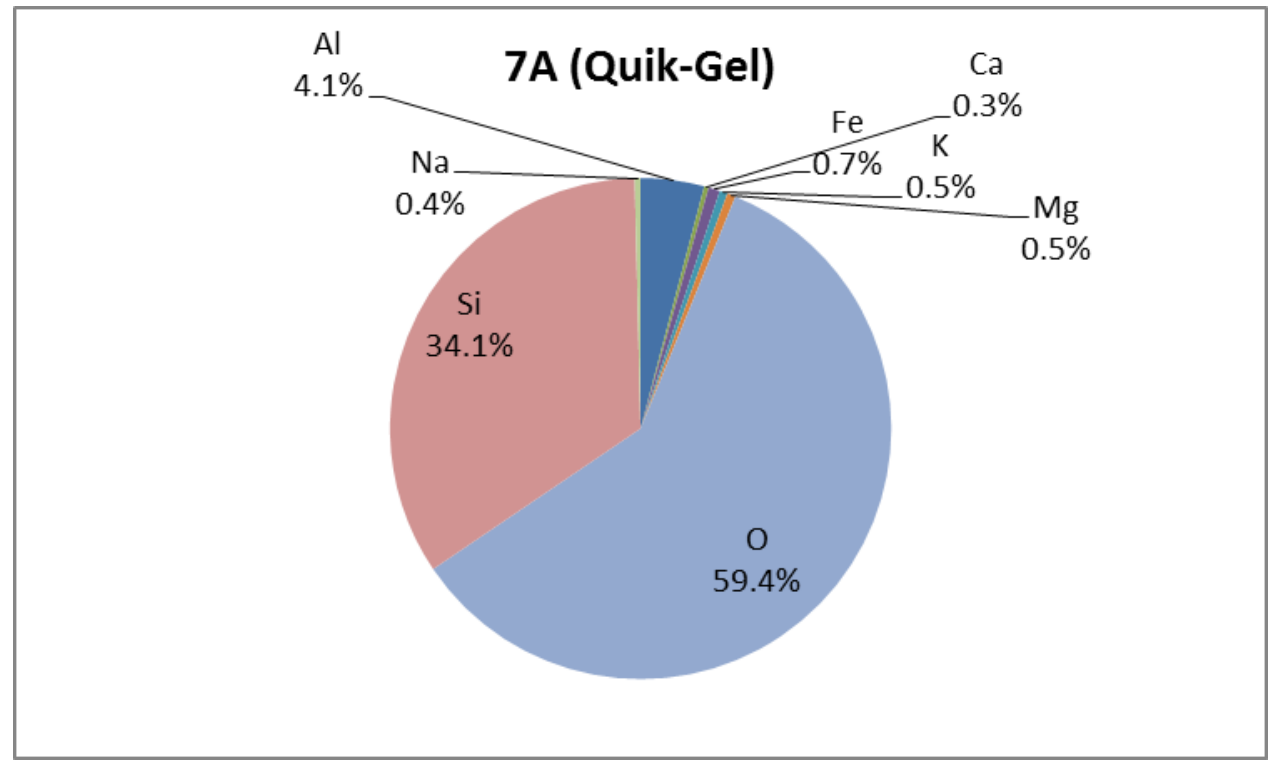

Figure B.34 Elemental composition of the Quik-Gel® treatment sample for the seventh depth interval of Well A 


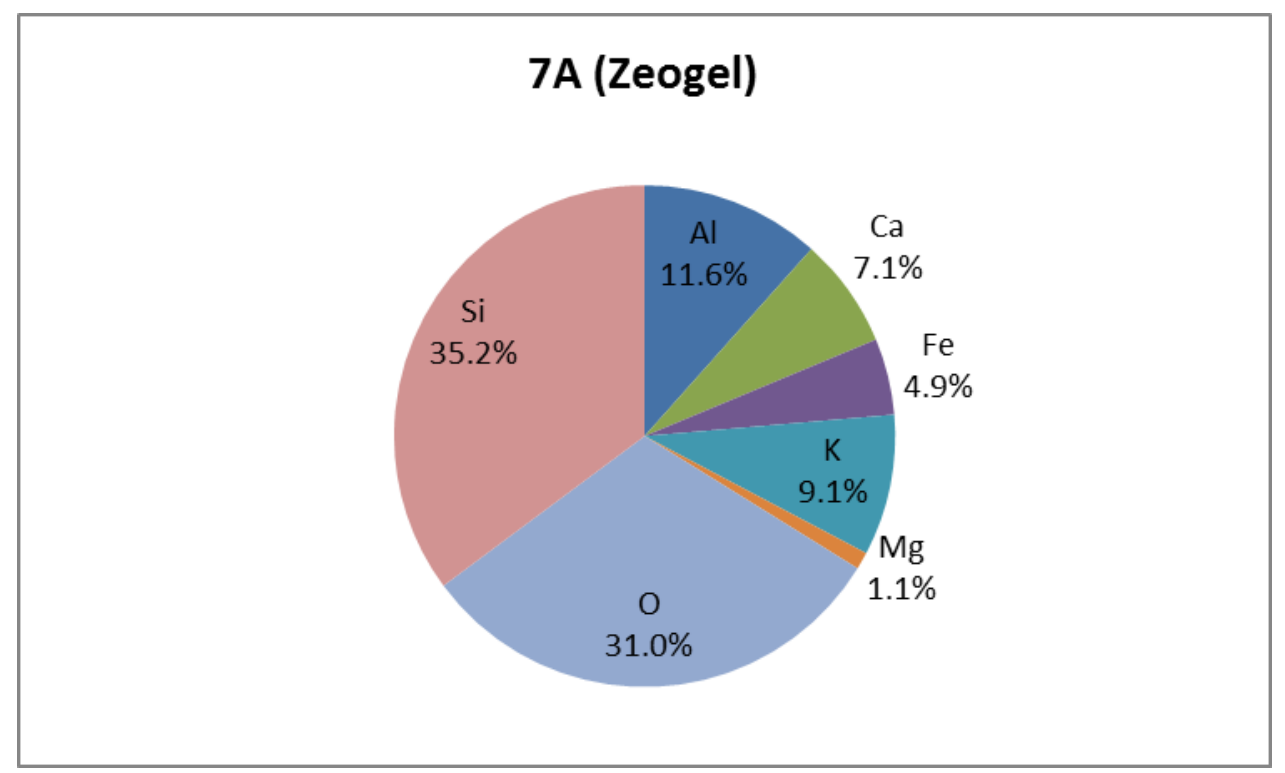

Figure B.35 Elemental composition of the Zeogel® treatment sample for the seventh depth interval of Well A 


\section{Monongalia County Well (Eighth Depth Interval)}

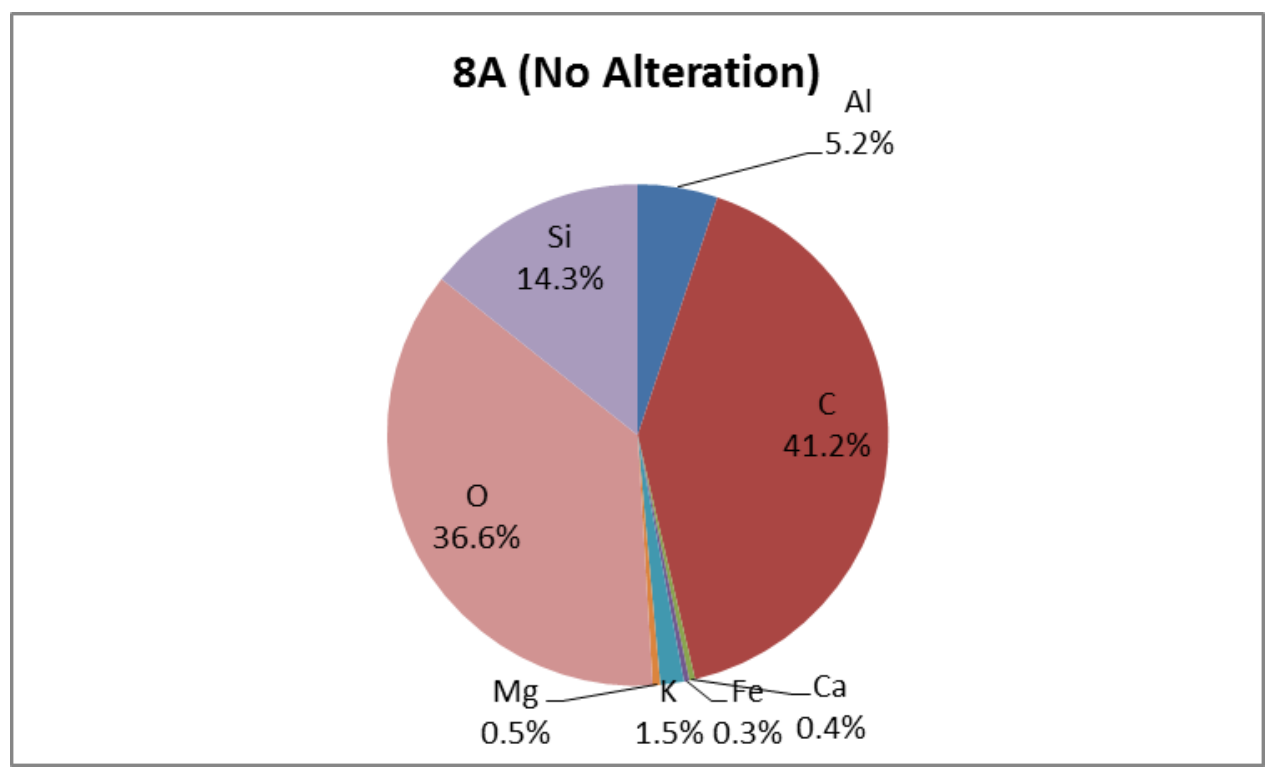

Figure B.36 Elemental composition of the control sample for the eighth depth interval of Well A

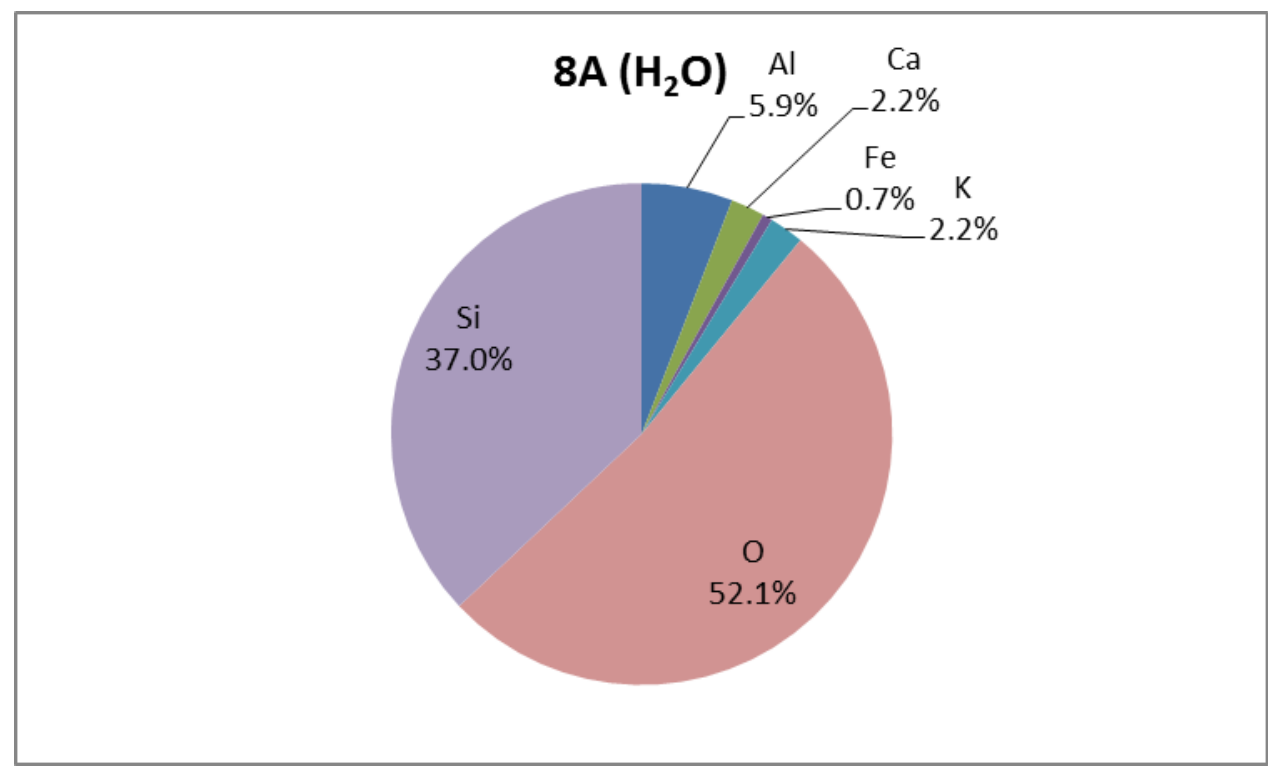

Figure B.37 Elemental composition of the water treatment sample for the eighth depth interval of Well A 


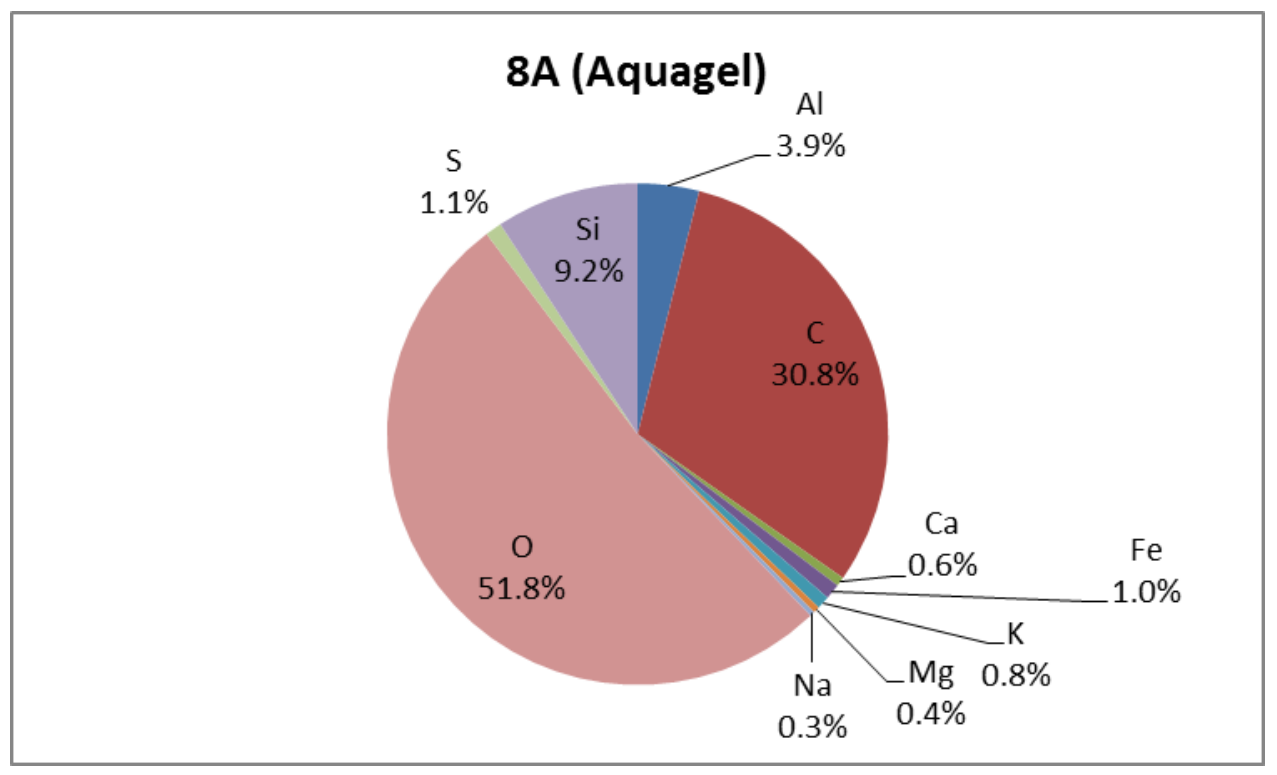

Figure B.38 Elemental composition of the Aquagel® treatment sample for the eighth depth interval of Well A

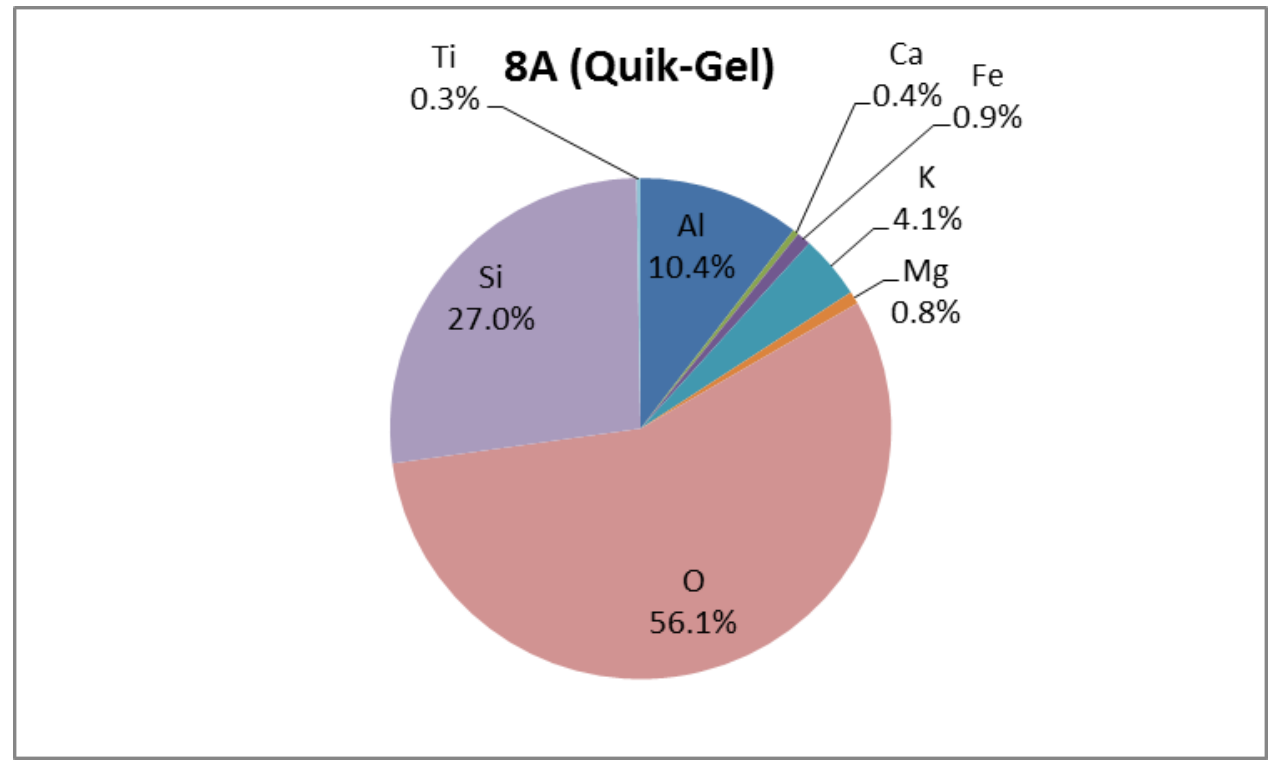

Figure B.39 Elemental composition of the Quik-Gel® treatment sample for the eighth depth interval of Well A 


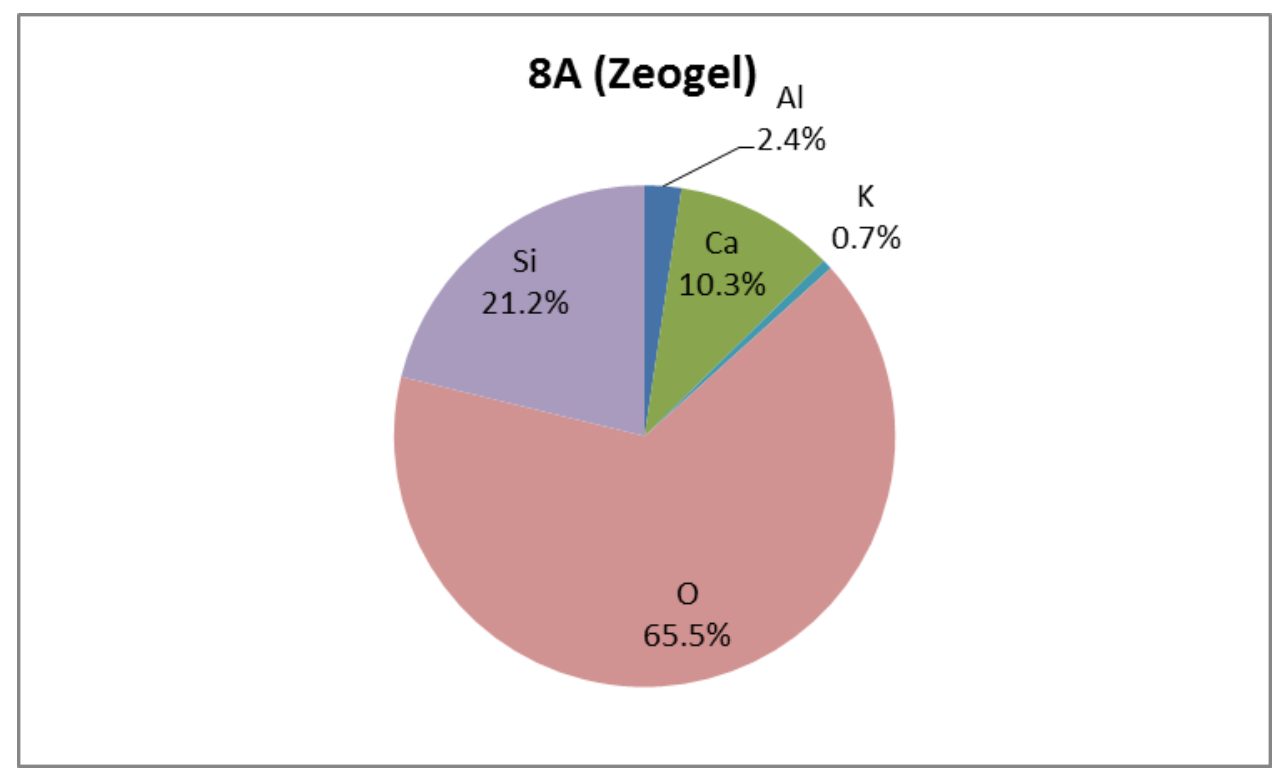

Figure B.40 Elemental composition of the Zeogel® treatment sample for the eighth depth interval of Well A 


\section{Monongalia County Well (Ninth Depth Interval)}

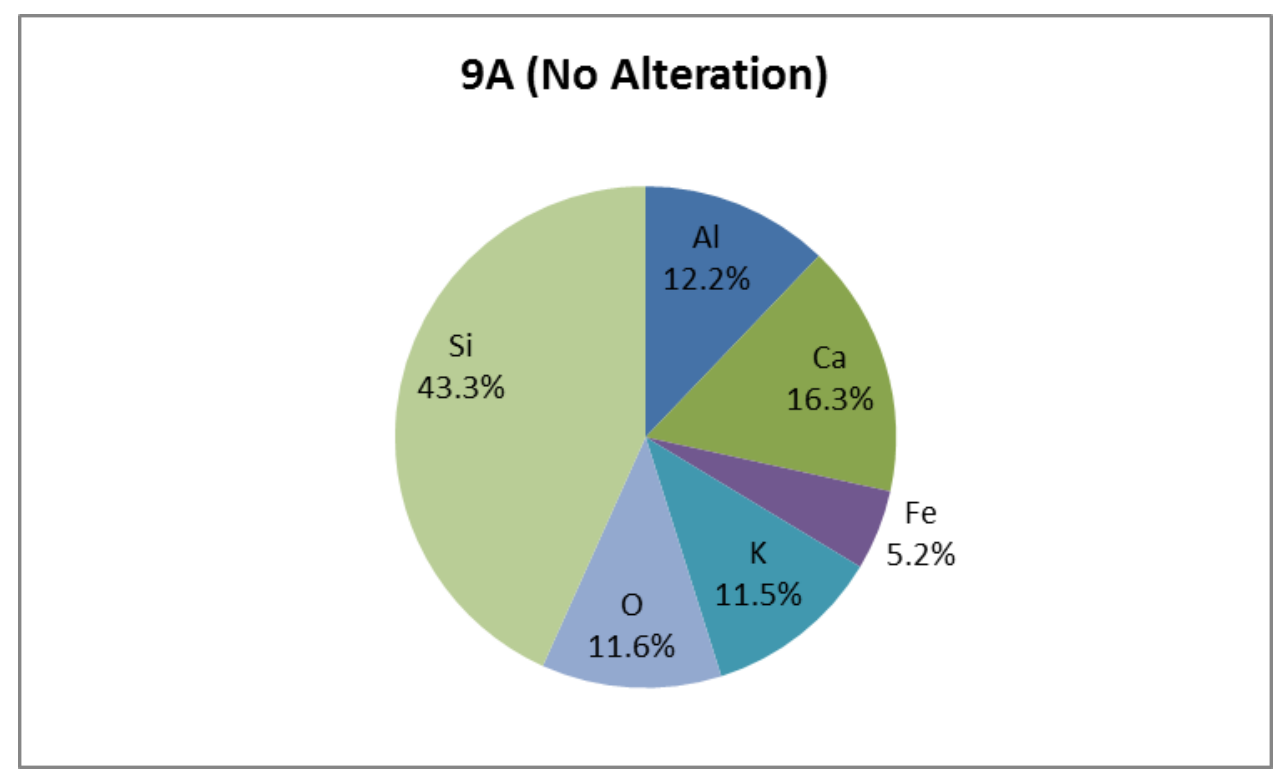

Figure B.41 Elemental composition of the control sample for the ninth depth interval of Well A

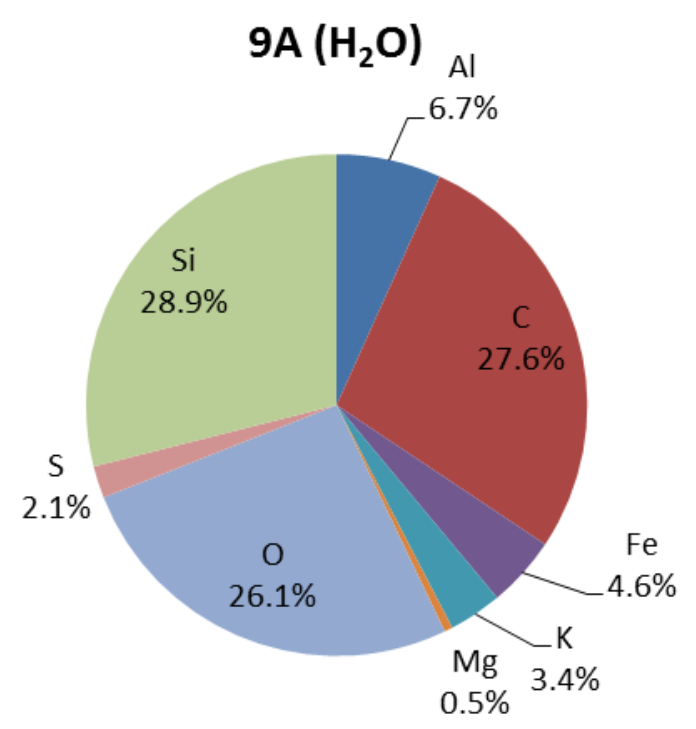

Figure B.42 Elemental composition of the water treatment sample for the ninth depth interval of Well A 


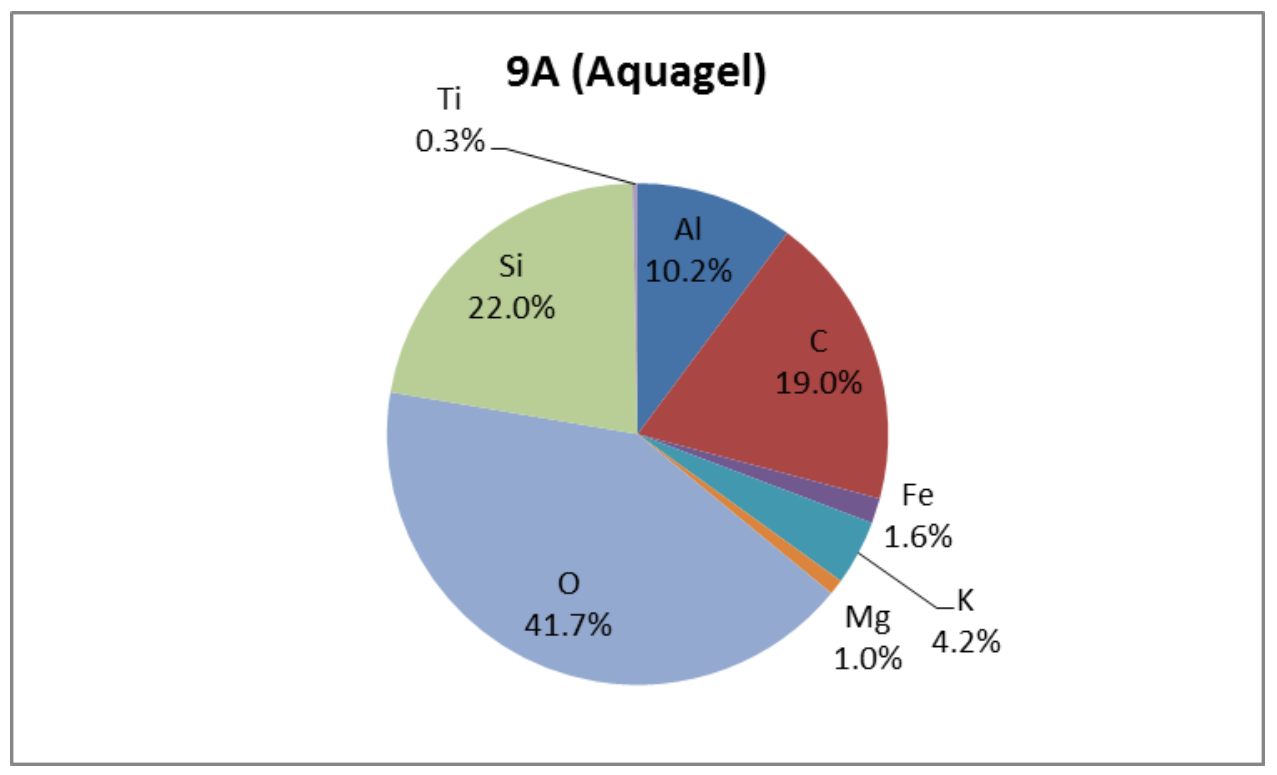

Figure B.43 Elemental composition of the Aquagel ${ }^{\circledR}$ treatment sample for the ninth depth interval of Well A

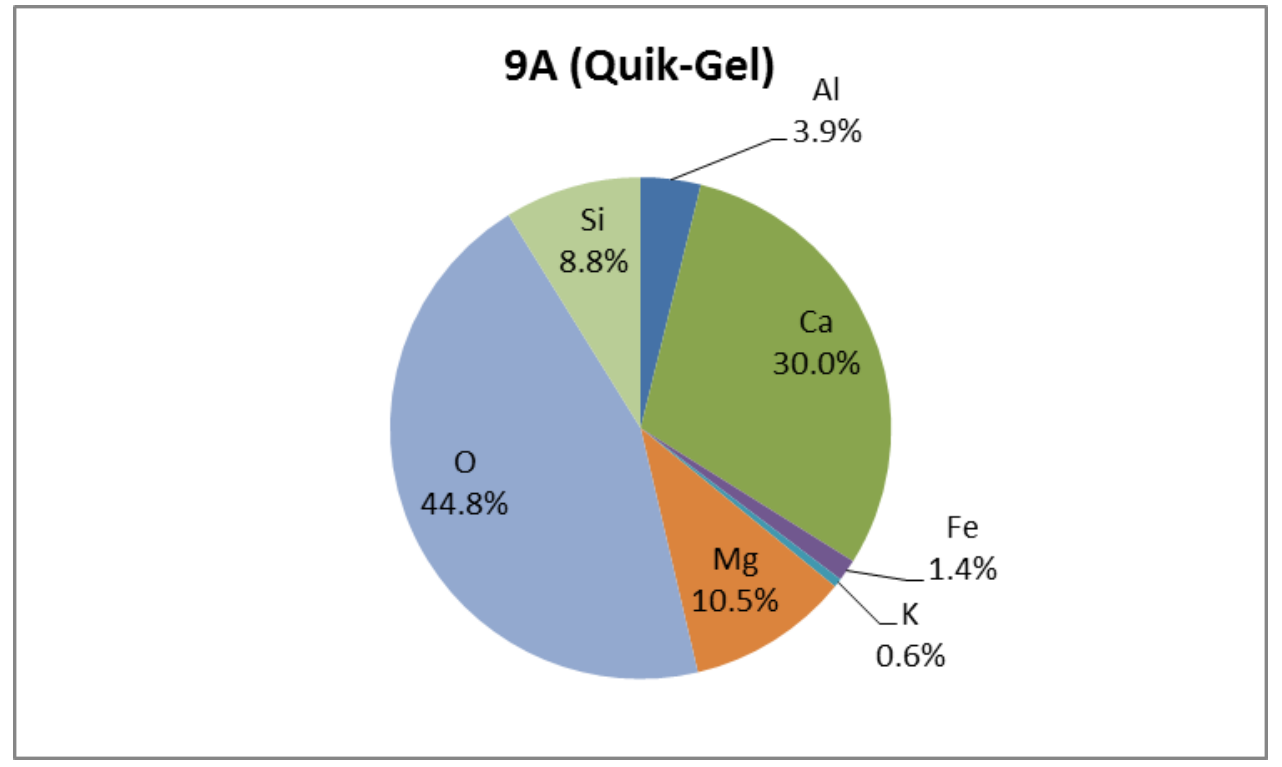

Figure B.44 Elemental composition of the Quik-Gel® treatment sample for the ninth depth interval of Well A 


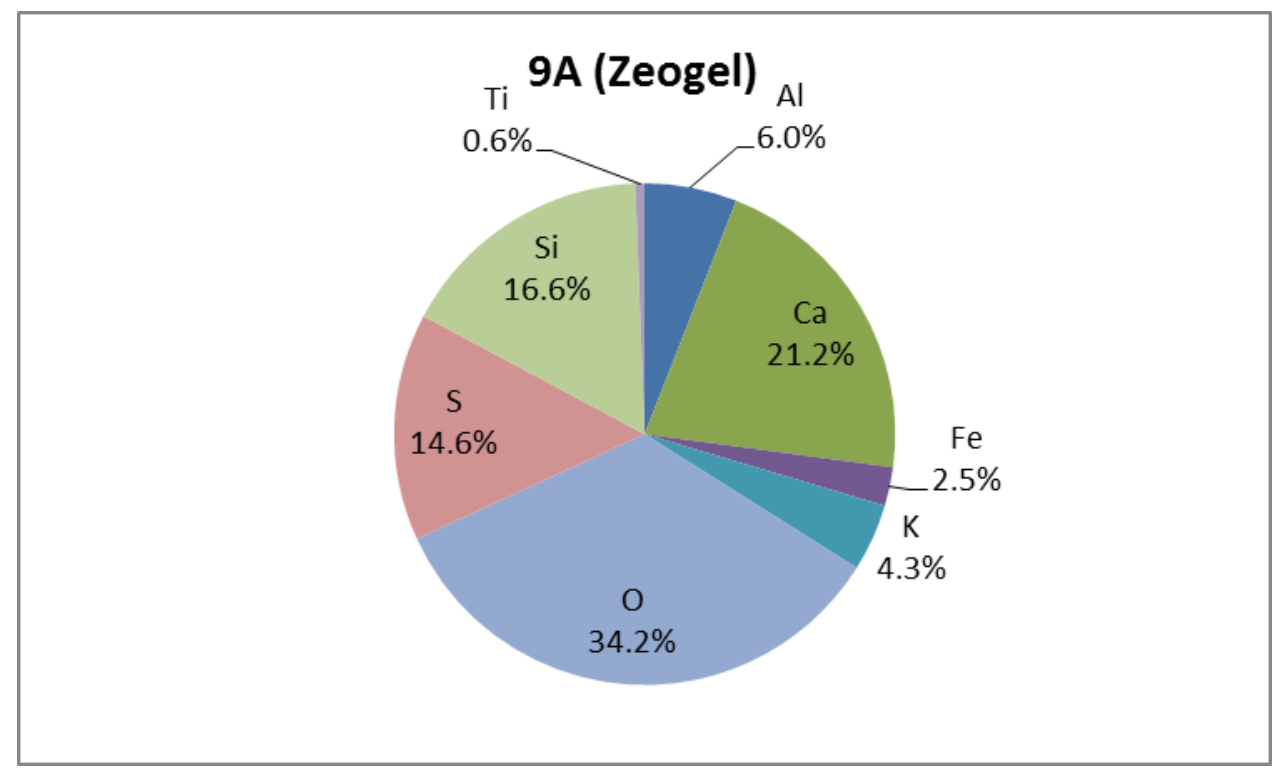

Figure B.45 Elemental composition of the Zeogel ${ }^{\circledR}$ treatment sample for the ninth depth interval of Well A 


\section{Wetzel County Well (First Depth Interval)}

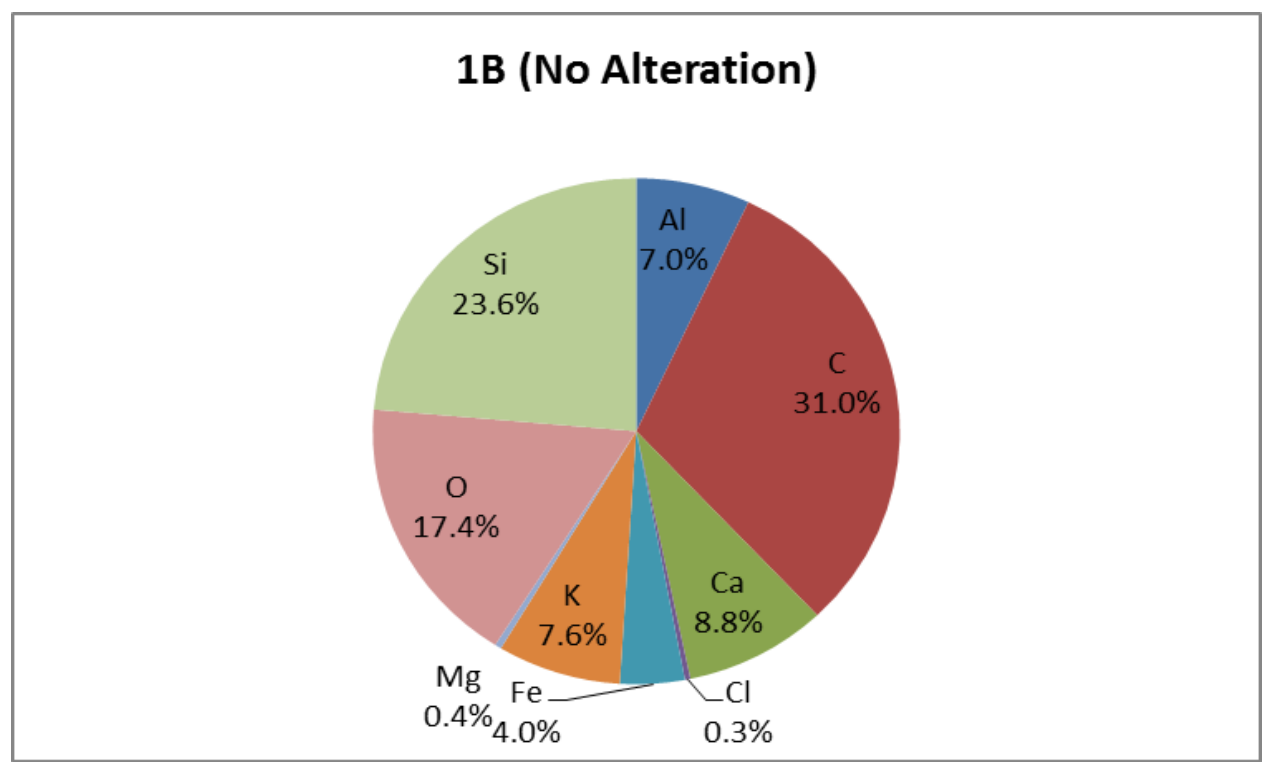

Figure B.46 Elemental composition of the control sample for the first depth interval of Well B

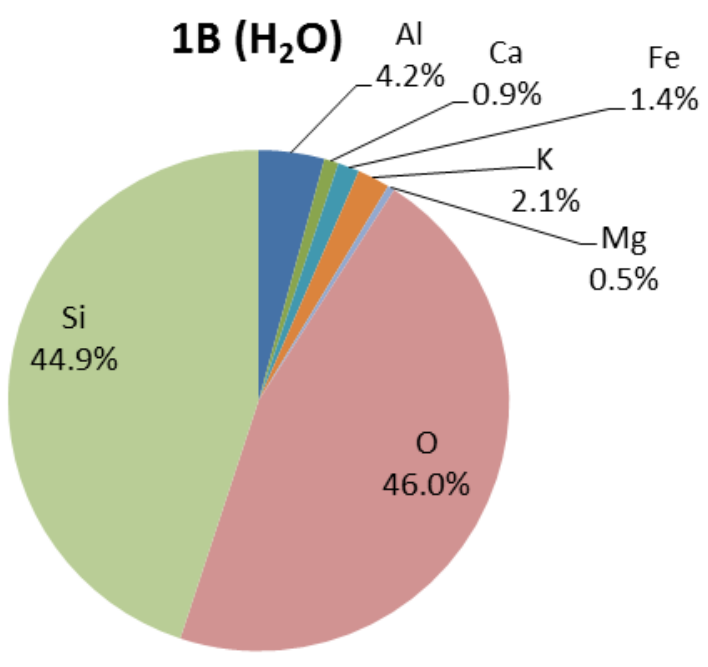

Figure B.47 Elemental composition of the water treatment sample for the first depth interval of Well B 


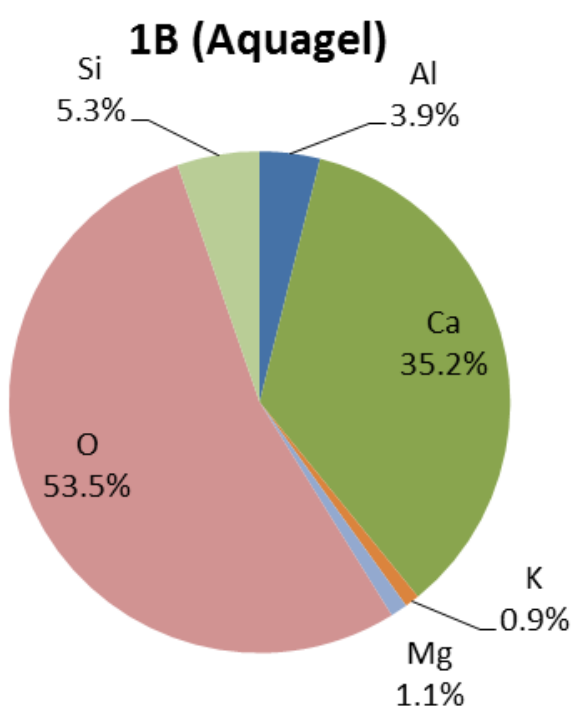

Figure B.48 Elemental composition of the Aquagel ${ }^{\circledR}$ treatment sample for the first depth interval of Well B

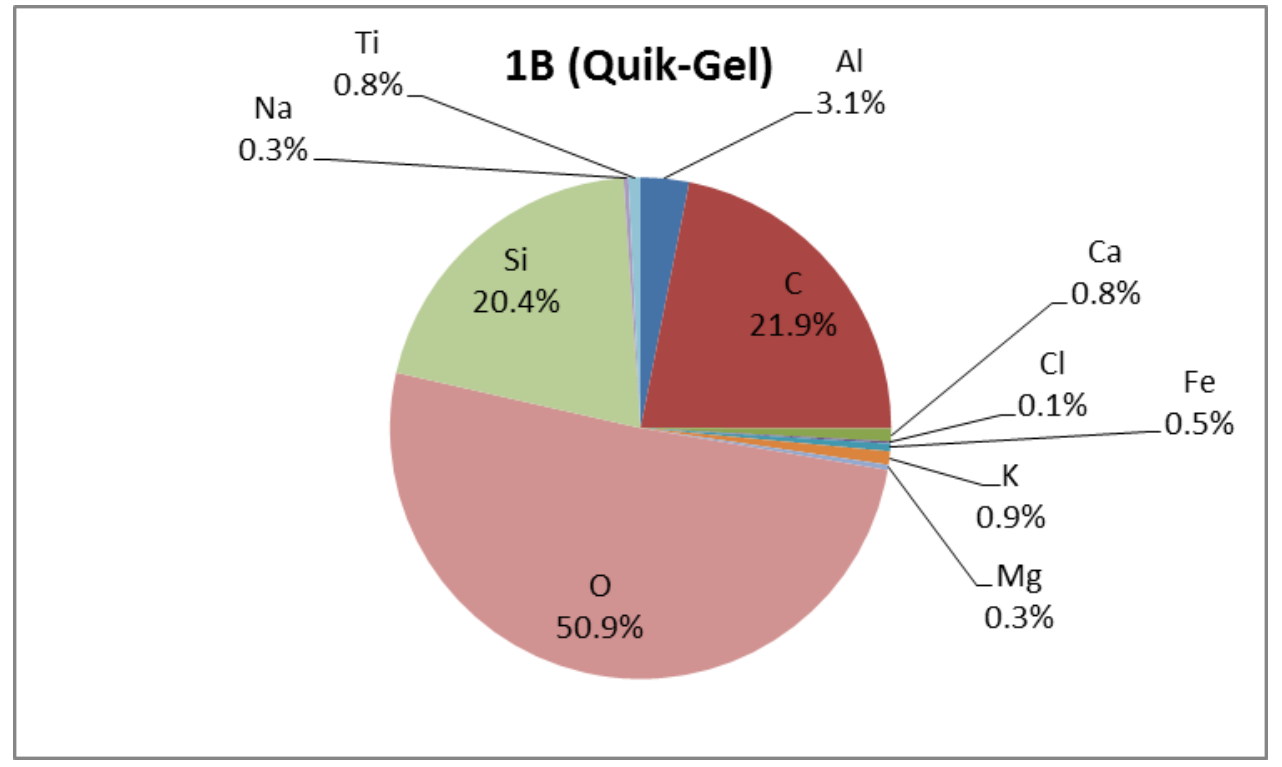

Figure B.49 Elemental composition of the Quik-Gel® treatment sample for the first depth interval of Well B 


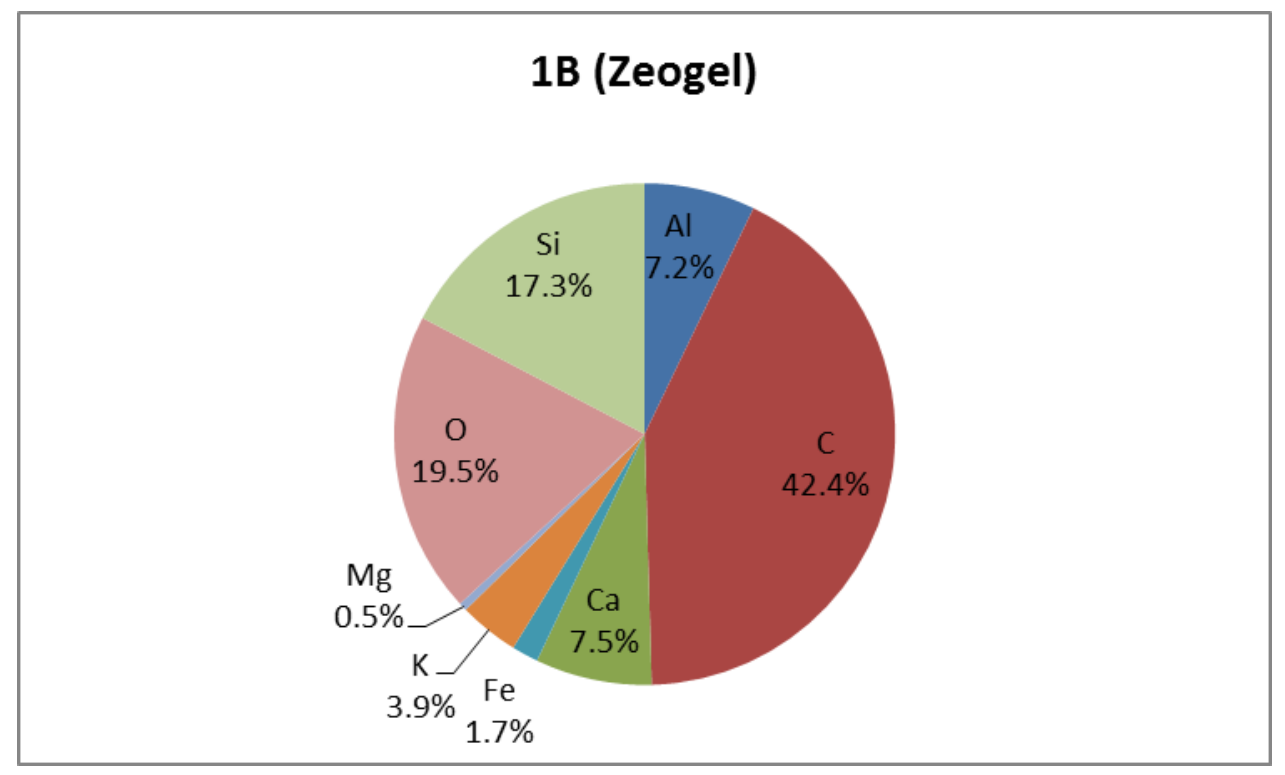

Figure B.50 Elemental composition of the Zeogel ${ }^{\circledR}$ treatment sample for the first depth interval of Well B 
Wetzel County Well (Second Depth Interval)

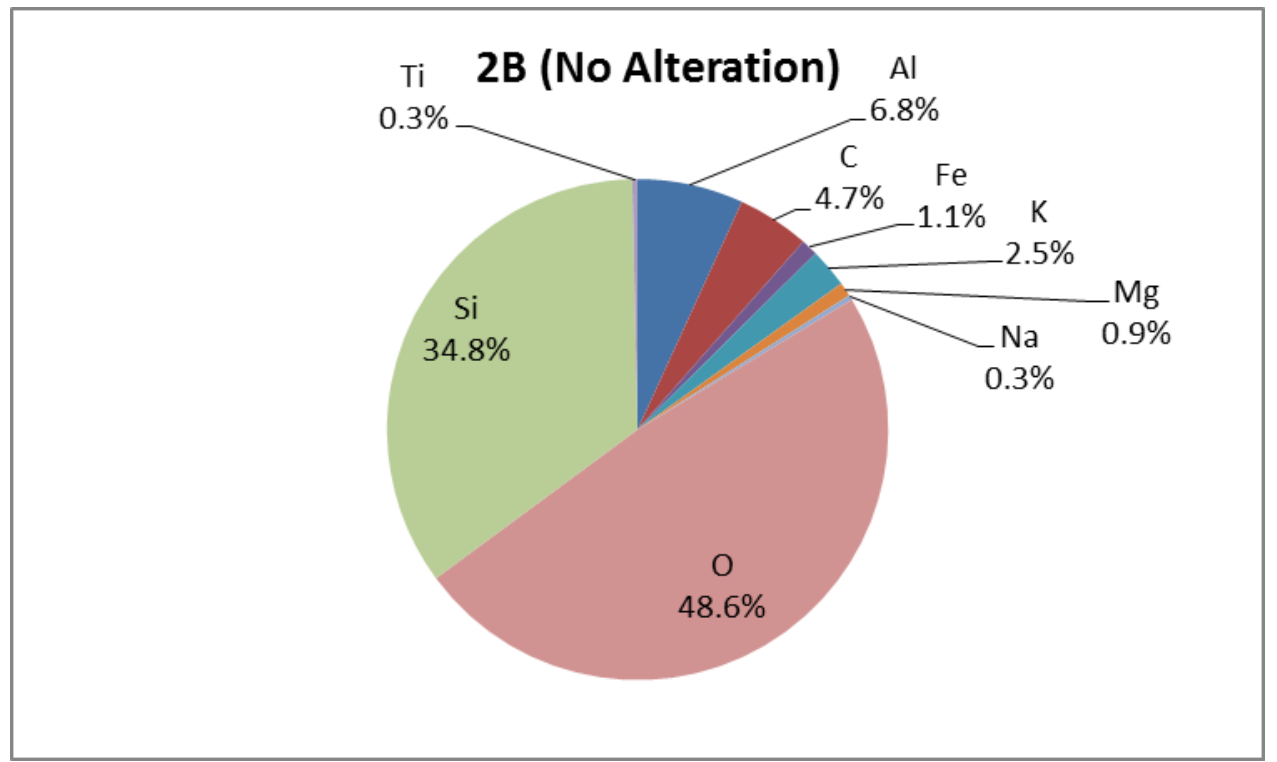

Figure B.51 Elemental composition of the control sample for the second depth interval of Well B

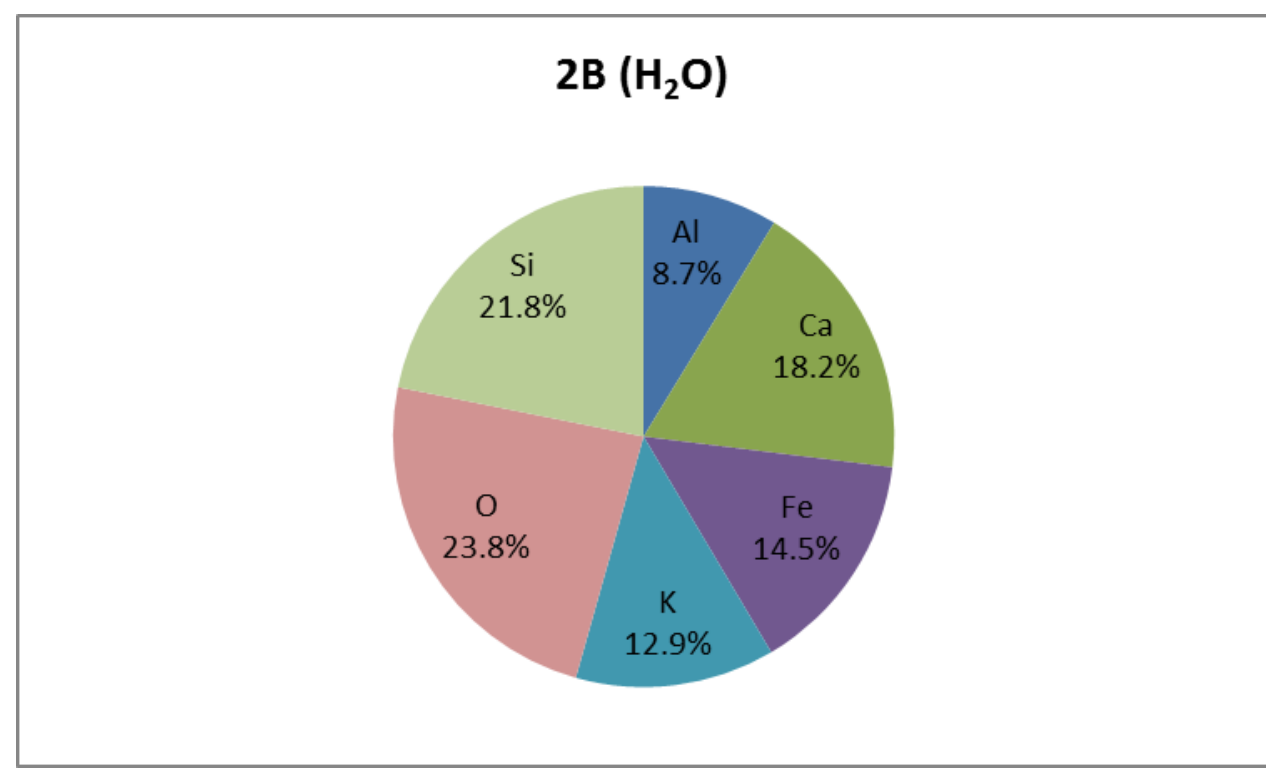

Figure B.52 Elemental composition of the water treatment sample for the second depth interval of Well B 


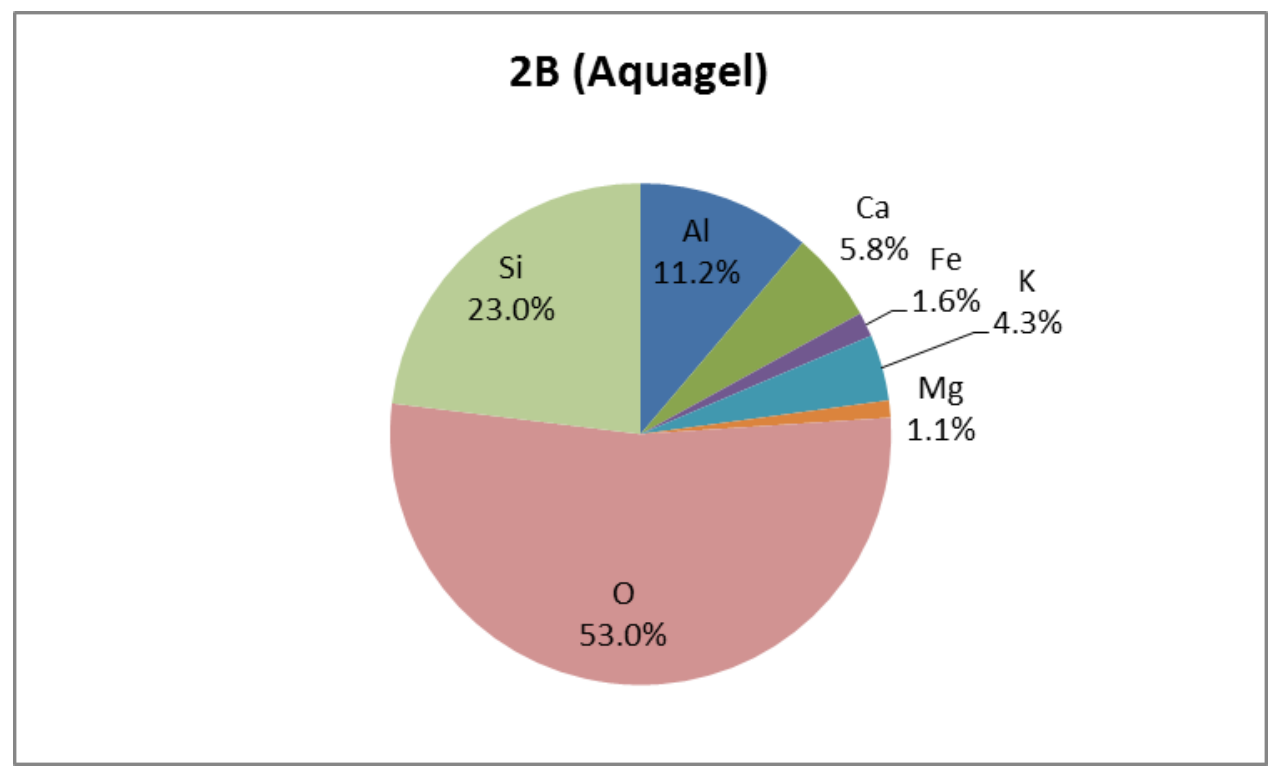

Figure B.53 Elemental composition of the Aquagel ${ }^{\circledR}$ treatment sample for the second depth interval of Well B

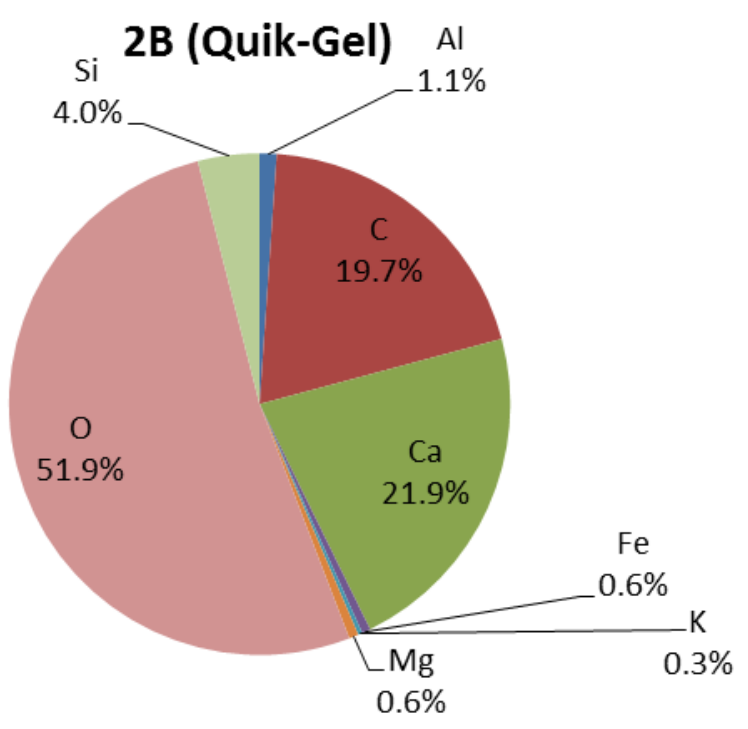

Figure B.54 Elemental composition of the Quik-Gel® treatment sample for the second depth interval of Well B 


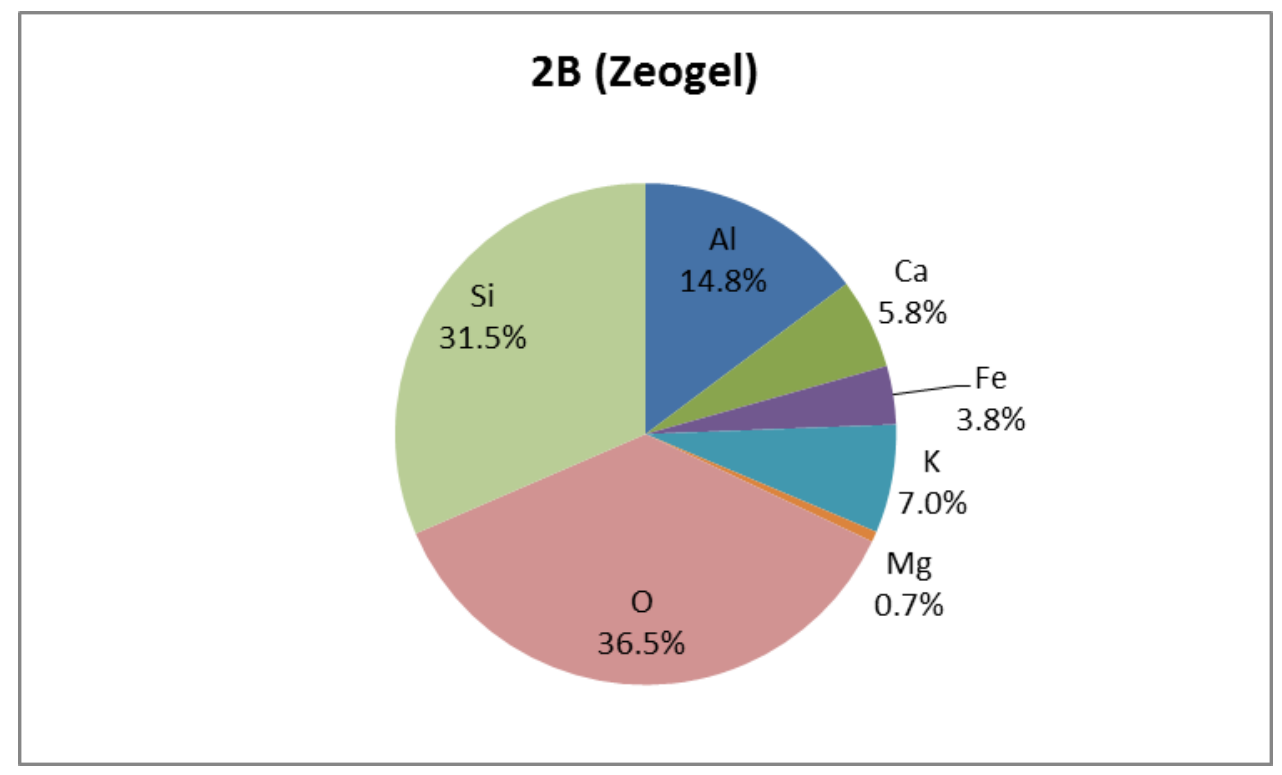

Figure B.55 Elemental composition of the Zeogel® treatment sample for the second depth interval of Well B 


\section{Wetzel County Well (Third Depth Interval)}

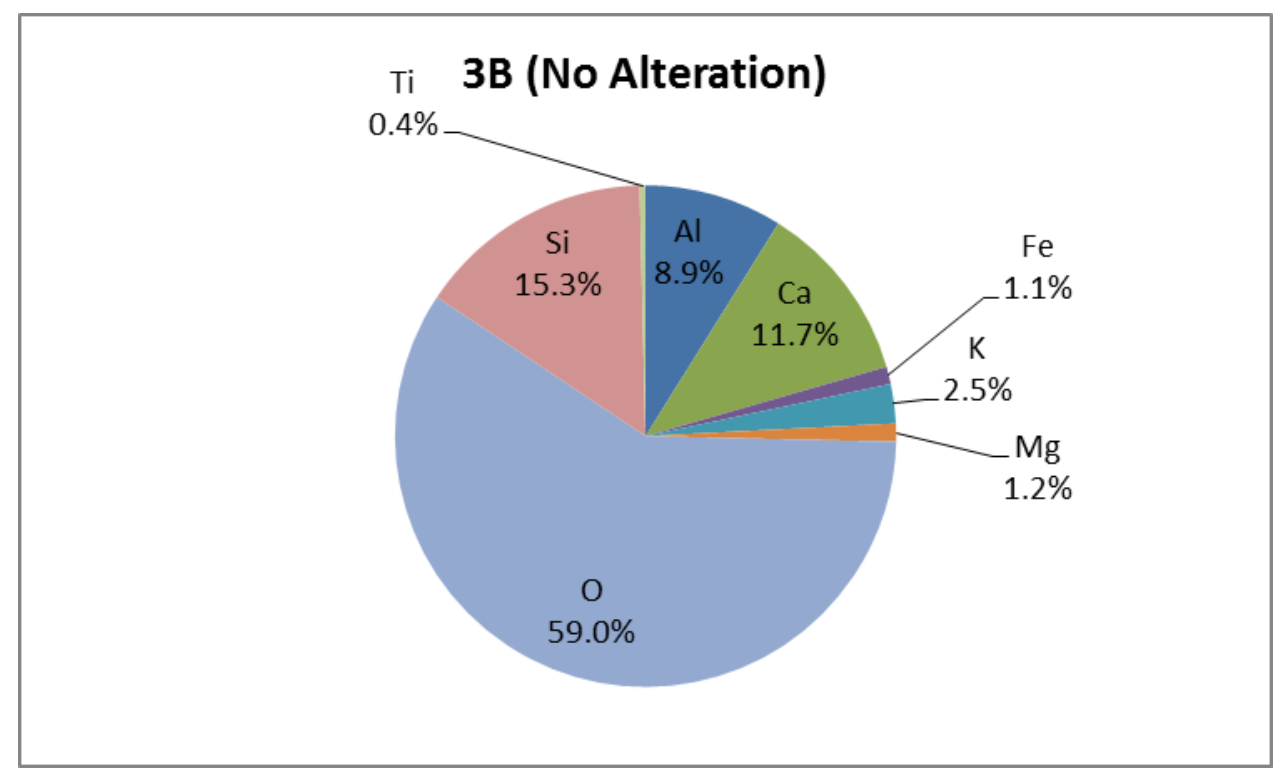

Figure B.56 Elemental composition of the control sample for the third depth interval of Well B

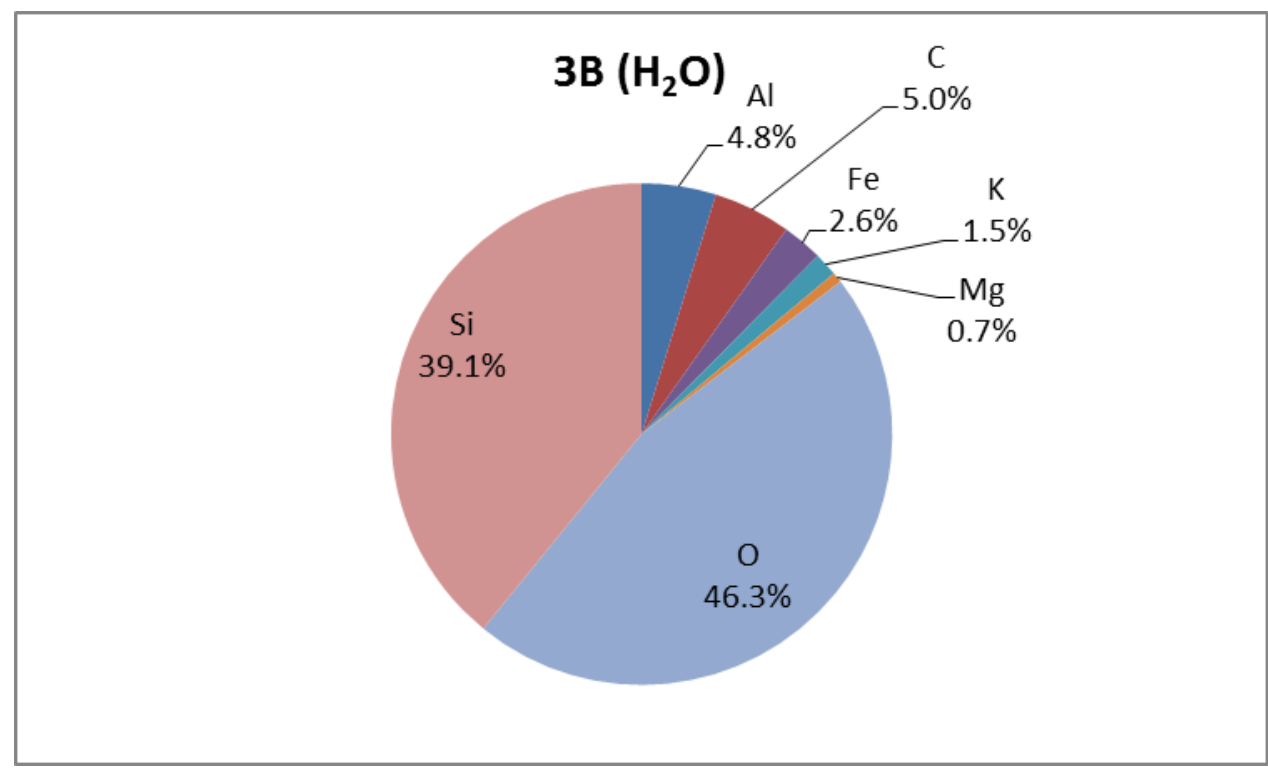

Figure B.57 Elemental composition of the water treatment sample for the third depth interval of Well B 


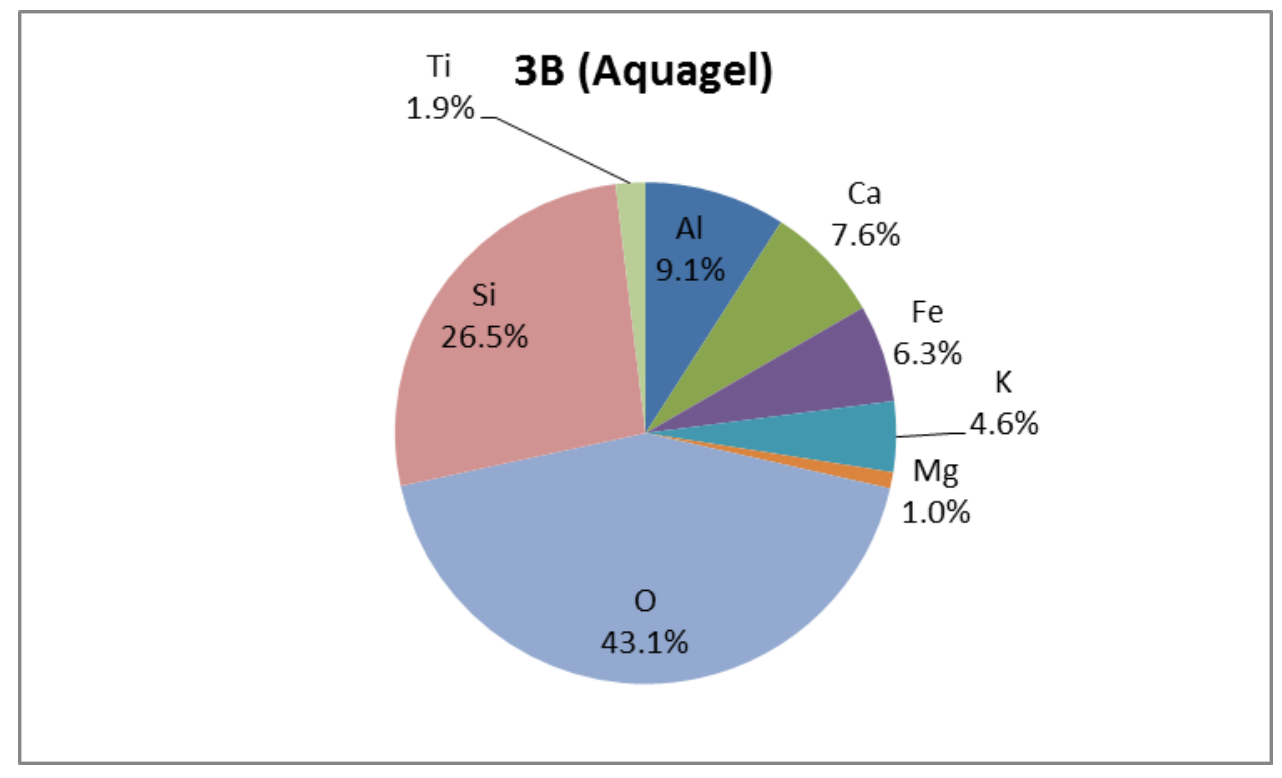

Figure B.58 Elemental composition of the Aquagel ${ }^{\circledR}$ treatment sample for the third depth interval of Well B

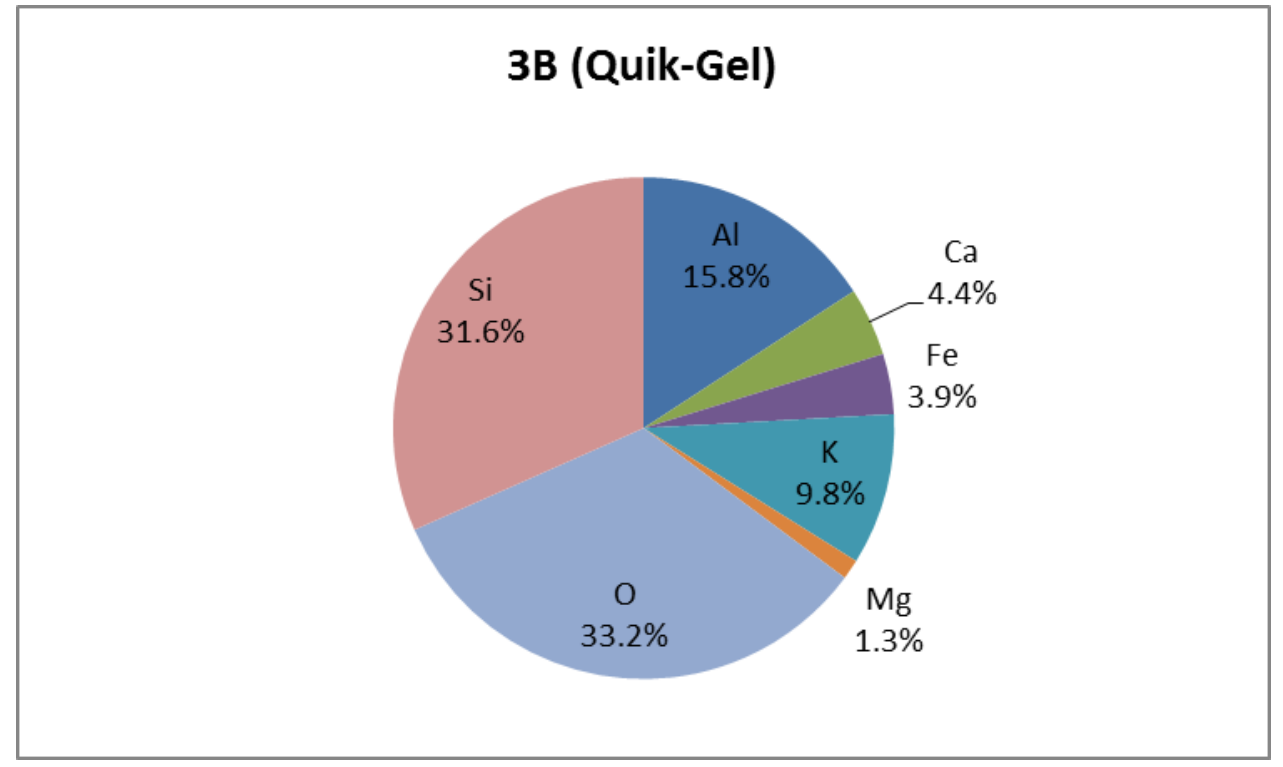

Figure B.59 Elemental composition of the Quik-Gel® treatment sample for the third depth interval of Well B 


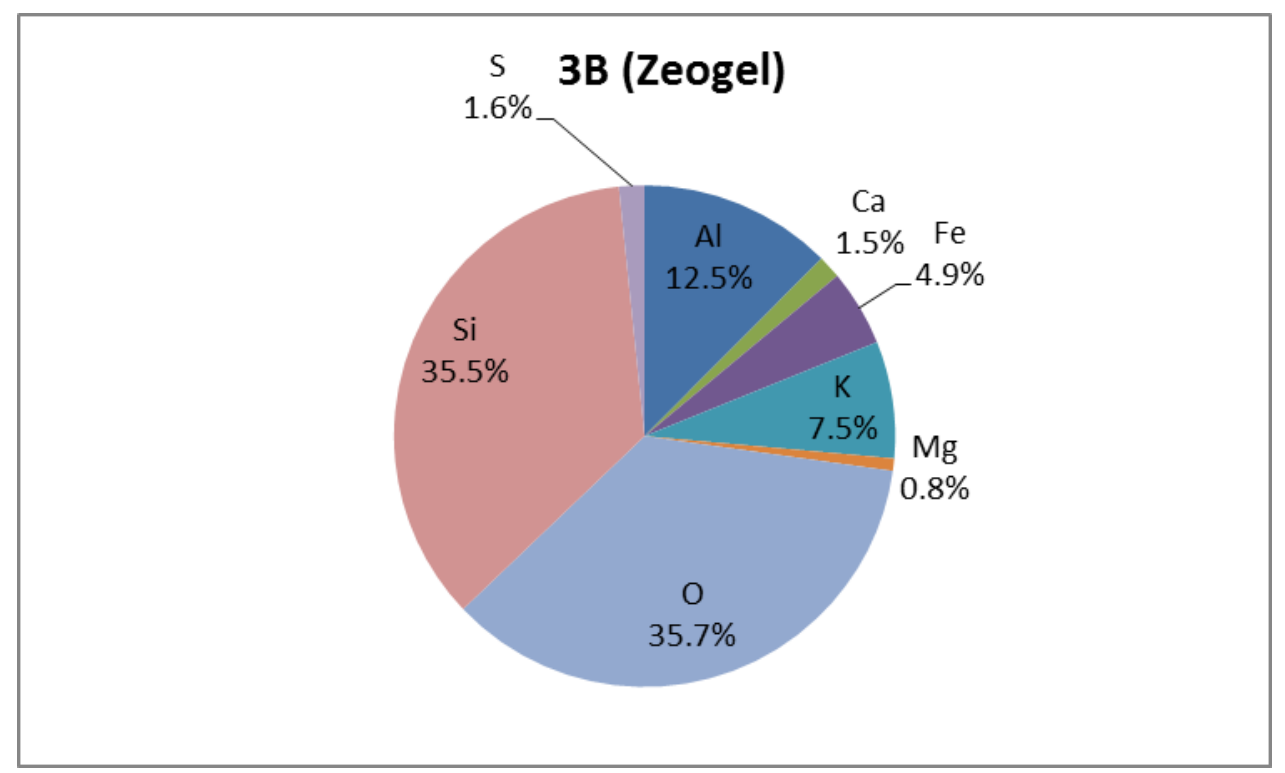

Figure B.60 Elemental composition of the Zeogel® treatment sample for the third depth interval of Well B 


\section{Wetzel County Well (Fourth Depth Interval)}

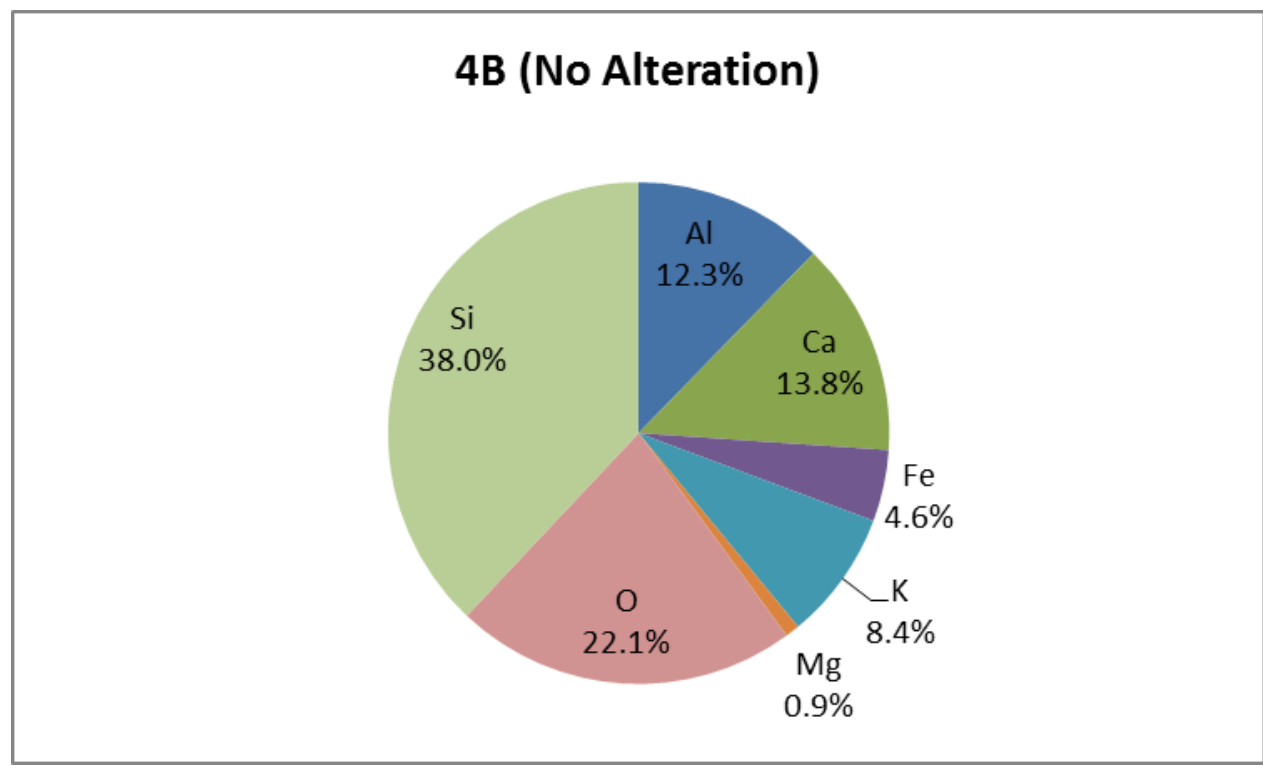

Figure B.61 Elemental composition of the control sample for the fourth depth interval of Well B

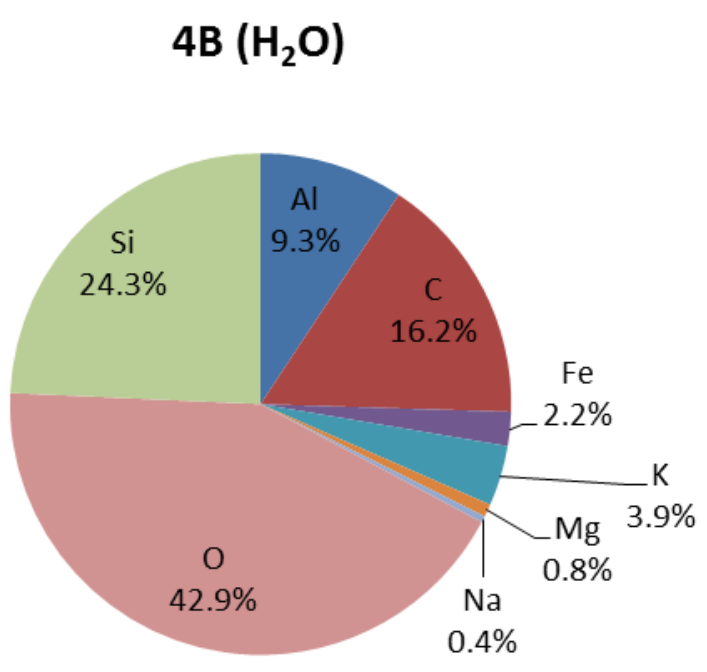

Figure B.62 Elemental composition of the water treatment sample for the fourth depth interval of Well B 


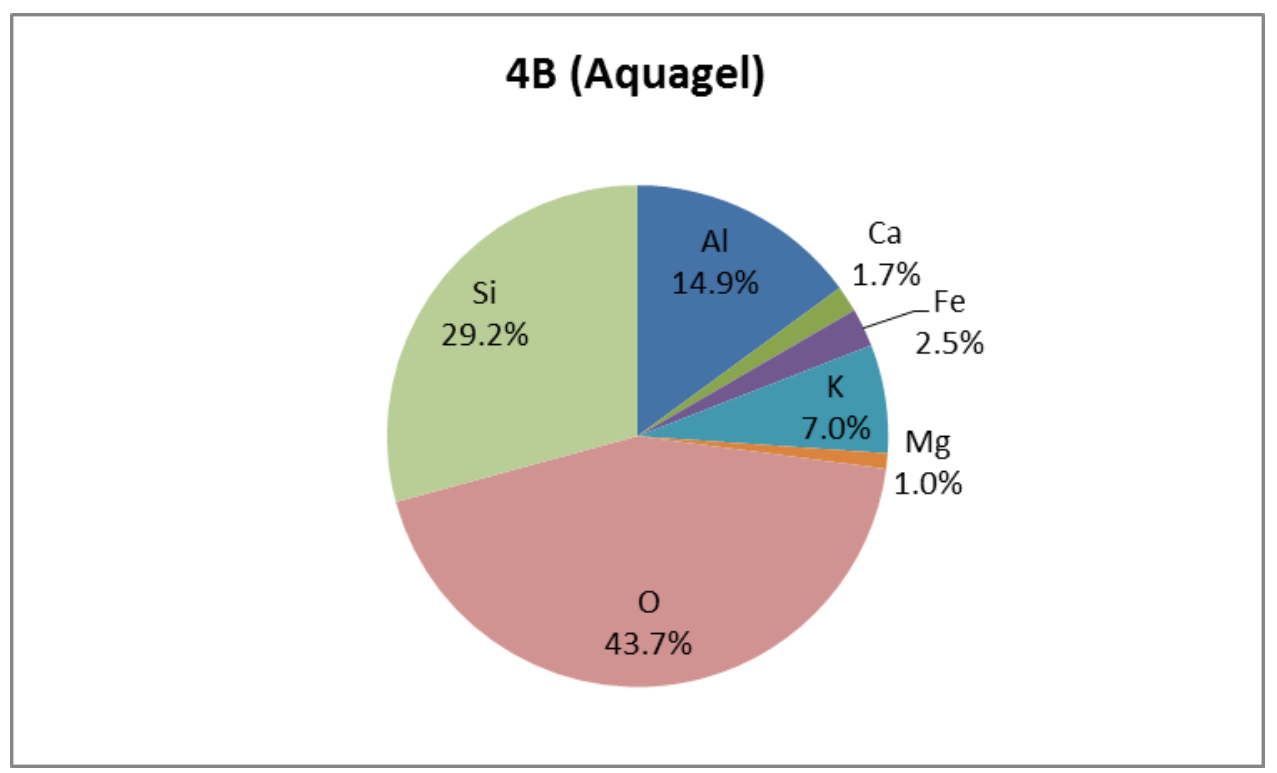

Figure B.63 Elemental composition of the Aquagel® treatment sample for the fourth depth interval of Well B

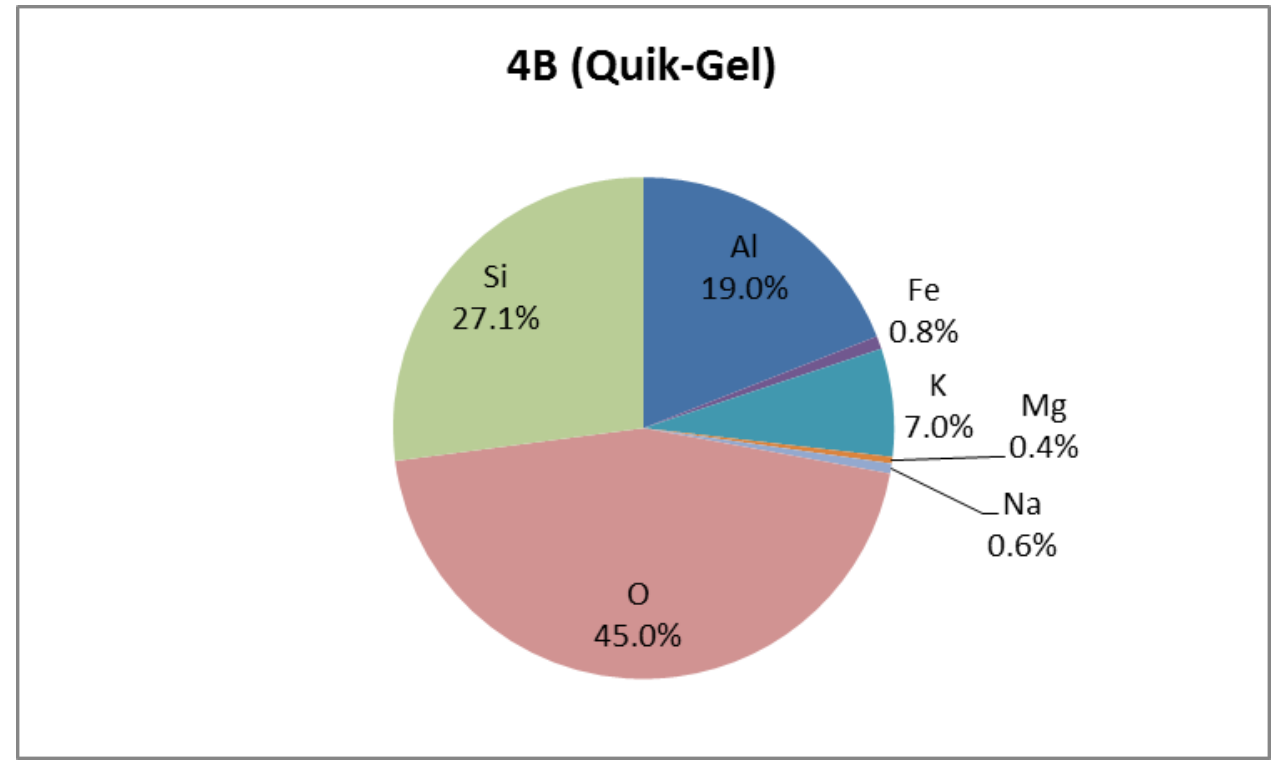

Figure B.64 Elemental composition of the Quik-Gel® treatment sample for the fourth depth interval of Well B 


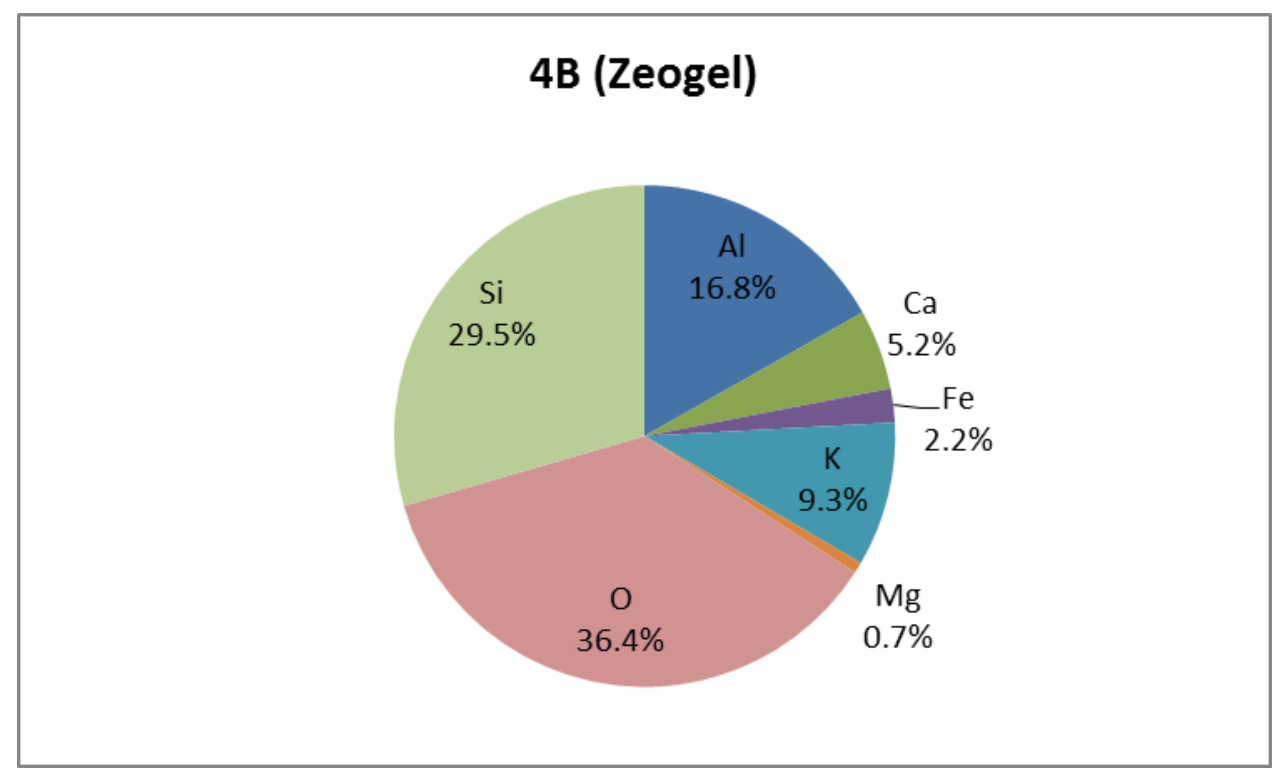

Figure B.65 Elemental composition of the Zeogel® treatment sample for the fourth depth interval of Well B 


\section{Wetzel County Well (Fifth Depth Interval)}

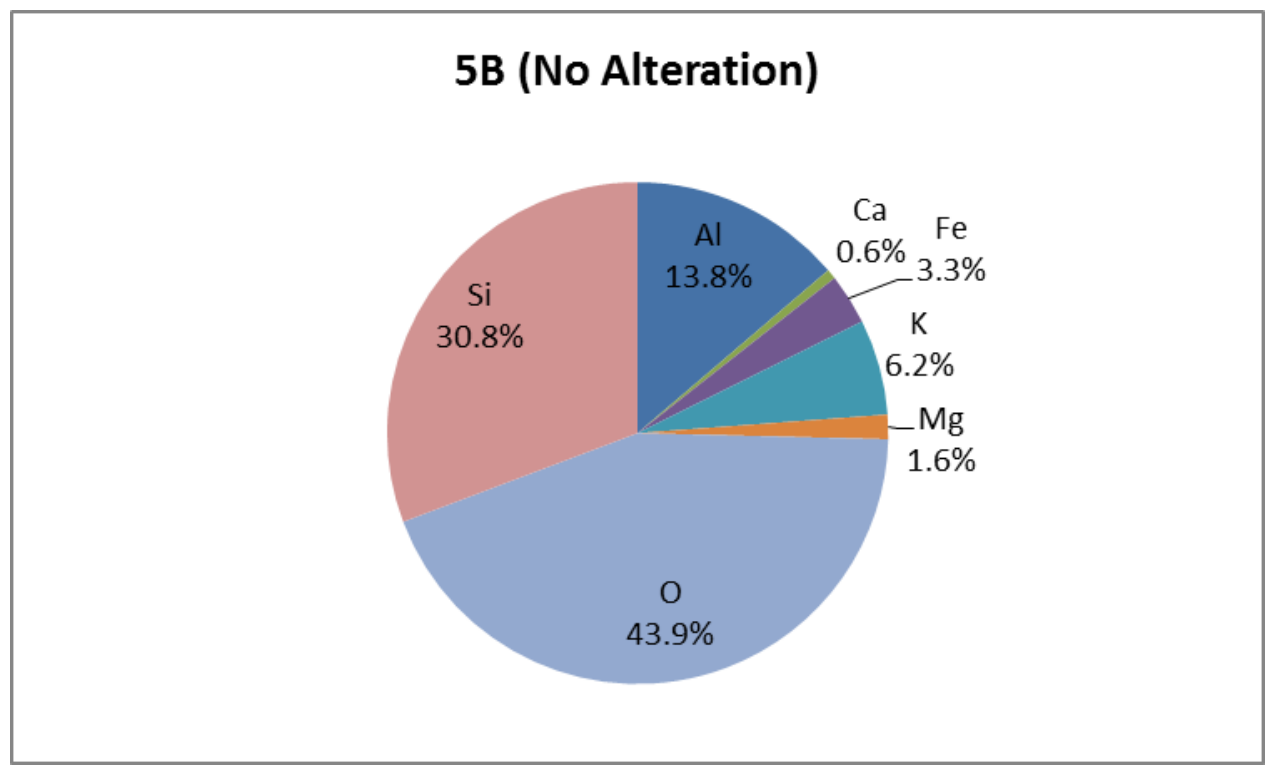

Figure B.66 Elemental composition of the control sample for the fifth depth interval of Well B

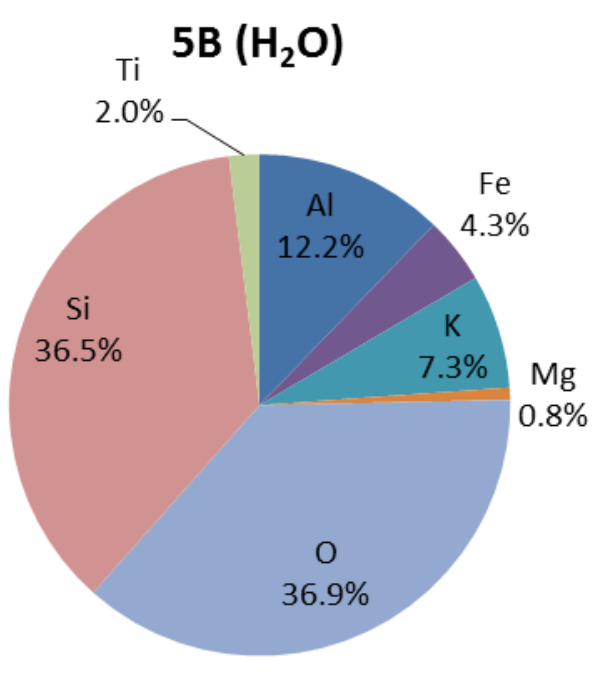

Figure B.67 Elemental composition of the water treatment sample for the fifth depth interval of Well B 


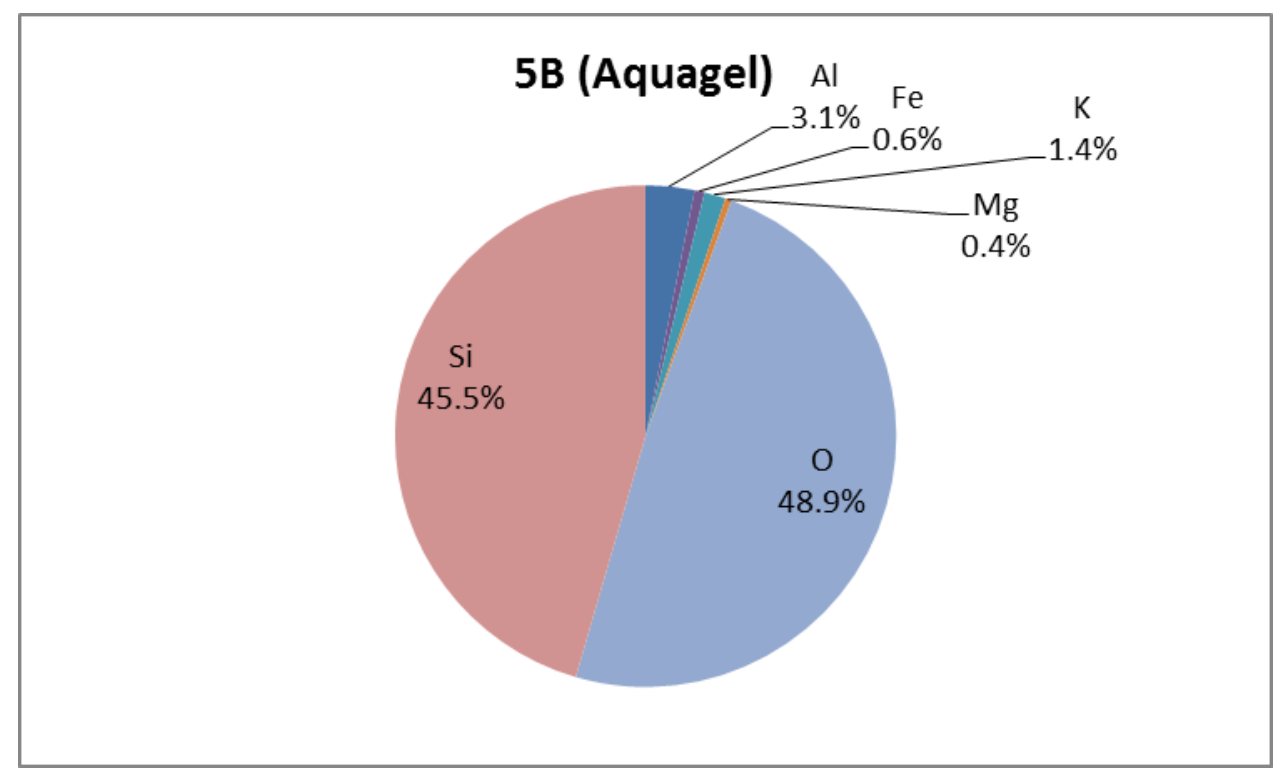

Figure B.68 Elemental composition of the Aquagel® treatment sample for the fifth depth interval of Well B

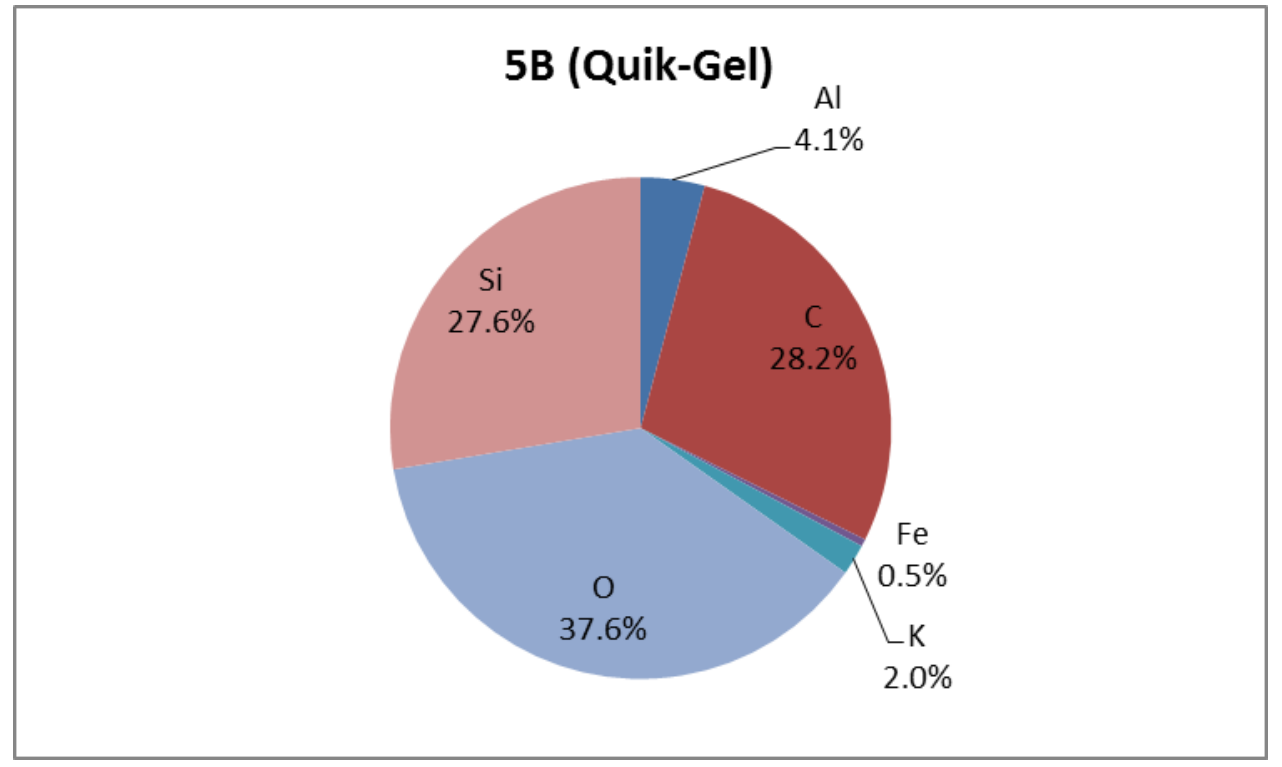

Figure B.69 Elemental composition of the Quik-Gel® treatment sample for the fifth depth interval of Well B 


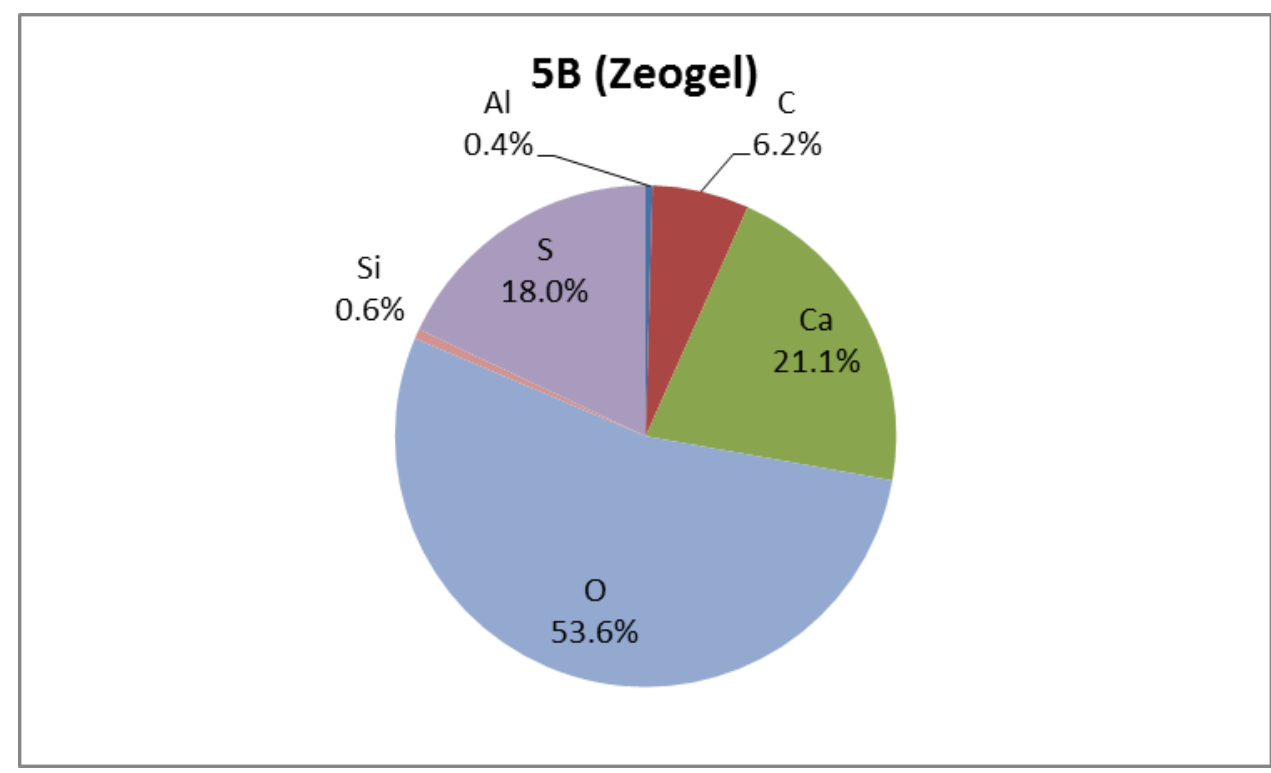

Figure B.70 Elemental composition of the Zeogel® treatment sample for the fifth depth interval of Well B 


\title{
A STUDY OF CHEMICAL INTERACTIONS BETWEEN THE MARCELLUS SHALE AND ATTAPULGITE AND BENTONITE CLAYS
}

\author{
Virginia Price Naryka \\ A Thesis submitted to the \\ Benjamin M. Statler College of Engineering and Mineral Resources \\ at West Virginia University \\ in partial fulfillment of the requirements for the degree of
}

\author{
Master of Science
}

In

Petroleum and Natural Gas Engineering

Department of Pertoleum and Natural Gas Engineering

APPROVAL OF THE EXAMINING COMMITTEE

H. Ilkin Bilgesu, PhD., Chair

Kashy Aminian, PhD.

Date

Sam Ameri, M.S. 